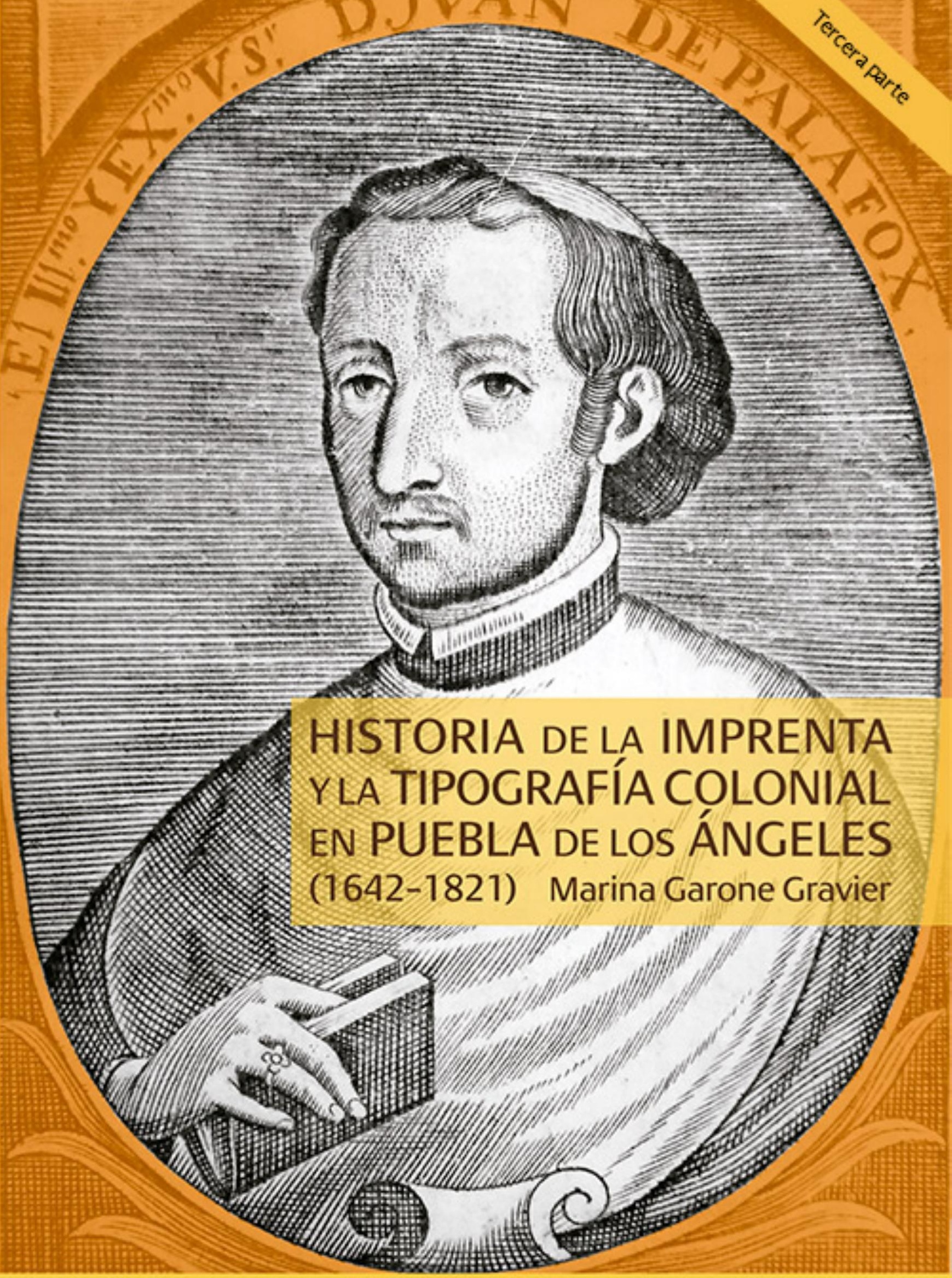




\section{HISTORIA DE LA IMPRENTA Y LA TIPOGRAFÍA COLONIAL EN PUEBLA DE LOS ÁNGELES \\ (I642-I82I)}




\section{HISTORIA DE LA IMPRENTA Y LA TIPOGRAFÍA COLONIAL EN PUEBLA DE LOS ÁNGELES (I642-182I)}

MARINA GARONE GRAVIER

Tercera parte

$$
\begin{aligned}
& \text { INSTITUTO DE INVESTIGACIONES BibLIOGRÁFICAS } \\
& \text { Universidad Nacional Autónoma de MÉXico }
\end{aligned}
$$


Garone Gravier, Marina, autor.

Historia de la imprenta y la tipografía colonial en Puebla de los Ángeles, I642-182I / Marina Garone Gravier. -- Primera edición. -México, D.F. : Universidad Nacional Autónoma de México, Instituto de Investigaciones Bibliográficas, Biblioteca Nacional / Hemeroteca Nacional, 2015.

766 páginas : ilustraciones; $24 \mathrm{~cm}$.

Bibliografía: páginas 679-702

ISBN impreso 978-607-02-6370-5

I. Imprenta - Puebla - Historia. 2. Libros - México - Historia. 3.

Editores y publicaciones - México - Historia. 4. Artes gráficas - Puebla - Historia. I. Universidad Nacional Autónoma de México. Instituto de Investigaciones Bibliográficas. II. Título.

$686.2097247-\operatorname{scdd}_{21}$

Biblioteca Nacional de México

Diseño de portada: Hilda Maldonado

Primera edición (impresa): 2015

Primera edición digital (PDF): 2018

Prohibida la reproducción total o parcial por cualquier medio sin la autorización escrita del titular de los derechos patrimoniales.

D. R. 2018 Universidad Nacional Autónoma de México

(C) Instituto de Investigaciones Bibliográficas

Biblioteca Nacional / Hemeroteca Nacional

Centro Cultural Universitario

Delegación Coyoacán 045ı, México, D. F.

Tels. (55) 5622-6807 y (55) 5622-68II

www.iib.unam.mx

ISBN (impreso): 978-607-02-6370-5

ISBN (PDF) Primera parte: 978-607-30-0242-4

ISBN (PDF) Segunda parte: 978-607-30-0243-I

ISBN (PDF) Tercera parte: 978-607-30-0244-8

ISBN (PDF) Obra completa: 978-607-30-024I-7

\section{(c) (1) (8)}

Historia de la imprenta y la tipografía colonial en Puebla de los Ángeles (1642-1821) por Universidad Nacional Autónoma de México se distribuye bajo una Licencia Creative Commons Atribución-NoComercial-SinDerivar 4.0 Internacional.

Impreso y hecho en México 


\section{ÍNDICE GENERAL}

Tercera parte

Capítulo IV. La imprenta y la tipografía en Puebla

durante la primera veintena del siglo XIX

Antecedentes

Tres imprentas vinculadas: José Garmendia Mosqueda,

los hermanos Moreno y los Troncoso

506

Pedro José Garmendia Mosqueda

Los hermanos Moreno

Los hermanos Troncoso

Resumen del material tipográfico de las imprentas de Garmendia,

Moreno y Troncoso

Joaquín Furlong Malpica y la Oficina del Oratorio de San Felipe Neri

Resumen del material tipográfico de la Oficina del Oratorio de San Felipe Neri 527

Los talleres poblanos en el contexto de las imprentas trigarantes (I820-I82I) 535

José María Macías

Conclusiones

Fuentes documentales y estudios consultados $\quad 55^{\mathrm{I}}$

Fuentes primarias $\quad 552$

$\begin{array}{lr}\text { Fuentes secundarias } & 575\end{array}$

Lista de ilustraciones $\quad 592$

Lista de cuadros $\quad 594$

Apéndices

I. Documentos para la historia de la imprenta y la tipografía poblanas 597

II. Bibliografía de los impresos coloniales poblanos consultados en la

$\begin{array}{ll}\text { Biblioteca Nacional de México } & 717\end{array}$

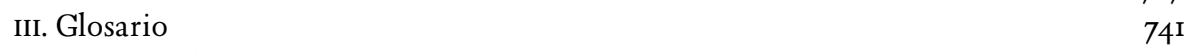

IV. Catálogo de autógrafos de los tipógrafos e impresores coloniales poblanos $\quad$ 76I 


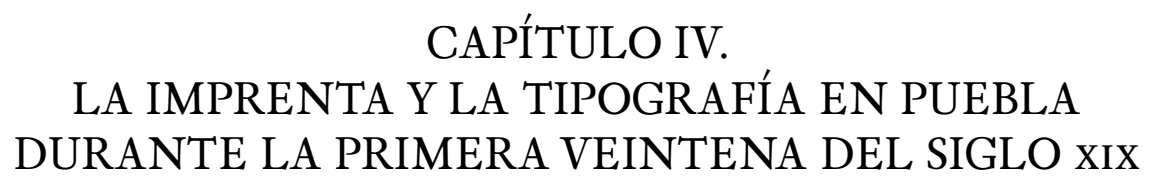




\section{ANTECEDENTES}

La actividad impresora del siglo XIX inició en Puebla con la continuidad de la prensa de la familia De la Rosa que, como vimos, para esa época ya tenía un verdadero emporio editorial que se extendía más allá de las fronteras poblanas, proveyendo de material de lectura a la ciudad de México y, posiblemente, a otras regiones del país. Sin embargo, hacia la segunda década del nuevo siglo surgió una serie de nuevas denominaciones tipográficas, aumento que estará en consonancia con los cambios en el ambiente político y social.

Tomando en consideración los ejemplares disponibles en la Biblioteca Nacional de México, los pies de imprenta poblanos que localizamos entre 1800 y I82I, inclusive, son los siguientes:

Pedro de la Rosa (1778 a I83I) ${ }^{708}$

José de la Rosa (I8Io)

Oficina del Oratorio de San Felipe Neri (1819-1820)

Oficina del Gobierno (1820), denominación que usarán tanto los De la Rosa como la Oficina del Oratorio.

Imprenta Liberal de Moreno Hermanos o Imprenta Liberal (1815, 1820-182I)

Oficina de Troncoso Hermanos (I8Ir?) e Imprenta Liberal de Troncoso Hermanos (I82I)

Imprenta Liberal de Pedro Garmendia (I82I)

Oficina del Gobierno Imperial o Imprenta Imperial, de los De la Rosa (I82I)

Imprenta portátil del Ejército de las Tres Garantías: D. Pedro de la Rosa (I82I) Imprenta de Macías (I82I)

\footnotetext{
${ }^{708}$ Como vimos en el capítulo anterior, bajo esta denominación aparecerá más de un "Pedro de la Rosa".
} 


\section{TRES IMPRENTAS VINCULADAS: JOSÉ GARMENDIA MOSQUEDA, LOS Hermanos Moreno Y LOS Troncoso}

El efecto del decreto de libertad de prensa firmado en la ciudad española de San Lorenzo, el I2 de noviembre de 1820 , hizo que cambiara radicalmente la naturaleza de la producción editorial de Puebla y México, pues el agitado panorama político será el fermento ideal para el surgimiento de numerosos libelos, papeles, proclamas, hojas sueltas con discusiones, y publicaciones periódicas que anticiparían el fervor independiente, muestras del deseo que había entonces por abrir nuevos foros y tribunas de expresión pública. ${ }^{709}$

En esa época encontramos algunas nuevas denominaciones tipográficas, por ejemplo la Imprenta Liberal, de la que Pérez Salazar dice: "según Medina [la imprenta] empieza sus labores en octubre de 1820 y era propiedad de Moreno Hermanos, sin consignar ninguna otra noticia", y agrega: "Yo tampoco tengo muchas [noticias] acerca de su fundación, pero sí, algunos datos sobre las personas que la regentearon" 70 $^{\text {Io }}$ historiador poblano manifestará en varias oportunidades las dificultades que tuvo en la identificación de la propiedad de los talleres de la segunda década del siglo XIX, como cuando describe los sucesivos responsables de la impresión de La Abeja Poblana: "Esta mezcla de Morenos, Troncosos y Garmendias, sin mayores datos documentales, hace difícil el saber con certidumbre, desde cuándo y por qué, aparecen como propietarios de la imprenta, cada uno de ellos" ${ }^{\text {.II }}$

Sin poder dilucidar completamente la transferencia y relaciones que mantenían entre sí esas imprentas, deseamos agregar algunas noticias y citar documentos que eran desconocidos hasta ahora para aclarar, al menos parcialmente, el complejo panorama editorial poblano de la segunda década del siglo XIX.

\section{PEDRO JOSÉ GARMENDIA MOSQUEDA}

Pedro José nació en la villa de Jalapa, Veracruz; sus padres fueron Pedro José de Garmendia ${ }^{72}$ y Rosa Mosqueda, y su hermano fue José Manuel María Nicolás. ${ }^{73}$ El 22 de enero de i8ıo Pedro José contrajo matrimonio en Puebla con María de los Dolores

\footnotetext{
${ }^{709}$ Algunos de los autores que han trabajado el tema de la lucha revolucionaria y la libertad de imprenta son: Carballo, García Díaz, Guzmán Pérez, Mathes, Ortega, Palacio, Montiel y Rangel, entre otros más. Remitimos al lector a las fuentes de consulta de esta obra.

${ }^{710}$ Pérez Salazar, op. cit., p. 360.

${ }^{711}$ Pérez Salazar, op. cit., p. 36 I.

${ }^{72}$ Sus padres se trasladaron al Real de Sultepec, donde vivieron varios años. En i78r su padre se hizo socio de la Real Sociedad Bascongada de los Amigos del País. Josefina Torales Pacheco. Ilustrados en la Nueva España. Los socios de la Real Sociedad Bascongada de los Amigos del País. México: Colegio de Vizcaínas / IAP / Universidad Iberoamericana, 200I, p. 225. De este personaje existen varios documentos en el AGN sobre sus negocios en el ramo de Tabacos entre I790 y I8I5: AGN, Reales cédulas originales, vol. I46, exp. Io8, junio I8 de I790, I f.; y AGN, Reales cédulas originales, vol. I65-A, exp. 96 BIs, marzo I6 de I796, I f.

${ }^{73}$ El 2I de enero de 1795 recibió el título de bachiller en Artes por la Universidad de México. AGN, Universidad, vol. I70, f. I6v.
} 
Moreno y Buenvecino, hermana del bachiller José María Moreno. ${ }^{74} \mathrm{He}$ aquí la primera relación entre el taller de Garmendia y el de los Hermanos Moreno.

En r82r Pedro Garmendia, quien aún residía en la ciudad de Puebla y continuaba casado con Dolores, pone por primera vez su nombre al frente de la Imprenta Liberal: nos referimos al número i4 de la Abeja Poblana, publicado el I $^{\circ}$ de marzo de I821, en el cual Juan Nepomuceno Troncoso editó el Plan de Iguala. Éste parece ser el acontecimiento que vincula a Garmendia con uno de los Hermanos Troncoso.

En la Biblioteca Nacional encontramos un solo impreso de 16 páginas que consigna a Garmendia como impresor. El documento fue escrito por fray José Servando Teresa de Mier Noriega y Guerra y se titula Carta de despedida a los mexicanos: escrita desde el Castillo de S. Juan de Ulúa, reimp. Puebla, México: Imprenta Liberal de D. Pedro. de Garmendia; oficina de Benavente y socios, 1821. ${ }^{15}$

Después, en el número 39 de La Abeja Garmendia volvió a aparecer como impresor de dicho semanario, al lado de su cuñado, el bachiller José María Moreno. ${ }^{76}$ Pocas semanas después de esa edición Garmendia dejó la imprenta en manos de su pariente político, Moreno, tal vez porque en septiembre de I82I comenzó a fungir como contador y tesorero del recién creado Consulado de Puebla. Volvemos a encontrar a Garmendia en enero de 1823 en la ciudad de México, cuando el ayuntamiento le propuso fungir como uno de los 72 jueces que vigilaban el cumplimiento de la libertad de imprenta, cargo que rechazó aduciendo que era incompatible con el empleo que desempeñaba como oficial de la Secretaría del Consejo del Estado. ${ }^{77}$ Después de esa actuación no se conoce más de la vida del impresor. ${ }^{78}$

El vínculo de Garmendia con la imprenta que pasaría a manos de los Moreno queda de manifiesto por otros documentos, como la fianza que dio del i6 de septiembre de 1821 por la impresión de billetes para la rifa de la Imperial Trigarante, para socorro del Ejército. ${ }^{79}$ En ese documento se menciona que se encargó la impresión de 70 billetes para ayudar a los gastos del Ejército a don José María Moreno, y que Garmendia fue el aval.

\section{LOS HERMANOS MORENO}

El taller de Moreno Hermanos inició sus trabajos el 28 de septiembre de I82I, al publicar El Amigo del Pueblo. La tendencia de los impresos salidos de esta oficina fue pro iturbidista, aunque también llegaron a editar escritos del Pensador Mexicano que

\footnotetext{
${ }^{714}$ Pérez Salazar, op. cit., p. 364 y Guzmán Pérez, op. cit., p. II2-Ir3.

${ }^{15}$ BNMeX, clasificación 213 LAF, 246 LAF, 439 LAF.

${ }^{716}$ BNMex, clasificación LAF 416, Meza y Olivera, op. cit., p. 248, núm. I304; Miguel I. Vergés. La independencia mexicana y la prensa insurgente. México: Instituto Nacional de Estudios Históricos de la Revolución Mexicana, Comisión Nacional para las Celebraciones del ${ }_{75}$ Aniversario de la Independencia Nacional y 75 Aniversario de la Revolución Mexicana, 1985, p. 293.

${ }^{77}$ AHCM, México, Ayuntamientos jurados de imprenta, vol. 2739, exp. II. Pedro José de Garmendia al Ayuntamiento de México, 9 enero de 1823. Citado por Guzmán Pérez, op. cit., p. II2-Irz.

${ }_{718}^{18}$ Guzmán Pérez, op. cit., p. II2-IIz.

${ }^{19}$ AGNP, not. 4, caja 29I, Protocolos de José Ramirez de Arellano, I6 de septiembre de I82I, ff. 8 fojas s/n.
} 
denostaban a Agustín de Iturbide; los últimos impresos del establecimiento están fechados en marzo de $1827 \cdot{ }^{720}$ Este taller también aparece bajo la denominación "La Liberal de Moreno Hermanos" y "Oficina Liberal." En i825 el establecimiento estaba ubicado en la calle de San Agustín número 8, como consta en las Tablas botánicas que para el más pronto y fácil estudio de esta ciencia dispuso el pbro. D. Julián Cervantes; y se imprimen á expensas de la Academia Medicoguirúrgica de esta ciudad de Puebla; a quien le fueron presentadas por su benemérito socio D. Antonio Cal. ${ }^{21}$

Los hermanos Moreno fueron tres: José María, María de los Dolores y, posiblemente, Pedro, siendo el más conocido el primero de ellos. José María Moreno Buenvecino era sobrino del presbítero doctor José Demetrio Moreno Buenvecino y se sabe que el 27 de agosto de 1805 contrajo matrimonio en el Oratorio de San Felipe Neri en Puebla, con Juana Josefa de la Luz Aguilar. ${ }^{722}$ Su formación fue amplia, a juzgar por la respuesta que dio al padre Rosillo en el número 5i de La Abeja Poblana:

es necesario, que responda con la moderación propia de mi educación, que en el colegio de San Ildefonso me calificaron por igual al catedrático de Retórica; que me saqué el "Supra Locum" en el curso de Artes, en el Carolino; que en el Seminario recibí buen concepto de mis catedráticos en Teología, tanto que los de Vísperas y Sagrada Escritura, me brindaron repetidamente con un acto, no ofreciéndome el Estatuto porque no se acostumbra en este colegio que lo tengan seglares; que en una Academia interior de buenas letras, de dicho colegio, me hacía mucha estimación los literatos más afamados. ${ }^{723}$

A partir del número i7 de la Abeja Poblana, correspondiente al 22 de marzo de I82I, José María Moreno se hizo cargo de la publicación del periódico, en calidad de "administrador de la Oficina”. ${ }^{24}$

De la "Imprenta Liberal de Moreno Hermanos" salieron publicados 4I números del periódico El Farol-incluido un Suplemento al número 9 y el Alcance al número 36-, cuyo primer ejemplar apareció el 28 de octubre de i82i y el último el 4 de agosto de I822, cubriendo un total de 372 páginas a numeración seguida. ${ }^{725}$ Otros periódicos que salieron de esa imprenta fueron El Invitador (jun. I826 - mayo i827), El Poblano (feb.-mar. 1827) y El Patriota (posiblemente, entre 1827 y diciembre del año siguiente), todos de tendencia liberal. ${ }^{26}$ Años más tarde, Moreno fue miembro del Congreso

\footnotetext{
${ }^{720}$ BNMex, clasificación LAF 4I6. Moreno Valle, op. cit., p. 26I, núm. 2232.

${ }^{221}$ Desverguenzas y excomuniones no destruyen las sólidas razones: o, Crítica juiciosa contra el seriesísimo papel... un guapo admite el desafio del excomulgado de José Joaquín Fernández, publicado en 1822, BNMex, Clasificación: Io6 LAF y 2II LAF, respectivamente; Ocurrencias interesantes sobre reclamaciones del congreso de Jalisco, hechas por sus diputados en la sesión pública de 28 de mayo en el congreso general de México. México: Oficina liberal de Moreno hermanos, 1824, BNMex, clasificación 4I6 LAF. Su domicilio aparece citado en un ejemplar que se encuentra en la BNMex, clasificación: 397 LAF.

${ }^{222}$ Pérez Salazar, op. cit., p. 364 .

${ }^{723}$ Idem.

${ }^{22}$ Teixidor, op. cit., p. 476.

${ }^{25}$ Ibid., p. 50I-502, núm. 790.

${ }^{726}$ Coudart, op. cit., p. I2I-I25.
} 
General en 1829. Se desconoce la vida posterior de este impresor, aunque es probable que haya muerto en la ciudad de Puebla.

Como mencionamos líneas arriba, una de los "Hermanos Moreno" fue María de los Dolores, por tanto esta mujer fue copropietaria de la imprenta. María contrajo matrimonio con Pedro José de Garmendia el 22 de enero de r8io. También hemos localizado otros Moreno, pero no sabemos el parentesco específico con la familia. ${ }^{27}$

Es posible que entre los hermanos o parientes de los Moreno figurara también Pedro, de quien tenemos un documento firmado por el escribano de cabildo, Nicolás Fernández de la Fuente, con fecha de enero de r8o8, que lo nombra "oficial examinador de aprensador", es decir, encuadernador, indicando que en la ciudad de Puebla no había quien desempeñara el oficio. ${ }^{728}$

Por último, es interesante hacer notar que las relaciones entre talleres se dieron también a nivel literario, ya que tanto José María Moreno imprimió obras de su autoría en el taller de los Troncoso en $1821,{ }^{729}$ como Juan Nepomuceno Troncoso lo hizo en el taller cuando éste pasó a manos de los Moreno, ${ }^{730} \mathrm{y}$ antes lo había hecho en la casa de Pedro de la Rosa. ${ }^{73}$

\section{LOS HERMANOS TRONCOSO}

Los Hermanos Troncoso provenían de una familia de abolengo del puerto de Veracruz; un pariente suyo por parte de madre instaló la primera imprenta en el puerto. ${ }^{732}$ José María Faustino Troncoso López Bueno nació en la ciudad de Veracruz el is de febrero de $1777{ }^{733}$ Fue el mayor de los hijos del matrimonio de Adrián Félix Troncoso, agente del Consulado porteño, y de Ana María López Bueno y Flores. Sus primeros estudios los realizó en el Colegio de Tehuacán, y los continuó en el Palafoxiano de Puebla, en I783. En I795 se recibió de bachiller en Artes en la ciudad de México, ${ }^{734}$ en I799 obtuvo el grado de licenciado en Artes y, finalmente, el 4 de agosto del mismo año recibió el título de maestro en Artes. ${ }^{735}$ En 1804 José María residía en Veracruz y

\footnotetext{
${ }^{727}$ AGNP, not. 4, caja 292, Protocolos de José Mariano Ortiz, 23 de octubre de 1826 , ff. 285v-287v. Los hermanos Moreno iniciaron un litigio testamentario por los bienes de Manuel Moreno (su tío), que vivió en Santa Anna Chiautempan, Tlaxcala, y para ello otorgaron un poder para que los representara Miguel Dorantes.

${ }_{728}$ AGMP 2I de enero de I808, ff. $62 \mathrm{f}$.

${ }^{22}$ Poesías del Br. D. José María Moreno. Puebla: Imprenta Liberal de Troncoso Hermanos, I82r. BNMex, clasificación: RSM I82I P6MOR, descripción: 2 v. ; I2 cm.

${ }^{73^{\circ}}$ Carta al Sr. D. Francisco Manuel Sanchez de Tagle de Juan Nepomuceno Troncoso. Puebla: Imprenta liberal de Moreno y Hermanos, 1822. BNMex, clasificación: 443 LAF, 444 LAF, 215 LAF.

${ }_{73 \mathrm{I}}$ Juan Nepomuceno Troncoso. Aviso al pueblo. Puebla: Oficina de D. Pedro de la Rosa, i82o. BNMex, clasificación: RLAF 127 LAF.

${ }_{732}^{2}$ José Toribio Medina. La imprenta en Oaxaca, Guadalajara, Veracruz, Mérida y varios lugares, I720-1820. México: UNAM, IIB, Dirección General de Publicaciones, I99I, 429 p.

${ }^{733}$ Francisco Sosa. Biografias de mexicanos distinguidos. México: Porrúa, 1985, p. 6II (Col. Sepan Cuántos, 472). ${ }^{734}$ AGN, Universidad, vol. 170, f. I5r. Citado por Guzmán Pérez.

${ }^{735}$ Guillermo Fernández de Recas. Grados de licencias, maestros, y doctores en artes, leyes, teología y todas las facultades de la Real y Pontificia Universidad de México. México: UnAm-IIB, 1963, p. 176; Diccionario Porrúa de historia,
} 
en i8ı6 era provisor de la diócesis de Puebla, durante la administración episcopal del sucesor de Manuel Ignacio González de Campillo Gómez del Valle, el obispo Antonio Joaquín Pérez (I815-I829), con quien entabló estrecha amistad.

José María era copropietario de la Imprenta Liberal, junto con su hermano Juan Nepomuceno, pero cuando este último se hizo cargo del curato de Molcajac, José María asumió la dirección del taller tipográfico. Además de una época del periódico La Abeja Poblana, en su imprenta se reeditó el Mejicano Independiente, periódico que dirigía José Manuel de Herrera y que apoyaba el movimiento Trigarante. ${ }^{736}$

Debido a su filiación política José María tuvo problemas con el gobernador militar Ciriaco de Llano, razón por la cual debió refugiarse en la ciudad de México, pero al consumarse la Independencia fue capellán del emperador Agustín de Iturbide, y más tarde desempeñó otros cargos públicos. ${ }^{737}$ José María Troncoso murió en la ciudad de México el 30 de mayo de $184{ }^{1 .} .^{78}$

Por su parte, Juan Nepomuceno Troncoso López Bueno, al igual que su hermano, nació en el puerto de Veracruz el i2 de mayo de i779. Estudió en su ciudad natal y más tarde en el Colegio de Tehuacán, donde permaneció hasta 1793, fecha en que ingresó al Seminario Palafoxiano. En enero de 1795 obtuvo el grado de bachiller en Artes en la Real y Pontificia Universidad de México ${ }^{739}$ y, finalmente, se graduó de abogado en r804. Cuando inició la guerra de Independencia Troncoso residía en Puebla y simpatizó con el movimiento insurgente; al parecer fue precisamente durante esa época cuando, junto con su hermano José María, compró la imprenta. ${ }^{74^{\circ}}$

Por participar en la impresión del Plan de Iguala, Juan Nepomuceno y su hermano fueron perseguidos por Ciriaco de Llano, jefe político de la provincia. De Llano mandó destruir el suplemento i4 de La Abeja Poblana, señalando que dicho papel era sedicioso. ${ }^{74}$ Dos números más tarde, en un "Aviso a los señores suscriptores" del mismo periódico, Troncoso informó que: "Largas y penosas enfermedades no le permiten al Editor de este Periódico continuar con su publicación; por tanto los señores suscriptores ocurrirán a la Oficina de esta imprenta con sus respectivos recibos y se les devolverá la parte que alcancen de sus suscripciones". ${ }^{742}$

\footnotetext{
biografia y geografia de México (4 $4^{\mathrm{a}}$ ed. correg. y aum.; con un suplemento). México: Porrúa, 1976, t. II, p. 2175. ${ }_{736}$ El Mejicano Independiente, núm. I3, 2 de junio de I821, p. 6, en García, Documentos, 1985, t. IV.

${ }^{737}$ Según Moisés Guzmán Pérez, José María Troncoso fue diputado en la Diputación Provincial de Puebla (1823), en la Legislatura de Veracruz (1828) y fue senador de la república por el estado de Puebla (I833). También fue miembro de la Academia Médico-Quirúrgica, institución a donde ingresó en el año de 1825 . Guzmán Pérez, op. cit., p. 24I-245.

${ }_{73^{8}}$ Sosa, op. cit., p. 612; Diccionario Porrúa, op. cit., t. II, p. 2175.

${ }^{739}$ AGN, Universidad, vol. 179, f. I5r. Citado por Guzmán Pérez.

${ }^{74^{\circ}}$ En la Biblioteca Nacional de México existe un impreso de los Troncoso, fechado en i8II, que no hemos podido ver; si efectivamente la obra se imprimió en ese año, debemos remontar el inicio de sus actividades io años antes, inclusive antecediendo el trabajo de Garmendia. La obra es Papel que la diputación mexicana dirige al Excmo. Señor Secretario de Estado y del despacho de la guerra. Oficina de Troncoso Hermanos [I8II], BNMex., clasificación: 328 LAF.

${ }^{741}$ Teixidor, op. cit., I991, p. 473-474.

${ }^{742}$ BNMex, clasificación LAF 416, Rocío Meza Olivier y Luis Olivera. Catálogo de la Colección Lafragua de la Biblioteca Nacional de México I8II-I82I. México: UNAM-IIB, 1996, p. 332, núm. i67I (Serie Guías).
} 
Por último en el número 23 de La Abeja, que apareció el 3 de mayo de I82I, se informa: "la imprenta liberal de esta ciudad está en venta: el que quiera comprarla

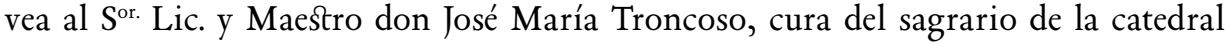
de Puebla, su legítimo dueño, con quien se ajustará sobre precio y condiciones”. Sin embargo, la venta no ocurrió sino hasta agosto, mes en que el taller volvió a manos de los hermanos Moreno, ${ }^{743}$ quienes lo conservaron hasta algunos años después de la independencia mexicana; en él imprimieron del número 3 al I3 del periódico Amigo del Pueblo, ${ }^{744}$ que inicialmente habían salido de las prensas de Troncoso Hermanos.

Según Pedro Henríquez Ureña, Juan Nepomuceno tuvo otro vínculo con una imprenta, a saber por el proceso que enfrentó por haber recibido dinero de parte de Iturbide para comprar una imprenta en Estados Unidos. ${ }^{745}$ Cuando Troncoso fue movido al curato de Acajaque, Iturbide le escribió invitándolo a verlo en Cholula, reunión en la cual le encomendó que adquiriera una imprenta para propagar las ideas de independencia. Con objeto de hacerse de recursos para la adquisición de la imprenta, el $\mathrm{I}^{\mathrm{o}}$ de septiembre, Iturbide giró una orden a su cuñado Ramón Huarte, intendente de Valladolid, para que reuniera la cantidad de 2500 pesos y se le entregaran al padre Troncoso. Sin embargo, hasta el 24 de ese mes Troncoso no había recibido aún el dinero prometido. Años más tarde, en I827, el inculpado escribió una aclaratoria donde señalaba que fue un tal señor Durán a quien se le dieron 2500 pesos para comprarla y no él. $7^{74}$

\section{Resumen de material tipográfico de las imprentas de Garmendia, Moreno y Troncoso}

Como hemos visto, estos talleres estuvieron vinculados entre sí, por lo que es natural encontrar continuidades en sus materiales tipográficos. Para ese momento del siglo XIX el empleo de letras capitulares ya no será usual en las ediciones, en su lugar se usarán iniciales de dos líneas, aquellas que tengan una relación de proporción mayor al cuerpo que se usa en la composición tipográfica del texto principal. Los cuerpos que se aplicarán a manera de "capitulares austeras" son 26 y 22 puntos.

Además de la ausencia de capitulares, habrá una dramática disminución en el repertorio de ornamentos tipográficos. Por ejemplo, en el taller de los Troncoso encontraremos solo dos pequeños motivos vegetales, a los que se sumarán bigotes o llaves de tres tamaños. Los bigotes se usarán para separar la información del título y los autores del pie de imprenta. Lo mismo observamos en los impresos de los Moreno, e incluso con un surtido ornamental más austero.

\footnotetext{
${ }^{743}$ Teixidor, op. cit., p. 476.

744 BNMex, clasificación: I27 LAF.

745 Pedro Henríquez Ureña, "Índice biográfico de la época”, en Antología del Centenario. Estudio documental de la literatura mexicana durante el primer siglo de independencia. Primera parte I800-182I, ed. facsimilar de la de I9IO. México: SEP, I985, vol. II, p. 960; Miquel, op. cit., I985, p. 250.

${ }^{746}$ Asedena, Histórico, exp. XI/48I.3/I54. Iturbide al Dr. Juan Nepomuceno Troncoso, cura de Acajaque, Cholula, 30 de julio de I82I, f. 2 y Asedena, Histórico, exp. XI/48I.3/154. Iturbide al Intendente de Valladolid, Tacubaya, 24 de septiembre de I82I, f. 3 .
} 
En los impresos consultados es escasísimo el uso de imágenes, siendo el más relevante el tosco grabadito xilográfico de La Abeja dispuesta dentro de una corona de hojas, posiblemente laureles, que se usó como emblema o "imagotipo" del periódico homónimo.747

En cuanto a las letrerías de estos talleres, hemos encontrado en los impresos de Troncoso 15 cuerpos o castas de letra distintas: desde el peticano a la perla, es decir, desde 26 a 4 puntos, y en los de Moreno hay $\mathrm{I} 3$, con algunas reminiscencias antiguas $^{74^{8}}$ en el cuerpo de palestina y gran parangón. Esto podría explicarse mediante el argumento de que los cuerpos grandes o mayores sufren un desgaste relativo menor al de los cuerpos de texto, por lo cual es más factible que los talleres tardaran más tiempo en reemplazar sus tamaños, en comparación con los cuerpos para la composición corriente del texto que, al ser los más usados, se renuevan con más frecuencia.

${ }_{747}$ El diseño y la tipografía de esta publicación han sido analizados por mí en el ensayo "La Abeja Poblana (I820): consideraciones básicas para el estudio de la tipografía en las publicaciones periódicas a través de un impreso poblano", en Irma Lombardo García, (comp.). Los impresos noticiosos a debate. Hacia una definición de conceptos. UNAM-IIB, 20I4, p. 165-198.

${ }^{74^{8}}$ Ver clasificaciones estilísiticas y tipográficas en el capítulo primero de esta investigación. 
Peticano

9.60 / $192 \mathrm{~mm}$

26 pts

1821 Rej Ami

Palestina

$8.45 / 169 \mathrm{~mm}$

$22 \mathrm{pts}$

1820 Ano Gen

1821 Ano Far

1821 Car Pat

Gran parangón

7.34 / $146.8 \mathrm{~mm}$

20pts

1820 Ano Gen /

Curs.

Parangona chico

6.62 / $132.4 \mathrm{~mm}$

$18 \mathrm{pts}$

1821 Car Pat

Lectura gorda

$4.59 / 91.8 \mathrm{~mm}$

$12 \mathrm{pts}$

1820 Ano Gen / Red

1821 Rej Ami / Red.

1821 Car Pat / Curs.
Moreno Hermanos Letrerías
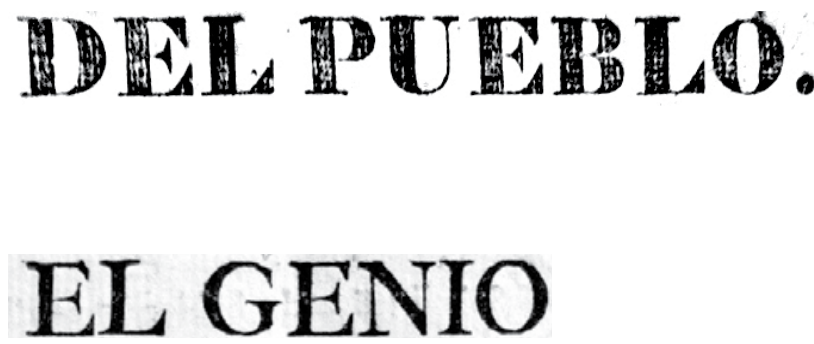

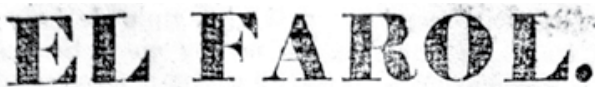

\section{DISCUTSO}

entusiasmo general de toda Antequera, el fue. rior vivo y sagrado, que animó á tan respePublico el veinte y ocho de Agosto para pedir $s$ la impresion de este mi discurso, aprontan. abriendose espontaneamente una subscripcion

Vicit Lè de tribú Judá . . el cuatuo bant amen.

Vencio el Leon de Judá... y los cuat cian amen.

Palabras tomadas del cap. 5 versiculos b y 14.

(Vos sois el Leon y Corder 
Moreno Hermanos Letrerías

Lectura chica

4.24 / $84.8 \mathrm{~mm}$

$11 \mathrm{pts}$

1821 Rej Ami / Red.

1821 Ano Far / Curs.

1821 Car Pat / Curs.

\section{PATETICO ALEGORICO}

En veinte y ocho de Agosto d inte y uno, el M. R. P. Presel rasco, Comendador actual del de la Merced de esi

\section{SEMANARTO DE LA}

Dalo à luz pablica el entusiasme macion universal ha pedido se dé. dio de una subscripcion espontas arrebatado del mayor jubrita com petable público en el mos

Filosofía - Entredós $3.66 / 73.2 \mathrm{~mm}$ $10 \mathrm{pts}$ 1821 Ano Far / Red. 1821 Car Pat / Red. 1821 Rej Ami / Curs. 1820 Ano Gen / Curs.

\section{PREVENCION ÁlAA CRITICA}

dra todos los domingos desde el 28 to esencial explicar en cada numero que debera contraerse la Ley fundan perio, aunque no sea por el orde dos en otras constituciones, sino por

\section{CARTA}

olvidemos que por el desmedido zelo - muchas veces esa libertad misma, $q$ is de no desacreditar las instituciones omedido y severo de la libertud, para

\author{
CELEBRARON
}

RELIGION, LIBERTAD

\section{$3.42 / 68.4 \mathrm{~mm}$}

9 pts

1821 Ano Far / Red.

1821 Car Pat / Curs.

\section{Gallarda}

2.99 / $59.8 \mathrm{~mm}$

$8 \mathrm{pts}$

1821 Ano Far
EN EL IMPERIO MEJICANO. 
Moreno Hermanos Letrerías

\section{Glosilla}

2.74 / $54.8 \mathrm{~mm}$

7 pts

1821 Ano Far

1821 Car Pat

1821 Rej Ami

\section{Miñona}

2.48 / $49.6 \mathrm{~mm}$

$71 / 2 \mathrm{pts}$

1821 Rej Ami / Red.

1821 Car Pat / Curs.

Jolie

2.28 / $45.6 \mathrm{~mm}$

$61 / 2 \mathrm{pts}$

1821 Car Pat / Curs.

Nompareil

$2.12 / 42.4 \mathrm{~mm}$

6 pts

1821 Car Pat
PROSPECTO.

OFICIAL DEL SITÍO DE MEGTCO.

Que en solemne accion de gracias

zs del Egèrcito Imperial Trigara

EL PATROCINIO DE MARIA SARTISTMA,

valle de oajaca. 
Moreno Hermanos Ornamentos

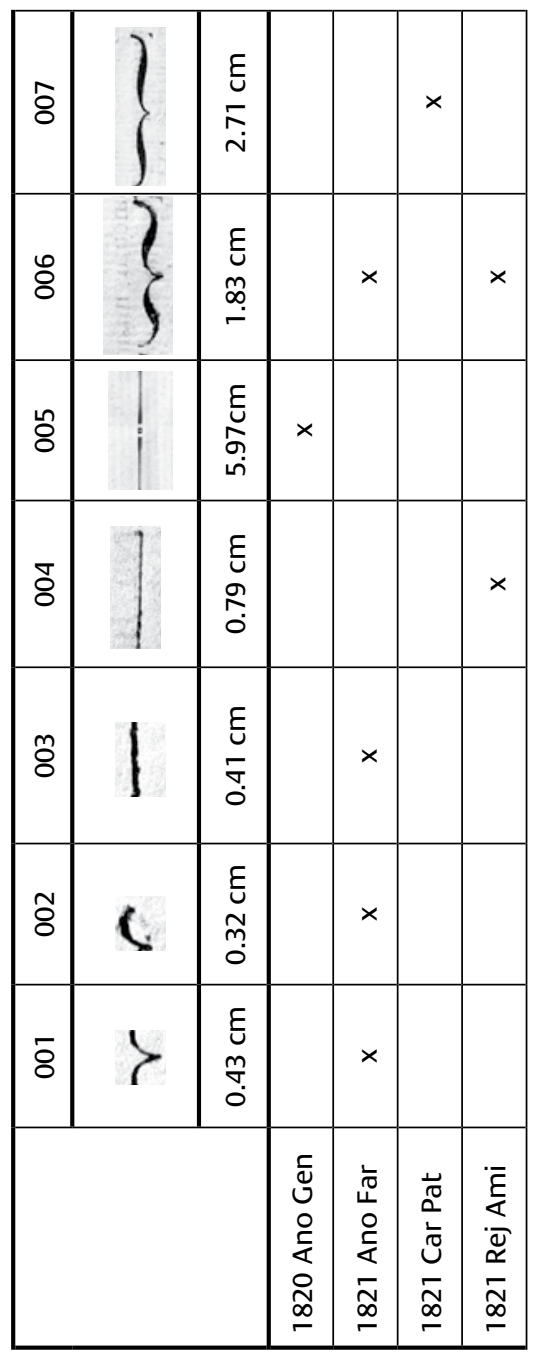




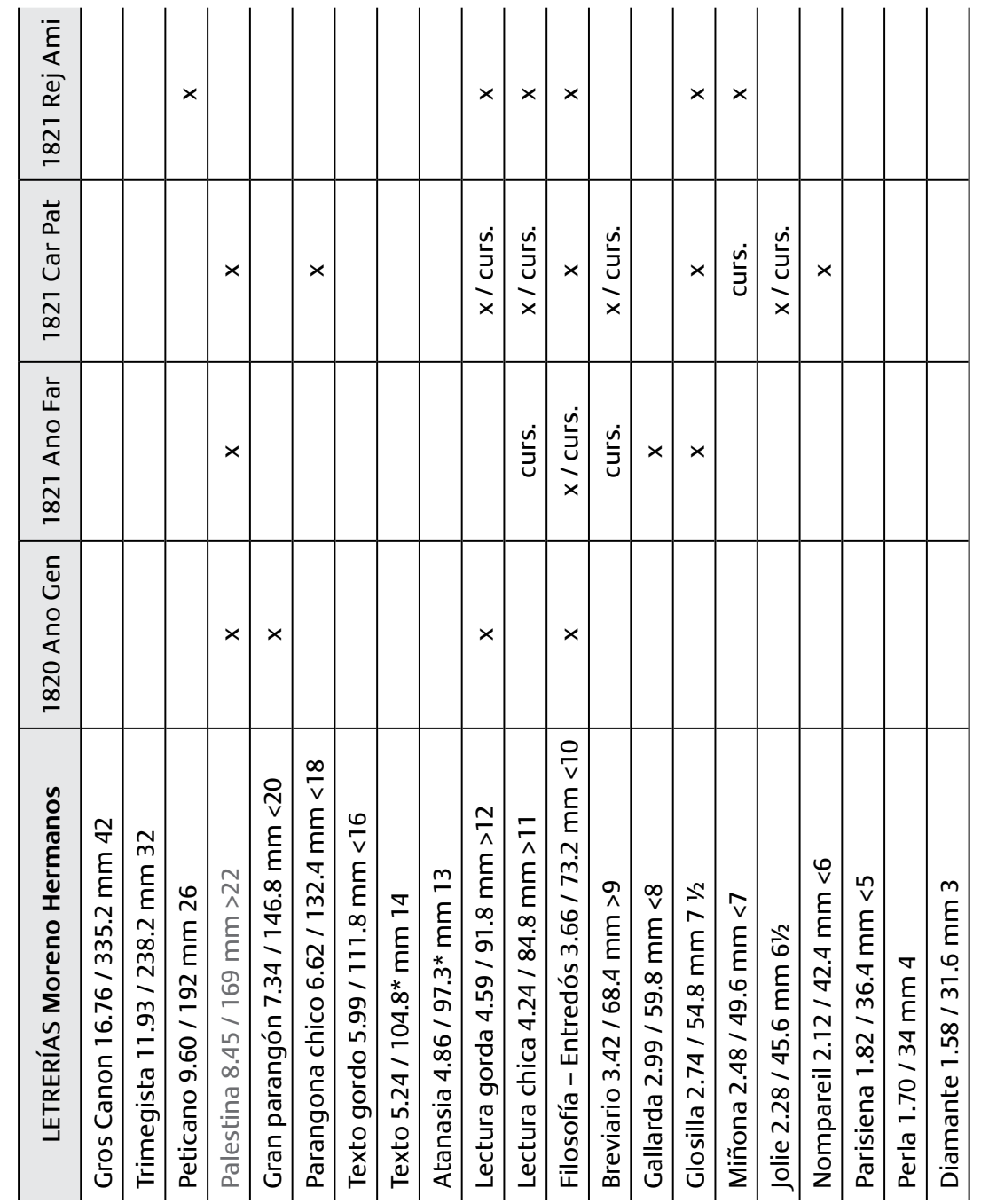


Imprenta Liberal Troncoso Hermanos Letrerías

Peticano

$9.60 / 192 \mathrm{~mm}$

$26 \mathrm{pts}$

1820 La abeja

1821 JNT Der

Palestina

$8.45 / 169 \mathrm{~mm}$

$22 \mathrm{pts}$

1821 Ano Tri

Gran parangón

7.34 / $146.8 \mathrm{~mm}$

20 pts

1821 Ano Tri

Parangona chico

6.62 / $132.4 \mathrm{~mm}$

18 pts

1821 Ano Viv

1821 Mor Poe

Texto gordo

$5.99 / 111.8 \mathrm{~mm}$

$16 \mathrm{pts}$

1821 Ano Viv

\section{Atanasia}

$4.86 / 97.3^{*} \mathrm{~mm}$

13 pts

1821 Ano Viv / Red.

1821 Mor Poe / Red.

1821 Ano Tri /

Red. Curs.
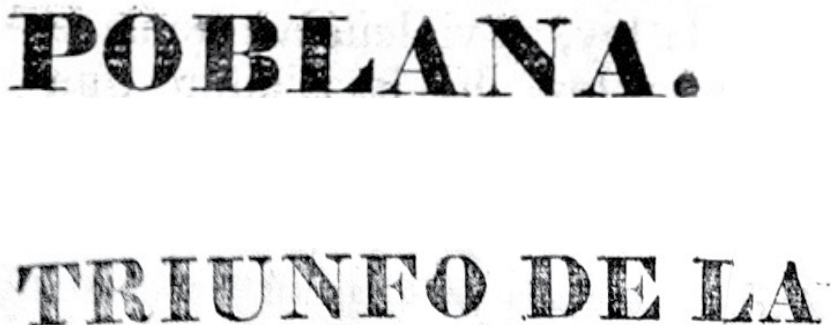

DE TA TIITENTA

VIVA HER GDANDD

\section{TOMO I}

Sc concluyò el Congreso de Tropam, y se cantò el Te-Deum celebrando de pontifical el Legado de su Santidad. Están convenidos los Soberanos, ó sus representantes en aprontar las sumas siguientes para la guerra . Rusia......16 millones de rulros. 


\section{Imprenta Liberal Troncoso Hermanos Letrerías} 4.59 / $91.8 \mathrm{~mm}$ 12 pts 1821 Ano Viv / Red. 1821 Ano Tri / Curs.

Lectura chica 4.24 / $84.8 \mathrm{~mm}$ $11 \mathrm{pts}$ 1821 Ano Viv / Red. / Curs.
Lectura gorda

La Ciudad de Puebla y sus Fue uarnecen en la nıañana del lunes y tropa saldrán con todos los ho y con mecha encendida, y se dirigir Egèrcito de las tres Garantias se transporte de los efectos de los c tropa. Los Oficiales cuyas familias prontitud de la salida de ella, poc que recesiten para disponer la su

Alcanse al indicador constitucional: Gazeta ministerial de Francia de de noviemzrc de 1820.

\section{IMPERIAL MEGICANO}

Debemos añadir para que no se nos culy $s$ que commenicamos, cuyas notas hemos pr Durango al mando del Sr. Mariscal de ado aun la Independencia; pero sin duda mado à aquellos. puntos una fugrza que o ten en todas partes, a que cedan al voto Reyno. La guarmicion de la espresada $\mathrm{C}$ tos hombres, que pronto ó entrarán por bligarán d obrar conforme d ella sino qui intereces y miras personales,

Filosofía - Entredós $3.66 / 73.2 \mathrm{~mm}$ $10 \mathrm{pts}$ 1820 Ano Nap 1821 Jnt Der
$\mathrm{O}$ no escribo comentarios, porque los àcontecios de mi vida son demasiado conocidos, y no obligacion de alimentar la curiosidad pública. ro de estos acontecimietos lo preciso, por que mi ter, $y$ mis intenciones pueden ser extraordinaria- 


\section{Imprenta Liberal Troncoso Hermanos Letrerías}

Breviario

3.42 / $68.4 \mathrm{~mm}$

9 pts

1821 Ano Viv / Red.

1821 Mor Poe / Curs.

\section{Gallarda}

$2.99 / 59.8 \mathrm{~mm}$

8 pts

1821 Ano Viv

1821 Mor Poe

Glosilla

2.74 / $54.8 \mathrm{~mm}$

7 pts

1820 Ano Vic

Miñona

$2.48 / 49.6 \mathrm{~mm}$

$71 / 2 \mathrm{pts}$

1821 Mor Poe

Jolie

$2.28 / 45.6 \mathrm{~mm}$

$61 / 2 \mathrm{pts}$

1821 Jnt Der

\section{Perla}

1.70 / $34 \mathrm{~mm}$

4 pts

1820 Ano Nap
Céfiro blando

Que ahora festiva

Las flores besas,

Rizas el rio,

Br. D. JOSE MARIA MORENO

IMPRENTA IIBERAT
Ermó. Sór. D. José Mariano del Consejo de Estado Sáa. 
Imprenta Liberal Troncoso Hermanos Ornamentos

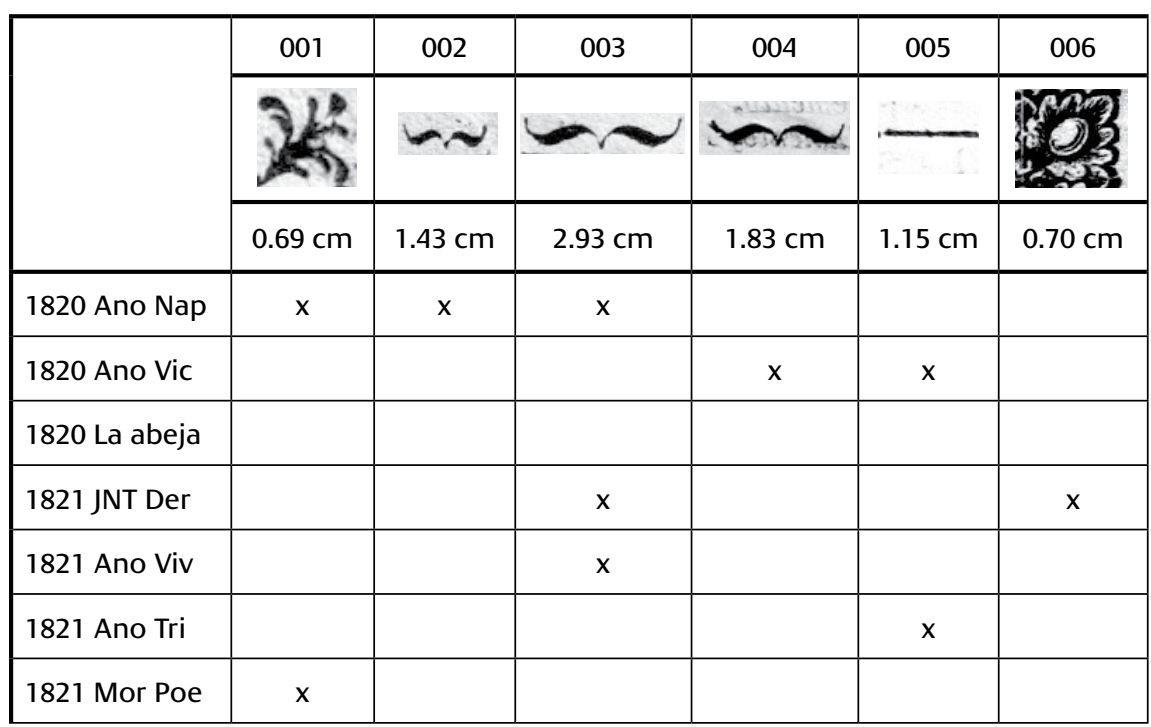


522 Marina Garone Gravier

Imprenta Liberal Troncoso Hermanos Grabados

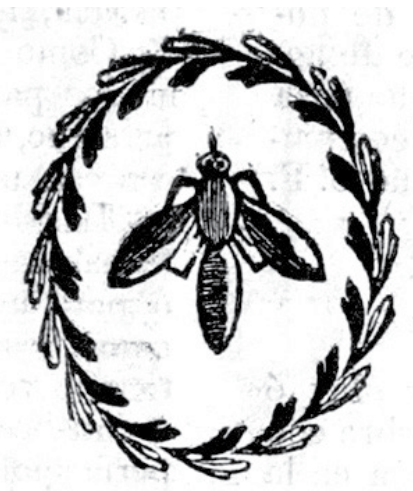

Abeja con corona de laurel Xilografía

$6.18 \mathrm{~cm}$

1820 La abeja 


\begin{tabular}{|c|c|c|c|c|c|c|c|c|c|c|c|c|c|c|c|c|c|c|c|c|}
\hline $\begin{array}{l}\searrow \\
0 \\
\overline{0} \\
\Sigma \\
\bar{\Sigma} \\
\infty \\
\infty\end{array}$ & & & & & & $x$ & & & $x$ & & & & & 彦 & $\times$ & & & & & \\
\hline 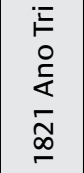 & & & & $\times$ & $\times$ & & & & $\times$ & $\times$ & & & & & & & & & & \\
\hline 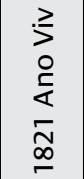 & & & & & & $\times$ & $\times$ & & $\times$ & $\begin{array}{c}\dot{\tilde{y}} \\
\bar{y} \\
x\end{array}$ & $\begin{array}{l}\dot{v} \\
\frac{\tilde{y}}{x} \\
x\end{array}$ & & $\times$ & $\stackrel{n}{\breve{u}}$ & & & & & & \\
\hline $\begin{array}{l}\bar{\Xi} \\
\underline{\Xi} \\
\underline{z} \\
\bar{\Xi} \\
\infty\end{array}$ & & & $\times$ & & $\times$ & $\times$ & & & $\dot{v}$ & & & $x$ & $\times$ & & $\breve{气}$ & $\begin{array}{l}n \\
\tilde{n}\end{array}$ & & & & \\
\hline $\begin{array}{l}\frac{\pi}{\pi} \\
\frac{0}{\pi} \\
0 \\
0 \\
0 \\
\infty \\
0\end{array}$ & & & $\times$ & & $\times$ & $\begin{array}{l}\dot{\omega} \\
\bar{J} \\
\dot{x} \\
\dot{x}\end{array}$ & & & & & & & & & & & & & & \\
\hline 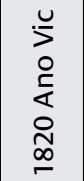 & & & & $\times$ & & & $\times$ & & $\frac{\breve{\Xi}}{\bar{y}}$ & & & & & & $\times$ & & & & & \\
\hline 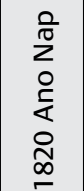 & & & & & & $x$ & & & & & $x$ & $x$ & $\stackrel{\omega}{\breve{u}}$ & 荇 & $\times$ & & & & $x$ & \\
\hline 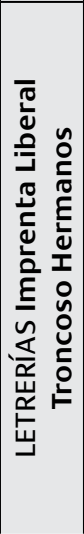 & 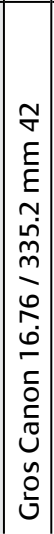 & 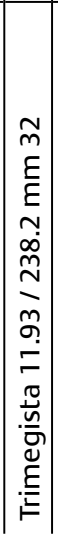 & 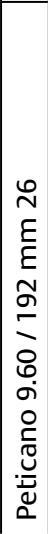 & 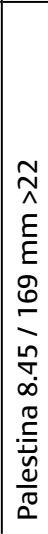 & 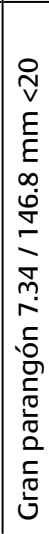 & 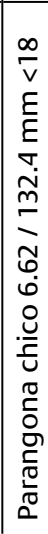 & 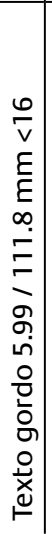 & 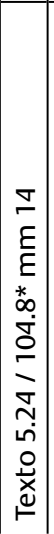 & 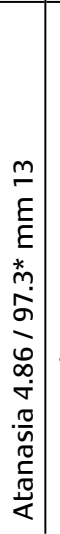 & 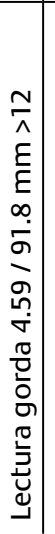 & 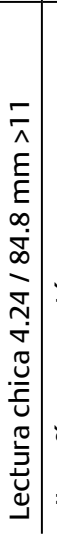 & 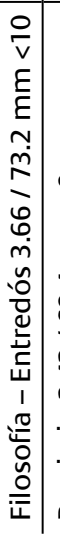 & 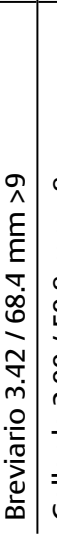 & 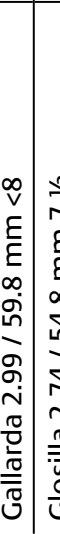 & 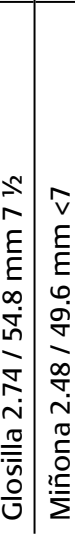 & 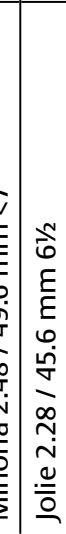 & 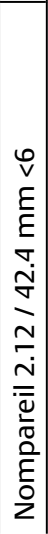 & 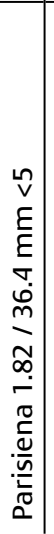 & $\begin{array}{c} \\
\sigma \\
\varepsilon \\
\varepsilon \\
\varepsilon \\
\bar{m} \\
\\
\frac{1}{-} \\
\frac{\sigma}{\bar{L}} \\
0\end{array}$ & 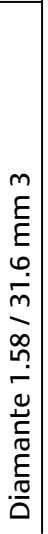 \\
\hline
\end{tabular}




\section{JOAQUÍN FURLONG MALPICA Y LA OFICINA DEL ORATORIO DE SAN FELIPE NERI}

Joaquín Furlong Malpica ${ }^{749}$ nació en la ciudad de Puebla el 28 de octubre de 1787; fue el sexto hijo de James Furlong, ${ }^{75^{\circ}}$ quien era natural de Belfast y militar a cargo de una compañía asignada al Regimiento Provisional de Dragones de Puebla, en el pueblo de Acazingo, ${ }^{751}$ y de Ana Malpica, criolla. Joaquín fue hermano de los que más tarde se convirtieron en militares de Puebla: generales Patricio y Cosme Furlong y Malpica, respectivamente; otros de sus hermanos fueron Tomás y Apolonio, quienes se dedicaron al sacerdocio. ${ }^{75}$

Sus primeros estudios los realizó en el Seminario de Puebla, luego se dedicó durante varios años al comercio y finalmente a la filosofía. Joaquín estudió Teología y, en i809, obtuvo un grado de bachiller en Artes por la Pontificia Universidad de México.753 Se dedicó al sacerdocio hasta 1813, año en que fue nombrado director del Oratorio de San Felipe Neri, y en 1816 ya era prepósito de esa institución. ${ }^{754}$

Aunque no precisa sus fuentes documentales ni da referencias de la procedencia de este dato, Moisés Pérez Guzmán indica que en 1818 Furlong viajó a Inglaterra y de regreso a México trajo consigo una imprenta, la cual ya funcionaba en julio de I819 con el nombre de "Imprenta del Oratorio de S. Felipe Neri".755 Sin embargo, es importante mencionar que hay al menos un dato que contradice la afirmación del investigador. En el expediente que se abrió por el litigio de los privilegios de impresión entre Furlong y los De la Rosa, ${ }^{756}$ el prepósito indica expresamente que trajo su imprenta de Madrid, y más precisamente que la letra procedía de la Imprenta Real

\footnotetext{
${ }^{749}$ Algunos datos familiares del religioso son proporcionados por J. Nidian. Los Furlong de la Puebla y de Mendoza, en México y Argentina. UNAM, Instituto de Investigaciones Históricas, en Biblioteca de Humanidades. Grupo tesis de historia 897 (NJ-56). Citado por Ramón Sánchez Flores. Puebla de los Ilustrados. Puebla: H. Ayuntamiento del Municipio de Puebla, 1994, p. I23 (Colección Crónica de Puebla, núm. 3). ${ }^{750}$ Moisés Guzmán Pérez dice que su padre se llamaba Diego, pero Ramón Sánchez Flores indica que su nombre era James. El militar se dedicó a la molienda de trigos y a la quincallería, es decir, a las actividades de metalurgia.

${ }^{755}$ Archivo General de Simancas, Guerra moderna, leg. 7005, exp. 5, fol. 287, Nombramiento de teniente expedido a don Vicente García Huesca, Aranjuez, mayo de 1798. Diego Furlong falleció a principios de noviembre de 1800 , según se deduce del testimonio de Félix Berenguer de Marquina, del día 27 de ese mes y año. AGSI Guerra moderna, leg. 6981, exp. 52, fol. 498.

${ }_{752}$ Sánchez Flores, op. cit., p. 123 .

${ }^{753}$ AGN, Universidad, vol. 170, f. I8gr. Citado por Guzmán Pérez.

${ }^{754}$ BNMex, clasificación LAF 125. En I8I8 publicó a sus expensas el Panegyrico de San Felipe Neri predicado en la iglesia de los Padres del Oratorio de la Puebla de los Ángeles el día 31 de mayo de $18 I 8$ por el ilustrísimo señor doctor Don Antonio Joaguín Pérez Martinez Obispo de esta diócesis del Consejo de S. M. Garriz, op. cit., t. I, p. 642, núm. 2864. 755 Guzmán Pérez, op. cit., p. rog.

${ }^{75} \mathrm{El}$ expediente es muy largo y lo transcribimos en los anexos documentales de esta obra, sin embargo, podemos decir que el litigio inició el i6 de marzo de i8ra y terminó, después de numerosas idas y vueltas, el 3r de marzo de i82o. En las declaraciones figura abundante información sobre la familia de impresores De la Rosa.
} 
Española. ${ }^{757}$ La letra entró por las costas de Campeche en $1818,{ }^{75^{8}}$ desde donde fue conducida a Puebla y establecida en la casa anexa a La Concordia, dedicada a los Santos Ejercicios, de allí que también se conociera a la imprenta del Oratorio con el nombre de "Imprenta de la Concordia". 759

Aparte del origen de las letras, lo cierto es que en su taller Furlong editó varios trabajos, entre los que destacan obras en latín, un catecismo en idioma mexicano, las obras selectas de Miguel Copín y una novela de Antonio Garcés. ${ }^{70}$ La imprenta tuvo una corta vida de dos años, ya que habiendo iniciado sus labores en r819, los últimos impresos a nombre de "Oficina del Oratorio de S. Felipe Neri" o "Imprenta de San Felipe" se publicaron en el año de I82o.

Pérez Guzmán señala también que "varios impresos salieron de esta misma Oficina [la de San Felipe Neri] con la razón social de 'Imprenta de Gobierno"', pero indica que "no se sabe si se refiere a impresos convenidos con la autoridad virreinal o bien con la Diputación Provisional que se había instalado" ${ }^{61}$

Con esta misma imprenta, a instancias de don Joaquín Furlong y con la colaboración de Monroy, el I2 de febrero de i82I quedaron impresos varios ejemplares del Plan de Iguala, junto con una proclama de Iturbide; además, el felipense mandó tinta y letras para que se pudiera imprimir en el campo insurgente. Estos acontecimientos fueron descritos por Carlos María de Bustamante, ${ }^{762}$ como transcribimos a continuación:

Carecía Iturbide de una imprenta para publicar su Plan, y en consecuencia, había enviado a la capital a su amigo don Miguel Cavalieri, subdelegado de Cuernavaca, con la instrucción de obtener los útiles necesarios al objeto. No pudiendo Cavalieri cumplir su encargo en México, no obstante sus diligentes esfuerzos, despachó á Puebla al Capitán Magán, dándole firma en blanco para comprar letra y prensas en aquella ciudad, y a cualquier precio. Este último comisionado se dirigió desde luego al impresor don Pedro de la Rosa, quien se negó a vender aquellos útiles; acudió en auxilio de Magán don Ignacio Alcone-

\footnotetext{
${ }^{757}$ José García Islas (Prepósito de la C. del Oratorio Puebla), en Documentos para la bistoria de los M.R.R.P.P. Prepósitos de esta Congregación..., Manuscrito publicado en parte en: Surge et Ambula, núm. 36, 1949, revista de la Apostólica Felipense, Puebla. Ejemplar consultado en la HNMex, clasificación: S257.

${ }_{75^{8}}$ Juan de Dios Pérez Galaz. La introducción de la imprenta en Campeche, Campeche, 1942.

759 Sánchez Flores, op. cit., p. Izo.

${ }^{760}$ En su bibliografía poblana Medina refiere los siguientes números para indicar la producción de la Oficina del Oratorio de San Felipe Neri: I677-1680, I682, I689-1699, I736, I744, I747, I750, I756, I766, I783, I797, I815, I829, I830 (en esta obra se expresa la ubicación del taller: "Imprenta de S. Felipe, calle de Herreros") y 1869 .

${ }^{761}$ Después de 1822 la imprenta conocida como "Imprenta del Gobierno Imperial" se ubicaba en la calle de los Herreros. Guzmán Pérez, op. cit., p. iıo; Garritz, op. cit., t. II, p. 653, 658, 569, 661,667; núm. 29i4, 2939, 2950 y 2975 .

${ }_{762}$ Carlos María de Bustamante. Cuadro Histórico de la Revolución Mexicana, edición facsimilar de la de 1843, prólogo de Roberto Moreno de los Arcos. México: Instituto Cultural Helénico / Fondo de Cultura Económica, 1985, t. v, p. 108 (Colección Clásicos de la Historia de México). Este documento también está citado por José Toribio Medina. La imprenta en Puebla..., p. XLI-XLII.
} 
do ${ }^{7{ }^{6}}$ hermano del platero del mismo apellido que fue pasado por armas en Apam el ig de Octubre de i8i4, y aquel celoso patriota lo puso en relación con el Presbítero don Joaquín Furlong, prepósito de la Concordia y dueño de una pequeña imprenta. Comunicado el secreto al cajista don Mariano Monroy, entre éste, el padre Furlong y el capitán Magán imprimieron el Plan que se llamó de Iguala y la proclama con que se publicó. ${ }^{76}$ Monroy y Magán, después de dejar prevenidas la letra y prensas que habían de enviar a Iturbide, marcharon a Iguala llevando los ejemplares que acababan de tirar; a su paso por Cholula comunicaron el objeto de su viaje al presbítero don José Manuel de Herrera... uniéndose Herrera a los dos comisionados y poco tiempo después empezó á publicar... El Mexicano Independiente, impreso con los útiles que fueron enviados de Puebla y que llegó a ser el órgano de la revolución acaudillada por Iturbide...

Del párrafo anterior se desprenden algunos nombres vinculados con las artes gráficas: Magán, ${ }^{765}$ Herreraa $^{766}$ y Monroy, de quienes nos detendremos sólo en el último. Suponemos que Mariano Monroy ${ }^{76}$ debió ser, además de impresor, fundidor de letra, a juzgar por la solicitud para ocupar la plaza de primer guardavista de Casa de Moneda u otro cargo administrativo, que encontramos en el Archivo General de la Nación, ${ }^{768}$ actividad que pudiera vincularlo con el manejo de metales.

En diciembre de 1824 el presidente de la república, Guadalupe Victoria, ordenó a Furlong la compra de la imprenta, pagándole la cantidad de 4500 pesos, de la misma manera que Iturbide lo había encargado sin resultado a Juan Nepomuceno Troncoso. El taller fue destinado en 1825 al estado de Occidente, conformado en ese entonces por las provincias de Sonora y Sinaloa. ${ }^{769}$ Ese mismo año el presbítero gestionó un pasaporte para viajar a Europa, documento que se encuentra en el Archivo General de la Nación. ${ }^{770}$ El 27 de febrero de i826, ante el notario poblano José Mariano Ortiz, José María Esteva, en representación de su hermano Ignacio que era Ministro de Hacienda, otorgó un poder general a Furlong. ${ }^{7{ }^{1}}$ El padre Joaquín murió en el convento de

\footnotetext{
${ }^{763}$ ¿Acaso pariente de los pintores?

${ }^{764}$ Pérez Salazar deduce: "Tales hechos nos demuestran, que este material, fue el que produjo los impresos de que se sirvió Iturbide para las proclamas y avisos que llevan el pie de 'Imprenta portátil del Ejército Trigarante', Pérez Salazar, op. cit., p. 360.

${ }^{765}$ Guzmán Pérez, op. cit., p. I45-I47.

${ }^{766}$ De este impresor hay en la Biblioteca Nacional un documento que, aunque está ubicado en la ciudad de México creemos que se trata de un impreso cholulteca: Agustín de Iturbide. Manifesto de S. $M$. el emperador. [México: José Manuel de Herrera, 1823]. Guzmán Pérez, op. cit., p. I2I-I24. Clasificación R 972.04108 MIS.L.

${ }^{767}$ Más datos curriculares ofrece Guzmán Pérez, op. cit., p. I62.

${ }^{768}$ AGN, Gobernación, Circular impresa del Ministerio de Relaciones Exteriores, Gobernación y Policía, vol. Io, exp. 48, año I82I, 39 fs.

${ }^{769}$ Héctor R. Olea. La imprenta y el periodismo en Sinaloa: 1826-1950. Sinaloa: Universidad Autónoma de Sinaloa / DIFOCUR, 1995, p. I8-I9 y, del mismo autor, La primera imprenta en las provincias de Sonora y Sinaloa. México: Gobierno del Estado de Sinaloa, 1943, 73 p.

${ }_{770}$ AGN, Pasaportes, vol. 2, exp. 188, año 1825, 40 fs., y AGN, Relaciones Exteriores, caja 36, exp. 204, in de abril de 1825 a ir de abril de 1828 , fs. $32-33$.

${ }^{771}$ AGNP, not. 4, caja 292, Protocolos de José Mariano Ortiz, 27 de febrero de i826, ff. 8If-82f.
} 
la Profesa de la ciudad de México el I4 de enero de 1852.772 En 1855, tres años después de su muerte, a solicitud del promotor de Hacienda se realizó una rectificación del cobro de su pensión testamentaria. ${ }^{773}$

\section{Resumen del material tipográfico de la Oficina del Oratorio de San Felipe Neri}

La oficina de los felipenses no tendrá capitulares y, al igual que las otras empresas contemporáneas, hará uso de iniciales de dos líneas. El oratorio tendrá i8 juegos de letrerías, desde peticano hasta diamante ( 26 a 3 puntos). Las letras son de corte neoclásico, aunque ya hay sutiles atisbos de cambio hacia el estilo moderno, el hecho de que sean cortes neoclásicos fortalece la idea del origen ibérico y no inglés del material de imprenta.

Los ornamentos tipográficos con los que contó el taller son pocos: además de crismones y asteriscos se usaron varios cuerpos distintos de cañas, dobles y triples. Hay en el escaso surtido de ornamentos un par de elementos vegetales y una pieza que, en composición de otras cuatro, compone un sol.

En los impresos del Oratorio que hay en custodia en la Biblioteca Nacional se usan pocas imágenes, las dos que localizamos son grabados calcográficos: un escudo de la orden dominica, un tanto adornado y grabado por Nava, y una imagen que se refiere a la comunión y alude a la Última Cena, grabada por Galicia en i8r9, con la inscripción latina: Si quis manducaverit ex boc pane vivet in aeternum S. Ju 6.52.774

\footnotetext{
${ }_{772}$ BNMex, clasificación LAF I25; Miquel, op. cit., p. 209.

${ }^{773}$ AGN, Justicia, Contenedor 108, vol. 532, exp. 208, año 1855, fs. 305- 310.

774 "El que comiere de este pan, vivirá para siempre" se refiere a la comunión, tomado de http://www.statveritas. com.ar/Doctrina/CatRom_04_ro.htm, consulta realizada el 29 de septiembre de 2011.
} 
Oficina del Oratorio San Felipe Neri Letrerías

Peticano

$9.60 / 192 \mathrm{~mm}$

26 pts.

1819 Ano Cla

Gran parangón 7.34 / $146.8 \mathrm{~mm}$ 20 pts

1819 Per Pan 2 Red. / Curs.
Parangona chico 6.62 / $132.4 \mathrm{~mm}$ $18 \mathrm{pts}$

$1819 \mathrm{lgl} \mathrm{Sum}$

\section{Texto gordo} $5.99 / 111.8 \mathrm{~mm}$ $16 \mathrm{pts}$ 1819 Per Pan Red. / Curs.

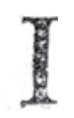

Para que te acuercies que solo Dios verdadero, á quis pedir te ayude para servirle

Traduccion de la explicacion las veintey guatro preguntas sobre los principales Mistei

$\mathrm{H}$

el plan de nuestra redencion s por una sabiduría voluptuosa, ine, podemos estar seguros de

Comunidad Religiosa de la Seráfica Santa CLARA, reconocida al singuor que V.E. le hizo autorizando 


\section{Oficina del Oratorio San Felipe Neri Letrerías}

Texto

5.24 / $104.8 \mathrm{~mm}$

$14 \mathrm{pts}$

1819 Per Pan 2

\section{Atanasia}

$4.86 / 97.3 \mathrm{~mm}$

13 pts

1819 Ano Cla

1819 Mor Col
Lectura gorda 4.59 / $91.8 \mathrm{~mm}$ 12 pts 1819 lgl Sum / Red. 1819 Per Pan / Red. 1819 Per Pan 2 / Red 1819 Mor Col / Curs.

Lectura chica $4.24 / 84.8 \mathrm{~mm}$ 11 pts 1819 Per Pan / Red. 1819 Mor Col / Curs.

Filosofía - Entredós $3.66 / 73.2 \mathrm{~mm}$ $10 \mathrm{pts}$ 1819 lgl Sum / Red. 1819 Mor Col / Red. 1819 Ano Cla / Curs.

\section{Breviario} 3.42 / $68.4 \mathrm{~mm}$ 9 pts 1819 Ano Cla $1819 \mathrm{lgl}$ Sum 1819 Mor Col 1819 Per Pan

\section{A LA GLORIOSA}

pobrecitos Indios por razon

is exigen de los Sacerdotes c ;en, el pasto espiritual de la abra, no en alimento sólido si en leche por expresiones las $n$ y comparaciones obias y $p$ 5: por pobres y muy ocupar

¿ se reduzca su instruccion á

\section{PANEGIRICO} Para la mejor instruccion
Indios, y de los que comien
dicho idioma.
Por un Sncerdote devoto de tisima de la Luz, bajo cuy $y$ á cura houra la

\section{NECESARIA.}

\section{CLARA X SUCINTA EXPOSICION}

hoy venir á mí $[a]$, ¡ó adorable So* para conquistar mi corazon, y esta4 Jestro Reyno. ¡O quan dichoso soy! uestras armas, disponed vuestro arco, iente contra vuestros enemigos que hasta ahora este corazon; $y$ deslos desalojaio, estableced en él para 


\section{Oficina del Oratorio San Felipe Neri Letrerías}

\section{Glosilla}

2.74 / $54.8 \mathrm{~mm}$

7 pts

1819 Ano Cla / Red.

1819 Mor Col / Red.

1819 Per Pan / Red.

1819 Per Pan 2 / Red.

$1819 \mathrm{lgl}$ Sum / Curs.

\section{Miñona}

2.48 / $49.6 \mathrm{~mm}$

$71 / 2$

1819 Mor Col / Curs.

1819 Per Pan 2 / Red.

Jolie

$2.28 / 45.6 \mathrm{~mm}$

$61 / 2$

1819 Mor Col

\section{Nompareil}

2.12 / $42.4 \mathrm{~mm}$

6 pts

1819 Ano Cla / Red.

1819 Per Pan / Red.

1819 Mor Col / Curs.
PUEBLA,

K 2

DEL ALTAR,

POR UN RELIGIOSO

MORENO ESTEPAR.

A LA COFRADia

1.82 / $36.4 \mathrm{~mm}$

5 pts

$1819 \mathrm{lgl}$ Sum

Red. / Curs.

1819 Per Pan / Red.

Perla

MPRESO EN, EL, IDIOMA MEXICANO

1.70 / 34 mm

4 pts

1819 lgl Sum / Red.

1819 Mor Col / Red.

1819 Ano Cla / Curs.

Diamante

PRIPARACION REMOTA,
CONSOLACION,

MARTINEZ

MARTINZ

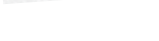

1.58 / $31.6 \mathrm{~mm}$

3 pts

1819 Mor Col 
Oficina del Oratorio San Felipe Neri Ornamentos

\begin{tabular}{|c|c|c|c|c|c|c|c|}
\hline$\overline{0}$ & ii & $\begin{array}{l}E \\
\vdots \\
\stackrel{2}{r} \\
\end{array}$ & & & & $x$ & \\
\hline$\frac{0}{0}$ & & $\begin{array}{l}\varepsilon \\
\tilde{z} \\
\tilde{o} \\
\dot{-}\end{array}$ & $x$ & & & & \\
\hline 8 & & $\begin{array}{l}\varepsilon \\
\tilde{\sigma} \\
\dot{\sigma} \\
r\end{array}$ & & & & & $\times$ \\
\hline$\stackrel{\infty}{8}$ & & 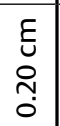 & & & & & $x$ \\
\hline$\overline{8}$ & $\Gamma$ & $\begin{array}{l}\varepsilon \\
\vdots \\
\\
0\end{array}$ & & & & & $\times$ \\
\hline$\stackrel{8}{8}$ & * & $\begin{array}{l}\varepsilon \\
E \\
\Sigma \\
\check{0}\end{array}$ & & & & & $\times$ \\
\hline 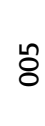 & जक & $\begin{array}{l}\varepsilon \\
5 \\
5 n \\
0\end{array}$ & & & & & $x$ \\
\hline ఫ̊ & $\begin{array}{l}\text { की } \\
\text { की }\end{array}$ & $\begin{array}{l}\varepsilon \\
\vdots \\
o \\
0 \\
0\end{array}$ & & & $x$ & & \\
\hline$\tilde{8}$ & 24 & $\begin{array}{l}\varepsilon \\
\tilde{m} \\
m \\
o\end{array}$ & & $x$ & & & \\
\hline \&ิ & is & $\begin{array}{l}\varepsilon \\
\tilde{0} \\
\stackrel{1}{0} \\
0\end{array}$ & & $\times$ & & & $\times$ \\
\hline$\overline{8}$ & शin & $\begin{array}{c}\varepsilon \\
\tilde{D} \\
\infty \\
m \\
o\end{array}$ & $x$ & & & $x$ & \\
\hline & & & $\begin{array}{l}\frac{\pi}{U} \\
0 \\
0 \\
\frac{1}{0} \\
\frac{0}{\infty} \\
\infty\end{array}$ & $\begin{array}{l}E \\
\bar{n} \\
\frac{\sigma}{\sigma} \\
\frac{\sigma}{\infty} \\
-\end{array}$ & $\begin{array}{l}\overline{0} \\
\overline{0} \\
\Sigma \\
o \\
\infty \\
\infty \\
\end{array}$ & 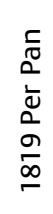 & 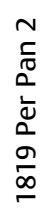 \\
\hline
\end{tabular}




\section{Oficina del Oratorio San Felipe Neri Grabados}

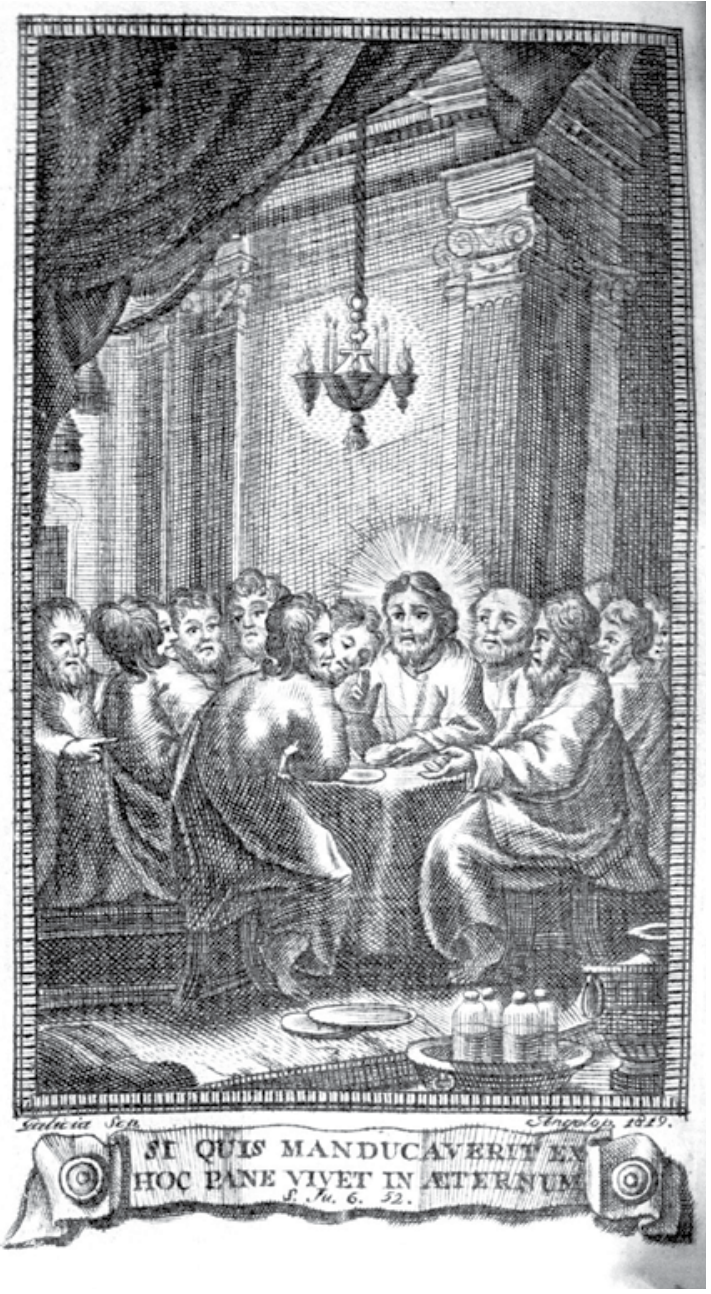

Lámina alegórica grabada en cobre de la Última Cena Inscripción: "Galicia Son. Angelop. 1819"; "SI QUIS MANDUCAVERIT EX HOC PANE VIVET IN AETERNUM. S. JU. 6. 52"

Calcografía

$12.69 \mathrm{~cm}$

1819 Mor Col 
Oficina del Oratorio San Felipe Neri Grabados

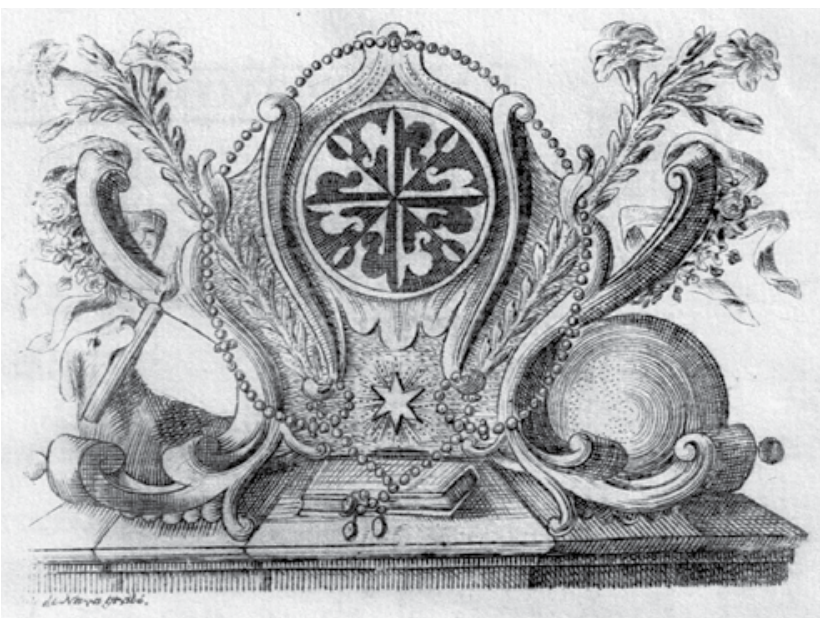

Escudo religioso de la Gloriosa Virgen Santa Catalina de Sena Inscripción: "de Nava grabó"

Calcografía

$6.18 \mathrm{~cm}$

1819 Per Pan 


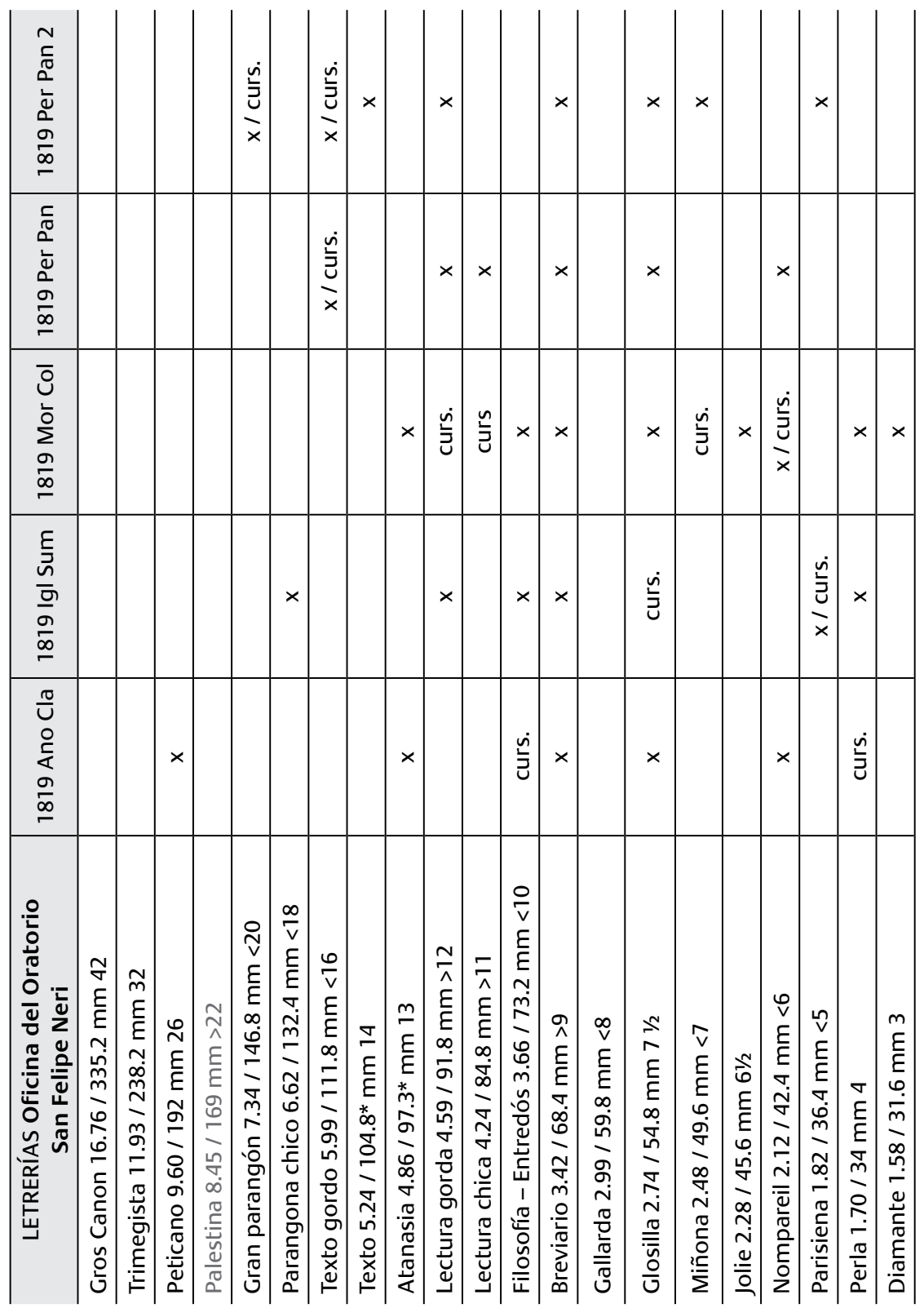




\section{LOS TALLERES POBLANOS EN EL CONTEXTO DE LAS IMPRENTAS TRIGARANTES (I820-I82I)}

El 9 de agosto de I82I los hermanos José María y Juan Nepomuceno Troncoso López Bueno publicaron en la ciudad de Puebla, con el pie de "Imprenta Liberal", un estado del movimiento del Ejército Trigarante iniciado por Agustín de Iturbide en el pueblo de Iguala, el 24 de febrero de ese año. ${ }^{775}$ En la difusión de esas ideas participó un grupo de impresores de diversas ciudades de México de los que no se sabe mucho, con excepción de Joaquín Furlong, Mariano Monroy ${ }^{776}$ y Victoriano Ortega, información dada a conocer por Carlos María de Bustamante, Lucas Alamán y Genaro García. ${ }^{777}$

Moisés Guzmán Pérez refiere que a los impresores y editores que apoyaron el movimiento trigarante, entre febrero y septiembre de I82I, se les puede organizar en tres grupos: I) Los militares, entre los que figuran Joaquín Arredondo, Rafael Escandón, Mariano Magán, Joaquín y Bernardo de Miramón Arriquivar, y Victoriano Ortega; 2) Los eclesiásticos, donde aparecen Joaquín Furlong Malpica, Juan Nepomuceno y José María Troncoso López Bueno, José María Moreno Buenvecino, José Manuel de Herrera Sánchez, José María Idiáquez Arrona y Manuel de la Torre Lloreda, y 3) Los civiles, entre los que están Pedro Garmendia Mosqueda, Mariano Monroy, Luis Arango Sotelo, José Joaquín Fernández de Lizardi, Rafael Núñez Moctezuma, una señorita de apellido Avilés, Mariano Rodríguez y Antonio José Valdés. En resumen, de ese grupo de impresores, seis tenían una formación castrense, siete eran eclesiásticos y nueve eran civiles con alguna experiencia en el trabajo tipográfico. ${ }^{77^{8}}$

En cuanto a la procedencia de estos impresores, con excepción de Manuel de la Torre Lloreda, natural de Pátzcuaro, Michoacán, y de la señorita Avilés, probablemente de México, la mayoría eran nativos de ciudades con una tradición tipográfica colonial: seis de ellos habían nacido en la intendencia de Puebla (Escandón, Furlong, Herrera, Magán, Monroy y Moreno); cinco en la ciudad de México (Arango, Fernández de Lizardi, los dos Miramón y Rivera); tres en Veracruz (Garmendia y los dos Troncoso); dos en Oaxaca (Idiáquez, 779 que era vecino de Antequera, y Núñez);

\footnotetext{
775 BNMex, Fondo Lafragua (BNM. LAF), 955. Triunfo de la Libertad Mejicana, o sea Resumen de los progresos de la Independencia de la Nueva España bajo el Plan que en los días I, 2 de Marzo del presente año de I82I proclamó y juró en Iguala el Sr. D. Agustín de Iturbide entonces Comandante General de las tropas del Sur, y hoy Primer Gefe del Ejército Imperial Mejicano de las Tres Garantías. Puebla: Imprenta Liberal de Troncoso Hermanos, 9 de agosto de 182I, 7 p. ${ }_{776}$ Guzmán Pérez, op. cit., p. 162.

777 Carlos María de Bustamante. Cuadro Histórico de la Revolución Mexicana...; Lucas Alamán. Historia de Méjico. Desde los primeros movimientos que prepararon su independencia en el año de 1808 hasta la época presente, ed. facsimilar de la de 1849, prólogo de Moisés González Navarro. México: Instituto Cultural Helénico / Fondo de Cultura Económica, 1985, t. v, p. 94 (Colección Clásicos de la Historia de México); Genaro García. Documentos Históricos Mexicanos, ed. facsimilar de la de igı. México: Comisión Nacional para las Celebraciones del 175 Aniversario de la Independencia Nacional y 75 Aniversario de la Revolución Mexicana, 1985, t. IV, p. I6-I7 del estudio introductorio.

${ }_{77^{8}}$ Moisés Guzmán Pérez,"Impresores, imprentas e impresos trigarantes en la Independencia de México, ı821", XIII Reunión de Historiadores de México, Estados Unidos y Canadá. México: El Colegio de México, 2ого (ed. electrónica), y Moisés Guzmán Pérez, op. cit.

779 El prepósito de la Congregación del Oratorio de Oaxaca, el bachiller José María Idiáquez, puso a
} 
uno en Guadalajara (Rodríguez) y otro en Matanzas, en la Capitanía General de Cuba (Valdés).

Los 22 impresores que estuvieron activos en ese periodo cuentan con diversos antecedentes profesionales, ya que había comandantes, sargentos y tenientes coroneles en activo ${ }^{780}$ y en retiro; ${ }^{78 \mathrm{r}}$ religiosos a cargo de congregaciones, curatos y sacristías de Oaxaca, Puebla y Michoacán. ${ }^{782}$ El resto eran civiles que tenían experiencia previa en el trabajo de imprenta. ${ }^{73}$

De acuerdo con Guzmán Pérez hubo ir imprentas al servicio del movimiento trigarante, ${ }^{784}$ de las cuales tres denominaciones eran poblanas: a) La "Imprenta del Ora-

disposición de Morelos la imprenta del Oratorio, que habían fundado hacia i8io en los anexos de la iglesia para enseñar oficios a los niños del Oratorio. Este taller fue denominado "Imprenta Nacional de Sur” y allí comenzó a imprimirse el Correo Americano del Sur, semanario que dirigió José Manuel Herrera y posteriormente don Carlos María Bustamante. El padre Idiáquez no sólo colaboró franqueando la imprenta oratoriana, sino que costeó la compra de nuevas fuentes tipográficas y él mismo las aumentó, fundiéndolas en los talleres de sus alumnos, para que las ramas de esta imprenta fuesen suficientes para transportarlas en prensas ambulantes. La noticia de la Imprenta del Oratorio de Oaxaca al servicio de los insurgentes es referida por Bustamante como decisiva para consolidar el prestigio de Morelos y la insurgencia, pues los periódicos impresos en Oaxaca circularon en Inglaterra, Francia y España. Tanto Bustamante como Alamán destacan el gesto de Idiáquez de entregar una imprenta a la lucha libertaria. En Sánchez Flores, op. cit., p. I28-I29. Para conocer más sobre la obra de este filipense oaxaqueño recomiendo la lectura del libro de Juan Pascoe: José María Idiáguez, impresor en el oratorio de la Congregación de San Felipe Neri de Oaxaca. Oaxaca: Fundación Alfrefo Harp Helú / UABjo / la Biblioteca Francisco de Burgoa, 2012. ${ }^{780}$ Arredondo, Escandón, Ortega y Bernardo Miramón.

${ }^{78 \mathrm{i}}$ Magán y Joaquín Miramón.

${ }^{782}$ Idiáquez: Oratorio de San Felipe Neri de Oaxaca, Furlong: Oratorio de San Felipe Neri de Puebla; Herrera: Parroquia de San Pedro Cholula; Troncoso: Provisor de la Diócesis de Puebla, y De la Torre Lloreda: Sacristía de Jacona.

${ }^{783}$ Arango, quien fue impresor del Despertador de Michoacán y el Sud, en Oaxaca; la señorita Avilés, que trabajó en la imprenta de Tlacotepec; Fernández de Lizardi, editor de El Pensador Mexicano, Alacena de Frioleras, Ratos Entretenidos o Miscelánea Util y Curiosa, El Conductor Eléctrico, en México; Garmendia, quien tuvo a su cargo la "Imprenta Liberal" de Puebla; Monroy, el cajista en la Imprenta del Oratorio de Puebla; Núñez, que intentó establecer una imprenta en Valladolid; Rivera tuvo imprenta en Tulancingo; Rodríguez, dueño de una imprenta en Guadalajara, y Valdés, que fuera director de El Censor, publicado en Buenos Aires en 1815 .

${ }^{784}$ La lista completa de imprentas es la siguiente: I) La "Imprenta del Egército Imperial de las Tres Garantías", que Luis Arango llevó de la ciudad de México a Valladolid a mediados de i82i y cuyo taller estuvo bajo la dirección del bachiller Manuel de la Torre Lloreda, amigo cercano a Iturbide; 2) La "Imprenta" que Joaquín Arredondo poseía en Monterrey, y que Xavier Mina había traído de Londres; 3) La "Imprenta del Oratorio de San Felipe Neri", que estaba en Puebla; 4) La "Imprenta del Egército de las Tres Garantías", que trajo Herrera de Nueva Orleáns y que tuvo a su cargo con la colaboración del capitán Magán y la señorita Avilés; 5) La "Imprenta Portátil del Ejército", que tenía a su servicio el mismo Iturbide y que uno de sus enviados sacó de la ciudad de México; 6) La "Imprenta de los ciudadanos militares D. Joaquín y D. Bernardo de Miramón”, que el primero había comprado en la ciudad de México desde octubre de 1820; 7) "Imprenta Liberal" de Moreno y Garmendia, que compraron a los Troncoso en 1821; 8) La "Imprenta Liberal de Troncoso Hermanos", con la que se publicó por primera vez el Plan de Iguala; 9) La imprenta de la "Oficina del Br. José María Ydiáquez" que, ubicada en Oaxaca, había servido al obispo Bergosa y Jordán en I8Io, a los insurgentes de Morelos de I8I2 a I8I4, a los realistas de Melchor Álvarez en 18i4 y a los trigarantes que comandaba Antonio León en julio de I82I; Io) La "Imprenta Liberal de las Tres Garantías", que Nicolás Bravo consiguió y puso bajo la dirección de Martín Rivera en Tulancingo, 
torio de San Felipe Neri", del padre Furlong Malpica; b) La "Imprenta Liberal", que Moreno y Garmendia compraron a los Troncoso en i82I, y c) La "Imprenta Liberal de Troncoso Hermanos".

Sin embargo, hay que señalar que otras de las imprentas que se adhirieron al movimiento fueron hijas de la letra poblana, por lo cual no es exagerado decir que las prensas angelopolitanas fueron el "caldo primigenio" de un nutrido grupo de imprentas mexicanas de la primera veintena del siglo XIX.

Entre las características físicas de las imprentas trigarantes se indica su transportabilidad, pero hubo otras - como la de Troncoso Hermanos de Puebla, la de José María Idiáquez de Oaxaca ${ }^{785}$ y la de Mariano Rodríguez de Guadalajara- ${ }^{786}$ que de manera fija funcionaban al interior de un establecimiento y contaban con todos los instrumentos necesarios del arte tipográfico.

Es poco lo que se sabe sobre la tecnología tipográfica de ese momento por fuentes directas, pero contamos con algunas imágenes que nos permiten conocer cómo eran los muebles de imprenta de ese periodo (ver imagen I).

Con la imprenta de los Troncoso, por ejemplo, se publicó el folleto: Triunfo de la Libertad de Imprenta, ${ }^{787}$ se reimprimieron algunos números del periódico El Mejicano Independiente y se dieron a conocer los Tratados celebrados en la villa de Córdova el 24 de agosto del presente entre los señores D. Juan O Donojú, teniente general de los ejércitos de España, y D. Agustin de Iturbide, primer Gefe del E. I. M. De las Tres Garantías, que fueron reimpresos en los números 3, 4 y 5 del Diario Político Militar Mejicano, del 3 al 5 de septiembre de 182I. ${ }^{78}$

Además de proclamas, panfletos y pliegos sueltos, y tras ponerse nuevamente en vigor la Constitución de Cádiz en Nueva España (1820), comenzó en Puebla la producción de periódicos políticos como El Farol, ${ }^{78}$ de tendencia monárquica. Al año siguiente, y después de la proclamación del Plan de Iguala, se produjo un segundo auge de prensa independiente: aparecieron entonces semanarios y diarios en distintos lugares de la Nueva España, entre los que destaca La Abeja Poblana.790

y iI) La "Imprenta de Rodríguez", que Mariano tenía en la ciudad de Guadalajara.

${ }^{785}$ José T. Medina. La imprenta en Oaxaca, I720-I820: notas bibliográficas. Santiago de Chile: Elzeviriana, 1904; s/A, La bistoria de la imprenta en Oaxaca [coord. editorial Verónica Loera Chávez], Oaxaca: Biblioteca Francisco de Burgoa / UABjo / 1999; José Toribio Medina. La imprenta en Oaxaca, Guadalajara, Veracruz, Mérida $y$ varios lugares, I720-I820. México: UNAM, IIB, Dirección General de Publicaciones, 1991; Francisco Ziga Espinosa. Adiciones a la imprenta en México de José Toribio Medina: Puebla, Oaxaca, Guadalajara, Veracruz y de la insurgencia, I706-I82I. México: UNAM, IIB, 1997. El estudio más reciente y específico sobre este impresor es el de Juan Pascoe. José María Idiáquez. Imprensor en el Oratorio de la Congregación de San Felipe Neri de Oaxaca (1807-1826). Oaxaca: Fundación Harp Helú, 2011.

${ }^{786}$ Carmen Castañeda. Imprenta, impresores y periódicos de Guadalajara, I793-18II. Guadalajara: Museo del Periodismo y las Artes Gráficas, Ágata, 1999, $190 \mathrm{p}$.

${ }^{787}$ José María Miquel i Vergés. La Independencia Mexicana y la Prensa Insurgente, ed. facsimilar de la de 1941. México: Comisión Nacional para las Celebraciones del 175 Aniversario de la Independencia Nacional y 75 Aniversario de la Revolución Mexicana, 1985, p. 33.

${ }^{788}$ Diario Político Militar Mejicano, t. I, núm. 3-5, 3 al 5 de septiembre de I821, p. 9-18, en García, Documentos, t. IV.

${ }^{789}$ HNMex, Fondo Reservado: clasificación 0.56 FAR.p.

${ }^{790}$ HNMex, Fondo Reservado: clasificación 320.972 ABE.p 


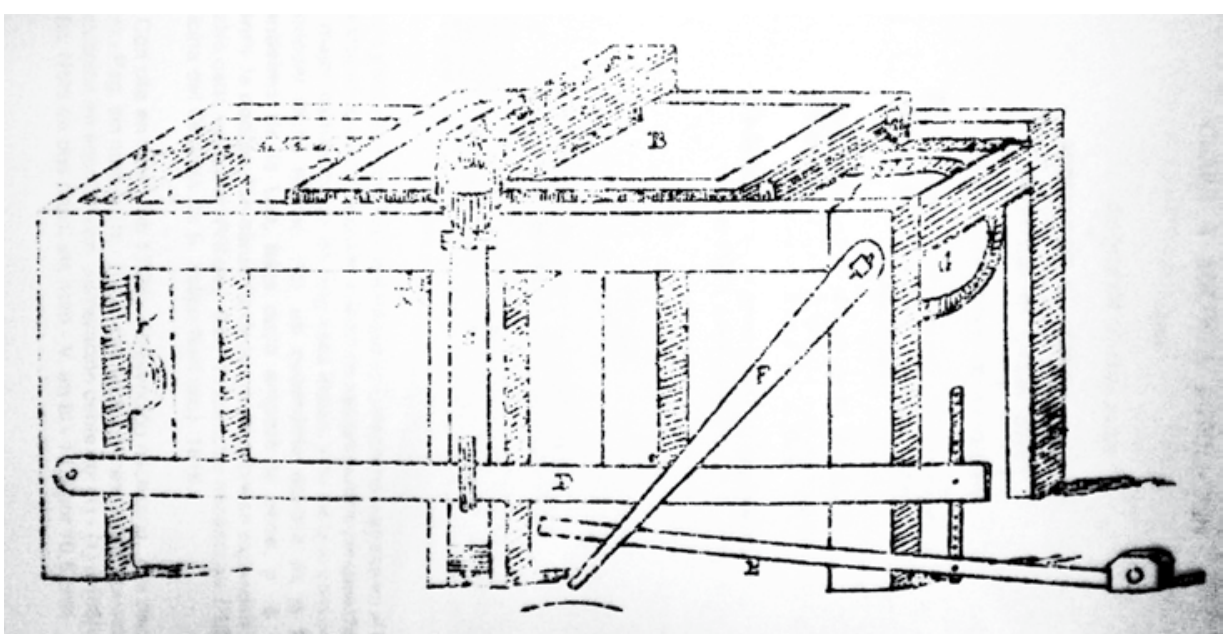

Imagen 1. Imprenta horizontal. Un modelo semejante al de la prensa insurgente, utilizada por el Ejército de las Tres Garantías (tomado de Ramón Sánchez Flores, 1994, p. 133).

De acuerdo con Lucina Moreno Valle, La Abeja Poblana fue un periódico de difusión de principios políticos, editado del 30 de noviembre de 1820 al 3r de diciembre de I82I por el presbítero Juan Nepomuceno Troncoso; el tomo I lo forman 52 números con 20 suplementos, y el tomo II solamente contiene 7 números. ${ }^{79 r}$ Sin duda, una característica fundamental de la prensa iturbidista de esta época es el corto periodo de duración de sus producciones, siendo La Abeja Poblana la más longeva de las publicaciones, ya que en su primera época apareció por primera vez en noviembre de I820 y estuvo en circulación II meses, hasta el ir de octubre de i82I en que dejó de salir. ${ }^{792}$

\footnotetext{
${ }^{791}$ Moreno Valle, op. cit., p. 7, núm. 4. BNMex, clasificación: LAF 4I6. La Abeja Poblana, Puebla, 24 de enero I5 de noviembre de r82I. Véase Garritz, op. cit., vol. II, p. 899, núm. 4176. De este periódico se registran únicamente los siguientes números: 15, 17, 20, 21, 23, 24, 26-33, 35-51 y los suplementos a los números 20, $23,24,38,39,4$ r y 42.

${ }^{792}$ Acerca de las imprentas a cargo de La Abeja, Francisco Pérez Salazar indica: "La Abeja Poblana, primer periódico que se imprimió en Puebla, y que empezó a salir de las prensas de la 'Imprenta Liberal', fecha su número prospecto el 9 de noviembre de $\mathrm{r} 820$, y en él, como es lógica costumbre, se expone el plan que se propone desarrollar el periódico, firmado por su director, don Juan Nepomuceno Troncoso. Con el mismo pie salen los trece primeros números; el número i4 y un suplemento al mismo, indican que se imprimieron en la 'Imprenta Liberal de don Pedro Garmendia'; del número i5 en adelante, hasta el número 38, que abarcan las fechas del 7 de marzo al i6 de agosto de $182 \mathrm{I}$, aparecen impresos en la 'Imprenta Liberal de Troncoso Hermanos', así como un suplemento a este último número; el siguiente 'Imprenta Liberal de Garmendia y Moreno', y desde un suplemento a este número, hasta el último de fecha 3 I de diciembre del mismo año, sigue autorizando la publicación la 'Imprenta Liberal de Moreno Hermanos'. En este último número se da el aviso de su clausura”. Pérez Salazar, op. cit., p. 36r.
} 


\section{JOSÉ MARÍA MACÍAS}

Para concluir con el recuento de denominaciones en los pies de imprenta poblanos hasta el año I82I, queremos mencionar que en la Biblioteca Nacional de México encontramos el nombre de "Macías", que posiblemente se refiere a José María Macías. La primera mención de su taller se encuentra en la Noticia interesante: de las personas que se distinguieron en Puebla durante la época de la guerra de independencia, [Puebla]: Imp. de Macías, 1821 ${ }^{793}$ y la última fue en la Ley que arregla la renta del papel sellado y los usos de éste, decretada en 14 de febrero de 1856.794 No hemos encontrado datos biográficos sobre este personaje. La de Macías es la última denominación editorial que encontramos en Puebla en el año i82I y, por tanto, con ella cerramos este recuento de la producción tipográfica angelopolitana del periodo de la imprenta manual.

793 BNMeX, clasificación: RLAF 395, descripción: [4] p.; $30 \mathrm{~cm}$.

${ }^{794}$ BNMex, clasificación: G 336.273097247 PUE.l, descripción: 20 p.; 18 cm. 


\section{CONCLUSIONES}

La historia de la tipografía en Puebla comienza en el siglo XVII como respuesta a las crecientes necesidades políticas, de comunicación y cohesión social. Dar a conocer y difundir una serie de textos de impacto y carácter eminentemente locales, presentar autonomía territorial respecto de las producciones impresas en la capital del virreinato y dar presencia pública a discursos políticos, religiosos y morales emanados mayoritaria pero no exclusivamente de la esfera local fueron tres de los pilares que activaron la cultura tipográfica angelopolitana y le dieron una presencia tangible en la dinámica editorial colonial. Por tanto, el contexto cultural, legal y tecnológico que permitió el establecimiento de la imprenta en Puebla se puede y se debe analizar de manera independiente al que permitió el establecimiento de este arte en la capital del virreinato y sin minusvalorar ni desatender las continuidades y similitudes en la producción de ambas ciudades. Esa mirada autónoma que proponemos tiene también que aplicarse al análisis de las características estéticas y a la naturaleza material de las letrerías, los grabados, los ornamentos tipográficos y las capitulares que encontramos en los libros y otros géneros editoriales salidos de las prensas angelopolitanas.

Si bien la lista de establecimientos tipográficos poblanos fue proporcionalmente menor a la que encontramos en la ciudad de México, ${ }^{795}$ el número de los talleres que funcionaron en Puebla -ya sea que hayan laborado como talleres únicos de la ciudad o de manera sincrónica con otros- y el volumen de títulos que produjeron, así como el aspecto visual de las ediciones que realizaron, permiten obtener una imagen general del "tamaño del mercado editorial", es decir, que los tres factores (talleres, número y calidad material de los impresos) nos permiten saber que existió el suficiente margen para el surgimiento de estas empresas culturales, sin temer a la competencia de los impresos de la ciudad de México.

\section{Tipografía y relaciones familiares}

$\mathrm{Al}$ igual que ocurrió en Europa prácticamente desde el inicio del arte tipográfico y en la ciudad de México desde el siglo XVI, las familias de impresores y el estrechamiento

\footnotetext{
795 La contabilidad de los pies de imprenta puede hacerse al menos de dos modos: tomando en consideración cada nombre diferente que aparece en los impresos, o advirtiendo las líneas familiares; en este segundo caso, y por obvias razones, vamos a tener un número más reducido de establecimientos.
} 
de las relaciones de parentesco entre estirpes de tipógrafos fue una de las características que podremos observar en la historia de la tipografía en Puebla. La primera de las familias que encontramos, aunque por breve tiempo, es sin lugar a dudas la de Borja y Gandia, compuesta por padre, madre e hijo. ${ }^{796} \mathrm{~A}$ finales del siglo XVII encontraremos otras dos líneas familiares: la de Fernández de León que, debido a la muerte del dueño, heredará el taller de manera transicional a su hijo y esposa; y la de Juan de Villarreal que, usufructuando el mismo taller que había sido de Fernández de León, pasará a sus herederos también por corto tiempo. En el siglo XVIII los lazos familiares se hacen especialmente evidentes en la casa de los Ortega y Bonilla, ya que de manos del padre, la oficina pasará a manos de la viuda, quien compartirá el negocio con dos de sus hijos - uno en México y otro en Puebla-. Es el hijo establecido en Puebla, Cristóbal, quien a su vez trasladará un privilegio de impresión de convites a una de sus hijas, que más tarde se desposará con Pedro de la Rosa, dándose de este modo la continuidad de una estirpe de impresores que arrancó en la primera década del siglo XVIII y seguirá hasta el final del periodo colonial, es decir, durante más de ioo años.

Sin embargo, es necesario advertir que las familias no fueron el seno exclusivo de la labor tipográfica poblana, pues desde el siglo XvII existieron instituciones que tuvieron imprenta. En este caso están el Colegio de San Luis y también el del Espíritu Santo de la Compañía de Jesús; en el siglo xviII, el taller del Colegio de San Ignacio, que tras la expulsión de los ignacianos se convertirá en la Imprenta del Colegio de San Pedro, San Juan y San Pantaleón, y finalmente se integrará al taller del Seminario Palafoxiano. Y antes de la independencia nacional, en r821, encontraremos otra imprenta institucional: la Oficina del Oratorio de San Felipe Neri.

\section{Los privilegios de impresión como fuerza motriz de la economía editorial colonial}

La gestión de los privilegios de impresión se hace evidente por primera vez en Puebla con la figura de Diego Fernández de León, quien promueve toda una renovación material y tipográfica del taller, para demostrar a las autoridades su solvencia y potencial profesional en la realización de actos y convites. A partir de él, el privilegio de impresión pasará, junto con el taller mismo, a manos de José Pérez, y de él a Miguel de Ortega y Bonilla. La importancia de esta concesión será tal que veremos llegar dicho privilegio hasta los hijos de Pedro de la Rosa, yerno de Miguel de Ortega, en el año i8rg. Asociado con este tema se aprecia un aumento de los géneros editoriales susceptibles de ser subastados, "privilegiados", ya que al primer permiso vinculado con la impresión de actos y convites se sumarán, en el siglo XVIII, los de impresión de cartillas y gramáticas. Al respecto, la documentación poblana es abundante y permite identificar que, de manera complementaria al dinero líquido que se daba para la obtención de dicho favor real, otra contraprestación fue la impresión de los documentos del gobierno. Lo que nos interesa señalar aquí es que en todos los casos las imprentas que detentaron algún tipo de privilegios consideraron necesaria la mejora en el aditamento de sus materiales tipográficos. Lo anterior arroja una primera explicación

\footnotetext{
${ }^{796}$ Como hemos mencionado, el primer ensayo sobre esta genealogía lo ha realizado Mercedes Salomón [2012] remitimos al lector a la bibliografía de esta obra.
} 
sobre cuáles eran las motivaciones para que un taller tipográfico decidiera mejorar su repertorio de letras.

El tema del privilegio nos permite, además, traer a colación que -al menos durante el siglo XVIII y en el caso de la familia Ortega y Bonilla- el privilegio de impresión estuvo vinculado al género, ya que la transferencia de este derecho se dio de mujeres a mujeres, fungiendo los hombres sólo como una figura testimonial, en lugar de ser ellos los propietarios del mismo.

\section{Los operarios de imprenta y el negocio editorial poblano}

Uno de los temas más oscuros de la historia de la tipografía antigua en general es identificar a los trabajadores: regentes, componedores y fundidores de los establecimientos, es decir, a todas aquellas "manos anónimas" que, sin ser dueños del negocio, hicieron posible la producción editorial durante el periodo de la imprenta manual. En el caso de Puebla, y a partir de varios de los documentos que surgieron en nuestra búsqueda, hemos localizado los nombres de varios trabajadores, algunos de los cuales aún no hemos logrado precisar en qué taller trabajaban; conocimos las condiciones laborales de los contratos que se establecieron para el aprendizaje del oficio de impresor y esclarecimos además las funciones, horarios y requerimientos que se pedían a los tipógrafos y entintadores en el siglo XVII. Para algunos momentos del periodo colonial hemos determinado cuánto se pagaba a los operarios, así como también ofrecimos datos financieros que, si bien no forman parte de largas series contables, nos permiten conocer las cotizaciones de trabajos de impresión y la forma en que se cobraba la producción de ciertas obras, dando indicios sobre el comportamiento económico y la rentabilidad del negocio editorial poblano.

\section{Los materiales tipográficos en las imprentas de Puebla}

\section{de los Angeles durante el periodo colonial}

El análisis detallado de los libros e impresos del Fondo Reservado y otras colecciones de la Biblioteca Nacional de México nos permitió conocer la naturaleza, surtido y características de los tipos de imprenta en Puebla. Con bastante precisión hemos podido observar, organizar y describir el repertorio tipográfico de 17 imprentas: seis del siglo XVII (Robledo, Borja y Gandia, Diego Fernández de León, Colegio de la Compañía de Jesús, Juan de Villarreal y Sebastián de Guevara y Ríos); siete del siglo XviII (José Pérez, Francisco Javier de Morales, familia de Ortega y Bonilla, Colegio de San Ignacio; Colegio de San Pedro, San Juan y San Pantaleón, Seminario Palafoxiano, y Pedro de la Rosa) y cuatro del siglo XIx (Oratorio de San Felipe Neri, Oficina Liberal, Oficina de Gobierno y la de Moreno Hermanos). Evidentemente, funcionaron algunas imprentas poblanas más durante el periodo colonial, que no hemos abordado en esta obra porque no están representadas en el acervo catalogado de la Biblioteca Nacional. Sin embargo no descartamos que, a medida que avance la revisión y catalogación de los fondos bibliográficos de ese acervo, puedan surgir algunos nuevos ejemplares de las imprentas que no analizamos en esta obra.

Por el trabajo realizado es posible ofrecer un acercamiento cuantitativo a los repertorios tipográficos de las imprentas poblanas, es decir presentar el surtido de letrerías y 
fuentes disponibles, el número y tipo de las series de capitulares, los diferentes diseños de ornamentos tipográficos y los grabados, tanto xilográficos como calcográficos. ${ }^{797}$ A continuación ofrecemos un resumen de las series de letras y de los promedios de los surtidos de material de imprenta, y damos unos primeros comentarios.

Cuadro 1. Resumen de las series de letras y de los promedios de los surtidos de material de imprenta.

\begin{tabular}{|c|c|c|c|c|c|c|c|}
\hline Imprenta & $\begin{array}{c}\text { Serie de } \\
\text { capitulares }\end{array}$ & $\begin{array}{l}\text { Series de } \\
\text { letrerías }\end{array}$ & $\begin{array}{c}\text { Rango de } \\
\text { tamaños } \\
\text { de letrerías }\end{array}$ & $\begin{array}{l}\text { Rango } \\
\text { mayor }\end{array}$ & $\begin{array}{l}\text { Rango } \\
\text { menor }\end{array}$ & $\begin{array}{l}\text { Ornamentos } \\
\text { de diferente } \\
\text { diseño }\end{array}$ & $\begin{array}{c}\text { Número } \\
\text { de } \\
\text { grabados }\end{array}$ \\
\hline Robledo & $2+4^{\star *}$ & 9 & $32-9$ & 32 & 9 & 5 & 4 \\
\hline Fam. Borja y Gandia & 6 & 13 & $42-7$ & 42 & 7 & 27 & $11^{*}$ \\
\hline Fernández de León & $5+23^{* *}$ & 21 & $42-3$ & 42 & 3 & 46 & $32^{*}$ \\
\hline $\begin{array}{l}\text { Colegio de la } \\
\text { Compañía }\end{array}$ & 1 & 4 & $16-10$ & 16 & 10 & 6 & $x$ \\
\hline Villarreal & 10 & 17 & $42-5$ & 42 & 5 & 32 & 18 \\
\hline Guevara & 5 & 11 & $24-9$ & 24 & 9 & 9 & $x$ \\
\hline Pérez & $2+2^{* *}$ & 13 & $32-8$ & 32 & 8 & 24 & 1 \\
\hline Morales & 5 & 16 & $52-8$ & 52 & 8 & 23 & 4 \\
\hline $\begin{array}{l}\text { Fam. Ortega } \\
\text { y Bonilla }\end{array}$ & 5 & 20 & $56-4$ & 56 & 4 & 62 & $32^{*}$ \\
\hline San Ignacio & 3 & 20 & $56-5$ & 56 & 5 & 12 & $9^{*}$ \\
\hline $\begin{array}{l}\text { San Pedro } \\
\text { y San Juan }\end{array}$ & 1 & 9 & $26-7$ & 26 & 7 & 2 & 1 \\
\hline $\begin{array}{l}\text { Seminario } \\
\text { Palafoxiano }\end{array}$ & 3 & 25 & $78-3$ & 78 & 3 & 25 & $21^{*}$ \\
\hline Pedro de la Rosa & 2 & 2 & $52-4$ & 52 & 4 & 79 & $14^{*}$ \\
\hline Oratorio San Felipe & $x$ & 17 & $26-3$ & 26 & 3 & 11 & $2^{*}$ \\
\hline Liberal & $x$ & 15 & $26-4$ & 26 & 4 & 6 & 1 \\
\hline Oficina de Gobierno & $x$ & 17 & $32-5$ & 32 & 5 & 21 & $x$ \\
\hline $\begin{array}{l}\text { Moreno / } \\
\text { Garmendia }\end{array}$ & $x$ & 13 & $26-6$ & 26 & 6 & 7 & $x$ \\
\hline Promedios & 4.7 & 15.3 & --- & 38.8 & 5.8 & 23.3 & 10 \\
\hline
\end{tabular}

(*): el asterisco indica qué imprentas contaron con grabados calcográficos

${ }^{(* *)}$ : La primera cifra indica las series y la segunda, los distintos diseños sueltos

Capitulares. De las I7 imprentas que hemos podido analizar, el promedio de series de capitulares de que dispusieron fue de ocho. Sin embargo, hay que hacer notar el excesivo número de series o variantes de letra que tiene la Imprenta de Fernández de León (55), algunas de las cuales hemos identificado en los impresos mexicanos del siglo XVI. Para evitar una distorsión en el promedio, sacamos del cálculo las 55 series

${ }^{797}$ La contabilidad de los grabados es relativa, ya que está directamente vinculada al número de libros analizados de cada taller, por lo cual se deberá tomar como un cálculo inicial. 
de este impresor, y de esa forma encontramos que el promedio de series de capitulares por imprenta poblana durante la Colonia es de cuatro. Las capitulares prácticamente "desaparecen" de las imprentas poblanas y mexicanas en el siglo XIX, y son reemplazadas por iniciales de dos líneas y también por letras de mayor peso, es decir, por las primeras "letras negritas".

Letrerías. El promedio de series de letras para texto en las imprentas poblanas es de I5 fuentes, siendo las dos imprentas con mayor número de fuentes las del Seminario Palafoxiano y las de Pedro de la Rosa, con 25 y 23 cada una, sólo antecediendo a las I8 fuentes que tuvo Fernández de León. El rango de tamaños en los cuerpos de las letrerías, bajo la escala de medición tipográfica contemporánea, va de 78 a 3 puntos, respectivamente. El promedio de cuerpos mayores en las imprentas fue de 38.8 puntos y el promedio menor de 5.8 puntos. Los cuerpos mayores se hacen presentes a partir de la segunda mitad del siglo XviII, al igual que los menores, con la única excepción de Fernández de León, que cuenta con un impresionante surtido de letrerías. La localización de los de cuerpos de letra extremos en la segunda mitad del xviII es indicio de que fue entonces cuando se estabilizó la oferta de series de cuerpos tipográficos completos, y cuando los impresores tuvieron la necesidad de contar con un amplio repertorio de tamaños.

Ornamentos. El promedio de ornamentos tipográficos por imprenta fue de 23.3; las imprentas mejor surtidas fueron las de Pedro de la Rosa (79 ornamentos), la de los Ortega y Bonilla (62) en el siglo xviII, y la de Fernández de León, con 46 ornamentos, en el siglo XVII.

Grabados. Respecto de los grabados, aunque la contabilidad que podemos ofrecer es parcial y está en relación directa con el número de ejemplares consultados en la Biblioteca Nacional de México, hemos encontrado que las imprentas con más grabados fueron, durante el siglo xVII, la de Fernández de León ( 32 grabados), y en el siglo XVIII las de Ortega (32) y el Seminario Palafoxiano (2I). No vamos a extendernos en este espacio sobre los aspectos estilísticos de las imágenes librescas poblanas, algunas de las cuales están firmadas (José Nava, Galicia, etc.), ya que esta parte del trabajo será abordada en un próximo libro dedicado al grabado libresco poblano.

Fundición de letra y matrices. En algunos de los pies de imprenta de los libros angelopolitanos y en varios documentos de archivo que hemos localizado se indica que los talleres realizaron labores de fundición tipográfica. Éste es un asunto que, al igual que el censo de prensas del periodo colonial, es difícil de aclarar; sin embargo, un apretado resumen de datos nos revela que en Puebla confluyeron y se sucedieron a través del tiempo cuatro tradiciones tipográficas. La primera que identificamos con claridad es la "plantiniana", también denominada "antuerpiana", denominación que encontramos en impresos de Fernández de León, Villarreal, Guevara y Miguel de Ortega y Bonilla, y que aparece explícitamente entre i692 y 1713, aunque no excluimos que poco antes o poco después de esas fechas se hubiera usado material flamenco. La segunda denominación que localizamos en la tercera década del siglo xviII fue la "castellana y latina", en el pie de imprenta de obras realizadas por Morales. La tercera tradición localizada fue la "parisina", en impresos del Seminario Palafoxiano, y la última denominación localizada fue la "matritense", en algunas obras de Pedro de 
la Rosa; estas últimas dos, a partir de la década de i770. Aunque en los impresos de la Oficina del Oratorio de San Felipe Neri no lo dice explícitamente, por el proceso entre Furlong y los De la Rosa sabemos que sus letras procedían de Madrid. Asimismo, aunque no hay mención en el pie de imprenta, lo que observamos en algunos impresos poblanos del siglo XIX es el inicio de un corrimiento del diseño de corte neoclásico al estilo moderno, con letras pesadas que podrían pertenecer a una tradición de didonas o bodonianas, o más seguramente a fundiciones anglosajonas (inglesas y/o norteamericanas); sin embargo, los indicios documentales para probar esto último aún son muy endebles. Los cambios en las denominaciones que acabamos de transcribir señalan no solamente la transformación en el gusto tipográfico a lo largo del periodo colonial, sino también los cambios en las rutas y circuitos de aprovisionamiento de letras de Europa a México, lo que de alguna forma es a la vez causa y consecuencia en el cambio de los gustos tipográficos.

Sin que hayamos realizado y sin que aún exista para la ciudad de México un trabajo similar al que aquí presentamos, si analizamos el comportamiento tipográfico y estilístico de los impresos de la capital del virreinato, es posible observar que hay una cierta consonancia entre ambas ciudades, por lo que a tradiciones tipográficas se refiere, salvo en el caso de la castellana y latina de Morales, y la parisina del Seminario Palafoxiano, denominaciones que solamente encontramos en Puebla. Lo anterior nos permite establecer la hipótesis de que, al menos en esos dos momentos, hubo circuitos diferenciados en el aprovisionamiento de material tipográfico para ambas ciudades, es decir, que existió una cierta autonomía del negocio tipográfico entre México y Puebla.

\section{Algunas líneas de investigación que se abren para el futuro}

Es evidente que, si bien en este trabajo se ha ofrecido un panorama de la historia de la imprenta y la tipografía poblana que a la fecha no teníamos, con una gran cantidad de documentos desconocidos y con un método de análisis que no se había ensayado para el estudio de una de las facetas más decisivas de la materialidad de los impresos antiguos, no se han respondido todas las preguntas que la cultura impresa angelopolitana plantea. Por el contrario, este libro propone y deja señalados nuevos temas, a la vez que sugiere líneas de investigación que deberán ser abordadas en el futuro. Aunque tal vez resulte obvia la aclaración, consideramos necesario decir que la organización de las series del material tipográfico que presentamos, así como las mediciones de las mismas, son susceptibles de ser ampliadas, revisadas y mejoradas, para lograr una mejor estabilización de la imagen de conjunto. Asimismo, en un futuro se puede integrar al repertorio ya clasificado, el material tipográfico de los impresos que no tienen pie de imprenta y, siguiendo las estrategias de identificación tipográfica que se usaron en la incunabulística, dar una primera atribución tentativa a los mismos, tomando como base principal los aspectos formales, visuales y estéticos, en relación con los libros aquí descritos y plenamente identificados en sus formas tipográficas.

Por otro lado, al haber establecido unas primeras relaciones formales de las corrientes estilísticas de la tipografía poblana con algunas de las tradiciones europeas 
más relevantes (flamenca, española, francesa), en trabajos futuros se podrán vincular los impresos del Viejo Continente con los impresos americanos, es decir, que en materia de estética tipográfica y editorial se podrán trabajar de forma conjunta dos ámbitos bibliográficos geográficamente diferenciados, con el objetivo de establecer análisis comparativos más precisos e identificar las continuidades y rupturas en los aspectos materiales entre el libro antiguo americano y el europeo. Afortunadamente la historia y conformación de nuestros acervos locales, en especial el de la Biblioteca Nacional de México, permite llevar a cabo esta tarea bajo una perspectiva de tipografía comparada.

La labor realizada en eśta obra posibilitará además adentrarnos en la descripción pormenorizada de los aspectos formales del diseño del libro antiguo poblano, es decir, pasar del análisis microestructural que hemos hecho de la tipografía a uno de naturaleza macroestructural, tomando en consideración los formatos y las secciones informativas, la puesta en página y la distribución espacial de los diversos objetos del aparato tipo-iconográfico de las distintas ediciones y géneros impresos angelopolitanos. Sobre el estudio del diseño editorial colonial ya hemos hecho aportaciones en cuanto a las ediciones en lenguas indígenas, $79^{98} \mathrm{y}$ para el caso poblano nos hemos inmerso en el análisis de 170 portadas de los ejemplares de la Biblioteca Nacional de México. 799

Los modelos de análisis y propuestas de catalogación y organización del material de imprenta que aplicamos para el caso poblano se pueden emplear también para estudiar las producciones bibliográficas de otras ciudades, tanto de México como del extranjero, toda vez que el nuestro no es un modelo cerrado, sino que permite la incorporación de nuevos objetos tipográficos. Asimismo, el modelo podrá aplicarse y usarse en el estudio de los impresos de otros acervos y bibliotecas. De esta manera, si se emprendieran las tareas de forma sistemática en otros acervos, se daría una mayor nitidez en la representación de los materiales de imprenta de Puebla y, por extensión, de una parte importante de la historia de la imprenta mexicana y americana. El reconocimiento e identificación precisos de nuevos objetos tipográficos (capitulares, letrerías, ornamentos y viñetas) no sería una tarea aislada, sino que se les pondría en relación con los objetos bibliográficos que hoy forman parte de nuestro patrimonio documental, enriqueciendo las catalogaciones que tenemos.

Además del material tipográfico en sí, y aunque parezca obvia la precisión, en los talleres las prensas eran muebles imprescindibles para la elaboración de los libros y otros productos editoriales. Aunque no es posible establecer con absoluta certeza el número de los muebles que hubo en Puebla durante el periodo colonial, ofrecemos la siguiente contabilidad, que deberá tomarse sólo como una estimación tentativa:

\footnotetext{
${ }^{798}$ Remitimos al lector a nuestros trabajos citados en la bibliografía de esta obra.

${ }^{799}$ Ver el ensayo de mi autoría: "Las portadas de las ediciones coloniales poblanas de la Biblioteca Nacional de México. Elementos informativos, diseño y periodización", en Garone Gravier (comp.). Miradas a la cultura del libro en Puebla. Consejo Estatal para la Cultura y las Artes / Ediciones de Educación y Cultura / UNAM, IIB, $20 \mathrm{I2}$.
} 


\section{Siglo XVII: cuatro prensas}

a. La de Juan Blanco de Alcázar, y que tras su muerte pasó al Colegio de San Luis. Después de San Luis no sabemos con precisión adónde pudo haber ido a parar, aunque creemos que pudo haber salido rumbo a Guatemala.

b. La de Juan de Borja, que pasó a Diego Fernández de León, más tarde a los Villarreal, a Guevara, nuevamente a Fernández de León, su viuda, y de ella a Pérez, quien finalmente la vendió a Ortega.

c. Una más que compró Fernández de León en la ciudad de México, y que Miguel de Ortega adquirió e hizo llevar a Puebla.

d. Miguel de Ortega tuvo dos prensas (la que compró a Pérez y que era de Fernández de León, e hizo conducir de México a Puebla), a la que su viuda Manuela Cerezo le sumó una más, obtenida de los Herederos de Guillena y Carrascoso que compró en México, tuvo trabajando en aquella ciudad a manos de su hijo y más tarde debe haber conducido a Puebla.

Es importante mencionar que en 1706 Fernández de León puso taller en Oaxaca y posiblemente ese taller, con prensa incluida, permaneció en Antequera y con largos periodos de aparente inactividad (tal vez los tórculos se destinaron principalmente a la producción efímera de convites) tuvo una primera reactivación en 1720 y una segunda, a finales del siglo XVIII. ${ }^{800}$

Siglo XVIII: tres prensas que venían del siglo anterior, a las cuales se sumó con seguridad una más, o posiblemente dos.

e. De las imprentas familiares, las que siguieron vigentes fueron las de la familia Ortega que pasó a los De la Rosa (tres prensas a las que tal vez Pedro de la Rosa sumara una más, aunque no tenemos plena evidencia del hecho y sólo lo deducimos por el denodado esfuerzo que hizo por renovar su repertorio de letras entre las décadas I770-I780).

f. De las imprentas institucionales es posible rastrear el tránsito de un mismo mueble que inicia en el taller jesuita del Colegio de San Ignacio, sigue en el del Colegio de San Pedro, San Juan y San Pantaleón, y de allí termina en la Oficina del Seminario Palafoxiano, aunque no sabemos adónde fue a dar ese objeto.

Siglo XIX: a las cuatro prensas que venían del siglo XVIII se sumó con seguridad al menos una más, o posiblemente dos. De los talleres establecidos en esa época, del único que tenemos referencia clara es del de la Oficina del Oratorio de San Felipe Neri, que según el expediente de Furlong vs. De la Rosa provino de la Imprenta Real Española, aunque no nos queda claro si en ese caso por "imprenta" sólo se refiriera a la letra o también al mueble de la prensa. Finalmente, no sabemos de dónde sacaron el mueble los Troncoso y Garmendia. En este periodo se ha hablado abundantemente

\footnotetext{
${ }^{800}$ Sobre este asunto ver las obras de José Toribio Medina, Verónica Loera Chávez y Juan Pascoe, que citamos entre las fuentes de consulta de esta investigación.
} 
sobre las prensas portátiles, pero no sabemos con claridad cuántos de estos muebles transportables existieron.

Para terminar esta obra es preciso indicar que, además de las anteriormente descritas, al haber empleado en esta investigación un acercamiento diacrónico y de larga duración y en contacto directo con los libros antiguos, otra de las aportaciones del trabajo ha sido identificar los grandes momentos de la estética del libro y la tipografía colonial poblana. El método que usamos convierte a esta obra en un trabajo pionero no sólo para el estudio material del libro antiguo mexicano, sino también para el estudio del libro latinoamericano, pues es la primera vez que se ensaya una mirada panorámica y descriptiva a la materialidad del libro antiguo americano a partir de un conjunto amplio y diverso de fuentes bibliográficas y documentales. Esperamos haber alentado a los interesados en los estudios del libro a sumar a la usual forma de historiar de raigambre teórica, y casi exclusivamente documentalista, la necesaria e impostergable mirada estética, material, tecnológica y comercial, ya que creemos que sólo de esta forma se podrá avanzar positivamente en el conocimiento y cuidado que nuestro patrimonio bibliográfico merece. 


\section{FUENTES DOCUMENTALES Y ESTUDIOS CONSULTADOS}

\section{ABREVIATURAS DE ARCHIVOS Y BIBLIOTECAS}

AASC: Archivo de la Academia de San Carlos

ACCP: Actas del Archivo Catedralicio de Puebla

AHNE: Archivo Histórico Nacional de España

Asedena: Archivo de la Secretaría de la Defensa Nacional

AGMP: Archivo General Municipal de Puebla (del Ayuntamiento)

AGI: Archivo General de Indias

AGN: Archivo General de la Nación

AGNM: Archivo General de Notarías de la ciudad de México

AGNP: Archivo General de Notarías de Puebla

ASMP: Archivo del Sagrario Metropolitano de Puebla

BNMex: Biblioteca Nacional de México

HNMex: Hemeroteca Nacional de México

\section{FUENTES PRIMARIAS}

Archivo Histórico Nacional de España

Archivo de la Academia de San Carlos

Hemeroteca Nacional de México, Fondo Reservado

Archivos poblanos

Inventarios de Bibliotecas, Biblioteca Lafragua, Puebla

Archivo General de la Nación

Archivo General de Notarías de la ciudad de México

\section{FUENTES SECUNDARIAS}

Artículos y capítulos de libros

Bibliografía

Recursos digitales y sitios electrónicos 


\title{
FUENTES PRIMARIAS
}

\section{Archivo Histórico Nacional de España}

Archivo Histórico Nacional de España: Diversos-colecciones 25, N. 56.

\section{Archivo de la Academia de San Carlos}

Documento I6o del Archivo de la Academia de San Carlos, Facultad de Arquitectura de la UNAM.

\author{
Hemeroteca Nacional de México, Fondo Reservado \\ Abeja Poblana (1820-182I) \\ Busca-Pies (182I) \\ Diario Político Militar Mejicano (182I) \\ Ejército Imperial Mejicano de las Tres Garantías (1821) \\ El Hispano-Americano Constitucional. Periódico filosófico de Mérida, Tucatán (1820) \\ El Mejicano Independiente (182I) \\ El Mosquito de Tulancingo (182I) \\ Gaceta del Gobierno de Guadalajara (I82I)
}

\section{Archivos poblanos}

Archivo General de Notarías de Puebla. Relación de notarías y cajas revisadas ${ }^{80 r}$

Not. I: caja I3 (I718-1725).

Not. 2: cajas 23, 42, 43 .

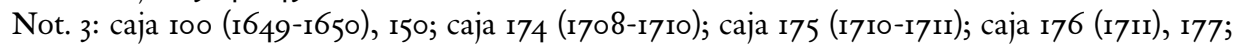
caja I78 (I703-1717); caja I77 (I713); cajas I79, 180, I8I, 205, 215, 216.

Not. $4:^{: 02}$ caja I77; caja 244 (I706-I707); caja 245 (I708-I709); caja 246 (I710-I7I4) y caja 247 (I7I7-I7I9); caja 248 (I8I8); caja 249 (I720-I723); caja 250 (I723-I724); caja 270 (I743-I744); caja, 26I, caja 280; cajas 288, 289290 (fechas consultadas, I800-I82I), 292; cajas 288 y 287 (fechas consultadas, I800-1804); cajas 290, 291, 292 (fechas consultadas, 1803-1832).

Not. 5: caja 2I.

Not. 6: caja 5I ( I710 ); cajas 60, 9I, 92, 93, 95, 98.

I758-I76I ACCP, folletos del estante 7, (AC). Libros 32/33 y 33/34 (fechas consultadas 1758-176I, los libros tienen doble numeración).

ASMP, Archivo del Sagrario Metropolitano de Puebla, libro de matrimonios, número 29 y 30.

I548-I553, AGMP. Libro número 6 de Cabildos de la Niña ciudad de Puebla. 1548-1553. No se terminó. Diciembre, 2010.

ı606-ı6ı2, AGMP. Libro número I4 de Cabildos de la Niña ciudad de Puebla. I6o6-ı6ı2. [Al margen izquierdo. Posturas de papel blanco. Que este dia estando en el portal de la audiencia ordinaria presente se pregono este acuerdo y postura fija en el papel por los pregoneros y de ello doi fe. Nicolas de la Fuente.] Este dia se acordó que el papel que manifiesta

\footnotetext{
${ }^{801}$ Buscando el testamento de Manuela Cerezo que menciona Pérez de Salazar (fechado en I723) se revisaron las notarías i a 6, que son las únicas que existieron en Puebla durante el periodo novohispano. En ninguna de ellas aparece el notario Pedro Ibáñez Cabellos que indica Pérez de Salazar. El notario sólo aparece en la notaría 4, aunque el documento testamentario no figura en ese expediente. El testamento de Miguel de Ortega y Bonilla se buscó en la notaría 3 desde I708 a I7I 4 .

${ }^{802}$ En el libro Las calles de Puebla... se cita esta notaría para los impresores de Puebla.
} 
ante (no se lee) de maior de esta ciudad se venda y se ponga en las tiendas de Geronimo Riqueño y Ygnacio de Cueto y en ella se venda y no en otra parte y no puedan vender lo mas de tres reales la mano que es el precio mandado por su excelencia de el Virrey lo mando vender en la ciudad de Mexico y se pregono para estas posturas y que el repartimiento se haga vendiéndolo a manos de por cien, tres o seis de esta ciudad y no junto y que no se exceda de caxa por una sola pena de ella. Ordenanza y que los dichos Geronimo Riquerio Ygnacio de Cueto acudan con el procedido del dicho papel a sus dueños.

I6ı3-1620, AGMP, Libro número I5 de Cabildos de la Niña ciudad de Puebla. I613-ı620. En este volumen no encontré nada.

I62I-1807, AGMP, exp. 224, visitas a obrajes y talleres. I62I-I807.

I636, 26-III, ACCP, AC, L. Io, f. IIov, 26 de marzo de i6 36 . Murió el señor tesorero Doctor Don Luis de Monçon, miércoles a las 6 de la mañana que se contaron 26 de marco de ${ }_{1} 6{ }_{3} 6$ años hasta el fin de la ora de maitines y se enterro en esta Cathedral. Por los señores dean y cavildo y el jueves 27 del dicho mes se le canto la misa. Por haver sido el entierro y vigilia el dia miércoles en que murió después de maitines.

I636, 28-VI, AGNP, not. 3, caja 79, Protocolos de Juan Guerra, recibo que otorgaron al bachiller Juan Blanco de Alcazar y a su mujer Luisa de Monçon a favor de Antonio Ximenes albacea testamentario del Dr. Luis de Monçon difunto, 28 de junio de i6 6 6, ff. I430f-I430v. En la ciudad de los Angeles compareció el Bachiller Joan Blanco de Alcazar y Doña Luisa de Monçon su mujer y otorgaron recibo a Antonio Ximenes albacea testamentario del Doctor don Luys de Monçon difunto por 600 pesos de oro común, que se les dio de contado por la clausula de un codicilio. Fueron testigos Joseph Vazquez y Antonio Cristobal vecinos de la ciudad.

I636, 28-VI, AGNP, not. 3, caja 79, Protocolos de Juan Guerra, recibo que otorgaron al bachiller Juan Blanco de Alcazar y a su mujer Luisa de Monçon a favor de Antonio Ximenes albacea testamentario del Dr. Luis de Monçon difunto, 28 de junio de I6 36 , ff. I430f-I $430 v$. I642, 30-I, AGNP, not. 3, Protocolos de Juan Guerra, año de I642, ff. I29r.-I29v. Carta de aprendizaje del oficio de impresor de Manuel de los Olivos con el bachiller Joan Blanco de Alcázar.

I642, 8-XI, AGNP, not. 3, Protocolos de Juan Guerra, año de I642, ff. I463-I465r. Poder especial otorgado por las hermanas Monzón a favor del Bachiller Juan Blanco de Alcázar.

I649, I6-XI, ACCP, AC, L. I2, f. 216v, I6 de noviembre de i649. En lo que pide Juan Blanco de Alcasar sobre que lo que se debe al general tesorero Don Luis de Monzon, cuyo derecho repite como heredero de Doña Aldonza de Monzon. En ajustándose las quentas se reconocerá para prover lo que convenga para satisfacer.

I649, 27-VII, AGNP, not. 3, caja IoI, Protocolos de Nicolás López Gallegos, 27 de julio de I649, Testamento de Juan de Borja, f. $5 \mathrm{~s} / \mathrm{n}$.

I649, 8-VII, AGNP, not. 3, Testamentos de Juan López Gallegos, año de I649, ff. 84-84v.

I652, I9-XI, ACCP, AC, L. I2, f. 4I4V, I9 de noviembre de I652. [Al margen izquierdo Juan Blanco] En quanto a lo que pide Juan Blanco de Alcasar como heredero del señor Don Luis de Monçon tesorero que fue de esta Santa Yglesia de que se le pague lo que se le deviere que resulta de las quentas de los años de 35 asta el 38 años. No ha lugar por no tener estado las quentas.

I653, I8-XI, ACCP, AC, L. I3, ff. 85f-85v, I8 de noviembre de I653. [Al margen izquierdo Juan Blanco] En lo que pide Juan Blanco de Alcasar de que lo perteneciente al señor Don Luis de Monzon tesorero que fue de esta Santa Yglesia, en los libramientos de los años de i6 35 asta el de ${ }_{16} 8$ se le pague. Resuelbe este Cavildo se guarde lo proveydo en razón de lo que pide el contenido. 
I653, 2I-I, ACCP, AC, L. I3, f. Iov, 2I de enero de I653. [Al margen izquierdo Juan Blanco] En quanto a lo que pide Juan Blanco de Alcasar como heredero del señor tesorero Don Luis de Monzon de que se le libre la parte que le cave de los años de i6 35 asta el de i6 38 en teniendo estado la quenta y estando revistas se reconocerán y la parte que le tocare se le librará.

I653, 9-V, ACCP, AC, L. I3, ff. 29f-30v, 9 de mayo de I653. Que en lo que pide Juan Blanco de Alcasar como marido de Doña Luisa de Moncon sobre lo que de certificación de lo que se le deva al señor tesorero Don Luis de Moncon de los años atrasado cuyas quentas ha hecho el contador Antonio de Otamendi, se remite a los señores hacedores para que reconozcan estas quentas y lo que pide.

I654, I9-V, ACCP, AC, L. I3, f. I26f, I9 de mayo de I654. [Al margen izquierdo Juan Blanco] En quanto a lo que pide Juan Blanco de Alcasar como heredero del Señor Doctor y tesorero Don Luis Monzon de que se le de lo que al dicho tesorero se le devia de los años de ${ }^{6} 635$ asta el de i638. Ymformen los contadores de esta iglesia se debe algo al dicho tesorero y se le provea sobre ello lo que convengan.

I654, 28-XI, AGNP, not. 3, Protocolos de Melchor Fernández de la Fuente, año de i654, legajo XI, ff. 78v-79r. Carta de obligación de pago otorgada por el Bachiller Juan Blanco de Alcázar y su mujer a favor de Domingo de la Hedessa, por cien pesos de oro común.

I656, I7-X, ACCP, AC, L. I3, f. 384v, I7 de octubre de i656. [Al margen izquierdo Presente escribano] Que se libren 18 pesos en masa general por el costo de la ympresion y papel de los edictos, que se formaron por mandato del sacratísimo y excelentísimo señor obispo, para lo tocante a los diezmos del obispado y consumo de las trojes y se le entreguen al presente secretario por cuya mano corrió la ympresion y los pague el señor racionero mayordomo. I656, 28-IV, ACCP, AC, L. I3, f. 32If, 28 de abril de i656. [Al margen izquierdo Juan de Borja] Que asi mismo se le despache libranza en dicha contaduría, en dicha masa general a Joan de Borja Ymfante librero de 24 pesos por la ympresión de edictos y cartas. Que se despachen a todos los ministros de este obispado para que embien razón a la contaduría de las haciendas y ranchos diezmables de cada doctrina para formar un padrón de ellos.

I656, 3-X, ACCP, AC, L. I3, f. 38If, 3 de octubre de i656. [Al margen izquierdo Presente escribano] Que se libren 9 pesos que costaron la impresión y papel de las cartas que se imprimieron del obispo para todos los ministros de este obispado. En raçon y que embien las relaciones tocantes a los diezmos de cada partido para formar el libro que a de haver en la contaduría de las haciendas y diezmatorios. Y se libren y paguen de masa general y se entreguen al presente secretario por cuya mano corrió la ympresion.

I657, 9-II, ACCP, AC, L. I4, f. Iof, 9 de febrero de I657. [Al margen izquierdo Joan de Borja] En quanto a lo pedido por Joan de Borja librero, de que se le paguen 20 pesos que se deven, los i4 por la enquadernacion de un libro de vísperas de choro de esta santa yglesia que hizo de orden del licenciado Joan Gutierrez Pacheco maestro de capilla y los 6 pesos restantes por el adereso de 4 misales de dicha hacienda de la yglesia de orden del señor tesorero Don Iñigo de Cuevas. Dijeron que el mayordomo de fabrica pague los 6 pesos del adereso de los misales y que en quanto a los i4 pesos informe al maestro de capilla.

I663, I4-VIII, ACCP, AC, L. I5, ff. 55f-55v, I4 de agosto de I663. [Al margen izquierdo Joan de Borja] Que se libren y paguen Joan de Borja Infante vezino de esta ciudad, I2 pesos por la quenta de masa general por otros tantos que suplió el señor licenciado Sebastian de Pedraza canónigo de la Santa Yglesia de Mechoacan para sacar los despachos de una provisión executoria sobre los diezmos de los naturales. Y una escritura que otorgo la religión de Nuestra Señora de la Merced de esta ciudad, quando se fundo el convento 
de ella en que se obligaron a pagar los diezmos de las haciendas que se adquiriesen a razón de dicha fundación, para lo qual se les dio el atrio y ermita de San Cosme y San Damian a donde actualmente esta el convento. Y el señor regidor Requena escriva carta en nombre de este cabildo a dicho señor canónigo con respuesta de la que escribió dando las gracias de la solicitud de dichos despachos. Asi lo proveyeron y decretaron y firmo el señor tesorero providente.

I667-I669, AGMP, exp. 227, gremios y oficios. I667-1669.

I675, ?, ACCP, estante 7, zera. impresión de Nuestra Señora y cajones de libros para el Dean Joan Sanchez Navarro, I675, ff. s/n., Mil ducados de vellon de España con un pago de 500 pesos para realizar la tercera impresión, y 3 cajones con 130 cuerpos para el señor Dean Joan Sanchez Navarro. Asi también la primera impresión de la reyna de Nuestra Señora con 40 pliegos de impresión dentro de los 4 libros de la vida.

I675, 30-XII, AGNP, not. 4, caja 209, Protocolos de Tomás de Ortega, año de i675, f. 492 r. Escritura de arrendamiento de casa otorgada por Lázaro Rodríguez de la Torre, mestizo libre, maestro impresor a favor del Lic. Alonso de Gamboa, presbítero.

I682, 23-IX, AGNP, not. 4, Protocolos de I682, ff. 819-825v. Escritura de obligación por 2,000 pesos que otorgó Diego Fernández de León a favor de la Santa Iglesia Catedral de Puebla para la compra de una imprenta. Fueron sus fiadores el doctor Joseph Gómez de la Parra y el alférez Joseph Gómez de la Parra.

I685, II-III, AGNP, not. 3, Protocolos de I685, f. 373r. Carta de obligación de pago otorgada por Diego Fernández de León a favor del capitán Francisco Canales Gassio, por concepto de los libros que le vendió en la ciudad de México.

I688, II-IV, AGNP, not. 3, caja I50, Protocolos de Pedro Gómez de Prado, carta de pago de María de Ortega y Bonilla y Juan de Ortega Yañez, in de abril de i688, f. 27iv.

I688, I4-IX, AGNP, not. 3, caja I5o. Protocolos de Pedro Gómez de Prado, obligación por pesos entre Diego Fernández de León impresor de libros y Marcos Romero, I4 de septiembre de i688, ff. 677 f-677v.

I688, 22-XI, AGNP, not. 3, caja I50. Protocolos de Pedro Gómez de Prado, arrendamiento de una casa de Diego Fernández de León, maestro librero, 22 de noviembre de ı688, ff. 85 of-85ov. I688, 27-VIII, AGNP, not. 3, caja I50. Protocolos de Pedro Gómez de Prado, obligación por pesos entre Diego Fernández de León impresor y Joseph Fernández de Bargas, 27 de agosto de I688, ff. $622 \mathrm{f}-622 \mathrm{v}$.

I688, 2-X, AGNP, not. 3, caja I50. Protocolos de Pedro Gómez de Prado, theniente Juan Payan, testamento de Ysabel de Ortega y Bonilla, 2 de octubre de i688, ff. I95f-I96v. Ysabel de Ortega y Bonilla, es hija de Cristobal de Ortega y Bonilla.

I688, 3I-III, AGNP, not. 3, caja I5o. Protocolos de Pedro Gomes de Prado, obligación por pesos e hipoteca de la imprenta de Diego Fernández de León, 3i de marzo de i688, ff. 253f-254f. I690, 4-II, AGNP, not. 6, Protocolos de Francisco Solano, año de i69o, ff. 7r.-8r. Fianza otorgada por Diego Fernández de León a favor de doña Barbola Polanco sobre el concurso de acreedores que se siguió contra el ingenio de Tlatecla, ejecutada por bienes de Alonso de Toro.

I693, 9-VI, AGNP, not. 6, Protocolos de I693, ff. 5or-5iv. Sobre una memoria de diferentes géneros de letras de imprimir que Diego Fernández de León le entregó al capitán Fernando Romero y Torres, vecino de la ciudad de Sevilla.

I694, II-V, AGNP, not. 4, Protocolos de Miguel García Fragoso, año de I694, ff. 5Ir-52v. Escritura de concierto que celebra Diego Fernández de León con Juan de Paredes y don Joseph Rodríguez de la Torre, oficiales de impresos, para que le asistan en su tienda e imprenta. 
I694, I4-V, AGNP, not. 4, Protocolos de Miguel García Fragoso, año de i694, ff. 55r-58r. Escritura de obligación, otorgada por el marqués de Altamira a favor del convento de la Limpia Concepción de la ciudad de los Ángeles por haber sucedido en la hipoteca que gravaba la hacienda que compró de Diego Fernández de León, ubicada en términos de Tecali y Cuautinchán.

I694, I7-v, AGNP, not. 4, Protocolos de Miguel García Fragoso, año de I694, ff. 62r-63r. Poder especial otorgado por Diego Fernández de León a favor de [...] Gutiérrez, para que administre su librería e imprenta y general para que represente su persona, derechos y acciones.

I694, I9-V, AGNP, not. 6, Protocolos de I694, ff. 48r-49v. Carta de obligación de pago otorgada por Diego Fernández de León a favor de doña Catarina del Castillo y Estrada, por pesos.

I694, I9-v, AGNP, not. 6, Protocolos de I694, ff. 95r-96v. Carta de obligación de pago otorgada por Diego Fernández de León a favor del convento de religiosas de la Limpia Concepción de la ciudad de Puebla, por pesos.

I694, 26-v, AGNP, not. 4, Protocolos de Miguel García Fragoso, año de ı694, ff. 87r-87v. Venta de esclava otorgada por Diego Fernández de León a favor de don Gerónimo de Salazar Méndez Monte, vecino de la ciudad de los Ángeles.

I694, 27-V, AGNP, not. 6, Protocolos de I694, ff. II2r-II2v. Poder otorgado por Diego Fernández de León y doña Ángela Ruíz Machorro, su legítima mujer a favor de Miguel González Moncayo, vecino de Tulancingo, para que a su nombre pida la certificación de muerte de doña Ana Machorro.

I694, 30-IV, AGNP, not. 6, Protocolos de I694, ff. 75r-78v. Solicitudes que dirige Diego Fernández de León al señor obispo, deán y cabildo de la catedral de Puebla para que le autoricen un préstamo en efectivo para aviar su imprenta y librería con su correspondiente respuesta.

I694, 5-VI, AGNP, not. 6, Protocolos de I694, ff. I22r-I22v venta de esclavo otorgado por Francisco Martínez de Viana a favor de Diego Fernández de León.

I696, 24-XI, AGNP, not. 4 [?], Protocolos de Manuel José de Uriarte, año de i696, ff. 78r-82r. Testamento otorgado por el contador Juan de Villareal, hijo legítimo de Nicolás de Villareal y de doña Magdalena Rodríguez, naturales de la villa de Trujeque, Provincia de Alcarrias, arzobispado de Toledo. Fue dueño de casas en el Portal de las Flores y de una imprenta y librería.

I696, 28-IX, AGNP, not. 4 [?], Protocolos de Manuel Juan de Uriarte, año de i696, ff, 39r-55v. Testamento otorgado por el Lic. Juan de Olivares Villarroel, Pbro. Hijo legítimo del capitán y regidor Antonio de Olivares Villarroel y de doña Inés Jiménez.

I697, 2-I, ASMP, Libro de entierros núm. 4 (I69I y I699), ff. I44V-I45r. Aça de entierro del capitán y contador Juan de Villarreal.

I709, Io-IX, AGNP, not. 3, caja I74, Protocolos de Diego de Neira, Io de septiembre de I709, Poder para vender esclavos, f. $3 \mathrm{~s} / \mathrm{n}$. Andres de Olarque Quiroz le otorgo poder a Sebastian de Guevara para que le venda dos esclavos. 3 fojas sin número.

I709, I0-X, AGNP, not. 3, caja I74, Protocolos de Diego de Neira, Io de octubre de 1709, Venta con aceptación de esclavo f. I s/n. Sebastian de Guevara vendió a Doña Josepha Maria de Algara dos esclavos. (I foja).

I709, II-XI, AGNP, not. 3, caja I74, Protocolos de Diego de Neira, II de noviembre de I709, Venta de esclavo, f. s/n. Sebastian de Guevara Rios vendió una mulata al Capitan Julio Peres de Aviles. Foja sin número.

I709, 27-IX, AGNP, not. 6, Protocolos de Francisco Solano, año de I709, ff. 88r-88v. Poder especial que otorgó Miguel Fernández Machorro, dueño de imprenta y vecino de la 
ciudad de los Ángeles, a favor del capitán Diego Fernández de León, para que le obligue a favor del licenciado Pedro Sánchez de Alcarás, abogado de la Real Audiencia de México, por la cantidad de pesos que importen los privilegios de su imprenta que ha de solicitar al rey.

I709, 27-VIII, AGNP, not. 3, caja I74, Protocolos de Diego de Neira, 27 de agosto de 1709, Carta de libertad de un esclavo otorgada por el Cap. Sebastián de Guevara Ríos f. 3 s/n. El capitán Sebastian de Guevara le otorgo libertad al esclavo Miguel Ysla.

I709, 28-I, AGNP, not. 6, Protocolos de I709, ff. I43r-I45v. Subrogación de obligación de fiadores otorgada por Diego Fernández de León a favor del Lic. D. Nicolás Álvarez, maestro de ceremonias de la catedral, para garantizar los un mil quinientos pesos que le facilitaron para comprar letra de Flandes para su imprenta

I709, 29-I, AGNP, not. 6, Protocolos de 1709, ff. I33r-I33v. Poder del capitán Bernabé López Berruecos a favor de Diego Fernández de León.

I709, 30-IV, AGNP, not. 3, caja I74, Protocolos de Diego de Neira, 30 de abril de 1709, Poder para pleitos otorgado por el Cap. Bartolome Murillo a Diego Fernández de León. f. s/n.

I7IO, II-XI, AGNP, not. 3, caja I74, Protocolos de Diego de Neira, II de noviembre de I7Io, Poder y obligación de Miguel de Ortega a Phelipe de Palazios. f. s/n.

I7IO, 20-I, AGNP, not. 6, caja 5I, Protocolos de Francisco de Solano, 20 de enero de I7io, Obligación por rentas de Diego Fernández de León al Capitán Juan de Villareal. ff. 6of-6rv. Este protocolo no paso. Se canceló. Toca: Año de i7io. Henero.

I7IO, 20-IX, AGNP, not. 2, caja 42, Protocolos de Nicolás de Guzmán, obligación por arrendamiento de Miguel Villarreal a Sebastián de Guevara, 20 de septiembre de I7Io. ff. 322f-322v.

I7IO, 20-XII, AGNP, not. 6, caja 5I, Protocolos de Francisco de Solano, 20 de diciembre de i7io, Cuaderno ${ }^{\circ} 2^{\circ}$, Fianza a favor de la Santa Iglesia Catedral. ff. $65 \mathrm{f}-66 \mathrm{f}$.

I7Io, 2I-I, AGNP, not. 6, caja 5I, Protocolos de Francisco de Solano, 2I de enero de i7io, Escritura de venta de Don Miguel Ximenes a Diego Fernández de León. ff. 123f-123v. Toca: Año de i7ıo. Henero.

I7IO, 25-IX, AGNP, not. 6, Protocolos de i7Io, ff. 73v-74v. Poder del Lic. D. Diego López de Pliego a favor de Diego Fernández de León, ante Francisco Solano.

I7Io, 29, I, AGNP, not. 6, caja 51, Protocolos de Francisco de Solano, 29 de enero de i7io, Poder de Doña Ynes de Torrez a Diego Fernández de León. ff. I27f-ı28f. Toca: Año de i7ıo. Henero.

I7Io, 29-I, AGNP, not. 6, caja 5I, Protocolos de Francisco de Solano, 29 de enero de i7io, Poder de Doña Ynes de Torrez a Diego Fernández de León. ff. I27f-ı28f. Toca: Año de i7ıo. Henero.

I7Io, 30-I, AGNP, not. 3, caja I74, Protocolos de Diego de Neira, 30 de enero de I7Io, Poder general, f. $3 \mathrm{~s} / \mathrm{n}$. El lic. Don Carlos Lozano Lechuga albacea y heredero de Bernabe Fernandez Lechuga otorgo poder a Diego Fernández de León vecino de la ciudad de México para que reciba y compra, entre otros más. No aparece la firma de Fernández de León.

I7Io, 3I-I, AGNP, not. 6, caja 5I, Protocolos de Francisco de Solano, 3I de enero de i7io, Contrato de trabajo de aprendiz de oficial componedor entre Diego Fernández de León y Antonio Gama. ff. I29v-ızov. Toca: Año de I7ı. Henero.

I7Io, 4-II, AGNP, not. 6, caja 5I, Protocolos de Francisco de Solano, 4 de febrero de i7io, Poder para albacea otorgado por Doña Michaela de Chaves a Diego Fernández de León. ff. IIv-ı2v. Toca: Año de i7ı́. Febrero.

I7IO, 4-IX, AGNP, not. 3, caja I74, Protocolos de Diego de Neira, 4 de septiembre de i7ıo, Poder para pleitos del Capitán Sebastián de Guevara y Ríos. f. s.n. 
I7IO, 4-VII, AGNP, not. 3, caja I75, Protocolos de Diego de Neira, 4 de julio de I7Io, Carta de dote, f. 6 s/n. Juan Martin Notario de Cabrera vecino y labrador del Valle de Huamantla, Tlaxcala menciona que es hijo legitimo del Capitán Juan Martinez Notario y de Gertrudis de Cabrera difuntos, dice que va a contraer matrimonio con Luisa Felisisima Vazquez Mellado y Borxa doncella, hija legítima del Capitán Miguel Vazquez Mellado Rexidor Perpetuo de la ciudad y Alcalde Juez Provisor de la Santa Hermandad y de Doña Maria Clara de Borxa y Gandia difunta y que le prometieron en dote 3 mil pesos de oro común y da cuenta con un listado de toda la dote que recibe.

I7IO, 5-II, AGNP, not. 6, caja 5I, Protocolos de Francisco de Solano, 5 de febrero de i7io, Poder y concierto de obra de Diego Fernández de León a Bartolomé del Rivero. ff. $15 \mathrm{f}$-15 v. Toca: Año de i7io. Febrero.

I7IO, 7-IX, AGNP, not. 3, caja I74, Protocolos de Diego de Neira, 7 de septiembre de I7Io, Poder para testar de Don Antonio de León Sotelo. f. s/n. Toca: Rexistro de testamentos del año de i7io pertenecientes al oficio público del Secretario Don Diego de Neira Escrivano Real y Publico.

I7Io, 8-II, AGNP, not. 3, caja I74, Protocolos de Phelipe Cortes y Brito, 8 de febrero de i7io, Poder de venta de Andrea Díaz de la Vega a Diego Fernández de León. f. 4 v.

I7II, ?, ACCP, estante 5, zera. Impreso de las reales y ordenanzas del choro de esta Santa Iglesia catedral de los Puebla de los Angeles, I7II, $3^{8} \mathrm{p}$.

I7I4, 2I-VIII, ACCP, AC, L. 22, 2I de agosto de I7I4, f. II6f. Que en atención para la impresión de los villancicos de la Natividad de Nuestra Señora están asignados solo io pesos y de tablas y papel llega a 17 pesos. Los 7 pesos que ban a dejar se rebajen de la porsión del aniversario y den al maestro de capilla para dicho costo con los io asignados.

I7I4, 28-IV, ASMP, LEE núm. 6 (I708-i7i6), f. ıз8r. Acta de entierro en la Santa Iglesia Catedral de Miguel de Ortega y Bonilla, español, que fue casado con María de la Asempción y Serezo.

I7I4, 9-IX, AGNP, not. 4, caja 246, Protocolos de I7I4, ff. 29rev-37v. Testamento de Joseph Peres Turzio, maestro en el arte de leer, escribir y contar.

I715, I6-IX, AGNP, not. 3, caja I8o, Protocolos de Joseph Martínez, obligación por arrendamiento de Manuela Sereso a Francisco Torres, I6 de septiembre de 1715. ff. 3If-32f.

I715, I7-II, AGNP, not. 3, caja I80, Protocolos de Lucas de Revilla, obligación por arrendamiento de Antonio de Mendiola Rivera representante de la Cofradía de las Benditas Animas a Manuela Zereso y Juan Francisco de Ortega, 17 de febrero de 1715, 2 fojas s/n.

I715, 26-vIII, AGNP, not. 3, caja I80, Protocolos de Joseph Martínez, obligación por 560 pesos de Antonio de Elizaga a Manuela Zereso, 26 de agosto de 17i5, ff. $63 \mathrm{f}-64 \mathrm{v}$.

I715, 26-VIII, AGNP, not. 3, caja 180, Protocolos de Joseph Martínez, obligación por 560 pesos de Antonio de Elizaga a Manuela Zereso, 26 de agosto de 1715, ff. $63 \mathrm{f}-64 \mathrm{v}$.

I7I6, II-IX, AGNP, not. 4, caja 249, Poder para testar de Doña Francisca Xaviera de Vargasllantes albacea de Don Antonio Caseres, in de septiembre de I7I6, ff. 29v, 3If y 34 f. [Toca] Registro de Testamentos otorgados ante Miguel García Fragosso Escrivano Real y Público del numero de esta ciudad, este año de I72r hasta 29 de julio de este dicho año.

I7I6, 9-IX, AGNP, not. 3, caja I8I, Protocolos de Diego de Neyra, fianza que otorga el Capitán Sebastián de Guevara y Ríos, 9 de septiembre de i7ı6, ff. 253 f-253v.

I7i6, septiembre aGNP, not. 4, caja 247, Protocolos de I7i6, $2^{\circ}$ cuaderno, f. I8. Registro de testamentos y poderes para testar otorgados este año de i7i6. Ante Miguel García Fragosso notario real y publico. Testamento del Lic. Miguel de Riva y Pastor, siendo su albacea Bachiller Don Manuel Díaz de Basterra, realizó el testamento en septiembre de i7ı6 e 
informa que Don Miguel falleció el I7 de octubre de i7iI. [... f. I8v.] y se imprimieron papeles de convites para las personas notables desta ciudad porque pagamos á Manuela Serezo dueña de la imprenta, cinco pesos, y a Sebastian Madrid seis pesos y quatro reales para que alquilasse cavallo y por la paga de su trabajo en repartir dichos papeles como consta de sus recibos...

I7I7, 2I-VI, AGNP, not. 3, caja 179, Protocolos de Joseph Martínez, compra-venta de un solar en precio de 75 pesos en esta ciudad, 2I de junio de I7I7, ff. $85 \mathrm{f}-87 \mathrm{v}$.

I717, 29-I, AGNP, nnot. 4, caja 247, Protocolos de 17I7, $2^{\circ}$ cuaderno, ff. 4 rev-5v. Poder para testar del Lic. Thomas de Torres Barantes clérigo del Obispado de Puebla realizado el 29 de enero de I7I7 ante el norario Francisco Solano escribano publico y real.

I7I7, 5-II, AGNP, not. 3, caja 179, Protocolos de Diego de Neyra, obligación a favor de los herederos de Miguel de Ortega, 5 de febrero de 1717, ff. $48 \mathrm{f}-50 \mathrm{f}$.

I7I8, 23-XII, ASMP, Libro de entierros núm. 7 (I716 y I72I), f. 50v. Acta de entierro del capitán don Sebastián de Guevara, español, casado que fue con doña Mariana de Villareal.

I7I8, 24-III, AGNP, not. 3, caja I8I, Protocolos de Joseph Martínez, poder para testar que otorgó el Doctor Francisco Maiorga Serbantes a su hermano Joseph de Maiorga Serbantes, 24 de marzo de i7i8, ff. iIff-irgv.

I7I8, 28-III, AGNP, not. 4, caja 247, Testamentos y poder del Lic. Don Manuel Francisco de Bañuelos, albacea testamentario de Don Ricardo Curzi de Alverto, de I7i8, ff. I6v-i7v y firmas f. I9v [Toca]. Registro de Testamentos, de todo el año de i7ı8 otorgados ante Miguel García Fragosso escribano real y público.

I7I9, 6-VI, AGNP, not. 4, caja 247 [Toca] Registro de escripturas publicas de los meses de octubre, noviembre y diciembre, otorgados ante Miguel Garcia Fragosso, escribano Real y Publico. Este año de i7ı. Quaderno I.

I7I9, 7-VI, AGNP, not. 4, caja 249, Poder para testar de Don Diego Gutierrez de Soto albacea de Don Diego de Vargas, 7 de junio de I7I9, ff. I6v, 2of y 2Iv. [Toca] Registro de Testamentos otorgados ante Miguel Garcia Fragosso Escrivano Real y Publico del numero de esta Ciudad este año de i72r. Hasta 29 de julio de dicho año.

I720, 25-V, AGNP, not. 4, caja 249, Poder para testar de Don Juan de Morales, 25 de mayo de I720, ff. 4v-7v. Es el padre del impresor Francisco Xavier de Morales Salazar. [Toca] Testamentos, de este [año] de mil setesientos y veinte desde el dia veinte nueve de febrero 1720.

I720, 6-II, AGNP, not. 4, caja 249, Testamento de Don Joseph de Luna y Arias, 6 de febrero de I720, ff. If-8v. [Toca] Registro de testamentos, poderes para testar y algunas disposiciones otorgadas ante Miguel García Fragosso escribano Real y Público este año de i729.

I72I, 27-IX, AGNP, not. I, caja I3, Protocolos de Pedro Ybañez Cavellos, 27 de septiembre de I72I, Poder para testar de Manuela Serezo. ff. 69v-70v o 295v-296v. Toca: Rexistro año de 1718. De instrumentos otorgados ante Pedro Ybañez Cavellos Escribano Real vezino de la ciudad de los Angeles en el año de i7i8. (Llega hasta i725 y le falta el año de i723).

I722, I4-VII, AGNP, not. I, caja I3, Protocolos de Pedro Ybañez Cavellos, I4 de julio de I722, Poder de Manuela Serezo al Lic. Don Gabriel de Rivero. ff. 79f-8ov o 5IIf-5I2v. Toca: Rexistro de instrumentos otorgados ante Pedro Ybañez Cavellos Escribano de su Magestad, vezino de la ciudad de la Puebla de los Angeles en el año del señor de i722.

I726-1862, AGMP. exp. 226, gremios y oficios. 1726-1862.

I728, 2I-XI, ASMP, Libro de matrimonios núm. I5 (I727-I730), ff. iI8v-IIgr. Acta de matrimonio de D. Francisco Xavier de Morales, español, soltero, mercader de libros, hijo legítimo de D. Juan de Morales y de Doña María de Salazar; y a Doña Joachina María de Loaiza y Erazo, española, doncella, hija legítima de D. Phelipe de Loaiza y Erazo y de Doña Francisca Rosete Goñi de Peralta. 
I732, ?, AGMP, exp. 223. Sobre gremios de artesanos 1732-1804. Foja: 3-250, Elecciones de alcaldes y veedores de los gremios y oficios de este año de i732. Noviembre, 20 Io.

I732-I804, AGMP, exp. 223, gremios de artesanos (elecciones). I732-1804.

I734, 7-VII, AGNP, not. 4, caja 26I, Protocolos de Diego Antonio Bermudes de Castro, inventario de los bienes del Almirante don Francisco Díaz Romero por su albacea y fideicomisario Francisco Rodríguez de Pedraza, 7 de julio de i734, ff. I24V-I29f.

I734, 9-VII, AGNP, not. 4, caja 26I, Protocolos de Diego Antonio Bermudes de Castro, carta de finiquito de una obligación por pesos que Joseph Ygnacio Arruti dio a doña Manuela de la Acencion Serezo, 9 de julio de I734, ff. I29f-r29v.

I734, 9-VII, AGNP, not. 4, caja 26I, Protocolos de Diego Antonio Bermudes de Castro, obligación e hipoteca de la imprenta de doña Manuela de la Acencion Serezo a la provincia de San Hipólito Mártir de la ciudad de Oaxaca, 9 de julio de I734, ff. I29v-Izof.

I736, ?, ACCP, estante 5, zera. Impreso de Reglas y ordenanzas del choro de esta Santa Iglesia catedral de los Puebla de los Angeles, I736, 62 pág.

I738, 20-IV, ASMP, Libro de matrimonios núm. I8 (I735-1738), ff. 224v-225r. Acta de matrimonio de D. Christoval Thadeo de Ortega y Bonilla, español, soltero, dueño de imprenta, hijo legítimo de D. D. Miguel de Ortega y Bonilla y de Doña María de la Asumpsión Serezo; y a Doña Agueda Juana Talledo y Castro, española, doncella, hija legítima de D. Domingo Talledo y de Doña Mariana González de Castro, ambos vecinos de esta ciudad y feligresía.

I743, 23-IV, AGNP, not. 4, caja 270, Protocolos de Diego Antonio Bermudes de Castro, 23 de abril de $\mathrm{I743}$, Testamento de Manuela de la Ascencion Zereso. ff. 56v-58f.

1757, II-III, AGNP, not. 6, caja 9I, Protocolos de Joseph Antonio de Saldaña, Francisco de Ortega impresor y Juan Vanegas platero fiadores de Agustín Antonio de Arriola por 2 mil pesos c/uno, in de marzo de I757, f. 83v.

I757, 20-I, AGNP, not. 6, caja 93, Protocolos de Joseph Antonio de Saldaña, poder que otorga Francisco de Ortega impresor de libros, 20 de enero de i757, f. Iov.

I757, 20-VIII, AGNP, not. 3, caja 205, Protocolos de Juan Fausto Montes de Oca, testamento de Nicolas Rogoso, 20 de agosto de 1757, ff. 47v-49f.

I757, 3-II, AGNP, not. 3, caja 205, Protocolos de Juan Fausto Montes de Oca, poder que otorga Manuela de la Asencion Sereso por ser albacea testamentaria de Pedro Navarrete, 3 de febrero de i757, ff. 33f-33v (o 32f).

I757, 8-III, AGNP, not. 3, caja 205, Protocolos de Juan Fausto Montes de Oca, poder que otorga Manuela Cereso a Christoval Ortega ambos albaceas testamentarios de Pedro Navarrete, difunto, 8 de marzo de I757, ff. IIgv-I26f.

I758, 4-v, ASMP, Libro de entierros núm. I2 (I753 y I76I), f. 84r. Acta de entierro de Doña Manuela de Ascensión Cerezo, española, viuda que fue de Don Miguel de Ortega

I759, 7-IX, ACCP, AC, L. 33/34, ff. I6f-I6v, 7 de septiembre de I759. El señor doctor don Lorenzo de Arevalo Mârela, de esta Santa Yglesia hizo presente como el reverendo padre procurador de carmelitas descalzos y que lo es en la corte de Roma de la causa de beatificación del ylustre excelentísimo y venerable señor doctor don Juan de Palafox digno obispo que fue de este obispado de tierna memoria le avia escrito que es su estilo a los altares y subalternos de los prinsipales señores a cuio cargo son los negocios de la curia romana hacerles algunas gratificaciones para el mas prompto expediente de las que se versan y que respecto a no tener horden para expenderlas si le parece a este venerable señor Dean y Cabildo prestar su consentimiento: dichos señores. 
I760, I4-X, ACCP, AC, L. 33/34, I4 de octubre de I760, f. 83f. [Al margen izquierdo. 50 pesos de avida de costa a el licenciado Rivas para la impresión de la Historia de Nuestra Señora de la Defenza].

I76o, I4-X, ACCP, AC, L. 33/34, I4 de octubre de I76o, f. 83v. [Al margen izquierda. Ioo pesos de suplemento devengadolos con sus mesadas a el celador].

I760, I4-X, ACCP, AC, L. 33/34, f. 83f, I4 de octubre de I76o. [Al margen izquierdo. ------ avida de costas a el Lizenciado Rivas para la impresión de la Historia de Nuestra Señora de la Defenza].

I762, 22-III, AGNP, not. 6, caja 98, Protocolos de Joseph Antonio de Saldaña, reconocimiento de deuda de Christobal de Ortega dueño de imprenta a la provincia de San Hipólito Mártir, 22 de marzo de i762, ff. in6f-inff.

I762, 2-IV, ACCP, AC, L. 33/34, 2 de abril de I762, f. I59f. [Al margen izquierdo. Suplemento a Joachim de Campos].

I763, 23-IV, ASMP, Libro de entierros de españoles y mestizos. núm. iz (I76r y I767), f. 78r. Acta de entierro de Francisco Xavier Morales.

I768, ACCP. Estante 7. Etiqueta documentos varios. Remate de la imprenta de los jesuitas (colegios tridentinos: San Pedro, San Juan y San Pantaleón), I768, ff. s/n.

I768, I5-I, AGNP, not. 4, caja 28o, Protocolos de Juan Visente de Vega, arrendamiento de una hacienda en Santiago Michaque, Tlaxcala, i5 de enero de i768, ff. Iv-4f.

I768, I8-I, AGNP, not. 4, caja 28o, Protocolos de Juan Visente de Vega, poder para pleitos, cobranzas y tomar cuentas que otorga Thomas Peres Turcios a Joseph Manuel de Guadalajara, i8 de enero de 1768 , ff. 4 f- $5 \mathrm{v}$.

I772, I7-III, ASMP, Libro de entierros núm. I4 (I767 y I773), f. I49r. Acta de entierro de D. Christoval de Ortega.

I775, ?, ACCP, Estante 7, zera reimpresión de un libro, I775, ff. s/n. zera reimpresión del libro de León de Francia por 2 mil ducados de platas.

I777, 2I-VIII, AGMP, tomo 7. Expediente sobre Tierras 1780-I792m Legajo 76, Foja I3-40, 2I de agosto de $\mathbf{1 7 7 7}$, Sobre alcabala del rancho de la San José el Chico vendido al censo de don Pedro de la Rosa.

I784, 7-XI, ASMP, Libro de matrimonios, núm. 3o, 7 de noviembre de I784, f. 7Iv. En la ciudad de los Angeles en 7 de noviembre de 1784 yo el bachiller Mariano Ramirez, teniente de cura de la Santa Iglesia Catedral les pregunte su consentimiento a Josef Antonio Fuentes, español, soltero, impresor, originario y vecino de esta ciudad y feligresía del sagrario, hijo legítimo de Josef Fuentes y Mariana Rivera; yo Catharina Farjon de los Godos, española soltera, originaria de la doctrina de San Agustín Tlaxco.

I786, 3-VII, ASMP, Libro de matrimonios, núm. 29, 3 de julio de I786, f. I68v. En la ciudad de los Angeles en 3 de julio de 1786 le pregunte su consentimineto a Josef Monfort soltero impresor, hijo legítimo de Manuel Monfort y de Juana Flores difuntos; y a Ignacia Josepha Acevedo doncella. Ambos contrayentes mestizos, originarios y vecinos de esta ciudad y feligresía.

I786, 5-v, AGNP, not. 3, caja 215. Protocolos de Jose Ygnacio del Castillo, Pedro de la Rosa como principal deudor y Jose Maria de la Carrera como su fiador por una deuda de ro mil pesos al capitán Mariano Gonzalez Maldonado, 5 de mayo de I786, ff. Io3f-Io4f.

I786, 7-VI, AGNP, not. 4, caja 249, Testamento de Doña Thomasa de Angon y Mondeza, ff.r2 v-r6f. Es una hoja suelta que estaba insertada allí. [Toca] Registro de testamentos, poderes para testar y ultimas disposiciones otorgadas ante Miguel Garcia Fragosso Escrivano Real y Público este año de i720. En el testamento de Doña Thomasa de Angón y Mon- 
deza en la f. I6 estaba insertada una hoja suelta en la que el 7 de junio de I786 Pedro de la Rosa solicitó al Capitán Don Jose Maria Zarate y Vera Alcalde Ordinario para que se le de un tanto de dicha disposición porque doña Thomaza de Angon y Mendoza murio el I5 de junio de 1720 .

I788, 2-III, AGNP, not. 3, caja 216. Protocolos de Jose Ygnacio del Castillo, Pedro de la Rosa otorga poder general a Manuel Domingo Chavero, 22 de marzo de I788, ff. $47 \mathrm{f}-48 \mathrm{f}$.

I80o, 24-XI, AGNP not. 4, caja 289. Protocolos de Jose Antonio Saldaña, el ayuntamiento del cabildo contrato al arquitecto Antonio de Santa María Ynchauriqui para realizar mejoras en el Portal de las Flores, 24 de noviembre de 1800 , ff. $2 \mathrm{f}-\mathrm{gf}$ o $17 \mathrm{f}-\mathrm{I} 8 \mathrm{v}$.

I8or, I4-VIII, AGNP, not. 4, caja 289. Protocolos de Jose Antonio Palacios, contrato de arrendamiento entre don Joseph Bernardo Ramírez de Arrellano González (poseedor del mayorazgo de Felipe Ramírez de Arellano) y don Mariano Yurre, I4 de agosto de i8or, ff. $204 \mathrm{v}-206 \mathrm{f}$.

I8or, 22-v, AGNP, not. 4, caja 289. Protocolos de Jose Antonio Palacios, Pedro de la Rosa vende a Miguel Ullate una ladrillera en el barrio de Xonacatepec, 22 de mayo de I8oI, ff. 87f-9of. Pedro de la Rosa vende una ladrillera ubicada en Xonacatepec, que compro anteriormente en remate de los bienes de Juna de Solano por 8 mil pesos. Fueron testigos: Mariano Osorio, José Gomez de la Sierra y Mariano José Velazquez, vecinos de esta ciudad.

I8o2, 4-II, AGNP, not. 4, caja 289. Protocolos de Jose Antonio Palacios, Pedro de la Rosa arrendo un mezón llamado Noche Buena a Antonio de Cadíz, 4 de febrero de 1802 , ff. 15v-17f.

I8o2, 8-IV, AGNP, not. 4, caja 289. Protocolos de Jose Antonio Palacios, los rectores de la Cofradía de San Nicolás Tolentino otorgan poder como administrador a Joseph Ygnacio Rodríguez Alconedo maestro farmaceútico, 8 de abril de i8o2, ff. 77f-8of.

I803, 27-IX, AGNP not. 4, caja 289. Protocolos de Francisco Monroy y Escandón, impresión y expendio de los quadernillos o análogos del rezo del oficio divino, 27 de septiembre de I803, ff. 397v-398v.

I804, 3-X, AGNP, not. 4, caja 289. Protocolos de Francisco Monroy, importe de 800 pesos por el traspaso de un billar entre Carlos Rivera y Mariano Santiago a Pedro Pascual de la Rosa, 3 de octubre de 1804 , ff. $326 \mathrm{f}-317 \mathrm{v}$.

I808, 2I-I, AGMP 2I de enero de I808, f. 62f. Nombramiento de Pedro Moreno como oficial examinador de aprensador porque en la ciudad no hay quien desempeñe el oficio. Se ordena se le de el sello. Lo firmo don Nicolas Fernández de la Fuente escribano de cabildo.

I8I6, 27-IV, AGMP, t. 7. Expediente sobre Tierras I780-I792, Legajo 76, Foja 4I-74, 27 de abril de 1816 al i6 de agosto de 1824, Expediente formado en averiguación de la persona que mando romper y sembrar de maíz una cuchilla de tierra perteneciente a los ejidos de esta nueva ciudad a la linde del Rancho San José el Chico en San Francisco Xonacatepec, perteneciente en el día al presbítero don Mariano de la Rosa, como heredero de su abuelo don Pedro, a quien se le remato al censo en 22 de mayo de 1807.

I8I8, 24-I, AGNP, not. 4, caja 29I, Protocolos de Jose Ramirez de Arellano, estanco de tabaco, polvora y papel sellado, 24 de enero de 1818,3 fojas $s / n$.

I820, 26-IX, ACCP, estante 7, folletos varios. Aviso al publico impreso de Pedro de la Rosa, 26 de septiembre de i82o. Aviso al público en el Orden publico que debe guardar la ciudad de Puebla y se pasa a los jefes políticos.

I821, ACCP, estante 7, folletos varios. Volante del superior oficio que el Excelentisimo señor Virrey Conde del Venadito dirigió al Excelentisimo señor comandante general D. Ciriaco del Llano, al remitirle los despachos de retiro, con goce de fuero criminal y uniforme, 
à los oficiales, sargentos, cabos y soldados que han servido cuatro años en el Batallón Urbano de esta ciudad, imprenta de Gobierno, I82I.

I82I, II-X, AGMP, exp. 192. Sobre Jurados de Imprenta I82I-I866. Foja: I-Io. II octubre de I82I. El impreso El pensador mejicano al excelentísimo señor general del ejército imperial americano de Agustín de Iturbide, fue calificado por el licenciado don José María San Martín fiscal de libertad de imprenta como sedicioso. Fue impreso en Puebla en octubre II de I82I.

I82I, I2-XI, AGMP, exp. 93. Sobre Jurados de Imprenta I820-I828, I2 de noviembre de I82I. Ley de doce de noviembre de 1820 sobre libertad de imprenta (impreso de Pedro de la Rosa). ff. 2-5.

I82I, I6-IX, AGNP, not. 4, caja 29I, Protocolos de Jose Ramirez de Arellano, impresión de billetes para la rifa de la Imperial Trigarante para socorro del ejército, I6 de septiembre de I82I, 8 fojas $\mathrm{s} / \mathrm{n}$.

I82I, I-VI, AGMP, t. 44. Expediente sobre Aguas, Legajo 365, Foja 96-98, I de junio de i82I, Arreglo de mercedes de agua en la ciudad, se presento titulo (impreso) por la imprenta de gobierno de la oficina de Pedro de la Rosa.

I82I, 22-XII, AGMP, exp. 93. Expediente sobre Jurados de Imprenta I820-I828, f. 6, 22 de diciembre de 182I. Reglamento adicional para la libertad de imprenta Pedro de la Rosa vuelve a imprimir un documentos sobre la libertad de imprenta en que se muestran adiciones y esta firmado por el licenciado Carlos García. En el expediente 93, a partir de la f. 7-24I.

I822, I7-II, AGNP, not. 4, caja 292, Protocolos de José Mariano Ortiz, contrato de establecimiento de una compañía entre José de la Rosa y Pedro de la Rosa, su primo, i7 de febrero de 1822 , ff. $s / n$ y mutilados.

I822, 8-III, AGMP, t. 44. Expediente sobre Aguas, Legajo 365, ff. 98-Ior, 8 de marzo de i822, Desorden introducido en el uso de las aguas potables y distintos proyectos para remediarlos. Impreso de Pedro de la Rosa.

1824, ACCP, estante 7, folletos varios. Exposición del cabildo eclesiástico de la Diocesis de Guadalajara al respetable y religioso publico mejicano impreso de Mariano Rodríguez, I824. I824, 20-XII, AGMP, t. 44. Expediente sobre Aguas. Legajo 365, ff. II9-I2I, 20 de diciembre de I824. El maestro Santa María pide que por ser nuevo en el cargo se le aumente el salario. En sesión de cabildo, don Antonio Santa María (cañero mayor) pide se le asigne 56 pesos anuales por ser el nuevo encargado de las tomas de agua y alcantarillado y se solicita se turne a los señores tesoreros para que se discuta. Piden que todo ello se publique en el bando.

I824, 7-IV, AGNP, not. 4, caja 292, Protocolos de Jose Mariano Ortiz theniente, notario Ygnacio Reyes Mendizabal y Pliego, Mariano de la Rosa vendió papel sellado a don Pedro de la Rosa, su padre, 7 de abril de I824, ff. If- $4 \mathrm{f}$.

I824, 8-v, AGNP, not. 4, caja 292, Protocolos de Jose Mariano Ortiz theniente, notario Ygnacio Reyes Mendizabal y Pliego, poder para pleitos que otorgó el presbítero Mariano de la Rosa al licenciado Manuel Lopes Torrecillas, 8 de mayo de I824, ff. $5 \mathrm{v}-7 \mathrm{f}$.

I825, 4-VIII, AGNP, not. 4, caja 292, Protocolos de Jose Mariano Ortiz theniente, notario Ygnacio Reyes Mendizabal y Pliego, poder general que otorga Francisco López, 4 de agosto de 1825, ff. 5v-7f. En este documento mencionan a Thomas Olvera encargado de los ramos de alcabalas, tabaco y papel sellado.

I826, ?-XI, AGNP, not. 4, caja 292, Protocolos de Jose Mariano Ortiz, Jose de la Rosa compro papel francés a Mateo Cao y Varela y a don Ygnacio Osuño por Io75 pesos con 4 reales, 6 de noviembre de 1826 , ff. $306 \mathrm{v}-307 \mathrm{v}$. 
I826, 23-X, AGNP, not. 4, caja 292, Protocolos de Jose Mariano Ortiz, poder para obtener el testamento de don Manuel Moreno otorgado por Mariano y Francisco Moreno y Gregorio García, 23 de octubre de 1826 , ff. $285 \mathrm{v}-287 \mathrm{v}$.

I826, 27-II, AGNP, not. 4, caja 292, Protocolos de Jose Mariano Ortiz, poder general que otorga Jose María Esteva en representación de su hermano Ygnacio, ministro de hacienda, otorga poder al presbítero bachiller don Joaquin Furlon prepósito del Oratorio de San Felipe Neri, 27 de febrero de i826, ff. 8If-82f.

I826, 27-VI, AGNP, not. 4, caja 292, Protocolos de José Mariano Ortiz, establecimiento de una compañía de imprenta entre José Apolinario Fernández vecino de Atlixco y José de la Rosa, administrador de la imprenta del Coronel Pedro de la Rosa, 27 de junio de 1826 , ff. $176 \mathrm{f}-\mathrm{i} 77 \mathrm{v}$.

I826, 30-III, AGNP, not. 4, caja 292, Protocolos de Jose Mariano Ortiz theniente, notario Ygnacio Reyes Mendizabal y Pliego, interinato del ramo de la administración de contribuciones directas de papel sellado, tabaco, trucos y villares y sello de libros, 30 de marzo de I826, ff. $58 \mathrm{f}-59 \mathrm{v}$.

I829, 30-X, AGMP, exp. 234 gremios y oficios. I744-1802. 30 de octubre de I829, ff. 385 f-385v. En este libro mencionan que se pretende establecer una fábrica de aguardiente de caña (chinguirito) y se encuentra establecida entre el rancho de Pedro de la Rosa y el molino de San Francisco y que por lo tanto, y se otorgó el permiso para establecerla en la plazuela de San Francisco, tomando en cuenta que se encuentra dentro del margen de los aguardientes y alejado del centro de la ciudad. Lo firmo Francisco Javier Ponce, Señor Secretario de Gobierno.

S/f. AGMP, Libro número I3 de Cabildos de la Niña ciudad de Puebla. Este libro está restringido.

$\mathrm{S} / \mathrm{f}$. Impresión de un libro para leerse en los cursos que se impartían en el colegio dominico de San Luis de la ciudad de Puebla. [aGNP), Suplemento del Libro núm. 2, ff. I33r-133-v.]

\section{Archivo General Municipal de Puebla}

AGMP, Libro de cabezón \# I de alcabalas de la Noble ciudad de Puebla i6o3. El libro empieza en ı6or. Descargo del año de ı6or, f. 6f (8). [Al margen izquierdo. Descargo que se le dio al librero] Da en descargo sesenta y un pesos del dicho oro por tantos que dio y pago a Diego Lopez librero en que concertó con el seis libros que se mandaron hazer para asentar el alcabala y tener quenta y razón de ella conforme el acuerdo del cavildo de veinte y siete de henero del dicho año de seiscientos y uno que exivio con carta de pago.

AGMP, Libro de cabezón núm. I de alcabalas de la Noble ciudad de Puebla I603, ff. $25 f$ (27). [Al margen izquierdo. Ydem.] Hazesele cargo de trese pesos y dos tomines de oro común que le dio y entrego el dicho Pedro Martinez de Briones receptor de la dicha real alcabala de veinte y cinco pesos del dicho oro que dio cobrados de la alcabala del repartimiento del año pasado de mil y seiscientos y dos desde fin de febrero del año pasado de seiscientos y tres saltados de abril del de los quales escalsando y onze pesos y seis tomines los once pesos por otros tantos que pago a Bartolome de Bonilla por tres libros en blanco enquadernados y unos papelones aguxerados que del compro el dicho Pedro Martinez para esta contaduría como parece por el pliego de gastos núm. 38 y los seis tomines que le pertenecieron de su cobranca a tres porciento quedaron liquidos los dichos treze peos y dos tomines como consta y parece del fenesamiento que liquide con el y carta de pago que el --- tesorero Geronimo Perez de Salazar le dio al pie del en su libro a foja tres.

aGMP, Libro de cabezón núm. I de alcabalas de la Noble ciudad de Puebla i604, f. 29-f (3I). [Resumen y claridad de esta quenta] Yten cobraro los dichos receptores de los recagos del 
repartimiento de los años de seiscientos y uno y seiscientos y dos, ochocientos y quarenta y nueve pesos quatro tomines y seis pesos de los quales se pagaron a los dichos receptores veinte y cinco pesos de su cobranca a tres por ciento y onze pesos a Bartolome de Bonilla librero de ciertos libros y papelones que dio para esta contaduría y los ochocientos y treze pesos quatro tomines y seis granos entraron en poder del dicho Geronimo Perez de quales esta dicho cargo como consta por las partidas de esta quenta.

AGMP, Libro de cabezón núm. I de alcabalas de la Noble ciudad de Puebla, i de junio de i605, f. 3I (33). [Al margen izquierdo. Ydem] Hazele cargo de trecientos y diez y ocho pesos y seis granos de oro común que le dio y entrego el dicho Pedro Marinez de Briones de trecientos y quarenta y un pesos y quatro tomines del dicho oro que dio cobrados de la alxavala del viento desde treinta de junio del dicho año de seiscientos y quatro hasta por treze de junio dicho año de seiscientos y quatro hasta por treze de julio de el de los quales escalfando veinte y tres pesos, tres tomines y seis granos. Los veinte pesos, tres tomines y seis granos que el pertenecieron de su cobranca a seis por cierto y los tres pesos por otros tantos que pago a Bartolome de Bonilla por dos libros en blanco enquadernados que le compro en que ban asendo los pesos de oro queban cobrando asi del viento como del repartimiento quedaron liquidados los dichos trezientos y diez y ocho pesos y seis granos como consta y parece del fenescimiento que liquido con el y carta de pago que dicho tesorero le dio al pie del libro del fojas ciento y quarenta y seis.

AGMP, Libro de cabezón \# I de alcabalas de la Noble ciudad de Puebla, I de septiembre de i607, ff. 5of-5Iv. (52 y 53). [Al margen izquierdo. Martin Grillo Maldonado] Hazesele cargo al dicho tesorero de trezientos y diez y ocho pesos y seis granos de oro común que ledio y entrego Martin Grillo Maldonado receptor de trezsientos y treinta y dos pesos del dicho oro que dio cobrados de la alcabala del repartimiento. Los seis pesos de los pertenecientes al repartimiento del año pasado de seiscientos y quatro y los trezsientos y veinte y seis pesos pertenecientes al repartimiento de seis cientos y cinco desde primero dia de henero asta treinta y uno del de dicho año de mil y seiscientos y seis de los quales escalfando treze pesos, siete tomines y seis granos de oro común. Los quatro pesos de los que dio y pago a Geronimo Viquerio Mercader por el costo de una rezma de papel blanco para el gasto de esta contaduría y los nueve pesos, siete ------ y seis granos que le pertenecieron de su cobranca al dicho receptor a tres porciento quedaron liquidos los dichos trezientos y diez y ocho pesos y seis granos como consta y parece por el fenesamiento que liquide con el y carta de pago que le dio dicho tesorero Geronimo Perez de Salazar al pie de el en su libro a fojas quatro y cinco. f. 54v. (56). Y para mas claridad y resumen desta quenta se declara que los pesos de oro que en todo el dicho año de mil y seiscientos y seis se cobraron del repartimiento de los vecinos son catorce mil trezientos y diez y seis pesos. Los treze mil y ochocientos y treinta y dos pesos y tres tomines dicho oro que por la dicha quenta parece haver sentado en poder del dicho tesorero Geronimo Perez de Salazar y los quinientos tres pesos y cinco tomines. Los quatrocientos y treinta y un pesos ------ de los que llevaron y pertenecieron a los dichos receptores de su cobranca a tres porciento y quatro pesos que el dicho Martin Grillo Maldonado dio y pago a Geronimo Riquerio mercader por el costo de una resma de papel blanco que compro para el gasto de esta contaduría como parece en la partida de trezientos y diez y ocho pesos y seis granos liquidos que entrego el dicho receptor al dicho tesorero que esta en esta quenta a foja cinquenta.

AGMP, Libro de cabezón núm. 2 de alcabalas de la Noble ciudad de Puebla 1612-1627, 3 de septiembre de 1627, f. $7 \mathrm{v}$. [Que se compre un libro para los negocios de este nuevo asiento.] Este día se acordó que Juan Perez de la Fuente depositario nombrado de los pesos de oro 
tocantes al nuevo asiento y cabeçon de la real alcabala de esta ciudad mandazen un libro grande a donde se escriban y asienten los repartimientos y negocios tocantes a la dicha renta acosta de ella, como se hizo en los asientos pasados y lo costare se le pasen en virtud del testimonio de este acuerdo, recibiendo carta de pago de librero que lo hiziere.

AGMP, Libro de cabezón núm. 2 de alcabalas de la Noble ciudad de Puebla I612-1627, 3 de septiembre de I627, f. Iof. Dan una lista calle por calle y de cada persona que paga alcabalas. Calle del Carmen en la iglesia menor, f. I7v. / Diego López, librero ------ 4 pesos./ Calle del Carmen a la iglesia mayor, f. 39f. / Diego López, librero ------ 4 pesos. / 20 de febrero de I629, f. 6rv. /Calle del Carmen a la iglesia menor. / Diego López, librero. ------ 4 pesos.

AGMP, Libro de cabezón núm. 2 de alcabalas de la Noble ciudad de Puebla i612-I627, I de enero de i628, f. 78f. [Al margen izquierdo. Viento Andrés de la Cueba.] Hasesele el xcargo al dicho cofre de 93 pesos, 7 reales y 6 granos de oro común que el dicho Andres de la Cueba de la ciudad metió en el I22, 3 reales y 6 granos que dio cobrados de la alcabala del viento desde 3 I de diciembre de 1627 hasta 3 I de enero de 1628 , de que se escalfaron al dicho receptor 28 pesos, 4 reales, los 9 pesos, 6 reales que le pertenecieron de su cobrança a $8 \%$ y el I7 que dio y pago a Diego López, librero por la tinta, canones y papel y 2 libros en blanco para la cobrança de la alcabala que dio para el gasto de esta cantidad, desde I de julio de 1626 hasta fin de diciembre y 27 y un peso y 6 reales que dio al pregonero y tropetero que asistieron a pregonar un auto tocante a la basta administración de la alcabala y quedaron liquidos los dichos 93 pesos, 7 reales y 6 reales como parece por el fenesimiento que se liquido con el dicho recetor que esta en su libro primero del tercer cavezon a foxas 125 .

AGMP, Libro de cabezón núm. 2 de alcabalas de la Noble ciudad de Puebla 1612-1627, 20 de febrero de i63o, f. 86. Calle de la Audiencia. Juan Borja y Gandia, librero 3 pesos.

AGMP, Libro de cabezón núm. 2 de alcabalas de la Noble ciudad de Puebla 1603-1632, 20 de febrero de i630. Calle del Carmen a la Yglesia menor, f. 97f. / Diego López, librero. 4 pesos.

AGMP, Libro de cabezón núm. 2 de alcabalas de la Noble ciudad de Puebla ı6о3-1632, ro de octubre de i63г / Calle de San Pedro, f. ro8v. / Joan de Vorja Gandhia, librero. 3 pesos / Calle del Carmen a la iglesia mayor, f. irff. / Diego López, librero. 3 pesos.

AGMP, Libro de cabezón núm. 2 de alcabalas de la Noble ciudad de Puebla 1603-1632, I6 de marzo de I632 / Calle de San Pedro, f. I2zf. / Joan Vorja Gandhia, tienda de menudencias 6 pesos / Calle del Carmen a la iglesia mayor f. izof. / Diego López, librero. 4 pesos. AGMP, Libro de cabezón núm. 2 de alcabalas de la Noble ciudad de Puebla i603-1632. Añadidos a 1632 / Calle de San Pedro, f. I53f. / Juan de Borja Gandia, librero 6 pesos / Calle del Carmen a la iglesia menor, f. I6of. / Pedro Sanchez de Lorencano, librero io pesos / Diego López, librero. 4 pesos.

AGMP, Libro de cabezón núm. 3 de alcabalas de la Noble ciudad de Puebla 1612-1633, 8 de junio de i6ı2 / Calle de San Pedro iglesia maior f. igf. / Diego López, librero. 5 pesos.

AGMP, Libro de cabezón núm. 3 de alcabalas de la Noble ciudad de Puebla ı6ı2-ı633, 2 de enero de $\mathrm{I}_{6} \mathrm{I} 3$, f. 24f. [Al margen izquierdo. Ydem] Hacesele cargo al dicho tesorero de ochosientos y once pesos, 4 tomines de oro común, que le dio y entrego el dicho recetor Andres Alonso de la Cueva de ochosientos sesenta y siete pesos, cinco tomines de la alcabala de el viento desde primero de octubre de I6I2 hasta fin del delos quales excalfando a el dicho recextor $5^{6}$ pesos y un tomin, los $5^{2}$ pesos un tomín de su cobranca a $6 \%$ y los 4 pesos de una resma de papel, tinta y carrocel para el gasto de la contaduría quedaron liquidos los dichos 8ir pesos, 4 tomines como parece por el fenecimiento que con el liquido y carta de pago a el pie del dicho tesorero en su libro, octavo a fojas 69. 
AGMP, Libro de cabezón núm. 3 de alcabalas de la Noble ciudad de Puebla ı6ı2-ı633, 3 de mayo de i6rз. Calle que ba del Carmen a la iglesia mayor, f. 36 / Diego López, librero. 3 pesos.

agmp, Libro de cabezón núm. 3 de alcabalas de la Noble ciudad de Puebla i6ı2-1633, 24 de febrero de i6ı 4 / Calle del Carmen que va a la iglesia mayor, f. 48f. / Diego López, librero. 3 pesos / Barrio de San Francisco, f. 49f / Pedro Fernandez Moreno, aprensador 6 pesos.

AGMP, Libro de cabezón núm. 3 de alcabalas de la Noble ciudad de Puebla ı6ı2-ı633, 2 de enero de $\mathrm{I}_{14}$, f. 54f. [Al margen izquierdo. Ydem] Yten me hago cago del ducientos y quarenta y cinco pesos, quatro tomines, 6 granos de oro común que el dicho Andres Alonso de la Cueva medio y entrego a ducientos del alcabala del viento desde 30 de septiembre de seiscientos y treze hasta treinta y uno de octubre de los quales se escalfaron veynte pesos, 3 tomines, los quatro pesos, quatro tomines de papel, tinta y canones y los 15 pesos, 7 tomines que le pertenecieron de su cobranca, a $6 \%$ quedaron liquidados los dichos ducientos y quarenta y cinco pesos, 4 tomines, 6 granos como consta y pareze y el fenecimiento que liquide con el dicho receptor que esta en su libro octavo a fojas io6.

\section{Inventarios de Bibliotecas, Biblioteca Lafragua, Puebla*}

Índice general de los libros que tiene la librería de el colegio de el Espíritu Santo de la Compañía de Jesús de la Puebla. Puebla. Hecho en 1757. Tamaño folio. Encuadernado en piel. Consta de 516 folios. Este inventario fue digitalizado a libro abierto (a baja resolución) por el Dr. Efraín Castro. cb. I0039.

Inventario del Colegio de San Ildefonso (I7 de abril de I769). Tamaño folio. Carece de encuadernación. Está separado por cuadernillos que tienen una numeración en la primera hoja. El resto carece de foliación. Este inventario fue digitalizado (baja resolución) por el Dr. Efraín Castro y veo que consta de 473 imágenes tomadas a libro abierto; supongo que por ahora el dato sirve de referencia. (Disco: Librerías 3; a partir de imagen 373 a 486), Cb. 48283.

Inventario del Colegio de San Ildefonso (I7 de abril de I769) Parte A: Abecedario de los Libros Sagrados Expositivos Concilios y de S.S. P.P. que se hallan colocados en esta Libreria del Colegio de San Ildefonso de Puebla. Tamaño folio. Carece de encuadernación y foliación. Está separado por cuadernillos cosidos y por temática. Este inventario fue digitalizado a baja resolución por el Dr. Efraín Castro; está incompleto. (Disco: Librerías 3; a partir de imagen I a 90). La digitalización inicia con los libros Ascéticos, que es prácticamente a la mitad del legajo. s/Cb. (En teoría, continuación del 48283).

Inventario del Colegio del Espíritu Santo de la ciudad de la Puebla de los Angeles en Nueva España. Documento $8^{\circ}$ (octavo) [texto tachado] que satisface a los puntos contenidos en el Artículo is de la Real Instrucción en 3 de Diziembre de 1784 por lo respectivo à la Libreria del dicho Colegio y obras particularmente encontradas en los Aposentos. Ref. $4_{2283}$ B. Legajo sin encuadernar. Carece de foliación original. Fue foliado a lápiz con la siguiente numeración: 18 cuadernillos: [2 h], [156 h]. Este inventario fue digitalizado -incompleto- a baja resolución por el Dr. Efraín Castro (Disco: Librerías 3; imágenes de la 9r a la 372). .... Cb. S/D. (En teoría, continuación del 48283).

Inventario de los libros Sagrados del Colegio de San Ildefonso. Tamaño folio. Carece de encuadernación. Está cosido. Este inventario fue digitalizado a baja resolución y a libro abierto por el Dr. Efraín Castro. (Disco: Librerías 2; 444 imágenes). Cb. 48282 (código duplicado).

Memoria de los Libros, que Componen la Libreria de este Oratorio de Nuestro Padre San Phelipe Neri. Desta Ciudad de los Angeles que se hizo siendo Prep..$^{\text {to }}$ el Padre Don Blas Davila Galindo en 26 de Junio del año de 1756. Tamaño $4^{\circ}$. Encuadernado en pergamino. Consta de 30 folios. Cb. Ioo42.

\footnotetext{
*Agradecemos las referencias de estos inventarios a Mercedes Salomón Salazar.
} 


\section{Fuera del periodo novohispano}

Entrega de la Biblioteca del Colegio [del estado] hecha por el Sr. Lic. Manuel Treiria al Sr. Lic. Manuel Brito y Cota. Tomo II. Octubre de Igoo. Tamaño folio. Encuadernado. Manuscrito. Cb. 25375.

Inventario General de las obras existentes en la Biblioteca Palafoxiana de la Ex-Universidad Católica, y que se trasladan por disposición del Superior Gobierno del Estado, a la Biblioteca Lafragua, dependiente del Colegio del Estado. Diciembre de 19I5. Tamaño folio. Encuadernado. Mecanografiado. 608 folios. Cb. 25382 .

Inventario de la biblioteca Lafragua del Colegio del Estado de Puebla. Tamaño folio. Encuadernado. Manuscritos. Primer libro firmado en marzo de 1893 . Cb. 25376-25383.

\section{Archivo General de la Nación}

I6oI, AGN, Inquisición, vol. 254, exp. I8, año I6oI, f. I8. Guillermo Enríquez, residente de México contra el procurador del Real Fisco sobre una prensa confiscada a Cornelio Adrián, Impresor, México.

I626, AGN, not. Juan Pérez de Rivera, libro 3362 bis I, ff. 3709-370v.

I666 AGN, Reales Cédulas Duplicadas, vol. 24, exp. 95, 4 de noviembre de I666, f. I48v. Religiosos. Libros. Comisión que se dio a Antonio de Peralta, canónigo de la catedral de Puebla para que revise y corrija las obras publicadas por Inés Vázquez Infante en esa ciudad.

I704-I772, AGN, Indiferente Virreinal, cajas Iooo-I999, caja I432 (digitalizado), exp. 025, año I704-I772, 20 ff. Peticiones de licencia para imprimir almanaques de pronósticos del tiempo hechas a la Santa Inquisición por el Bachiller Juan Martel de Villavisencio, cura Joseph Bernardo de Nogal, impresor de libros, María de Rivera, dueña de Imprenta, María Francisca Gonzaga del Castillo, Joseph Antonio de Villaseñor y Sanchez, Joseph Bernardo de Nogal, impresor y mercader de libros, Christoval de Zuñiga Ontiveros, impresor, el Bachiller Juan Antonio de Ribilla Barrientos clérigo, celador de la Iglesia Catedral de Puebla, Felipe de Zuñiga y Ontiveros, matemático.

I7I4, AGN, General de Parte, vol. 23, exp. 95, año I7I4 (I7 de agosto), f. 8I. Se concede privilegio a la imprenta de Manuel Zerezo para que pueda imprimir los papeles de convite, actos y demas por haber servido a su majestad con cien pesos. Puebla.

I73I, AGN, Matrimonios, vol. 83, exp. I6, año I73I, ff. 335-339. Solicitud matrimonial ambos solteros. Contrayentes: Manuel Joseph Rossales, español, 20 años; Maria de la Candelaria Valverde, mulata, libre, I7 años. testigos y ocupacion: Pedro Nolasco, español, oficial de sastre, 3r años; Manuel Guadarrama, mestizo, oficial sastre, 22 años; Francisco de la Rosa Ladron de Guebara, español, maestro de leer y escribir, 20 años; Juan Francisco Fernandez Orosco, español, 2I años, español, impresor de libros, 2I años; Joseph Gabriel Medina, oficial zapatero, 2I años. Parroquia de San Miguel.

I749, AGN, Inquisición, exp. 94, caja 4779, año I749, I f. Petición de María de Ribera, impresora de la ciudad de Puebla, de licencia para imprimir el pronóstico de temporales para el año siguiente, hecho por el profesor de Matemáticas Miguel Francisco Yllaregui.

I753, AGN, Ordenanzas, vol. I4, exp. I20, fecha junio 26 de I753, ff. IIO-III Despacho de nombramiento de administrador-comisario de la real fábrica y estampa de naipes para los partidos de Cuernavaca e iguala a don José de Jáuregui, junio 25 de I753. En la forma regular y sin premio alguno de las barajas, se libro despacho de administrador-comisario de la real fabrica y estampa de naipes para la ciudad de puebla y su obispado a don Juan de Urra, junio 26 de 1753 . Diversos lugares.

I754, AGN, Colegios, vol. I7, exp. 7, año I775. Reglas de la congregacion de nuestra señora del populo, reimpresa en Puebla, en la imprenta de la viuda de Miguel de Ortega, año de 
I754. Una hoja impresa, corresponde al colegio del espiritu santo de puebla de los angeles en la nueva españa. Puebla.

I762, AGN, Inquisición, vol. Io21, exp. 6, año 1762, ff. 34-19I. Denuncia hecha por el comisario del santo oficio de Puebla de un impreso sin nombre de autor ni de imprenta (la carta manuscrita se dicto en las aulas de gramatica del Colegio del Espiritu Santo, de la c. de j.; y se imprimió en la oficina del colegio de San Ildefonso de la misma compañia) su titulo: defensa de los rr. jesuitas. manuscritos en las fojas 39 a 4I, 60 a 87, 96 a IoI, I34 a I37, I42, I43, I6I a I80, I82 a I87. Edicto impreso prohibiendo su lectura y mandandolos recoger en la foja 42. Puebla de los Ángeles.

1764, AGN, Matrimonios, vol. 33, exp. 37, año 1764, ff. 155-157.

I773, AGN, General de Parte, vol. 51, exp. I27, año I773, ff. I33r-I33v. Se ordena al gobernador proceda en la pretension de pedro de la rosa, vecino y comerciante, para que se le permita a su hija y otras mujeres, imprimir. Se ordena sea con anuencia del administrador de la imprenta perteneciente a los colegios. Puebla.

I775, AGN, Colegios, Contenedor 07, vol. I7, exp. 7, año I775. Reglas de la congregacion de nuestra señora del populo, reimpresa en Puebla, en la imprenta de la viuda de Miguel de Ortega, año de i754. una hoja impresa, corresponde al Colegio del Espiritu Santo de Puebla de los Ángeles en la Nueva España. Puebla.

I777, AGN, General de Parte, vol. 57, exp. 249, año I777, ff. 2IIv-212. Para que la justicia haga que Pedro de la Rosa reconozca la firma del escrito y confirmando ser suya y cierto el contenido le requiera a pagar a Francisco Espinosa y darle las cartillas que estan depositadas en el oficio del cabildo. Puebla.

I777, AGN, Reales Cédulas Originales, vol. 238, exp. Io9, año agosto I4 de I777, f. 3. Imprentas. Al virrey de Nueva España, ordenandole, que enterado de los particulares que se citan, relativos al privilegio concedido a Pedro de la Rosa, para que en su imprenta, y no en otra, se puedan imprimir las actas, conclusiones y papeles de combite que se ofrezcan en la ciudad de puebla, informe lo que se ofrezca, y que ejecute lo que se expresa.

I778, AGN, General de Parte, vol. 6o, exp. 233, año I778, ff. 202-203v. Se aprueba y confirma el remate en arrendamiento, hecho por la ciudad de Puebla, de la plaza publica, cajones, jacales, a Pedro de la Rosa, por 5 años. Puebla.

I778, AGN, Inquisición, vol. II82, exp. 7, año I778, ff. 98-99. Don Manuel Antonio Valdes de esta ciudad de Puebla, solicita a nombre de don Miguel Francisco de Ilarregui licencia para publicar el pronostico de temporales para el año de i779. Puebla.

I779, AGN, Mapas, Planos e Ilustraciones, Plaza pública de Puebla, Pue., año I779, i Plano, soporte papel marquilla con dimensiones de 36.4 x $49.6 \mathrm{~cm}$ [Don Pedro de la Rosa]. Puebla. Imagen de la Plaza Pública de Puebla en donde se muestran las calles aledañas, construcciones como portales, el cementerio de la catedral, el Palacio, la Alhóndiga, los jacales antiguos y nuevos, las Plazuelas de Cajones, la picota y en el centro una fuente de dos pisos adornada en su parte superior con un ángel sosteniendo en la mano derecha una espada. En la parte inferior se encuentran las especificaciones de las medidas y de uso de las construcciones. El documento y plano van dirigidos a don José de Cossio, Administrador de la Real Renta, a fin de que se le mande el presupuesto para la obra a Don Pedro de la Rosa. Digitalizado.

I78I, AGN, Reales Cédulas Originales y Duplicados, vol. I2I, exp. 32, 2 fojas, año julio 23 de I78I.

I783, AGN, Inquisición, I208, 24, año I783, ff. 292-322. Expediente formado con motivo de una denuncia hecha contra el br. Don Juan Caballero, Capellan y musico de la santa iglesia catedral de Puebla por el padre fray Manuel de Borja y Gandia, religioso, laico de san 
Diego, morador actual del convento de Santa Maria Magdalena de religiosos descalzos, del pueblo de San Martin Texmelucan y, por las sospechas que contra este resultan de falso denunciante, se le dio una audiencia de cargos y en ella se declaro por tal. Mexico. I783, AGN, Alcaldes Mayores, vol. 8, año marzo 21 de I783, f. I25. Arrendamiento de imprenta. Se ordena al gobernador de puebla mande pregonar en esa capital el arrendamiento del privilegio de impresion de catecismos y cuadernillos de gramatica, para todas aquellas personas que quieran hacer postura a dicho arrendamiento. Puebla.

1784, AGN, Inquisición, vol. I2II, exp. I3, año 1784, ff. 276-277. Don Jose Francisco de Odria, solicita el pase correspondiente para ocho cajones de cartillas, catones y catecismos etc. que remite de Puebla el impresor don Pedro de la Rosa.

I785, AGN, General de Parte, vol. 69, exp. I43, año I785, ff. 239-245v. Se aprueba el remate en arrendamiento del privilegio de la impresion de catecismo y otros cuadernillos, celebrado en Pedro de la Rosa, por tiempo de cinco años. Mexico.

1786, AGN, Indiferente Virreinal, caja 5592, exp. 031 (Archivo Histórico de Hacienda, caja 5592), año 1786, io ff. Intendencia de Guadalajara, Contenido: Fragmento de una cuenta de haberos en Cocula, de abril y mayo de 1786, pago de renta en la casa de Ana Santacruz, cuenta de Pablo Villegas y Joachin de Ortega, por maíz y pastos para mulas.

I786, AGN, Inquisición, vol. I254, exp. 2, año I786, f. 4. Don Joaquin de Echarte, dice: que en esta Real Aduana estan detenidos 3 cajones de catecismos del p. Ripalda, dos balones de cartillas, y un balon de cartones censorinos que remite de la ciudad de Puebla d. Pedro de la Rosa, solicitando se le de el pase correspondiente para que se le entregen.

1787, AGN, Inquisición, vol. I273, exp. 8, año I787, f. 83. Don Pedro de la Rosa, vecino y del comercio de Puebla, solicita se le entreguen en la aduana dos cajones de catecismos del p. Ripalda, y un cajon con veinte resmas de catones censorinos y evangelios. Mexico.

1787, AGN, Inquisición, vol. I292, exp. I8, año 1787, f. 209. Don Pedro de la Rosa presenta la factura de 8 cajones de libros y un balon de cartillas.

I788, AGn, Mapas, Planos e Ilustraciones, Casa en Puebla de los Ángeles, Pue., año 27 de agosto de i788. I Plano, soporte papel con dimensiones de 29.3 x 21 cm, José Ignacio del Castillo, Escribano Real y Público, Contenido: Puebla. Se demuestra la inútil disposición en que se hallaba la casa habitada por Don Pedro de la Rosa antes de ser realizadas las mejoras y construir en ella la disposición para la imprenta. Se encuentra manifestado por orden del alfabeto, de la siguiente forma: A: Tienda, B: Bodega Obscura, C: Zaguán y entrada por el patio, D: Patio, E: Tránsito a otra casita, F: Trastienda, G: Tres cuartos obscuros y bajo techo, H: Canalillo, I: Caballerías, J: Un cuarto inútil, K: Dos escalerillas, cada una ascendía a un cuarto pequeño, y L: Ancon de la otra casa. El plano fue elaborado bajo la supervisión del Maestro de Arquitectura Don Antonio de Santa María Inchaurregui y el oficial de Albañilería Francisco Baltazares, teniendo lugar esta causa en la Ciudad de Puebla de los Ángeles.

I788, AGN, Mapas, Planos e Ilustraciones, Casa en Puebla de los Ángeles, Pue., fecha 27 de agosto de I788. I Plano, soporte papel con dimensiones de 29.4 x 2I cm, José Ignacio del Castillo, Escribano Real y Público, Contenido: Puebla. Se muestra la última disposición de la Casa habitada por Don Pedro de la Rosa, así como los cambios y reparaciones realizadas en ella, donde tiene lugar su imprenta. En color rojo y con las letras "A", "B" y "C" son indicados las partes antiguas de la casa, correspondiendo a la Tienda, trastienda y zaguán, así como, son delineadas en color amarillo, las partes reparadas y sus mejoras en la siguiente disposición: D: Patio, E: Pieza de Laminas, F: Gateron y G: Escaleras y corredores. Causa seguida de la anterior. 
I788, AGN, Indiferente Virreinal, caja 6232, exp. 068, año I788, 4 ff. Real Audiencia. Real provición para que el Gobernador Intendente de Puebla, notifique a Manuel Navarro el traslado de los autos que contra el se siguen de una imprenta. México.

I789, AGN, Inquisición, vol. I273, exp. I, año I789, f. I5. Don Pedro de la Rosa, solicita se le entreguen en la Real Aduana, 3 cajones conteniendo catecismos del p. Ripalda.

I790, AGN, Inquisición, vol. I327, exp. 3, año I790, ff. II-I2. Don Pedro de la Rosa solicita se le entreguen en la aduana 2 cajones de efectos de imprenta, con los libros cuya factura adjunta. Mexico.

I790, AGN, Inquisición, vol. I309, exp. I2, año I790, f. I37. Diego Fernandez de Leon, impresor y mercader de libros de la ciudad de la Puebla de los Ángeles, solicita se le entregue en la Real Contaduria un cajon conteniendo los libros cuyos titulos adjunta.

I79I, AGN, Inquisición, vol. I3I4, exp. 5, año I79I, f. 15, 22. Don Juan Jose Mauriño, solicita se le entreguen tres cajones que contienen catecismos y catones cristianos, que le remite de puebla d. Pedro de la Rosa. Mexico.

I793, AGN, Inquisición, vol. I264, exp. 5, año I793, f. 257. Don Juan Manuel Gomez Dosamantes, solicita el pase para 2 balones de cartillas que el impresor de Puebla d. Pedro de la Rosa remite a esta para su expendio.

I795, AGN, Inquisición, vol. I325, exp. 6, año I795, f. I24. Don Jose Carballo, vecino de esta capital, ha recibido de d. Pedro de la Rosa impresor de Puebla, cinco cajones de catecismos, dos balones de cartillas, y un sobornal con evangelios, que se hallan en esta Real Aduana, pidiendo el pase para extraerlos.

I795, AGN, Inquisición, vol. 1354, exp. I7, año I795, f. I29. Factura de dos cajones de devocionarios impresos, que remitio d. Pedro de la Rosa al r. p. fr. Gabriel de la Madre de Dios, misionero apostolico del Colegio de Pachuca, cuya lista adjunta.

I795, AGN, Inquisición, vol. I390, exp. II, año I795, f. 399. Factura de Io cajones y I2 balones de efectos de imprenta que remite dn. Pedro de la Rosa a dn. Jose Carballo Angeles.

I796, AGN, Inquisición, vol. 1253, exp. 5, año 1796, f. I3. Don Diego Martinez Movellan solicta el pase correspondiente, para sacar de la Real Aduana, cuatro cajones con catecismos del p. Ripalda, 2 cajones de catones cristianos, y 5 balones de cartillas, que de Puebla le remite d. Pedro de la Rosa. Mexico.

I796, AGN, Inquisición, vol. 1357, exp. 5, año 1796, f. 98. Don Jose Garballo, vecino de esta capital, solicita el pase correspondiente para 5 cajones de catecismos del p. Ripalda que le remite para su expendio d. Pedro de la Rosa. Mexico.

I796, AGN, Inquisición, vol. 1357, exp. 5, año 1796, f. I47. Don Pedro de la Rosa, solicita se le entreguen en la Real Aduana 6 valones de cartillas, 3 de catecismos y 3 de catones cristianos que le remite de Puebla d. Pedro Pascual de la Rosa.

I797, AGN, Inquisición, vol. 1354, exp. 17, año 1797, f. 6. Don Juan Manuel Gomez Dosamantes, vecino de esta ciudad, suplica se le de el pase correspondiente para 22 tercios y cajones de catones, catecismos y cartillas, que de Puebla remite don Pedro de la Rosa. Mexico.

I798, AGN, Inquisición, vol. I325, exp. 6, año I798, f. 47-48. Don Pedro de la Rosa, solicita el pase para i6 balones y cajones de impresos que le remite de Puebla d. Pedro Pascual de la Rosa.

I8or, AGN, Indiferente Virreinal, caja 5515, exp. I24, año ı8or, 2 ff. Pedro de la Rosa, Contenido: Pedro de la Rosa, solicita al Ilustrísimo Sr. le otorgue pase para que en la Real Aduana no le retengan, cartillas, relaciones, catecismos y catones cristianos que necesita. México.

I8or, AGN, Inquisición, vol. I264, exp. 5, año I8or, f. 330. Don Pedro Marcos Gutierrez, solicita el pase de un cajon de catecismos que de Puebla le remite d. Pedro de la Rosa. 
I8oI, AGN, Inquisición, vol. I405, exp. 2, fecha I8oI, f. II7. Don Pedro Marcos Gutierrez solicita el pase para que le sean entregados en la Real Aduana, i balon de cartillas y i cajon de catones y catecismos que le remite don Pedro de la Rosa. Mexico.

I8oI, AGN, Inquisición, vol. I406, exp. 27, fecha I8or, f. 266. Don Pedro de la Rosa, del comercio de Puebla, residente en Mexico, solicita el pase para que se le entregue en la Real Aduana, 2 piezas con cartillas, catecismos, margaritas seraficas, colectivos y estampas del arbol genealogico de Cristo, ademas tres resmas de evangelios y tres de catones sensorinos. Mexico.

I802, AGN, Inquisición, vol. 1408, exp. 5, fecha I802, f. 49. Diego Martinez, vecino de esta capital, solicita se le entreguen 4 cajones del caton cristiano, y catecismo del p. Ripalda, que remitio para su venta dn. Pedro de la Rosa, impresor en Puebla. Mexico.

I802, AGN, Inquisición, vol. I4II, exp. 17, fecha 1802, f. 136. Don Roque Perez Gomez solicita se le entregue en la Real Aduana los libros cuya lista adjunta, un balon de cartillas que le remite de Puebla, dn. Pedro de la Rosa.

I802, AGN, Inquisición, vol. I4II, exp. 17, fecha I802, f. I46. Don Diego Martinez solicita un pase para I cajon de libros que contiene 85 docenas de catones cristianos, y 17 docenas de catecismos, que le remitio de Puebla, dn. Pedro de la Rosa.

ı803-1810, AGN, Civil, vol. 356, exp. 2, fecha ı803-18ıo, f. 56. Puebla. Demanda puesta por Pedro de la Rosa, a la testamentaría del Bachiller José Fernández de Jauregui; sobre pesos, por valor de unas cartillas y otros libros, que dicho Pedro puso para su venta en la imprenta que fue del Bachiller y que hoy pertenece a Francisco de Sales Quintero.

I803, AGN, Inquisición, vol. I4II, exp. I67, fecha I803. Diego Martinez solicita el pase para un balon conteniendo cartillas catones y evangelarios que le remite Pedro de la Rosa impresor de Puebla.

I803, AGN, Inquisición, vol. I419, exp. 2, fecha 1803, f. I64. Don Diego Martinez, vecino y de este comercio, solicita el pase para un balon con 25 resmas de cartillas, que remite para su venta, dn. Pedro de la Rosa.

I803, AGN, Inquisición, vol. I4I6, exp. 2, fecha ı8о3, ff. II2-II3. Don Leonardo Alvarez solicita el pase para los efectos de imprenta que le remiten de Puebla, segun la nota adjunta.

I804, AGN, General de Parte, vol. 65, exp. 263, fecha I804, ff. 225-228. Para que se notifique a Pedro de la Rosa acuda a recibir el despacho de aprobacion del asiento de impresion de cartillas. Puebla.

1804, AGN, Inquisición, vol. I423, exp. 6, fecha 1804, f. 98. Don Diego Martinez Mobellan solicita el pase para que se le entreguen en la Real Aduana, 2 balones con 50 resmas de cartillas impresas, y que le remite dn. Pedro de la Rosa, de Puebla. Mexico.

I805, AGN, General de Parte, vol. 8o, exp. 70, fecha I805, ff. 8I-88v. El virrey aprueba y confirma el remate del privilegio de impresion de cartillas del reino que finco en Pedro de la Rosa, concediendose el tiempo de nueve años si su majestad se digna dispensarlo y la de que solo se han de satisfacer al asentista, las impresiones de secretaria y gobierno que excedan de 5 o 6 pliegos de impreso y no de manuscrito. Puebla.

ı805, AGN, Reales Cédulas Originales y Duplicados, vol. 196, exp. 176, fecha octubre 3 de 1805, f. 2. Cartillas para niños, aprobando el remate del arrendamiento del privilegio de imprimir cartillas por nueve años, en don Pedro de la Rosa.

I805, AGN, Inquisición, vol. I429, exp. I, fecha 1805, ff. 75-76. Don Juan Bautista de Arizpe solicita que le entreguen los efectos de imprenta, que estan detenidos en la Real Aduana y que le remite dn. Pedro de la Rosa, librero en la Puebla de los Ángeles.

I806, AGN, Inquisición, vol. I43I, exp. II, fecha I806, ff. I20-I2I. Don Juan Bautista de Arizpe presenta la razon de los efectos de imprenta que remite de Puebla el impresor, don Pedro de la Rosa. 
1807, AGN, Inquisición, vol. I436, exp. 9, fecha 1807, f. 200. Don Tomas del Cañizo solicita el pase para un cajon de catecismos y catones que le remite de Puebla, don Pedro de la Rosa. I8Io, AGN, Inquisición, vol. I447, exp. I3, fecha I8Io, f. 222 bis (13 de octubre). Don Dionisio Martinez Movellan solicita el pase para los libros que le remite de Puebla don Pedro de la Rosa.

I8Io, AGN, Inquisición, vol. I449, exp. I, fecha I8Io, f. I5 (Io de enero). Don Dionicio Martinez Movellan solicita el pase para un balon con 24 resmas de cartillas y un cajon con 206 docenas de catecismos del p. Ripalda, que remite de Puebla el impresor don Pedro de la Rosa. I8Io, AGN, Inquisición, vol. I449, exp. I, fecha I8Io, f. 46 (8 de marzo). Don Dionisio Martinez de Movellan solicita el pase para un balon con 40 resmas de cartillas que le remite de Puebla el impresor don Pedro de la Rosa.

I8Io, AGN, Inquisición, vol. I449, exp. I, fecha I8Io, f. II4 (II de mayo). Don Dionisio Martinez Movellan solicita el pase para 24 resmas de cartillas, Izo docenas de catones, y 2 II docenas de catecismos del p. Ripalda, que le remite de Puebla don Pedro de la Rosa.

I8I3, AGN, Indiferente Virreinal, caja 5998, Lotería 5998-024, fecha I806, 6 ff. Oficio de Joseph María Lassos y Joseph de Vildosola, para el virrey, sobre que franquearán a don Manuel Antonio Valdes I40 balones de papel que escoja del que vendió la Renta del Tabaco para impresiones de la Real Lotería. México; NR 9360, GD 7, vol. 2, exp. Io, fecha I8I3, ff. 219220. Gastos grales, pago de \$221 a Desiderio Maza por el importe de I3 resmas (resmas) de papel que compraron para reintegrar al impresor al que suplió las bandas y guías que se imprimieron México.

I8I5, AGN, Inquisición, vol. I458, exp. 2, fecha I815, f. 30, 31-32 (8 de febrero). Don Pedro de la Rosa, vecino de Puebla, pide el pase para 5 tercios y i envoltorio de impresos de catones, catecismos y cartillas. Factura de los libros que remite don Agustin de la Peña y Santiago, que remiten a Mexico a don Francisco de Santiago Orrantia.

I8I5, AGN, Inquisición, vol. I458, exp. 2, fecha 1815, f. 70 (2I de agosto). Don Pedro de la Rosa, del comercio de Puebla, solicita el pase para cinco piezas con los libros que constan en la factura que adjunta.

I8I5, AGN, Inquisición, vol. I458, exp. 2, fecha I8I5, f. 87 (2I de agosto). Don Pedro de la Rosa presenta la factura de los impresos que remite don Mariano de la Rosa.

I8I5, AGN, Inquisición, vol. I458, exp. 2, fecha I815, f. 36 (I2 de junio). Don Pedro de la Rosa solicita el pase para 6 tercios, y cajones y un envoltorio con los impresos siguientes: "catecismos del p. Ripalda". "caton censorino", "caton cristiano", cartillas y silabarios.

I8I6, AGN, Inquisición, vol. I458, exp. 2, fecha I8I6, f. 9I (II de junio). Don Dionisio Cicero de Lombraña presenta la lista de los impresos que en 7 bultos le remite don Pedro de la Rosa, de la imprenta de Puebla.

I8I7, AGN, Indiferente Virreinal, caja I227, exp. o22 (Impresos Oficiales, caja I227), fecha I8ı7, 4 ff. Milicia. Provincias de Oaxaca, Puebla y Cuautla Amilpas. Gaceta del Gobierno de México. Tomo viII, núm. Io98, 7I7. Imprenta de Juan Bautista de Arizpe.

I8I7, AGN, Inquisición, vol. I464, exp. I4, fecha I8ı7, f. 59 (17 de mayo). Jose de Merodio solicita el pase para 5 cajones conteniendo catesismos, catones y cartillas que remite de Puebla $\mathrm{d}$. Pedro de la Rosa. Lista incompleta de libros. Mexico.

I8I8, AGN, Inquisición, vol. I421, exp. 22, fecha 1818, f. I75. Don Pedro de la Rosa solicita el pase para un cajon de catones cristianos, que le remite de Puebla dn. J. Antonio Porras, de aquel comercio. Mexico.

I8I8, AGN, Inquisición, vol. I458, exp. 2, fecha I8I8, f. I87 (I4 de abril). Don Jose Merodio pide el pase para varios impresos que le remite don Pedro de la Rosa. 
I8I8, AGN, Inquisición, vol. I458, exp. 2, fecha I818, ff. 208-209, contenido: (I3 de febrero). Don Tomas Lopez, vecino de esta capital, presenta la lista de los impresos que don Pedro de la Rosa le remite a esta capital, cuyo pase solicita.

I8I9, AGN, Inquisición, vol. I469, exp. 4, fecha 1819, f. 53 (I de diciembre). Don Tomas Lopez, vecino de esta capital, dice: que su poderdante, d. Pedro de la Rosa, vecino de la ciudad de Puebla, le remite dos balones de cartillas y tres de catecismos y entre ellos 40 docenas de catones.

I82I, AGN, Gobernación, Circular impresa del Ministerio de Relaciones Exteriores, Gobernación y Policía, vol. I6/I, exp. 27, fecha ı821, f. r. Puebla. Notificacion de Carlos García de haber recibido la orden al editor de la Imprenta Libertad de remitir todos los periódicos a la Intendencia.

I82I, AGN, Gobernación, Circular impresa del Ministerio de Relaciones Exteriores, Gobernación y Policía, vol. ıo, exp. 48, fecha ı821, f. 39. Puebla. Solicitud de Mariano Monroy, pide la plaza de rer. guarda vista de Casa de Moneda u otro.

I822, AGN, Gobernación, Circular impresa del Ministerio de Relaciones Exteriores, Gobernación y Policía, vol. 19, exp. 198, fecha 1822, f. 32. México. Solicitud de Baltazar Ruiz, en Puebla, para establecer una imprenta de gobierno.

I823, AGN, Gobernación, Circular impresa del Ministerio de Relaciones Exteriores, Gobernación y Policía, vol. 55, exp. 3, fecha I823. México. Imprenta Nacional del Supremo Gobierno. Cuadernos del i al 7 de comprobantes de partida y muestras de algunos impresos hechos en las imprentas.

I825, AGN, Movimiento Marítimo, Pasaportes y Cartas de Seguridad, vol. 2, exp. I88, fecha I825, f. 4 O. México. Furlong, Joaquín.

I825, AGN, Relaciones Exteriores, caja 36, exp. 204, fecha I825, 04/II-1828, ff. 32-33. México. Notas de la Secretaría de Relaciones, que refieren la autorización para expedir un pasaporte a favor de Joaquín Furlong, ciudadano mexicano que viajará a Europa.

I829, AGN, Gobernación, Circular impresa del Ministerio de Relaciones Exteriores, Gobernación y Policía, vol. I20, exp. I, fecha I829. Puebla. Relaciones con los estados. Imprenta del Gobierno. Noticia de los ingresos y egresos de dinero que ha habido en la cuarta semana del mes de marzo en la imprenta del Gobierno del Estado, con expresión de los ramos que han producido unos y otros.

I855, AGN, Justicia, Contenedor Io8, vol. 532, exp. 208, fecha i855. Puebla. Solicitud del promotor de Hacienda para la rectificación del cobro de la pensión testamentaria del presbítero Joaquín Furlong, ff. 305-310.

I888, AGN, Historia, vol. 599, exp. Único: Constitución Federal de los Estados Unidos Mexicanos con sus adiciones y reformas. Traducido al idioma Azteca o mejicano, fecha I888. $59 \mathrm{ff}$. frente y vuelta. En total II8 páginas. Impreso. Miguel Trinidad Palma, Imprenta de Hospicio. Texto de la Constitución Federal de los Estados Unidos Mexicanos de 1857, con sus adiciones y reformas hasta 1887. Traducida al idioma azteca o mexicano por Miguel T. Palma, catedrático, Puebla, Imprenta del Hospicio. Con dedicatoria “Al eminente hombre de Estado C. General Porfirio Díaz y á la muy ilustre y distinguida Academia del Colegio de Estado de Puebla”. Condiciones de Acceso: Documento reservado. Disponible para consulta la versión digital

S/fecha, AGN, Inquisición, ts. 65, núm. 5, 252 A.5, 236 A.I8. Citado por Francisco Fernández del Castillo, Libros y libreros del siglo XVI, México, FCE, I982, p. 530.

$\mathrm{S} /$ fecha, AGN, Indiferente Virreinal, caja 5282, exp. 047 (Real Hacienda, caja 5282), sin fecha, 2 ff. $\mathrm{S} /$ fecha, AGN, Indiferente Virreinal, caja I338, exp. oI7, sin fecha, 2 ff. Colegio Real de San Ignacio. Memoria de los caracteres que se han de remitir al Colegio Real de San Ignacio de la ciudad de Puebla de los Ángeles, para completar su imprenta. 
S/fecha, AGN, Inquisición, vol. 1264, exp. 5, fecha s/a, f. 28o. Don Pedro de la Rosa, impresor, remite a don Jose Carballo, catecismos, cartillas y evagelios. Mexico.

\section{Archivo General de Notarías de la ciudad de México}

AGNM, not. Antonio Alonso, libro 2, f. 323-324 (495/497).

AGNM, not. Antonio Alonso, libro 5, f. I389-1392v, México, 2I de julio de 1576: "Unas tijeras viejas, a peso y medio, 3 ruedas para oro, 3 gusanillos, 2 punzones y I flor, en I2 pesos; I2 listones para breviarios, a 3 tomines cada uno y roo manos de libros en blanco, encuadernados, a 2 tomines y medio la mano, todos de 4 manos para arriba, montan $3^{\mathrm{I}}$ pesos".

AGNM, not. Juan Pérez de Rivera, libro 3362 bis I, ff. 3709-370v, I626/II/20. Catálogo IIE-29, ficha 301.

AGNM, Antonio Alonso, libro 9, ff. 520-520v (I239-I240).

\section{FUENTES SECUNDARIAS}

\section{Artículos y capítulos de libros}

Aznar Grasa, José Manuel, "La ilustración del libro impreso en Salamanca: Siglos xv y XVI. Análisis cuantitativo y temático", en El libro antiguo español: Actas del Segundo Coloquio Internacional. Madrid: Pedro Manuel Cátedra García y María Luisa López-Vidriero Abello (coords.), I992, p. 6I-95.

BÁEz Macías, Eduardo, "El grabado durante la época colonial", en Historia del arte mexicano. México: Secretaría de Educación Pública / Salvat Editores, 1986, t. 8, p. II9I-I205.

Calvo, Hortensia, "The Politics of Print: The Historiography of the Book in Early Spanish America", en Book History, vol. 6, 2003, p. 277-305.

Corbeto López, Albert, "Tipografía y caligrafía en España durante la segunda mitad del siglo XviII. Carácterísticas de la letra bastarda en los caracteres de Jerónimo A. Gil”, en Actas del II Congreso de Tipografia de España. Valencia, 2006, p. 54-59.

Cruickshank, D. W., "Some Aspects of Spanish Book-production in the Golden Age", en The Library, $5^{\text {th }}$ serie, vol. XXXI, núm. I, March 1976, p. I-I9.

Cruickshank, Don, “Towards an Atlas of Italic Types Used in Spain, I528-1700”, en Bulletin of Spanish Studies, vol. LxxxI, núm. 7-8, 2004, p. 973-гого.

Dibble, Charles, "The Wathermarks in the Florentine Codex," en Arthur Anderson y Charles Dribble. Florentine Codex, Introductory volume. Salt Lake City: University of Utah Press, I982, p. 25-29 + apéndices.

Estrada DE GERlero, Elena, "El arte plumario colonial novohispano y el grabado europeo. Un ejemplo de interacción” (Nuevo Mundo Mundos Nuevos, 02-06-2006).

, "El monograma de Jesús-María en las mitras de plumaria" (XXVIII Coloquio Internacional de Historia del Arte). La imagen sagrada y sacralizada. Campeche, 2004).

FAHY, Conor, "Descrizioni cinquecentesche della fabricazione dei caratteri e del proceso tipográfico," en The Library, I986, año LXxxviII, núm. I, p. 47-76.

FERNÁNDEZ, Justino, "Las conferencias de Atilio Rossi sobre tipografía” y "Mexican Art and Life”, en Anales del Instituto de Investigaciones Estéticas, vol. I, núm. 3, I939, p. 76-77.

— "Las ilustraciones en el libro mexicano durante cuatro siglos I539-1939", en Maso Finiguerra, núm 4, Milano, 1939, p. I26.

Galí Boadella, Montserrat, "El patrocinio episcopal en la ciudad de Puebla: el caso del obispo Manuel Fernández de Santa Cruz, I677-1699", en Actas del III Congreso Internacional del Barroco Iberoamericano. Sevilla, Universidad Pablo de Olavide, 8 al I2 de octubre de 200I, p. 7I-90. 
Galí Boadella, Montserrat, "La llegada de libros de arte a la Nueva España, siglos XVII-XviII", conferencia inédita pronunciada en el Museo de la Basílica de Guadalupe, i2 de enero de 2008. "La ornamentación en la imprenta poblana de los siglos xviI y xviII. El caso de la imprentas de la vda. de Borja y Gandia y la viuda de Miguel de Ortega,” en Marina Garone Gravier (comp.). Las otras letras: mujeres impresoras en el mundo del libro antiguo. Memorias del ciclo de conferencias. Puebla: Secretaría de Cultura del Estado de Puebla, 2009.

García Aguilar, María Idalia, "Legislar para preservar el patrimonio documental mexicano: un reto para el nuevo milenio", en Investigación Bibliotecológica: Archivonomía, Bibliotecología e Información, UNAM, CUIB, 2000, núm. 28.

Garone Gravier, Marina, "Diseñadores de la lengua propia: calígrafos y tipógrafos indígenas en la Nueva España”, en Beatriz Arias Álvarez, María Guadalupe Juárez Cabañas y Juan Nadal Palazón (coords.). Mosaico de estudios coloniales (I Coloquio Internacional Lenguas y Culturas Coloniales 2008), Instituto de Investigaciones Filológicas, UNAM, 2013, pp. 327-348.

, "Sahagún's Codex and Book Design in the Indigenous Context", Gerhard Wolf y Joseph Connors (eds.), en Colors between Tro Worlds. The Florentine Codex of Bernardino de Sabagún. Florence: Villa I Tatti, 20II, p. 156-197.

"Herederas de la letra: mujeres y tipografía en la Nueva España", en Casa de la Primera Imprenta de América. México: UAM / Gobierno de la Ciudad de México, 2004, p. 63-8I.

, "Kuati'a guarani: tres momentos de la edición tipográfica del guaraní (siglos XVII, XIX y XXI)", en $V$ Foro de lenguas indígenas. Barcelona, Casa América en Catalunya, 2010.

, "La imagen en las ediciones novohispanas en lenguas indígenas (siglos XVI-XIX)," en Actas de la III Reunión de la Sociedad Mexicana de Historiografia Lingǘítica [en prensa].

, "Las ediciones poblanas en lenguas indígenas (siglos XVII-XIX)", en La Imprenta de los Ángeles. Panorama bistórico de la imprenta poblana (I642-I822), Ciclo de conferencias. Biblioteca Lafragua, 24 de septiembre de 2009 .

, "Las lenguas otomangues y tipografía colonial poblana: comentarios en torno a ediciones en zapoteco, mixteco, y mixe," en Cologuio Thomas Smith-Stark, IV Conferencias sobre las lenguas otomangues y oaxaqueñas. Oaxaca: Biblioteca Burgoa, abril de 2010 [en prensa].

, "Muestras tipográficas mexicanas: comentarios en torno a nuevos hallazgos (siglos XVIII-XX)", en Marina Garone Gravier y Ma. Esther Pérez Salas (comp.). Las muestras tipográfcas y el estudio de la cultura impresa. México: UNAM, IIB, Ediciones del Ermitaño, 20II, p. 233-266.

, "Sonidos sobre el papel: composición tipográfica y estrategias de edición para las lenguas indígenas de la Nueva España”, en Paradigmas de la palabra, actas del ciclo de conferencias realizadas con motivo de dicha exposición bibliográfica. Museo Nacional de Historia / Sociedad Mexicana de Historiografía Lingüística [en prensa].

, "El impresor Diego Fernández de León (I683-I7Io). Primero de la edición colonial poblana en lenguas indígenas" en Lenguas, estructuras y hablantes. Estudio en Homenaje a Thomas C. Smith Stark. México: El Colegio de México, 2014, p. 337-368.

Garza, Sonia, "La cuenta del original", en Imprenta y crítica textual en el siglo de oro. Valladolid: Universidad de Valladolid, 2000, p. 65-95.

Gaskell, Phillip, "The lay of the Case", en Studies in Bibliography, XXII, 1969, p. 135-I42.

GómEz DE Orozco, Federico, "La tipografía colonial mexicana", en Universidad, t. v, núm. 25, México, febrero de 1938.

GrañÉn Porrúa, Isabel, "El grabado libresco en la Nueva España, sus emblemas y alegorías”, en Juegos de ingenio y agudeza. La pintura emblemática en la Nueva España. México: Munal, 1994. 
Griffin, Clive, "Vida personal y profesional de los operarios de imprenta en la España de Felipe II”, en Alberto González S., Carlos y Enriqueta Vila Vilar. Grafias del imaginario. Representaciones culturales en España y América (siglos XVI-XVIII). México: FCE, 2003, p. II5 (Col. Historia).

Hampe, Teodoro, "The Diffusion of Books and Ideas in Colonial Peru: A Study of Private Libraries in the Sixteenth and Seventeenth Centuries," en Hispanic American Historical Review 73, num. 2 (I993), p. 2II-233.

Hernández Sautto, Circe, "Impresos poblanos en la Biblioteca José María Lafragua: Siglos XVII-XVIII, en Graffylia: Revista de la Facultad de Filosofia y Letras (Benemérita Universidad Autónoma de Puebla, nov. 2006, p. 206-219).

Hirschberg, Julia, "La fundación de Puebla de los Ángeles, mito y realidad", en Historia Mexicana, vol, 28, núm. 2 (oct.-dic, I978).

Janssen, Franss A., "Reconstruction of the Common Press: Aims and Results", en Quarendo 32/ 3-4, Leiden, 2002, p. 175-198.

LaíneZ, Marcelo, “Apuntes históricos de Segovia”, s/f., s/e.

López, François, "Los oficios. Las técnicas de venta", en Víctor Infantes, François López y Jean-François Botrel (dirs.). Historia de la edición y la lectura en España (I472-I9I4). Madrid: Fundación Germán Sánchez Ruypérez / Pirámide / Biblioteca del Libro, 2003, p. 348-357.

ManRiQue, Jorge Alberto, "La estampa como fuente del arte en la Nueva España", en Anales del Instituto de Investigaciones Estéticas, México, vol. XII, núm. 50, I982, p. 55-60.

Moreno, Delfino C, "Noticia histórica de la Biblioteca Lafragua, de la Universidad de Puebla", Revista de la Universidad de Puebla, año I, núm, 3 (nov. I943).

MoREt ViÑals, Oriol, "La medida en la tipografía” y "Las otras relaciones tipográficas", en Primer y Segundo Congresos de Tipografía de España (Valencia, 2004 y 2006, respectivamente).

Mosley, James, "Trajan revived”, en Alphabet, vol. i, ig64, p. I7-48.

O’Gorman, Edmundo, “An Early Mexican Xylograph Incunable”, en Mexican Art and Life 7, 1939.

, "Mexican Books in the Sixteenth Century"; "Printing in Mexico in the $17^{\text {th }}$ Century" y "An Early Mexican Xylograph Incunable"; Mexican Art and Life, núm. 7, 1939.

Pascoe, Juan, "Dos notas en torno a Juan Pablos", en Casa del Tiempo. Revista de la Dirección de Difusión Cultural de la UAM, vol. IX, núm. 90, octubre de 1989, p. 42-45.

Salomón Salazar, Mercedes, "Los Borja: una dinastía de libreros e impresores en la Puebla de los Ángeles del siglo XviI. Un primer acercamiento”, en Marina Garone Gravier (comp.). Miradas a la cultura del libro en Puebla. Puebla: UNAM, IIB / Consejo Estatal para la Cultura y las Artes / Ediciones de Educación y Cultura, 2012, p. 205-242.

SMith, Percy, "Initial Letters in the Printed Book", en Fleuron Antbology, Francis Maynell y Herbert Simon (eds.). Toronto: University of Toronto Press, 1973, p. 38-6o.

Thiemer-SachSe, Úrsula, 'Los complejos 'libros e imprenta' en el vocabulario españolzapoteco (1578) de Juan de Cordova”, en Del autor al lector. Carmen Castañeda (coord.). México: Miguel Ángel Porrúa / CIESAS, 2002.

VALton, Emilio, “Algunas particularidades tipográficas de los impresos mexicanos del siglo xvi”. México: Asociación de Libreros de México, 1939, p. 24I-277. (Sobretiro de la obra: IVCentenario de la Imprenta en México, la Primera en América. Conferencias sustentadas en su Conmemoración.

Ward, Kenneth C., "Conjeturas sobre los orígenes de la imprenta en Puebla”, en Marina Garone Gravier (comp.). Miradas a la cultura del libro en Puebla. Puebla: UNAM, IIB / Consejo Estatal para la Cultura y las Artes / Ediciones de Educación y Cultura, 20I2, p. I6I-204. 
Yhmoff Cabrera, Jesús, "Iniciales ornamentadas de dos abecedarios utilizadas en México y en Estella, España, durante el siglo xvi”, en Boletín del Instituto de Investigaciones Bibliográficas, UNAM, 1987, núm. 29, p. 17-30.

\section{Bibliografía}

Alamán, Lucas. Historia de Méjico. Desde los primeros movimientos que prepararon su independencia en el año de 1808 hasta la época presente, edición facsimilar de la de I849, prólogo de Moisés González Navarro. México: Instituto Cultural Helénico / Fondo de Cultura Económica, 1985, 5 t. (Col. Clásicos de la Historia de México).

Alcalá y Mendiola, Miguel de. Descripción en bosguejo de la imperial cesárea, muy noble y muy leal ciudad de Puebla de los Angeles. Puebla: Junta de Mejoramiento Moral, Cívico y Material del Municipio de Puebla, I992.

Altamirano, Ignacio Manuel. Obras completas. México: Secretaría de Educación Pública, 1987, t. 7. ANDrade, Vicente de Paula y Agustín Fischer. Ensayo bibliográfico mexicano del siglo XVII. México: Imprenta del Museo Nacional, I899 [1900].

AGN. Cartografia de Puebla en el Archivo General de la Nación. Puebla: Centro de Estudios Históricos de Puebla núm. 8, 1958, 22 p., mapas.

Audin, Marius. Les livrets typographiques des fonderies françaises créés avant 1800 : étude bistorique et bibliograpbique. París: A l'Enseigne de Pégase, 1933.

BÁEz Macías, Eduardo. Jerónimo Antonio Gil y su traducción de Gérard Audran. México: UNAM, IIE, 2002.

y Judith Puente León. Libros y grabados en el Fondo de Origen de la Biblioteca Nacional. México: UNAM, I989.

BaSkerville, John. A Specimen by John Baskerville of Birmingham in the County of Warwick, Lette. [Birmingham: John Baskerville], I754.

Bátiz Vázeuez, José Antonio. Historia del papel moneda en México. México: Fomento Cultural Banamex, 1987 .

Benito, Javier Blas. Bibliografia del arte gráfico: grabado-litografia-serigrafia, historia-técnicas-artistas, prol. Juan Carrete Parrondo. Madrid: Real Academia de Bellas Artes de San Fernando, 1994, $402 \mathrm{p}$.

Bermúdez de Castro, Diego. Theatro Angelopolitano ó Historia de la ciudad de Puebla. Ed. facsimilar. Puebla: Junta de Mejoramiento Moral, Cívico y Material del Municipio de Puebla, 1985.

Bernat Vistarini, Antonio y John T. Cull. Enciclopedia de emblemas españoles ilustrados. Fuentes clásicas y traducción de los motes. Rev. Edward J. Vodoklys, S. J.; presentación: Peter M. Daly y Sagrario López Poza. Madrid: Ediciones Akal, 1999. [Es un diccionario de fácil consulta que remite a los principales tratadistas del mundo hispano, sumado a que contiene ilustraciones de tratados, así como parte de la explicación de cada emblema].

Berry, W. Turner. Catalogue of Specimens of Printing Types by English and Scottish Printers and Founders 1665-1830, with a new introduction by James Mosley. New York; London: Garland, 1983 (facsim. of 1935 ed. originally published: Oxford, Oxford University Press, 1935).

Biblia. Sagrada Biblia. 37 ed. Versión directa de las lenguas originales: Eloíno Nácar Fuster y Alberto Colunga, O. P. Madrid: Editorial Católica, ${ }_{9} 85$ (Biblioteca de Autores Cristianos, I).

Biblioteca Palafoxiana (Puebla, México). Centro de Investigaciones Bibliográficas, Impresos poblanos de la muy ilustre Biblioteca Palafoxiana, Catálogo comentado (I645-I823). Puebla: Centro de Investigaciones Bibliográficas, Biblioteca Palafoxiana / Secretaría de Cultura, Estado de Puebla, I998. / M. O. [México, 1836, 2] p. 
Blades, William. Some Early Type Specimen Books of England, Holland, France, Italy, and Germany. London: [Printed by J. M. Powell], 1875 .

Boletin Bibliográfico, UNAM, segunda época, tomo viII, julio-septiembre de 1957, núm. 3.

Bolton, Claire. DeLittle: an English Wood-letter Manufacturer: Including a BriefHistory of the Development of Wood-type. Winchester: Alembic Press, 198r.

BRINGHURST, Robert. Los elementos del estilo tipográfico. México: Libraria, FCE, 2008.

BRIQUET, Charles. Les filigranes: dictionnaire historique des margues du papier. New York: Hacker Art Books, 1966, 5 vol.

Buelna Serrano, María Elvira. Proceso inquisitorial contra don Agustín Beven; coronel del regimiento de dragones de México. México: Universidad Autónoma Metropolitana, 1987.

Bustamante, Carlos María de. Cuadro Histórico de la Revolución Mexicana, edición facsimilar de la de 1843, prólogo de Roberto Moreno de los Arcos. México: Instituto Cultural Helénico / Fondo de Cultura Económica, 1985, 8 t. (Col. Clásicos de la Historia de México).

Butler, Alban. Vidas de los santos de Butler. Traducida y adaptada al español por Wifredo Guinea, S. J., de la segunda edición inglesa revisada por Herbert Thurston, S. J. y Donald Attwater. México: John W. Clute, 1969. [Edición anterior, en español, de 1965].

Buxó, José Pascual (dir.). Impresos poblanos de la muy ilustre Biblioteca Palafoxiana. Catálogo comentado (I645-I823). Puebla: Secretaría de Cultura de Puebla, 1998.

Campos-Farfán, César. Gral. Juan N. Almonte. Insurgente, liberal y conservador (Ensayo biográfico). Morelia: Casa Natal de Morelos, 200r (Ediciones Casa Natal de Morelos 2).

Caramuel, Juan de. Syntagma del arte typográfica. Madrid: Fundación Germán Sánchez Ruipérez, 2004 (Serie Menor).

Carballo, Emmanuel. El periodismo durante la Guerra de Independencia, prólogo y selección de... México: Delegación Política de Cuajimalpa de Morelos, 1985.

Carmona Muela, Juan. Iconografia clásica. Guía básica para estudiantes. Madrid: Ediciones Istmo, 2000 (Colección Fundamentos, I6I).

Carrera STAMPa, Manuel. Los gremios mexicanos: la organización gremial Nueva España, I52I-I86I. México: Ediapsa, 1954, I, p. 76 (Col. de Estudios Histórico-económicos Mexicanos de la Cámara Nacional de la Industria de Transformación).

Carta de Diego, Obispo de la Puebla, a S. M. sobre los colegios de San Juan y San Pedro, de Puebla. Puebla de los Ángeles: 30 de mayo de i658 [en línea], en "Manuscritos de América en las Colecciones Reales", Patrimonio Nacional de la Real Biblioteca y Biblioteca Virtual Miguel de Cervantes Saavedra. Madrid, España. http://www.cervantesvirtual.com/ [consulta: 3 de junio de 2008].

CARTER, Harry. Orígenes de la tipografia. Punzones, matrices y tipos de imprenta (siglos XV y XVI). Madrid: Ollero \& Ramos, 1999, 214 p., p. 179. I83.

Caslon, William. A Specimen of Printing Types by William Castlon Letter Founder of bis Majesty. London: Galabin and Baker, 1785 .

Caslon Old Face Roman EF Italic: Cast Entirely from Matrices Produced from the Original Punches Engraved in the Early Part of the Eighteenth Century in Chiswell Street. London: H. W. Caslon \& Co. Ltd., I924.

Castro GutiÉRrez, Felipe. Extinción de la artesanía gremial. México: UNAM, IIH, I986, I88 p. (Serie Historia Novohispana, 35).

Castro Morales, Efraín. La Biblioteca Palafoxiana de Puebla / Efraín Castro Morales. [Puebla]: Editorial del Gobierno del Estado de Puebla, Subsecretaría de Cultura, 198I, I vol., il. La Biblioteca Palafoxiana de Puebla. [Puebla]: Editorial del Gobierno del Estado de Puebla, Subsecretaría de Cultura, I98I, I vol., il. La Biblioteca Palafoxiana de Puebla. Puebla: Gobierno del Estado de Puebla, 198I. 
Castro Regla, Elizabeth. "Comentarios en torno a la marca tipográfica de Diego Fernández de León”. UNAM, FFyL, Historia del Arte, 2008, tesis de maestría.

"Catálogo de los libros españoles que se hallan en la casa del ciudadano José María Romero, calle primera de los Mercaderes, número in en Puebla”, Patriota, núm. 37 (oct. Io, I827). Suplemento.

Caxton Celebration 1877: a Bibliographical Notice of William Caxton, the First English Printer, Reprinted from the Leisure Hour for May, 1877, in Phonetic Spelling with a Specimen Page of Caxton's Type and Woodcuts. London: Fred. Pitman, 1877 .

Cervantes, Enrique A. Bosquejo del desarrollo de la ciudad de Puebla. México: 1938, I5 p.

Cid Carmona, Víctor Julián. “Antonio Ricardo impresor de dos ciudades”, tesis de maestría UNAM, 2005.

Cien impresos coloniales poblanos. México. Instituto Mora, I99I, 2I2 p., il.

Ciм, Albert. Le livre. Histoire, fabrication, achat, classement, usage et entretien. Paris: Flammarion, I905-8, 5 vol.

CirLot, Juan Eduardo. Diccionario de simbolos. Madrid: Siruela, 2000.

Cloister Press. A Display of Fleurons, Ornaments, Flowers, Head and Tail Pieces, Borders, Rules and Frames, Egc. at the Disposal of Clients of the Cloister Press. Heaton Mersey: Cloister Press, 1922. The Garamond Type: Roman and Italic. Heaton Mersey [ca. I92I].

Códice Mendieta. Guadalajara, Jal., Edmundo Ávila Levi, I97ı, t. I.

Colección de los decretos y órdenes más importantes que expidió el Congreso Constituyente del Estado de Puebla en los años I824 y 1825. Puebla: Imprenta del Gobierno, Calle del Hospicio, I827.

Colección de los decretos y órdenes más importantes que expidió el congreso constitucional del Estado de Puebla en los años de 1826, 1827 y I828. Puebla: Imprenta del Gobierno, I828.

Commons de la Rosa, Aurea. Geobistoria de las divisiones territoriales del estado de Puebla. México: UNAM, I97I.

"Copia del oficio dirigido por el Sr. Secretario de Gobierno don Pedro de Azcué y Zalvide, en I3 de julio de I830, al rector del Colegio del Estado, y de la contestación de éste, con los documentos a que se refiere". Puebla: Imprenta del Gobierno, i8zo.

Conbeto, Albert. Daniel Updike y la bistoria de la tipografia en España. Valencia: Comparagraphic, 2011 .

Muestras de tipos de imprenta españolas anteriores al año I833. Madrid: Calambur, 2010.

Cordero y Torres, Enrique. Diccionario general de Puebla / Enrique Cordero y Torres. Puebla de Zaragoza: Unión, 1958, 3 vol.

Historia compendiada del Estado de Puebla [Puebla, México]: Grupo Literario "Bohemia Poblana", 1965-1966.

Historia del periodismo en Puebla. Puebla: Bohemia Poblana, 1947.

Cottrell, T. A Specimen of Printing Types. London, 1765.

Dávila Padilla, Agustín. Historia de la fundación y discurso de la Provincia de Santiago de México de la Orden de Predicadores, ${ }^{\mathrm{a}}$ ed. México: Academia Literaria, 1955.

Davison, William. New Specimen of Cast-Metal Ornaments and Wood Types. Alnwick, I835.

DE PAREDES, Alonso Víctor. Institución y origen del arte de la imprenta y reglas generales para los componedores. Edición y prólogo de Jaime Moll; nueva noticia editorial de Víctor Infantes. Madrid: Calambur, 2002 (Biblioteca Litterae, I).

Delacolonge, Louis. Les caracteres et les vignettes de la fonderie du Sieur Delacolonge, The Type Specimen of Delacolonge. (Lyons 1773). Introduction and notes by Harry Carter. Ámsterdam-London: Van Gendt, Routledge \& K. Paul, 1969.

Díaz Cayeros, Irma Patricia. "Ornamentación y ceremonia: la activación de las formas en el Coro de la catedral de Puebla”, tesis doctoral, UNAM, 2004. 
Diccionario de los símbolos. Bajo la dirección de Jean Chevalier, con la colaboración de Alain Gheerbrant; traducción, Manuel Silvar y Arturo Rodríguez. Barcelona: Herder, 2003.

Diego, Hugo. Lafragua. Viaje al interior de la biblioteca. México: Ediciones de Educación y Cultura / BUAP, 2008.

Don Juan de Palafox y Mendoza su virreinato en la Nueva España, sus contiendas con los P. P. jesuitas, sus partidarios en Puebla, sus apariciones, sus escritos escogidos, छб., छбc. [microforma] Cambridge, Mass.: General Microfilm Co. / Omnisys Co. [199-].

Donahue-Wallace, Kelly. Prints and Printmakers in Viceregal Mexico City, I600-I800. University of New Mexico, 2000, tesis doctoral.

DreYFus, John. Aspects of French Eighteenth Century Typography: a Study of Type Specimens in the Broxbourne Collection at Cambridge University Library, with a Handlist Compiled by David McKitterick. Cambridge: Printed for presentation to members of the Roxburghe Club, 1982.

. Type Specimen Facsimiles [general editor John Dreyfus]. London: Bodley Head, 1972.

Type Specimen Facsimiles, general editor John Dreyfus. (Reproductions of Fifteen Type Specimen Sheets Issued between). London: Bowes \& Bowes-Putnam, I963.

DrUCKER, Johanna. The Alphabetic Labyrinth. The Letters in History and Imagination. Londres: Thames and Hudson, 1995 .

Duprat, F. A. Histoire de l'Imprimerie Impériale de France suivie des spécimens des types. Paris, I86I.

Durero, Alberto. Instituciones de geometría. México: UNAM, IIB, Biblioteca Nacional de México, I987, p. I60-ig8.

Eguiara y Eguren, Juan José de. Bibliotheca Mexicana. Español EG Latín; compilación, prólogo y notas de Ernesto de la Torre Villar, con la colaboración de Ramiro Navarro de Anda. México: UNAM, Coordinación de Humanidades [1986-1990].

EnschedÉ, Charles. Fonderies de caractères et leur matériel dans les Pays-Bas $d u X V^{e}$ au XIX siècle. Typefoundries in the Netherlands from the Fifteenth to the Nineteenth Century: a History Based Mainly on Material in the Collection of Joh. Enschedé en zonen at Haarlem (an English translation with revisions and notes by Harry Carter, with the assistance of Netty Hoeflake; edited by Lotte Hellinga). Haarlem: Stichting Museum Enschedé, 1978.

Escriptura de conveniencia Joan Coronverguer, Joan Pablos e Gil Barbero, Archivo Notarial, Protocolo de Alonso de la Barrera, Ofiçio I, Libro I, folios 1069-1072, I2 de junio de 1539. Sevilla; México: Juan Grijalbo, 1989, reproducción.

EsTABRIDIS CÁRDENAS, Ricardo. El grabado en Lima virreinal. Documento bistórico y artístico (siglos XVI al XIX). Lima: Fondo Editorial Universidad Nacional Mayor de San Marcos, 2002, p. I73, lám. $5^{8 .}$

FeLl, John. A Newly-Discovered Broadside Specimen of Fell Type Printed in Oxford about ${ }_{1} 685 ;$ Reproduced in Collotype Facsimile (with a bibliographical note by Philip Hofer). Cambridge: Department of Printing and Graphic Arts, Harvard College Library, I940.

Fernández de Santa CruZ y Sahagún, Manuel. Constitociones y Ordenancas para el govierno de la familia, y la casa del Illustrissimo señor doctor D. Manuel Fernandez de Santa Cruz. Obispo de la Puebla de los Angeles, del Consejo de su Magestad. $Y$ las que cada vno de ducha Familia ha de observar, conforme el exercicio, y puesto, en que estuviere ocupado. Puebla de los Ángeles: por Diego Fernández de León, I683.

FernándeZ Del Castillo, Francisco. Libros y libreros en el siglo XVI. $2^{\mathrm{a}}$ ed. México: Fondo de Cultura Económica, I982.

Fernández Echeverría y Veytia, Mariano. Historia de la fundación de la Puebla de los Ángeles en la Nueva España, su descripción y presente estado. Tomo I. México: Labor, I93I, p. 385.

. Historia de la fundación de la Puebla de los Ángeles en la Nueva España, su descripción y presente estado. Tomo II. México: Labor, I931, p. 6r7. 
Fernández Echeverría y Veytia, Mariano. Historia de la fundación de la ciudad de la Puebla de los Ángeles en la Nueva España. México: Gobierno del Estado de Puebla / Consejo Nacional para la Cultura y las Artes / Instituto Nacional de Bellas Artes, t. I y II, I990.

FERnández Esquivel, Rosa María. "Los impresos mexicanos del siglo xVI: su presencia en el patrimonio cultural del nuevo siglo", tesis doctoral. México, UNAM, 2006.

Fernández Mantecón, José M. Memoria sobre la administración del Estado de Puebla en I849. México: Imprenta de Ignacio Cumplido, 1849 .

FERRANDo RoIG, Juan. Iconografia de los santos. Barcelona: Omega, 1950.

Fevre, Lucien y Jean Henri Martín. La aparición del libro. México: Libraria, FCE, 2005.

Figgins, Vincent. Specimen of a Fount of Telegú Types Cast by Vincent Figgins. London, 1802.

FrY, Edmund. Specimen of Modern Printing Types by Edmund Fry 1828: a Facsimile by Edmund Fry (intr. David Chambers). London: Printing Historical Society, 1986.

Fry and Sons, Joseph. A Specimen of Printing Types. London, 1785.

Galí Boadella, Montserrat (coord.). La pluma y el báculo, Juan de Palafox y el mundo bispano del seiscientos. Puebla: BuAP, Instituto de Ciencias Sociales y Humanidades, 2004, 355 p.

Estampa popular, cultura popular. Puebla: BUAP, Instituto de Ciencias Sociales y Humanidades, 2007, $178 \mathrm{p}$. Estampa popular novohispana. Puebla: Biblioteca Palafoxiana, 2008, I42 p.

García, Genaro. Documentos Históricos Mexicanos, edición facsimilar de la de r9ı. México: Comisión Nacional para las Celebraciones del 175 Aniversario de la Independencia Nacional y 75 Aniversario de la Revolución Mexicana, 1985, 7 t.

. Don Juan de Palafox y Mendoza, Obispo de Puebla y Osma, Visitador y Virrey de la Nueva España. Puebla: Gobierno del Estado de Puebla, Secretaría de Cultura, I991, 426 p., il.

García Aguilar, María Idalia. Legislación sobre bienes culturales muebles: protección del libro antiguo. México: UNAM, CUIB, 2002.

García DíAz, Tarsicio. La prensa insurgente, vol. vI, t. II de la obra: La República Federal Mexicana. Gestación y nacimiento. Obra conmemorativa de la fundación de la República Federal y de la creación del Distrito Federal en 1824. México: Departamento del Distrito Federal, I97I.

García Granados, Rafael. Huejotzingo, la ciudad y el convento franciscano. México. Talleres Gráficos de la Nación, 1934, 375 p., il.

García ICAZBALCETA, Joaquín. Bibliografia mexicana del siglo XVI. México: FCE, 1954. Bibliografía Mexicana del siglo XVI, catálogo razonado de libros impresos en México de 1539 a I60o. México: FCE, I954, p. 58I.

Nueva Colección de Documentos para la Historia de México. V. Códice Mendieta. México, I899, citado por Manuel Romero de Terreros, Encuadernaciones artísticas mexicanas. México: SRE, I939.

García Lastra, Leopoldo A. y Silvia Castellanos Gómez. Utopía angelopolitana. Puebla: Secretaría de Cultura del Gobierno del Estado de Puebla, 2008, 327 p.

García Palacios de Juárez, Emma. Los barrios antiguos de Puebla. Puebla: Gobierno del Estado de Puebla, Secretaría de Cultura, 1995, I47 p.

García VeGA, Blanca. El grabado del libro español (siglos $X V$-XVIII). Valladolid: Instituto Cultural Simancas, 1984 .

Garone Gravier, Marina y Albert Corbeto (eds.). Muses de la impremta. La dona $i$ la imprenta en el món del llibre antic. Barcelona: Museo Diocesano de Barcelona / Asociación de Bibliófilos de Barcelona, 2009, $286 \mathrm{p}$.

Breve introducción al estudio de la tipografia en el libro antiguo. Panorama bistórico y nociones básicas para su reconocimiento. México: Biblioteca Lafragua, BUAP / Biblioteca Histórica del Colegio 
Preparatoriano de Xalapa / Asociación Mexicana de Bibliotecas e Instituciones con Fondos Antiguos, 2009, $80 \mathrm{p}$.

Garone Gravier, Marina (comp.) Miradas a la cultura del libro en Puebla. Puebla: Consejo Estatal para la Cultura y las Artes / Ediciones de Educación y Cultura / UNAM, IIB, 20I2, 406 p.

"Historia de la tipografía colonial para lenguas indígenas", México, CIESAs / Universidad Veracruzana, 2015.

Garritz, Amaya. Impresos Novohispanos I808-I82I, Virginia Guedea (coord.), colaboración de Teresa Lozano. México: UNAM, I990, 2 vol. (Serie Bibliografías, 9).

Gaucher, Charles-Étienne. Iconologie, ou Traité de la science des allégories à l'usage des artistes, en 350 figures, gravées d'après les dessins de MM. Gravelot et Cocbin... Grabados de Gravelot y CharlesNicolas Cochin. París: Le Pan, s.f. [I79I]. [Nueva edición: Iconología. Traducción de María del Carmen Alberú Gómez. México: Universidad Iberoamericana, 1994].

Gavito, Florencio. Adiciones a la Imprenta en la Puebla de los Ángeles, de J. T. Medina. Prefacio y compilación de Felipe Teixidor. México: Colección Gavito, I96r.

Gerhard, Peter. "Un censo de la diócesis de Puebla en i68I”, en Historia Mexicana, vol, 30, núm. 4 (abr.-jun. 198I).

Gojman DE BACKal, Alicia. Imprentas, ediciones y grabados de México barroco. México: Ediciones Backal, 1995, $25^{8}$ p., p. 39-45.

Gómez Álvarez, Cristina. Un hombre de estado y sus libros, el obispo Campillo, I740-i8rz. Puebla: BUAP, Instituto de Ciencias Sociales y Humanidades, 1997, 205 p., il.

GonzáLEZ, Luis. Once ensayos de tema insurgente. México: El Colegio de Michoacán / Gobierno del Estado de Michoacán, 1985.

González Sánchez, Carlos Alberto. Mundos del libro: Medios de difusión de la cultura occidental en Indias de los siglos XVI y XVII. Sevilla: Universidad de Sevilla / Diputación de Sevilla, I999.

Grañén PorRÚa, Isabel. "El ámbito socio-laboral de las imprentas novohispanas," en Anuario de Estudios Americanos, XLVIII, I99I, p. I3.

Green, Ralph. A Check List of American I9 ${ }^{\text {th }}$ Century Type Specimen Books. Chicago, $195 \mathrm{I}$.

GRIF FIN, Clive. Los Cromberger: la bistoria de una imprenta del siglo XVI en Sevilla y Méjico. Madrid: Cultura Hispánica, I991, 384 p., il.

Guía del turista en la ciudad del Puebla. Puebla: Imprenta del Colegio Pío de Artes y Oficios, 1896.

Guzmán Pérez, Moisés. Impresores y editores de la Independencia de México, I808-I82I. Diccionario. México: Editorial Porrúa / Universidad Michoacana de San Nicolás de Hidalgo, 2010.

HAEbleR, Konrad. "Las iniciales", en Introducción al estudio de los incunables. Madrid: Ollero \& Ramos, I995, p. I4I-I47.

Introducción al estudio de los incunables. Madrid: Ollero \& Ramos, 1995, $282 \mathrm{p}$.

Harvard, Stephen. Ornamental Initials: the Woodcut Initials of Christopher Plantin: a Complete Catalogue (by Stephen Harvard, New cork). American Friends of the Plantin-Moretus Museum, I974.

Henestrosa, Cristóbal. Espinosa, rescate de una tipografia novobispana. México: Designio, 2005.

Hernández TAPIA, Germán. Bibliografia poblana de geografia e bistoria del estado. Puebla: Bohemia Poblana, 1962, $525 \mathrm{p}$.

Hidalgo Brineuis, María del Carmen. La fabricación del papel en España e Hispanoamérica en el siglo XVII. Instituto del Patrimonio Histórico Español, sin fecha.

Homero. Ilíada. Prólogo: Alfonso Reyes; versión directa y literal del griego: Luis Segala y Estalella. $32^{\mathrm{a}}$ ed. México: Editorial Porrúa, 2003 (“Sepan Cuántos...”, 2).

IguínIZ, Juan B. Disquisiciones bibliográficas. México: UNAM, 1965, p. 239. . El libro. Epitome de bibliología. México: Porrúa, 1946.

La imprenta en la Nueva España. México: Porrúa Hermanos, I938, Enciclopedia Ilustrada Mexicana. 
Iguíniz, Juan B. La imprenta en México durante la dominación española. Separata de Sonderabzub aus der Gutenberg-Festschrift. Mainz: s.e., 1925, 3 p.

Importancia de la probibición de malos libros, esplanadas en la defensa que ba becho de los sres, obispos, así sobre éste, como sobre otros puntos propios de su jurisdicción un literato oculto bajo el nombre de, El Retirado. México: Imprenta del ciudadano Alejandro Valdés, I8z2.

Imprimerie Nationale (France). Le cabinet des poinçons de l' Imprimerie Nationale, $3^{\mathrm{e}}$. éd. Paris: ${ }_{1963 .}$

Infantes, Víctor, François López y Jean-François Botrel (dirs.) Historia de la edición y la lectura en España (I472-I9I4), Fundación Germán Sánchez RuyPéres. Madrid: Pirámide, 2003, p. 37 (Biblioteca del Libro).

Johnson, A. F. (Alfred Forbes). Decorative Initial Letters, Collected and Arranged with an Introduction by A. F. Jonson. London: The Cresset Press, printed at the Curwen Press, I93I.

. Draft of Some Notes to Accompany a projected Series of Type Specimens up to I70o (Reproduced in Facsimile) Showing Roman Type Faces. (Contents the Specimens Annotated Are: Ratdolt I486, Berner 1592, Fuhrmann 1616, Berner 1622, Luther 1664, Fievet i664, I682, Voskens i670, Moxon, Kannewet, Adamsz, Orme i698, Janicolo I529, Meere I710, Schmidt, Motte, Rolu, Le Bé, Anderson, Blaeu, Elzevier, Goeree. Duplicated, 1952.)

The Type-Specimen Books of Claude Lamesle and Nicolas Gando. The Library, I937; serie 4-XVIII: 2OI-2II.

. Selected Essays on Books and Printing. Muir, Percy H. (editor). Amsterdam: Van Gendt \& Co. 1970 , xi, $489 \mathrm{p}$.

Jornadas Mexicanas de Biblioteconomía, Bibliografia y Canje ( $17^{\mathrm{a}}$, 1986 , Puebla), Memorias, XVII Jornadas Mexicanas de Biblioteconomía. México: SEP, Dirección General de Bibliotecas, 1988.

Kelly, Rob Roy. American Wood Type, I828-1900: Notes on the Evolution of Decorated and Large Types and Comments on Related Trades of the Period. New York; London: Van Nostrand-Reinhold, I969.

Kubler, George. A New History of Stereotype. New York, I94I, edición de autor.

Arguitectura mexicana del siglo XVI. México: FCE, I983.

La ciudad y el campo en la bistoria de México, memoria de la VII Reunión de Historiadores Mexicanos y Norteamericanos $=$ Papers presented at the VII Conference of Mexican and United States Historians, Oaxaca, Oax., I985. México: UNAM, IIH, I992, 2 vol., il.

La eucaristía en el arte español. Barcelona: Ayma, 1952.

La fundación de Puebla de los Ángeles. H. Ayuntamiento de Puebla (198i-1984), i98i, p. $5^{8 .}$

Lara Barba, Othón. La Biblioteca Lafragua de la Universidad Autónoma de Puebla. Puebla: [s.n.], I979.

LEICHT, Hugo. Las calles de Puebla. Ed. facsimilar. Junta de Mejoramiento Moral, Cívico y Material del Municipio de Puebla, 1992.

Lemoine Villicaña, Ernesto. Morelos. Su vida revolucionaria a través de sus escritos y de otros testimonios de la época. México: UNAM, 1965.

LenZ, Hans. Historia del papel en México y cosas relacionadas (I525-1950). México, Miguel Ángel Porrúa, I990, p. 8o-83.

y Federico Gómez de Orozco. La industria papelera en México. México: s.n., I940.

LEONARD, Irving. Los libros del conquistador. México: FCE, 1996.

Les caractères de l'Imprimerie Nationale. Paris: Impr. Nationale Éditions, I990.

López TorriJos, Rosa. La mitología en la pintura española del Siglo de Oro. Madrid: Ediciones Cátedra, 1995. [En el primer capítulo se da una idea general de los autores y fuentes aprovechados en España del siglo XVI al XVII. Hay referencias a autores clásicos (Homero, Ovidio, Virgilio) y a obras hispanas sobre mitología clásica (Juan Pérez de Moya, Baltasar de Vitoria)].

Losilla, Edelmira. Breve bistoria y técnicas del grabado artístico. Xalapa, Veracruz: Universidad Veracruzana, 1998, 23i p., il. 
Lucía Megías, José Manuel. “El cajista”, en Aquí se imprimen libros. La imprenta en la época del Quijote. Madrid: Ollero y Ramos, 2005, p. III.

MÂLE, Emile. El Barroco. Arte religioso del siglo XVII: Italia, Francia, España, Flandes. Introducción de A. Chastel y Gilles Chazal; prólogo de la edición española de Santiago Sebastián; traducción del texto de Emile Mâle: Ana María Guasch. Madrid: Encuentro, I985.

Mantilla Trolle, Marina y Nora Jiménez Hernández (coords.). Colección de Lenguas Indígenas. Biblioteca Pública del Estado de Jalisco Juan José Arreola. Guadalajara: Universidad de Guadalajara / Colegio de Michoacán, 2007, 394 p.

María. Iconografia de la Virgen en el arte español. Madrid: Plus Ultra, 1946.

Márquez Montiel, Joaquín. Hombres célebres de Puebla. México: Jus, 1952, t. 2.

Martínez de Souza, José. Diccionario de bibliología y ciencias afines. $3^{\mathrm{a}}$ ed. Gijón: Trea, 2004, p. 495-503.

Diccionario de tipografía y del libro. Madrid, Paraninfo: 1995 , xvi-547 p.

Martínez Pereira, Ana. Manuales de escritura de los siglos de oro. Repertorio crítico y analítico de obras manuscritas e impresas. Mérida: Editorial Regional de Extremadura, 2006.

Mathes, Miguel. "La voz de la Independencia, religión, unión: la prensa del Ejército Trigarante". Ponencia presentada en el VII Simposio Internacional de Historia Militar, realizado en el Castillo de Chapultepec de la ciudad de México, 25-26 de marzo de 2010.

Maza, Francisco de la. La mitología clásica en el arte colonial de México. México: Unam, IIE, I968 (Estudios y Fuentes del Arte en México, 24).

Las tesis impresas en la Antigua Universidad de México. [México: Imprenta Universitaria (1944), I994].

y Jesús Yhmoff Cabrera. Los impresos universitarios novobispanos del siglo XVI. [México: Biblioteca Nacional de México, I993].

McKitterick, David. “A Type Specimen of Christoffel van Dijck”, en Quaerendo 7 (1977), p. 66-75.

McMurtrie, Douglas C. Four Reproductions of Type Specimen Broadsides of the Eighteenth Century. Chicago, I931.

Medina, José Toribio. Historia de la imprenta en los antiguos dominios españoles de América y Oceanía, t. I, prólogo de Guillermo Feliu Cruz; complemento bibliográfico de José Zamudio Z. La imprenta en la Puebla de los Ángeles (I640-I82I). México: UNAM, IIB, I990. La imprenta en la Puebla de los Ángeles (I640-I82I). México: UNAM, I99I. La imprenta en México. México: UNAM, 1990, t. I, p. LXIII.

La imprenta en la Puebla de los Angeles, I640-I82I. México: UNAM, IIB, I99I, p. 823.

Mena, Ramón. Filigranas o marcas transparentes en papeles de la Nueva España del siglo XVI, núm. 5 . México: Secretaría de Relaciones Exteriores, 1926, 29 p. (Monografías Bibliográficas Mexicanas).

MÉNDEZ, Francisco. Tipografia española, ó, Historia de la introducción, propagación y progresos del arte de la imprenta en España: á la que antecede una noticia general sobre la imprenta de la Europa y de la China: adornado todo con notas instructivas y curiosas. Madrid: Imprenta de Escuelas Pías, I86I, xiv, 436 p.

Mendieta, fray Gerónimo de. Historia eclesiástica indiana. Estudio preliminar Antonio Rubial García. México: Conaculta, 2002 (Cien de México).

Meza Oliver, Rocío y Luis Olivera López. Catálogo de la Colección Lafragua de la Biblioteca Nacional de México i800-i8ro. México: Unam, IIB, I993 (Serie Guías).

Millares Carlo, Agustín y Julián Calvo. Juan Pablos, primer impresor que a esta tierra vino. México: Joaquín Porrúa, editor, I990, 220 p. (Biblioteca Mexicana Manuel Porrúa, núm. VIII).

Miller and Richard (Firm). Specimens of Bobemian Type, Borders and Ornaments. Edinburgh, I9Io. 
Miquel i Vergés, José María. La Independencia Mexicana y la Prensa Insurgente, edición facsimilar de la de 194I. México: Comisión Nacional para las Celebraciones del 175 Aniversario de la Independencia Nacional y 75 Aniversario de la Revolución Mexicana, 1985.

Moreno, Francisco. Fundación del Colegio Seminario de San Pedro Seminario de la Santa Iglesia Catedral de la Puebla de los Ángeles [s.p.i.].

Moreno Valle, Lucina. Catálogo de la Colección Lafragua, I82I-I853. México: UNAM, 1975.

MoRET VIÑals, Oriol. "El mitjà tipogràfic (La medida en tipografía)". Universidad de Barcelona, 2006, Departamento de Diseño, tesis doctoral.

Morison, Stanley. John Fell, the University Press, and the 'Fell' types. New York: Garland Pub., I98I, ca. 967 .

. John Fell. The University Press and the "Fell" Types. Londres: Garland Publishing Co. 198I, capítulo x, "The Fell Ornaments", p. I66-187.

MosLey, James. British Type Specimens before I831: a Handlist. London: s.n., 1978.

, et al. Le roman du roi, la typographie au service de l'État, I702-2002. Lyon: Museé de l'Imprimerie et de la Banque, 2002, I25 p., catálogo de la exposición.

Moxon, Joseph. Mechanick Exercises on the Whole Art of Printing (London, I683), edited by Herbert Davis \& Harry Carter. New York: Dover Publications, 1978, John Smith, The Printer's Grammar, London, I755.

Mujica Pinilla, Ramón. Rosa limensis. Mística, política e iconografia en torno a la patrona de América. Lima: FCE, 2005.

Musacchio, Humberto. Diccionario Enciclopédico de México. Ilustrado. México: Andrés León, editor, $1994,4 \mathrm{t}$.

Nelly, Rob Roy. American Wood Type. 1828-1900. Notes on the Evolution of Decorated and Large Types and Comments on Related Trades of the Period. New York: Van Nostrand Reinhold Company, I969.

Noticia del estado en que se encuentra el Colegio del Espíritu Santo. Puebla: Imprenta de J. M. Rivera, I85I.

Olivera López, Luis y Rocío Meza. Catálogo de la Colección Lafragua de la Biblioteca Nacional de México (I800-I8Io). México: UNAM, IIB, I998, I72 p.

Catálogo de la Colección Lafragua de la Biblioteca Nacional de México (I8II-I82I). México: UNAM, IIB, I996, 515 p.

Catálogo de la Colección Lafragua de la Benemérita Universidad Autónoma de Puebla, I6I6-I873.

México: UNAM, IIB / BUAP, Biblioteca Lafragua, 2006, 568 p.

Ortega, Miguel F. La imprenta y el periodismo en el sur en el siglo XIX. México: Editorial Pluma y Lápiz de México, 1943.

Osorio Romero, Ignacio. Historia de las bibliotecas en Puebla. México: SEP, Dirección General de Bibliotecas, Consejo Nacional de Fomento Educativo, 1988, 225 p., il. (Historia de las bibliotecas en los estados de la república mexicana).

Ovidio. Las metamorfosis. Estudio preliminar de Francisco Montes de Oca. 9a ed. México: Editorial Porrúa, 1999 (“Sepan Cuántos...”, 316).

Oxford University Press. A Specimen of the Several Sorts of Printing-Types Belonging to the University. Oxford, 1768.

Palacio Montiel, Celia del. La disputa por las conciencias. Los inicios de la prensa en Guadalajara I809I835. México: Universidad de Guadalajara, 200I.

Palavicini, Félix Fulgencio. México, bistoria de su evolución constructiva. México: Distribuidora Editorial Libro, I945. (Datos sobre material tipográfico de Pedro de la Rosa, vol. 4, p. 177).

Palou, Pedro Ángel. Breve noticia bistórica de la Biblioteca Palafoxiana y de su fundador, Juan de Palafox y Mendoza; y los colegios de San Juan, San Pedro y San Pablo. Puebla: Gobierno del Estado de Puebla, Secretaría de Cultura, I991, 30 p.; (Lecturas Históricas de Puebla, 42). 
Pérez Salazar, Francisco. El grabado en la ciudad de Puebla de los Angeles. Puebla: Gobierno del Estado de Puebla, Secretaría de Cultura, I990, 68 p., il.

Pérez Salazar, Francisco. Historia de la pintura en Puebla, ed., introd. y notas de Elisa Vargas Lugo; rev. y notas de Carlos de Ovando. $3^{\mathrm{a}}$ ed. México: UNAM, IIE, I963, 245 p., il.

. Historia de la pintura en Puebla: y otras investigaciones sobre Historia y Arte. México: Imprenta Universitaria, 1963 , p. 868.

, Hugo Leicht Mayer, Enrique Gómez Haro y Enrique Juan Palacios. La fundación de la ciudad de los Ángeles. comp. Pedro Ángel Palou Pérez. Puebla: Consejo de la Crónica, Instituto Municipal de Arte y Cultura [2006], p. I39.

Los impresores de Puebla en la época colonial. Puebla: Gobierno del Estado de Puebla, Secretaría de Cultura, 1987, 251 p. (Biblioteca Angelopolitana r).

Los impresores de Puebla en la época colonial. Puebla: Biblioteca Angelopolitana I, Gobierno del Estado de Puebla, Secretaría de Cultura, 1987, 25r p., il.

PICINELli, Filippo. El mundo simbólico. Los metales. Los instrumentos eclesiásticos (Libros XIII-XIV). Editoras: Rosa Lucas González y Bárbara Skinfill Nogal; traductores: Pascual Guzmán de Alba, Alberto Carrillo Cázares. Zamora: El Colegio de Michoacán, 2006.

El mundo simbólico. Los cuatro elementos. Editores: Eloy Gómez Bravo, Rosa Lucas González, Bárbara Skinfill Nogal; traductores: Pascual Guzmán de Alba, Rosa Lucas González. Zamora: El Colegio de Michoacán, 1999.

El mundo simbólico. Los cuerpos celestes, libro I. Traductor: Eloy Gómez Bravo. Zamora: El Colegio de Michoacán, 1997.

El mundo simbólico. Serpientes y animales venenosos. Editores: Eloy Gómez Bravo, Rosa Lucas González, Bárbara Skinfill Nogal; traductores: Rosa Lucas González, Eloy Gómez Bravo. Zamora: El Colegio de Michoacán, I999.

PLA, Jaume. Técnicas del grabado calcográfico y su estampación, con unas notas sobre bibliofilia. Barcelona: Blume, I977, I8I p., 20 p. de láminas; il.

Plantin, Christopher. Calligraphy \& Printing in the Sixteenth Century. English translation and notes by Ray Nash. Foreword by Stanley Morison. Antwerp: Plantin-Moretus Museum, 1964 .

Puebla a través de los siglos, panorama bistórico de la ciudad / [Dir. general José García Valseca; redactores: Fausto Marín Tamayo, Olga Yolanda Couoh ... et al.]. Puebla: El Sol de Puebla, 1962, 240 p., il.

Quintana, José Miguel. Artes gráficas en Puebla. Antigua Librería Robredo, ig6o.

RaGon, Pierre. Imprentas novobispanas e bistoria de las devociones en México (siglos XVII y XVIII). Revista Redial, núm. 8-9, p. 33-42. Texto disponible en: http://www.red-redial.net/doc/redial _1997-98_n8-9_pp33-42.pdf [consulta: abril 2009].

Rangel, Nicolás, "Las Imprentas I80o-182I", en Antología del Centenario. Estudio documentado de la literatura mexicana durante el primer siglo de la Independencia. Primera parte I800-I82I, edición facsimilar de la de i9ıо. México: SEP, I985, vol. 2, p. IO3I-IO79.

RÉAU, Louis. Iconografia del arte cristiano. Traducción Daniel Alcoba. Barcelona: Ediciones del Serbal, 1996-1998 (Cultura Artística).

Ríos Arce, Francisco R. de los. Puebla de los Ángeles y la orden Dominicana. Puebla: Imprenta Colegio Pío, I910, 2 v.

RIPA, Cesare. Iconología de Cesare Ripa [...] en la que se describen diversas imágenes de virtudes, vicios, afectos, pasiones bumanas, artes, disciplinas, bumores, elementos, cuerpos celestes, provincias de Italia, ríos, todas las partes del mundo y otras infinitas materias... Siena: Herederos de Matteo Fiorimi, I6r3. [Nueva edición: Iconología. Tomos I y II. Prólogo de Adita Allo Manero. Madrid: Ediciones Akal, 2002 (Arte y Estética, 8)]. 
Rodríguez-Buckingham, Antonio. "Colonial Peru and the Printing Press of Antonio Ricardo". The University of Michigan, tesis doctoral, 1977.

Roggiano, Alfredo A. "Documentos”; Pedro Henríquez Ureña y Félix Lazaso, "Cartas de un maestro (I9I7-1924)”, en Revista Iberoamericana, vol. 34, núm., 65 (ene-abr. I968), p. I58.

Romero De Terreros, Manuel. Grabados y grabadores en la Nueva España. México: Ediciones Arte Mexicano, 1948, $575 \mathrm{p}$.

Ronaldson Lyell, James Patrick. La ilustración del antiguo en Espana, Julián Martín Abad (ed., prol. y notas); tr. de Hector Silva. Madrid: Ollero y Ramos, 1997, $44^{2}$ p.

Rosart, Jacques François. The Type Specimen of Jacques-François Rosart, Brussels I768. (2 ${ }^{\mathrm{e}}$. éd. augmentée reprinted). Amsterdam: Van Gendt; London: Routledge and Kegan Paul, 1973.

Rueda, Pedro. Negocio e intercambio cultural: El comercio de libros con América en la Carrera de Indias (siglo XVII). Sevilla: Diputación de Sevilla / Universidad de Sevilla / CSIC, EEHA, 2005.

Ruiz Moreno, Luisa. Las más bellas biblias de las Bibliotecas José María Lafragua y Palafoxiana; fotografías de Everardo Rivera y Ángela Arziniaga. Puebla: BUAP, Instituto de Ciencias Sociales y Humanidades, 1998, 93 p., il.

Salazar Exaire, Celia. Puebla colonial: bibliohemerografia comentada. México: Instituto Nacional de Antropología e Historia, 2002 (Colección Fuentes. Serie Catálogos).

Salazar Monroy, Melitón. Convento franciscano de Huejotzingo. [Puebla: López], i944.

SaLomón, Mercedes. "Los Borja: puerta de entrada al devenir de la imprenta en Puebla", en La Imprenta de los Ángeles. Panorama histórico de la imprenta poblana (I642-I822). Ciclo de conferencias, Biblioteca Lafragua, 24 de septiembre de 2009.

Sánchez, María Cristina. El papel del papel en la Nueva España. México: INAH, I993.

SÁnchez Flores, Ramón. José María Lafragua, vida y obra. Puebla: Secretaría de Cultura, 1985.

Schenone, Héctor H. Iconografia del arte colonial: Jesucristo. Buenos Aires: Fundación Tarea, 1998.

Sebastián, Santiago. Contrarreforma y Barroco. Madrid: Alianza, I98I. . Emblemática e Historia del Arte. Madrid: Ed. Cátedra, 1995 (Arte. Grandes Temas).

Seminario El libro antiguo, impartido por la Lic. Elvia Carreño, Imprenta La Purísima Coronada. Morelia, Michoacán, septiembre de 2004 [Notas personales].

Seznec, Jean. Los dioses de la Antigüedad en la Edad Media y el Renacimiento. Versión castellana de Juan Aranzadi. Madrid: Taurus, 1985 (Serie Maior. Ensayistas, 206).

SigüenZa Vera, Juan José. Mecanismos del arte de la imprenta, publicado en Madrid en i8II (edición facsimilar, Tipus Almarabu, I992).

Simmons, J. S. G. (John Simon Gabriel). Specimens of Printing Types before 1850 (desde I695) in the Typographical Library at the University Press. Oxford [s.d.], Reprinted: The Book Collector, Winter 1959.

SMith, Clara. Alphabets. Lyon, L'Aventurine, 2005.

Southworth-Anthoensen Press. Specimen of Printing Types Together with a Collection of Printer's Flowers. Portland, 1937.

St. Bride Printing Library. List of Type Specimens in the Saint Bride Printing Library from the $1 \sigma^{\text {th }}-20^{\text {th }}$ Century. [London: St Bride Printing Library, ca. 960].

Stamperia Vaticana. The Type Specimen of the Vatican Press, I628: a Facsimile, with an introduction and notes by H. D. L. Vervliet. Amsterdam: Menno Hertzberger \& Co., 1967 (Facsimile reprint of "Indice de caratteri con l'inventori \& nomi di essi, essistenti nella stampa Vaticana \& Camerale" [compiled by Andrea Brogiotti], Rome, I628).

STEPHENSON S. \& C. First Part of a Specimen of Printing Types. London, 1796.

. A Specimen of Printing Types EG Various Ornaments 1796: Reproduced Together. London: Printing Historical Society, I990, v [almost completely unpaginated]. 
STIEBNER, Erhardt. Initialen + bildbuchstaben $=$ Initials + Decorative Alphabet, Erhardt d. Stiebner, Dieter Urban. Munchen: Bruckmann, 1983, 334 p.

Stols, Alexandre A. M. Antonio de Espinosa. El segundo impresor mexicano. México: UNAM, Biblioteca Nacional, IIB, I989, p. 6-7. Antonio de Espinosa. El segundo impresor mexicano. México: UNAM, IIB, I989, I20 p. Pedro Ocharte. El tercer impresor mexicano. México: UNAM, IIB, I990, I38 p.

Teixidor, Felipe. Adiciones a la imprenta en la Puebla de los Ángeles de J. T. Medina. México: unam, IIB, I99I. Ex-libris y bibliotecas de México. México: Secretaría de Relaciones Exteriores, I93I.

Terán Binilla, Antonio y Luz de Lourdes Velásquez Thierr. José Miguel de Santa María, arquitecto del barroco poblano. Puebla: Secretaría de Cultura del Gobierno de Puebla, 2007, I84 p.

Thorowgood W. and Company. Fann Street Letter Foundry: a Supplement to Thorowgood's Specimen of Printing. London: 1832 .

TINTO, Alberto. Il corsivo nella tipografia del cinguecento dai caratteri italiani ai modelligermanici e francesi. Milano: Il Polifilo [1972].

Tito Livio. Historia de Roma desde su fundación. Libros I-III. Introducción de Ángel Sierra; traducción y notas de José Antonio Villar Vidal. Madrid: Editorial Gredos, I997.

Torre Revello, José. "Los manuscritos de Veytia y el origen de la colección de fray Manuel de la Vega", en Revista de Historia de América, núm. 55, 56 (1963), p. 27-50.

El libro, la imprenta y el periodismo en América durante la dominación española. Buenos Aires: Peuser, 1940, $269 \mathrm{p}$.

Orígenes de la imprenta en España y su desarrollo en América española. Buenos Aires: Instituto de Cultura Española, I940, 354 p.

Torre Villar, Ernesto de la. "Diego Antonio Bermúdez de Castro en la historiografía novohispana,” en Historia Mexicana, El Colegio de México, vol. 39, núm. 2 (oct.-dic. 1989), p. 387-416.

"Nuevas aportaciones sobre la Biblioteca Palafoxiana", en Boletín de la Biblioteca Nacional, t. II, núm. I (I960).

"Reseña histórica de la Biblioteca Palafoxiana”, Puebla: [s.n.], I957.

Ex libris y marcas de fuego [ $2^{\mathrm{a}}$ ed. aum.]. México: UNAM, Dirección General de Publicaciones y Fomento Editorial, 2000.

El Colegio de San Juan. Centro de formación de la cultura poblana. Puebla: Universidad de las Américas, 2007.

Historia de la educación en Puebla, época colonial. Puebla: Universidad Autónoma de Puebla, 1988, I48 p.

La Biblioteca Palafoxiana / reseña bistórica por Ernesto de la Torre Villar. Bibliografia bistórica de Puebla formada por Fausto Marín-Tamayo y Gregorio de Gante. [Puebla: Gráficos Oaxaca, I957], 50 p., il.; (Centro de Estudios Históricos de Puebla, núm. 4).

. Notas para la bistoria de la instrucción pública en Puebla de los Ángeles. México: [s.n.], 1953. Separata de Estudios Históricos Americanos.

- Notas para una bistoria de la instrucción pública en Puebla de los Ángeles. [México, I953], p. 565-684, il. Separata de Estudios Históricos Americanos.

Torres, Miguel de. Dechado de príncipes eclesiásticos, que dibujó con su ejemplar, virtuosa y ajustada vida el llust, y Exc, señor José Manuel Fernández de Santa Cruz y Sabagún. Madrid, España: [s.n., s.a.]

Tory, Geoffroy. Champ Fleury. Paris: 1529 [CD-ROM del ejemplar de la Library of Congress, Grolier Club, New York, 1927]. Octavo Editions, 2003. [Agradecemos a la maestra Elena de Gerlero habernos permitido consultar la edición facsimilar de la obra.] 
Toussaint, Manuel. Arte colonial en México. México: UnAm, IIE, I990. La catedral y las iglesias de Puebla. México: Porrúa, 1954.

Pintura colonial en México. México, 1936, p. 220-223. Y Xavier Moyssen (ed.). México: UNAM, IIE, I990.

Traslado notarial ante Nicolás Álvarez del auto de aprobación real de la fundación del Colegio Seminario de San Pedro de Puebla de los Ángeles, Puebla de los Ángeles, 3 de noviembre de i662 [en línea], en "Manuscritos de América en las Colecciones Reales", Patrimonio Nacional de la Real Biblioteca y Biblioteca Virtual Miguel de Cervantes Saavedra. Madrid, España. http://www.cervantesvirtual.com/ [consulta: 3 de junio de 2008].

Trens, Manuel. El arte en la pasión de nuestro señor (siglos XIII al XVIII). Barcelona: Palacio de la Virreina, 1945.

Updike, D. P. Printing Types, Their History, Forms and Use. Cambridge, 1937.

VALle, Juan No del. Guía de forasteros de la capital de Puebla, para el año de I852. Puebla: Imp. del edit. [I9--], xii, 4I5 p.

Vargas Ugarte, Rubén. Historia del culto de María en Iberoamérica y de sus imágenes y santuarios más celebrados. Tomos I-II. Madrid: [Jura-San Lorenzo], I956.

Vargaslugo, Elisa (ed.). Imágenes de los naturales en el arte de la Nueva España. Siglos XVI al XVIII. México: UNAM, IIE, DGAPA / Fondo Cultural Banamex, 2005, p. 137-185.

VERINI, Joan Baptista. Luminario: el tercer libro de elementos de las letras (ca. 1525-1526), versión inglesa de A. F. Johnson con introducción de Stanley Morison. Studies in the History of Calligraphy I. Londres: Harvard, Newberry Library, 1947, 32 p.

Vervliet, Hendrik D. L. Sixteenth-Century Printing Types of the Low Countries, with a foreword by Harry Carter; translated from the Dutch manuscript by Harry Carter. Amsterdam: Hertzberger, 1968.

Vetancourt, Agustín de. Teatro mexicano. México: María de Benabides viuda de Juan de Ribera, 1967.

VIllaseñor y SÁNCHeZ, Joseph Antonio de. Theatro americano. México: Imprenta de Hogal, 1746-1798.

Virgilio. Eneida; Geórgicas; Bucólicas. Edición revisada por Francisco Montes de Oca. I2 ${ }^{\mathrm{a}}$ ed. México: Editorial Porrúa, 2000 (“Sepan Cuántos...”, I47).

VoráGine, Santiago de la. La leyenda dorada. Tomos I-II. Traducción del latín: fray José Manuel Macías. Madrid: Alianza, 1982 (ed. 1914).

vv. AA. Enciclopedia de la Religión Católica. Barcelona: Dalmau y Jover, 1952.

Whittaker, Martha Ellen. "Jesuit Printing in Bourbon Mexico City: The Press of the Colegio de San Ildefonso, I748-1767”. California, University de Berkeley, 1998, tesis doctoral.

Woodbridge, Hensley C. y Lawrence S. Thompson. Printing in Colonial Spanish America. Troy, Nueva York: Whitson Publishing Company, 1976.

YáñEZ Delgado, Alfonso. "Librería de libros.., para los estudiantes, lectores y predicadores", Universidad, núm, 24 (oct. 3, 1985).

Yhmoff Cabrera, Jesús. Los impresos mexicanos del siglo XVI en la Biblioteca Nacional de México. MéxiCo: UNAM, IIB, 1989, $260 \mathrm{p}$.

Zerón Zapata, Miguel. La Puebla de los Ángeles en el siglo XVII, crónica de la Puebla. Misiones en Puebla y sus contornos / De re metalica de Manuel Fernández de Santa Cruz; Pról. de Mariano Cuevas, S. J. México: Patria [1945], 247 p., il.

Zubillaga, Félix. Monumenta Mexicana, 5 vol. Roma: Missionum Societatis Iesu, 1956 (vol. v, doc. 213, p. 702-722).

Zulaica GáRATe, Román. Los franciscanos y la imprenta en México en el siglo XVI. México: UNAM, IIB, I99I, $373 \mathrm{p}$. 


\section{Recursos digitales y sitios electrónicos}

Archivo Municipal de Puebla, Guía General del Archino Histórico Municipal de Puebla [recurso electrónico] / Felicitas Ocampo López (coord.). México: Adabi / Ayuntamiento de Puebla / Fundación Alfredo Harp Helú, 2007 (I CD-ROM : son., col. ; 12 cm).

Archivo Municipal de Puebla, Catálogo de ilustraciones [recurso electrónico] / Archivo Municipal de Puebla. ${ }^{a}$ ed. México: Apoyo al Desarrollo de Archivos y Bibliotecas de México, 2004 (I CD-ROM : col. ; I2 cm).

Archivo Municipal de Puebla, Tesoros de las actas de cabildo del siglo XVI [recurso electrónico] / Archivo Municipal de Puebla. México : Publicaciones Electrónicas de México, 1996 (I CDROM : col. ; $12 \mathrm{~cm}$. + I manual del usuario, 56 p.).

Catálogo de Arte y Arquitectura de la Universidad Nacional de Australia, que contiene materiales de capitulares y ornamentos de algunos impresores europeos (http://rubens.anu.edu.au/htdocs/ bytype/prints/ornament.html).

Glosario básico de biblioteca y libro antiguo, Apoyo al Desarrollo de Archivos y Bibliotecas de México, A. C. (Adabi), http://www.adabi.org.mx/adabi.htm, consulta realizada el 27 de enero de 2005 .

Histoire de la Typographie (http://histoire.typographie.org/caracteres/classification/thibaudeau. html).

"Papeles con Marca al Agua" (http://www.watermarks.info/links.htm, consulta realizada el I de octubre de 2008).

Rómulo, Ignacio y Dimas García, "La nomenclatura tradicional de los tamaños de letra de imprenta", Unos tipos duros (http://www.unostiposduros.com/paginas/historz.html, página consultada el i6 de mayo de 2007). 


\section{LISTA DE ILUSTRACIONES}

\section{Capítulo I}

IMAGEN I. Las partes de una prensa antigua de frente y perfil.

IMAGEN 2. Mobiliario de la imprenta (Joseph Moxon, I683).

IMAGEN 3. Esquema de técnica de impresión sobre relieve y bajorrelieve.

IMAGEN 4. Cajas tipográficas españolas de los siglos XVII y XIX (imágenes procedentes los manuales de Paredes, I68o, y Sigüenza, I8II).

IMAGEN 5. Explicación de la elaboración del contrapunzón (Fournier, Manuale typographigue, París, 1764 ).

IMAGEN 6. Molde para fundir tipos. Museo de Artes Gráficas de Lérida, España.

IMAGEN 7. Dimensiones del caracter.

IMAGEN 8. Versalitas.

IMAGEN 9. Cursivas y números elzevirianos.

IMAGEN Io. Elementos constitutivos de la letra.

IMAgEN Ir. Clasificación de Thibaudeau: (I) Elzeviriano, (2) Didot, (3) Egipcio, (4) Antiguo o Sans serif (adaptación de la imagen procedente de Martínez de Souza, Diccionario de tipografía y el libro, il. 26, 83).

ImAGEN I2. Descripción de fuentes (imagen procedente de Juan B. Iguíniz, El libro. Epítome de bibliología. México: Porrúa, 1946, p. 34-35).

IMAGEN I3. Comparación de estilos góticos (imagen procedente de Garone, Kimura y Esponda, “Tipos de remate”, en DeDiseño, núm. 33).

IMAGEN I4. Clasificación de ojos comunes en la tipografía antigua (imagen procedente de Gaskel, tabla 2 , p. 2I).

IMAGEN I5. Gótica textura y gótica rotunda (imagen procedente de Corbeto y Garone, p. 27 y 31).

IMAGEN I6. Gótica fractura y gótica Schwabacher (imagen procedente de Corbeto y Garone, p. 188, y Updike, t. I, lámina 77).

IMAGEN 17. Romanas y cursivas barrocas: Kiss y caracteres de la romana del rey (imagen procedente de Corbeto y Garone, p. 85, 94).

IMAGEN I8. Romanas y cursivas barrocas: Flienschman (imagen procedente de Updike, t. II, lámina 2II), Pierre Simon Fournier y John Baskerville (imagen procedente de Corbeto y Garone, p. 105, I22).

IMAGEN I9. Redondas y cursivas neoclásicas de Didot (imagen procedente de Corbeto y Garone, p. I3I).

IMAGEN 20. Capitulares tipo lombarda (imagen procedente de Rob Roy Kelly, American Wood Type. 1828-1900. Notes on the Evolution of Decorated and Large Types and Comments on Related Trades of the Period. New York: Van Nostrand Reinhold Co., 1969).

IMAGEN 21. Inicial de un impreso de David Sartorius, 1582. Los puntos negros que se observan en las cuatro esquinas son las cabezas de los clavos que sostenían la letra al taco de madera (imagen procedente de Rob Roy Kelly, op. cit.).

IMAGEN 22. Capitulares de danzas macabras, atribuidas a Hans Holbein (Basilea, ca. I530) (imagen procedente de Rob Roy Kelly, op. cit.).

IMAGEN 23. Iniciales utilizadas por Robert Estienne, I502 (BNMex).

IMAGEN 24. Capitulares italianas. Vocabulario de Molina, I555 (вNMex).

IMAGEN 25. Capitulares de tradición española utilizadas en impresos poblanos del siglo XVII (BNMex).

IMAGEN 26. Letras floreadas de Fournier (BNMex). 
IMAGEN 27. Letras retrabajadas de Fournier. Muestra tipográfica mexicana, I782 (Garone Gravier, $2012 \mathrm{~b})$.

IMAGEN 28. Letras retrabajadas de Rosart presentes en el muestrario tipográfico de Mariano Galván, I827 (Garone Gravier, 2012 a).

IMAGEN 29. Letras pesadas de inicios del siglo XIX. Puebla: Imprenta Liberal, I82I (BNMex).

IMAGEN 30. Letras inclinadas de inicios del siglo XIX, Oficina del Gobierno Imperial, I82I (BNMex).

Imagen 3i. Letras historiadas del siglo xix. Puebla: El Amigo del Pueblo, i848 (вNmex).

IMAGEN 32. Hierros para encuadernación, Imprenta Artesanal del Ayuntamiento de Madrid.

IMAGEN 33. Ornamentos de Granjon (imagen procedente de Stanley Morison, John Fell. The University Press and the Fell Types. Londres: Garland Publishing Co., 198I, cap. X "The Fell Ornaments", p. I66-187).

IMAGEN 34. Ornamentos de Fournier (BNMex), Bodoni (biblioteca de la autora) y de muestras españolas (gentileza de José Ma. Ribagorda).

\section{CAPÍtULO II}

IMAGEN I. Sumario (I642).

IMAGEN 2. Alabado (lámina 5, procedente de Pérez Salazar).

IMAgEN 3. Vida y milagro del bienaventurado Sant Antonio de Padua, de fray Juan Bautista (México: Diego López Dávalos, I605).

IMÁGENES 4 y 5. Portada de la Primera parte del sermonario, dominical, y sanctoral en lengra mexicana; de fray Juan de Mijangos (México: Juan Blanco de Alcázar, I624); y ornamentos del Manual mexicano de la administración de los santos sacramentos, de Lorra Baquio (México: Diego Gutiérrez, I634).

Imagen 6. Vocabulario manual en las lenguas castellana y mexicana [...] de Pedro de Arenas (México: Enrico Martínez, I6II).

IMÁGeNES 7 y 8. Primera parte del sermonario, dominical, y sactoral en lengra mexicana, de fray Juan de Mijangos (México: Juan Blanco de Alcázar, I624); Alabado (lámina 5, procedente de Pérez Salazar).

IMAGEN 9. Historia real y sagrada, I643.

IMÁGENES io y ir. Primera parte del sermonario, dominical, y sanctoral en lengva mexicana, de fray Juan de Mijangos (México: Juan Blanco de Alcázar, I624); portada de Instrucción de la forma que han de tener ... Manuel de los Olivos, I645 (lámina 4, procedente de Pérez Salazar, p. 310).

IMÁGENES I2 y I3. Oración panegírica (lámina 6, procedente de Pérez Salazar); fray Martín de León, Manual breve y forma de administrar los sacramentos (México: Blanco de Alcázar, I6I7).

IMAGEN I4. Voto y joramento de la congregación de Nuestra Señora la Virgen Maria.

IMÁGENES I5. Impreso de Inés Vázquez Infante (I673).

ImÁGENes i6 y i7. Impresos de la Vda. de Borja e impreso de Diego.

IMAGEN I8. Juan Castaneira, Epilogo metrico de la vida y virtvdes de el venerable padre Fr. Sebastian de Aparicio natural de la Gudina (en Galicia) é Hijo de el Orden Seraphico en esta Provincia de el Santo Evangelio de Mexico (Diego Fernández de León, I689).

IMAGEN 19. Marca tipográfica de Diego Fernández de León.

IMAGEN 20. Breve summa de la oración mental (I692).

IMÁGENES 2I y 22. Portada de Luzeiro Evangélico (I7Io); portada de Gritos del purgatorio (I708).

IMÁGENES 23 y 24. Portadas de los libros de Diego Fernández de León.

IMAGEN 25. Impreso de Ángela Machorro, viuda de Fernández de León (I7io).

IMAGEN 26. Reglas de la Compañía de Jesús.

IMÁGENES 27 y 28. Libros impresos por el capitán Villareal y sus herederos.

IMAGEN 29. Impreso del capitán Guevara. 


\section{CapÍtulo III}

IMAgEN i. Exercicio práctico... reimpreso en Puebla, en la imprenta de Miguel de Ortega, i68I.

IMAGEN 2. Genealogía de la familia Ortega y Bonilla.

Imagen 3. Esquema genealógico de la familia de Pedro de la Rosa.

Imágenes 4 y 5 . Privilegio de Pedro de la Rosa. Ediciones de 1785 y de 1793.

Imagen 6. Plaza Pública de Puebla, con la marcación de cajones y jacales (I778, AGN).

Imágents 7, 8 y 9. Planos de los arreglos de la casa e imprenta de Pedro de la Rosa (I787, AGN).

\section{CAPÍtUlo IV}

IMAGEN I. Imprenta horizontal. Un modelo semejante al de la prensa insurgente, utilizada por el Ejército de las Tres Garantías (tomado de Ramón Sánchez Flores, 1994, p. 133).

\section{LISTA DE CUADROS}

\section{INTRODUCCIÓN}

CUADRO I. Relación de ejemplares revisados por impresor.

Cuadro 2. Relación de los libros que no fueron revisados por impresor.

Cundro 3. Relación de los impresos de Pedro de la Rosa, consultados y no consultados, por periodo.

CuAdro 4. Relación de los libros del siglo XIX, consultados y no consultados.

\section{Capítulo I}

Cuadro r. Tamaños de papel usuales en el libro antiguo (cuadro procedente de José Martínez de Souza, Diccionario de bibliología y ciencias afines. $3^{\mathrm{a}}$ ed. Gijón: Trea, 2004, p. 433).

Cuadro 2. Tipos de papeles empleados en la Nueva España y precios (siglo XVII).

Cuadro 3. Papel importado a la Nueva España (I748-i793).

Cuadro 4. Denominaciones usuales en la tipografía antigua y su equivalencia en $\mathrm{mm}$ en 20 líneas de texto.

Cuadro 5. Nombres y tamaños de tipos antiguos.

Cuadro 6. Nombres y tamaños de tipos antiguos (procedente de Oriol Moret, La medida tipográfica).

CuADRo 7. Esquema comparativo de las clasificaciones tipográficas (imagen procedente de Garone, Kimura y Esponda, “Tipos de Remate”, en DeDiseño, núm. 32).

\section{CAPÍtUlo II}

Cuadro i. Descripción de los pagos que se harán a oficiales de Diego Fernández de León por cada clase y género de obra.

\section{CAPÍtUlo III}

CuAdro i. Relación del número, frecuencia y años de envíos de Puebla a México.

Cuadro 2. Relación de las unidades y cantidades de envíos de Puebla a México.

\section{CONCLUSIONES}

Cuadro i. Resumen de las series de letras y de los promedios de los surtidos de material de imprenta. 


\section{APÉNDICES}




\section{APÉNDICE I}

\section{DOCUMENTOS PARA LA HISTORIA DE LA TIPOGRAFÍA POBLANA (TRANSCRIPCIONES Y PALEOGRAFÍAS)}

\section{Juan Blanco DE Alcázar}

(I642, 30-I) Carta de aprendiz del arte de impresor otorgada por Lázaro de Birves a nombre del menor Manuel de los Olivos, con el bachiller Juan Blanco de Alcázar, por tiempo de 3 años. [AGNP, Not. 3, Protocolos de Juan Guerra, Año de 1642, ff. I29r-I29v.] [Citado por Pérez Salazar sin indicar localización precisa, p. 307. Transcribo nueva versión paleográfica de Arturo Córdoba Durana, en adelante $\mathbf{A C D}$ ].

[f. I29r.] En la ziudad de los Ángeles, a treinta días del mes de henero de mil y seiscientos y quarenta y dos años, ante el contador Antonio López de Otamendi, alcalde hordinario en esta ziudad por su magestad y ante mí, el escrivano y testigos, parezió un mansebo español que dijo llamarse Manuel de los Olivos y ser natural de la ziudad de Xeres de la Frontera, en los reinos de Castilla y huérfano de padre y madre [tachado: y ma] y que tiene boluntad de deprender el arte de la ynprenta con el bachiller Joan Blanco de Alcássar; y por ser menor de veynte y zinco años, aunque mayor de quinze, para que por él otorgue escriptura, nonbró por su curador a Lázaro de Birves, vezino desta ziudad, pidió a su merced le aya por nonbrado y le mande paresca, asepte y jure; el qual, estando pressente por mandado del dicho alcalde, lo aseptó y juró a Dios y a la cruz en forma de derecho de lo usar como debe y es obligado. Y el dicho alcalde le dizirnió el cargo y dio poder para el uso del con general administrazión; del qual usando el dicho curador, otorgó que pone al dicho Manuel de los Olibos, a deprender el dicho arte de la ynprenta con el dicho bachiller Joan Blanco de Alcásar por tiempo de tres años, que an de enpesar a correr y contarse desde oy dicho día, durante los quales le a de enseñar el dicho arte bien y cunplidamente, de suerte que sea ofisial y travaxe por tal; donde no, a de poder asentar con otro maestro del dicho arte que se lo acave de enseñar; y el tienpo que en esto ocupare, le a de pagar lo que un ofisial que lo acava de deprender suele ganar. Y le a de tener en su cassa y hazerle buen tratamiento, darle de comer, cama, ropa linpia, curarlo en sus enfermedades con médico y botica, y el bestido y calsado nesesario; y al fin de los dichos tres años le a de dar un bestido de paño diez y ocheno de la tierra, que se entiende calsón, ropilla, ferresuelo, un jubón, dos camisas de Rúan con sus balonas, media, zapatos, sonbrero y petrina, todo hecho y acavado a su costa. Y desta manera, el dicho curador obligó al dicho su menor por su perssona [f. I29v.] y bienes a que no se yrá ni ausentará, pena que a su costa sea buscado y conpelido como convenga a que cunpla el tienpo que le faltare con más las fallas que ubiere hecho, en que a de ser creydo el dicho Joan Blanco con su juramento sinple. El qual, estando pressente [tachado: a quien yo], aseptó esta escriptura y rezivió por su aprendis al dicho Manuel de los Olivos, con el qual se obligó de hazer y cunplir lo que es obligado y no despedirlo ni hazerle mal tratamiento, pena de quedar obligado al cunplimiento de todo lo que dicho es; y lo que requiera prueba difiere en el juramento sinple del dicho curador y de quien fuere parte por el dicho menor, y a la firmeza obligó su persona y bienes avidos y por aver; y anbos otorgantes a quienes yo, el escrivano, doy fe conosco, dieron poder a las justicias de su magestad de qualesquier parte, en espessial a las desta ziudad, para que a ello les apremien como por sentencia passada en cosa jusgada, renunciaron leyes de su favor y la general del derecho; y el dicho alcalde aprovó esta escriptura y en ella, para su balidación, digo ynterponía e ynterpuso su utoridad y judicial decreto, y lo firmó con los otorgantes, siendo testigos: An- 
drés Ruiz de Aguilar, escrivano de su magestad, Alonso de Çoria y Nicolás Álvares, vesinos desta ziudad. Testado: a quien yo, y ma ${ }^{\mathrm{a}}$. Antonio López de Otamendi [rubricado], Laçaro de Birves [rubricado], Br. Juan Blanco de Alcázar [rubricado], Manuel de los Olibos [firmado]. Ante mí: Joan Guerra, escrivano público [rubricado]. Derechos: gratis, doy fe.

(I642, o8-XI) Poder especial otorgado por las hermanas Monçón a favor del Br. Juan Blanco de Alcaçar. aGNP, Not. 3, Protocolos de I642, ff. I463-1465r. Escribanía pública de Juan Guerra, escritura fechada en la ciudad de los Ángeles el 8 de noviembre de i642. [Documento no citado por Pérez Salazar, paleografía de ACD].

[f. I463r.] Sepan quantos esta carta vieren como nos, doña Aldonça de Çarate y Monçón y doña Luissa de Monçón, mujer legítima del Bachiller Juan Blanco de Alcássar, vesinos desta ciudad de los Ángeles, ambas hermanas y io la dicha doña Aldonça heredera del doctor don Luis de Monçón, tessorero que fue de la santa yglessia cathedral desta ciudad y ambas herederas de doña Beatris de Herrera y Monçón, muger que fue del capitán Juan de Ulloa, que según tenemos noticias falleció avintestado en el Partido de Tepexi donde el dicho capitán Juan de Ulloa es alcalde maior con licencia, que para lo que yrá declarado, io la dicha doña Luissa, pido a mi marido y io, el dicho Bachiller Juan Blanco de Alcaçar, se la concedo y io, la dicha doña Luissa la acepto; y della ussando ambas, de un acuerdo e conformidad por lo que nos toca, y por el título y actión de dichas herensias: Otorgamos que damos nuestro poder bastante en derecho al dicho Bachiller Juan Blanco de Alçasar para que haga averiguación de la muerte avintestado de [f. I463v.] la dicha doña Beatris de Herrera y Monçón, nuestra hermana, y pida seamos declaradas por sus herederas a causa de no aver dejado otros hermanos ni heredero forsoso ascendiente ni deszendiente, cuia herencia acepte con beneficio de ynventario y protestación de no confundir actiones, haciendo instancia en que se nos entreguen los vienes en que por su fin y muerte quedaron, y los que pertenecen a mi la dicha doña Aldonça como a heredera del dicho doctor don Luis de Monçón, y apruebe o contradiga ymbentarios, ventas y remates, pidiendo se hagan en la forma que combengan y pidiendo quentas a lo dar las perssonas que nos las devan dar, haciendo los cargos y reciviendo sus descargos, justos i competentes, nombrando terçeros contadores partidores y apreciadores, ynstando en que las dichas partes los nombren y en rebeldía o discordia la justicia de oficio, y apruebe o adicione las dichas quentas hasta que estén hechas a su satisfación, y reciva los alcanses en vienes o en espeçie, o en reales, [f. I464r.] y todo lo demás que se nos aplicare y perteneciere por dichas herencias, y los pesos de oro, plata, joyas, esclavos, mercadurias y géneros de qualquier calidad que se nos deven y debieren por qualquier título, caussa o raçón, por escripturas o sin ellas; y de todo lo que reciviere o cobrare, otorgue cartas de pago, finiquito, lasto y otros recaudos con cesión de derechos y renunciación de pecunia y entrego no siendo ante escrivano que dello de fe, en cuia raçón, y generalmente en todos los pleitos, caussas y negocios seviles y criminales que tenemos y tuviéremos con qualesquier personas o comunidades, demandando o defendiendo, paresca en juicio en tribunales superiores o ynferiores, eclesiásticos y seculares que a nuestro derecho combenga y ponga demandas o responda a las de contrario; que conteste o niegue, haga pedimentos, requerimientos, citaciones, protestaciones, juramentos, alegaciones, declinatorias, contradiçiones, querellas, acussaçiones [f. I464v.], recussaciones, apartamientos, embargos, desembargos, entregas, execusiones, prissiones, solturas, ventas y remates de vienes, de los quales y de los que nos pertenesieren tome posesión y la defienda, continué y ampare, presente testigos, escriptos, escripturas, provanças, testimonios y recaudos, que saque de poder de quien los tuviere, tache y redarguya los de contrario, pressentados cevil y criminalmente, como le pareciere; saque censsuras y las haga leer, yntimar y publicar asta las de anatema y testimonio 
de lo que resultare, y qualesquier mandamientos, reales provissiones y cartas de justicia, e pida su cumplimiento, concluía y oiga sentencias ynterlocutorias y difinitivas, y las dadas en nuestra favor consienta y apele y suplique de las que nos perjudicaren, y siga el grado por todas ynstançias, y haga los demás autos y diligencias que importen judicial y extrajudicialmente, que para ello y lo dependiente le damos este poder con general administraçión y facultad de sustituir en quanto a enjuiçiar y relevación en forma. Fecho en la ciudad de los Ángeles a ocho días del mes de noviembre de mil y seiscientos y quarenta [f. I465r.] e dos años, e yo el escrivano doy fe conozco los otorgantes que lo firmaron, ecepto la dicha doña Aldonça que dixo no saver, firmó a su ruego un testigo. Testigos: Nicolás Álvarez, Benito Román [sic] Sánchez y Rodrigo Días, vezinos y estantes en esta ciudad. Br. Juan Blanco de Alcaçar [rubricado], doña Luisa de Monçón [firmado]. Testigo Nicolás Álvarez [rubricado]. Ante mí: Joan Guerra, escrivano público [rubricado]. Sin derechos, de que doy fe.

(I649, o8-VII) Poder para tetar de doña Luisa de Monzón, mujer del Br. Juan Blanco de Alcázar. AGNP, Not. 3, Testamentos de I649, ff. 84-84v. escribanía d Juan López Gallegos. Poder para testar fechado en la ciudad de los Ángeles el 8 de julio de i649. [Documento no citado por Pérez Salazar, paleografía de Viridiana Vera Gracia, en adelante vvG].

[f. 84r.] En el nombre de Dios. Amén. Sepan quantos esta carta vieren como yo, doña Luissa de Monçón, muger lexítima del Bachiller Juan Blanco de Alcassar, natural desta ciudad de los Ángeles, hija lexítima de Luis de Monçón y de doña Juana de Herrera, mis padres difuntos. Estando enferma, en cama y en mi libre juiçio y entendimiento natural qual la magestad inmensa de Dios, nuestro señor, fue servido darme, digo que por la gravedad de mi enfermedad no sé si me dará lugar a hacer y ordenar mi testamento, el qual y las cosas tocantes al descargo de mi conciencia tengo comunicadas con el dicho mi marido. Por tanto, creyendo como firme y verdaderamente creo el misterio de la Santísima Trinidad, Padre, Hijo y Espíritu Santo, tres personas distintas y una sola esencia divina, y en todo lo demás que tiene, cree y confiessa la santa madre ygleçia de Roma, devajo de cuya fe y creensia me huelgo de aver vivido y protesto vivir y morir, eligiendo por mi avogada e ynterçesora a la sereníssima Reyna de los Ángeles, la Virgen Santa María, madre de Dios y señora nuestra, concevida en gracia y gloria para que sea mi yntersesora con su pressioso Hijo en el tribunal divino y me alcanse perdón de mis pecados, otorgo que doi mi poder cumplido, bastante en derecho, al dicho bachiller Juan Blanco de Alcasar, mi marido, para que en mi nombre y aunque sean pasados los términos que disponen las leyes de Toro, pueda haçer y ordenar mi testamento con las mandas, limosnas, obras pías y legados que le paresiere según se lo tengo hordenado, que de la suerte que lo hisiere y otorgare lo otorgo, apruebo y ratifico. Y quando Dios, nuestro señor, fuere servido de llevarme, le de a mi cuerpo sepultura en la santa ygleçia catedral desta ciudad o en otra qualquiera parte, la que les pareciere a mis alvaseas, a cuia elección lo dejo. Declaro que al tiempo que contraje matrimonio con el dicho Juan Blanco no lleve a su poder dote ninguna y el susodicho tenía de capital más de diez mil pesos, declárolo para que conste. Y nombro por mi alvaçea testamentario al dicho bachiller Juan Blanco de Alcasar, mi marido y le doi poder cumplido con libre y general administrazión para el usso del dicho cargo e que entre en mis vienes y los venda y remate en almoneda o fuera della, y de su preçio cumpla este poder y el testamento que en su virtud hiciere aunque sea passado los términos de la ley. Y en el remaniente que quedare de todos mis vienes [f. 84v.], derechos y acciones ynstituyo y nombro por mi heredero universal al dicho bachiller Juan Blanco de Alcasar, mi marido, atento a no tener como no tengo, herederos forçosos asendientes ni desendientez que conforme a derecho me puedan y devan heredar. Revoco y anulo y doy por ninguno y de ningún valor ni efecto 
qualedsquier testamentos, codicilos, poderes para testar y otras disposisionez que antes de aora aya fecho y otorgado por de escripto o de palabra, para que no valgan ni hagan fe en juicio o fuera del, sino este poder y el testamento que en su virtud se hisiere que quiero se guarde y cumpla por mi última boluntad en aquella vía y forma que mejor lugar aya en derecho, que es fecho en la ciudad de los Ángeles, en ocho días del mes de julio de mil seiscientos quarenta y nueve años e yo, el escrivano doy fe conozco a la otorgante que lo firmó, siendo testigos Juan del Barco, Bernardo Monsón y Miguel de la Pressa, vezinos desta ciudad. Doña Luissa de Monsón [firmado]. Ante mí: Nicolás López Gallegos, escrivano público [rubricado]. No e recibido derechos. Doi fe.

(1654, 28-XI) Carta de obligación de pago otorgada el Br. Juan Blanco de Alcázar y su mujer. AGNP, Not. 3, Protocolos de 1654, legajo XI, ff. 78v-79r. Escribanía de Melchor Fernández de la Fuente. Escritura suscrita en la ciudad de los Ángeles el 28 de noviembre de i654. [Documento no citado por Pérez Salazar].

[f. 78v.] Sepan quantos esta carta vieren como nos, el Bachiller Juan Blanco de Alcasar y doña Luisa de Monsón, ambos vesinos desta dicha ciudad, con lizencia que yo la susodicha pido al dicho mi marido para juntamente con él otorgar y jurar esta escriptura, la qual le concedo yo, el dicho bachiller, en bastante forma, en cuya asetación yo la susodicha y anbos juntamente de mancomún, a bos de uno y cada uno por el todo ynsolidum, con renunciación de leies de la mancomunidad, división y excursión, otorgamos que devemos y nos obligamos de pagar a Domingo de la Hedesa, vezino y mercader della y a quien tuviere su poder, cien pesos de oro común por otros tantos que por hacernos amistad y buena obra nos a prestado y suplido en reales de contado, de que nos damos por entregados, renunsiando leyes del entrego y su prueba y excepción de la pecunia, por cuya rassón, devajo de dicha mancomunidad haremos la paga de los dichos sien pesos en reales, en esta ciudad u en la parte que se nos pidan para de la fecha desta en un año cumplido, con costas de la cobransa a la qual se pueda enviar persona a la parte y lugar donde estuviéremos y nuestros vienes, con salario de dos pesos de oro de minas que gane cada día delos que se ocupare en la yda, estada y vuelta; y por los salarios y la deuda principal se nos pueda executar con el juramento del cobrador en que lo diferimos, y para seguridad desta deuda ypotecamos por especial y expresa ypoteca, no derogando la general ni por el contrario, un mulato nonbrado Nicolás, de hedad de diez y ocho años poco más o menos [f. 79r.], el qual queda en poder del dicho Domingo de la Hedesa, y se a de dar de salario dose reales cada mes, y emos rescibido del susodicho diez y ocho pessos que monta el primer año para bestir al dicho mulato para que si al requerirnos, cuyo benefisio y requisitos expresamente renunciamos, benderlo y de su precio hacerse pago; y por lo que nos alcansare executarnos con su juramento simple en que lo diferimos, y en ynterín no prosederemos a venta ni otra especie de enajenasión del dicho esclavo, pena que sea de ningún efecto y lo pueda sacar de ageno poder, venderlo y de su presio hacerse pago, y por lo que no alcansare executarnos con su juramento simple como va referido; para lo qual y otorgar escriptura de venta en forma, con sesión de derechos, le damos el poder que se requiere con declaración que si antes de cunplido el plazo desta escriptura pagaremos al dicho Domingo de la Edesa los dichos sien pesos nos a de volver el dicho esclavo, y a la firmesa obligamos nuestras personas y vienes. $Y$ presente yo, el dicho Domingo de la Hedesa, otorgo que rescivo al dicho Nicolás, mulato, de que me doy por entregado, renunsiando leyes de su entrego y prueba y a la firmesa obligo mi persona y vienes, y todos los otorgantes damos poder a las justisias de su magestad, espeçial a las desta ciudad donde por derecho estamos sometidos, para que a ello nos apremien como por sentencia pasada en cosa jusgada, renunsiamos leyes de nuestro favor y la general; y yo la dicha doña Luisa 
de Monsón renuncio el benefisio del Velyano, nuevas constitusiones, leyes del Toro y partidas y las demás que favoresen el derecho de las mugeres, de cuyo efecto fui apersevida por el presente escrivano, de que yo el escrivano doy fe; e yo, la otorgante, juró por Dios, nuestro señor y la señal de la Crus según derecho que entiendo bien el efecto desta escritura contra la qual no tengo fecha protestasión ni haré reclamaçión y contra su tenor y forma no me opondré por el previlegio de mi dote, arras, vienes parafernales, hereditarios, ni mitad del multiplico ni por otros derechos que me competan; y declaro que para otorgarla no e sido yndusida, apremiada ni atemorisada por el dicho mi marido ni por otra persona en su nonbre, porque declaro la otorgo de mi libre boluntad y este juramento, so cargo del no pedir absolusión ni relajasión a ningún jues ni prelado que facultad tenga para me lo conseder, y si de ofisio o propio motu se me consediere, del no usaré aunque sea para efecto de ser oyda en juisios, pena de no serlo y caer en caso de menos valer. Fecha en la ciudad de los Ángeles a veynte y ocho días del mes de nobiembre de mil y seiscientos y sinquenta y quatro años e yo, el escrivano doy fe conosco a los otorgantes que lo firmaron. Testigos: Miguel de Ortega, Joseph del Castillo y Antonio de Torres, vezinos desta ciudad. Doña Luisa de Monçón [rubricado], Br. Juan Blanco de Alcásar [rubricado], Domingo de la Hedesa [rubricado], Ante mí: Melchor Fernández de la Fuente, escrivano público [rubricado]. Derechos [ilegible], doy fe.

1657, Testamento De Juan Blanco De Alcazar. Documento no localizado en archivos poblanos. [Documento citado por Pérez Salazar sin indicar localización precisa, p. 37r. Transcribo paleografía ofrecida por el investigador].

Notaría ${ }^{\circ}{ }^{3}$. Ante n. Lopes Gallegos el P. Maestro Fr. Isidro de Sevallos del orden de Predicadores Vice rector del Colegio de S. Luis, otorgo el testamento de Jn ${ }^{\circ}$ Blanco de Alcazar y declara "que murió el 24 de Junio de 1657 y se enterro en Sto. Domingo "Declaro por sus bienes "Primeramente una Ymprenta de libros co todos sus aderentes" Declaro ser heredero de cierta cantidad de pesoso del Tesorero de la Catedral Dr. D. Luis de Monzon a quien heredo su muger D. Luisa de Monzon que le había el Cavildo. Declaro que queria "fundar una capellania de misas resadas por su alma y las demas de su intención de la qual queria que fuese yo primero patron y Capellan por todos los dias de mi vidad y al fn dellos me subsediesen en el dhl Patronato los Padres Rectores del dho Colegio de San Luis Y la dha Capellania se sirviese por los Relixiosos del, en quienes a de permanecer perpetuamente Y que de no cobrarse la dha deuda o nosiendo suficiente la cantidad que se cobrase della Para la fun ${ }^{\text {don }}$ de la dha Capellania se bendiera la Ymprenta que dejaba por sus bienes Y lo que montare su precio con lo que asi se hubiese cobrado se asegure por su principal dote juntando e yncorporando la una cantidad con la otra y siendo suficiente la dha deuda haviendo en ella bastante cantidad para hacer la dha fundass ${ }^{\text {on }}$ era su voluntad no se vendiese ni enagenase la dha ymprenta sino que yo la administrase como vienes suyos durante el tiempo d mi vida y con el usufructo que rindiese cumpliere lo que me dejaba comunicado en orden a el descargo de su conciencia sin que los dhos Padres Rectores del dho Colegio de San Luis ni otro ningun prelado superior se yntrometiese a pedirme quenta del usfructo de la dha ymprenta por ser como va referido para distribuirlo en las cosas que me encargo que hiciese que miran al decargo de su conciencia Y Por mi fallecimietno Era su determinada voluntad subsediese en la Propiedad de dha Ymprenta el dho Colegio de San Luis a quien della le hasia manda y legado por fin de mis dias Para quel Padre Rector que en aquella ocasión fuere del disponga della a s voluntad como le pareciese cumpliendose primero y ante todas las cossas lo dispuesto en esta clausula caso que noa suficiente la cntidad que de la deuda que debe la dha Sancta Yglesia se cobrare para la dundadcion del adha capellania que en tal acontecimietno no se a de vender la dha Imprenta [...] todo lo qual asi se a de guardar en 
conformidad de la voluntad del dho difunto[...] Con lo qual declaro haber cumplido con la voluntad del dho $\mathrm{B}^{\mathrm{r}}$ Juan Blanco de Alcazar segun me lo dejo comunicado" "En la Ciudad de los Angeles a veynte y dos dias del mes de Junio de mily ses ${ }^{\circ}$ y sinquenta y ochoans" Fr. Isidro Zeballos. -Rúbrica".

\section{FAMILIA BORJA Y GANDIA}

(1636, 26-I) Escritura de compraventa de libros otorgada por Juan de Borja, librero y Pedro de Lorenzana. AGNP, Not. 3, Protocolos del año i636, ff. 24or-247r. [f. 24or.] [Documento no citado por Pérez Salazar, paleografía de Mercedes Salomón Salazar].

En la ciudad de los Angeles a veinte y seis dias del mes de henero de mill Seiscientos y treinta y seis años. Ante mi el escrivano publico parecieron de una parte Pedro de Lorençana y de otra Juan de Borxa, librero, vecinos de esta ciudad a quienes doy fe que conosco, y dixeron que el dicho Pedro de Lorençana vendió al dicho Juan de Borxa los libros que tenía en su tienda a los precios que se tasaren de que le abia de bajar el tercio y de nombramiento de anbos se hiço tasacion de dichos libros en la manera siguiente:

Doscientos y ochenta cuerpos de libros de a quatro a dies y ocho pesos cada uno que montaron seiscientos y treinta pesos que bajado el tercio quedaron quatrocientos y veinte pesos. If 420

Quatroscientos y trece cuerpos de libros de ocho a doce reales montaron seiscientos y diez y nuebe pesos y quatro tomines que bajado el tercio quedaron cuatrocientos y trece pessos. If 4I3 Ciento y ochenta y seis cuerpos de libros de doce [f. 24ov.] y diez y seis a nuebe reales montaron docientos y nuebe pesos y dos tomines que bajado el tercio quedaron ciento y treinta y nuebe pesos y quatro tomines. I $1394^{\mathrm{t}}$

Siete cuerpos de libros de marca mayor de la letura de Paulo sobre el derecho en treinta pesos que bajado el tercio quedaron veinte pesos. If 20

Cien cuerpos de libros de a quatro a diez y ocho reales montaron cien pesos veinte y cinco pesos que bajado el tercio quedaron ciento y cinquenta y dos pesos. . 152

Ciento y cinquenta y un cuerpos de libros de a folio a quatro pesos montaron seiscientos y quatro pesos que bajado el tercio quedaron quatrocientos y dos pesos y cinco tomines. If $4025 \mathrm{t}$

Conforme a lo qual montaron un mill quinientos quarenta y siete pesos y cinco tomines.

\section{I $5475^{\mathrm{t}}$}

Y despues el dicho Pedro de Lorençana por peticion que [f. 24Ir.] a diez de este mes pressentó ante el alferez mayor don Geronimo Perez de Salaçar alcalde hordinario desta ciudad hiço relacion del dicho trato y que abiendo puesto cada uno su apreciador para la tasacion de dichos libros y conformadosse en que la hiciesse por ambos Juan Francisco Balberde enpeço a tasarlos y pareciendole al dicho Juan de Borja que en algunos excedia dixo que no abia de passar adelante la tasacion fin que asistiesse a ella Diego Lopes librero y la hiciesse junto con el dicho Juan Francisco los quales lo tassaron en la forma y manera que se contenia en la memoria que pressentó y quedó efectuada la venta y el monto de todo se asentó en mill y quinientos quarenta y siete pessos cinco tomines y la forma de su paga fue como concertaron [f. 24Iv.] con lo qual el dicho Juan de Borja llebó todos los libros y los tenia en su tienda y a bendido parte dellos por su quenta y para que constasse en todo tiempo el dicho trato y tubiesse recaudo en virtud de que pudiesse hacer la cobrança pidió que abiendo por pressentada la dicha memoria de tasacion mandase que el dicho Juan de Borja declarasse con juramento si era berdad lo que en su escrito referia y efectuaron la dicha venta y tenia en su poder los dichos libros por la dicha tasacion abiendo precedido la baja del tercio y se le mandase otorgase scriptura en forma de la dicha conbencion y en virtud de auto probeido por el dicho alcalde el dicho Juan de Borja hiço cierta declaracion confessando que tratando [f. 242r.] el dicho Pedro de Lorençana 
de benderle los dichos libros que tenia en su tienda ofrecio comprarselos todos efectuaron la benta por lo que se tasassen quitandole el tercio y lo que montasse se pagaria cinquenta pesos cada mes que abian de contarsse ocho messes adelante de la scriptura que quedaron de otorgar y al principio entrambos nombraran por tercero a Juan Francisco Balberde el qual enpeçó a tassar los dichos libros y pareciendole no ser a proposito su tassacion no quisso que pasasse adelante sino que se nombrasse a Diego Lopez y a Tomas Nuñez y aunque despues consintió en que los tasasen los dichos Juan Francisco y Diego Lopez abia sido por cortesia y no por boluntad e hicieron la dicha tasacion segun lo declaraba la dicha memoria [f. 242v.] y llebó los [tachado: d] cuerpos de libros que contenia a su cassa y pidió mediante algunas perssonas se ajustasse el excesso de la tasacion y se le hiciesse alguna equidad y como esto fuesse assi pagaria passados dos messes cinquenta pessos cada mes al dicho Pedro de Lorençana y por que los libros eran de poco balor y separados y maltratados y no aberle entregado enteramente los que le bendió era engañado en el dicho trato en mas de seiscientos pessos y bolbiendose a tazar por perssonas entendidas juridicamente nombradas por las partes entregandosele todos los libros que faltaban y baxandole el tercio de lo que se tasasse le pagaria su precio cinquenta pessos cada mes pasados dos meses como tenia dicho y abiendo precedido a los autos por uno a cinquenta pessos cada mes [f. 243r.] que el dicho alcalde probeyó a los doçe deste mes mandó que el dicho Juan de Borxa otorgasse scriptura en fabor del dicho Pedro de Lorençana de los dichos mill y quinientos y quarenta y siete pesos y cinco tomines que montaba el precio en que se tasaron los dichos libros a los plaços y en la forma en que se contenia en los autos y le dejó su derecho a salbo en quanto al engaño que alegó y deste se apeló por el dicho Juan de Borja pasa ante el alcalde mayor desta ciudad donde se pressentó y expressó sus agrabios de que se mandó dar traslado al dicho Pedro de Lorençana como consta de los autos que pasan ante mi el escrivano a que se refieren y por escusar pleitos y diferencias atendiendo los quales fines son dudosos trataran [f. 243v.] de medio y concierto y por la pressente por bia de transacion y en aquella que mexor lugar tenga en derecho otorgan que la efectuan en tal manera que el dicho Juan de Borxa aprueba y ratifica la tasacion de dichos libros para estar y pasar por ella y confiessa tenerlos en su poder y aber montado los dichos un mill quinientos y quarenta y siete pesos y cinco tomines de mas de lo qual el dicho Pedro de Lorençana le entregó y el dicho Juan de Borxa declaró aber recibido lo siguiente:

Diez y ocho resmas de coplas a doçe pessos resma montaron docientos y diez y seis pesos. I) 216

Quarenta y quatro docenas de estampas de marca mayor a peso [f. 244r.] La docena mon$\tan$, T) 44

El expurgatorio del año de mill y seiscientos y treinta y dos en catorce pessos. If I4

Cantidad de estanpas chicas y grandes treinta y ocho pessos y [arriba: y cinco tomines], of $385 \mathrm{t}$

Dyez y siete oratorios de Fray Luis de Granada dorados y llanos y unos hierros de dorar en veinte y nuebe pesos. If 29

Unas caxas de escribanias y antojos [sic] que son beinte y siete pares en nuebe pessos. I 9

Que estas partidas que nuebamente se le entregaron montaron trecientos y cinquenta pesos $\mathrm{y}$ cinco tomines, I $3505 \mathrm{t}$

Que juntos con los un mill quinientos quarenta y siete pesos y cinco tomines del primer entrego valieron [f. 244v.] un mill ochoscientos y nobenta y siete pesos y dos tomines de los quales el dicho Pedro Lorençana remite y perdona al dicho Juan de Borxa nobenta y siete pesos y dos reales para no pedirsselos agora ni en ningun tiempo pena de no ser oydo en juicio y queda debiendo liquidamente el dicho Juan de Borxa un mill y ochocientos pesos y dandose por entregado de dichos libros estampas y coplas y lo demas que expecifica esta scriptura por 
tenerlos en su poder conefecto sobre que renuncia poder alegar cossa en contrario leyes de la entrega y su persona se obliga de pagar al dicho Pedro de Lorençana y a la perssona que tubiere su poder los dichos un mill y ochocientos pessos en reales en esta ciudad o en la parte que se le pidan cinquenta [f. 245r.] pessos a fin de abril deste año de la fecha y assi suscesibamente cinquenta pessos por fin de cada mes hasta aberle acabado de satisfacer y pagar la dicha deuda con cartas de la cobrança y con esto anbos contrayentes confiessan esta scriptura y conbencion esta echa con ygualdad y caso que alguna demasia aya de una parte a otra se la remiten y perdonan y hacen de la cantidad que fuese gracia y donacion perfecta yrebocacable por firme contrato entre bibos con la fuerças y requisitos ymportantes a su balidacion y con renunciacion de el dicho fraude ynormissima lession y engaño ni otro remedio de que pudieran balersse y se desisten y apartan del dicho pleito y lo en el deducido declarado [f. 245v.] alegado y an autuado y lo dan por nullo roto y chancelado y de ningun balor ni efecto para no seguirlo ni proseguirlo por las acciones que pudieran oponer dentro del termino que tienen por derecho que dan por passado y sus excepciones y acciones por prescriptas y acabadas dejan declaraciones deducidas al rigor de esta scriptura por la qual el dicho Juan de Borxa permite que no haviendo paga puntual a los dichos plaços pueda el dicho Pedro de Lorençana enbiar perssona a la cobrança con salario de dos pessos de oro de minas que gane cada dia de los que se ocupare en la yda estada, negociacion y buelta a esta ciudad hasta la Real paga que por los salarios [f. 246r.] como por la deuda principal se le execute con el juramento simple del cobrador en que lo difere sin otra... y ambos prometen aber por firme esta conbencion y no yr contra su tenor y forma por ningun remedio que les competa pena de quinientos pesos de oro comun que se ponen de conbencional y aplican por mitad camara de su magestad y parte obediente y pagada o remitida todabia segun descumpla para lo qual obligaron sus perssonas y bienes abidos y por aber y dieron poder a las justicias de su magestad es pena la lei desta ciudad donde se sometieron y renunciaron su fuero juridicion y de mi [f. $246 \mathrm{v}$.] a los que la ley si[t] conbenerit de juridicione para que a ello les apremien como por sentencia definitiba pasada en cossa juzgada. Renunciaron leyes de su fabor y la general del derecho. Juraron a Dios y a la Cruz en forma que contra esta scriptura no an echo protestacion ni reclamacion y pareciendo la rebocan y prometen aberla por firme en todo tiempo sin enbargo de qualesquier acciones que pudieran oponer en su contrabencion y no pediran relaxacion de este juramento a quien se la deba conceder aunque sea para ser oydos en juicio pena de no serlo y caer en la dicha de menosbaler y lo firmaron todos. Pedro [f. 247r.] Francisco Martinez escribano Real, Laçaro de Birciel y Diego de Abiña vecinos desta ciudad. = + dos.= entre renglones y cinco tomines. Juan de Borja Gandia [Rubricado] Pedro Lorensana [Rubricado]. Ante mi Joan Guerra [Rubricado], Escribano Publico. Derechos tres pesos no mas. Doy fee.

1685, Acta de Entierro de Doña Ynes Vasquez. [Documento no localizado por mí en archivos poblanos, citado por Pérez Salazar sin indicar localización precisa, p. 372. Transcribo paleografía ofrecida por el investigador].

"En la Ciudad de los Ang ${ }^{8}$ en seis de disiembre de mil i seiscientos y ochenta y sinco años se enterro en la Yglesia de Sancta clara $\mathrm{D}^{\mathrm{a}}$ Ynes basques viuda de $\mathrm{Jn}^{\circ}$ de borja su hijo. resibio los sanctos sacramentos e mando se digan treinta y tres misas resadas."

I690, Acta de Entierro de Juan De Borja Infante. [Documento no localizado por mí en archivos poblanos, citado por Pérez Salazar sin indicar localización precisa, p. 372. Transcribo paleografía ofrecida por el investigador]. 
"En la Ciudad de los Ang ${ }^{8}$ a nuebe de Octubre de mill seiscientos i nobenta años se enterro en la Yglesia del Convento de Religiossos del Senor Sancto Domingo el Capitan Juan de Borja Infante i Gandia Casado que fue con Doña Geronima de Birgueña Soberanes dio poder para testar a la dha su muger al Li ${ }^{\text {do }}$ Don Antonio de Borja Soberanes Presbitero su hijo i al Capitan i Regidor Don Miguel Vasques Mellado su llerno testó ante Francisco Solano escribano real y Publico recibio los Santos Sacramentos."

Imprenta del Colegio Dominico de SAn Luis de la Ciudad de Puebla S./f. AGMP, Suplemento de el Libro Número dos de el mismo establecimiento y dilatación de la Ciudad de Puebla, ff. I33r-I33 v. Sin fecha. [Documento no citado por Pérez Salazar].

[f. 133r.] Fr. Francisco de Gracia, rector de el colegio real de San Luis, fundado en esta ciudad de los Ángeles, de que es patrón el rei, nuestro señor, paresco ante vuestra señoría en la mejor forma que a mi derecho convenga, y digo que como a vuestra señoría le consta, se allaban los hijos de vecinos el año pasado, sin estudios mayores ni maestros para su educasión, y pretendiendo remedio en esta quiebra se intentó con medios eficases que en el colegio de San Ilifonso se leyera todos los años cursos de artes con que se estorbase el nuestro en los mancebos y no se perdiesen los hijos de los vesinos, lo qual no tubo efecto por las rasones que están en los autos y diligensias que vuestra señoría hiso por rasón de bien común, de que tocó adbitrar que en este colegio de San Luis se diesen estudios mayores a los dichos, y con orden de vuestra señoría se señaló para el dicho efecto catedrático, que fue el padre presentado fray Thomás de San Juan, que era rector del dicho colegio, en cuya consequensia tiene trabajado el primer tomo de el curso con ánimo de imprimirle, dedicado a vuestra señoría como dueño propio de este colegio, para cuyo efecto la presentó ante el excelentísimo señor marqués de Serralbo, y aviéndole remitido para su aprobasión, se dio con satisfasión la lisensia para la imprenta, antesediéndo riguroso examen de su doctrina por tres reverendos padres maestros, cuyas diligensias an costado mucho trabajo y dineros; si bien, bien empleados por ser en servisio de esta república; y por mostrar con el efecto el que tiene este colegio a las ordenes de vuestra señoría, pues ha sombra suya se dio esta acsión, sobre la qual se hisieron algunos autos que se remitieron a el rey, nuestro señor y a su real Consejo de Indias, sobre cuya materia se aguarda su resolución; y de averse dilatado se ha seguido que los religiosos de la Compañía de Jesús en el colegio de San Ilifonso empiesen nuebo curso de artes; para el qual congregan todos los estudiantes disiéndoles que sólo los cursan en él se pueden graduar, de que resulta alterarse el estilo y orden que vuestra señoría dio el año pasado a este colegio; siendo así que en el de los padres de la compañía dio no an de leer curso, sino cada tres años vendrán a quedar en pie los mismos inconbenientes (ya experimentados) [f. I33v.] que fueron los que vuestra señoría pretendió obiar por mirar paternalmente el bien y aumento de los hijos de esta muy noble y muy leal siudad. Por tanto a vuestra señoría pido y suplico me mande ordenar lo que deba haser, ponderados los dichos inconvenientes, para que para que en todo se cumplan sus ordenes y mandatos; y este colegio asierte a servir a vuestra señoría.

Otro si, pido y suplico, en porsecusión de la honra que asta aquí an servido, le asista vuestra señoría y honre al inisio. el día de San Lucas, en la tarde, como principio de estudios, pues estos se an puesto al amparo de vuestra señoría, probeyendo en todo lo que más convenga a el servicio de su magestad, como patrón del dicho nuestro colegio, que en ello reciviré bien y merced, con justicia, etc. Fray Francisco de Gracia, rector [firmado]. 


\section{LÁzARO RODRÍGUEZ DE LA TORRE}

(I675, 30-XII) Escritura de arrendamiento de casa otorgada por Lázaro Rodríguez de la Torre, mestizo libre, maestro impresor a favor del Lic. Alonso de Gamboa, presbitero (I675, 30-XII) [AGNP, Not. 4, caja 209, Protocolos de Tomás de Ortega, año de 1675, f. 492r.] [Documento no citado por Pérez Salazar, paleografía de ACD].

Sepan quantos esta carta vieren como yo, Lásaro Rodrígues de la Torre, mulato libre, maestro impresor, vesino de la ciudad de los Ángeles, otorgo que me obligo de pagar al licenciado Alonso de Gamboa, presvítero, domisiliario deste obispado, y a la perssona que tubiere su poder, quarenta y ocho pesos de oro común por el arrendamiento de una cassa en esquina de la calle que ba de el convento de San Augustín al obraje de Acuña, linde por una parte cassa de el dicho Alonso de Gamboa y por otra de el señor Macario de Ansúres, por tiempo de un año, que es el que viene de mil y seissientos y setenta y seis, desde principio de henero asta fin de disiembre de el, en dicha cantidad, por cuia raçòn, renunsiando poder alegar cossa en contrario, leyes de el entrego y su prueva, pagaré dichos quarenta y ocho pesos en reales, en esta ciudad o en la parte que se me pidan, por los tercios corridos de el dicho año, al fin de cada quatro meses la tercia parte, con costas de la cobranza. Y no dejaré la dicha cassa durante el dicho tiempo, pena de pagar la renta de vacio, y a la firmesa obligo mi perssona y bienes y doy poder a las justisias de su magestad, especial a las de esta ciudad donde soy vesino y por derecho estoy sometido para que a ello me apremien como por sentencia pasada en cossa jusgada, renuncio leyes de mi favor y la general del derecho, que es fecha en la ciudad de los Ángeles, a treinta días de el mes de disiembre de mil y seiscientos y setenta y sinco años e yo, el escrivano, doy fe conosco al otorgante qu lo firmó. Testigos: Juan Godínes, escrivano de su magestad, Joseph de Trujillo e Ignacio Lópes, vesinos de esta ciudad. Lázaro Rodríguez de la Torre [rubricado]. Ante mí: Thomás de Ortega, escrivano real y público [rubricado]. Derechos III) [Iv] reales, doy fe.

\section{Diego FERNÁNDEZ DE LEÓN}

(I682, 24-IX) Compra de imprenta por parte de Diego Fernández de León. AGNP, Notaría No. 4, Protocolos de I682, ff. 819-825v. [Documento no citado por Pérez Salazar, paleografía de ACD].

[f. 8igr.] [Al margen izquierdo: fecho para el ospital de San Cristóval; fecho para la parte del Licenziado Lucas Cortés; fecho para la parte de Theresa García] Sepan quantos esta carta vieren como yo, don Nicolás Ruis Machorro, vesino y labrador de la provincia de Thepeaca y residente en esta ciudad de los Ángeles, otorgó que doi mi poder cumplido a Diego Fernández, maestro librero, vessino desta ciudad, para que obligándose el susodicho como principal deudor obligado, me obligue como su fiador y principal pagador, juntamente con el susodicho de mancomún, a vos de uno y cada uno de nos, por si y por el todo ynsolidum, con renunciassión de leies de la mancomunidad, divissión y escurssión, asta en cantidad de dos mil pesos de oro común y allándolos los reciva a su poder por vía de préstamo o suplemento, y los reciva de qualesquier conventos, cofradías, obras pías y personas particulares, con los yntereses que consertare, de que se de por entregado con renunciasión de pecunia y entrego no siendo ante escrivano que dello de fe, obligándome devajo de dicha mancomunidad a la satisfación y paga de dichos dos $\mathrm{ml}$ pesos y de los yntereses que conser[f. 8Igv.]tare para que la aremos en reales a las perssonas a quien tocare, a los tiempos, plasos y lugares y devajo de las penas y salarios que pussiere y asentare, otorgando la escriptura o escripturas que importaren, con las fuerssas, vínculos, firmesas, salarios, sumiciones, revocasiones de pruevas, 
renunciassiones de leies y de fuero, poderío y sumición a las justisias reales y las demás que conbengan a su validassión; que de la suerte que la hiciere y otorgare las otorgo, apruevo y ratifico y me obligo a su observanssia, guarda y cumplimiento y a la firmessa deste poder y de lo que en su virtud se hiciere obligo mi persona y vienes havidos y por haver, doi poder a las justisias reales, en especial a las donde en virtud deste fuere sometido, a cuyo fuero y jurisdissión me someto, renuncio el mío propio domicilio y vesindad, y la lei sid convenerit de juriditione para que a ello me apremien como por sentencia pasada en cossa jusgada, renuncio leyes de mi favor y la general del derecho; que es fecho en la ciudad de los Ángeles, a tresse días del mes de septiembre de mil y seiscientos y ochenta y dos años, y el otorgante que yo el [f. 82or.] escrivano doy fe que conosco lo firmó, testigos: don Pedro Queto de la Madris, Christóval de Roblez, Domingo Méndes de Herrera y Pedrosa, vecinos esta ciudad. Nicolás Ruis Machorro. Ante mí: Antonio Gómes de Escobar, escrivano real y público. Hago mi signo [signo] en testimonio de verdad: Antonio Gómes de Escobar, escrivano real y público [rubricado]. Derechos viI reales.

[f. 82ov.] Poder. Año de i682. Don Nicolás Ruis Machorro vesino y labrador de la provincia de Thepeaca a Diego Fernándes, maestro librero, vesino de la de los Ángeles.

[f. 822r.] Sepan quantos esta carta vieren como yo, Diego Fernández de León, vezino desta ciudad de los Ángelez, digo que teniendo nesesidad de dos mil pesos de oro común para conprar una ynprenta, presenté memorial al Ylustrísimo Señor Doctor Don Manuel Fernándes de Santa Cruz, obispo digníssimo deste obispado, del Consejo de su magestad, pidiéndole fuese servido de mandar se me diessen de qualesquier capellanías y obras pías, de que otorgaría escriptura para pagarlos dentro de seis años e ypotecaría dicha ynprenta con todos sus avíos y me fiaría en toda la cantidad Nicolás Machorro, dueño de assiendas de lavor y ganado menor en la provincia de Tepeaca, y que a falta del susodicho se obligaría mi muger a quinientos pessos con la dote y el Doctor Joseph Gómez de la Parra a otros quinientos pessos y el alférez Joseph Gómez de la Parra a otros un mil pessos, que hacen los dichos dos mil pessos, y pagaría a sinco por ciento. Y por decreto de veinte y tres deste presente mes y año fue servido su Ylustrísima de mandar se me diessen e por dicho tienpo de seis años mil pessos pertenesientes al ospital del Señor San Christóval, quinientos de la capellanía del licenziado Lucas Cortés, y quinientos y quarenta y seis pessos y quatro tomines de la capellanía de Teressa García, que las tres cantidades suman y montan [f. 822v.] dos mil y quarenta y seis pessos y quatro tomines, obligándose, como ofresió por toda dicha cantidad, el dicho Nicolás Ruis Machorro, como mi fiador y la dicha mi muger en los dichos quinientos pessos del favor de la dicha capellanía del dicho licenziado Lucas Cortés y el dicho doctor Joseph Gómes de la Parra en los dichos quinientos quarenta y seis pessos y quatro reales de la de la dicha Teressa García y en los un mil pessos restantes, pertenesientes a dicho capital, el dicho alféres Joseph Gómes de la Parra; y constando de escriptura en la Secretaría de govierno se me despacharía mandamiento para que se me entregasse dicha cantidad como más largamente consta y paresse por dicho memorial y decreto cuyo tenor es el siguiente. Aquí el memorial y decreto: [f. 82Ir.] Ylustríssimo Señor. Diego Fernández de León, vecino de esta ciudad de la Puebla y mercader de libros, digo que para comprar una imprenta necesito de dos mil pesos y asi suplico a vuestra señoría ylustrísima si los hubiere de capellanías, obras pías u otra cosa, mande se me den, que de la cantidad dicha haré escriptura a satisfaser dentro de seis años, obligando mi persona y vienes y en particular dicha ymprenta con todos sus avíos. Y ofresco por principal fiador a esta cantidad y su paga a Nicolás Machorro, vezino desta ciudad y dueño de haziendas de labor. Y para mayor seguridad, por falta de este se obligará mi muger, con su dote, a quinientos pesos y el doctor Joseph Gómez de la Parra a otros quinientos pesos y el alféres Joseph Gómez de la Parra, vezino desta ciudad, a un mil pesos, reconosiendo las personas a quienes tocaren los réditos de sinco por 
siento. Por tanto, a vuestra Señoría Ylustrísima pido y suplico se sirva de mandar se me de dicha cantidad de dos mil pesos, haziendo antes para su seguridad [sic] la escriptura con los fiadores dichos. Espero conseguirlo de la piedad y grandeza de vuestra Señoría Ylustrísima. Diego Fernández de León [firmado]. [Al margen izquierdo: Ángeles, 23 de septiembre de 1682 años. Que se le den al suplicante a cinco por ciento, por seis años, mil pesos pertenecientes al hospital de San Christóval, quinientos de la capellanía del Lizenciado Lucas Cortés, quinientos quarenta y seis y quatro tomines de la capellanía de Theresa García, obligándose como ofrece por toda la cantidad con Nicolás Machorro, su fiador en ella, añadiéndose su muger con la obligación de la dote en los quinientos pesos del dicho licenziado Lucas Cortés. El Dr. Joseph Gómez de la Parra en los quinientos quarenta y seis pesos y quatro reales de dicha capellanía de Theresa García y en dichos un mil pesos de San Christóval el alféres Joseph Gómez de la Parra. Y constando de la escriptura, en nuestra Secretaría se le despachará mandamiento para que se le entregue la cantidad. Así lo proveyó, mandó y rubricó el Ylustrísimo Señor Obispo, mi señor. Enmendado: seis, Lucas, vale. Ante mi: Juan de Salaçar y Bolea, escrivano [rubricado].

[Continuación después de "Aquí el memorial y decreto" citado ut supra] Y cumpliendo con mi ofrecimiento y con el tenor de dicho decreto. Por el presente, en aquella vía y forma que mejor en derecho lugar aya, otorgo que me obligo como principal deudor y obligado, y en vos y en nombre del dicho Nicolás Machorro y en virtud de su poder que es el que va por prinsipio desta escriptura y usando del, otorgo assí mesmo que lo obligo como mi fiador y prinsipal pagador; y estando presentes nos, los dichos doña Ángela Ruis Machorro, su muger, con la lizensia que yo la susodicha pido al dicho Diego Fernándes de León, mi marido, para otorgar esta escriptura y fiarle en los dichos [f. 823r.] quinientos pessos y jurarla me de y conseda, la qual le consedo yo, el susodicho, en vastante forma so expressa obligassión que para ello ago de mi persona y vienes. Y el dicho doctor Joseph Gómes de la Parra y alféres Joseph Gómes de la Parra, vesinos desta dicha ciudad, juntos y de mancomún con el dicho Diego Fernándes de León, a vos de uno y cada uno de nos, por sí y por el todo ynsolidum, otorgamos que nos obligamos como sus fiadores y prinsipales pagadores a pagar los dichos dos mil quarenta y seis pesos y quatro tomines del dicho oro que a mí, el dicho Diego Fernándes de León, por aserme amistad y buena obra se me an prestado y suplido en reales de contado, de que me doy por entregado, renunciando leyes del entrego y su prueba y esepción de la pecunia, los un mil pessos, al dicho ospital del Señor San Christóval, y a su rector y administrador que al presente es y al que adelante lo fuere y por dicho hospital parte lexítima, en cuya cantidad le fio yo, el dicho alferés Joseph Gómes de la Parra, y no en más. Y los quinientos a la dicha capellanía del dicho licenziado Lucas Cortés y a sus patronos y capellanes y a quien por ella fuere parte lexítima, en los quales le fío yo, la dicha doña Ángela Ruis Machorro, su muger y no en más, en conformidad de dicho decreto. Y los quinientos y quarenta y seis pessos y quatro tomines restantes a la capellanía de la dicha Teressa García y a sus patronos y capellanes y a quien por ella fuere parte lexítima, en cuya cantidad le fío yo, el dicho doctor Joseph Gómes de la Parra, y no en más. [f. 823v.] y todos tres fiadores asimismo en los réditos correspondientes a las cantidades que así mismo vamos obligados cuya paga aremos todos los dichos, principal y fiadores, y ará el dicho Nicolás Machorro, fiador en toda ella, en reales, en esta ciudad u en las partes que se nos pidan y se le pidan dentro de seis años, que empiesan a correr y contarsse desde oy día de la fecha desta escriptura en adelante hasta ser cumplidos, con más a sinco por siento por la detensión y mora mediante a ser senssos pertenesientes a dicho ospital y capellanías que forsossamente se avían de ynponer para que redituassen, con costas de la cobranssa, en la qual se pueda enbiar persona donde estubiéremos y nuestros vienes y estuviere el dicho Nicolás Machorro y los suyos, con salario de dos pessos de oro de minas que gane en cada un día de los 
que se ocupare en la yda, estada, negosiassión y buelta a la parte donde saliere asta la real paga, y por los salarios como por los dichos réditos se nos pueda y se le pueda executar con el juramente sinple del cobrador, en que por nos y en dicho nonbre lo diferimos sin otra prueba de que le relevamos. Y con calidad de es [f. 824r.] pressa que casso que el dicho prinsipal falte por algún acsidente a la satisfassión de la cantidad de su obligación, nosotros los dichos sus fiadores no emos de lastar mas que la cantidad en que le fiamos cada uno y ba expressada y réditos correspondientes a la de cada uno, ni se nos a de poder compeler a otra cossa por ser dichas fianssas sin exceder del decreto de dicho señor ylustríssimo suso ynsertos; y una ves lastada, cada uno se a de entender queda libre y sus vienes del rigor desta escriptura y fianssa sin que se pueda ynobar en lo referido en manera alguna. Y para más seguridad de la deuda yo, el dicho Diego Fernándes de León, hipoteco por expesial y expressa hipoteca, no derogando la general ni por el contrario, la dicha ynprenta y todos los avíos y peltrechos de que se conpone, que es mía propia en virtud de la conpra que tengo fecha della y está libre de enpeño, otra hipoteca, ynajenasión expesial ni general para que si al plasso que va declarado no hisiere paga puntual puedan la parte del dicho ospital y capellanías, sin sitarme ni requerirme cuyo benefissio y requisitos expressamente renuncio, venderla judicial y extrajudicialmente, como les paresiere [f. 824v.] y de su presio asserse pago y por lo que no alcansare, executársseme con sólo su juramento sinple de cada parte en que lo difiero sin otra prueva de que le relevo y asta tanto que esta deuda este pagada me prohivo de su venta y otra enajenasión, pena que el trato enajenatorio a que prosediera sea de ningún valor ni efecto y las puedan sacar de tercero poseedor, para lo qual y otorgar venta real en forma de dicha ynprenta y todo lo que le pertenesse con sesión de mis derechos, les doy tan bastante poder como de derecho se requiere y es nesessario; y a la firmessa obligamos yo, el dicho Diego Fernándes de León, mi persona y vienes, la de dicho mi parte y los suyos; e nos, los dichos doctor Joseph Gómes de la Parra y alferés Joseph Gómes de la Parra, nuestras personas y vienes; e yo, la dicha doña Ángela Ruis Machorro los míos, ávidos y por aver; y todos los otorgantes damos poder a las justicias que de nuestra caussas y las del dicho Nicolás Machorro conforme a derecho puedan y devan conoser, en especial a las desta ciudad, y a las demás de la parte y lugar donde se pidiere cumplimiento desta escriptura a cuyo fuero y jurisdisión nos sometemos y le sometemos, renunsiamos el nuestro y suyo propio domisilio y vezindad y la ley sit convenerit de juriditione, para que a ello nos apremien y le apremien como por sentencia passada [f. 825r.] en cossa jusgada, renunsiamos leyes de nuestro favor y suyo y la general del derecho, e yo la dicha doña Ángela Ruis Machorro, renuncio el veneficio del Velyano, nuevas constitusiones, leyes de Toro, Madrid y partidas y las demás que favoresen el derecho de las mugeres y que prohiven el obligarsse con sus maridos ny como sus fiadoras a sus deudas, de cuyo efecto fue apercevida por el presente escrivano, de que yo el escrivano doy fe, e yo la otorgante juro por Dios, nuestro señor y la señal de la Cruz en forma de derecho, que entiendo bien el efecto desta escriptura contra la qual no tengo fecha protestasión ni aré reclamasión en contrario y paresiendo la revoco y contra su tenor y forma no me opondré por el previlejio de mi dote, arras, vienes parafrenales creditarios ni mitad de multiplico ni por otro derecho que me conpeta que renuncio ni alegaré que para otorgarla fuy indusida, apremiada ni atemorisada por el dicho mi marido ni por otra persona en su nombre, porque declaro la otorgo de mi libre y espontánea voluntad por conbertirse su efecto en mi pro, utilidad y de mis vienes. Y deste juramento no pediré absulusión ni relajasión a ningún jues ni prelado que facultad tenga para consedermela, y si de ofisio u en otra manera se me consediere, no usare della aunque sea para ser oyda en juicio, pena de no serlo y de caer en casso de menos valer [f. 825 v.] y tantas quantas veses me fuere absuelto y relajado tantas renunsio [[...]], que es fecha en la ciudad de los Ángeles a veynte y quatro días del mes de septiembre de mil y 
seiscientos y ochenta y dos años, y el otorgante a quien yo, el escrivano, doy fe que conosco lo firmó, siendo testigos: Nicolás Belendes, Domingo de Herrera y [[...]], vecinos desta ciudad. Diego Fernández de León [firmado], Dr. Joseph Gómes de la Parra [rubricado], Joseph Gómes de la Parra [firmado], doña Ángela Ruis Machorro [firmado]. Ante mí: Antonio Gómez de Escobar, escrivano real y público [rubricado].

(1685, II-III) Carta de obligación de pago otorgada por Diego Fernández de León a favor del capitán Francisco Canales Gassio, por concepto de los libros que le vendió en la ciudad de México. [aGNP, Not. 3, Protocolos de 1685 , f. 373r.] [Documento no citado por Pérez Salazar, paleografía de ACD].

[Al margen izquierdo: Obligación por reales] Sepan quantos esta carta vieren como yo, Diego Fernándes de León, mercader de libros, vecino de esta ciudad de los Ángeles, otorgo que devo y me obligo de pagar al capitán Francisco Canales Gassio [sic] cargador de flota, vecino de los reinos de Castilla y residente en la ciudad de México desta Nueva España y a la persona que tubiere su poder y su derecho representare, novesientos y sesenta pesos de oro común por otros tantos prosedidos de cantidad de libros que me vendió y entregó en dicha ciudad de México, de que me doi por entregado, renunsio leyes del entrego y su prueva, por cuya rasón se los pagaré en reales en esta dicha ciudad u en la parte que se me pidan para el despacho de flota que viniere de dichos reinos de Castilla a estos el año que viene de mil seissientos y ochenta y seis porque así fue trato, $u$ en otra que en adelante viniere, con costas de la cobransa a la qual no hasiendo paga puntual tengo por vien se enbié persona donde estubiere y mis vienes, con salario de dos pesos de oro de minas que gane en cada un día de los que se ocupare en la yda, estada, negosiasión y buelta a esta ciudad hasta la real paga; y por los salarios como por la deuda prinsipal se me pueda ejecutar con el simple juramento del cobrador en que lo difiero sin otra prueba de que le relevo. $\mathrm{Y}$ a la firmesa de esta escriptura obligo mi persona y vienes avidos y por aver, doi poder a las justisias de su magestad, en espesial a las desta ciudad para que me compelan a lo dicho como por sentensia pasada en cosa jusgada, renunsio leyes de mi favor con la general del derecho, que es fecha en la ciudad de los Ángeles de la Nueva España, a once días del mes de março de de mil seissientos y ochenta y cinco años, e yo el escrivano doi fe que conosco al otorgante que lo firmó, testigos: Luis López Sandoval, Juan Cortés y Joseph Corona, vecinos desta ciudad. Testado: p. no vale. Diego Fernández de León [firmado], Ante mí: Pedro Gómez de Prado, escrivano real y público [rubricado]. Derechos: IIIJ reales.

AGN, Inquisición, vol. 1309, exp. 12, 1690, f. 137r. Diego Fernández de León, impresor y mercader de libros de la ciudad de Puebla de los Angeles, solicita se le entregue en la Real Contaduría un cajón conteniendo los libros cuyos títulos adjunta, México, I790 [sic]. [Documento no citado por Pérez Salazar].

[...] Don Diego Fernández de Leon, impressor y mercader de libros de la Ciudad de la Puebla de los Angeles paresco ante vss. Y digo q[...] haviendoseme ofrecido el venir à esta Ciudad con otros trastornos que un cajon de libros y tenerlos detenidos en la Real Aduana de esta Ciudad que son los siguientes $=$ Cathecismos del Padre Ripalda $=$ Artes de Antonio de Nebrija $=$ hozes de las Propocisiones Condenadas = Cardenas sobre las Propocisiones condenadas. A Vs. ${ }^{\text {as }}$ Pido, y suplico sean servidos de mandar à los contadores oficiales de la real Contaduría me entreguen dicho cajon donde vienen dichos libros que en ello recevire merced de Vss. ${ }^{\text {as }}$ [...]

I69o, 18-v, Certificación de la Imprenta de Diego Fernández De León. [Documento citado por José Toribio Medina]. 
Don José de Meneses, escribano del Rey, nuestro señor, vecino de esta ciudad de los Angeles de la Nueva España, certifico y doy testimonio de verdad cómo hoy día de la data de éste, á hora de las nueve de la mañana, poco más o menos, estando en la casa de la morada de Diego Fernández de León, maestro impresor de libros, que es en esta dicha ciudad, en la plaza pública debajo de el portal que llaman de las Flores, en un cuarto alto que está en el descanso de la escalera de ella, veo estarse imprimiendo en una imprenta en que están trabajando cinco oficiales, y nueve cajones de diferentes moldes de letras de plomo, al parecer. Y para que conste de pedimiento de dicho Diego Fernández, dí el presente en la ciudad de los Angeles de la Nueva España a diez y ocho días del mes de Mayo de mill y seiscientos y noventa años, siendo testigos Diego Sánchez Conchoso, Domingo de Herrera y Diego de Neira, vecinos de esta ciudad. - Diego Fernández de León. - Una rúbrica. - Hago mi signo (hago mi signo) en teśtimonio de verdad. - Joseph de Meneses, escribano de S. M. (una rúbrica).

I688, Solicitud de privilegio de impresión, refrendado g de mayo de I690. [Documento citado por José Toribio Medina].

Don Gaspar de Sandoval Cerda Silva y Mendoza, Conde de la Monclova, etc., Virrey, Gobernador y Capitán general de esta Nueva España y Presidente de la Real Audiencia de ella. Por cuanto ante mí se presentó un memorial del tenor siguiente:

Excmo. señor: Diego Fernández de León, vecino y mercader de libros de la ciudad de la Puebla de los Angeles, como más haya lugar y a en derecho convenga, ocurre á la grandeza de V. E. y dice que con ocasión de haberse avecindado en dicha ciudad y tener en ella hoy una imprenta de toda perfección y limpieza, que nuevamente trajo de España, y que se le está con todos costos en más de dos mil pesos, y ha introducido en dicha ciudad por su lustre y conveniencia de sus habitadores, como en algunos lugares comarcanos, é imprimir papeles de convites para entierros, honras de república para este efecto, siendo de la utilidad que se deja entender, por la república ocupación de dicho ministerio en que se ejercita, imprimiendo también actos, conclusiones y otras obras de letras, sin tener salario ó ayuda de costa, sino sólo los pocos provechos que puede adquirir por medio de este trabajo, por no ser tanta la copia de obras, ni haber en aquella ciudad Real Universidad como en ésta; y es así que, sin embargo, algunas personas que conducen mercaderías é hacen trato y comercio de esta materia llevando papeles impresos que vender por manos en dicha ciudad y en los demás lugares del obispado, quitando por este medio al suplicante la corta utilidad que le rinde la pública que resulta á dicha ciudad y su comarca, y respecto de que no teniendo salarios públicos y siendo conveniente y lustroso el tener en aquel obispado la dicha imprenta, es conforme á razón y equidad el que en él donde se extiende el bien no se defraude de el corto fruto que le puede rendir por medio de tanto costo y trabajo, y; en atención á todo.

A V. E. pide y suplica se sirva de concederle previlegio particular para que sólo el suplicante pueda imprimir y imprima en dicha ciudad y su obispado los dichos papeles que se estilan para convidar en las funciones y para que ninguna otra persona los pueda llevar impresos para venderlos de los que tratan y comercian, con penas graves pecuniarias para los que contraviniesen y á las justicias de todas partes para que así lo hagan cumplir y ejecutar inviolablemente, que en ello recibirá la merced que espera de la grandeza de V. E., y en lo necesario, etc. - Diego Fernández de León. - De que mandé dar vista al señor Fiscal de Su majestad, que dió esta respuesta:

Excmo. señor: El Fiscal de su Majestad ha visto este memorial y licencia adjunta del juez eclesiástico de el obispado de la Puebla que presenta el suplicante, para poder imprimir en aquella ciudad, donde es impresor, papeles de convites de entierros y otras funciones y dice, 
que respecto de ser útil en la república que haya este ministerio para no necesitarse con mayores costos á ir á otras partes sus vecinos en busca de la imprenta cuando se les ofrece, y que en la referida de la Puebla no tendrá continuamente qué hacer el suplicante, y así no podrá mantenerse, sino es valiéndose de estas menudencias, podrá V. E. siendo servido, concederle esta gracia y previlegio de que el susodicho sólo queda imprimir dichos papeles de entierro y otros de cualquier género de convites, sin que otra persona lo pueda hacer, ni llevarles a vender de esta ciudad á otras partes, pena de cincuenta pesos por cada vez que lo hicieren y de doscientos á las justicias que lo consintiesen y por esta gracia podrá servir el suplicante con cincuenta pesos para Su Majestad y pagar la media annata que se le regulare. V. E. mandará lo que sea lo mejor. Mégico y Julio diez mill seiscientos y ochenta y ocho años. - Doctor don Benito de Navas Salgado.

Y por mí visto, conformándome con dicha respuesta y atento á que tiene enterados los cincuenta pesos de esta gracia, que apliqué para las obras de este real palacio, con más lo que se le reguló al derecho Diego Fernández de León pueda imprimir dichos papeles de entierros y otros cualesquier que se ofrezcan en la dicha ciudad de los Angeles y su obispado; sin que otra ninguna persona lo pueda hacer, ni llevarlos de esta ciudad ni de otras partes á vender á ella, pena de cincuenta pesos aplicados en la misma forma, se los consientan ni le pongan impedimento ni embarazo en el uso de este previlegio y licencia al dicho Diego Fernández de León, en consideración de las razones propuestas por dicho señor Fiscal. Fecho en México, á once de Julio de mill seiscientos ochenta y ocho años. - El Conde de la Monclova. - Por mandado de S. E. - D. Joseph de la Zerda Morán.

Y ahora, don Joán Bermúdez de Castro, en nombre del dicho Diego fernández de león, por memorial que ante mí presentó, me hizo relación, diciendo habérsele despachado á su parte el dicho mandamiento para el efecto referido, y que aunque el susodicho lo había presentado ante un juez ordinario de dicha ciudad y obedecídolo, sin embargo se estaba contraviniendo á lo dicho y mandado, por causa de que muchas personas comerciantes hacían empleos de dichos papeles impresos en esta ciudad y los llevaban á vender á la dicha de los Angeles, en grave perjuicio de su parte, y que esto no se podía remediar, porque, como la dicha ciudad es grande y de mucho concurso, no eta fácil averiguar las personas que á ello contravenían, pues de practicarse se le causarían crecidas costas y gastos en la averiguación, y á veces fuera infructuosa por no poderse con certeza averiguar los trasgresores, además de la dificultad en andar ocurriendo á la justicia en tiempos y horas que suelen ser incómodas; y porque ninguno de los que contravinieren alegasen ignorancia y todos fuesen sabidores del dicho previlegio concedido á su parte y se le pudiese imputar mejor la culpa y ejecutar la pena impuesta en dicho mandamiento en los trangresores, me pidió y suplicó me sirviese de haberlo por demostrado con los recaudos á él adjuntos y mandar se guardase y cumpliese, añadiendo mayor pena de la impuesta, y que se pregonase públicamente, en al dicha ciudad de los Angeles y demás lugares de su obispado que conviniesen para que por este medio fuesen todos sabidores por lo notorio, y que para ello se le despachase recaudo, en que recibirá merced.

Y por mí visto, por el presente mando se guarde, cumpla y ejecute el mandamiento despachado por el Excmo. señor Conde de la Monclova, Virrey, gobernador y Capitán general de esta Nueva España, y presidente de su Real Audiencia, aquí inserto, según y en la forma que en él se contiene y declara; y en su conformidad mando á los jueces y justicias de S. M. de la ciudad de la Puebla de los Angeles hagan se publique en ella el referido despacho en las partes acostumbradas, para que llegue á noticia de todos y no se pretenda ignorancia en contravención de lo en él dispuesto. Fecho en México, á diez y seis de Diciembre de mill seiscientos ochenta y ocho años. - El Conde de Galve. - Por mandado de S. E. - D. Joseph de la Zerda Morán. 
Concuerda con el mandamiento original que para efecto de sacar este traslado exhibió ante mí el dicho Diego Fernández de León, vecino de esta ciudad de los Angeles, á quien lo volví con el obedecimiento pregones en su virtud dados en ella y firmó aquí su recibo, y va cierto y verdadero, y refiriéndome á él, de su pedimiento, doy el presente en dicha ciudad de los Angeles, á nueve días del mes de Mayo de míl y seiscientos y noventa años, siendo testigos de lo ver sacar y corregirlo Joán García de Pereda y Jorje Antonio, presentes. - Diego Fernández de León (rúbrica). - En testimonio de verdad (hay un signo). - Joán Bautista de Barrios, escribano público, etc. (rúbrica). Sigue la legalización de tal escribano.

29 mayo I690, Información del Regente de la Imprenta de México Juan Francisco Fernández de Orozco. [Documento citado por José Toribio Medina].

En la ciudad de México á veinte y nueve día del mes de Mayo de mil y seiscientos y noventa años, ante el capitán don Francisco de la Peña, caballero del Orden de Calatrava, alcalde ordinario de esta ciudad por S. Majestad, se leyó esta petición.

Petición. - Juan Francisco Fernández de Orozco, vecino de esta ciudad, en nombre de Diego Fernández de León, impresor y mercader de libros en la de los Angeles, en virtud de su poder, que con la solemnidad necesaria demuestra para que se me vuelva original, parezco ante vuestra merced, como mejor proceda en derecho, y digo: que al de mi parte conviene se le reciba información de cómo por su cuenta se está trabajando en la Casa Profesa de la Compañía de Jesús de esta ciudad en la impresión de la Vida de la Venerable Sierva de Dios Cathalina de San Juan, y para que en todo tiempo conste la solicitud de dicho trabajo, y ser la imprenta del dicho Diego Fernández de León, y estarla administrando yo; y los testigos que presentare se examinen al tenor de este scripto, por ante el presente escribano, y fecho se me den los treslados que pidiese autorizados en pública forma y manera que haga fe, que los quiero para remitírselos al dicho mi parte que le conste de lo referido y ocurra con ellos donde le convenga. A Vuestra Merced suplico mande se me reciba dicha información en la forma que llevo pedido con justicia, y juro en ánima de mi parte este escrito ser cierto, y en lo necesario, etc. - Bachiller D. Buenaventura del Guijo. -Juan Francisco Fernández Orozco.

Auto. -Y por su merced visto, hubo por demostrado el poder, y mandó se le reciba á esta parte, en nombre de la suya, la información que ofrece, y los testigos que presentare se examinen al tenor del pedimiento, por ante el presente escribano, y fecha, se le den los traslados que pidiere, autorizados en pública forma y manera que haga fe y obren lo que hubiere lugar en derecho, y se le vuelva el dicho poder; y así lo proveyó y firmó. - D. Francisco de la Peña. - Francisco de Valdés, escribano real y público.

Información. - En la ciudad de México, á veintinueve días del mes de Mayo de mil seiscientos y noventa años, Juan Francisco Fernández de Orozco, en nombre de Diego Fernández de León, impresor de libros en la ciudad de los Angeles, para la información que tiene pedida y le está mandada recibir presentó por testigo á un hombre español que dijo llamarse Juan Manuel de Castañeda, vecino de esta ciudad, impresor de libros, de quien por mí el escribano fué recibido juramento, que lo hizo por Dios Nuestro Señor y al señal de la cruz y prometió de decir verdad, y siendo preguntado por el tenor del pedimiento, dijo que conoce á el que le presenta, de cinco años á esta parte, y asimismo conoce á Diego Fernández de León, impresor y mercader de libros, y que lo que sabe es que el dicho Juan Francisco Fernández de Orozco está administrando en esta ciudad, en la Casa profesa de la Compañía de Jesús, la dicha imprenta de los libros de la Vida de la Madre Cathalina de San Juan, por cuenta del dicho Diego Fernández de León, cuya es: y este testigo está actualmente como oficial trabajando en dicha imprenta, y el dicho Juan Francisco Fernández corre con todo lo necesario para ello y paga los oficiales, 
y lo demás, como tal administrador del dicho Diego Fernández de León; y que esto es lo que sabe y la verdad, so cargo del juramento, en que se afirmó y ratificó ser de edad de veintisiete años, y que las generales de la ley no le tocan, y lo firmó. - Juan Manuel de Castañeda Ruiz. - Ante mí. -Francisco de Valdés, escribano real y público.

Testigo. En esta ciudad de México, á veintinueve días del mes de Mayo de mil seiscientos y noventa años, el dicho Juan Francisco Fernández de Orozco para la dicha información que tiene ofrecida en nombre de Diego de Fernández de León, impresor y mercader de libros en la ciudad de los Angeles, presentó por testigo al sargento mayor Joseph de Mesa, vecino de esta ciudad, de quien por mí el escribano fué recibido juramento, que lo hizo por Dios Nuestro Señor y la señal de la cruz, so cargo de el cual prometió decir la verdad; y siendo preguntado por el tenor del pedimiento, dijo: que conoce al que lo presenta y asimismo conoce al dicho Diego Fernández de León de más de cuatro años á esta parte y que le trató y comunicó en la dicha ciudad de los Angeles, por cuya causa sabe que la imprenta en que actualmente se está trabajando en la Casa Profesa de la Compañía de Jesús de esta ciudad en la impresión de la Vida de la venerable sierva de Dios Cathalina de S. Juan es del dicho Diego Fernández de León, y la trujo á esta ciudad á pedimiento de Padre Alonso Ramos, prepósito de dicha Casa Profesa, para el efecto de dicha impresión de dicha Vida y con ella y su administración por cuenta de dicho Diego Fernández está corriendo el dicho Juan Francisco Fernández Orozco, y paga los oficiales que en ella se ocupan; y que esto es lo que sabe por las razones referidas, que es la verdad, so cargo del juramento, en que se afirmó y ratificó, y ques de edad de cincuenta años, y que las generales de la ley no le tocan, y lo firmó. - Joseph de Mesa. - Ante mí. - Francisco Valdés, escribano real y público.

Testigo. En la ciudad de México, á veinte y nueve días del mes de Mayo de mil seiscientos y noventa años el dicho Juan Francisco Fernández de Orozco, para la dicha información que tiene ofrecida en nombre de Diego Fernández de León, vecino de esta ciudad de los Angeles, impresor y mercader de libros, presentó por testigo á Juan Joseph Guillena Carrascoso, mercader de libros y vecino de esta ciudad, de quien por mí el escribano fue recibido juramento, que lo hizo por Dios, Nuestro Señor, y la señal de la cruz, so cargo del cual prometió de decir verdad, y preguntado por el tenor del pedimientoo dijo: que conoce al que le presenta, y á el dicho Diego Fernández de León de siete años á esta parte, y que lo que sabe es que la imprenta que está en la Casa Profesa de la Compañía de Jesús pertenece al dicho Diego Fernández de León, que la trujo á esta ciudad á pedimiento del padre Alonso Ramos, prepósito de dicha Casa, para la impresión de la Vida de la venerable Cathalina de San Juan, en que se está trabajando, y que corre condicha administración el dicho Juan Francisco Fernández de Orozco, quien paga los oficiales: y questo es lo que sabe, y la verdad, so cargo del juramento, en que se firmó y ratificó, y declaró ser de edad de treinta y dos años, y que las generales de la ley no le tocan, y lo firmó. -Juan Joseph Guillena Carrascoso. -Ante mí. -Francisco de Valdés, escribano real y público.

Testigo. En la ciudad de México, á veinte y nueve días del mes de Mayo de mil seiscientos y noventa años, el dicho Juan Francisco Fernández de Orozco, para la dicha información que tiene ofrecida en nombre de dicho Diego Fernández de León, presentó por testigo á un hombre español, que dice llamarse Antonio de Orozco, vecino de esta ciudad, oficial de impresor de libros, de quien por mí el escribano fue recibido juramento, que lo hizo por Dios, Nuestro Señor, y la señal de la cruz, prometió de decir verdad, y preguntado por el tenor del pedimietno, dijo: que conoce al que le presenta, yá Diego Fernández de León de cinco años á esta parte, y que lo que sabe y pasa es que en la Casa Profesa de la Compañía de Jesús de esta ciudad se está trabajando en la imprenta de los libros de la Vida de la venerable sierva de Dios Cathalina de San Juan, que murió con opinión ejemplar en la ciudad de los Angeles; 
y que la dicha imprenta es del dicho Diego Fernández de León, y sirve para la dicha Vida de dicha madre Cathalina, quien la remitió para dicho efecto á pedimietno del padre Alonso Ramos, prepósito de dicha Casa Profesa, donde actualmente está trabajando este testigo en dicha impresión; y que esta es la verdad, so cargo de su juramento, en que se afirmó y ratificó; declaró ser de edad de veinte y ocho años, y que las generales de la ley no le tocan, y lo firmó. -Antonio De Orozco. -Ante mí. -Francisco de Valdés, escribano real y público.

Concuerda con la dicha información, que original queda en el oficio de Francisco de Quiñones, escribano público, que al presente despacho como su teniente, á que me refiero. Y para que conste doy el presente en la ciudad de México á treinta días del mes de Mayo de mil seiscientos y noventa años, siendo testigos, Miguel González, Diego de Marchena y Antonio Ramírez de Segura, vecinos de México. - Hago mi signo, en testimonio de verdad. - (Hay un signo). -Francisco de Valdés, escribano público. (Rúbrica). Archivo de Indias, 59-3-XII.

(I690, 4-II) Fianza otorgada por Diego Fernández de León a favor de doña Barbola Polanco sobre el concurso de acreedores que se siguió contra el ingenio de Tlatecla, ejecutada por bienes de Alonso de Toro. [aGNP, Not.6, Protocolos de Francisco Solano, año de i69o, ff. 7r-8r.] [Documento no citado por Pérez Salazar, paleografía de ACD].

[f. 7r.] [Al margen Izquierdo: fianza]. En la ciudad de los Ángeles, a quatro días del mes de febrero de mil seisientos y noventa años, ante mi, el escrivano y testigos paresió Diego Fernándes de León, vesino desta ciudad, que doi fe conosco y otorgó que en conformidad del auto proveído por los señores presidente y oidores de la Real Audiencia de la ciudad de México, su fecha en ella a los dies y seis del mes de diziembre del año pasado de mil seis sientos y ochenta y nuebe, en los del pleito de execusión y concurso de acreedores que se a seguido contra el Yngenio de haser asúcar nombrado Tlatecla, que se ejecutó por vienes de Alonso de Toro, otorga fía a doña [f. $7 \mathrm{v}$.] Barbola de Polanco, vesina desta ciudad, en tal manera que la susodicha estará en derecho en razón del entero y satisfación de las partes interesadas en dicho auto, según el prorrateo que se hicieren sobre los un mil ciento y noventa pesos corridos y los que corrieren hasta la real y efectiva paga que se le mandan pagar, en virtud de la Real Provición despachada en la ciudad de México a los veinte y seis días del mes de henero próximo pasado deste presente año de la fecha, refrendada de Joseph de Anaya, escrivano de Cámara, que presentó Antonio de Escandón, marido y conjunta persona de la dicha doña Barbola Polanco, su mujer, ante el capitán don Miguel Antonio de Santa María Hidalgo de Vargas, alcalde ordinario en esta ciudad por su magestad, para efecto de dar las fianzas que por efecto de dicho auto se mandan pagar al capitán don Alonso Hordoñes, poseedor de dicho ynjenio, en cuya conformidad la dicha doña Barbola dará y pagará a las demás partes ynteresadas las porsiones que le tocaren conforme a dicho rateo, luego que se le pidan, en reales con costas, sin gosar de término alguno; y si así no lo hisiere, el otorgante como tal su fiador que se constituie y hasiendo, como hase, de causa y negosio ageno suio propio, y sin que contra la dicha doña Barbola Polanco ni sus vienes se haga diligencia ni excursión de [f. 8r.] fuero ni de derecho, cuio beneficio renuncio, hará juicio en dicha causa por la dicha doña Barbola Polanco y pagará todo aquello que contra ella fuere jusgado y sentenciado por todas ynstansias, con costas, luego que se requiera; sin gozar de término alguno con su persona y vienes que para ello obligó; dio poder a las justicias de su magestad que de dicha causa conozca, a cuio fuero y jurisdición se sometió, renunció el suio propio domicilio y vesindad y la ley sit conbenerit de juridicione para que a ello le apremien como por sentencia pasada en cosa jusgada, renunció leyes de su favor y la general del derecho. Y así la otorgó y firmó, siendo testigos Antonio de Gálves, Francisco Basán y Juan de Cháves, vesinos desta ciudad.- Diego Fernández de León 
[rubricado]. Ante my: Francisco Solano, escrivano real y público [rubricado]. (Sigue otra fianza otorgada por Miguel Balero con el mismo fin).

(I69I, 7-VI), Confirmación Real del Privilegio de Impresión A DFL. Archivo de Indias, 87-6-I4, t. XLI, f. 279v. (Signatura antigua). [No hemos podido localizar el documento, transcribimos lo citado por José Toribio Medina].

El Rey.- Por cuanto en nombre de vos Diego Fernández de León, vecino y impresor de libros de la ciudad de la Puebla de los Angeles, de mi Nueva España, os concedió privilegio y facultad para que pudiéseis imprimir papeles para convites de entierros y otras cualesquier funciones que se ofreciesen en la dicha ciudad y su obispado, prohibiendo el que otra ninguna persona lo puediese hacer ni llevarlos á vender á ella de otras partes, habiendo servido por esta gracia por cincuenta pesos, que el dicho mi Virrey aplicó para obras del Palacio y asimismo enterado lo que debísteis satisfacer al derecho de la media annata, cuyo privilegio aprobó y revalidó el Conde de Galve, mi virrey actual de dichas Provincias, suplicándome fuese servido de aprobar y confirmar el referido privilegio para que se observe y cumpla en la forma que se os concedió por dichos mis Virreyes; y habíendose visto en mis Consejo de las Indias con los papeles que en su justificación se presentaron por vuestra parte, he venido en concedéroslo aprobando y confirmando (como por la presente lo hago) el referido privilegio en la forma y con las calidades que os le dieron dichos mis Virreyes, pero entendiéndose que la prohibición de que otra persona pueda vender es sólo por lo que mira á papeles de convites de entierros y para otras funciones de este género, respecto de que con ellos sólo habéis de correr vos el dicho Diego Fernández de León. Por tanto, mando al Consejo y demás justicias de dicha ciudad de la Puebla de los Angeles y su obispado no os pongan ni permitan poner embarazo en el uso de todo lo que por dicho privilegio os está concedido, ni consientan que otra ninguna persona venda los referidos papeles, incurriendo, si lo hicieren, en las penas impuestas en el título que os dió dicho mi Virrey, Conde de la Monclova, el cual mando se cumpla y observe enteramente, que así es mi voluntad. - Fecha en Buen Retiro á siete de Junio de mil seiscientos y noventa y uno. - Yo EL REY. - Por mandado del Rey, nuestro señor. - Don Juan de la Real. - Señalado del Consejo. - (Hay una rúbrica).

(I693, 9-VI) Sobre una memoria de diferentes géneros de letras de imprimir que Diego Fernández de León le entregó le entregó al capitán Fernando Romero y Torres, vecino de la ciudad de Sevilla. [AGNP, Not. 6, Protocolos de 1693, ff. 5or-5Iv.] [Documento citado por Pérez Salazar sin indicar localización precisa, p. 37i. Paleografía de ACD].

[Al margen izquierdo: Fecho para Fernando. Fecho para Diego León] [f. 5or.] En la ciudad de los Ángeles de la Nueba España, a los nueve días del mes de junio de mil seiscientos y noventa y tres años. Ante my, el escrivano y testigos paresió el capitán Fernando Romero y Torres, vezino de la ciudad de Sevilla y pasajero en la presente flota surta en el puerto de San Juan de Ulúa, del cargo del señor general conde de San Romi, residente en esta ciudad y dijo tiene recevido de Diego Fernándes de León, vesino desta ciudad, ynpresor y mercader de libros, una memoria de barios géneros de letras de inprimir, con sinco duplicados, los quatro ynpresos y firmados del dicho Diego Fernándes y el uno firmado de anvos, manuscripto con obligassión que le tiene hecha de traerle todos los géneros de letras de inpresión que resa dicha memoria para cuio efecto tiene recividos del dicho Diego Fernándes de León quinientos pesos de oro común, en plata doble del cuño mexicano, con obligasión de pagarle la demasía en reales al despacho de la primera flota que navegare a estos reinos, en que se obligó a traerle toda la can- 
tidad de letra que mensiona dicha obligasión, como de ella más largamente consta, su fecha en eśta ciudad a nueve de maio del año passado de mil novecientos y noventa. Y haviendo llegado de salvamento a los reinos de Castilla la flota passada que fue del cargo del señor general conde de Villanueba, y habiendo puesto en execusión el mandar hacer dicha letra, tarjas de barios santos y letra florida en los estados de Flandes, en la ciudad de Anveres, y aunque de su parte hiso todas las dilixencias posibles por conseguirle no tubo efecto mediante las guerras de Europa, por cuia rasón sólo pudo traerle sesenta y tres arrovas y media que será poco más o menos la tersía parte de la que contenía dicha memoria, de la qual le tiene pagado su valor en reales de contado, de que se da por contento y entregado. Y viendo la falta de dicha letra y que no podía tener utilidad de ella hasta traerle la que faltava y que contiene esta memoria que para en su poder, rubricada de mí, el escrivano, se han avenido en que el otorgante en la primera flota que navegare a estos reinos, le traiga y condusga en una de las naos del rexistro de ella lo que falta de dicha memoria para que en el todo esté cunplida, costeado de todos costos, a mas, [f. 5ov.] firmar yndulto, y otros qualesquiera gastos hasta que por la quenta y riesgo en el puerto de la Veracrus de la Nueva España, a rasón de quatro reales y medio libra si traiendola sin disminussión alguna, sin cargarle otros costos ni derechos, para cuio efecto le a entregado el dicho Diego Fernándes de León otra memoria ynpresa y firmada de su nombre, en que refiere lo que tiene resevido en quatro duplicados, la qual puesta en la forma referida en la dicha ciudad de la Veracrus la entregará a la persona que ordenare el dicho Diego Fernándes, o la persona que representare su derecho, con calidad y condisión expressa que aunque en dicha ciudad de la Veracrus se entregue por pesso se a de volver a pessar de nuebo en esta ciudad para rebajar la tara, líos y cajones y demás cosas que fueren nesesarias. Y cunpliendo con lo referido se a de obligar el dicho Diego Fernándes de León y doña Anjela Ruís Machorro, su lexítima muger, de mancomún ynsolidum a pagarle y satisfaserle el monto de dicha letra y ynprenta, tarjas de santos y letras floridas, y [entre renglones: todo lo demás que contiene dicha] memoria, a razón de quatro reales y medio libra, puesta en la dicha ciudad de Veracrus, un mes antes del despacho de la flota en que viniese dicha letra y ynprenta, que a de ser la primera que navegare a estos Reinos. Y para que todo lo referido tenga cunplido efecto, por la presente en aquella vía y forma que mejor lugar tenga en derecho, y siendo cierto y savidos del que en este caso le conpete, otorga se obliga de guardar y cunplir con el thenor y forma de lo que ba referido sin que falte cosa alguna, entera y cunplidamente, por cuio defecto pagará todos los daños y menoscavos que se le siguieren y recresieren en el cobro, con costas, porque se le a de poder ejecutar con el juramento sinple de quien fuere parte en que lo deja diferido, sin otra prueba de que le releva. Y presentes los dichos Diego Fernándes de León y doña Anjela Ruís Machorro, su lexítima muger, con lisensia que pidió al dicho su marido para otorgar esta escriptura, que le consedió en bastante forma, en cuia aseptassión anvos, marido y muger, juntos de mancomún, a vos de uno y cada uno de por sí y por el todo ynsolidum, con renunsiassión de leyes de la mancomunidad, división y excursión, otorgaron se obligan en tal manera que pagarán al dicho capitán Fernando Romero de Torres y a la persona que tubiere su poder y fuere parte lexítima lo que monta [f. 5Ir.] las dichas letras, imprenta, tarjas de santos y letra floridas, a rasón de los dichos quatro reales y medio la libra, puesta en la dicha nueba ciudad de la Veracrus un mes antes del despacho de la primera flota en que las condujeren, como ba referido en reales en esta ciudad o donde se les pidan, con costos de la cobrança, porque se les a de poder executar con el juramente sinple de quien fuere parte, devajo de la dicha mancomunidad, en que lo difieren sin otra prueba de que le relevan. Y a la firmessa todos los otorgantes obligaron sus personas y vienes y la dicha doña Anjela Ruís Machorro los suios. havidos y por haver, dieron poder a las justisias y jueses de su magestad para que a ello los apremien como por sentencia passada en cosa jusgada, renunsiaron leyes de 
su favor y la general del derecho y la dicha doña Anjela Ruís Machorro renunsió el benefisio del Belyano, nuebas constitusiones, leyes del Toro, Madrid y partidas y las demás favorables a las mugeres, de que confesó ser savidora y de que le aperceví yo, el ecrivano, de lo qual y del conosimiento de los otorgantes doy fe y la susodicha juró por Dios, nuestro señor y la señal de la crus en forma, de que entiende bien el efecto desta escriptura contra la qual no tiene fecha protextassión ni hará reclamasión en contrario; y paresiendo, la revoca y contra su thenor y forma no se opondrá por el previlejio de su dote, arras, vienes parafernales, ereditarios ni mitad de multiplico ni otro derecho que les conpeta, que renunssia y declara la otorga de su libre y espontánea voluntad, sin fuerça, apremio ni yndusimiento del dicho su marido, ni otra persona en su nombre por convertirse su efecto en su pro y utilidad y de sus vienes. $Y$ de este juramento no pedirá absolusión ni relajassión a ningún jues ni prelado que se la deva conseder, y si de ofissio u de otra manera se le consediere, de ella no usará aunque sea para efecto de ser oída en juisio, pena de no serlo y caer en caso de menos valer. Y así lo otorgaron y firmaron [f. 5iv.], siendo testigos: Miguel Ximénes Solano, Antonio de Herrera y Juan de Cháves, vezinos desta ciudad. Testado: meol. Entre renglones: todo lo demás que contiene. Fernando Romero y Torres [rubricado], D. Ángela Machorro [firmado], Diego Fernández de León [rubricado]. Ante my: Francisco Solano, escrivano real y público [rubricado]. Derechos: viIJ reales.

(I694, 30-IV) Solicitudes que dirige Diego Fernández de León al señor obispo, deán y cabildo de la catedral de Puebla para que le autoricen un préstamo en efectivo para aviar su imprenta y librería con su correspondiente respuesta. [aGNP, Not. 6, Protocolos de I694, ff. 75r-82v. [Documento no citado por Pérez Salazar, paleografía de ACD].

[Al margen izquierdo: Ángeles, 30 de abril de i694. Remítase al señor vicario superintendente para que nos informe sobre lo referido en este memorial. Así lo proveyó, mandó y rubricó el ilustrísimo señor obispo de la Puebla de los Ángeles, etcétera, mi señor [rúbrica]. Ante mí: D. Pedro de Lara Mogrovejo, escrivano real [rúbrica]

[f. 75r.] Ilustrísimo Señor. Diego Hernández [sic] de León, vesino de esta ciudad, marido lexítimo de doña Ángela Ruís Machorro y de doña Ysavel Ortis de Ávila, su muger y en virtud de su poder, digo: que por quanto el capitán don Pedro de Luey Escandón, mayordomo del combento de religiosas de la Limpia Consepción de Nuestra Señora de esta dicha ciudad, tiene executadas las haziendas de lavor y demás bienes que fueron del regidor Domingo Machorro, abuelo de dicha mi parte que oy posseemos, cuya execussión [entre renglones: hiço] por cantidad de pesos de réditos, que ajustada la quenta se verifican ser hasta fin de este mes de abril de este año de nobenta y quatro dies mil novesientos sinquenta y tres pesos, sinco tomines y ocho granos prosedidos de dos censos, el uno de siete mil pesos de prinçipal ympuesto sobre unas cassas en esta ciudad, en la calle que va del Colegio de Niñas Vírgenes a la plazuela que llaman de San Augustín, y sobre una hazienda de lavor nombrada Santa María Tetela en el valle de San Pablo de la provincia de Tepeaca; y el otro de dos mil quinientos pesos de prinçipal sobre dichas cassas y otras grandes junto a ellas, y sobre dos hasiendas de lavor, la una en dicho valle, nombrada San Pedro y la otra en términos de Nopaluca en dicha provincia, como de lo referido consta en las escripturas de su ympoçisión que paran originales en dichos autos de execussión, y para que cese el curso de ella pagaré a dicho combento por cuenta de dichos réditos y costas ocho mil pesos, los dos mil efectivos que entregaré a dicho combento de que me ha de dar recivo dicho capitán, su mayordomo y los seis mil pesos que entregará el señor marqués de Altamira por otros tantos de que me es deudor, de parte de la venta que le hise de la hasienda de obejas pertenesiente a dichos bienes que es en términos del pueblo de Tecali, cuya 
venta le hise con la obligasión de dársela libre de la sujeción y grabámen que tiene en dichos censos por la general hipoteca, causa que me obliga [f. $75 \mathrm{v}$.] a ocurrir al patrosinio de vuestra señoría, suplicándole a vuestra señoría que para que cesen los cresidos gastos y costas que pueden resultar y se le de el devido corriente a dicha materia, que ha tantos años que padese tan graves confuciones, se sirva vuestra señoría de dar su benia y permiso a la parte de dicho combento para que apruebe la venta de dicha hasienda de obejas, y la de por libre de la referida hipoteca general, pues aun dado casso de que al combento le quedasen dichos dos censos en solas las dichas dos haziendas de San Pedro y San Joseph y en las dos pares de cassas mencionadas quedan bastantemente saneados y seguros, respecto de que estas quatro fincas si se abaluan valen más de setenta mil pesos, mayormente estando oy vien haviadas y aperadas con lo que he gastado de mi caudal y el buen havío con que las hallé. Y assimismo suplico a vuestra señoría se sirva de consederme espera por los dos mil nobesientos sinquenta y tres pesos, sinco tomines y ocho granos que se restavan de los dichos réditos, o lo más que de ellos se deviere hasta fin de este mez de abril, satisfechas las costas de dichos dos mil pesos que assí prometo entregar efectivos, cuyos réditos pagaré a doscientos y setenta y sinco pesos cada año, con uno de hueco para poder continuar en el havío de dichas haziendas y más el annual de dichos censos, el qual començaré a satisfacer desde luego corriendo desde primero de mayo próximo venidero deste año; de manera que en quanto a lo que prometo de lo atrasado, es la misma cantidad por que se le esperó al regidor don Juan Francisco Machorro, sobre que se otorgó escriptura que para en dichos autos; en cuya atención:

A Vuestra Señoría Ilustrísima pido y suplico que en atençión a lo referido se sirba de concederme lo que llevo pedido, en que el combento y este criado de vuestra señoría resiviremos todo vien y merced de la grandesa de vuestra señoría. Entre renglones: hiço, de San Joseph. Vale. Enmendado: Pedro. Vale. Diego Fernández de León [rubricado].

Ilustrísimo Señor. En ovedesimiento del mandato de vuestra señoría he visto el memorial precedente en que Diego Fernández de León, suplicante por sí y en nombre de Ángela Ruís Machorro, su muger, como poseedores de las haziendas y cassas que fueron del regidor Domingo Machorro, su abuelo, [f. 76r.] pende sobre que la parte del convento de la Limpia Concepsión de Nuestra Señora desta ciudad, uno de los acreedores a dichas fincas delibera aprobando la escriptura de venta, que el suplicante hiso al señor marqués de Altamira, de la hazienda de obejas en el término del pueblo de Tecali, dándole por libre y disuelta de la general hipoteca que contraxo por rasón de los censsos pertenesientes a dicho convento, como a una [entre renglones: de las] que poseyó dicho regidor por cuia rassón ofrece pagar al dicho convento por quenta de los réditos que se le deven ocho mil pessos, los dos por sí y los seis que ha de entregar dicho señor marqués, y lo demás que pide cerca de la espera por el resto de los réditos, plassos que promete y que çesse la vía ejecutiva que se ha demandado contra las fincas por parte del convento que está pendiente en el oficio de Antonio de Robles, escrivano público, haviendo visto los instrumentos que para este efecto presentó el suplicante y los actos antiguos del concurso de acrehedores que paran en dicho oficio, hallo que (según mi sentir) puede la parte del convento, presediendo facultad de vuestra señoría, deliberar asintiendo en todo lo que el suplicante pide por las rasones, de congruencia, siguientes:

Lo primero, en lo que mira al censso de siete mil pesos impuesto por Gabriel de Arrieta y doña Mariana Beltrán, su muger, en favor de Melchor de Cuéllar, regidor que fue de esta ciudad y ensayador mayor que fue de la Casa de la Moneda, por escriptura su fecha a los veinte y siete de noviembre del año de mil seiscientos y ocho ante Pedro Gutiérres, escrivano público; que por otra escriptura, su fecha a los dies y siete de septiembre de seiscientos y quinse ante Alonso de la Parra, los çedió al convento y después lo reconoció el regidor Domingo Machorro a los veinte i seis de abril del año de seiscientos y veinte y nuebe ante Diego Corona, 
escrivano público, [f. 76v.] este censso según la dicha escriptura de imposición se registró a primero de diziembre del mismo año, en que se otorgó dicha escriptura dentro de los seis días dispuestos por la ley real y por la certificación dada por el capitán Juan de Carabajal y Cardona, escrivano del cavildo de esta ciudad consta no tener otro censso anterior que se haya registrado contra sus fincas [tachado: expesiales] que son la una de ellas unas cassas edificadas en un solar en la calle que va del colegio de Niñas Vírgenes a la Plazuela del convento de San Augustín de esta ciudad, en la quadra siguiente a la de las religiosas de la Limpia Consepción, tasadas por Diego y Domingo de Santa María, maestros de arquitectura, en quatro mil y quinientos pessos, según que de dicha tasación consta de otra escriptura, su data a los onze de henero del año de setenta i ocho ante Antonio de Robles, escrivano público, que otorgaron los hijos del dicho regidor Domingo Machorro, a favor del regidor don Juan Machorro, assimismo su hijo, haziendole entrego de todas las fincas y por dueño y señor de ellas para que satisfaciesse sus créditos a todos los acrehedores; y la otra de dichas fincas, una hazienda de lavor nombrada Santa María Tetela en el valle de San Pablo en la provincia de Tepeaca, en que al tiempo de su imposisión constava tener dies cavallerías de tierra, demanda que el dicho convento de la Concepción en quanto a dicho censso de siete mil pessos está seguro su crédito y no puede padecer detrimento ninguno en lo futuro.

Lo otro, en lo que toca al censo de dos mil y quinientos pesos, el origen de su imposición emanó de siete mil pessos [f. 77r.] ympuesto por el dicho regidor Domingo Machorro a favor de dicho regidor Melchor de Cuellar por escritura, su data en esta ciudad a los dies y ocho de abril de mil seisçientos y catorce ante Hernán Sánchez Gallardo, registrada en ella nuebe días después del otorgamiento, especialmente sobre cassas grandes, en la calle que va de la Pila de Carrasco al convento de Santa Inés, y otras junto a ellas, avaluadas por los maestros expresados en el parrapho antecedente, según la escriptura que en él va citada, en siete mil y quinientos pessos y sobre dos haziendas de labor, la una en el valle de San Pablo nombrada San Pedro, con veinte y seis caballerías de tierra, tassada por los regidores don Alonso Barruecos y don Melchor de Linares, en dies y ocho mil pessos, y la otra nombrada San Joseph en términos de Nopaluca, con catorze cavallerías avaluada por los dichos en veinte mil pessos, esto el año de setenta i ocho, al tiempo que [entre paréntesis: como va dicho] se hizo entrega de las fincas al regidor don Juan Francisco Machorro que entonces es verisímil carecían de algunos habíos y aperos no teniendo los que oi tienen como se reconoce de las mismas tasaciones. Y aunque es verdad, que al tiempo de la imposiciones de dichos censsos consta por las certificaciones que están al principio de sus escripturas estar gravadas las dichas haziendas de San Pedro a catorze mil pessos de prinsipal de sensos en favor de dicho regidor Melchor de Cuellar, y la de San Joseph a tres mil pessos a favor de don Manuel Fransisco de Gaona, que hazen dies y siete mil pesos, oi [entre paréntesis: según el testimonio citado dado a los doze del corriente] se han reducido sólo a seis mil pessos en la de San Pedro, de los quales los [f. 77v.] tres mil pertenesen al conbento de Sancta Isavel de México, cuios réditos están satisfechos según consta de instrumento auténtico; y de los tres mil pessos restantes, no consta tener dueño ni que por ellos se hayan opuesto al concurso antiguo de acrehedores que se principió a quarenta y siete años. Y en la de San Joseph, según dicho testimonio, tiene el dicho convento su censso sin otro anterior por constar el estar libre la finca el día de oi. Y en lo que toca a la espera que el suplicante pide en quanto a los dos mil novecientos cincuenta i tres pessos, cinco tomines y ocho granos, que resta de los diez mil novesientos cincuenta y tres pessos, cinco tomines y ocho granos de réditos de ambos censsos, causados hasta fin de abril pasado de este año, se le puede conceder como la pide en su memorial, ajustándolos a su satisfacción el Mayordomo de dicho convento, a quien le hará entrega el suplicante de los dos mil pessos que por sí ofrece excivir, vajando lo que montaren las costas de la execución y reintegrando el resto en el arca de principales del convento con despacho de la contaduría. Y esto 
fecho se ajustará con el señor marqués de Altamira por los seis mil pessos, que ha de entregar por quenta de dichos réditos, en conformidad de lo que el suplicante promete y al thenor del orden que se le diere por vuestra señoría en el decreto que se proveyere al memorial presentado por dicho señor marqués, en esta rassón y haviendo ajustado [f. 78r.] su escriptura el susodicho, puede el Mayordomo deliberar sobre la venta de dicha hazienda de obejas, aprovándola y dándola por libre de la hipoteca general a que está afecta, a que procegirá por las rasones que llevó dadas en rassón de la seguridad que le queda en los censsos de su convento y respecto de que con esta diligencia consigue la paga de ocho mil pessos por quenta de tan cresida cantidad de corridos y se le da al suplicante desaogo para ir satisfasiendo lo demás, cesando tan grave confución como en está materia se havía recresido y que no proçiga la ejecución interin que el suplicante satisface con puntualidad, la qual ha de correr su cursso no cumpliendo con el trato. Este señor es mi sentir. Vuestra Señoría Ilustrísima mandará todo lo que fuere servido, que será lo más acertado. Ángeles y trece de mayo de mil seiscientos y nobenta y quatro años.

Y asimismo se servirá vuestra señoría de mandar se tome rasón de este memorial y decretos que a él se proveyere en la contaduría de conventos. $\mathrm{Y}$ en la escriptura que se ha de otorgar se exprese que el aprobar dicha renta la parte del convento, es solamente dar liberación de la hipoteca general a que dicha hazienda de ovejas estava afecta a dichos censsos que le pertenecía para que quede libre de ellos, sin que sea visto innovar las obligaciones y contratos de sus imposiciones y reconocimientos expresados en este ynforme en quanto a los demás vienes obligados por especial hipoteca sobre que están impuestos. [f. 78v.] Y por la general, porque eceptuada la dicha hacienda de ovejas que ha vendido, los demás vienes así obligados le quedan su fuersa y vigor, antigüedad y prelacía dichas obligaciones. Y el suplicante otorgue reconocimiento en forma a dicho senso ut supra. Dr. Diego de Victoria Salazar [rubricado].

Ángeles, I8 de mayo de I694 años. Concedemos la espera que pide Diego Fernández de León remitiéndonos en todo al informe precedente del señor vic[ario] superintendente y en esta conformidad damos facultad al Mayordomo del Convento de la Concepción para que en su nombre apruebe la venta de la hazienda de obejas referida hecha por el dicho Diego Fernández de León [al] señor marqués de Altamira, haçiendo el sussodicho reconossimiento de los dos censos y dándoseles a las partes los traslados que pidieren para en guarda de su derecho. Assí lo proveyó, mandó y rubricó el Ilustrísimo Señor Obispo de la Puebla de los Ángeles, etcétera, mi señor. Y mandó que los dos mil pessos que excive el suplicante se pongan en el arca y [se] pague las costas de contado. Ante mí: Don Pedro de Lara Mogrovejo, escrivano [rubricado].

[f. 79r.] [Al margen izquierdo: En I8 de mayo de I694 años. Fecho en dicho día para Diego Fernández de León. Fecho en 25 del mes de mayo de dicho año para el señor marqués. Fecho en 22 de mayo de 1694 años y se sacó para la parte del convento en papel del sello quarto, doy fe. Fecho en nuebe de abril de 1695 por duplicado para Diego Fernández de León en papel del sello segundo, de ello doy fe. Rúbrica].

Sepan quantos esta carta vieren como yo, el capitán don Pedro de Loey Escandón, familiar del sancto ofisio de la ynquisissión y mayordomo del conbento de relijiosas de Nuestra Señora de la Linpia Concepsíon desta ciudad, digo que haviendo executado la parte de dicho conbento unas casas en esta ciudad, en la calle que ba del colejio de niñas virjines [tachado: por los] a la Plasuela que llaman de San Augustín y una hasienda de lavor nombrada Santa María Tetela en el valle de San Pablo, de la provincia de Thepeaca, por los corridos de un sensso de siete mil pesos de prinsipal. $\mathrm{Y}$ asimismo sobre dichas cassas y otras grandes junto a ellas, por los corridos de otro senso de dos mil y quinientos pesos de prinsipal y sobre dos hasiendas de lavor, la una en dicho valle de San Pablo nombrada San Pedro; y la otra, en términos de Nopaluca nombrada San Joseph, y otros vienes que quedaron por fin y muerte del rexidor Domingo Machorro. Y aviendose seguido sobre dicha execusión diferentes artículos y 
formádose concurso de acreedores contra dichos vienes desde el año passado de mil seissientos y quarenta y siete hasta el presente de la fecha, donde parese que haviendosele adjudicado dichos vienes a doña Anjela Ruís Machorro, muger lexítima de Diego Fernándes de León, como nieta lexítima del dicho rexidor Domingo Machorro por escriptura, su fecha en esta ciudad a onse de febrero pasado deste presente año de la fecha ante Miguel Garsía Fragosso, escrivano real y público; y por Memorial presentado por el dicho Diego Fernándes de León, a los treinta de abril passado deste año ante el ylustríssimo señor obispo deste obispado, le representó que mediante a que se estavan deviendo hasta fin de dicho mes de abril pasado deste año dies mil novecientos cinquenta y tres pesos y sinco tomines y ocho granos de los corridos de dichos senssos, y para que cesase el curso de dicha execusión ofresía pagar a dicho conbento por cuenta de dichos corridos y costas ocho mil pesos, los dos mil que entregaría de contado y los seis mil restantes que satisfaría a dicho conbento el señor marqués de Altamira por otros tantos de que le era deudor, [f. 79v.] prosedidos de la benta que le havía hecho de la hasienda de ovejas y trasquila nombrada Santa Anna, en términos del pueblo de Thecalí y Guantinchán, devajo de obligassión de dársela libre de la sujessión y gravamen de dichos senssos por lo que tocava a la general hipoteca como consta de la escriptura que en esta rasón le otorgó en esta ciudad a dose de marso passado deste presente año ante el dicho Miguel Garsía Fragoso, escrivano real y público. Y que por los dos mil novecientos cinquenta y tres pesos, sinco tomines y ocho granos que se restavan de dichos corridos, se le consediese espera ofresiendo pagarlos a rassón de docientos y setenta y sinco pesos en cada un año, dándosele el primero de hueco para poder continuar con el havío de dichas hasiendas, pagando los corridos anuales de dichos senssos, desde primero [tachado: de maio pasa] deste presente mes de maio, con lo demás que contiene dicho memorial; que haviendose remitido al señor vicario superintendente de los conventos de relijiosas sujetas al ordinario desta ciudad para que informasse, y haviendolo echo por decreto de oy, día de la fecha de dicho señor ilustrísimo, se me consedió facultad para otorgar dicha espera y aprovar la venta de dicha hazienda de ovejas, declarándola por libre de dicha general hipoteca sin que sea visto hinovar en ninguna manera las obligasiones y contratos de imposisiones y reconosimientos echos de dichos sensos en quanto a los demás vienes obligados por especial hipoteca, otorgando el dicho Diego Fernándes de León reconosimiento dellos en forma, como más largamente se contiene en dicho memorial, ynforme y decretos, cuio thenor a la letra es como se sigue:

Aquí el memorial y ynformes.

En cuia conformidad y usando de la facultad consedida por dicho decreto y del poder que me tienen otorgado las ma[f. 80 r.]dres abadesa y definidores de dicho conbento de Nuestra Señora de la Linpia Concepsión, su fecha en esta ciudad a treinta días del mes de septiembre del año passado de mil seiscientos y setenta y siete ante Antonio Gómez de Escovar, escrivano real y público; por la presente, en aquella vía y forma que mejor lugar tenga en derecho, otorgo haver recevido los dichos ocho mil pesos de oro común a quenta de dichos réditos, los dos mil dellos del dicho Diego Fernándes de León y los seis mil restantes por otros tantos que [tachado: se ob] está obligado a pagar a dicho conbento el dicho señor marqués de Altamira por escriptura, su fecha en esta ciudad a catorse deste presente mes de maio y año de la fecha ante el dicho Miguel Garsía Fragoso, escrivano real y público, de que en nombre de dicho conbento me doy por contento, satisfecho y pagado, sobre que renunssio poder desir ni alegar lo contrario, leyes del entrego, su prueba y esepssión de la pecunia, de que le otorgo recivo y carta de pago en forma con las fuersas y firmesas ynportantes a su balidassión y consiguientemente, en conformidad de lo mandado por dicho decreto, le consedo espera al susodicho por los dos mil novecientos y cinquenta y tres pesos, sinco tomines y ocho granos, que se restan de los dichos 
réditos, cunplidos a fin de abril próximo passado deste pressente año para que los pague y satisfaga a rassón de docientos y setenta y sinco pesos en cada un año, corriendo la primera paga desde primero de maio del año que viene de mil seiscientos y noventa y sinco consecutivamente, quedándole de hueco [Tachado: el año] un año que comensó a correr desde primero deste pressente mes de maio, desde quando a de satisfaser y pagar lo anual de dichos senssos, sin que en ello aiga falla en ningún año de lo uno y otro, porque haviéndola e de poder, en nombre de dicho conbento y quien por él fuere parte, seguir dicha execusión [f. 8ov.] como se convenga, para lo qual la dejo en su fuersa y vigor por lo que toca a dicho resto, y en dicho nombre la apruebo y ratifico la dicha escriptura de benta sitada, otorgada por el dicho Diego Fernándes de León al dicho señor marqués de Altamira de la dicha hasienda de ovejas y trasquila en jurisdissión del pueblo de Tecali y Guautinchán, con todo lo que le pertenese y en la forma y manera que se declara y contiene en dicha escriptura, dándola por libre en el todo de la general hipoteca a que estuvo comprehendida por la obligassión y reconosimiento de dichos senssos, para que por rassón de ellos ni sus corridos no se le pueda pedir ni demandar ahora ni en ningún tiempo cosa alguna por quedar libre de dicho gravamen, sin que por esta rassón sea visto ynnovar ni alterar en manera alguna las obligassiones ni contratos de inposisiones ni reconosimientos de dichos sensos en quanto a los demás vienes, obligados por espesial hipoteca sobre que están ynpuestos y cargados, ni por la general, porque eseptuando la dicha hasienda de obejas nombrada Santa Anna que posee dicho señor marqués de Altamira, en virtud de dicha benta, los demás vienes obligados se a de entender quedarlos en el todo y sus obligasíones en su fuersa y vigor, autoridad y prelassía como ba referido; y a la firmessa obligo los vienes y rentas de dicho conbento havidos y por haver. Y estando presentes nos, los dichos Diego Fernándes de León y doña Ánjela Ruís Machorro, su lexítima muger, con lisenssia que pido al dicho mi marido para otorgar lo que irá declarado; y yo el dicho Diego Fernándes de León se la consedo en bastante forma, en cuia aseptassión y della usando anvos, marido y muger, juntos y de mancomún, a vos [f. 8Ir.] de uno y cada uno de nos, por sí y por el todo ynsolidum, con renunsiassión de leyes de la mancomunidad, división y excursión como en ella se contiene, otorgamos reconosemos los dichos nueve mil y quinientos pesos de sensos prinsipales, los siete mil de ellos ynpuestos y cargados sobre dichas hasiendas y casas por Gabriel de Arrieta y doña Maríana Beltrán, su muger, a favor de Melchor de Cuellar, por escriptura en esta ciudad a veinte y siete de noviembre del año passado de mil seiscientos y ocho ante Pedro Gutiérrez, escrivano público, los quales sedió y traspasó el dicho Melchor de Cuellar al dicho conbento de la Linpia Concepsión por escriptura [tachado: a los] en esta ciudad, a los diesisiete de septiembre de mil seiscientos y quinse ante Alonso de la Parra que reconoció el regidor Domingo Machorro, nuestro abuelo, por escriptura a los veinte y seis de abril de mil seiscientos veinte y nueve ante Diego Corona, escrivano público, que se hallan rexistrados en los libros del cavildo desta ciudad a primero de disiembre de dicho año de seiscientos y ocho debajo del número tresientos y trese; y el otro de dos mil y quinientos pesos de prinsipal, resto de siete mil pesos, ynpuestos y cargados sobre dichas hasiendas de San Pedro y San Joseph y casas referidas por el dicho regidor Domingo Machorro y doña Leonor de Escalante, su muger, a favor del dicho Melchor de Cuellar, por escriptura, su fecha en esta ciudad a los dies i ocho de abril del año passado de mil seiscientos y catorze ante Hernán Sánchez Gallardo escrivano público, que se halla rexistrada en dichos libros a los veinte y siete de dicho mes y año, los quales se sedieron a dicho conbento, mediante lo qual se halla dueño y señor de dichos nueve mil y quinientos pesos, y por tal lo reconosemos [f. 8Iv.] para pagarsselos quando los quitemos y redimamos; y en el ynterín, sus réditos desde primero deste presente mes de mayo y año de la fecha a los tiempos, plasos, partes, lugares y devajo de las condisiones, penas y salarios que se contienen y declaran en las escripturas de sus ynposisiones que que ban sitadas, de que confesamos ser 
savidores y a cuio rigor nos sujetamos. Y consiguientemente nos obligamos de pagar devajo de la dicha mancomunidad al dicho conbento de relijiosas de la Linpia Consepssión de Nuestra Señora desta ciudad y a el dicho capitán don Pedro de Loey Escandón, su mayordomo, que al presente es y al que adelante lo fuere y por él parte lexítima, los dichos dos mil novecientos y cinquenta y tres pesos, sinco tomines y ocho granos de resto de los dichos dies mil novesientos y cinquenta y tres pesos, sinco tomines y ocho granos que se estavan deviendo de réditos atrasados asta fin de abril próximo pasado deste año [tachado: a rasón de] en reales, en esta ciudad u en la parte que se nos pidan, a rassón de docientos setenta y sinco pessos en cada un año, comensanso a aser la primera paga a primero de mayo del año que viene de mil seiscientos y noventa y seis, consecutivamente una paga subsesiva a otras, de suerte que no falte ningún plaso en la cantidad referida, porque de faltar se a de entender ser cunplido enteramente toda la dicha cantidad y executarnos por ella dicho conbento en la forma que le [f. 82r.] paresiere; y no hasiendo las pagas puntuales por fin de cada un año en la forma referida, tenemos por bien y consentimos se envié persona donde estubiéremos y qualquiera de nos y nuestros vienes, con salario de dos pesos de oro de minas que gane en cada un día de los que se ocupare en la ida, estada, negosiasión y buelta hasta la real paga, y por los salarios como por el prinsipal se nos pueda executar con el juramento sinple del cobrador en que lo diferimos, sin otra prueba de que le relevamos; y a la firmesa obligamos yo, el dicho Diego Fernándes de León, mi persona y vienes; y yo, la dicha doña Ánjela Ruís Machorro, los mios, havidos y por haver. Y todos los otorgantes damos poder a los jueses y justissias que de nuestras causas y de dicho conbento puedan y devan conoser conforme a derecho para que a ello nos apremien y le apr[em]ien como por sentenssia passada en cossa jusgada, renunsiamos leyes de nuestro favor y suyo, y la general del derecho; y yo, la dicha doña Ánjela Ruís Machorro, renunsio el benefissio del Beleiano, nuebas constitusiones, leyes de Toro, Madrid y Partidas, y las demás favorables a las mugeres, de cuio efecto fui apersivida por el pressente escrivano, de lo qual y del conosimiento de los otorgantes doy fe; y yo, la susodicha juro por Dios, nuestro señor y la señal de la Sancta Crus en forma de derecho que entiendo bien el efecto desta escriptura contra la qual no tengo hecha protestassión ni haré reclamassión en contrario y paresiendo la revoco y contra su tenor y forma no me opondré por el privilejio de mi dote, [f. 82v.] arras, vienes parafrenales, hereditarios ni mitad de multiplico, ni otro derecho que me conpeta, que renunssio, porque declaro la otorgo de mi libre y expontánea voluntad sin fuersa, apremio ni yndusimiento del dicho mi marido ni otra persona en su nonbre, por conbertirse su efecto en mi pro i utilidad y de mis vienes; y de este juramento no pediré absolussión ni relajasión a quien me la deva conseder; y si de ofissio u de otra manera se me consediere, de ella no usare aunque sea para efecto de ser oyda en juissio, pena de no serlo y de caer en caso de menos valer; que es fecha en la ciudad de los Ángeles a dies y ocho días del mes de mayo de mil seiscientos y noventa y quatro años. Y los otorgantes lo firmaron y declararon que en lo que toca al monto de las costas que se les mandan pagar por dicho decreto están ajustados con la parte del dicho conbento, en virtud de otro decreto de dicho señor ilustríssimo, siendo testigos: Joseph Corona, Juan de Cháves y Francisco Basán, vesinos desta ciudad. Entre renglones: sobre. Enmendado: dichas; y todos; o. Testado: más; pas; el año; a los; a rassón de. Enmendado: onse. Diego Fernández de León [rubricado], Doña Ángela Ruís Machorro [rubricado], Don Pedro de Luey Escandón [rubricado]. Ante mí: Francisco Solano, escrivano real y público [rubricado]. Derechos: XV maravedíes. Doy fe.

(I694, II-V) Escritura de concierto otorgada por Diego Fernández de León a favor de Juan de Paredes y José Rodríguez de la Torre para que atiendan la imprenta por tiempo de 6 años. En el contrato se indica que estos pondrian papel y tinta (el documento se encuentra mutilado en la parte inferior). [AGNP, Not. 4, 
Protocolos de Miguel García Fragoso, año de I694, ff. 5Ir-52v.] [Documento no citado por Pérez Salazar, paleografía de ACD].

[f. 5Ir.] [Al margen izquierdo: Pacto y consierto ir de mayo de 94. Fecho en diez y ocho de mayo de mil seiscientos y nobenta y quatro años en papel de sello [...] de que doy fe, un traslado para Diego Fernándes. Ante mí: Miguel García Fragoso, escrivano real y público rubricado]

En la ciudad de los Ángeles, a once días del mes de mayo de mil y seisientos y noventa y quatro años. Ante mi, el escrivano y testigos, paresieron de una parte Diego Fernándes de León, mercader [repetido: mercader] de libros, y de la otra Juan de Paredes y Joseph Rodríguez de la Torre, ofisiales de ynpresor, todos vezinos desta ciudad que doy fe conosco, y dijeron que por quanto el dicho Diego Fernándes de León se halla presizado a la asistensia de las haziendas de lavor que posee en la provinsia de la çiudad de Tepeaca, para que la ynprenta que en esta çiudad tiene se conserve en el corriente que hasta aquí a conservado, tiene pactado y consertado con los dichos Juan de Paredes y don Joseph Rodrígues de la Torre, el que asistan continuamente a travajar en dicha ynprenta, dando el dicho Juan de Paredes el avasto nesesario de tinta y el dicho don Joseph Rodrígues de la Torre en el tiro [?] por tienpo de seis años. Y para mayor firmesa de dicho contrato, han tratado de redusirlo a escriptura pública y poniéndolo en efecto; por la presente, en aquella vía y forma que mejor aya en derecho, otorgan se avienen y consiertan en la manera siguiente:

Que los dichos Juan de Paredes y don Joseph Rodrígues de la Torre se obligan de asistir y travajar continuamente en la ynprenta del dicho Diego Fernándes de León, el dicho Juan de Paredes dando el avasto de tinta nesesario: y el dicho don Joseph Rodrígues de la Torre en el tiro de dicha ymprenta, por tienpo de seis años que empiesan a correr y contarze desde oy día de la fecha, asistiendo en su casa desde la hora acostumbrada de las siete de la mañana hasta el medio día y desde las dos de la tarde hasta acavarze la tarea de aquel día. Y que acudirá (ilegible por manchas de humedad y falta texto por mutilación) [f. 5rv.] quedare dicha ynprenta para ynprimir qualesquiera papeles de conbites para entierros. Irán puntualmente a dicha casa e ynprenta, sin dilasión ni réplica alguna. Y el dicho Diego Fernándes de León se obliga de que durante el dicho tienpo se dará a los dichos Juan de Paredes y don Joseph Rodrígues de León en la dicha su ynprenta todo lo que hubiere que aser en dichos ministerios; y que acudiendo con puntualidad a la obligasión referida no les [tachado: consentirá] despedirá ni les consentirá les despida la persona a cuyo cargo quedare la ynprenta y tienda. Y así por dicha asistensia como por el travajo personal de los dichos Juan de Paredes y don Joseph Rodrígues de la Torre, les pagará lo que hisieren en dichos ministerios, a los presios siguientes:

Por una resma de pliego caval de blanco y buelta, aunque sea de hijuelas, se a de dar a cada uno ocho reales y medio, tanto al tiro como a la tinta. Por una resma sólo de blanco de un solo lado, se les ha de dar a cada uno, sinco reales. Por una resma de medio pliego, que llaman a la carda, se les a de dar por su trabajo seis reales del tiro y siete reales de la tinta. Por un acto de a dos pliegos con quatro de seda, se les a de dar seis reales al tiro y seis reales a la tinta. Con adbertensia que si pasaren de tresientos se les a de dar a cada uno más, como uno o dos reales. Y si los actos de seda pasaren de quatro, se les a de dar por cada uno de los que pasaren un real al dicho oficial del tiro y otro al de la tinta; [falta texto por mutilación] de a pliego, con quatro de seda [ilegible por manchas de humedad, y falta texto por mutilación] siendo tresientos actos [f. 52r.] tres reales a dicho ofisial del tiro y otros tres a el de la tinta; y si pasaren de dicho número de tresientas, se les a de dar en los de papel uno o dos reales más y en los de seda medio real de cada uno de los que pasaren de quatro, tanto a el uno como a el otro. Por unas conclusiones de a medio pliego con quatro de seda se les a de dar dos reales al dicho ofisial del tiro y otros dos reales a el de la tinta y si fueren más de tresientos, en la misma forma se les a de dar uno y 
dos reales. Por unos papeles de conbite, siendo dosientos se les ha de dar de su travajo dos reales a dicho ofisial del tiro y otros dos a el de la tinta; y si pasaren de dosientos, los que así pasaren les ha de pagar a rasón de un real por cada siento a cada uno. Por qualquiera remiendo, como no pase de quatro manos, se les ha de dar por su travajo a dos reales a cada uno; pasando de las dichas quatro manos, se les ha de pagar respectivamente lo que así pasare a rasón de dos reales por dichas quatro manos; y siendo el remiendo de blanco y buelta, se les ha de dar por quatro manos tres reales a cada uno; y si pasaren de quatro manos los remiendos de blanco y buelta, se les ha de pagar los que así pasaren a rasón de dichos tres reales por quatro manos; cuyas pagas se obliga de haser el dicho Diego Fernándes de León luego, en reales, con costas, por que se le pueda executar con el sinple juramento de dichos ofisiales en que lo difiere sin otra prueba de que les releva; y que les dará todo lo que hubiere que aser en dicha ynprenta, sin acomodar para ello otros ofisiales. Y en esta conformidad, todos tres otorgantes se obligaron de guardar y cumplir este pacto y contrato, y no hir contra el por ningún derecho, acsión sin que [?] sujeta u expresamente les conpeta cuyo benefisio y requisito renunsian. Y los dichos ofisiales se obligan de tener dicha continua asistencia en la casa y ynprenta del dicho Diego Fernándes de León todo el dicho [tienpo de] seis años [ilegible por manchas de humedad, y falta texto por mutilación] (f. 52v.) de derecho, con el sinple juramento de la parte del dicho Diego Fernándes de León en que lo difieren sin otra prueba de que le relevan. Y todos se obligan de estar y pasar por esta escriptura sin reclamarla ni alterarla en cosa alguna, pena que la parte que contra ella fuere incurra en la de dosientos pesos de oro común que se ponen por vía conbensional y la aplican la mitad para la Real Cámara de su magestad y la otra mitad para la parte obediente; y pagada o no, o grasiosamente remitida y perdonada la dicha pena, todavía se guarde y cumpla esta escriptura, a cuya firmesa todos tres otorgantes obligaron sus personas y vienes havidos y por haver, dieron poder a la justisias reales, expesialmente a la de la parte y lugar donde se pidiere cunplimiento desta escriptura, a cuyo fuero y jurisdisión se sometieron y renunsiaron el suyo propio domisilio y vesindad y la ley si conbenerit de jurisdisione para que a ello les apremien como por sentensia pasada en cosa jusgada, renunsiaron leyes de su favor y la general del derecho. Y así lo otorgron y firmaron, esepto el dicho Don Joseph Rodrígues que dijo no saver, firmó un testigo a su ruego. Testigos Antonio Coronel Nicolás de Gusmán y Pedro de Atondo [?], vesinos desta ciudad. Testado: consentirá.- Juan de Paredes [firmado], Diego Fernándes de León [rubricado]. Por testigo: Antonio Coronel [rubricado]. Ante mí: Miguel García Fragoso, escrivano real y público [rubricado] Derechos: $\mathrm{x}$ reales.

(1694, I4-V) Anexo: Escritura de obligación, otorgada por el margués de Altamira a favor del convento de la Limpia Concepción de la ciudad de los Ángeles por haber sucedido en la bipoteca gue gravaba la hacienda que compró de Diego Fernández de León, ubicada en términos de Tecali y Cuautinchán. [AGNP, Not. 4, Protocolos de Miguel García Fragoso, año de 1694, ff. 55r-58r.] [Documento no citado por Pérez Salazar, paleografía de ACD].

[f. 55r.] [Al margen superior izquierdo: Ángeles, 7 de Mayo de i694 años. Remítase al Señor Vicario Superintendente para que nos ynforme sobre lo ofreçido en este memorial. Así lo proveyó, mandó y rubricó el Ilustrísimo Señor Obispo de la Puebla, etcétera, mi señor rúbrica. Ante mí: José de Lara Mogrovejo [rubricado].

[Al margen superior derecho: I4 de mayo de I694. Obligassión] [En el margen superior central hay un crismón] Ilustrísimo Señor. Bartholomé Ortis de Casqueta, Marqués de Altamira, digo que Diego Fernándes de León, vesino de esta ciudad y doña Ángela Ruis Machorro, su mujer, poseedores de las haziendas y demás bienes que fueron del regidor Domingo Machorro, su abuelo, me hiçieron venta real de una de dichas haciendas, la de ovejas en términos del 
pueblo de Tecali, con el cargo de que de parte de su precio entregase al combento de la Limpia Concepsión de Nuestra Señora de esta dicha ciudad, seis mil pesos por quenta de los réditos de dos censos que componen nuebe mil y quinientos pesos de prinçipal, ympuestos sobre dichas haziendas, y le entregué recivo de la parte de dicho combento, auténtico por donde constase su paga, con condición de que el dicho Diego Fernándes me entregase instrumento de la parte de dicho combento por donde constase haver aprobado la venta y dado la finca por libre de la general hipoteca que tiene en ella por raçón de dichos censos según el contrato que hicimos, por quanto tiene presentado memorial a vuestra señoría haciendo relaçión de lo referido; para que se le pueda dar corriente, se ha de servir vuestra señoría de conseder permisso a la parte de dicho combento para que me de recibo auténtico de dichos seis mil pesos, de llano en llano, para entregárselo al susodicho, y me obligare con hipoteca espeçial de dicha haçienda de obejas, sin derogasión de la general, a pagarlos dentro de seis años, a un mil en cada uno, corriendo los plasos desde primero de este mes corriente de mayo; y sobre ello otorgaré la escriptura necessaria, por tanto:

A Vuestra Señoría Ilustrísima pido y suplico se sirva de condesender en la súplica referida, en que reciviré favor de la grandesa de vuestra señoría ilustrísima. El Marqués de Altamira [rubricado].

Ilustrísimo Señor. Cumpliendo [ilegible por manchas de humedad, y falta texto por mutilación inferior del manuscrito].

[f. 55v.] por el memorial de la buelta, y haviendolo considerado con atensión, jusgo no tiene icombeniente, por cuia razón se puede hazer como lo pide, prosediendose a las escripturas por ambas partes al tenor del memorial, con el aditamento de que faltando a qualquiera de los plasos, quede nula la espera. Este es mi sentir, salvo lo que vuestra señoría fuere servido de mandar, que será lo más acertado. Ángeles, I3 de Mayo de I694 años.

Los motivos de combeniensia que sin perjuicio del combento tiene, lo que a vuestra señoría proponga en esta respuesta, se reconoserán en el ynforme que a vuestra señoría hice en el memorial que presentó Diego Fernándes de León sobre eśta materia ut supra.- Menor criado de vuestra señoría. Diego de Victoria Salazar [rubricado].

Ángeles, 14 de Mayo de 1694 años. Concedémosle al Señor Marqués de Altamira, en la conformidad que ofreze en el memorial de la buelta, la espera que pide con condiçión que faltando a qualquiera de los plazos que se mençionan sea nulo y de ningún valor, y se buelva a proçeder a la execusión de la cobranza de la cantidad referida. Así lo proveyó, mandó y [rubricó el Ilustrísimo] Señor don Manuel [f. 56r.] Fernándes de Santa Cruz, obispo de la Puebla de los Ángeles, del Conssejo de su magestad, etcétera, mi señor. Entre renglones: la espera que pide. Vale. [rúbrica]. Ante mí: Don Pedro de Lara Mogrovejo, escrivano [rubricado].

[f. 57r.] [Al margen izquierdo: [...] en veinte de [...] de mil y seis sientos y noventa y quatro años, sacose en papel del sello [...] y las demás del corriente, de que doy fe. Miguel García Fragosso, escrivano real y público [rubricado]. Sepan quantos esta carta vieren como yo, don Bartholomé Hortis de Casqueta, cavallero del orden de Santiago, marqués de Altamira, vezino desta ciudad de los Ángeles, otorgo que devo y me obligo de pagar al convento de relijiosas de Nuestra Señora de la Linpia Consepsión desta çiudad, o en su nonbre al capitán don Pedro de Luey Escandón, familiar del Santo Ofisio de la Ynquisisión, su mayordomo actual y al que adelante lo fuere y parte lexítima por dicho convento, seis mil pesos de oro común por otros tantos que en dicho convento libró sobre mí Diego Fernándes de León, vesino desta ciudad, en quenta y parte de pago de mayor cantidad que le está deviendo de réditos del senzo en su favor ynpuestos sobre las haziendas de lavor que posee en propiedad, que fueron del capitán y regidor Domingo Machorro, y deviéndozeles de entregar en reales de contado, en virtud de 
dicho libramiento, por quenta del presio en que le conpré la hasienda de ovejas que asimismo quedó por vienes del dicho regidor Domingo Machorro; por memorial que presenté a vuestra señoría ilustrísima, señor doctor don Manuel Fernándes de Santa Cruz, dignísimo obispo deste obispado, del Consejo de su magestad, pedí y supliqué a su señoría ilustrísima se sirviese de conzederme espera para los plasos que irán declarados. Y con vista del ynforme y pareser del señor vicario superintendente de los conventos de relijiosas se sirvió su señoría ilustrísima de consedérmela por su decreto de oy día de la fecha, que con dicho memorial e ynforme ba por prinsipio, en cuyo cumplimiento, confesando lo referido por sierto y verdadero, y ser real de valer de la dicha cantidad, sobre que renunsio alegar lo contrario, leyes de la entrega y su prueba, y exsepsión de la pecunia, les pagaré los dichos seis mil pesos a rasón de un mil pesos por fin de cada un año de los que corrieren desde primero día deste presente mes de mayo y año de la fecha, unas pagas subsesivas a otras en reales, en esta ciudad u en la parte que se nos pidan, con costas de la cobransa y [ilegible por manchas de humedad, y falta texto por mutilación inferior del manuscrito].

[f. 57v.] desta escriptura y se puedan executar mis vienes por toda la dicha cantidad, diferida su verificación y [...]dasión en el sinple juramento de la parte del dicho convento, sin otra prueba de que le releva, y a dicha cobranza tengo por bien se envié persona donde estubiéren mis vienes con salario de dos pesos de minas que gane cada día de los que se ocupare en la yda, estada, negosiasión y buelta hasta la real paga; y por los salarios como la deuda prinsipal se me execute con el sinple juramento del cobrador en que lo difiero sin otra prueba de que le relevo. Para cuya seguridad hipoteco, sujeto y gravo por expesial y expresa hipoteca, no derogando la general ni por el contrario, la dicha hazienda de obejas, con veinte mil cavesas de todas hedades, y la hasienda de trueque, la que le pertenese, nonbrada Sapotlán, con todas sus tierras en los términos de los pueblos de Santiago Tecali y Cuautinchán, con los sitios y comederos que le pertenesen en la costa de Guajan [Guajaca?] devajo de los linderos que contienen sus títulos, con todo lo que les pertenece de fecho y de derecho por mía propia, sujeta y gravada a dos mil y quinientos pesos de senso prinsipal sobre ella impuesto en favor del convento de relijiosas de Santa Catharina de Sena de la çiudad de Antequera [en el] valle de Oaxaca, libre de otro y de enpeño, hipoteca y enajenasión expesial ni general, para no venderla, asensuarla ni en otra manera enajenarla hasta tanto que esta deuda enteramente esté pagada, pena que el trato enajenatorio a que procediere sea ninguno y no valga y pueda la parte de dicho convento de sacarla de poder de tersero posedor y venderla judisial o extrajudisialmente [ilegible por manchas de humedad, y falta texto por mutilación inferior del manuscrito].

[f. 58r.] lo difiero sin otra prueba de que le relevo. Y a la firmesa obligo mis vienes havidos y por haver, doy poder a las justisias y jueses conpetentes del conosimiento de mis causas para que a ello me apremien como por sentensia pasada en cosa jusgada, renunsio leyes de mi favor y la general del derecho. Que es fecha en la ciudad de los Ángeles, a catorse días del mes de mayo de mil seisientos y noventa y quatro años. Y el otorgante, que yo el escrivano doy fe conosco lo firmó, siendo testigos el licenciado Blas de Mayorga, clérigo presvítero Nicolás de Gusmán y Manuel Garsía, vesinos esta ciudad. testado: otor, de. El Marqués de Altamira [rubricado]. Ante my: Miguel Garsía Fragosso, escrivano real y público [rubricado]. Derechos: $v$ reales.

(1694, I7-v) Poder especial otorgado por Diego Fernández de León a favor de [...] Gutiérrez, para que administre su librería e imprenta y general para que represente su persona, derechos y acciones. [AGNP, Not. 4, Protocolos de Miguel García Fragoso, año de 1694, ff. 62r-63r.] [Documento no citado por Pérez Salazar, paleografía de ACD]. 
[f. 62r.] [Al margen izquierdo: Poder] Sepan quantos esta carta vieren como yo [Diego Fernándes de León, im]presor y mercader de libros [vesino desta ciudad de los Ángeles] otorgo que doy mi poder [ilegible por manchas de humedad, y falta texto por mutilación inferior del manuscrito].

[f. 62v.] Gutiérres administre la tienda de dicha mi librería que tengo en esta ciudad en los portales de la plasa pública, vendiendo a reales de contado a las personas que le paresiere y consertando por los presios que le tengo hordenado los libros y demás obras de dicha tienda y ynprenta. Consertando a su satisfasión y por los presios que por dicha memoria lehen [sic], e no todas las horas que se ofressiere hazer y ynprimirse qualesquier particulares, obligándome a entregarlas a las personas a quien tocaren en las partes, a los tiempos y plasos y devajo de las condisiones, pena y salarios que asentare, cuidando de que los ofisiales que para dicha ynprenta y tienda tengo consertados cunplan con las obligasion de la asistensia a que están obligados por escriptura en mi favor, conpeliéndoles a que tengan continua asistencia en mi casa y ynprenta a los tienpos y por los orarios que tenemos asentados, y pidiendo que se les compela al cumplimiento de dichas escripturas judisial o extrajudisialmente, como les paresiere, pagándoles y satisfasiéndoles su travajo conforme a los presios que tenemos consertados y no más. Y asimismo venda realmente a las personas y por los presios que le paresiere y consertare qualesquiera mis vienes y esclavos, declarando las hipotecas, empeños y gravámenes a que estubieren afectas; y reciva y cobre lo que de dichas ventas y obras de dicha tienda y ynprenta prosediere, en reales u otros efectos que conchave a su satisfasión; de que otorgue recivos, cartas de pago, finiquitos, lastos y otros recaudos con sessión de derechos, chanzelasión de instrumentos y renunsiasión de leyes de la entrega y su prueba, y exsepsión de la pecunia no siendo ante escrivano que de ello de fe; y me desista y aparte de los derechos y acsiones reales y personales, de propiedad, posesión, señorío y otros que tengo y tuviere a los vienes que así vendiere, sediendolos en los compradores a quienes les entriegue; y las obras, libros y demás cosas que se [negosiaren] y vendieren en dicha tienda de que cobre [ilegible por humedad] que a ello con expesial cláusula de cons[ilegible por humedad] en forma para darles y en [ilegible por mutilación] y dueños de dichas obras y [...] posesión en [f. 63r.] cada que me lo pidan, obligándome a su evissión, seguridad y saneamiento en la más vastante forma que por derecho pueda y deva ser obligado; y en razón de los efectos deste poder, paresca en juisio en tribunales superiores e inferiores y ante qualesquier jueses y justisias eclesiásticas y seculares que a mi derecho ynporte; ponga demandas, responda a las contrarias, haga pedimentos, requerimientos, sitasiones, protestas, apelasiones, súplicas, juramentos, recusasiones, declinatorias, oposisiones, contradisiones, querellas, acusasiones, envargos, desenvargos, entregas, execusiones, mejoras, prisiones, solturas, apartamientos, consentimientos, ventas y remates de vienes, presentasiones de testigos, escriptos, escripturas, provansas, testimonios y otros papeles y recaudos que saque de cuyo poder estén y los avone, tache y redarguya lo de contrario presentado, como le paresiere; consienta autos y sentensias favorables y apele y suplique de las perjudissiales, siga de grado por todas ynstansias, pida y saque mandamientos reales, provisiones, cartas de justisia y otros despachos que presente donde convenga, pidiendo su cumplimiento, haciendo los demás autos y diligensias judisiales y extrajudisiales que se requiera; con las fuerzas y firmessas, suministre salarios, relevasiones de prueba, renunsiasiones de leyes y de fuero, poderío y sumisión a las justisias reales y las demás que convengan a su validasión; que apruebo y ratifico me obligo a su guarda y cumplimiento y firmesa deste poder y lo que en su virtud se obrare por mi persona y vienes havidos y por haver, doy poder a las justisias reales donde en virtud deste fuere sometido, a cuyo fuero y jurisdisión me someto y renunsio el mío propio domisilio y vesindad y la ley si convenerit de jurisdisione para que a ello me apremien como 
por sentensia pasada en cosa jusgada, renunsio las leyes de mi favor y la general del derecho, que para ello y su dependiente le doy este poder, con facultad de sustituirlo en quanto a pleitos y no en más y relevasión en forma; que es fecho en la ciudad de los Ángeles, a diez y siete días del mes de mayo de mil seisientos y noventa y quatro años y el otorgante, que yo el escrivano doy fe conosco, lo firmó. Testigos: Nicolás de Gusmán, Antonio Coronel y Pedro de Atondo vezinos desta ciudad. Testado: las: en. Diego Fernández de León [rubricado]. Ante my: Miguel Garsía Fragosso, escrivano real y público [rubricado]. Derechos: v reales.

(1694, I9-v) Carta de obligación de pago otorgada por Diego Fernández de León a favor de doña Catarina del Castillo y Estrada, por pesos. [AGNP, Not. 6, Protocolos de i694, ff. 48r-49v.] [Documento no citado por Pérez Salazar, paleografía de ACD].

[f. 48r.] [Al margen izquierdo: Obligassión por reales, en I9 de mayo de I694, fecho en dicho día para doña Catarina] Sepan quantos esta carta vieren como nos, Diego Fernándes de León y doña Ánjela Ruís Machorro, su lexítima muger, vesinos desta ciudad de los Ángeles, con lisensia que io, la susodicha pido al dicho mi marido me de y conseda para otorgar lo que irá declarado, la qual le consedo yo, el dicho Diego Fernándes de León en bastante forma, de cuia aseptassión y de ella usando, anvos marido y mujer, juntos y de mancomún a vos de uno y cada uno de nos, por sí y por el todo ynsolidum, con renunsiassión de leyes de la mancomunidad, división y excursión como en ella se contiene, otorgamos que devemos y nos obligamos de pagar a doña Catarina del Castillo y Estrada, donsella, vesina desta ciudad y a la persona que tubiere su poder y su derecho representare, dos mil pesos de oro común en reales, que por hasernos amistad y buena obra nos a suplido y prestado en reales de contado para el havío de nuestras hasiendas nombradas San Joseph y Santa María en el valle de Nopaluca, y la nombrada San Pedro en el valle de Acasingo, de que nos damos por entregados. Renunsiamos leyes del entrego y su prueba y esepssión de la pecunia, por cuia rasón pagaremos dichos dos mil pesos devajo de la dicha mancomunidad, en reales, en esta ciudad u en la parte que se nos pidan para de la fecha desta escriptura en tres años con más sus réditos correspondientes de a sinco por ciento, con el demás tiempo de la [f. 48v.] retensión y mora, con costas de la cobranza, a la qual no hasiendo paga puntual tenemos por bien y consentimos se enbié persona donde estubiéremos y qualesquiera de nos y nuestros vienes, con salario de dos pesos de oro de minas que gane en cada un día de los que se ocupare en la yda, estada, negosiassión y buelta hasta la real paga, y por los salarios como por el dicho prinsipal y réditos se nos pueda executar devajo de la dicha mancomunidad, con el juramento sinple del cobrador en que lo diferimos, sin otra prueba de que le relevamos. [Al margen izquierdo: Hipoteca]. Y para más seguridad de esta deuda, hipotecamos y obligamos por especial y expresa hipoteca, no derogando la general ni por el contrario, unas casas de edificio vajo que poseemos en esta ciudad en la calle que ba del conbento de relijiosas de la Linpia Consepsión a la Plasuela de San Augustín, linde por una parte con casas altas que poseemos y por otra con casas del lizenciado Antonio de Asarte; y una ynprenta, con todo lo que le pertenese, que tenemos en esta ciudad, lo uno y otro por nuestro propio y dichas casas libres de censso, y todo de enpeño, hipoteca y otra enajenassión espesial ni general para no benderlas ni dichas cassas asensuarlas ni en otra manera enajenarlas hasta tanto que ésta deuda esté pagada, pena que el trato enajenatorio a que prosediéramos sea en si ninguno y no valga y pueda sacar la parte de la dicha doña Catarina del Castillo y Estrada dichas casas y ynprenta [f. 49r.] de ajeno poder y benderlas judisial o extrajudisialmente, sin sitarnos ni requerirnos, cuio benefissio y requisitos expresamente renunsiamos y de su presio haserse pago; y por lo que no alcansare executarnos con sólo su juramento sinple en que asi- 
mismo lo diferimos, sin otra prueba de que le relevamos, para lo qual y otorgar ecriptura de benta real en forma de dichas casas y ynprenta, le damos el poder y facultad que de derecho se requiere y es nesesario con sessión de nuestros derechos y obligassiones de saneamiento, a cuia firmessa obligamos yo, el dicho Diego Fernándes de León, mi persona y vienes; y yo, la dicha doña Ánjela Ruís Machorro, los míos, havidos y por aver, y las dicha tres hasiendas que poseemos en propiedad en la provincia de Thepeaca y dos pares de cassas de vivienda alta en esta ciudad. Y anvos otorgantes damos poder a las justisias y jueses que de nuestras causas puedan y devan conoser conforme a derecho, para que a ello nos apremien como por sentensia passada en cosa jusgada. Renunsiamos leyes de nuestro favor y la general del derecho; y yo, la dicha doña Ánjela Ruís Machorro, renunsio el benefissio del Beleyano, nuebas constitusiones, leyes de Toro, Madrid y Partidas y las demás favorables a las mugeres, de cuio efecto fui apersevida por el presente escrivano, de lo qual y del conosimiento de los otorgantes yo, el escrivano, doy fe; y yo, la susodicha, juro a Dios, nuestro señor y la [f. 49v.] señal de la santa crus en forma de derecho, que entiendo bien el efecto desta escriptura contra la qual no tengo hecha protestasión ni haré reclamasión en contrario; y paresiendo la revoco y no me opondré contra su thenor y forma por el privilejio de mi dote, arras, bienes parafernales, hereditarios ni mitad de multiplico, ni por otro derecho que me conpeta, que renuncio; y declaro la otorgo de mi libre expontánea voluntad, sin fuersa, apremio ni yndusimiento del dicho mi marido ni otra persona en su nombre por conbertirse su efecto en mi pro y utilidad y de mis vienes. Y de este juramento no pediré absolución ni relajassión a quien me la deva conceder, y si de ofisio u en otra manera se me consediere, de ella no usaré aunque sea para efecto de ser oída en juicio, pena de no serlo y caer en caso de menos valer. Que es fecha en la ciudad de los Ángeles a dies y nuebe días del mes de maio de mil y seisientos y noventa y quatro años, y los otorgantes lo firmaron siendo testigos Juan de Chaves y Ortega, Francisco Basan de Arévalo y Juan Antonio de Segura y Conde, vesinos desta ciudad. Testado: en. Enmendado: Catharina. Diego Fernández de León [rubricado], Doña Ángela Ruís Machorro [firmado]. Ante mí: Francisco Solano, escrivano público [rubricado]. No e recivido derechos.

(1694, I9-v) Carta de obligación de pago otorgada por Diego Fernández de León a favor del convento de religiosas de la Limpia Concepción de la ciudad de Puebla, por pesos. [AGNP, Not. 6, Protocolos de i694, ff. 95r-96v.] [Documento no citado por Pérez Salazar, paleografía de ACD].

[f. 95r.] [Al margen izquierdo: Fecho en 29 de maio de 1697 y se sacó en papel del sello quarto, doy fe] Sepan quantos esta carta vieren como nos, Diego Fernándes de León y doña Ánjela Ruís Machorro, su lexítima muger, vecinos desta ciudad de los Ángeles, como principales deudores y obligados; y Antonio Ortís de Mora, vesino de ella, como su fiador y principal pagador, juntos y de mancomún, a vos de uno y cada uno de nos, por sí y por el todo ynsolidum, con renunciasión de leies de la mancomunidad, división y escursión; yo, la dicha Ánjela Ruís Machorro, con licencia que pido al dicho mi marido para otorgar esta escriptura, la qual le consedo yo, el dicho Diego Fernándes de León en bastante forma, de cuia aseptasión y de ella usando todos los otorgantes, principales y fiador, otorgamos que devemos y nos obligamos de pagar a el convento de religiosas de Nuestra Señora de la Limpia Consepción desta ciudad y a el capitán don Pedro de Luey Escandón, su maiordomo, que a el presente lo es y al que lo fuere y por el dicho convento parte lexítima, quinientos y quarenta y tres pesos y siete reales de oro común por otros tantos que se an causado de costas en el pleito ejecutivo que dicho convento a seguido [f. 95v.] contra los vienes y haciendas que quedaron por fin y muerte del capitán y rexidor Domingo Ruís Machorro, de que somos poseedores, para lo qual, por haversenos consedido esperas por cantidad de réditos que se debían por lo que tocava a dichas costas, 
presenté memorial yo, el dicho Diego Fernándes de León, ante el ilustrísimo señor obispo deste obispado, pidiendo se me consediese de un año para satisfaserlas dentro del, y haviéndose remitido al señor vicario de los conventos, con vista de lo que informo; y el maiordomo del dicho convento, por decreto de oi día de la fecha, se nos consedió dicha espera en la forma que más largamente se expresa en dicho memorial, ynformes y decreto que van por principio desta escriptura y confesando, como confesamos, lo referido por sierto y verdadero; y constituiéndonos, como nos constituimos, por reales deudores de dichos quinientos quarenta y tres pesos y tres reales causados de dichas costas, sobre que renunciamos poder desir ni alegar lo contrario, leies del entrego y su prueba y esepsión de la pecunia, todos, principales y fiadores, devajo de la dicha mancomunidad, [f. 96r.] pagaremos dicha cantidad en reales en esta ciudad $\mathrm{u}$ en la parte que se nos pidan, con costas de la cobransa para de la fecha desta escriptura en un año, sin más plaso ni dilación, a la qual no haciendo paga puntual, tenemos por bien y consentimos se embié persona donde estubiéremos y nuestros vienes con salario de dos pesos de oro de minas que gane en cada un día de los que se ocupare en la yda, estada, negosiasión y buelta hasta la real paga, y por los salarios como por la deuda principal se nos pueda ejecutar devajo de la dicha mancomunidad con el juramento simple del cobrador en que lo diferimos sin otra prueba de que le relevamos, para lo qual dejamos en su fuersa y bigor dicha ejecución para que no pagando las dichas costas al plaso referido, pueda la parte de dicho convento por ellas y los réditos que se le devieren de los principales de los zensos a que los vienes que poseemos están afectos y de que prosede esta deuda, proseguirla en toda forma como le conbenga, y a la firmesa obligamos nos, el dicho Diego Fernandes de León y Antonio Ortís de Mora, nuestras personas y vienes; y yo, la dicha doña Ánjela Ruís Machorro los míos, havidos y por haver, dando poder a los jueses y justisias que de esta causa puedan y devan conoser conforme a derecho para que a ello nos apremien como por sentencia pasada en cosa jusgada [f. 96v.] renuncíamos leies de nuestro favor y la general del derecho y yo, la dicha Ánjela Ruís Machorro, el beneficio del Beleiano, nuebas constituciones, leies del Toro, Madrid y Partidas, y las demás favorables a las mugeres, de que confieso ser savidora y fui apersivida por el presente escrivano, de lo qual y del conosimiento de los otorgantes yo, el escrivano doy fe; y yo, la susodicha juro por Dios, nuestro señor y la señal de la Crus en forma que entiendo bien el efecto desta escriptura contra la qual no tengo hecha protestasión ni haré reclamasión en contrario; y paresiendo la revoco y no me opondré contra su thenor y forma por el privilejio de mi dote, arras, bienes parafernales, hereditarios ni mitad de multiplico, ni por otro derecho que me conpeta, que renuncio porque la otorgo de mi libre voluntad sin fuersa, apremio ni yndusimiento del dicho mi marido ni otra persona en su nombre por convertirse su efecto en mi pro y utilidad y de mis vienes. Y de este juramento no pediré absolución a quien la deva conseder y si se me consediere, de ella no usaré en manera alguna aunque sea para efecto de ser oída en juicio, pena de no serlo y caer en caso de menos valer. Que es fecha en la ciudad de los Ángeles a dies y nuebe días del mes de maio de mil seissientos y noventa y quatro años, y los otorgantes lo firmaron siendo testigos Juan de Cháves, Francisco Basán y Miguel Solano, vesinos desta ciudad. Enmendado: quatro. Diego Fernández de León [rubricado], Doña Ánjela Ruís Machorro [firmado], Antonio Hortís de Mora [firmado]. Ante mí: Francisco Solano, escrivano real y público [rubricado]. Derechos: vij reales.

(1694, 27-v) Poder otorgado por Diego Fernández de León y doña Ángela Ruíz Machorro, su legítima mujer a favor de Miguel González Moncayo, vecino de Tulancingo, para que a su nombre pida la certificación de muerte de doña Ana Machorro. [AGNP, Not. 6, Protocolos de i694, ff. II2r-II2v.] [Documento no citado por Pérez Salazar, paleografía de ACD]. 
[f. II2r.] [Al margen izquierdo: Poder en 27 de mayo de I694, fecho dicho] Sepan quantos esta carta vieren como yo, Diego Fernándes de León, vesino de esta ciudad de los Ángeles, marido y conjunta persona de doña Ánjela Ruís Machorro, su lexítima muger, hija lexítima del capitán don Garsía Ruís Machorro y doña Ysavel Ortis de Ávila y como tal posedor de los bienes y hasiendas que quedaron por su fin y muerte, otorgo que doi mi poder bastante en derecho a Miguel Gonsáles Moncaio, vesino del pueblo de Tulansingo, para que en mi nombre paresca ante qualesquiera jueses y justisias eclesiásticas y seculares que con derecho pueda y deva, e pida e le den qualesquier testimonios, sertificasiones y otros recaudos que a mi derecho convengan tocante a la berificasión de la muerte de doña Anna Machorro, muger que fue de Juan de Juberra, hija del dicho capitán don Garsía Ruís Machorro y de no haver dejado hijos ningunos y habiendo otorgado testamento la susodicha, pida se le de traslado de el y todos los demás instrumentos que reconosiere ser nesesarios y conbenientes para la conprobasión y verificasión de mi derecho, en cuia rasón haga pedimentos, requerimientos, sitasiones, protestas, súplicas, alegasiones, contradiciones, juramentos, oposisiones, declinatorias, recusasiones, apelasiones con presentasión de testigos, escritos, testimonios, probansas y otros qualesquier papeles y recaudos; que pida y saque, de cuio poder estén, tache y redarguia lo de contrario, presentando como le paresiere y qualesquier mandamientos, testimonios, sertificasiones, reales probisiones, cartas de justisia y otros despachos que gane para todos efectos; y siendo nesesario, ante las justisias eclesiásticas pida sensuras que haga leer, intimar y publicar asta la de anathema y testimonio de lo que en su birtud resultare, que uno y otro presente donde convenga y pida su obedesimiento y cumplimiento, oiga autos y sentensias ynterlocutorias y difinitivas, consienta las fa[f. II2v.]borables y apele y suplique de las perjudisiales, siga sus grados en todas instansias asiendo todos los demás autos y diligensias judisiales y extrajudisiales que se requieran; que para lo dicho y su dependiente le doi este poder con libre y general administrasión y facultad de sostituirlo en una o más personas todas las beses que le paresiere, revocar sostitutos y nombrar otros, y a todos relevo según forma de derecho; que es fecho en la ciudad de los Ángeles de la Nueba España a veinte y siete días del mes de mayo de mil seisientos y noventa y quatro años y el otorgante a quien yo, el escrivano doy fe que conosco, lo firmó siendo testigos Juan de Cháves y Ortega, Miguel Ximénes Solano y Juan Antonio de Segura, vesinos de esta dicha ciudad. Testado: testamentos. No vale. Diego Fernández de León [rubricado]. Ante mí: Francisco Solano, escrivano público [rubricado], derechos: vJ reales.

(I694, 5-VI) Venta de esclavo otorgado por Francisco Martínez de Viana a favor de Diego Fernández de León. [AGNP, Not. 6, Protocolos de I694, ff. I22r-122v.] [Documento no citado por Pérez Salazar, paleografía de ACD].

[f. I22r.] [Al margen izquierdo: Benta minuta a Thepeaca en 5 de junio de 1694 años, fecho dicho día y se sacó en papel de sello segundo. Doy fe] Sepan quantos esta carta vieren como yo, Francisco Martínez de Viana, vesino del pueblo de Nopaluca de la jurisdicción de Tepeaca, residente en esta de los Ángeles, otorgo vende realmente a Diego Fernándes de León, vesino de esta dicha ciudad, un mulato, mi esclavo cocho, nonbrado Francisco, de edad de beinte y un años poco más o menos, soltero, por mío propio que lo conpré de Juan de Morales Ladrón de Guevara, vesino y mercader de esta dicha ciudad, por escriptura, su fecha en ella a primero día del mes de septiembre del año pasado de mil seiscientos y noventa y tres ante Pedro Gómes de Prado, escrivano público, en cuia birtud me toca y pertenese y está libre de enpeño, hipoteca y otra enaxenasión espesial ni general, [f. I22v.] sin asegurarlo de ningunas tachas, visios, defectos, ni enfermedades públicas ni secretas, porque con todas las que tubiere o paresiere tener se lo bendo en presio de dusientos y quarenta pesos de oro común, que me a dado y pagado 
en reales de contado de que me doi por entregado, renunsio leies de la entrega y su prueba, y esepsión de la pecunia y me desisto y aparto de los derechos acsiones reales y personales de propiedad, señorío y otros que a dicho esclavo tengo y me pertenecen, y los sedo, renunsio en el conprador a quien por mi parte se entregó a la suia en el dicho pueblo de Nopaluca en señal de posesión y tradisión berdadera; y como real bendedor me obligo a la evisión, seguridad y saneamiento de esta benta en la más bastante forma que por derecho puedo y debo serlo; y a la firmesa obligo mi persona y bienes ávidos y por aver, doi poder a las justisias de su magestad, en espesial a las de esta ciudad y a las demás donde se pidiere cunplimiento de esta escriptura a cuio fuero y jurisdisión me someto con renunsiasión del mío propio domisilio y vesindad y la lei si convenerit de juridictione para que a ello me apremien como por sentensia pasada en cosa jusgada, renunsio leies de mi favor y la general del derecho; que es fecha en la ciudad de los Ángeles a sinco días del mes de junio de mil seisientos y noventa y quatro años, y el otorgante a quien yo el escrivano doi fe que conosco no firmó porque dijo no saver, a su ruego lo firmó un testigo, siendo testigos Juan de Segura, Francisco Basan y Juan Chaves, vesinos de esta ciudad. Por testigo Juan de Chaves [firmado]. Ante mí: Francisco Solano, escrivano público [rubricado], derechos: vi reales.

1704, Contrato de Diego Fernández de León. [Documento no localizado en archivos poblanos, citado por Pérez Salazar, p. 377. Transcribo la paleografía ofrecida por el investigador].

“Ante Francisco Solano con fecha veinticuatro de Mayo de mil setecientos cuatro se otorgó una larguísima escritura de transacción para dar fín al pleito que emprendió doña Bernardina Ortiz de Cuéllar viuda de don Francisco Ruiz Machorro contra Diego Fernandez de León; en ella se hace mención detalladamente de toda la tramitación judicial y como final el Capitán Nicolás Ruiz Machorro se comprometió entregarle a doña Bernardina diez mil quinientos pesos en reales y respecto de Diego Fernández de León dice lo siguiente "se han havenido y concertado como por la presente se havienen y conciertan por vía de transacción paz y concordia, pacto entre vivos o como mejor haya lugar [...] y obligándose el susodicho (Nicolás Ruiz Machorro) a darle al dicho Don Diego Fernández de León y doña Angela Ruiz Machorro su mujer, tres mil quinientos pesos, los tres mil por la herencia de la susodicha y de los derechos que tienen deducidos y los quinientos restantes por la herencia del dicho Domingo de San Antonio Ruiz Machorro, cedida al dicho don Miguel Fernández de León hijo de los susodichos”.

1706, Testimonio de Diego Feránandez de León. [Documento no localizado en archivos poblanos, citado por Pérez Salazar, p. 377-380. Transcribo su paleografía].

"Diego Fernández de León Ympresor i mercader de libros Vecino de eśa Ciudad, como mejor aiga lugar en derecho, paresco ante Vm. I digo que abiendo seguido pleito con el Rdo. Pe. Frai Miguel de Balberde Religioso de la Sagrada horden de predicadores i procurado de su provincia de Sn Ipolito mártir de Oaxaca ante el exelentisimo señor Duque de Alburquerque Primer Gobernador y Capn. General de esta nueva España sobre que se me concediese sierta espera para la paga de cantidad de pesos que debo a dha. Provincia y a que esta grabada por especial ypoteca la Imprenta que poseo en propiedad en esta Ciudad se sirbio su Excelensia de determinar definitivamente el que gosase de la espera que pretendía en la forma que conviene el despacho que se me libro por fines del año pasado de Setesientos i cinco que tengo presentado i parece que dho. Rdo. P. no obstante la superior determinasion de su Excelencia, Todabia pretende impugnar sobreella pues saco Testimonio de siertos instrumentos que se allan en los autos egecutibos i de concurso de acreedores que se an seguido contra mis bienes 
i dha. Imprenta ante la Rl. Justisia de esta Ciudad i en el ofisio del presente $s^{\text {no }}$. Para ocurrir con el por bia de recurso o grado de suplica pretendiendo embarasar el efecto de lo determinado sobre dicha espera y para ocurrir ante su Excelensia a rrepresentar mis derechos i que dha. espera corra como esta mandado y dar satisfasion a los artículos que dho. Pe. Procurador intenta combine a mi derecho $\mathrm{q}^{\mathrm{e}}$ em preparatorio Juisio se me resiba infromasion al tenor de las preguntas Siguientes.

I.- Primeramente sean preguntados los testigos por el conocimiento de las partes notisa de la causa i generales de la Lei.

2.- Si saben que io el dho. Diego Fz. De León fui el Fundador de la imprenta que poseeo por que no abiendo en esta Ciudad otra sino una mui antigua i gastada que poseía la Viuda de Jno. de Borja embie a Antuerpia por la que asi tengo que después surti Con otras dos que también inbie a traer que todas tres puestas en esta Ciudad en corriente me subieron de Costo mas de nueve mil $\mathrm{p}^{\mathrm{s}}$. y que también Compre a dha. Viuda de Juan de Borja la suia vieja maltratada que fundi i reduje a planchas que bendi a Diego Monte y Gallo por no estar serbirble la letra.

3.- Ytt si saben que abiendo quatro imprentas en la Ciudad de Mexco. Por los años de Mil y Seiscientos y noventa i uno y noventa i dos el Rdo. Pe. Alonzo Ramos de la Sagrada compañía de Jesus siendo prepósito de la Casa profesa de ella por reconocer quan buena era mi imprenta y el mucho conocimiento e inteligencia mia en esta materia i arte me llebo a dha. ciudad de Mexco. A dha. Casa profesa Con la mitad de dha. mi imprenta nueva i en dha. Casa profesa se imprimieron muchos y barios libros Como fueron las Doctrinas del Pe. Jn ${ }^{\circ}$. Martines de la Parra - Segundo y Tersero Tomo de la Vida de la venerable Catharina de san Juan i otros papeles de debosiones en cuia imprenta me ocupe tiempo de tres años poco mas o menos digan etta.

4.- Ytt si saben que abiendo en dha. Ciudad de $\mathrm{Mex}^{\mathrm{co}}$. dhas. Quatro imprentas me yamo a ella el Excelentisimo señor Conde de Galbe Virei que fue de esta Nueva España para que imprimiese Como imprimi en esta Ciudad por primera i segunda bes las Reales hordenanzas de la Rl. Casa de la Moneda de aqueya Corte Con todas las sedulas leyes i hordenanzas Rs. que para dho. Efecto se me entregaron originales por Dn. Joseph Antonio Callejas oficial maior del ofisio de Gobernasion y Gerra de Dn. Joseph Moran de la Serda; mediante a tener su Excelensia noticia de mi inteligencia i bondad de dha Ymprenta nueva digan ett.

5.- Ytt si saben que no solo llega mi inteligensia a ser Ympresor sino también a gaser y formar letras para imprimir teniendo com tengo para ello Moldes suficientes en la Casa de mi morada con que ago i formo letras nuevas i con que ise i forme el año pasado de Mil Seissientos i ochenta y sinco Una imprenta que tengo mia propia en la ciudad de Antequera Balle de Oaxaca a cargo de Antto. Dias Maseda Vezino de ella que Consta por su carta que tengo presentada en dos autos digan etta.

6.- Ytt si saben que Con ocasión de la Carestia de papel que hubo desde dho. año de ochenta i sinco asta el de ochenta y nueve seso el Corriente de dha. Ymprenta de suerte que era tampoco lo que abia que imprimir que me atrase en mis dependencias Causando distintas deudas i empeños que llegaron a Diesisiete niensia volvió el Corriente de dha. Ymprenta su tal suerte que en el discurso de tres años poco mas o menos pague todas las dhas. Mis deudas digan etta.

7.- Ytt si saben que por el años pasado de Mil Seiscientos i noventa y quatro me fui a la provincia de Tepeaca a unas haz ${ }^{\text {das. }}$ de Labor Con mi familia i el Caudal que tenia i el año

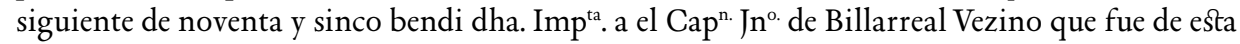
Ciudad que ia es difunto tan solamente Con dos mil quinientos $\mathrm{p}^{\mathrm{s} .}$ de gravámenes de deudas a que estaba sujeta por especial Ypoteca: y que aunque dho. Comprador se obligo a la paga de dos. Grabamenes no lo Cumplio ni la iso etta.

8.- Ytt si saben Como respecto de aber perdido mi Caudal por malos sucesos que tuve en dhas. haz $z^{\text {ads. }}$ Bolbi a Comprar dha. Ymprenta por el año pasado de Mil Setesientos i quatro a 
los herederos de dho. Juan de Billarreal para volver a empesar a trabajar de nuevo en ellos por aiarme muy pobre y por no aberme pagado estaba yo obligado i que me apuraban sus dueños mis acreedores i que la necesidad de tener en que ocuparme me iso comprar la dha. Ymprenta a pensionados i Cargada en ocho mil pesos antes mas que menos de sensos empeños Ypotecas i deudas sueeltas a que la grabaron i que causaron dho. Juan de Billarreal i sus herederos i remítanse los testigos a la escriptura de venta que me isieron digan etta.

9.- Ytt si saben que dicha imprenta al presente se alla en mi poder entera según i como la Compre de los herederos de dho. Juan de Billarreal sin que le falte Cosa alguna por que ni e sacado vendido ni consumido Molde Letra ni tarja alguna - antes si la e aviado de todo lo necesario y puse en Corriente una prensa que estaba ia Maltratada aruinada, inservible, que en el prinsipio i fundasion de dicha Imprenta me abia Costado Un mil pesoso i con lo que gaste en su adereso volvió a su primero ser i ezta en Corriente Como en sus principios: Con lo que no solo no esta deteriorada dha. Ymprenta sino mejorada en esto i en tenerla puesta en forma i arte para su fasil uso i manejo i para imprimir quanto se ofresca digan etta.

Io.- Yten si saben que con la ultima i terrible Carestia de papel que abido de dos años a esta parte que todavía esta existente lo mas deste tiempo e estado parada dicha Ymprenta sin que ella se imprima Cosa de importancia sino papeles de Cobites algunos actos literales i menudensias tan cortas que no alcansan a sustentarme ni mantener los ofisiales de $\mathrm{q}^{\mathrm{e}}$. necesitaba quando abia papel i mucho que imprimir porque entonces mantenía seis ofisiales Continuos i ahora solo dos que se mantienen con mucha Cortedad digan etta.

II.- Yten si saben que no obstante los atrasoso referidos e pagado de dos años a esta parte algunas de mis deudas y gravámenes de dhs. Ymprenta asi de mis principales Como de réditos mas de quatro mil pesos que constaran po recibos que tengo presentados en dichos autos su $\mathrm{Ex}^{\mathrm{a}}$. a que se remitan los testigos digan etta.

I2.- Yten de publico y notorio publica bos i fama digan etta. A Um pido i suplico se sirva de mandar se me resiba dha. informasion al tenor de las preguntas insertas en este escripto e que de la que dieren se me den uno o mas traslados autorizados en forma i manera que agan fee para ocurrir con ellos ante su Ex ${ }^{a}$. en su superior gobierno i donde me combenga en seguimieto de mi Justisia i dar satisfasion de mi buen proceder verdad y legalidad en lo que tengo alegado Sobre conseguir dha. espera i lo demás que me Combenga y por que algunos de los testigos de que pretendo valerme son eclesiásticos Se me despache recurso para que el $\mathrm{s}^{\mathrm{r} .}$ Jues provisor y Vicario General de este obispado Se sirva conceder Su lisensia i permiso para que puedan aser sus deposisiones por el tenor de dhas. Preguntas los que asi presentare interponiendo la religión del Juramento por ante el presente ssno U otro Ral Con Comision que se de para ello pido Justisia Costas i Juro este escripto en forma de no se de malisia y en lo necesario etta.

En la mui noble y mui Leal Ciudad de los Angeles a diez y nuebe de henero de mill sietesientos y seis años ante el señor cappitan de caballos corazas - Don hipolito de Saldaña y tapia justicia maior y teniente de cappitan General en esta Ciudad por su magestad se leio esta petision que presento el contenido de Auto y por su mersed Vista la huvo por presentada y mando que con sitasion de el Reverendo padre frai Miguel de Balberde de la horden de predicadores procurador General de su provincia de San hipolito Martin de Oaxaca se resiva al dho. Diego Fernández de León la ynformasión que ofrese y los testigos que presentare se examinen al thenor de las preguntas ynsertas en este scripto por ante mi el escribano $\mathrm{O}$, otro Real a quien da Comision en forma y de la que assi diere se le den los traslados que pide a la letra authorisados en forma y manera que hagan fee para el efecto que los pide y obren el que hubiere lugar en derecho y de partte de su Magestad ruega i encarga y de la suia suplica y pide de merced al señor Doctor Don Juan de Xauregui y Barsena chantre de la Santa iglesia catedral de esta Ciudad y jues provisor y bicario General de este obispado se sirva conceder su lisensia y per- 
miso para que qualesquier eclesiasticos que fueren presentados por testigos por el dho. Diego Fernández de León se examinen al thenor de este escripto y hagan sus deposissiones interponiendo la religion de el juramento por ante qualesquier escribano sin incurrir por ello en pena Alguna con que su mersed administrara justisia y al tanto hara por las suias assi lo proveio.

1706, Testimonio de Miguel de Villarreal. [Documento no localizado en archivos poblanos, citado por Pérez Salazar, p. 380. Transcribo la paleografía ofrecida por el investigador].

"En la muy noble y muy Leal Ciudad de los Angeles a veinte y un dias del mes de Enero de mil Siete cientos y seis años el dicho Diego Fernández de Leon para la dicha su información presentó por testigo al $\mathrm{Br}$ don Miguel de Villareal clérigo Presvitero Domiciliario deste Obispado vecino de esta ciudad de quien petición precedente y de la licensia de las foxas antes desta consedidas por el Señor Juez provisor y Vicario dese Obispado recebi juramento y lo hizo in verbo Sacerdotis puesta la mano en el pecho según forma de derecho y prometió decir verdad y siendo preguntado al tanto de las preguntas incertas en dicha petición dijo lo siguiente.

I. A la primera pregunta dijo conoce al dicho Diego Fernández de León que lo presenta desde que el susodicho vino de los Reinos de Castilla a esta Ciudad que era este testigo niño estudiante filósofo y conoce al reverendo Padre Frai Miguel E. Valverde desde el año pasado de mil seiscientos y noventa y cinco que a mas de diez años y tiene noticia desta causa y las generales de la Ley no le tocan y esto responde.

2. A la segunda pregunta dijo que sabe y le consta que el dho Diego Fernández de León fue el fundador de la imprenta que al presente posee porque no habiendo en esta ciudad mas que una muy antigua y gastada que poseia la viuda de Juan de Borja, envió el dho. Diego de Fernández a Antuerpia por la que asi tiene y después las unió con otras que también envió a traer que ambas se las trajo Fernando Romero, la cual recibió este testigo como dueño que fue de dha imprenta como heredero del Capitan Juan de Villarreal su Padre, quien la había comprado a dho Diego Fernández, con que se surtio por tercera vez esta imprenta, toda la letra de Antuerpia, letras floridas, remates, guarniciones y componedores todo sumamente bueno y que no sabe cuanto le tuvo de costo al dho Diego Fernández las dos que asi le vendió su Padre porque la tercera y última la pago este testigo dando quinientos pesos por la letra que recibió y dejando dha imprenta en obligación de pagar cuatrocientos y tantos pesos a los herederos de dho Capitan Juan de Liñán, cuando le traigan el demás surtimiento que falto a dha tercera imprnta que toda ella importó novecientos y tantos pesos pero que aunque no se traiga lo que le falta no lo necesita dha Ymprenta sino es de las suertes de la letura porque con lo que al presente tiene está bien surtida para poder imprimirse cualesquier cosas de importancia que se ofrezcan porque aunque esta de vida dha suerte de letura no le falta este género de letras la dha Ymprenta que la tiene aunque no está tan buena como las demás- Y que es cierto y sin duda que el dho Diego Fernández de León compró a dha viuda de Juan de Borja la dha imprenta vieja que por mal tratada la fundió y redujo a planchas, que vendió a Diego Monte y Gallo por no estar servible. Lo cual probó plenamente el Capitan Sebastian de Guevara, cuñado de este testigo vezino de esta ciudad en los autos ejecutivos y concurso de acreedores que contra dha Ymprenta se siguieron abra tiempo de tres años ante la Real Justicia de esta Ciudad por ante mi y en mi oficio y esto responde.

3. A la tercera pregunta dijo que sabe y le consta que habiendo cuatro Ymprentas en la Ciudad de México, por los años de mil seiscientos y noventa y uno y noventa y dos, el Reverendo Padre Alonso Ramos de la Sagrada Compañía de Jesús, Siendo préposito de la Casa Profesa de ella, por reconocer quan buena era la Ymprenta del dho Diego Fernandez y la mucha inteligenia que el suso dho tiene en este ministerio y arte le llevó a dha Ciudad de México y Casa 
Profesa con la mitad de dha Ymprenta nueva y su prensa y en dha Casa Profesa, con ella se imprimieron muchos y variados libros como fueron la Doctrina del Padre Juan Martínez de la Parra, Segundo y Terceros tomos de la vida de la Venerable Catharina de San Juan y otros varios papeles en que se ocupó bastante tiempo pero no sabe este testigo quanto y que sabe lo referido porque de ello a tenido muchas y siertas noticias que le dieron distintos Religiosos de dha Sagrada compañía y los mismos oficiales que llebó a Mexico dho Diego Fernandez que siendo este testigo dueño de dha Ymprenta pretendieron dos Religiosos dela Compañía por mano del Capitán Joseph Gómez de la Parra pariente de dho Padre Juan Martinez de la Parra el que este testigo les imprimiese por segunda vez dhas Doctrinas y que por reconocer que les tendría dha segunda Ymprenta mas conbeniencia la embiaron a imprimir a España como de facto vinieron impresas y esto responde.

4. A la quarta pregunta dijo que habiendo en dha Ciudad de México dhas quatro imprentas por reconoser el Exmo Señor Conde de Galves Virrey que fue de la Nueva España la bondad dha Ymprenta e ynteligencia del dho Diego Fernández de León le llamó a dha Ciudad de México para que imprimiese como imprimio en esta Ciudad por primera y segunda vez las Reales Ordenanzas de la Real Casa de la Moneda de aquella Corte entregándose para este efecto las Reales Cedulas, Leyes y Ordenanzas, y que en esta misma ocasión Juan Guillena Carrascoso vezino Y impresor de la Ciudad de México le dio a imprimir un curso de arte mediante aser tan buena y cumplida de letra dha Ymprenta, 1 qual oye decir este testigo a los oficiales que trabajaron en dhas obras que después lo fueron de este testigo y trabajaron en dha Ymprenta en su cassa y que también mientras este testigo fue dueño de dha Ymprenta Ymprimio muchas cosas de la Ciudad de México, de actos ynformes en derecho, por la vondad y crédito de dha Ymprenta y esto responde.

5. A la quinta pregunta dijo que sabe y le consta que no tan solamente tiene el dho Diego Fernández de León la inteligencia de ser impresor sino que también sabe hacer y formar letras para imprimir teniendo como para ello tiene moldes que llaman matrises suficintes echos en Flandes. Con los quales oyo desir este testigo a Juan Francisco oficial que fue primero de dho Diego Fernandez y después de este testigo que el dho Diego Fernandez había echo y formado la Ymprenta que tenia y tiene en la Ciudad de Oaxaca, en cuya formación trabajo el dho Juan Francisco de Orozco con otros dos que el uno se llamaba fulano Buitragueño y el otro Lázaro Rodriguez, oficiales de componedores que este testigo no le ha visto haser dha letra solo si ha visto los moldes o matrises en poder del dho Diego Fernández de tres o dos dias a esta parte, por que fue exprofeso a su casa a verlos para certificarse en la verdad de este juramento, y esto responde.

6. A la sexta pregunta dijo no sabe de ella mas que el dho Diego Fernández de León con dha Ymprenta pago muchas y considerables deudas que tenia por las quales estuvo quebrado y retraido en la Yglesia del Señor San Marcos de esta Ciudad teniendo entonces dha Ymprenta en la casa del Lizdo Nicolas Alvarez Presbitero hasta que se compuso y con haber venido flotas y haber abundancia de papel pudo empeñarse y esto responde.

7. A la séptima pregunta dijo que sabe y le consta por haberlo visto como por el año pasado de mil seiscientos y noventa y quattro se fue el dho Diego Ferández a la provincia de Tepeaca a unas haciendas de labor con su familia y el caudal que tenía y que al años siguiente de nobenta y cinco vendió dha Ymprenta al dho Capitan Juan de Villarreal Padre de este testigo tan solamente con dos mil y quinientos pesos de gravámenes de deuda a que estaba sujeto por especiales hipotecas que el dicho su Padre se obligó de pagar y que no se las pagó sino sus réditos, y esto responde.

8. A la octava pregunta dijo que sabe y le consta que por malos sucesos que tubo el dho Diego Fernández de León en dhas haciendas se volvió a esta Ciudad y en ella por el año pasado de mil siete cientos y quatro compró dha Ymprenta del Capitan Sebastián de Guevara cuñado de este 
testigo a quien este testigo le había vendido como año y medio antes poco más o menos; que la vendió este testigo a causa de no hallarse con reales para pagar las deudas que sobre si tenía en dha Ymprenta, que el dho su cuñado se obligó a pagar. Y estando gravada en ocho mil pesos tan solamente pagó el dho su cuñado quinientos y tantos pesos a dho Padre Frai Miguel Valverde del principal quatro mil pesos que se le debían con que la compro el dho Diego Fernandez de León al dho Capitan Guevara gravada en siete mil quatrocientos y tantos pesos que cerca de los cinco mill pesos de ellos fueron gravámenes causados por el dho Capitán Juan de Villarreal su Padre, y por este testigo, en que se remite a la Scriptura de venta que en esta razon le otorgaron y esto responde.

9. A la novena pregunta dijo que sabe que dha Ymprenta al presente se haya en poder de dho Diego Fernandez de León caval y entera según y como la tuvo este testigo y el dho su Padre y con las mismas mejoras y ventajas sin que le falte cosa alguna porque ni ha sacado, vendido, ni consumido letra, molde, ni tarja alguna porque este testigo el día de ayer veinte del corriente y hoy día de la fecha fué a la casa de dho Diego Fernandez y vio que la tiene aviada de todo lo necesario, puesta en corriente y aderezada su prensa de nuevo porque se había maltratado y también hallo aderezada otra prensa, con que tiene dos corrientes, pero no sabe lo que le costaron al dho Diego Fernandez solo si sabe que la una de ella que es la principal, es la mejor que hay en este Reino porque tiene el hucillo de acero hecha en Flandes con que no está deteriorada dha Ymprenta sino los aumentos referidos, puesta en toda forma y arte para poder Ymprimir en ella quanto ofrezca y esto responde.

Io. A la décima pregunta dijo que el principal motivo que tuvo el dho Capitán Guevara su cuñado para vender dha Ymprenta fué el descargarse de los gravámenes que tenía sobre ella y reconoser que faltando flota se iba encareciendo el papel y había de ser causa de inopia de obras como ha sucedido, pues de dos años a esta parte y carestía de papel no ha visto este testigo que se hayan impreso obras gruesas y de importancia, sino papeles de combites, actos literarios, y un libro del Padre Señeri, y algunos villancicos que todo ello es cosa corta de suerte que al presente no mantiene más que dos oficiales, un componedor, y un tirador siendo así: que en tiempo que ha habido papel barato ha visto este testigo que ha mantenido dha Ymprenta, quatro oficiales componedores sin los tiradores quando ha tenido mucho quehacer y que este testigo mantuvo en dha Ymprenta dos oficiales componedores, un tirador y otro que daba tinta que hacen quatro por lo cual juzga este testigo, por la experiencia que tiene de ha Ymprenta del tiempo que la tuvo por suya y los dos su Padre y cuñado que sin duda por las causas referidas se mantendrán el dho Diego Fernandez y sus oficiales con mucha cortedad y esto responde.

II. A la undécima pregunta dijo que sabe y consta que no obstante los atrasos referidos a pagado el dho Diego Fernandez de León en el discurso de estos dos últimos años como quatro mil pesos poco más o menos, los mill y quinientos poco mas o menos a dho Capitan Guevara y un mill seiscientos y cincuenta pesos a la Real Alcavala y difirentes porciones de réditos causados antes y en dos dos años y esto responde.

I2. A la duodecima pregunta dijo que todo lo que ha dicho es público y notorio publica voz y fama y verdad so cargo de dho su juramento en que se afirmó; declaró ser de edad de mas de cuarenta años y lo firmó. Bachiller Don Miguel de Villa Rl -Rubrica.- Ante mi. - Miguel García Fragoso Escribano Real y Público.

1709, Obligación de Diego Fernández de León. [Documento no localizado en archivos poblanos, citado por Pérez Salazar, p. 384. Transcribo la paleografía ofrecida por el investigador].

"Sepan cuantos esta carta vieren como Nos el Capitan don Diego Fernandez De Leon impresor y mercader de libros de esta Ciudad por su Magestad como principal deudor y obliga- 
do y don Miguel Ximenes Solano y Juan Alvarez Barrientos, vecinos de esta Ciudad como sus fiadores y principales pagadores justos de mancomún a vos de uno y cada uno de los nos por si y por el todo insolidum con renunciación de las leyes de la mancomunidad y el beneficio de la división y excusion, otorgamos que nos obligamos de pagar a la Campellania de Misas resadas que sirve al Licenciado don Nicolás Alvarez Presbitero y a quien fuere parte legítima, un mill y quinientos de oro comun por otros tantos que por memorial que yó el principal presente ante el Yllustrísimo señor don Pedro de Nogales Davila Obispo de este Obispado del Consejo de su Magestad y le suplique se me concediere espera por dicha cantidad que se le había entregado al Licenciado don Miguel Villarreal Prebistero para la compra de la letra de Flandes para dicha Imprenta a que se obligaron con dicho Licenciado como sus fiadores el Capitán Juan Díaz Gómez y Sebastian de Guevara el mozo, con hipoteca de dicha letra y por haber sucedido en ella con el cargo de dicho principal y haberme instado que libre de dicha fianza a dicho Sebastian de Guevara por haber muerto el dicho Juan Diaz Gómez y lo demás que dicho memorial contiene y habiéndose remitido al señor Juez de Capellanías e informado sobre ello, por decreto del treinta del corriente se mandó que obligandome en la forma que en dicho memorial ofrecia y dándo los nuevos fiadores que van expresos, se deban por libres a los fiadores antecedentes, a cuya conformidad y constituyendome como me constituyó por real y verdadero deudor de los dichos un mill quinientos pesos sobre que renuncio poder alegar lo contrario, leyes del entrego, de su prueba y expeción de la pecunia y dejando como dejo en su fuerza y vigor, anterioridad y prelacia, la dicha escritura de la primera obligación otorgada en ésta razón, sin que sea visto en cuanto a ella quedar innovada ni alterada en manera alguna antes corroborada... Y para mayor seguridad de esta deuda ratificando yó el prncipal como ratifico la expecial hipoteca dela dicha letra y dejandola en su fuerza y vigor y a mayor abundamiento la hipoteco y obligo por especial y expresa hipoteca dn dicha Imprenta no derogando la general ni por el contrario por mis quinientos pesos a favor de diferentes interesados y está libre de otros censos propia libre de toda enagenación dicha letra y la dicha Imprenta sujeta a dos mil especiales y generales para no venderla a censuarlas y en otr manera enagenarlas hasta que tanto esta deuda esté enteramente satisfecha y pagada... En la muy Leal y Muy Nomble Ciudad de los Angeles a treinta y un días del mes de enero de mil setecientos y nueve años... Ante mi Francisco Solano, Escribano Público.

(I709, 25-IX) Poder del Lic. D. Diego López de Pliego a favor de Diego Fernández de León, ante Francisco Solano (falta paleografía). [AGNP, Not. 6, Protocolos de I7Io, ff. 73v-74v.] [Documento citado por Pérez Salazar, p. 385. Transcribo la paleografia proporcionada por el investigador].

"Sepan cuantos esta carta vieren como yo el Licenciado don Diego López de Pliego Presbítero domiciliario de este Obispado otorgo y doy mi poder bastante en derecho a don Diego Fernandez de León Agente de Negocios en la Real Audiencia de la Ciudad de México, general para en todos mis pleitos, causas y negocios, civiles y criminales que al presente tengo y en adelante tuviere con cualquier persona... Angeles a veinte y cinco días del mes de Septiembre de mil setecientos y nueve años. Siendo testigos Luis Bermudes y Diego Torillo y José Avilés. - Ante mí. - Francisco Solano.- Escribano Real y Público”.

I709, Poder de Diego Fernandez de León. [Documento no localizado en archivos poblanos, citado por Pérez Salazar, p. 385. Transcribo la paleografia proporcionada por el investigador].

"Sepan cuantos esta carta vieren como yo el Licenciado don Bustamante y Herrera, Promotor Fiscal de este Obispado, otorgo mi poder bastante en derecho a don Diego Fernández de 
León residente en la Ciudad de México, para que en mi nombre y como tal Promotor, siga, prosiga, fenezca y acabe por todos artículos grados e instancias, los autos que están pendientes ante los señores Presidente y oidores de la Real Audiencia de la Ciudad de México, sobre las disposiciones y mandas y legados y cumplimientos de el Capitán Antonio García Fragoso y cualesquier artículos que se hayan movido contra bienes del dicho Capitán [...] Angeles a dieciséis dias del mes de Enero de mil setecientos y nueve años [...] Ante mi. -Francisco Solano.- Escribano Real y Público".

(I709, 29-I) Poder del capitán Bernabé López Berruecos a favor de Diego Fernández de León [AGNP, Not. 6, Protocolos de 1709, ff. I33r-133v.] [Citado por Pérez Salazar sin indicar localización precisa, p. 385. Transcribo paleografía ofrecida por el investigador].

"Sepan cuantos esta carta vieren como nos el Capitan don Bernabé López Berrueco, Alcalde Ordinario actual de esta Ciudad y de doña Nicolasa Rosete de Peralta su legítima mujer vecinos de esta ciudad, albaceas testamentarios, fideicomisarios y universales herederos de Nicolás Rosete de Peralta nuestro hermano, difunto labrador que fue en la Provincia de la Ciudad de Tlaxcala y vecino de esta [...] Otorgamos nuestro poder bastante en derecho a don Diego Fernández de León residente en la Ciudad de México, generalmente para en todos nuestros pleitos, cargas y negocios civiles y criminales que al presente tenemos y ena delante tuvieramos [...] Angeles a veinte y nueve dias del mes de Enero del año de mil setecientos nueve [...] Ante mi. -Francisco Solano. -Escribano real y Público”.

(I709, 27-IX) Poder especial que otorgó Miguel Fernández Machorro, dueño de imprenta y vecino de la ciudad de los Ángeles, a favor del capitán Diego Fernández de León, para que le obligue a favor del licenciado Pedro Sánchez de Alcarás, abogado de la Real Audiencia de México, por la cantidad de pesos que importen los privilegios de su imprenta que ha de solicitar al rey. [AGNP, Not. 6, Protocolos de Francisco Solano, año de I709, ff. 88r- 88v.] [Documento no citado por Pérez Salazar, paleografía de ACD].

[f. 88r.] [Al margen izquierdo: Fecha en 27 de (septiembre) de 1709 años, (en el) día de su (otor) gamiento, (en pa)pel del sello (se)gundo, doy fe (rúbrica)]. En la muy noble y muy leal ciudad de los Ángeles, a veynte y siete días del mes de septiembre de mil setesientos y nueve años, ante my, el ecrivano y testigos, paresió don Miguel Fernándes Machorro, vesino de esta dicha ciudad y poseedor de ynprenta en ella, a quien doy que conosco; y otorga su poder vastante en derecho al capitán don Diego Fernándes de León, su padre, residente en la ciudad de México, generalmente para en todos sus pleitos, causas y negosios siviles y criminales que tiene y tuviere, demandado o defendiendo, paresca en juicio en qualesquier tribunales superiores e ynferiores, jueses y justisias eclesiásticas y seculares que a su derecho ymporte, haga demandas, responda a las contrarias [[...] etc. [...]]. Y asimismo le da este poder para que le pueda obligar y obligue a favor del señor lisenciado don Pedro Sánches de Alcarás, abogado de la Real Audiencia de México, a la cantidad de pesos que importare los pribilexios que a de ynpetrar a su magestad, que Dios guarde, de la ynprenta que para lo qual le tiene el otorgante otorgado poder y a favor de otras personas que a su dita y crédito le quiera suplir qualesquier cantidades de pesos, y a las que fueren le obligue a su satisfasión y paga que lo hará a los tiempos, plaços, partes y lugares, y devaxo de los premios e yntereses que lisitos ajustare y pactare, otorgando en esta raçón las escripturas que fueren nesesarias, con las fuersas, vínculos firmesas, penas, juramentos, condisiones, sumisiones, salarios, relebasiones de personas, renunsia[sio]nes de leyes y demás sircunstansias importantes a su validasión; que de la suerte que la otorgare la otorga, aprueba y ratifica, y se obligó a su observancia, paga, guarda y cumplimiento, y fir- 
mesa de este poder que le otorga para que oiga autos y sentencias, consienta las favorables y suplique de las perjudisiales, siga sus grados por todas ynstansias, hasiendo las demás [f. 88v.] dilixensias que se ofrescan. Y para lo dicho le da este poder con libre y general administrasión y facultad de sustituir en quanto a [su tenor] y relevasión en forma, a cuya firmesa obliga su persona y vienes havidos y por haver, dio poder a los jueses y justisias que sus causas puedan conoser conforme a derecho, para que a ello lo apremien como por sentensia pasada en cosa jusgada, renunsió leyes de su favor y la general del derecho. Y así lo otorgó y firmó, testigos don Francisco de Saldaña y Tapia, don Luis de Venavides y Juan Fernándes, vesinos de esta ciudad.- D. Miguel Fernández Machorro [rubricado] Ante my: Francisco Solano, Escribano real y público [rubricado]. Sin derechos.

(I710, 29-I). Representación que bace Diego Fernández de León, impresor y mercader de libros, como agente de negocios de la Real Audiencia de México a nombre de doña Inés de Torres y Cano, viuda del capitán don Alexandro Favián, del capitán don Antonio de Benavides y Medinilla, albacea y beredero del licenciado Juan de Rivera, del licenciado Tomás Sarmiento de Figueroa, y del licenciado Carlos Lozano Lechuga, presbiteros todos ellos del obispado de Puebla, sobre el remate del ingenio de hacer azúcar nombrado San Juan Bautista Tilapan. (AGNP, Not. 6, Protocolos de I7ı, ff. I27v.-I28r.). [Documento no citado por Pérez Salazar, paleografía de ACD].

[f. I27r.] [Al margen izquierdo: [...] en 29 [...] de i7io años. Fecho en el día de su otorgamiento en el papel del sello segundo. Doy fe-- rúbrica]. En la muy noble y muy leal ciudad de los Ángeles, a veynte y nueve días del mes de henero de mil setesientos y diez años ante my, el escrivano y testigos, paresió el capitán don Diego Fernández de León, recidente en esta dicha ciudad y ajente de negosios de la Real Audiencia de la ciudad de México, en nombre y vos de doña Inés de Thorrez y Cano, viuda del capitán don Alexandro Favián, vesina de esta dicha ciudad; y en virtud de su poder que le otorgó vastante para lo aquí conthenido, su fecha en ella a veinte y quatro días del mes de enero del año pasado de setecientos y ocho ante my, y en nombre y vos del capitán don Christóval de Benavides y Medinilla, como albasea y heredero del lisenciado don Juan de Ribera Graxeda y en virtud de su poder que le otorgó, su fecha en esta ciudad a nueve días del mes de mayo del año pasado de setesientos y ocho por ante my; y en nombre y vos del lisenciado Thomas Sarmiento de Figueroa y en virtud de su poder que le otorgó en esta ciudad, a trese de febrero de setesientos y nueve por ante my; y en nombre y vos del licenciado don Carlos Losano Lechuga, presbytero deste obispado y en virtud de su poder que le otorgó a veynte y un días del mes de febrero de setesientos y nueve por ante my; de lo qual y del conosimiento del otorgante doy fe. Y usando de dichos poderes dixo que haviendose seguido autos del concurso de acreedores ante los señores presidente y oidores de la Real Audiencia de la ciudad de México contra el yngenio nombrado San Juan Bautista Tilapan por bienes de doña Francisca Colón, y haviendose prosedido a su remate y pronunsiada sentencia de graduasión, se graduó la dicha doña Inés de Thorres Cano en décimo tercio lugar, mandándole pagar, por despacho que le mandó librar, siete mil dosientos sesenta y sinco pesos, siete tomines y ocho granos del principal de su senso hasta en la cantidad que le cupo, con más [tachado: seisientos y dose pesos y dos tomines que importaron los réditos corridos hasta diez de enero del año pasado de setesientos y seis (f. I27v.), un mil quatrosientos sinquenta y seis pesos y quatro reales, los seisientos y sesenta y seis que pagó el convento del señor Santo Domingo por un año y dos meses, que por ello dicho ingenio pagó los setesientos ochenta y siete pesos y quatro reales del tiempo de dos años y dos meses que poselleron dicho ingenio el licenciado don Juan Rodrígues Calado y capitán Domingo Pérez Mederos; y asimismo se mandaron pagar a dichos poseedores actuales un mil sinquenta 
y nueve pesos, un tomín y medio pertenesientes al capitán don Christóval de Venavides y Medinilla, como albacea y heredero del licenciado don Juan de Ribera Graxeda, los siento quarenta y ocho pesos y los novezientos y onze pesos y un tomín y medio pertenecientes al capellán licenciado don Diego López, cullas porsiones son de las que devió pagar el convento del señor Santo Domingo de un año y diez meses que poselló dicho ingenio y la que deben pagar dichos poseedores de dos años y dos meses. Y así mismo, se mandaron pagar al licenciado don Carlos Lozano Lechuga, como capellán de una capellanía, quinientos nueve pesos, tres tomines y medio, dinero que debía dicho convento del tiempo que poseelló y del que deben pagar los poseedores actuales del que han poseeido, como también demandaron pagar al licenciado don Tomás Sarmiento Figueroa, como capellán de una capellanía de dos ml pesos de principal, quatrocientos y quarenta y quatro pesos y un real de réditos que se le debían, así por el dicho convento del señor Santo Domingo del tiempo que poselló dicho ingenio como del que han poseido los dichos poseedores; que todas las referidas cantidades importan tres mil quatrosientos sesenta y siete pesos, tres tomines y ocho granos, de suerte que lo que pagó dicho convento del señor Santo Domingo a los referidos interesados fueron un mil quinientos ochenta y nuebe pesos un real y medio, del tiempo que poselló dicha finca, y lo que pagaron los dichos licenciado don Juan Fernándes Rodrígues Calado y capitán Domingo Pérez Mederos de Castro importó un mil ochosientos setenta y siete pesos seis tomines y medio; y de una y otra cantidades, el otorgante en nombre de dichos sus partes, a cada lo que le tocó se dio por entregado [f. I28r.] a su contento y satisfación en reales de contado, sobre que renunció en sus nombres poder decir ni alegar en contrario leyes del entrego y excepsión de la pecunia; y de los dichos un mil ochosientos setenta y siete pesos, seis tomines y medio, otorgó rezivo y carta de pago en forma a los dichos licenciado don Juan Rodrigues Calado y capitán Domingo Pérez Medreros, en nombre de dichos sus partes, hasta el día diez deste presente mes y año de la fecha; y de los un mil quinientos ochenta y nuebe pesos y un real que pagó dicho convento se otorgó rezivo y carta de pago en forma, con las fuerzas y firmezas inportantes a su validazión, a culla firmeza obligó las personas y vienes de los dichos sus partes, avidos y por aver y en su nombre dio poder a los juezes y justicias que de sus causas puedan y devan conozer conforme a derecho, para que a ello los apremien como por sentencia pasada en cosa jusgada, renunsió leyes de su favor y la general del derecho; y así lo otorgó y firmó, siendo testigos: Joseph Díaz de Avilés, Balthazar Gómez de la Parra y Luis de Venavides, vezinos desta ciudad.- tes.- seisientos treze pesos y dos tomines que inportaron los créditos corridos hasta diez de enero del año pasado de setesientos y seis.- dicha.- como.- entre renglones.- una, vale.- Diego Fernández de León [rubricado]. Ante my: Francisco Solano, escrivano real y público [rubricado]. No e recivido derechos.

(I7Io, 3I-I) AGNP, Not. 6, caja 5I, Protocolos de Francisco de Solano, 3 I de enero de I7Io, Contrato de trabajo de aprendiz de oficial componedor entre Diego Fernández de León y Antonio Gama, ff. I29v-Izov. Toca: Año de I7Io. Henero. [Citado por Pérez Salazar sin indicar localización precisa, p. 386. Transcribo paleografía ofrecida por el investigador].

En la ciudad de los Angeles a zi de enero de i7io, comparecieron Don Diego Fernandez de León impresor y mercader de libros y Antonio Gama oficial y componedor de letras y vecino de la ciudad de México. Mencionan que han tratado y convenido que lo va asistir en su imprenta que tiene en la ciudad de México por el tiempo de 4 años para que realice en su compañía obras de papeles de combitez y cualquier obra y que va a enseñarlo a oficial de componedor y que este va a recibir una paga como consta en su libro de cuentas por los cuatro años que este a su lado. 
Diego Fdz. de Leon Ympresor y mercader de libros de una parte y de la otra Antonio Gama Oficial y componedor de letras vecino de la Ciudad de México a quienes doy fee que conozco y dixeron que están ajustados y convencidos en tal manera que el dho Don Diego Fernandez de Leon en la Ciudad de México por tiempo de quatro años que an de correr desde oy día de la fecha con toda puntualidad y vigilancia sin que por ningún pretexto no motivo ayga falta componiendo alternativamente todas las obras que se ofrecieren y mandare hazer con otro oficial del mismo exersicio el que nombrare y señale el dho Dn. D. F. de Leon para que en su compañía haga todas las obras de papeles y combites de entierros como de los actos y otras cualesquiera obras que se ofrecieren y durante dho tiempo no a de poder trabajar el dho Antonio de Gama en otra imprenta por ningún acontecimiento y por su trabajo le a de pagar por dichas obras a los precios cada que contiene una memoria que está en el libro de cuentas que para en poder de dho Dn. D. F. de Leon y tiene reconocida el dho Atonio de Gama y el suso dicho se obligó a conserbar de oficial de componedor al dho Antonio de Gama por el dho tiempo de quatro años y sin desacomodarlo. Ante Francisco Solano. 3I de Enero de i7io.

(I710, 25-IX) Poder del Lic. D. Diego López de Pliego a favor de Diego Fernández de León, ante Francisco Solano [aGNP, Not. 6, Protocolos de I7Io, ff. 73v-74v.] [Documento no citado por Pérez Salazar, paleografía de ACD].

[f. 73v.] [Al margen: fecho día de su otorgamiento en papel del sello segundo doy fe. Rúbrica] Sepan quantos esta carta vieren como yo, el lizenziado don Diego López de Pliego, Presvítero domisiliario deste obispado, otorgo que doy mi poder, bastante en derecho, a don Diego Fernándes de León, agente de negosios [entre renglones: en la Real Audiensia] de la ciudad de México, general para en todos mis pleytos, cauzas y negocios siviles y criminales, que al presente tengo y en adelante tubiere con qualesquiera perzonas, así demandando como defendiendo; paresca ante el rey, nuestro señor (que Dios guarde), en sus reales audienzias, chanzillerías y otros tribunales, juezes y justizias eclesiásticas y seculares, que a mi derecho ymporte; y ponga demandas, responda a las contrarias, que conteste o niegue; haga pedimentos, requerimientos, sitasiones, protextas, suplicas, juramentos, alegasiones, oposisiones, declinatorias, recusasiones, contradisiones, querellas, acusasiones, embargos, desembargos, entregas, excusiones, mexoras, prisiones, solturas, ventas y remates de vie[f. 74r.]nes de que tome posesión y la defienda, continue y ampare; presente escritos, escrituras, provanzas, testimonios y otros papeles y recaudos que pida, y saque de cuyo poder estén, y los abone, tache y redarguia lo de contrario presentado, sivil o criminalmente, como le paresiere; y pida y saque qualesquier mandamientos, reales provisiones, cartas de justizia y otros despachos que gane para todos efectos, pidiendo su obedesimiento y cumplimiento y ante las justizias eclesiásticas qualesquiera sensuras generales, que haga leer, yntimar y publicar hasta las de anathema y testimonio de lo que en su virtud resultare; que asimismo presenten donde convengan, oyga autos y sentenzias, consienta las favoravles y apele y suplique de las perjudiziales, siga sus grados en todas instanzias, haziendo todos los demás autos y diligenzias judiziales y extrajudiziales que se requieran; que para lo dicho y su dependiente le doy este poder, con libre y general administrazión y facultad de sobstituyr en todo o en parte las veses y en las perzonas que le paresiere, revocar sobstitutos y nombrar otros; y a todos [f. 74v.] relevo según derecho; y a la firmeza obligo mis vienes avidos y por aver, doy poder a los juezes y justizias que de mis cauzas devan y puedan conoser conforme a derecho, para que a ello me apremien como por sentensia pasada en cosa jusgada, renunsio leyes de mi favor y la general del derecho; que es fecha en la Muy Noble y Muy Leal Ciudad de los Ángeles, a veinte y sinco días del mes de septiembre de mil setesientos y nueve años; y el otorgante, a quien yo, el escrivano, doy fe que conosco, 
lo firmó, siendo testigos: Luis de Benavides, Diego Torillo y Joseph Días de Avilés, vezinos de esta ciudad. Entre renglones: en la Real Audienzia. Vale. Bachiller Diego López de Priego [rubricado]. Ante my: Francisco Solano, escrivano real y público [rubricado]. Derechos: vi reales.

I7Io (?), AGN, Jesuitas, Expediente 049, sin fecha. Sebastián Vásquez Alcance y contenido: Correspondencia de Sebastián Vásquez relativa a la licencia de impresión que se entregó a Diego Fernández de León. [Documento no citado por Pérez Salazar].

Ilmo Sr. Sebastian Vasquez Cm.c dela Sagrada Religión dela Compania de shp. por lo que toca al colegio de Sán Andres L: digo que los actos quese an hecho sobre que diego fam.v de leon impresor [letra ilegible] en la Ciu.d d los Ang.e ex.ma el privilegio que sele entrego para la impresión, el qual lo rel. me. ensupoder. muchos mas ha.n, L. DN abuelo alo her. porque lo apuro Rev. A.V.E.X Suplico lahaya por apurada y Mandar se cobren del juro dho con todas las demás. pido que hiría con [palabra ilegible] [Rúbrica] Sebastian Vasquez. VN Cuartillo SELLOQVARTO, VNQVAR-/TILLO, AÑOS DE MIL SETECIENTOS Y QVATRO, Y SETE-/CIENTOS Y CINCO. /VNQVARTILLO/ I7IO.

I790 (sic) AGN, Inquisición, vol. 1309, exp. 12, fojas: 137. Diego Fernandez de Leon, impresor y mercader de libros de la ciudad de la Puebla de los Angeles, solicita se le entregue en la real contaduria un cajon conteniendo los libros cuyos titulos adjunta. [Documento no citado por Pérez Salazar].

Diego Fernandez de Leon impresor y mercader de Libros de la Ciudad de la Puebla de los Angeles paresco ante Vll. y digo q haviendoseme ofrecido el venir a esta Ciudad con otros trastemas que un cajón de Libros y tenerlos detenidos en la Real Aduana de esta Ciudad que son los siguientes $=$ Cathecismos del Padre Ripalda $=$ Artes de Antonio de Nebrija $=$ hozes de las Proposiciones condenadas $=$ Cardenas sobre las proposiciones condenadas. A.V.S.as Pido y suplico sean servidos de mandar a los contadores oficiales de la Real Contaduría me entreguen dicho cajón don de vienen dichos libros. que en ello recivire merced de V.S.S.as. Diego Fernandez de Leon, Mx.o slle S, He reconocido por man.do del VSa los h =.

(I7Io, 5-II) Diego Fernandez de León vecino de la ciudad de México otorga poder a Don Bartolome del Rivero mercader de libros para que imprima en la imprenta que él tiene en la ciudad de México todos los papeles de convites de entierros, honras y otros quales quiera y pueda venderlos en su tienda tanto lo que deja impreso como lo que se imprimiere en tres años. También puede hacer vales o escrituras que le pidieren. Al mismo tiempo le otorga poder general a Don Carlos de Olavarría Procurador de Causas de la Audiencia Ordinaria de la Ciudad de México para que lo represente en todos sus pleitos, causas y negocios civiles y criminales.

agnP, Not. 6, caja 5I, Protocolos de Francisco de Solano, 5 de febrero de I7Io, Poder y concierto de obra de Diego Fernández de León a Bartolome del Rivero, ff. 15 f-i5v. Toca: Año de I7Io. Febrero. y. [Documento citado por Pérez Salazar sin indicar localización precisa, p. 386. Transcribo su paleografía].

"Sepan cuantos esta carta vieren como yo don Diego Fernandez de León residente en esta ciudad y vecino de la de México otorgo que doy mi poder bastante en derecho a don Bartolomé de Rivero mercader de libros y vecino de esta ciudad, especial para que me obligue a que imprimiré en la imprenta que pongo en dicha ciudad de México, todos los papeles de combites, de entierros, honras y otros cualesquiera que se ofrezcan y pueda venderlos en su tienda asi los que le dejó impresos como los demás que le remitiere y así mismo actas de conclusiones y los entregará a esta ciudad a la persona o personas con quien los ajustare el dicho 
don Bartolomé del Rivero, otorgando si fuere necesario en mi nombre los o escrituras que se le pidan o sean necesarias con las fuerzas, vínculos fianzas y obligaciones que convengan [...] Y así mismo otorgo mi poder generala don Carlos de Olavarria Procurador de causas de la Audiencia Ordinaria de esta Ciudad para que en todos mis pleitos causas y negocios civiles y criminales que al presente tengo y en adelante tuviere [...] (siguen las cláusulas comunes del poder). En la Ciudad de los Angeles a cinco días del mes de Febrero de mil setecientos y diez años. -Ante mí. -Francisco Solano. -Escribano Real y Público”.

i7io, Testamento de Diego Fernández de León. [Documento no localizado en archivo, citado por Pérez Salazar, p. 386. Transcribo su paleografía].

En el nombre de Dios Todo Poderoso Amen sepan quantos esta carta Vieren como Yo Dn Diego Fernandez de Leon vecino desta Ciudad natural de la Ciudd de Balladolid en los Reinos de Castilla hijo lexitimo de Antonio Fernandez y Luisa Albares que ya son difuntos estando enfermo $[\ldots]$

Declaro soy casado según orden de nuestra Sta Madre Yglesia con Da Angela Ruiz Machorro natural y vecina de la Ciudad de los Angeles y al tiempo y cuando contrahimos Matrimonio Trujo a mi poder Trescientos pesos de oro comun por su dote aunque no le otorgué instrumento alguno, ni tenia yo ningun capital entonces y durante nuestro matrimonio hubimos y procreamos por nuestro hixo lexitimo a Dn Miguel Fernandez de Leon y Machorro que sera de edad de veinte años poco mas o menos y se halla ya casado declarolo por tal mi hixo lexitimo y de la dicha mi muger para que en todo tiempo conste.

Declaro por mis bienes los que se hallaron en la casa de mi morada en que se incluye la plata labrada que me costó mas de seiscientos pesos y asi mismo declaro por mis bienes una imprenta que tengo en esta Ciud de dha casa de mi morada qe me costo de todos costos embios a España por ella, condiciones y traerla a esta Ciudad y premios de los leales, doce mill pesos antes mas que menos.

Ytem declaro que en dha casa de mi morada tengo una tienda que aunque al presente no tiene libros, tiene varias herramientas de Enquadernar, Estampas y Ympresionistas echas en casa que todo lo que es constara por el imbentario que de el o se a de hazer [...]

Declaro asi mismo por mis bienes un forlon con seis mulas dos negras que estan en esta ciudad y quatro que están en el Agostadero a cargo de Juan Granados mi come quien las entregará por haberlas remitido por su mano y dho mi compae tiene en su poder las quatro guarniciones de gruas y etregruas con su silla delantera bolea y azote luego que le deje a guardar quanto viene de Puebla este año declaro asi mismo mis vienes doscientos pesos que le di a mi compe por una litera y mozos para que me llevaran a la Ciudad de Zacatecas y por si acaso falleciere yo antes de hacer dicho viaje se le cobre [...]

Ytt declaro por mis bienes una obra de un libro en lengua Portuguesa de que se están haciendo de dha mi Ymprenta dos ill cuerpos que ajuste con el Capitan D. Jullian Osorio del orden de Sntiago en Vn mill y quinientos pesos dha impresión de la qual tengo ya impresos como treinta pliegos poco mas o menos en que tengo devengado haciendo el cálculo como setecientos y mas pesos poco mas o menos a cuya quenta tengo rezividos quinientos pesos y porque necesita mi esposa e Hijo asi para las cartas de los pliegos que se an de proseguir como para los gastos de mi enfermedad curacion y demas menesteres y quizas para mi entierro en tal caso le pediran a dho Capitan Dn Jullian Osorios otros quinientos pesos a lo mas que fuere necesario pues en cuidado del tamaño del presente no dudo lo executara dho Capitan.

Y porque el Pe Fray Juan de Castelnovo del orden de descalzos de nro Pe Sn Franco le e Ympreso otros mill y quinientos cuerpos de libros pequeños en dha lengua portuguesa que el 
costo de los pliegos que tuvo según ajuste que hicimos al principio y por querer dho Pe fuese la letra maior que la que tenia el original crecio tres pliegos y medio teniendo el original suyo ocho pliegos por ser de letra menuda, con que asi mismo se acrecio papel que compré par dha impresion como la manufactura de Oficiales de la imprenta que se les pagaron dos pliegos mas y lo mismo un libro con las encuadernaciones pues se trabaja mas en plegar, cortar y en los pergaminos y correas de manera que la impresión importa ciento ochenta y nueve pesos y el papel doscientos y veinte y dos pesos y la enquadernacion ciento y cincuenta pesos que todo monta quinientos y sesenta y un pesos a cuia cuenta tengo recibidos [...]

Asi mismo declaro por mis bienes las obras que actualmte se estan haziendo en dha y Ymprenta las quales tienen ajustadas en presencia de dho mi hijo declarolo pa qe conste - con adbertencia que en algunas cuentas de pleitos que he seguido y costeaodolos se cobren con equidad por la cortedad de los tiempos y porque no quiero que se ponga duda en mi punto aun después de muerto, sino que la que estuviere dudosa se componga con la mayor conveniencia que fuere posible.

Declaro soy deudor de la Sa Yglesia Cathedral de la Ciudad de Puebla por cierta dependencia que contraje con su Cauildo de ocho cientos pesos de que no es sauidora dha Sta Yglesia declarolo para qe conste y mando qe dho mi hijo y esposa se compongan con el V. Sr Dean y cabildo [...] (Sigue declarando algunas cantidades que le deben por pleitos que siguió y entre ellos uno contra los herederos de D Frco de Estrada Galindo, administrador y comisario del Sto. Oficio en Veracruz. Nombra albacea a Da Angela Ruiz Machorro su esposa y a su hijo D. Miguel Fernandez de Leon y Machorro heredero). Otorgado el 5 de Agosto del año del Sor. de mil setecientos y dies.

I7Io, Acta de Defunción de Diego Fernández de León. Sagrario Metropolitano de México, Tomo 6, p. I85 vta. [Documento citado por Pérez Salazar, Dos familias de impresores, p. 483].

"El 7 de agosto del año del señor de i7ıo murió D. Diego Fernandez de Leon casado con Da Angela Ruiz Machorro testo ante Jose Manuel de Paz Escribano Real en sinco de dho mes y año nombro por albaceas a la dha Esposa y a D. Miguel Fernandez de Leon y Machorro: y a este por heredero; por clausula manda que del quinto de sus bienes sacado el funeral y entierro lo restante manden desir de Misas por su alma. Recibio los Santos Sacramentos. Vivia en las Rejas del Conbento de Balbanera. Enterrose en S. Franco. -Larrave. -Rubrica”.

\section{FAMilia del CAPITÁN JUAN DE VillarReal}

I695, Contrato de Juan de Villarreal. [Documento no localizado por mí en archivos poblanos, citado por Pérez Salazar sin indicar localización precisa, p. 372. Transcribo paleografía ofrecida por el investigador].

"En la Ciudad de los Angeles a diecinueve dias del mes de Noviembre de mil y seiscientos y noventa y cinco años, ante mi el Escribano Real y Público y testigos, parecieron de una parte don Juan José de Liñán vecino de la Ciudad de Sevilla cargador en la presente flota surta en el Puerto de San Juan de Ulua del cargo del señor General don Ignacio de Varrios Leal Bachiller Miguel de Villarreal Clérigo Presbitero, su hijo, domiciliario en este Obispado vecino de esta ciudad que doy ffé que conozco y dijeron que por escritura que otorgaron el Capitan Fernando Romero y Torres vecino de dicha Ciudad de Sevilla y Diego Fernandez de León impresor y mercader que fué de esta ciudad a nueve dias del mes de Junio del año pasado de mil seiscientos noventa y tres, ante Francisco Solano Escribano Real y Público, pactaron y concertaron el dicho Capitan Fernando Romero que en esta presente flota les había de traer cantidad de letras 
de impresión que faltaron por entregar en la que por entonces les habia traido, por cuanto la una sin la otra no le era de utilidad y provecho y especificaron con toda claridad y distinción así la que tenía recibida de qie que dó pagado y satisfecho el dicho Capitán Fernando Romero, como la que faltaba por entregar y dar cumplimiento al trato antecedente que tenía celebrado en cuya virtud se trajo la recibida como consta por una memoria impresa hecha en esta ciudad a quince dias del mes de Junio del propio año de mil setecientos noventa y tres, en que en sus primeras columnas de cada plana se expresaron las letras y demás cosas recibidad y pagadas y en las segundas columnas de cada plana se expresan las letras y demás cosas que faltaron por entregar y debieron haber traido en la presente flota, el dicho Capitan Fernando Romero en cumplimiento de la obligación en que quedó cosntituido por dicha escritura citada y no habiendo cumplido con dicha su imprenta y lebrería al dicho Capitán Juan de Villarreal por escritura sucecha en esta ciudad a dos dias del mes de julio pasado de este año de la fecha ante Francisco de Herrera Calderón Escribano Público y en ella le dió y traspasó el derecho que por dicha escritura le competia contra el dicho Capitán Fernando Romero para que recibiese dicha letra, pagara su monto y usase de los derechos de que pudiera usar el dicho Diego Fernandez de León sobre los daños, pérdidas, menoscabos que se le siguiesen por falta de dicha letra, Deseando la paz y quietud quitándose de litigios, tuvo noticias el dicho Capitán Juan de Villarreal de que en poder de los herederos o albaceas de Tomás López de Haro difunto impresor y mercader de libros que fué de dicha ciudad de Sevilla paran todas las letras y demás cosas contenidas en dichas faltas y que debiera haber traido el Capitán Fernando Romero, quien falló a dicho trato por injustos motivos que tuvo para ello y que a cargo del dicho don Juan José de Liñan quedó la diligencia de solicitar el que Diego Fernandez de León recibiese la dicha letra y demás cosas contenidas y dichas faltas, así para que los herederos del dicho difunto no perdiesen su valor como porque la dicha imprenta quedase completa y para esto los otorgantes han pactado y concertado que el dicho Capitán Juan de Villarreal sus herederos y sus sucesores y el dicho Bachiller Miguel de Villarreal y los suyos o quien sus derechos representare en cualquier manera han de pagar y satisfacer al dicho Juan José de Liñán el valor de toda la dicha letra y demás cosas contenidas en dicha memoria a razón de cinco reales libra puesta en la Nueva Ciudad de la Veracrúz hasta donde ha de llegar por cuenta y riesgo de dicho don Juan José de Liñán y desde dicha Ciudad de la Nueva Veracruz ha de venir a esta Ciudad y por cuenta y riesgo de los dichos Capitán Juan de Villarreal y Bachiller Miguel de Villarreal, de suerte que todos los costos de fletes, riesgos, cajones, presintos, indultos y demas que se recrescan hasta estar puesta en la Nueva ciudad de la Veracrúz los ha de pagar el dicho don Juan José de Liñán y son por su cuenta y riesgo y todos los costos de cajones, presintos, fletes y demás gastos que fueren necesarios para conducir dicha letra de la Nueva Veracrúz a esta ciudad, los ha de pagar dicho Capitán Juan de Villarreal y su hijo demás del precio de dicha letra que se ha de liquidar por lo que pesare en esta ciudad neta. -Y por cuanto puede acontecer el que la letra y demás cosas que así se hayan en poder de los herederos del dicho Thomás López de Haro no se hallen cavales conforme a dicha memoria y en ello hubiere alguna falta para que se reconozca por persona inteligente y no vengan diminutas a de ser a cargo del dicho don Juan José de Liñán el solicitar y hacer que un Oficial componedor la reconozca y coteje con dicha memoria y vea si lo que se pide en ella está conforme y con las circunstacias que contiene. -Con declaración que aunque siga mas versales o otras letras mas, no importa que las traiga seanze las que se fueren. -Pero si hubiese faltas ha de ser obligado el dicho don Juan José de Liñán a solicitarlas y traerlas de los Estados de Flandes porque dicha memoria se ha de cumplir enteramente y lo que costare del ofical que reconociere dicha letra lo ha de pagar el dicho Capitán Juan de Villarreal de más de dicho precio de cinco reales libra y para que lo contenido en dicho pacto tenga cumplido efecto ha tratado de reducirlo a escritura pública como por la presente 
en aquella vía y forma que mejor haya lugar en derecho el dicho don Juan José Liñán otorga que se obliga de tal manera que para la primer flota que de los Reinos de Castilla vinieren a estos de la Nueva España trairá o enviará a los dichos Capitán Juan de Villarreal y Bachiller Miguel de Villarreal su hijo o quien su derecho representaren en cualquier manera todas las dichas letras y demás cosas contenidas en las segundas columnas de dicha memoria impresa de que lleva en su poder una y otra queda en poder del dicho Capitán Juan de Villarreal ambas rubricadas de mí al presente Escribano, que han de ser de calidades tamaños y géneros que contiene dicha memoria y conforme a la muestra que de cada cosa lleva, de suerte que no sea mas alta ni mas baja dicha letra, que hará reconocer a un oficial componedor a costa de los dichos Capitan Juan de Villarreal y su hijo y las faltas que se reconocieren han de traer de los Estados d Flandes para que enteramente se cumpla con todo lo que contiene dicha memoria. -Y por si algún accidente subsidiera perderse el convoy de Flandes, lo cual dios no permita, que es de donde ordinariamente en él viene dicha letra de imprenta, constanto por conocimiento o otros instrumentos o noticia verídicas que viniendo en dicho convoy se pierda dicha letra entonces no ha de ser obligado a cumplir dichas faltas sino traer solamente lo que para en poder de los herederos del dicho Tomás López de Haro, por cuanto desde dichos Estados de Flandes hasta dicha Ciudad de la Nueva Veracrúz ha venir lo uno y lo otro por cuenta y riesgo del dicho Juan José Liñán y desde la Ciudad de la Nueva Veracruz a ésta ha de pagar costos y fletes cajones y demás gastos el dicho Capitan Juan de Villarreal o quien su derecho representare. - Y luego que estén dichas letras y demás cosas en la Ciudad de la Nueva Veracruz ha de ser obligado el dicho Capitán Juan de Villarreal o el dicho su hijo a dar y pagar al dicho Capitan Juan de Villarreal o el dicho su hijo a dar y pagar al dicho don Juan José de Liñán o a la persona que trajere dicha letra por cuenta de su precio y monto quinientos pesos de oro común puestos en dicha Ciudad de la Nueva Veracruz y después de recibida y pesada en ésta Ciudad se ha de ajustar su monto a precio de cinco reales libra y la cantidad de pesos cumplimiento de él, se le ha de pagar para el despacho de la flota en que así viniere con declaración de las tarjas de madera se han de pagar aparte, las grandes a razón de doce reales cada una y las medianas a razón que ocho reales y dichas tarjas han de ser de los tamaños y medidas de lleva muestra y memoria separada firmada de entre ambas partes y con pretexto alguno no ha de poder faltar a traer las dichas letras y demás letras faltantes, en la primera flota que de dichos Reinos de Castilla vinieren por cuyo defecto pagará todas las costas daños y pérdidas y menoscabos que por la dilatación y falta de entrego se siguieren y recrecieren a los dichos Capitan Juan de Villarreal y su hijo a dicha su imprenta y quien su derecho representare, en reales con las costas de su cobranza porque le pueda ejecutar con su simple juramento en con que lo difiere, sin otra prueba de que les releba[...] Siguen cláusulas y renuncias de estilo, termina siendo testigos, Juan Francisco Orozco, Nicolás Guzmán y Juan Crisóstomo de Alzérreca, vecinos de la ciudad.

(I696, 24-XI) Testamento otorgado por el contador Juan de Villareal, bijo legítimo de Nicolás de Villareal y de doña Magdalena Rodríguez, naturales e la villa de Trujeque, Provincia de Alcarrias, arzobispado de Toledo. Fue dueño de casas en el Portal de las Flores y de una imprenta y librería. [AGNP, Notaría No. 4 [?], Protocolos de Manuel José de Uriarte, año de 1696, ff. 78r-82r.] [Documento citado por Pérez Salazar sin indicar localización precisa, p. 375. Transcribo paleografía ofrecida por el investigador].

"en el nombre de Dios nuestro Señor todopoderoso amen. Sepan cuantos esta carta vinieren como Yo el contador juan de Villa Real hijo lex ${ }^{\text {mo }}$ Nicolas de Villa Real y de mag ${ }^{\text {na }}$ Rodriguez 
mis padres difuntos vecinos que fueron de la Villa de trujeque en la probincia de las alcarrias del arzobispado de toledo de a donde soi nacido Y vecino de esta ciudad [...] Declaro fui albacea testamentario de $\mathrm{D}^{\mathrm{a}}$ Maria de Morales mi lexima muger cuyo testamento no tengo fecho y hordeno que mis albaceas lo hagan para el descargo de mi conciencia [...] Declaro que debo al $\mathrm{R}^{\text {do }}$ Padre frai Miguel Balberde del horden del Sr SS ${ }^{\text {to }}$ domingo Y procurador de Oaxaca quatro mill $\mathrm{p}^{\mathrm{s}}$ de oro comun que me suplio y presto a cinco por ciento al año para comprar la imprenta de que otorgue scriptura cuyo Redito le tengo pagado asta fin de septiembre pasado deste año. $-Y$ asi mismo otros dos mill $\mathrm{p}^{\mathrm{s}}$ de oro comun que diego fernandez de leon dueño de dha imprenta libro $\mathrm{p}^{\mathrm{a}}$ que Se le pagaran a dha probincia de Oaxaca a quien meobligue d pagarlos. $-\mathrm{Y}$ asimismo otros novecientos pesos de oro comun que debo al dho $\mathrm{R}^{\mathrm{do}}$ padre frai Miguel Valverde queme presto para dhs compra ordeno se le paguen declaro fui casado y velado lexitimamente segun horden de nuestra madre yglesia con la dhs $\mathrm{D}^{\mathrm{a}}$ Maria de Morales la qual trajo por su dote $\mathrm{Y}$ caudal conocido tres mil pesos de oro comun en alajas y otros bienes de que no le otorgue recibo $\mathrm{Y}$ yo no tenia ningun capital $\mathrm{Y}$ durante nuestro matrimonio hubimos y procriamos por nuestros hijos lex ${ }^{\text {mos }}$ al $\mathrm{R}^{\mathrm{do}}$ padre presentando frai Diego de Villa $\mathrm{R}^{1}$ del horden de nuestra Señora de la Merd Redención de captiuos desta ciudad a $\mathrm{D}^{\mathrm{a}}$ Mariana de Villa $\mathrm{R}^{1}$ muger lex ${ }^{\text {ma }}$ del Cap Sebastian de Guebara. - al Liz ${ }^{\text {do }} \mathrm{D}^{\mathrm{n}}$ Miguel de Villarreal Clerigo presbiero. -a la madre Isabel de San Juan Religiosa profesa de belo y coro en el conv ${ }^{\text {to }}$ de Santa Clara desta ciu. -Y asi lo declaro para que conste y a los susodichos por mis hijos lex ${ }^{\text {mos }} \mathrm{Y}$ de la dha mi muger. Declaro dejo por mis bienes una imprenta y vna libreria Y dhs imprenta con todo lo della anexo Y perthneciente sobre la qual estan impuestos a senso dos mill y quinientos $\mathrm{p}^{s}$ que son los que pertenecen a la obra pia de San Xptobal del con $^{\text {to }}$ de religiosas de San Geronimo desta ciudad Y los otros quinientos pesos de la capellania que sirve el Liz ${ }^{\text {do }} \mathrm{D}^{\mathrm{n}}$ Geronimo de Alda de que tengo pagados sus reditos [...] nombro por mis albaceas testamentarios a dho Liz ${ }^{\mathrm{do}} \mathrm{D}^{\mathrm{n}}$ Miguel de Villa Real presbitero al R ${ }^{\text {do }}$ Padre presentando frai Diego de Villa Real y al dhs cap ${ }^{n}$ sebastian de quebara mis hijos [...] fho en la mui noble y mui leal ciu ${ }^{\mathrm{d}}$ de los Ang a veinte $\mathrm{y}$ quatro dias del mes de nobiembre de mill seis cientos Y nobenta y seis años [...] Juan de Villa $\mathrm{R}^{1}$. Ante mi Manuel Jn ${ }^{\circ}$ de Vriarte. $-S c r i n^{\circ} \mathrm{R}^{1}$ y $\mathrm{Pu}^{\circ}$.”

(I697, 2-I) ASMP, Libro de Entierros No. 4. (I69I y I699), ff. I44 D-I45r.] [Documento citado por Pérez Salazar sin indicar localización precisa, p. 375. Transcribo la paleografía del investigador].

Acta de entierro del capitán y contador Juan de Villareal, natural de la Villa de Trujeque en el arzobispado de Toledo, reinos de Castilla, y vecino de esta dicha ciudad. Hijo legítimo de don Nicolás de Villa Real y Avendaño y de doña Magdalena Rodríguez Verres y Campuzano; viudo de doña María de Morales. Otorgó testamento ante Miguel García Fragoso, escribano público y del número de eśa dicha ciudad, nombrando por sus albaceas al reverendo padre fray Diego de Villa Real, religioso del convento de Nuestra Señora de la Merced, a el bachiller don Miguel de Villa Real, presbítero, sus hijos, y al capitán Sebastián de Guevara, su yerno, no declararon sus herederos ni las misas. Recibió los santos sacramentos y fue enterrado en la santa iglesia catedral.

\section{Sebastián de Guevara}

(I718, 23-XII) Acta de entierro del capitán don Sebastián de Guevara, español, casado que fue con doña Mariana de Villareal. Otorgó testamento ante Joseph Martínez, escribano de si majestad, nombrando por sus albaceas al Licenciado D. Manuel de Guevara, don Juan de Guevara y don Sebastián de Guevara, sus bïos y herederos. 
Recibió los santos sacramentos y fue enterrado en la santa iglesia catedral. [ASMP, Libro de Entierros No. 7 (I7I6 y I72I), f. 5ov.] [Documento citado por Pérez Salazar, p. 376. Transcribo la paleografía ofrecida por el investigador].

"En la Ciudad de los An": a veinte y tres dias del Mes de Diciembre de Mill Sett ${ }^{\text {os }}$ y dies y ocho: se enterro en esta Santa Ygle Cath $^{1}$ el Capp ${ }^{\text {an }} \mathrm{D}^{\mathrm{n}}$ Sevastian de Guebara español casado que fue con Doña Mariana de Villa Real, otorgo testamento ante Joseph Martinez Escribano de su Mag. Nombro por sus Albaceas al Liz ${ }^{\text {do }}$ Dn Manuel de Guebara Don Juan de Guebara y Dn Sabastian de Gubara sus hijos y herederos los dhos. Recibio los Santos Sacramentos”.

\section{José PÉREZ Turzio}

(I7I4, 9-IX) [AGNP, Not. 4, caja 246, Protocolos de I7I4, ff. 29r.-37v.] [Documento no citado por Pérez Salazar, paleografía de ACD].

Testamento de Joseph Peres Turzio, maestro en el arte de leer, escribir y contar. El notario fue Miguel Garcia Fragosso. Realizó su testamento estando en cama el 9 de septiembre de I7I4, nombró a su mujer Francisca Díaz de Miguelles como su albacea porque sus hijos eran menores de edad y ordenó que se vendiera todo. El testamento está firmado por su hermano Thomas Peres Turcio. Sus hijos fueron: Ana Maria Theresa de San Joseph de once años. Manuel Cayetano de cinco años. Rosa Maria Peres de dos años. Todos fueron herederos en partes iguales. (fotografías). Registro de Testamentos, codicilios y poderes para testar otorgados ante Miguel Garcia Fragosso escribano real y publico I7I4 [portada del legajo].

[ff. 4r.-5v.] Testamento de Joseph Peres Turcio. Despreocupación Miguel Garcia Fragosso. Y papel treinta Hernández ---- Francisco En el nombre de dios nuestro señor todo poderoso Amen, Sepan cuantos esta carta vieren como yo Don Joseh Perez turcio maestro del arte de leer exscritura y centar hijo legitimo de Geronimo Peres turcio y dona Isabel Sanchez de Leon su mujer difuntos vecinos que fueron de esta muy noble y leal ciudad de los Angueles de don de yolosoi y tanto enfermo en cama y en mi libre juicio y entendimiento natural creyendo como firmente creo el misterio de la santísima trinidad Dios Padre, dios hijo, y Dios espíritu santo tres personas Distintas y una sola esencia Divina y en todo lo Demas que tiene cree y con fuerssa nuestra santa madreIglesia Catholica Romana de bajo de una fee y creencia enviado y pretexto de vivir y memoria elegiendo pormas rogada e intersession a la seremisima Reyna de los Angueles la virgen santa Maria madre Dios y señora nuestra conceda conceda en gracia y gloria permanente desde el primer instante de quien natural, D cargo que hago y grabo mi testamento en la manera siguiente en comiendo mi alma a Dios nuestro señor que la envio a su hechura y semejanza y la redimió su preciosso hijo consu sangre passion y muerte $=\mathrm{y}$ ordeno mi cuerpo sea sepultado en la iglesia parte y lugar en la forma y con el a compañamiento y dispossion que pareciere a mis albaceas a una elección lo dejo.

Declaro que no tengo vienes ni caudal con que podermandar decir missas por mi alma.

A las mandas forssosas y acostumbradas manado a cada uno de ellas dos reales de plata la Beatificacion del benerable ciervo de Dios Gregorio Lopes en cumplimiento de lo mandado por cedula de su magestad con que las deposito y aparto del derecho de mis bienes.

Declaro ser cassado y legítimamente según orden de nuestra santa madre iglesia con francisca Diaz de Miguelless española natural y vecina de esta ciudad la qual no trajo a mi poder dote alguno y al tiempo que contraje dicho matrimonio tenia por mi capital tres mil quiñientos diez y ocho pesos y tres granos que me dejaron mis legitimas herencias paterna y materna que fueron acargo de miguel leal de peresta maestro platero que ya es difunto vecino que fue de esta ciudad y durante nuestro matrimonio emos tenido y procreado por nuestros hijos legiti- 
mos a Ana Maria Teresa de San Joseph Perez y turcio doncella que seria dehedad de once años o mas o menos : Manuel Cayetano Perez y turcio, dehedad de cinco años.

Y Rosa Maria Perez turcio de edad de dos años declarolo para que ante lo su sudicho y por mis hijos legitimos y de la dicha mi mujer con quien e hecho y al pressente estoy haciendo vida maritable.

Declaro que por los autos del juicio divisorio de los bienes de los dichos mis padres que pasaron ante la Real justicia de esta ciudad y por Francisco Solano escribano Real y publico meracion y seme apliacaron por mis legitimas herencias paternas y maternas los dichos tres mil quiñientos diez y ocho pesos y tres granos en buen ahacienda que entraron en poder y fueron acargo del dicho Migel Leal de Peralta como mi tutor y curador alguno del qual fue fiador, Phelipe de los Rios dueños de obraje de hacer paños vecino que fue de esta ciudad que al presente lo es de la de Mexico y es el dicho mi tutor su plico y presto adicho Fhelipe de los Rios un mil y diez y ocho pesos que mi hermano Thomas Perez Turcio les pago de alcance que se le dio en dichos autos por que tenia mas de lo recibido y los dos mil quiñientos pesos quedaron en poder del dicho Miguel Leal Peralta mi tutor y despues que contraje matrimonio eido cobrando assi de dicho mi tutor como de dicho Felipe de los ríos diferentes porciones en partidas menudas e gastadas en el sustento de mi persona y familia sin el temido como tengo en cuenta ni razón formada.

Por saber lo que se esta haciendo y el dicho mi tutor falleció sumamente pobre y asi ordeno que por los recibos que paran en poder de su mujer y albacea de lo que medio por cuenta de su dicha decida y por los que paran en poder de dicho Fhelipe de los Rios assi por dicho suplemento como fiador dicho mi tutor para mia heredades.

Declaro a de ello a Thomas Palomino que ya es difunto vecino que fue de la ciudad de Cholula diez pesos que ordeno se pagen a mis herederos de lo que se cobrase de dichas mis legitimas por que no tengo otra cosa de que pagados.

Y para la ejecución y cumplimiento de este mi testamento unir deauyo y nombres por mis albaceas testamentarios al reverendo padre predicador fray Joshep de Bustamente religiosso sacerdote del sagrado orden de los predicadores a la dicha Francisca Diaz de arguelles y les doy poder bastante en derecho y cada uno con libre y general administración para el peso gerencia recaudación y cobranza de mis bienes que se apoderen de ellos y los vendan y rematen en publica almoneda afuera de ella judicial o extrajudicialmente como les pareciere y de esta parecido cumplan y paguen este mi testamento aun que sea para el termino por que el mas fuere necesario les procure sin limitacion alguna y usando de la patria protestad y facultad de derecho nombro por benedora y administradora de mis bienes y curadora alguna de las personas de los dichos mis hijos a la dicha Francisca Diaz de arguelles mi mujer, y las recibió mis fianzas por la entera satisfacción que tengo de su ajustado proceder y pido a suplico a las justicias reales la ayan por nombrada y se gistran - de dicho cargo.

$\mathrm{Y}$ en el testamento que quedarre de todos mis bienes deudas derecho y acciones que me tocan y pertenecen y en qual quier manera puedan tocarme y pertenecerme un tituyo nombro por mis herederos conversales a los dichos Ana Maria Theresa de San Joseph = Manuel Cayetano y Rossa Maria Perez mis hijos legitimos que son forsozos para que lo importare lo hayan y hereden por iguales partes con la bendición de Dios y Roma.

Yrenocoyanula los testamentos y codicilios poderes para testar y otras disposciones que antes de esta aya hecho y otrorgado por escrito y de palabra para que no salgan ni hagan en función ni fuera de el y solo se guarde y cumpla este testamento que al presente otorgo por mi firma voluntad en aquella y forma que mejor haya lugar en derecho que es fecho en el dicha ciudad de los Angueles aniedidas en el mes de septiembre de mil setecientos y catorce años aoar 
de las ocho poco mas o menos de la noche y el oorganete que yo el escribano doi fee conozco y de estas a lo que paresca enentero juicio y entendimiento natural no firmo porquano pudo por la gravedad de su enfermedad y no poderse lo cueasentar firmo lo asu ruego el dicho su hermano como le hizo que lo fue con Juan Antonio Diaz Josepeh Diaz demojo Miguel Diaz y el dicho Thomas Perez y turcio vecinos de esta ciudad en mendad los $=$ matrimonios $=$ conste $=$ separlos =su jura= Valer. [Rubrica] Por testigos Thomas Peres Turcio, Miguel Garcia Fragosso, Escribano real.

\section{FAMILIA ORTEga Y Bonilla}

(I7I4, 28-IV) Acta de entierro en la Santa Iglesia Catedral de Miguel de Ortega y Bonilla, español, que fue casado con María de la Asempción y Serezo. Otorgó poder para testar ante Diego de Neyra, escribano real y público del número de esta ciudad. Nombró como su albacea a su mujer y como su heredera a su bija. Recibió los Santos Sacramentos. [ASMP, LEE No. 6 (I708-17i6), f. 138r.] [Documento citado por Pérez Salazar sin indicar localización precisa, p. 388. Transcribo paleografía ofrecida por el investigador].

"En la Ciud de los Anges a veinte y ocho dias del mes de Abril desde año de mil settos y catorce: se enterro en Santa Yga Cathl Miguel de Ortega y Bonilla, Español casado con Doña Maria de la Asempcion y Serezo Otorgo poder para testar ante Diego de Neyra Escribano Real y Publico del Numero desta dha Ciud nombro por sus albaceas a la dha su Muger y herederos sus hijos. Resivio los Santos Sacramentes =enmendado cea $=$ Vale".

\section{Manuela Cerezo}

I7I6, [AGNP, Not. 4, caja 247, Protocolos de 1716, $2^{\circ}$ cuaderno, f. I8] Registro de testamentos y poderes para testar otorgados este año de I7I6. Ante Miguel Garcia Fragosso notario real y publico. [Documento no citado por Pérez Salazar].

(1716, Septiembre) Testamento del Lic. Miguel de Riva y Pastor, siendo su albacea Bachiller Don Manuel Díaz de Basterra, realizó el testamento en septiembre de i7i6 e informa que Don Miguel falleció el I7 de octubre de i7ı. [[...] f. I8v.] y se imprimieron papeles de convites para las personas notables desta ciudad porque pagamos á Manuela Serezo dueña de la imprenta, cinco pesos, y a Sebastian Madrid seis pesos y quatro reales para que alquilasse cavallo y por la paga de su trabajo en repartir dichos papeles como consta de sus recibos [...]

(I7I9, 6-VI) AGNP, Not. 4, caja 247, [Toca] Registro de escripturas publicas de los meses de octubre, noviembre y diciembre, otorgados ante Miguel Garcia Fragosso, escribano Real y Publico. Este año de I7I9. Quaderno I. [Documento no citado por Pérez Salazar].

Testamento y poder de Don Antonio de Cazares albacea de Don Andrés Freyre, 6 de junio de I719, ff. $25 \mathrm{f}-25 \mathrm{v}$, firmas 29v. Don Antonio de Cazares albacea testamentario de Don Andrés Freyre informa que Don Andrés falleció el $\mathrm{I}_{4}$ de del presente mes y que fue enterrado el 15 en el Convento de San Francisco y que [f. 25v.] [...] se imprimieron papeles de combite para los Republicanos de esta ciudad que le asistieron porque a Juan Francisco de Ortega y Bonilla impresor le pagaron siete pesos y seis reales y a la persona que los repartió pague quatro pesos como consta de sus recibos [...] (Se anexan fotos de las fojas $25 \mathrm{f}, 25 \mathrm{v}$ y las firmas 29v.)

1723, Testamento de Manuela de la Ascensión y Zereso. No hemos localizado el documento en Archivos poblanos. [Documento citado por Pérez Salazar, p. 388-39o. Transcribirmos su paleografía]. 
En el nombre de Dios ntro. Sñor todo poderoso Amén. -Sepan cuantos esta carta vieren como yo Doña Manuela de la Ascensión y Zereso vecina de esta ciudad de los Angeles viuda de Miguel Ortega y Bonilla hija de lexma de Jacinto Zereso difunto y de Juana Sánchez de Olarte que hoy vive vecina de esta dha ciudad de donde soy natural estando enferma en cama y en mi libre juicio memorial y entendimiento natural y creyendo como firme y verdaderamente creo [...]

Lo primero encomiendo mi alma a Dios que la crió a su imagen y semejanza, y redimó su preciosísimo hijo con sangre pasión y muerte, y de mi cuerpo a la tierra de que fue formado, y ordeno sea sepultado en la Santa Yglesia Catedral junto a la Capilla del Santísimo Xpto de la columna, donde está enterrado mi marido [...]

Declaro fui casada y velada lexma según orden de Ntra. Santa Madre Yglesia con el dho Miguel de Ortega Y Bonilla difunto y cuando contraje matrimonio con el suso dho trajo por su capital tres mil pesos de oro común y yo nollevé a su poder cosa alguna de dotes y durante dho matrimonio ubimos, y procreamos por ntros hijos lexmos, a Juan Francisco de Ortega que hoy es casado con doña Rosa de Sandoval, vecino de México, a las madres María Ynes de Jesús y Manuela de San Fraco de Sales religiosas profesas de Belo y choro del convento de Señor San Gerónimo de esta ciudad, y a Cristobal Tadeo de Ortega que será de edad de diez y ocho años que se halla cursando los estudios en el Colegio del Santo San Ignacio de esta Ciudad. -Declaro para que conste a los susodichos por mis hijos lejitimos y de dho marido. -Declaro tengo enterada la lejitima paterna que le tocó a dho Juan Francisco de Ortega mi hijo, en la cuenta de división y partición que hizo de los vienes que quedaron por fin y muerte de dho mi marido de que tengo recibo que para entre mis papeles. -Y así mismo declaro le tengo dados al su sodicho quinientos ps de oro común por cuenta de la lexma y futura subseción que mi parte le pueda caber en los vienes que quedaren por mi fallecimiento y así mismo le tengo prestadas una Ymprenta que está en la ciudad de México, y me tiene otorgada escritura para no venderla, empeñarla, ni enagenarla, la cual declaro por mis bienes, $\mathrm{Y}$ es mi boluntad que si dho mi hixo quisiere demandar alguna cosa a mis hixas las religiosas, Se le tome quenta de todo el tiempo que ha sido a su cargo dha Ymprenta, Y se le haga cargo de lo que Ymportaren sus Aprovechamientos, Y se le pase en quenta de lo que deba perseuir de Erencia materna excalfado su trauaxo por ser asi mi voluntad [...]

Ytem tengo por mis vienes Vna casa en el Portal de las flores ques la de mi hauitación linda con casa de Dn Ignacio Maria de la Carrera, Y con casa de la Cofradia de los Anímas que tengo arrendada y en ella una tienda de mercería Vien auiada Y Vna Sala de dha casa diferentes auios pertenecientes a dha tienda y así lo declaro para que conste. -Declaro tengo por mis vienes la casa de la referida en la Calle de los Mercaderes de esta Ciudad y los títulos de vna y otra paran en mi poder [...]. Ytem tengo por mis bienes la Ymprenta que se halla en la Ciudad de México en Poder de dho Juan Franco de Ortega mi hixo en empréstito cuyo valor consta en la escriptura de propiedad que para en mi poder. -Y tengo por mis Vienes otra Ymprenta en corriente en esta Ciudad cuyo valor consta de Scriptura de propiedad que Así mismo para en mi poder. -Y tengo por mis bienes otra Ymprenta que compré a los herederos de Juan José Guillena Carrasco cuio valor y precio consta así mismo por Scriptura que para en mi poder. Ytem tengo por mis Vienes diferentes piezas de plata Perlas y demás Omenaje de casa de que se hará Ynventario por menudo de mis Albaceas. - Declaro no tengo al presente Reales algunos Y asi lo declaro para que conste [...]. Declaro tengo quenta con el Lizdo Dn Gabriel Ribera Presvitero Domiciliario del Arzobispo de México causada de la compra de la Ymprenta de Juan Carrascoso y diferentes géneros de librería que meha dado para el surtimiento de mi tienda y le tengo entregado diferentes cantidades que constan por cartas con mis quinientos y que le di en mano propia en esta Ciudad y hordeno amis albacesa ajusten dha quenta y si me alcanzare se le pague al alcanze de mis Vienes y si yo le alcanzare se cobre lo que fuere por dos mis Albaceas [...] 
Declaran me debe el Sr Lizdo don Felipe Rodriguez de Ledezma Canónigo desta Santa Yga la cantidad que constará por las cuentas de libros, procedida de la Impresión de su Genealoxia, Rasos, Capicholas, Y otros Géneros que le supli Y loque fuere ordeno se cobre por mis bienes. - Declaro me debe Dn Franco Xavier de Ortega esno Real Publico y de cauildo de la Ciudad de Tlaxcala la cantidad de ps que constará por un bale que me otorgó, con más dose pesos que le suplí en reales separadamente, $\mathrm{Y}$ más ciento y siete pesos que importaron diferentes trastes y genéros que le dió el moso Gachupín que estaua en mi tienda quando fue Padrino de un Casamiento en esta Ciudad y ordeno se le cobre todo por mis bienes [...]

$\mathrm{Y}$ en el Remanente que quedare [...] nombro por mis herederos Universales a los dos Juan Francisco de Ortega y Bonilla y Xptoval Tadeo de Ortega y Bonilla las dhas Reverendas Madres María Ines de Jesús y Manuela de San Francisco de Sales mis hixos legítimos [...]. Revoco y anulo [...]. Que es fecho en la Ciudad de los Angeles a diez y ocho días del mes de junio de mill setecientos y veinte y tres as $\mathrm{Y}$ la otorgante a quien yo el escribano doy fee que conozco, $\mathrm{Y}$ de estar a lo que notoriamente parece en su entero Juicio memoria y entendimiento Natural así lo otorgó firmó siendo testigos Juan de Villarreal. Manuel Cayetano Muñoz. Cristoval Muñoz y José Toribio de Estrada. Ssno Rl y Pubco. -Rubrica.

1727, Privilegio de Impresión Para Manuela Zereso. [Documento citado por Pérez Salazar sin indicar lozalicación precisa, p. 340-342. Transcribo su paleografía].

Cédula Real, fechada en San Ildefonso el 9 de septiembre de I725 EL REY. -POR QUANTO POR parte de Doña Manuela Zereso vecina dela Ciudad de la Puebla de los Angeles, como Madre, tutora, y curadora de sus menores hijos, se me ha representado que Don Miguel de Ortega su Marido fué dueño de una imprenta por seción que le hizo de ella don Diego Fernández (ubicación de lámina I6) de León con el privilegio que le competía, de que él y no otro pudiese imprimir, los actos, conclusiones, y papeles de combite, para entierros, y demás funciones que se ofrecen en la expresada Ciudad de la Puebla; y que habiendo fallecido el referido su Marido poco tiempo después de habérsele transferido esta acción, ocurrió antes el Marqués de Valero siendo mi Virrey, Gobernador y Capitán General de las Provincias de Nueva España y Presidente de la Real Audiencia de la Ciudad de México, pidiendo se entendiese este Privilegio con ella, sus hijos, y herederos, cuya pretención se le negó, y reservó su derecho para pedirle de nuevo, como lo ejecutó; y habiendo servido con cien pesos y pagado diez de media anhata, se le confirió con calidad de llevar confirmación mía dentro de cinco años, y habiéndose pasado ese término, sin haberlo hecho por ignorancia suya y no haber tenido de quien poderse valer para conseguirlo, ocurrió segunda vez ante el expresado mi Virrey solicitando se le prorrogase el referido término, en atención a ser el único medio para mantener su dilatada familia, y no seguirse de ello, perjuicio a tercero, y no haber otra imprenta en la expresada Ciudad de la Puebla; y en su vista condecendió el referido mi Virrey Marqués de Valero a su instancia, con calidad de que sirviese con setenta y cinco pesos, por lo correspondiente al derecho de media anhata y de llevar confirmación mía dentro de cinco años que había de empezar a correr y contarse, desde cinco de septiembre de mil setecientos y veinte y dos, como constaba del testimonio que presentaba, suplicándome fuese servido mandar despachar confirmación del expresado Privilegio, a favor de la mencionada doña Manuela Zereso, sus hijos, herederos, y a succesores; y habiéndose visto esta instancia en mi Consejo de las Indias, con el Testimonio que se ha presentado por donde consta ser cierto lo referido; he venido en conceder a ella. Por tanto, confirmo, y apruebo (Como por la presente lo hago) el privilegio concedido a la expresada doña Manuela Zereso, para que pueda imprimir los actos, conclusiones, y papeles de combite para entierros y demás funciones que se ofrezcan en la Ciudad de la Puebla de los 
Angeles, y que en la propia conformidad lo ejecuten sus hijos, herederos, y succesores, según y en la forma que lo han hecho sus antecesores, sin diferencia alguna y sin que lo pueda hacer otra persona, con la calidad que contiene el despacho del referido mi Virrey Marquez de Valero de cinco de Septiembre de mil setecientos veinte y dos, sin que en ello se ponga ala expresada doña Manuela Zerezo, sus hijos, herederos, y succesores embaraso, ni impedimentos alguno, por ningún ministro ni otra persona, que así es mi voluntad. Fecha en San Ildefonso a nueve de Septiembre de mil setecientos y veinte, y cinco. -Andrés de Elcorobarrutia y Zupíde. -Señalado con tres Rúbricas. -Queda asenta esta Real Cédula en los Libros del Oficio de Gobernación Guerra de esta Nueva España de mi cargo; México, y Julio ocho de mil setecientos veinte y siete. -Morán.

(1758, 4-v) Acta de entierro de Doña Manuela de Ascensión Cerezo, española, viuda que fue de Don Miguel de Ortega [...] Otorgó testamento como consta de la certificación de D. Juan Fausto Montes de Oca, escribano real y público de la ciudad, la cual para en este archivo del Sagrario de la Catedral. [ASMP, Libro de Entierros No. I2 (I753 y I76I), f. 84r.] [Citado por Pérez Salazar sin indicar lozalicación precisa, p. 390. Transcribo paleografía del investigador].

"En la ciud de los Angs en cuatro de Maio de este año de mil sets sinqta y ocho se enterro en la Ygla del Convto de Sn Geronimo Da Manuela de la Ascencion Serezo española viuda que fue de Dn Miguel de Ortega. Recibio los Sacramentos y otorgo testamento como consta por la sertificacion de D. Juan Fausto Montes de Oca escribano Rl y publico de esta dha Ciud la qual para en este Archivo del Sagrario de la Sta Ygla Cathl”.

(I772, I7-III) Acta de entierro de D. Christoval de Ortega, casado que fue con doña Agueda Talledo. No recibió los santos sacramentos por haber fallecido de repente. Se le enterró en la iglesia del Colegio de Niñas Vírgenes por parte Bachiller Manuel de Lara, teniente de cura del Sagrario de la Santa Iglesia Catedral. [ASMP, Libro de Entierros No. I4 (I767 y I773), f. I49r.] [Documento citado por Pérez Salazar sin indicar lozalicación precisa, p. 39I. Transcribo paleografía del investigador].

"En la Ciud de los Angs en dies y siete de Marso de este año de mill setts setenta y dos: yo el Br Manuel de la Lara Theniente de cura de Sta Ygla Cathl di sepultura a eclea en lla Ygla del Colegio de Niñas Virgenes del Cuerpo de Dn Christoval de Ortega español casado que fue con Da Agueda Talledo, no recibio Stos Sacrantos por haver muerto de repente. Manuel de Lara. Rúbrica”.

\section{IMPRENTA DEL COLEgio de SAN Ignacio}

\section{DE La Compañía de Jesús en la Puebla}

I758, Permiso de Establecimiento de Imprenta al Colegio de San Ignacio de la Compañía de Jesús en la Puebla. [No hemos localizado el documento en archivos de México, citado por Pérez Salazar, p. 349].

"Por parte del Colegio de San Ignacio de la Compañía de Jesús en la Puebla, se me ha representado que en aquella ciudad por no haber mas que una imprenta y esta defectuosa, se padecía mucho trabajo en la impresión de actos, sermones, y otras obras que se imprimían, por lo que se hacia preciso ocurrir a México para efectuar las impresiones que se ofrezcan, en cuya consideración y de la utilidad que de ello resultaría a favor del expresado Colegio digno de mi atención instituido y fundado para educar a la juventud, y que se les enseñe la filosofía y teología como se les enseñaba, y también el que era muy conveniente que estuviesen las im- 
prentas y a cargo de personas literatas, pues así se conseguía que saliesen sin erratas las obras, concluyó pidiendo me dignase conceder mi venia y permiso, para que en dicho Colegio se abriese una imprenta que tenía: Y en su vista conformándome con lo que pidió, el señor Fiscal de su Magestad, en repuesta de veinte y uno d Junio próximo pasado: Atendiendo ha haberse enterado lo perteneciente al Real derecho de media anata en las Reales Cajas de las Ciudad de México, Por el presente doy, y concedo licencia al Colegio de San Ignacio de la Compañía de Jesús de la Puebla, para que abra una imoprenta qu en él tiene, para el efecto de imprimir actos, sermones y otras obras que se puedan ofrecer, y mando se mantenga dicho colegio, en el uso, goce y posesión de dicha imprenta, sin que por las Justicias que son de dicha Ciudad de la Puebla, ni las que en adelante fueren, ni otra persona alguna, se le impida, moleste, ni perjudique: San Angel, primero de Julio de mil setecientos cincuentas y ocho.- El Marqués de las Amarillas. -Por mando de su Excelencia. -Don Juan Martín de Osorio”.

\section{Francisco Javier Morales y Salazar}

(I728, 2I-XI) [ASMP, Libro de Matrimonios No. I5 (I727-I730), ff. II8v-II9r.] [Documento citado por Pérez Salazar, sin indicar localización precisa, p. 390. Transcribo paleografía del investigador].

"En la ciud de los Angs a veinte y undias del mes de Noviembre de mill setts y veinte y ocho habiendose lydo las tres amonestaciones que dispone el Santo Consilio de Trento en tres dias festivos inter Missarum Solemnia y no habiendo resultado ningun impedimento canónico Yo el Lisdo D. Manuel de Loaiza y Erazo con licencia de los Señores curas desta Santa Yga Cathedral les pregunte su consentimiento -a D- Franco Xavier de Morales español soltero mercader de libros hijo sexmo de D. Juan de Morales y de Da Maria de Salazar = y a Doña Joaquina María de Loaiza y Erazo, española donsella hija lexma de D. Fhelipe De Loaiza y Erazo y de Da Franca Rossete Goñi de Peralta ambos naturales vecinos desta Ciud a esta feliga y habiendolo expresado mutuo es casse por palabras de presente que hicieron verdadero y sexmo Matrimonio siendo testigos D. Juan de Morales y D. Diego Rubin de Celis y el dia veinte y dos de dho mes el Lisdo D. Joseph de Morales con licencia de los Señores Curas desta Santa Yga Cathedral le dio las Bendiciones Nupciales y en fee de ello lor firme -D. Br Manuel Mariano Loaiza. Rúbrica”.

1773, Entierro Francisco Xavier de Morales. [Documento citado por Pérez Salazar sin indicar lozalicación precisa, p. 39I. Transcribo paleografía del investigador].

"En la Ciud de los Angs en veynte y tres de abril de este año de mill setts y tres yo el Br Franco Prieto Theniente de Cura, di sepultura Ecleca en la Ygla del Convo de la Concepon a Dn Xavier Morales español, casado que fue con Da. Joaquina de Loaiza rezivio los Stos Sacramentos y lo firme. Br Franco Prieto, rúbrica”.

\section{PEDRO DE LA Rosa}

1762, Acta de matrimonio de don Pedro de la Rosa. [Documento citado por Pérez Salazar sin indicar lozalicación precisa, p. 39i. Transcribo paleografía del investigador].

"En la Ciud de los Angs en ocho dias de Maio deste año de mill sees sesenta y dos haviendose leydo las tres amonestaciones que dispone el Sto Consilio de Trento en tres dias festivos inter misarum solemnia yu no habiendo resultado impedimento canonico: yo el Br Luis Bernardo Mellado Rivadeneyra Con licencia de los señores curas de la Sta Ygla Cathl les pregunte su 
consentimiento a Pedro Joseph de la Rosa, español, soltero tratante hijo lexo de Franciosco Xavier de la Rosa y de Micaela Jacinta Contreras = y a María de la Luz Ortega española donsella hija lexa de Christoval Tadeo de Ortega y de Agueda Talledo, ambos contrayentes naturales y vecinos de esta filigrecia y habiéndolo expresado mutuo les dispuse por palabras de presente que hicieran verdadero matrimonio siendo testigos D. Franco de Ortega y Dn Juan de Alba: y el dia 9 de dicho mes recivieron las Bendiciones Nupciales y en fee dello lo firme. Luis Bernardo Mellado de Rivera de Neira. -Rubrica”.

I767, Segunda Acta de Matrimonio de Pedro de la Rosa. [Documento no localizado en archivos poblanos, citado por Pérez Salazar sin indicar lozalicación precisa, p. 39I. Transcribo paleografía del investigador].

[Acotación a la izquierda: Los contenidos de esta partida recibieron las bendiciones Nupciales en el santuario de Loreto] "En la Ciud de los Angs en primero de Nove de este año de mil sets sesenta y siete haviendose leido las tres amonestaciones que dispone el Sto Concilio de trento en tres días festivos inter misarum solemmnia y no haviendo resultado impedimento canónico yo el Br Joseph Marin Theniente de Cura de la Sta Ygle Cathl les pregunte su consentimiento a Dn Pedro de la Rosa español comerciante viudo de Da María de Ortega= y a Da Anna María de la Carrera española doncella hija lex ma de Dn Joseph Maria de la Carrera, y de Da Ysabel de Fuentes ambos contrayentes naturales y vecinos de esta dha Ciud desta feligresia y habiendo expresado mutuo les dispuse por palabras de presente que hicieron verdadero y lexmo matrimonio siendo testigos Dn Mariano Marin, D. Nicolas Laños de Gevara y en fee dello lo mirmee. - $\mathrm{Br}$ Joseph Marin. Rubrica”.

1768, Acta de Nacimiento de Don Pedro Pascual de la Rosa. [Documento no localizado en archivos poblanos, citado por Pérez Salazar sin indicar localización precisa, p. 392. Transcribo paleografía del investigador].

"En la Ciud de los Angeles en veinte y cinco de Octe de este año de mil sete sesenta y ocho: yo el $\mathrm{Br}$ Joseph Marin theniente de Cura Baptlse solemnemente a Pedro Ygnacio Cayetano que nacio el dia veinte y tres dho mes hijo lexmo de D. Pedro de la Rosa y de Da María Anna de la Carrera españoles, fue su padrino Da Mariano Marín todos vecinos de esta dha Ciud y feligresia, a el qual hise notorio el parentesco espiritual que contrajo y la obligación que tiene de enseñarle los rudimentos de nra Sta fee y lo firme. -Br Joseph Marin Rubrica”.

1786, Privilegio de la impresión de Cartillas celebrado en Don Pedro de la Rosa Archivo Nacional, Tomo Reales Cédulas, I786. [Documento no localizado en archivos mexicanos, citado por Pérez Salazar sin indicar lozalicación precisa, p. 392. Transcribo paleografía del investigador].

V. E. Aprueba y confirma el remate incierto del Privilegio de la impresión de Cartillas celebrado en Don Pedro de la Rosa por el tiempo precio y condiciones que se expresan como se previene.

Don Manuel Antonio Flores etc. Habiéndo el Mayordomo Administrador del Hospital Real de Indios representado en consulta el is de Abril del año proximo pasado de 87 a la Real Audiencia Gobernadora de esta Nueva España hayarse próximo a cumplir en Julio de aquel año el arrendamiento del Privilegio de imprimir Cartillas, concluyó en pedir a aquel Superior Tribunal se sirviese mandar salir al pregón el nuevo asiento y que se pusiesen los róulos de estilo en los parages públicos de esta Capital, a fin de que llegando a noticia de los que quisiesen hacer postura se rematase en el que más ofreciera, cuya instancia pasó con los autos del ante- 
rior remate al Señor Juez de Hospitales y proveyó a este Señor Ministro el 28 del citado Abril como pidió el enunciado Mayordomo Administrador. Pidio en otra consulta el 25 de Junio del mismo año se hiciese saber a el de la Puebla de los Angeles don Pedro de la Rosa a efecto de que si querian hacer postura lo verificacenen la forma, regla y modo, practicándose asi por el Señor Juez en turno, en 26 de insignado Junio (como se ejecutó) previo auto en 27 de inmediato Julio, señalando el dia 9 de Agosto para la Almoneda o remate del arrendamiento de la enunciada impresión de Cartillas previo aviso del Señor Fiscal de lo Civil, citación del Señor Mayordomo Administrador del citado Hospital Real, e Impresores de esta Ciudad, asi se ejecuto y estando pregonandose el denominado arrendamiento en la Real Almoneda y comparecido en ella el Licenciado don Blas Ochoa Abadiano Abogado de esta Real Audiencia y de su Ilustre y Real Colegio a nombre de don Manuel Valdés su suegro, exhibio las condiciones que se incertan. -El Administrador de la imprenta don Felipe Ontiveros, instruido a fondo de los motivos particulares que tuvieron para la extraordinaria puja en el remate último, los dos sujetos que salieron y que a uno le ha sido consecuente una irremediable muy considerable pérdida y asi mismo considerando la multitud de impresiones que ha habido en el Gobierno a que se le han agregado las de la Superintendencia General; desde luego hace su postura en los términos siguientes: -Dará quinientos pesos anuales adelantados para el Hospital. -Ytem, Lo que ha sido costumbre en el quinquenio pasado para los oficios del Superior Gobierno. -Ytem. Hará las impresiones de la Secretaría del Virreynato solamente; mas nunca entrando en la obligación, semejantes obras a las que ha impreso en el quinquenio anterior, como han sido Reglamentos de Presidios de Marina, y otros semejantes, estableciendo como regla fija que no debe entrar en cuaderno que pase de cinco o seis pliegos, y ultimamente que deberá se de paga (como siempre lo fue) cuanto se ofrezca imprimir de los ramos de tabaco, Casa de Moneda, papel sellado, polvora y naipes, tributos y otros Reales Ramos, cuyos fondos siempre han erogado estos costos. - Manuel Antonio Valdés. -Se produjo haciendo postura bajo de ellos dar quinientos pesos en cada un año, por tiempo de cinco, al Hospital Real por el referido Privilegio de imprimir Cartillas; la que admitida se mandaron agregar dichas condiciones al expediente. Se continuó pregonando la postura y no pareciendo otro postor se supendió el remate hasta nueva Almoneda, con atención de haber manifestado el Mayordomo Administrador del Hospital, tener noticia de que no faltaría en ella quien adelantase la postura hecha. Notificada esta resolución a don Manuel Antonio Valdés y ratificada su postura, se hizo saber igualmente a los impresores; vuelto a pregunar en Almoneda de 2I de Agosto de aquel año sin que hubiese adelantado alguno a la insignada postura, mandó el Señor Oidor Juez del Hospital que se entregasen los autos de Mayordomo Administrado para que en su visita y de la escritura otorgada por el último arrendatario don Pedro de la Rosa pidiese lo conveniente a beneficio del Hospital y con lo que dijese se pasara el expediente al Señor Fiscal. -En cuyo cumplimiento dicho Mayordomo Administrado presentó el escrito que sigue. -Señor Oidor Juez Protector del Hospital Real de Indios, don Eusebio Ventura de Beleña. De orden de V. S. Se me han entregado los autos formados para el nuevo arrendamiento del Privilegio de imprimir Cartillas, una de las fincas del Hospital Real de Indios que está a mi cargo, por haberse concluido el 4 de Octubre del presente año, el anterior que se celebró por cinco años. Que sobre los particulares que ministran los referidos autos pida lo que convenga a beneficio del Hospital; en cuya consecuencia y de las anteriores circunstancias que han procedido para los otros arrendamientos, hallo que toda la dificultad de proporcionarse un asiento ventajoso a favor del Hospital, consiste en el fundado temor de los Impresores, por las execivas impresiones que el Supremo Gobierno se les han encomendado aún fuera de aquellas obligaciones que contrajeron en su contrata, de modo que retraidos de introducirse en semejantes obligaciones se ve no haber salido otro postor a favor del Hospital, que de jantes obligaciones se ve no haber salido otro 
postor a favor del Hospital, que de quinientos pesos cuando acaba de finalizarse el un mil setecientos y cincuenta pesos. Este deterioro puede arreglarlo la exactitud, prudencia y caridad hacia este Hospital del Superior Gobierno, declarando no tener mas obligación el asentista que de imprimir aquellas coas que sean del puro Gobierno, declarando no tener mas obligación el asentista que de imprimir aquellas cosas que sean de puro Gobierno y que no intervenga que hiciese, como se ha hecho de inmemorial tiempo a esta, y aunque en lo primitivo eran mucho menos que ahora las impresiones de mero Gobierno toleraban esta carga por el logro que les daban los demas particulares, balanceando de este modo sus utilidades con la del Hospital. -La cuota fija que prudencialmente se ha hecho por la Secretaría del Virreynato y que consta en estos autos son 18 bandos al año y 30 ordenes circulares, esto es de puro Gobierno y cien pesos para el papel de los testimonios y oficio de ambas Secretarías de Gobierno; se animarán los postores hasta conseguir el anterior arrendamiento si esta declaración del punto fijo se dignare la superioridad de resolvérla y se les pueda hacer a los Impresores para ampliarles el ánimo y que formen otro concepto mas benigno hacia sus intereses y los del Hospital. -Sobre todo, la sabia dirección de V. S. promoverá lo que fuere de su mayor agrado. -México 25 de Agosto de I787. -Antonio de Arroyo. -En vista de lo pedido por el Señor Fiscal de lo Civil en zo de indicado Agosto, se proveyó que solicitándose en el Archivo del Hospital el Privilegio de concesión que obtuvo de este asiento, se notificase al Mayordomo Administrador cumpliese previamente con lo resuelto en el último auto de Almoneda acerca de arrendamiento que finalizaba. Así lo verificó en este informe: Señor Oidor Protector del Hostal de Indios don Eusebio Belaña. - En vista del decreto de V. S. Que debo exponer que habiendo registrado el testimonio de la escritura que otorgó don Mariano Marín, a nombre y con poder de don Pedro de la Rosa impresor y vecino de la Ciudad de Puebla para el arrendamiento de imprimir Cartillas que se le remató por cinco años en la ciudad de un mil setecientos y cuarenta pesos para el papel y los testimonios y oficios de las dos Secretarías de Gobierno del Virreynato, fuera de los asientos en que interviniese persona interesada, no consta ni parece haberse obligado el referido Marín en nombre de su parte que cumplidos los cinco años de su arrendamiento si quisiere para más tiempo pagará los mil setecientos pesos estipulados como las demás obligaciones en que se constituyo y se le administraron como parece del referido testimonio que queda en mi poder al que me remito. En cuyo supuesto debo exponer a V. S. que el referido arrendamiento cumplido el 4 de Julio del presente año, está debiendo ciento cuarenta y seis pesos medio real, con mas aquel tiempo que va corriendo en la posesión de imprimir las cartillas, hasta que se le mante cese en esta operación, cuyo intermedio graduará la justificación de V. S. -El Privilegio o facultad de imprimir las referidas Cartillas, tuvo principio en el año de I74I [debe ser I64I] por concesión que hizo el Exelentisimo señor Duque de Escalona Virrey de este Reino, a Paula de Venavides y a sus sucesores, dueños de imprenta de esta Ciudad, a quienes por tiempo limitado se les concedió esta gracia, que en lo sucesivo fueron disfrutando por prórroga que les concedieron los Virreyes que sucedieron, hasta el tiempo del Exelentísimo Señor Marqués de Casafuerte el año de 1725 en cuyo tiempo era dueña de imprenta doña María de Ribera Calderón, la cual estuvo en posesión de ésta facultad, cumpliendo con las obligaciones anexas a ella que eran, de dar papel blanco que se ofreciese en las oficinas de Gobierno para los testimonios de Oficio que suelen ocurrir, y imprimir de valde los despachos que en aquel tiempo se ofrecieren, como igualmente dar al Hospital Real de Indios cincuenta pesos anuales por via de limosna. -En esta actuación y tiempo se presentó a dicho señor Marqués de Casafuerte Don José Bernardo de Hogal dueño de imprenta en esta ciudad pidiendo se le concediese la referida facultad de imprimir las cartillas y Doctrinas ba de cumplir con las mismas obligaciones a que estaba anexa y dar al Hospital Real de Indios, quinientos pesos nuales ápara ayuda de su manutención. -Esta prestación la comitió su Exelencia el señor Fiscal con la contradicción de la 
referida doña María de Ribera, el que fue de dictamen que no por ser Privilegio especial de la dicha doña María de Ribera, sino una concesión por vía de asiento se sirvise su Exelencia, mandar saliese al pregón este privilegio o facultad para que se rematase en el mayor postor; con cuyo parecer se conformó su Exelencia y consta de su derecho de 2 de mayo de 1726. -Siguieron las competencias de una y otra parte hasta el año de 28 en que por decreto del referido Exelentisimo señor Virrey, de 2 de Octubre del mismo año se le concedió la gracia de esta impresión a la dicha doña María de Ribero, por diez años con calidad de cumplir con las obligaciones referidas, como de dar al Hospital 800 pesos anuales. -Cumplidos los diez años tuvo el Hospital esta finca de su cuenta, hasta el año de 1750 se arrendó en I,I25 pesos, por cinco años y bajo las mismas obligaciones antecedentes, después en el año de 55 se volvió a arrendar en 850 pesos, bajo de dichas obligaciones. -En el año de 60 se arrendó en I,025 pesos. -En el año de 67 se arrendó en 900 pesos. -En el año de 74 se volvió a arrendar con los mismos 900 pesos. $-\mathrm{Y}$ el que ha finalizado se arrendó en el año de 82 en $1,75^{\circ}$ pesos. Que es cuando puedo informar a V. S. en orden a lo que se sirva mandarme. -México a 7 de Septiembre de 1787. Antonio de Arroyo. -Y vuelto el expediente a dicho señor Fiscal, expuso lo que se percibe de esta respuesta. -El fiscal de lo Civil dice: Que el Hospital Real de Indios no ha promovido cosa alguna en su antecedente informe acerca de la cesación o continuación del arrendamiento que se hizo a don Pedro de la Rosa por el término de cinco años por el privilegio de impresión de Cartillas. -Solo dice que por el testimonio de la escritura que otorgó no consta que el se hubiese querido obligar a continuar en dicho arrendamiento después de concluidos los cinco años; pero que importa esto, si al cabo, por el hecho de no ocurrir al expresado De la Rosa ha de haber dejación del expresado asiento, se entiende continuar bajo la tácita reconducción? Por todo el tiempo que corriere de más, sin hacer dicho ocurso, conforme para lo que en semejante caso disponer la Ley 20 del artículo $8^{\circ}$ partida $5^{\text {a }}$-Por esto y porque el Mayordomo no ha dicho ni solicitado en su antecedente informe que se mande cesar al dicho Rosa en el expresado asiento, porque acaso le fuese más útil al Hospital administrar por su cuenta dicho Privilegio, entretanto resultare postor a el, le servirá V. S. mandar que por ahora no se le haga novedad en el asunto; pasándose después el expediente al Superior Gobierno, para que allí allanen las dificultades que ofrecen para la concurrencia del postor el excesivo número de impresiones que se le encomiendan por este Superior Gobierno, según pedimento del Fiscal en su anterior respuesta que reproduce en este particular. -México 25 de Septiembre de i787. -Alva. -Y conformándose con ella el referido Juez por decreto de 28 de Septiembre mandó se hiciese saber al apoderado de don Pedro de la Rosa para su inteligencia y que se remitiesen los autos a mi superioridad para que en vista de las dificultades que ofrece el remate de que se trata por las muchas impresiones que expresa el Mayordomo del Hospital Real, se encargan por este Superior Gobierno al [??] Providencie lo que conceptuare oportuno, reducida a efecto esta providencia y dirigiéndome al expediente con oficio de 8 de Octubre, mando en consecuencia de lo pedido por el propio señor Fiscal el 28 del mismo, se agregasen a él, la concesión del Privilegio de imprimir Cartillas al hospital Real y los ejemplares de los anteriores que cita el Mayordomo Administrador, en los parrafos 2, 3, 4, 5, 6, 7, 9 y ro de su informe de 7 de Septiembre inserto. Y vuelto el expediente a su vista puso este pedimento. -Exelentísimo Señor. -El fiscal de lo Civil dice: Que no es la primera vez, en que se representa a esta Superioridad de la causa de no proporcionarse mejores postores al asiento del Privilegio de imprimir Cartillas perteneciente al Hospital Real de Indios, es el del excesivo número de impresiones que por este Superior Gobierno se encomiendan al asentista por lo que toca a la causa pública y a la Real Hacienda; y en otras varias se ha consultado lo mismo y sin embargo siempre se ha creido no haber arbitrio para remover embarazo, o ya minorando las impresionas reduciendolas a punto fijo, o ya es levando al asentista en lo absoluto este gravamen que se impuso a beneficio de la Real Hacienda como calidad 
inherente a la concesión que se hizo de dicho Privilegio al Hospital Real,, aque es consiguiente de que haya de continuar en la misma conformidad, no obstante que sea motivo para que no se proporcionen posturas más ventajosas. -Así lo dijo el Señor Fiscal don Juan Antonio Velarde en su respuesta del 7 de Marzo de 1767 que corre en uno de los cuadernos agregados; los mismos repitió el señor don José Antonio de arecho en la suya el I7 de Septiembre de I772 y i2 de Junio de 1773 que se hayan en otros de dichos cuadernos y lo mismo el señor Juez de Hospitales don Eugenio Melgarejo en su informe de 3 de Agosto, también de 1773 a cuyos dictámenes fueron conformes los Superiores Decretos, de io de Marzo de 1767, 23 de Septiembre de 1773 y I2 del citado Agosto del mismo año, sin que hubiera habido lugar a otra declaración que a la que dicho gravámen se entendiese no habiendo particular interesado en dichas impresiones porque entonces deberá contribuir este con lo que correspondiese, queriendo que se hiciese la impresión por el mismo asentista, según parece todo de la misma respuesta del citado Señor Areche y referido informe del Señor Juez de Hospitales. -Las impresiones no son tantas como se pondera, pues habiendo hecho el año pasado i78o un computo prudencial vino a salir que no exedían los bandos de 18 cada año y de órdenes circulares como 30 habiéndole creido por el Mayordomo del Hospital Real en su informe de I4 de Octubre, el mismo año que todo podia hacerse con el costo de 200 pesos y no más supuesto que regularmente no son muy crecidos los bandos y órdenes; y aunque se dice que en el día son mas las impresiones que antes, esto ni se acredita, ni tampoco hay motivo para cree que sea así, en un número exhorbitante como se quiere dar a entender; haciéndose también mucho menos persuadible que se le hayan encomendado a dichos asentistas otras impresiones que aquellas que contrajeron obligación de la contrata, por que lo hubiesen reclamado si fueren otras que las tocantes a la causa pública y al Real Herario en que no haya algún particular interesado, que deberá contribuir con lo que corresponde. - En atención a todo el Mayordomo del Hospital Real promovió en su representación de informe de 2i del último Agosto sobre que se minoren las impresiones del asentista del referido Privilegiado reduciéndolas a cierto número; mandándose en consecuencia, que separándose los cuadernos agregados, se devuelva el presente al señor Juez de Hospitales para que bajo el indicado concepto tome las providencias oportunas en punto al remate de dicho asiento y deberá continuar con las mismas cargas que hasta aquí y hacer todas las impresiones que se ofrezcan en lo tocante a la cosa publica y Real Herario exepto aquellos en que hubiere particulares interesados que deberán contribuir en la parte que corresponde, dando también a las Escribanías del Superior Gobierno los cien pesos de los testimonios de oficio. México 22 de Diciembre de 1787. -Alva. -Con el que me conformé por derecho de 7 de Enero del año corriente. Mando pasar los autos al señor Juez en turno de Hospitales para su efecto. En este estado se presentó la presente a don Pedro de la Rosa. [...] Don Pedro de la Rosa haciendo postura a el asiento de cartillas como consta del escrito y condiciones siguientes:

Condiciones con las cuales hago postura al privilegio de imprimir cartillas de todo este Reino de Nueva España.- A Saber: La primera la hago por el termino de diez años dando en cada uno de ellos $55^{\circ}$ pesos por un año cumplido y no de otra manera: 50 pesos por cada uno de las oficinas de Gobierno, para el papel blanco como ha sido costumbre.- la segunda me obligo a la impresión de los bandos que se ofrezcan a este Superior Gobierno como igualmente a las circulares sin que se entienda dicha obligación a lo que al presente se imprime de Intendencias; ni en las demás oficinas de la Real Audiencia, por haber sido costumbre el que estas eroguen sus cuotas, ni a otra ninguna pieza que no sea de las expresadas.- Tercera que inficado en mi el remate ha de quedar a mi arbitrario el imprimirlos en esta Corte o en la Ciudad de Puebla; venderlos por menos y por mayor bajo las mismas reglas que hasta ahora ha sido costumbre.Cuarta, que se ha de despachar por este Superior Gobierno a Veracruz orden para qué no dejen pasar ningunas Cartillas, como en este quinquenio se ha verificado según lo acredita la gaceta 
del 22 de mayo del año pasado de 87 en la Fragata mercante de San Antonio, su Maestre, don Fernando Velasquez y Guerra trajo cuarenta y dos resmas resueltas de cartillas y a este tenor viene entre cajones de libros de cantidad de ellas en grave prejuicio de este asiento, poniendo la pena de dos mil pesos al que contraviniese contra este Privilegio sea impresor o mercader de libros, quedando su distribución a disposición del Señor Exelentísimo.- Lo asiento que ha de quedar a cargo del Mayordomo del Hospital concluidos los diez años, dar oportunas providencias para que salga subasta publica este privilegio, para dar tiempo a que tenga verificativo el remate aunque sea antes de habersele cumplido los diez años, pues solo mi postura a esta y de ninguna a él interinato que ahora pretende el Mayordomo: bajo de cuyas cualidades y condiciones me obligo al cumplimiento del expresado y a lo mas que nos conviniéremos en el acto de la Almoneda. Mexico I5 de Enero de i788.- Manuel Domingo Chavero.- Exelentísimo Señor.- Manuel Domingo Chavero, por don Pedro de la Rosa vecino e impresor y del Comercio de la Ciudad de Puebla en los autos sobre el arrendamiento de Cartillas del Reino, como mejor proceda digo que se me entregaron para hacer postura a dicho asiento y haciéndolo en forma bajo las condiciones que se expresan en el papel que con el juramento y solemnidad necesaria en una foxa útil presento, y no lo hago de papel de abono lo que verificaré el dia que se asigne para el remate, y admitidas que sean dichas condiciones, se ha de servir la justificación de V. E. de que este asigne en la más posible brevedad respecto a estar mi parte ausente de su casa, y enfremo y deseoso de regresar a ella por el prejuicio que le resulta de la demora por haber venido a esta Ciudad solo con este fin estando pronto para hacer las posturas y pujas que a mi parte convengan. -Por tanto, a V. E. suplico asi lo mande.- Juro etc. - Manuel Domingo Chavero.- Que remitido todo al expresado señor Juez mando entregar al expediente al Mayordomo Administrador del Hospital Real, don Antonio Arroyo para que impuesto de las condiciones y postura de don Pedro de la Rosa pedirá lo que a su Hospital conviniere; lo cual hecho y señalado dia para el remate previa noticia del Señor Fiscal citación de los licitantes y dueños de la imprenta se celebró el remate siguiente:

En la Ciudad de México a 26 de Enero de i788: Estando en el Puente del Real Palacio y Portal en que se celebran las Reales Almonedas los Señores: Don Eusebio Ventura Beleña del Consejo de S. M. su Oidor en esta Real Auda Assesor de los Juzgados General de Naturales, Renta de Correo, Tribunal de la Mineria, Consultador del Santo Tribunal de la fee y Juez Protector en turno de los Hospitales de esta Corte.- D. Lorenzo Hernandez de Alva del mismo Consejo y Fiscal de lo Civil y Criminal en dha RL Auda con el Mayordomo Administrador del Hospital RL General de Indios D. Anto Arroyo: para continuar el acto de la almoneda o remate del arrendamiento del Privilegio de impresión de Cartillas para consumo de todo el reino; a cuyo fin estando presentes don Manuel Valdes, el Procurador Dr. D. Manuel Domingo Chavero y su parte D. Pedro de la Rosa exhibió este el papel de habono de la antecedente foja firmando de D. Geronimo Jose Gonzalez. Y para dar principio reconociendo los Señores las condiciones con que este tiene hecha la postura con el escrito presentado por el referido Mayordomo Administrador previniéndole al mencionado D. Pedro en serle admisibles las dos primeras y segunda condiciones y quedo convenida en cuanto a la primera a que solo sea y se entienda en el arrendamiento por 5 años y en cuanto a la segunda se le leyó e impuso de la tercera con que hace su postura D. Manuel Valdes reducida a que hará las impresiones de la Sria del Virreynato solamente; mas nunca entrando en la obligación, semejantes otras a las que ha impreso en el quinquenio anterior como han sido reglamentos de Presidios de Marina, y otros semejantes estableciendo como regla fija que no deba entrar con cuaderno que pase de 5 ó 6 pliegos y ultimamente que debera ser de paga (como siempre lo fue) cuando se ofrezca imprimir de los ramos de tavaco, casa de moneda, papel sellado, polvora y naipes, tributos y otros ramos cuyos fondos siempre han erogado estos costos de cuya condicion bien entendido hizo 
aceptacion y bajo della y las tres ultimas de su pliego presentado ofrecio continuaba su postura hecha de $S 5^{\circ}$ ps. Lo que oido por el referido D. Manuel Valdes pidió lizencia para retirarse y haviendosele concedido y verificado se mando a pregonar la de Chavero y Rosa voceándose por Jose Santos Padilla que hace oficio de Pregonero público. "550 ps. dan en arrendamiento por el privilegio de la impresión de cartillas para el consumo de todo reino en cada un año y por tiempo de 5 bajo las condiciones tratadas en este acto y las 3 ultimas de pliego de ellas presentado por el licitante, si hay quien la mexore paresca, se le admitirá la que hiciere, se ha de rematar ahora" cuyo pregón se estuvo repitiendo, y en el intermedio tiempo el Sr. Instando y persuadiendo a D. Pedro de la Rosa para que hiciera algun adelanto con respecto a ser corta su postura a vista de su anterior arriendo de qe resulto que el referido D. Pdro adelanto su postura hasta en cantidad de 900 ps en que por orden del mismo Sr. Juez y convencimiento del Sr. Fiscal y Mayordomo administrador se hicieron los dos apercivimientos de estilo y en tercero el remate diciendo el citado Jose Santos Padilla "9oo pesos dan en cada año y por tiempo de 5 en arrendamiento por el privilegio de imprimir cartillas para consumo en todo el reino bajo las 3 ultimas condiciones de las 5 con que hace su primer postura el licitante D. Manuel Valdes. Si hay quien la mejore paresca, se le admitirá la que hiciere, que apersivo de remate y pues que no hay quien puje ni dé mas, que buena, que buena pro le haga", con la que quedó concluido y perfecto este remate en el ya mencionado D. Pedro de la Rosa que en su cumplimiento guarda y observancia obliga en toda forma su persona y bienes y con ellos se somete al fuero y jurisdicción de todos los Sres. Jueces y Justicias de S. M. renuncia a su propio fuero, domicilio y vecindad. Ley si convenent de Jurisdictione omnium.- y las demas de su favor y defensa con la general del derecho y lo firmó con dichos señores su Procurador y el Mayordomo administrador siendo testigos al dicho acto D. Joaquín Zamora, D. José Velasco y D. Joaquín Monlon de esta vecindad.- Eusebio Ventura Beleña.- Lorenzo Hernandez de Alva.- Anto de Arroyo.- Manuel Domingo Chavero.- Pedro de la Rosa.- Mariano Zepeda esno Rr. Y pasado el término de 9 días presentó el apoderado de D. Pedro de la Rosa nuevo escrito ante el Sr. Juez de Almoneda pidiendo se sirviese aprobar dicho remate y que me hiciere la correspondiente consulta para la certificación de el a fin de que se librase el despacho oportuno a cuya instancia defirio dicho Sr. Ministro en auto de 4 del próximo pasado Febrero con la calidad de que previamente afiansase de D. Pedro de la Rosa el seguro de la renta anual a satisfacción del Mayordomo Administrador del Hospital Real General de Naturales de esta Capital en cuyo estado el mencionado Sr. Juez en consulta de 3 de Marzo me hizo presente lo expuesto acompañándolo con el expediente al asunto para el fin propuesto. En esta atención la de haber afianzado la parte del mencionado D. Pedro de la Rosa a satisfacción del Administrador D. Antonio Arroyo la renta expresada con Antonio de la Barrera vecino del Comercio de la Ciudad de la Puebla de los Angeles: he resuelto de conformidad de mi decreto de 4 del acta que sigue expedir el presente por el cual apruebo y confirmo el remate inserto del privilegio de la impresión de cartillas para la enseñanza de los niños en este reino celebrado en el expresado D. Pedro de la Rosa. Vecino asi mismo de la referida ciudad de Puebla por tiempo de 5 años contados desde el aludido dia 4 de Marzo en que aprobe el remate y pensión en cada uno de 900 ps bajo las condiciones que el el se refieren y en su consecuencia mando a todos los jueces y justicias de S. M. Selen y velen su puntual cumplimiento sin que en todo o parte de su contenido se contravenga, dandóle el auxilio que necesite para que ninguna persona sea de la calidad y condición que fuere durante el tiempo de este remate pueda imprimir ni vender cartillas sin expresa licencia del predicho D. Pedro de la Rosa. En la inteligencia de que a este y su Apoderado les concedo la correspondiente facultad para que puedan visitar las Escuelas e Imprentas a fín de que en encontrando algunas las decomice. Y de este despacho se toma razón en el Tribunal de la Contaduria Mayor de Cuencas de esta N. E. y en la Real Chana. Mexico ig de Abril de i788.- Manuel 
Antonio Flores.- Por mandato de S. E. el Conde del Valle de Orizaba.- Orizaba rúbrica. Concuerda con su original.

I805, AGN, General de Parte, vol. 80, exp. 70, fecha(s): 1805, ff. 8I-88v. El Virrey aprueba y confirma el remate del privilegio de impresion de cartillas del reino que finco en Pedro de la Rosa, concediendose el tiempo de nueve años si su majestad se digna dispensarlo y la de que solo se ban de satisfacer al asentista, las impresiones de Secretaria y Gobierno que excedan de 506 pliegos de impreso y no de manuscrito. Puebla. [Paleografía ofrecida por Pérez Salazar, p. 355].

"El Virrey de la Nueva España, aprobandoles el remate en arrendamiento del Privilegio de imprimir Cartillas, celebrado con don Pedro de laRosa por nueve años, y ordenado lo demás que expresa.-El Rey. El Virrey Gobernador y Capitán General de las Provincias de Nueva España y Presidente de mi Real Audiencia que reside en la Ciudad de México. En carta de 27 de Marzo de este año, número 249 disteis cuenta con testimonio del remate del arrendamiento dl privilegio de imprimir cartillas para los mismos verificado en don Pedro de la Rosa por nueve años en Abril de 1799 en Junta de Almoneda, precedida del Regente de esa Audiencia Juez Privativo del Hospital Real de Naturales: Que aunque el Fiscal de lo Civil, convino en ello, lo resistió el de Real Hacienda por oponerse al artículo 39 de la Ordenanza de Intendentes que prohibe pasen de cinco años los arrendamientos de los Propios: Pero en consideración a que no había otro postor y que Rosa no admitia el remate no cumpliéndosele las condiciones que tenía entre otras de durar los nueve años, convino vuestro antecesor don Miguel de Aranza por decreto de 8 de Noviembre de dicho año de 99 el que se ampliara a ellos con calidad d eponerlo en mi Real noticia, como lo hicisteis, para que me sirviera probarlo o resolver lo que fuere de mi soberano agrado. Visto en mi Consejo de las Indias, con lo que en su inteligencia expuso mi fiscal, ha parecido aprobar como por la presente apruebo, el expresado remate, y ordenaros mandaros dispongais que en lo sucesivo no se admitan posturas, ni condiciones contrarias a lo mandado en el particular, por ser asñi mi voluntad. Fecha en San Lorenzo a 8 de Octubre de 1805. -Yo el Rey. - Por mandado del Rey Nro. Sr. - Antonio Porcel. - Señalada por tres rúbricas. -México, 28 de Enero de i8o6. - Guárdase, cúmplase y ejecútese lo que S. M. manda en esta Real Cédula y asentada en los libros de Superior Gobierno a que toca agréguese testimonio a sus antecedentes y déseme cuenta. - José de Iturrigaray. - Concuerda consu original a que me refiero”.

1787, AGN, Inquisición, vol. 1292, exp. 18, año 1787, ff. 209. Don Pedro de la Rosa presenta la factura de 8 cajones de libros y un balón de cartillas. [Documento no mencionado por Pérez Salazar, paleografía de Marina Garone Gravier, en adelante MGG].

Factura de 8 cajones de libros y un balón de cartillas...

Número i. Con i2oo estampas de a bara de devoción.

25 juegos [tachado] de las diez Naciones

200 [ilegible: ydn.] Mapamundis

Número 2. con 8000 estampas de medio pliego 4000 dichas de a cuarto...

Número 3. con rooo estampas de a pliego 2000 dichas de amo. pliego del Benerable señor don Juan de Palafox

44 Docenas Catones Cristianos

Número 4. con 156 docenas catesismo del padre Ripalda

Número 5. con 25 resmas de cartillas...

Número 6. con 146 docenas catesismos del padre Ripalda 
Número 7. con 266 Vives... Ioo Margaritas seráficas.

Número 8. con roo sarsas Siestas Docmaticas..

6 manuales del padre Lopes...

Número 9. con 300 comedias de Santa Genoveva... 200 dichas de Afectos de Odio y de Amor... 200 dichas de la Vida de Sueño 3000 dichas Reynar, después morir. 200 dichas del Desden...

Número iz. con Iı2 docenas catesismos del padre Ripalda. I2 Docenas Caton Cristiano...

[Rúbrica: Pedro de la Rosa]

I79I, AGN, Inquisición, vol. I3I4, exp. 5, año I79I, ff. I5, 22. Don Juan José Mauriño, solicita se le entreguen tres cajones que contienen catecismos y catones cristianos, que le remite de Puebla don Pedro de la Rosa. México. [Documento no citado por Pérez Salazar].

[Foja 15] Señores Inquisidores. Sírvase Vuestra Señoría Santísima mandar se me de el correspondiente para que en esta Real Aduana se me entreguen tres cajones de catesismos y catones christianos, que me remite de Puebla don Pedro de la Rosa, con el arriero Tomás Pinto. México y enero 26 de i79r. [Rúbrica: Juan Jossef Mauriño].

[Foja 22] Cuenta de tres cajones de catesismos y catones que remiten a la corte de México a entregar a don Juan José Mauriño y a don Pedro Aguirre, por mano de don José [palabra incompleta]. A saber

[Palabra incompleta: Cajón]

Número I. con I3I 2/3 docenas catecismos. a $22 \% \ldots, 370,2 \%$

Número 2. 98 docenas de dichos. a $22 \% . .,, 275,5$

Número 3. 65 docenas catones christianos.......................................... a 2 pesos.. 130,, o 775 p. 7\% Imprenta los tres cajones (S.Y.) setecientos setenta y cinco pesos siete y medio reales. Áng[ele]s y enero I5 de i79i. [Rúbrica: Pedro de la Rosa].

I790, AGN, Inquisición, vol. I327, exp. 3, año I790, ff. II-I2. Don Pedro de la Rosa solicita se le entreguen en la aduana 2 cajones de efectos de imprenta, con los libros cuya factura adjunta. México. [Documento no citado por Pérez Salazar, paleografía de MGG].

[Foja II] [Centrado al borde superior: Ilustrísimo señor, I79o] Don Pedro de la Rosa, ante Vuestra Señoría Ilustrísima con el devido rendimiento, digo que habiendo entrado a esta Real Aduana, dos cajones de efectos de imp[ues]tos con los libros que la factura adjunta presenta, se ha de servir la benignidad de Vuestra Señoría Ilustrísima mandar se me de el pase correspondiente para que se me despache prontamente, por tanto a Vuestra Ilustrísima pido se sirva mandar como llevo pedido, y hacerme Merced. México y octubre I5 de I79o= [Rúbrica: Pedro de la Rosa].

[Foja 12] Factura de dos cajones de efectos de imprenta que se le remiten a don Pedro de la Rosa a la corte de México con el arriero Francisco Pastrana, vecino de Tlaxcala... A saber.

Cajón número 1, , Con ${ }_{13} 6$ docenas de catesismos del Padre Ripalda

Cajón número 2 , Con 36 docenas de dichos Catecismos

6 docenas de cuartos del Padre Zamora

6 dichos de Quintos de dicho Padre 
I2 dichas de Colec[ilegible]

I2 dichas de Supuesta Inteligencia

I2 dichas de Sepa el Niño

50 Comulgadores Agustinianos en Pergamino

I5 dichos en Pasta

50 Artes de Encomendarme a Dios

I2 dichos en Pasta...

Ángeles y octubre 6 de 1790 [Rúbrica: Pedro Pasqual de la Rosa] Pasen por el Santo oficio [Rúbrica: Dr. Suarez]

I795, AGN, Inquisición, vol. 1354, exp. I7, año 1795, f. I29. Factura de dos cajones de devocionarios impresos, que remitió don Pedro de la Rosa al reverendo Padre fray Gabriel de la Madre de Dios, misionero apostolico del colegio de Pachuca, cuya lista adjunta. [Documento no citado por Pérez Salazar, paleografía de MGG].

Factura de dos Cajones de devocionarios, impresos en esta oficina que remito al reverendo Padre fray Gabriel de la Madre de Dios, misionero Apostólico del Colegio de Pachuca, que contiene lo siguiente....... A saber.

Mil Libritos del Matrimonio

Dos mil, y quinientas vías Crúsis con las Alabanzas...

Dos mil del Alma en Gracia...

Mil de las cuatro Máximas...

Mil Catesismos con la protesta de la Fee...

Dos mil del infierno abierto...

Veinte, y cinco siertas Docmaticas del Padre Zarza...

Veinte, y dos manuales de Sacramentos del Padre Lopez... Angeles, I3 de Octubre de 1795. [Rúbrica: Pedro de la Rosa].

I795, AGN, Inquisición, vol. 1325, exp. 6, año 1795, f. I24. Don José Carballo, vecino de esta capital, ba recibido de don Pedro de la Rosa, impresor de Puebla, cinco cajones de catecismos, dos balones de cartillas, y un sobornal con evangelios, que se ballan en esta Real Adwana, pidiendo el pase para extraerlos. [Documento no citado por Pérez Salazar, paleografía de MGG].

[Centrado en el borde superior: Muy Ilustre Señor] Don José Carballo, vecino de esta capital, ante Vuestra Señoría Ilustrísima, digo que he recibido de don Pedro de la Rosa, impresor de Puebla, cinco cajones de catesismos, y dos balones de cartillas, y un sovernal con evangelios, que se hallan en esta Real Aduana, por lo que la justificación de Vuestra Señoría Ilustrísima se ha de servir conceder su permiso y licencia para que se me entreguen en él. Por tanto, a Vuestra Señoría Ilustrísima se sirva conceder lo que le pido juro en forma, y lo necesario [Rúbrica: Jose Carballo].

I795, AGN, Inquisición, vol. I390, exp. II, año 1795, f. 399. Factura de Io cajones y I2 balones de efectos de imprenta que remite don Pedro de la Rosa a don José Carballo Ángeles. [Documento no citado por Pérez Salazar, paleografía de MGG].

Factura de diez cajones y doce balones de efectos de imprenta [no se ve palabra: que] remito con el Arriero José Cabrera, vecino de Yxtapaluca a en [no se ve palabra: tregar] en México a don José Carballo, vecino de dicha Ciudad ---- A saber. 
[Ilegible: No.] 3 Con i6o. docenas de Catesismos del Padre Ripalda.

[Ilegible: No.] 4 Con $6_{7}$ docenas dichos.

[Ilegible: No.] 5 Con 165 docenas dichos.

[Ilegible: No.] 6 Con i6o docenas dichos.

[Ilegible: No.] 7 Con 165 docenas dichos.

[Ilegible: No.] 8 Con 167 docenas dichos.

[Ilegible: No.] 9 Con roo docenas catones cristianos.

[Ilegible: No.] io Con roo docenas dichos.

[Ilegible: No.] II Con roo docenas dichos.

[Ilegible: No.] I2 Con 9I docenas dichos.

[Ilegible: No.] I3 Con 25 resmas cartillas.

[Ilegible: No.] I4 Con 25 resmas dichas.

[Ilegible: No.] 15 Con 25 resmas dichas.

[Ilegible: No.] i6 Con 25 resmas dichas.

[Ilegible: No.] I7 Con 25 resmas dichas.

[Ilegible: No.] 18 Con 25 resmas dichas.

[Ilegible: No.] is Con 25 resmas dichas.

[Ilegible: No.] 20 Con 25 resmas evangelios.

[Ilegible: No.] 2I Con 25 resmas caton sonsorino.

[Ilegible: No.] 22 Con 25 resmas dichas.

[Ilegible: No.] 23 Con 25 resmas dichas.

[Ilegible: No.] 24 Con 25 resmas dicho.

Angeles y Febrero de 1795 = Pedro de la Rosa [ilegible] los libros que resa la vista por el Santo Oficio.= Dr. Suares---- [ilegible] por esta Real Audiencia de Puebla, I9 de Febrero de 95 = Yo la di----

I796, AGN, Inquisición, vol. 1357, exp. 5, I796, f. 98. Don José Garballo (sic), vecino de esta capital, solicita el pase correspondiente para 5 cajones de catecismos del padre Ripalda que le remite para su expendio don Pedro de la Rosa. México. [Documento no citado por Pérez Salazar, paleografía de MGG].

[Centrado al borde superior: Muy Ilustre Señor] Don José Carballo, vecino de esta capital, ante Vuestra Señoría Illustrísima digo: que me ha remitido el impresor de Puebla don Pedro de la Rosa cinco cajones de catesismos del padre Ripalda, para su expendio, los que se hallan detenidos en esta Real Aduana, y suplico a la justifición de Vuestra Señoría Ilustrísima se sirvan conceder su permiso, y su licencia, para que se me entreguen. Por tanto.

A Vuestra Señoría Ilustrísima suplico así se sirva mandar hacer, juro lo necesario en forma. Firma. [Rúbrica: Jose Carballo].

I796, AGN, Inquisición, vol. 1357, exp. 5, año 1796, f. I47. Don Pedro de la Rosa solicita se le entreguen en la Real Aduana 6 balones de cartillas, 3 de catecismos, y 3 de catones cristianos que le remite de Puebla don Pedro Pascual de la Rosa. [Documento no citado por Pérez Salazar, paleografía de MGG].

[Centrado: Ilustrísimo Señor] Sírvase Vuestra Señoría mandar se me de el correspondiente pase de 6 balones de cartillas, 3 cajones de catecismos y tres de catones christianos que de Puebla me remite don Pedro Pasqual de la Rosa. México, julio 22, 96. [Rúbrica: Pedro de la Rosa] 
I797, AGN, Inquisición, vol. 1354, exp. 17, año I797, f. 6. Don Juan Manuel Gomez Dosamantes, vecino de esta ciudad, suplica se le de el pase correspondiente para 22 tercios y cajones de catones, catecismos y cartillas, que de Puebla remite don Pedro de la Rosa. México. [Documento no citado por Pérez Salazar, paleografía de MGG].

[Centrado al borde superior: Ilustrísimo Señor] Don Juan Manuel Gomez Dosamantes, vecino de esta ciudad, suplica a Nuestra Señoría Ilustrísima se sirva mandar dar pase para veinte y dos tercios, y cajones de catones, catecismos, y cartillas, que de Puebla remite don Pedro de la Rosa para su venta. México y mayo I2 de 1797 [Rúbrica: Juan Dosamantes].

I798, AGN, Inquisición, vol. 1325, exp. 6, año 1798, ff. 47-48. Don Pedro de la Rosa, solicita el pase para I6 balones y cajones de impresos que le remite de puebla don Pedro Pascual de la Rosa. [Documento no citado por Pérez Salazar, paleografía de MGG].

[Foja 47] Ilustrisimos Señores. Don Pedro de la Rosa suplica a Vuestra Señoría Ilustrísima se sirva mandar dar el correspondiente pase para diez cajones de catesismos y catones christianos y seis balones de cartillas y catones sensorinos y evangelinos, que de Puebla me remite don Pedro Pasqual de la Rosa. México, 2 de mayo de 1798. [Rúbrica: Pedro de la Rosa].

[Foja 48] Factura de diez y seis balones y cajones de impreso que de Puebla me remite don Pedro Pasqual de la Rosa. Vecino de la Ciudad de Puebla... A saber.

Por 6 cajones de catesismos con 718 docenas.............................................. a

Por 4 dichos de catones christianos con 385 docenas.............................. a

Por 4 balones de cartillas con roo resmas.................................................... a

Por 2 balones de catones sensorino y evangelios con 50 resmas....... a

Ángeles y abril 10 de 1798. [Rúbrica: Pedro Pasqual de la Rosa].

I80I, AGN, Inquisición, vol. I405, exp. 2, año I80I, f. II7. Don Pedro Marcos Gutiérrez solicita el pase para que le sean entregados en la Real Aduana, I balón de cartillas y I cajon de catones y catecismos que le remite don Pedro de la Rosa. México. [Documento no citado por Pérez Salazar, paleografía de MGG].

[Al borde superior: Ilustrísimo Señor] Don Pedro Marcos Gutiérrez introduce en ésta un balón de cartillas y un cajón de catones y catecismos y suplica a su ilustrísima se sirva mandar se le de pase, que de Puebla me remitió don Pedro de la Rosa. México y marzo 6 de i8or. [Rúbrica: Pedro Marcos Gutierrez]

I8oI, AGN, Inquisición, vol. I406, exp. 27, año I8or, f. 266. Don Pedro de la Rosa, del comercio de puebla, residente en México, solicita el pase para que se le entregue en la Real Aduana, z piezas con cartillas, catecismos, margaritas seráficas, colectivos y estampas del árbol genealógico de Cristo, además tres resmas de evangelios y tres de catones sensorinos. México. [Documento no citado por Pérez Salazar, paleografía de MGG].

[Centrado al borde superior: Ilustrísimos Señores] Don Pedro de la Rosa, del comercio de Puebla, residente en esta de México, ante Vuestra Señoría Ilustrísima, en debida forma digo= me vienen de mi casa e imprenta dos piezas con cartillas, catecismos, catones, margaritas seráficas, colectivos, y estampas del árbol genealógico de Christo, y para su paso de la Real Aduana, suplico a Vuestra Señoría Ilustrísima se sirva mandar dar el pase correspondiente. A Vuestra Señoría Ilustrísima suplico así lo mande, firma. Ángeles y febrero 12 de I8or. [Rúbrica: Pedro de la Rosa] así mismo tengo en dicha aduana tres resmas de evangelios y tres catones 
sensorinos, lo que juro por Dios Nuestro Señor ser cierto como llevo expuesto [Rúbrica: Pedro de la Rosa].

I802, AGN, Inquisición, vol. I408, exp. 5, año I8o2, f. 49. Diego Martinez, vecino de esta capital, solicita se le entreguen 4 cajones del catón cristiano, y catecismo del padre Ripalda, que remitió para su venta don Pedro de la Rosa, impresor en Puebla. México. [Documento no citado por Pérez Salazar, paleografía de MGG].

[Centrado al borde superior: Ilustrísimo señor] Diego Martinez, vecino de esta capital, suplica a Vuestra Señoría Ilustrísima se sirva mandar dar pase para cuatro cajones de catón cristiano, y catecismo del padre Ripalda, que se hallan detenidos en esta aduana, y remitió de Puebla para la venta el impresor don Pedro de la Rosa. Dios guarde a Vuestra Señoría Ilustrísima muchos años: México y agosto I9 de i8o2. [Rúbrica: Diego Martinez].

I802, AGN, Inquisición, vol. I4II, exp. 17, año I802, f. I36. Don Rogue Pérez Gomez solicita se le entregue en la Real Aduana los libros cuya lista adjunta, un balón de cartillas que le remite de Puebla don Pedro de la Rosa. [Documento no citado por Pérez Salazar, paleografía de MGG].

[Al borde superior: Ilustrísimo Señor] Don Roque Pérez Gomez de este com[erci]o suplica a Vuestra Señoría Ilustrísima se sirva decretar para que me entreguen en esta Real Aduana un balón de cartillas que me remite de Puebla don Pedro de la Rosa, favor que espero recibir de Vuestra Señoría Ilustrísima: México, diciembre 20, 1802. Por don Roque Perez Gomez Tirso Manuel González de Salzedo.

I802, AGN, Inquisición, vol. I4II, exp. 17, año I802, f. I46. Don Diego Martínez solicita un pase para I cajón de libros que contiene 85 docenas de catones cristianos, y I7 docenas de catecismos, que le remitió de Puebla don Pedro de la Rosa. [Documento no citado por Pérez Salazar, paleografía de MGG].

[Centrado al borde superior: Ilustrísimo Señor] Don Diego Martínez, vecino y del comercio de esta ciudad suplica a Vuestra Señoría Ilustrísima se sirva mandar dar pase para un cajón con 25 docenas catones cristianos, y 17 docenas de catecismos que para su venta remitió de Puebla el impresor don Pedro de la Rosa: Dios guarde a Vuestra Señoría Ilustrísima muchos años. México y febrero Io, a I8o2. [Rúbrica: Diego Martinez].

I803, AGN, Inquisición, vol. I419, exp. 2, año I8o3, f. I64. Don Diego Martínez, vecino y de este comercio, solicita el pase para un balón con 25 resmas de cartillas, que remite para su venta don Pedro de la Rosa. [Documento no citado por Pérez Salazar, paleografía de MGG].

[Centrado al borde superior: Ilustrísimo Señor] Don Diego Martinez, vecino de este comercio suplica a Vuestra Señoría Ilustrísima se sirva mandar dar pase para un balón con resmas de cartillas que para su venta remitió de Puebla el impresor don Pedro de la Rosa, y se hallan detenidas en esta Real Aduana. Dios guarde a Vuestra Señoría Ilustrísima muchos años. México y septiembre 6 de i803. [Rúbrica: Diego Martinez].

I8I8, AGN, Inquisición, vol. I421, exp. 22, año I818, f. I75. Don Pedro de la Rosa solicita el pase para un cajón de catones cristianos, que le remite de Puebla don Juan Antonio Porras, de aquel comercio. México. [Documento no citado por Pérez Salazar, paleografía de MGG]. 
[ilegible]n de Mexico y diciembre i9 de i818. [Centrado: Ilustrísimo Señor] Sírvase Vuestra Ilustrísima de mandar dar el correspondiente pase a un cajón de catones christianos, que me remite de Puebla don José Antonio Porras de aquel comercio. México ig de i818. [Rúbrica: Pedro de la Rosa].

1804, AGN, Inquisición, vol. I423, exp. 6, año 1804, f. 98. Don Diego Martínez Mobellán solicita el pase para que se le entreguen en la Real Aduana, 2 balones con 50 resmas de cartillas impresas, y que le remite don Pedro de la Rosa, de Puebla. México. [Documento no citado por Pérez Salazar, paleografía de MGG].

[Centrado al borde superior: Ilustrísimo Señor] Don Diego Martinez Mobellan suplica a Vuestra Señoría Ilustrísima se sirva mandar dar pase para dos balones con 50 resmas de cartillas impresas en Puebla, y se hallan detenidas en esta Real Aduana, las que remite de aquella ciudad para su espendio el impresor don Pedro de la Rosa. México, septiembre 7 de I804: [Rúbrica: Diego Martínez Mobellan].

I805, AGN, Inquisición, vol. I429, exp. I, año I805, ff. 75-76. Don Juan Bautista de Arizpe solicita que le entreguen los efectos de imprenta, que están detenidos en la Real Aduana y gue le remite don Pedro de la Rosa, librero en la Puebla de los Ángeles. [Documento no citado por Pérez Salazar, paleografía de MGG].

[Foja 75] [Centrado al borde superior: Ilustrísimo Señor] Juan Bautista de Arizpe, ante Vuestra Señoría Ilustrísima con el debido respeto expone: que se hallan detenidos en esta Real Aduana los efectos de imprenta contenidos en la adjunta nómina; para los cuales se suplica a Vuestra Señoría Illustrísima se sirva mandar dar el correspondiente pase y juro no ser otros efectos de imprenta que los expresados. México, 25 de mayo de i805. [Rúbrica: Juan Bautista de Arizpe].

[Foja 76] Lista de efectos de imprenta que remite don Pedro de la Rosa, librero en la Puebla de los Ángeles a don Juan Bautista de Arizpe.

Cartillas

Relaciones y romances de diferentes títulos

Caton Zensorino

Catecismos del Padre Ripalda

Catones por Don Pedro Barreda y Lombera

Margarita Serafica

México, 25 de mayo de I805. [Rúbrica: Juan Bautista Arizpe].

I806, AGN, Inquisición, vol. I43I, exp. II, año 1806, ff. I20-I21. Don Juan Bautista de Arizpe presenta la razón de los efectos de imprenta que remite de Puebla el impresor don Pedro de la Rosa. [Documento no citado por Pérez Salazar, paleografía de MGG].

[Fojas: I2O, I2I, I22. Pases para efectos de imprenta].

[Foja I20] [Centrado al borde superior: Ilustrísimo Señor] Juan Bautista de Arizpe, ante la vondad de Vuestra Señoría Ilustrísima con el debido respeto expone: que se hallan detenidas en esta Real Aduana, los efectos de imprenta constantes en la adjunta nomina, para los cuales suplico a Vuestra Señoría Ilustrísima se sirva mandar dar el correspondiente pase; y juro no ser otros efectos de imprenta que los expresados. México, y septiembre 9 de i8o6. Ilustrísimo. Por Juan Bautista de Arizpe. 
[En la parte inferior izquierda: El Santo Tribunal de la Inquisición]

[Foja I2I] Razón de los efectos de imprenta que remite don Pedro de la Rosa, librero e impresor en Puebla.

Catecismos del Padre Ripalda

Dichos Catecismos de letra grande

Cartillas corrientes para niños

Romances y varios títulos

México y septiembre 9 de 1806 [Rúbrica: Juan Baupt.ta de Arizpe].

[Foja I22] [Al borde superior: Ilustrísimo Señor] Don Diego Martínez, de esta vecindad y comercio suplica a Vuestra Señoría Ylustrisima se sirva mandar dar el correspondiente pase para un cajón con ochenta docenas catones de San Cassiano que se hallan detenidos en esta Real Aduana, y remite de Puebla don Pedro de la Rosa, juro no contener otra cosa en el cajón. Dios guarde a Vuestra Señoría Ilustrísima muchos años. México y agosto 29 de i8o6. [Rúbrica: Diego Martínez].

1807, AGN, Inquisición, vol. 1436, exp. 9, año 1807, f. 200. Don Tomas del Cañizo solicita el pase para un cajón de catecismos y catones que le remite de Puebla don Pedro de la Rosa. [Documento no citado por Pérez Salazar, paleografía de MGG].

México en 3 de marzo de 1807.

[Al margen superior izquierdo: (ilegible) en 3 de marzo de I807, señor inquisidor Flores] [Centrado al borde superior: Ilustrísimo señor] Dese el pase. Suplico a Vuestra Señoría Ilustrísima se sirva mandar me entreguen en esta Real Aduana un cajón de catecismos y catones que me remite de Puebla don Pedro de la Rosa, pues juro no es otra cosa. Dios guarde a Vuestra Señoría Ilustrísima muchos años. México, marzo 3 de 1807 años= [Rúbrica: Tomas del Cañizo].

I8Io, AGN, Inquisición, vol. 1447, exp. I3, año I8Io, f. 222 bis. Don Dionisio Martínez Movellan solicita el pase para los libros que le remite de Puebla don Pedro de la Rosa. [Documento no citado por Pérez Salazar, paleografía de MGG].

[Al margen superior izquierdo: (ilegible) en I3 de octubre de i8io [Centrado: Ilustrísimo señor] Don Dionisio Martínez Mobellan, vecino de este comercio, a Vuestra Señoría Ilustrísima suplica mande dar pase para 25 resmas de cartillas, I20 docenas catones cristianos y 206 de catecismos que de Puebla me remite don Pedro de la Rosa y están detenidos en esta Real Aduana, y juro no contener otra cosa. A Vuestra Señoría Ilustrísima así se lo suplico, etcétera. México, octubre i8 de i8ıo. [Rúbrica: Dionisio Martinez Movellan].

I8Io, AGN, Inquisición, vol. I449, exp. I, año I8ıо, f. I5. Don Dionicio Martínez Movellan solicita el pase para un balón con 24 resmas de cartillas y un cajon con 206 docenas de catecismos del padre Ripalda, que remite de Puebla el impresor don Pedro de la Rosa. [Documento no citado por Pérez Salazar, paleografía de MGG].

[Al margen superior izquierdo: (ilegible) en ro de enero de i8Io] [Centrado al borde superior: Ilustrísimo Señor] Don Dionisio Martinez Movellan de esta vecindad y comercio, suplica a Vuestra ilustrísima se sirva mandar dar pase para un balón con 24 resmas de cartillas y un cajon 206 docenas de catecismos del Padre Ripalda, que remite de Puebla el impresor don Pedro de la Rosa y se hallan detenidos en esta Real Aduana. Juro no contener otra cosa que lo 
que va expresado. Dios guarde a Vuestra Ilustrísima muchos años: México y enero io, de I8ı. [Rúbrica: Dionisio Martinez / Movellan].

I8Io, AGN, Inquisición, vol. I449, exp. I, año I8Io, f. 46. Don Dionisio Martinez de Movellan solicita el pase para un balon con 40 resmas de cartillas que le remite de Puebla el impresor don Pedro de la Rosa. [Documento no citado por Pérez Salazar, paleografía de MGG].

[Al margen superior izquierdo: Presentado en 8 de Marzo de i8ıo Señor Inquisidor Flores] [Centrado al borde superior: Ilustrísimo Señor] [Al margen superior derecho: Dese el pase] Don Dionisio Martínez Movellan de esta vecindad y comercio suplica a Vuestra Ilustrísima se sirva mandar dar pase para un balón con 20 resmas de cartillas que de Puebla me remite el impresor don Pedro de la Rosa, y se hallan detenidas en esta Real Aduana. Juro no contener otra cosa. Dios guarde a Vuestra Ilustrísima muchos años: México, 8 de marzo de ı8ıo. [Rúbrica: Dionisio Martinez Movellan].

I8Io, AGN, Inquisición, vol. I449, exp. I, año I8ıo, f. II4. Don Dionisio Martínez Movellan solicita el pase para 24 resmas de cartillas, I3O docenas de catones, y 2 II docenas de catecismos del padre Ripalda, que le remite de Puebla don Pedro de la Rosa. [Documento no citado por Pérez Salazar, paleografía de MGG].

[Al margen superior izquierdo: Presentado en in de Mayo de I8Io] [Centrado al borde superior: Ilustrísimo Señor] Don Dionicio Martínez Movellan, vecino de este comercio suplica a Vuestra Señoría Ilustrísima se sirva conceder el permiso para sacar de esta Real Aduana tres docenas con 24 resmas de cartillas, I3O docenas de caton cristiano y 2II docenas catecismos del padre Ripalda, que don Mariano de la Rosa me manda de Puebla, pues juro no contener otra cosa. A Vuestra Señoría Ilustrísima así suplico lo mande. México, mayo ıo de ı8ıo. [Rúbrica: Dionisio Martinez Movellan].

I8I5, AGN, Inquisición, vol. I458, exp. 2, año I815, f. 70. Don Pedro de la Rosa, del comercio de Puebla, solicita el pase para cinco piezas con los libros que constan en la factura que adjunta. [Documento no citado por Pérez Salazar, paleografía de MGG].

[Al margen superior izquierdo: ilegible] da Presentada en 2I de Agosto de 1818 [Centrado al borde superir: ilustrísimo Señor] [Al margen superior derecho: Désele el pase] Don Pedro de la Rosa, vecino y del comercio de Puebla ante Vuestra Señoría Ilustrísima con el debido respeto expone: que se hallan detenidos en esta Real Aduana cinco piezas con los libros que constan de la factura que acompaña todos de mi imprenta de Puebla. A Vuestra Señoría Ilustrísima suplico se sirva mandar dar el correspondiente pase para que se me entreguen. México, 2i de agosto de I8I5. [Rúbrica: Pedro de la Rosa].

I8I5, AGN, Inquisición, vol. I458, exp. 2, año I815, f. 87. Don Pedro de la Rosa presenta la factura de los impresos que remite don Mariano de la Rosa. [Documento no citado por Pérez Salazar, paleografía de MGG].

[Foja 86] Lista de los Romances y Relaciones venidas de Puebla remitidas por don Mariano de la Rosa... A saber

La Ciudad de [...] auja, El Oso, El Negro mas Prodigioso, Sta. Ma. Magdalena, El Testamento del Pobre anson, D. Bernardo Montejo Celirrada y Antonio Moreno, Travajos de David y tinezas de Micol, Carta de Fray Diego de Cadiz, Casa de Locos, Fiesta de los Remedios, El 
Monstruo de los Zelos, Azañas de Pedro Yldefonso, Ntra. Señora del Carmen, Los Amantes de Feruet, Antonio Montero, Plaza de Gallos, Estadio Birzanico, Testamento de la Virgen, Lucinda y Belardo Verdades del Tiempo, Desposorios de S. S. José, Rosaura, D. Eugenia, El Grillo y el Leon, Los Hijos de la Fortuna, El Juramento ante Dios, El Mariscal de Jirón, Los Foros, Cancion del P.e Bocanegra, Escuchen todos los Tristes [reclamo: Pasa a la B.ta Sta. Maria Magdalena, El cortesano discreto, El Desden Riqueza y Pobreza, Apartamiento del Cuerpo y el Alma, Tienda de Cupido, Festibidades del año, D.a Teresa de Llanos, S. Dimar, Combercion de un Pecador, Cancion del P.e Soria, Fénix Alva, El Belorio, Folias curiosas, D. Blanca, Los treinta [reales] México y septiembre 2 de i8i5. [Rúbrica: Pedro de la Rosa].

[Foja 87] Factura de los efectos siguientes que con el arriero Francisco Martínez me ha remitido de Puebla mi hijo don Mariano de la Rosa. A saber

No. I. I Cajón con I45 Io/12 Docenas Catecismos sin recortar........................ a

2. I Dicho con 250, Lavalles sin forrar................................................... a

30 Dichos forrados en pasta............................................................. a

36 Dichos chiquitos id<em> id<em>.............................................. a

2 Resmas de Romances......................................................................... a

I Dicha de Cartillas .......................................................................... en /

2 Docenas Catones Cristianos........................................................... a

3. I Otro con I6 Resmas de Romances.................................................... a

4. I Cajón con 52 docenas Catecismos................................................. a

8o dichas de Catones Cristianos........................................................ a

2 Resmas de Cartillas............................................................................ a

5. I Otro con 7 Resmas de Cartillas....................................................... a

2 Dichos de Evangelios........................................................................ a

3 Dichos de Silavarios......................................................................... a

2 Dichos de Romances........................................................................ a

$\mathrm{I}, 500$ Calendarios de bolsa.............................................................. a

300 Dichos estendidos............................................................................ a

México, agosto 2i de 1815. / [Rúbrica: Pedro de la Rosa].

I8I6, AGN, Inquisición, vol. I458, exp. 2, año 18ı6 (II de junio), f. 9I. Don Dionisio Cicero de Lombraña presenta la lista de los impresos que en 7 bultos le remite don Pedro de la Rosa, de la imprenta de Puebla. [Documento no citado por Pérez Salazar, paleografía de MGG].

[Centrado al margen superior: Ilustrísimo Señor] Don Dionisio Zicero de Lombraña: Ante Vuestra Señoría Ilustrisima con el debido respeto espongo: que tengo detenidos, en esta Real Aduana los impresos que en 7 bultos me ha remitido don Pedro de la Rosa, todos de la imprenta de la Puebla de los Ángeles y por los siguientes.

No. I. 91 Docenas de Catones christianos.

2. 25 Docenas Catones y i2o Docenas de catecismos del P. Ripalda.

3. II Resmas Romances surtidos 4 resmas catones y i caton censorio.

4. I6 Resmas de Cartillas.

5. 8 resmas cartillas y 4 resmas Caton censorio.

6. con Libros de Lavalle sin encuadernar.

7. 500 catecismos del Padre Ripalda: Asegurando a Vuestra Señoría Ilustrísima no contener otros libros que los espresados. A Vuestra Señoría Ilustrísima suplico mande se me de el correspondiente pase para que se me entreguen. Dios guarde a Vuestra Señoría Ilustrísima muchos años: México, junio ir de i8ı6. [Rúbrica: Dionisio Zicero de Lombraña]. 
I8I8, AGN, Inquisición, vol. I458, exp. 2, año I8I8 (I4 de abril), f. 187. Don Jose Merodio pide el pase para varios impresos que le remite don Pedro de la Rosa. [Documento no citado por Pérez Salazar, paleografía de MGG].

[Al margen superior izquierdo: Inquisición de México y abril I4 de I8I8. Señores inquisidores Pereda y Tirado] [Centrado: Ilustrísimo] Suplico a Vuestra Señoría Ilustrísma se sirva mandar me den el pase correspondiente para cinco catones de cartillas, catones y catecismos que don Pedro de la Rosa me remite de la Puebla de los Ángeles y son comprendidos en el privilegio de que goza, lo que juro ser verdad y no contener los citados cajones otros libros que los relacionados. México, abril I4 de ı8ı8. [Rúbrica: Jose Merudio].

1824, Cuentas entre Mariano de la Rosa y Mariano José de Zúniga y Ontiveros. Protocolo de don Ignacio Reyes Mendizábal. [Documento citado por Pérez Salazar, p. 357-359].

Señor don Mariano de la Rosa. -México I4 de enero de I824. Mi estimado amigo y Sor, de todo mi aprecio: -En virtud del apunte de cuentas que hicimos las cuales quedaron cerradas, por ellas se ve, serme usted deudor de cuatro mil quinientos treinta y un pesos líquidos, abonados los ciento con que abriamos nueva cuenta como Ud. consta y quedó firmada de su puño; pero hallñandome en la inacción desde que fenecieron los privilegios y los efectos que ellos tenían, se imprimen en varias partes y ha motivo de paralización de nuestro comercio, por cuya razón se hace indispensable el que Ud. me otorgue la escritura de reconocimiento con hipoteca de la imprenta y de dicha cantidad, la que se cancelará cuando Ud. con abonos anuales d setecientos cincuenta pesos haya satisfecho la que espero a vuelta de correo por que este documento debe parar en mi poder para mi resguardo; así mismo deberá venir con la nota del libro de censos e hipotecas. -Deseo a Ud. la mejor salud y mande a su afmo. servidor. -Q. S. M. B. -Mariano ontiveros. -Rúbrica. -en la ciudad de Puebla a diez y seis de enero de mil ochocientos veinticuatro. Ante mí el Escribano Nacional y testigos, el Sor. Corl. D. Pedro Pascl. de la Rosa a quien doy fe conozco: dijo: que D. Mariano José de Zúñiga y Ontiveros impresor y vecino de la Corte de México le ha dirijido a su hijo el Presbítero D. Maro. de la Rosa la carta que exhibe en una foja util, para que agregada al protocolo salga por principio de la copia de este instrumento: que siéndole deudor a dicho Ontiveros de los cuatro mil quinientos treinta y un pesos que expresa es documento, como resto de la cuenta corriente que ambos han llevado, y liquidaron últimamente estando el citado Presbitero en aquella corte; y habiendo convenido en satisfacerle esa cantidad en abonos parciales de setecientos cincuenta pesoso, anualmente y que para constancia de ese adeudo otorgase el relacionante un instrumento público por el dolo en efecto por el presente en el modo más oportuno y a derecho conforme, el anunciado Sor. Corl. D. Pedro Pascl. de la Rosa otorga: que es deudor a D. Mariano José de Zúñiga y Ontiveros impresor y vecino de México, de la cantidad de cuatro mil cuatrocientos treinta y un pesos, la que se compromete a pagarle abonándole setecientos cincuenta pesos cada día último de diciembre en los cinco años subsecuentes, y seiscientos ochenta y un pesos en el sexto en que debe quedar extinguido ese crédito y deberá ser de mil ochocientos veinte y nueve, haciendo esos abonos lisa y llanamente sin contienda de juicio y si lo hubiere, con la décima, costas y salarios de la cobranza le reintegrará, dependiendo el monto de todo en la simple ascersión de quien fuese parte legítima, sin otra prueba de que lo releva, hipotecando al mayor seguro de la enunciada cantidad la imprenta que tiene en esta Ciudad nombrada de Gobierno, con todos sus enceres, aperos, láminas, moldes y cuanto a ella es anexo la cual es suya propia, y sin que se entienda que esta especialidad derogue la generalidad de sus demás bienes habidos y por haber, con ellos se somete al fuero y jurisdicción d elas Justicias Nacionales que de sus causas deben 
conocer para que a lo dicho lo competan y apremien como por sentencia consentida y pasada en autoridad cosa juzgada, renunciando su propio fuero domicilio yvecindad, leyes de su favor y defensa con la queprohibe la general renunciación de todas. Así lo otorgó y firmó siendo testigos don Pedro Porras, don Francisco Morante y don Rafael Beltrán de esta vecindad. Doy fe. -Pedro Pascual de la Rosa. -Ante mí. -Ignacio Reyes Mendizábal y Pliego. - Rúbricas.

\section{JuAn NePOMUCENo Troncoso}

1827, Juan Nepomuceno Troncoso. [Documento citado por Pérez Salazar, p. 40o. Transcribo paleografía del investigador].

"En contestacion al oficio de V. S. de 7 del presente, en que se trancribe un auto del Sr. Juez de Distrito proveido en un espediente formado para cobrarme 2,500 pesos, que el Sr. Iturbide mandó entregar por mi mano al Sr. Durán debo decir.

Que hasta el dia no habia tenido noticia del espediente que se dice formado contra mí, ni ménos me creia con ninguna obligacion respecto del gobierno, con quien jamás he tratado ni de imprenta ni de otra cosa. Y por tanto ignorando qué trámites se hayan seguido, qué documentos le hayan agregado etc., y siendo muy probable que el mismo tribunal sea juez inmediato, un entero conocimiento del hecho.

A una simple pregunta que me hizo el Sr. Iturbide - ¿de quién nos facilitará una imprenta?respondí - el Sr. Duran, á quien V. S. (según se me dice) envia al Norte, la puede comprar y traer con prontitud- y su costo- una imprenta regular se compra allí con 2.500 pesos - pues se le entregaran á vd.

Duran estaba presente á este dialogo, Durán recibió (y por mi mano) mayores cantidades, y Durán pidió la órden para que el Sr. D. Carlos Garcia entregara los 2.500 pesos, pues que yo para nada volví al obispado; y por fin Duran hizo que mi bolsillo le acabalara la urgencia de su viage, de lo que hasta el dia se me debe parte, por las dificultades que ponía el Sr. Garcia con sus respuestas de - no hay dinero-

Saludado el Sr. Iturbide como emperador en la ciudad de Puebla, aun ántes de que se tomára México, me ví en la necesidad de hablarle como hombre de bien, y jurada desde entonces mi pérdida, sufrí y sufro hasta el dia una viva persecución, no solo del ministro Herrera, sino aun de otros superiores que no debo nombrar.

Como resultado de las contestaciones que había tenido conmigo el Sr. De Iturbide, después de haber preso en México á los señores Bravo y Victoria, se me llama con disimulo á la ciudad de Pueblo, y se me pone en Santo Domingo con centinela de vista. Ademas del espediente que se me formaba por enemigo del Emperador, se me preguntaba por el eclesiástico si había venido la imprenta, si tenia en mi poder el dinero, \&tc., y por conducto del ministro Herrera, se me pedían las contestaciones y conocimientos sobre Durán con la inversión que se había hecho el dinero. No puedo acordarme de lo que respondí en aquel; entonces rodeado de tantas amarguras al Sr. Provisor Posada; pero si tengo presente, que al ministro Herrera remití tres cartas de D. Manuel Martinez Priede y dos de Durán que me facilito el mismo Priede: advirtiéndole al ministro que estrañaba esos trámites con un hombre á quien se tenía en estrecha prisión, y que puesto en libertad, daría los documentos que tuviera por mi entero descargo.

La respuesta de esta contestación, fue enviar al cura de Tepeji con dos militares que cataron mi curato y registraron cuantos papeles tenía; puesto ya en libertad después de cinco meses de prisión, hallé de ménos entre mis papeles, todas las cartas de Durán Martinez Priede, toda la correspondencia que yo había tenido con el Sr. Iturbide, la del Dr. Mier y dos cartas que guardaba con un pequeño paquete del Sr. O’Donojú. A quién podía yo entonces representar mis agravíos? ¿A quién quejarme de tamañas injusticias y atropellamientos? Solo á Dios solamente lo hice. 
Desde entonces hasta la fecha del oficio de V. S., creo que han corrido cinco años, y en tan dilatado tiempo, no se me ha hablado ni de cobro ni de espediente. En el año pasado murió el capitán Lorenzana o Lorenzani: el mes de Febrero de este año, murió Martinez Priede. Estos individuos fueron los que me dieron relaciones con Durán, y los que podrían dar noticias que yo ignoro. No puedo comprender el motivo de tanta dilación en el espediente, y la causa que ahora los impele á proseguir sus trámites con tanta actividad.

Todo esto, señor provisor, hace un bello contraste con lo que voy a exponer: esposicion que juzgo muy necesria, aunque á primera vista se crea sin ninguna relación con el reclamo que se me hace.

Representé al ministro de hacienda por 4.000 pesos que en tabacos ministré al Sr. Matamoros para la toma de Oajaca: se me pidieron documentos, envié hasta el romaneage de los tercios, y hasta la fecha no he podido conseguir una contestación.

Representé al Supremo Gobierno, que el único capital que contaba, después de muchos servicios, para mis alimentos, era mi patrimonio, títulos de Orden; que esta cantidad, de 6.000 pesos, estaba en una casa de Veracruz, y que se había arruinado casi toda, con las bombas de San Juan de Ulúa envió Lemaur para los desgraciados que de que con nuestras ruinas habíamos de levantar los tronos que iban á ocupar otros; hasta el dia no hice ver que mis enfermedades me obligan á renunciar un pobre beneficio que sigo administrando por no tener de otro modo un pan que me quité de la boca por los demás americanos; y por toda respuesta, se me ha dicho (año y cuatro meses ha) que mi memorial que esta en la junta de prémios. ¡Que diferencia de tantos sacrificios, tantos cargos! Yo espero que saldrá de allí, después que yo haya entrado en el sepulcro.

Por lo espuesto, me parece que ha de conocer V. S., que yo no contraje ninguna obligacion con la hacienda pública y mucho menos con la del Estado de Puebla, que entónces no ecsistia: que Duran tenia mas íntimas relaciones con el Sr. Iturbide y con el ministro Herrera; que Durán, como otros muchos se fue a Nueva Orleans, desde donde están haciendo sus comercios, y desde donde no temieron caer bajo las ruinas del imperio de Iturbide; que Durán había venido y se había vuelto á ir mil ocasiones, sin necesidad de verme á mí, de quien debía desconfiar como enemigo del emperador: que tampoco tengo conocimiento de dicho espediente, ni ménos de quíen es el que pide contra mí; y finalmente, que no tengo ningun documento que presentar, ni sujetos que señalar para dar conocimiento de Durán.- permítame V. S., que añada que la reunion de la magistradura y de las funciones judiciarias, no pude convenir con los principios de una buena administración de justicia; que los deberes de magistrado y de juez, son muy distintos y no pueden confundirse; que conbinado esto con lo que sufrí en el cateo de mis papeles, y el silencio que se guardó hasta después de haber muerto los dos individuos que influyeron en este asunto, son motivos que deberán tenerse presentes para cualquiera providencia que se tome. Sin embargo, el señor juez de distrito dictaminará como le parezca; el presbítero Juan Nepomuceno Troncoso ha cumplido con hacer una esposicion sencilla y cierta sobre lo que se le pregunta. Dios \&c. Mayo I2 de I827".

\section{IMPRENTA DEL Colegio Real de SAN IgNacio}

S/fecha, AGN, Indiferente Virreinal, Caja 1338, exp. oI7, sin fecha., 2 fojas, Colegio Real de San Ignacio. Contenido: Memoria de los caracteres que se han de remitir al Colegio Real de San Ignacio de la ciudad de Puebla de los Ángeles, para completar su imprenta. [Documento no citado por Pérez Salazar, paleografía de MGG].

[folio r] Memoria de los Characteres, que se deberàn remitir a este Colegio Real de Sn Ignacio de la Ciudad de la Puebla de los Angeles, para el Complemento A su nueva Imprenta 
Parangona Redonda-Quatro libs de -r- Quatro de - $\mathrm{u}$ - Quatro de -l- Quatro de -t- Dos de $\iint \mathrm{i}$ y $\iint i-$ Una de Manitas. Quatro de -p- Dos de -s- Dos de - - - Dos de -c- Quatro de -d- Dos de -U- dos de -A- dos de -I- dos de -S- Media arroba de Viňetas- media de Espacios- quatro libras de -a- quatro de -n- quatro de -o- ocho de Quadrados - seis Abecedarios de letra de dos líneas que acá llamamos Titulos ------- U oo zax. ızlibs

Su Cursiva- Quatro arrobas, repartidas en todo lo necesario, para una Caja, con excesso estas letras: Q-A-S-J-û, por aver faltado en lo que antes vino, como también esta-h ------ Uoo 4 ax-oo-

Texto Redonda- Ocho arrobas, bien repartidas en todo lo necesario para abundar lo que hay en dho [dicho] Colegio, con especialidad estas letras -A-S- Vendran también seis Abecedarios de dos líneas, excediendo estas -A-J- no olvidándose de incluir Manitas -- Uoo\&ax-ou

$\mathrm{Su}$ Cursiva- tres arrobas, en la misma forma repartidas.- excediéndose en los Espacios. --Uoozax.oo

Athanasia Redonda- Quatro libras de -a- quatro de -r- quatro de -n- quatro de - $t$ - quatro de -1quatro de -o- quatro de -e- quatro de - $y$ - quatro de -u- quatro de -m- quatro de -c- quatro de -d- dos de -p- dos de -q- dos $\iint \mathrm{i}$ dos de $\iint \mathrm{i}$ de - quatro de -.- quatro de -s- quatro de -C- quatro de -M- dos de -P- dos de -U- dos de -E- dos de -I- una de -?- dos de Manitas dos de -i- ocho de Quadrados- doce de Espacios- doce de Viñetas---- U oo4ax I5 libs U o2zax 03 libs

[folio 2] Cursiva- Dos libras de cada una de estas letras -r-t-c-d-e-a-m-n-o-u-v-z-y-l-p-q-g-s- $\int$ -l-h-b-R-C-D-I-S-A- una libra de $\iint i$ una de $\int f i$ una de +-y de la n- vendran no dos, sino quatro, una de $\mathrm{x}$ - dos de P- U ozax I3 libs 4 libs

Lectura Redonda- Quatro libras de -S- Quatro de -M- dos de -C- dos de -P- quatro de $\int$ dos de E- dos de F- dos de +- dos de I- dos de 2- dos de 1- dos de -d- dos de -u- quatro de -c- quatro de -n- dos de -y- dos de -r- seis de -e- doce de Espacios- ocho de Quadrados- diez de Viñetas --- U оозахо 7 libs

Su Cursiva- Dos libras de cada una de estas letras -S-C-I-y-n-t-d- y quatro de -.- dos de Manitas -- U ooo ax 20 libs

Entre dos- Quatro libras de -i- quatro de -n- seis de S- quatro de M- quatro de +- quatro de numero - $\mathrm{I}^{-}$dos de -2- dos de -6- dos de -7- dos de -t- dos de -u- dos de -r- ocho de -.- una de Versículos- una de $\mathrm{R} \chi$ [responsorio] una de $\iint \mathrm{i}$-una de $\iint \mathrm{i}$-de cada letra de estas-q-ã- ẽ-õ-uuna libra -doce de Espacios- ocho de Quadratines- ocho de lineas -diez de Viñetas -quatro de $f$ cuatro de-s- quatro de C -dos de F- dos de J- dos de m- quatro de Quadratinillos

Su Cursiva- Dos libras de -m- dos de - $\mathrm{t}$ - dos de -i- dos de -r- dos de -n- quatro de -u- dos de -C- dos de -M- dos de -R- dos de -P- dos de -S-s seis de Espacios- dos de * estrellitas dos de estas - ã- ẽ-õ-u-q- ------U ooS ax 24 libs

Breviario Redondo-Diez libras de lineas-doce de Viñetas -dos de- + -dos de -S- dos de-M- dos

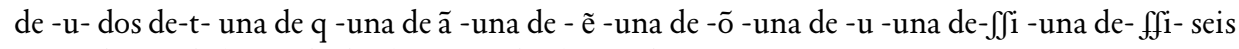
Abecedarios de letras de dos lineas--- dos libras de -i- --

Su Cursiva- Dos libras de -c- dos de-i- quatro de -.- puntos -Diez de Espacios ---

$\mathrm{U}$ o02 ax I5 libs passa $\mathrm{U}$ 038 ax in libs

[folio 3] Vendran 28 arrobas de Lectura Mediana, incluyéndose en ellas su Cursiva correspondiente, letras de dos lineas- Viñetas, y todo lo necesario, bien repartido, excediéndose en los Espacios, y algunas mas $\iint$ largas por ser los que mas presto padecen --- U $028 @$

Diez y ocho@de Peticanon con las mismas condiciones--- U oor8

Diez y ocho@ de Missal en la conformidad--- U oor8@

Diez y ocho Gran-Canon: todo bien surtido--- U oor8@U orzori@ir libs

Vendran dos Abecedarios de Letras labradas, uno mayor que el otro- 
Asimismo: tres Trechos para comenzar Obra, uno de Folio, otro de quatro y de octavo el otro, con la calidad de que los dos primeros han de tener un circulo en medio y èste abujerado, para poderle alli meter el Escudo de Armas de la Religión que le tocare; los cuales vendran tambien, V.g. [Verbigracia] Ths Maria, Joseph \&rc. Y unos mismos serviran al primero y segundo Trecho, abriendo los Circulos de un propio tamaño;

A mas de todo lo dho [dicho] vendran dos libras de ceros y dos divisiones en estas letras-Paran[folio 4] gona-Texto-Athanasia-Lectura, Entredos- Breviario-

Vendran tambien las de Entredos, repardidas entre Redonda y Cursiva, al respective excediéndose en las divisiones, por aver acà muy pocas-

Todo esto ha de ser del mismo Fundidor, o en las mismas Matrices, y con los propios metales, por que de no sera perder la letra que tiene dho [dicho] Colegio, con solo que desdiga en Carácter ô dureza, y así: las temas Castas de letra, que entera y muevam. Se piden, como Son: Gran-Canon-Peticanon-Lectura Mediana y Misal- han de venir uniformes en todo.

\section{IMPRENTA DEl ORatorio de SAN Felipe Neri}

Expediente instruido a instancia del R. P. Prepósito del Oratorio de San Felipe Neri sobre erección de una imprenta, a lo Que se opone D. Pedro de la Rosa a virtud del Privilegio que tiene para algunos papeles que él sólo puede imprimir, no se ejecute esto en dicha imprenta. [Expediente publicado por Ramón Sánchez Flores. Puebla de los Ilustrados. Puebla: H. Ayuntamiento del Municipio de Puebla, 1993-1996, p. 139-217. (Col. Crónica de Puebla número 3). Transcribo la paleografía del investigador].

Página blanca $[\mathrm{I} 4 \mathrm{I}]^{803}$

[Un sello que dice:] HISPANIA RUM MEX CAROLUS. IV. D. G.

Otro sello FERNANDO VII G.M. AÑOS I8I5 DOS REALES

Otro sello FERNANDO VII D. G.M. AÑOS I8I7 DOS REALES

Otro sello FERNANDo viI D.G.M. AÑos I8I8 i8I9 Dos REALEs Puebla i6 de Marzo i8I9 El Asesor SEÑor CONTAdor InTEndente. El presbítero D. Joaquín Furlong Prepósito del Oratorio de San Felipe Neri de esta ciudad, ante V. S. como mejor procede digo: Que agotados en la mayor parte los recursos para sostener esta Santa Casa, he meditado un arbitrio que al paso que pudiese contribuir a tan piadoso fin, fuese al mismo tiempo extensivo al bien público, con conocida utilidad del estado en la moral, y político. Dicho arbitrio consiste en una imprenta abastecida de lo más necesario y exquisito, que formada en la Imprenta Real de Madrid fue conducida a Campeche con las asistencias necesarias, y de allí a esta capital. Dispuestas las oficinas correspondientes sólo resta el beneplácito de V. S. para dar principio a las impresiones. En ellas por supuesto que se han de observar escrupulosamente los Reglamentos y Reales Cédulas que rigen en la materia, sin permitir se dé papel alguno a la luz sin el pase del Censor Regio, y también de la jurisdicción eclesiástica cuando sea necesario según lo disponible el Santo Concilio de Trento.

Es por demás asegurar a V. S. que tiene harto conocimiento y larga experiencia del modo de pensar de esta Congregación, que la referida imprenta estará siempre a disposición de Gobierno para servirlo a todas horas con la preferencia que corresponde y e cuanto ocurra, en esta virtud.

A V. S. rendidamente suplico se digne a concederme su beneplácito, para el fin referido en que recibiré merced.

$$
\text { Joaquín Furlong, Presbítero }
$$

\footnotetext{
${ }^{803}$ Debido a las infructuosas gestiones para consultar directamente los archivos de la Orden de San Felipe Neri, hemos decidido transcribir el documento que ofreció Ramón Sánchez Flores. Para poder citarlo pertinentemente se indica entre corchetes, en cada sección, la página del libro donde se encuentra.
} 
[142] La solicitud del Reverendo Padre Prepósito del Oratorio de San Felipe Neri de esta ciudad, Don Joaquín Furlong, se reduce a impetrar de V. S. permiso para poner en ejercicio la imprenta española, que se compró con objeto de auxiliar y sostener el recomendable instituto del Oratorio, manifestándose la disposición que anima ese virtuoso Prelado para respetar y obedecer ciegamente las resoluciones del gobierno, y para servirlo a todas horas, con preferencia y en cuanto ocurra.

Tal pretensión demuestra sin equivocación el escrupuloso conato con que el Padre Furlong consagra sus respetos a las autoridades, pues no estando prohibido el establecimiento de la imprenta, no sólo lo denuncia, sino que se sujeta al permiso de V. S. y acredita su ardiente celo y bien común, que es el que lo anima, siempre como es público y notorio, y lo mueve en esta vez y ella es tanto más apreciable cuanto que aumenta al Gobierno los arbitrios de que sea servid con fidelidad, eficacia y empeño, presentándole una ocasión en que sola la protección contribuya al aumento de fondos de una corporación, que compuesta de Ministros respetables es de una utilidad tan grande como indudable según que se está viendo.

Esto supuesto y que las protestas relativas a la observancia de las Leyes son de estimarse bien sinceras atendiendo el carácter de la persona que las hace y del cuerpo a que representa, es de parecer el Asesor que V. S. siendo servido puede otorgar su permiso para la apertura de la Imprenta, que quedará como todo establecimiento sujeto a las disposiciones que son respectivas, y de la que V. S. mismo se valdrá cuando lo estime conveniente, previniendo se haga saber de ruego y encargo al Padre Don Joaquín Furlong esta providencia, y el agrado con que V. S. ha visto y ve los sentimientos patrióticos de la congregación y de su cabeza, y mandando que si para resguardo se pidiere testimonio de el Expediente, que se franquee. Puebla Marzo 20 de i8ig.

Rúbrica. Puebla Marzo 26 de i8i9

Como parece al Asesor Rúbricas José Ramón Arellano

[I43]

Sello: ET. IND.RE ERDIN. VII. D.G HISPANIA. RUM.

otro G.M. AÑos DE

I8I8-I8 FERNANDO VII

Sello: FERDIN. VII G. HISP. ET. IND. REX

Sello: FERNANDO VII. D.G.M. AÑOS DE I8I2 I8I3 DOS REALES

Sello: FERNANDO VI D.G.M DOS REALES

Sello: FERNANDO VII D.G.M. AÑOS DE I8I8 I8I9 DOS REALES

La ciudad de Los Angeles a veinte y seis de marzo de ochocientos diez y nueve, yo el Escribano, habiendo pasado al Oratorio de San Felipe Neri, y presente en él, el Presbítero D. Joaquín Furlong en persona le ruego y encargo, le hice saber el Dictamen y Auto que sabedor y entendido dijo: que dando como da las debidas gracias al Tribunal por las expresiones tan agradables con que ha accedido a su solicitud, suplica se le dé testimonio de todo este expediente: esto respondió: "doy fe.-

Ramírez

Se sacó testimonio de todo este expediente en fojas de tres, la primera del sello segundo y las dos del común en Puebla a treinta y uno de Marzo de mil ochocientos diez y nueve.

Ramírez

EXMO. SEÑOR

El Presbítero D. Joaquín Furlong Prepósito de la Congregación de San Felipe Neri de esta ciudad, por el ocurso que sea más conforme a derecho ante V. E. digo: Que entre los diferentes 
arbitrios que he tomado para subvenir en algún modo a los gastos de mi Congregación, y reponer el estado decadente de sus rentas, uno de ellos fue, el de poner una imprenta, que administrándose por cuenta de la casa rindiese algunos productos en su favor.

Pero para dar corriente a esta oficina se presenta la dificultad que el Teniente Coronel D. Pedro de la Rosa alega tener un privilegio por el que varios papeles que se dan a la prensa sólo él, los puede imprimir. [I44] Así pues no encuentro otro arbitrio para allanar esta dificultad que dirigir a V. E. este curso para que con vista, y examen del referido privilegio tenga la bondad de poner fin a esta duda declarando lo que sea justo.

En cuya virtud se ha de servir V. E. de prevenir al citado Teniente Coronel, que exhiba su documento $u$ otros recados que tenga sobre el particular, que si hecha la exhibición considera V. E. de justicia que se me oiga sobre ello, se me entreguen formalmente; y que con presencia de lo que por una y otra parte se alegue, V. E.

A. V. E. suplico mande hacer como va dicho: justo lo necesario, etc.

Rúbricas

Joaquín Furlong

Lic. José María

Prepósito

Ponce y Rincón

Puebla Mayo I4, I8I9

Ante mí José Ramón Arellano

[I45] SELLO TERCER, SESENTA Y OCHO MARAVEDIS AÑO DE MIL SETECIENTOS Y SETENTA Y SIETE EL REY

Virrey, Gobernador y Capitán General de las Provincias de la Nueva España, y Presidente de mi Real Audiencia que reside en la ciudad de México.- Por parte de Don Pedro de la Rosa, vecino de la ciudad de Puebla de los Angeles se me ha hecho presente, que por representación de Doña María Manuela de la Rosa, y Ortega su hija y bisnieta de Don Miguel de Ortega, y de Doña Manuela Cerezo, ha recaído en él la imprenta que en la misma ciudad tenía Don Diego Fernández de León con el privilegio exclusivo de imprimir los actos, conclusiones y papeles de convite, para entierros y demás funciones que se ofrecen en ella, cuyo privilegio se confirmó por Real Cédula de nueve de Septiembre del año de mil setecientos veinte y cinco a la expresada Doña Manuela viuda del referido Don Miguel, para si sus hijos, herederos y sucesores, como todo contaba del testimonio que incluía, añadiendo que habiéndose amparado en la posesión de la enunciada imprenta y real privilegio y deseoso de que la exclusiva que éste contiene no se entienda limitada a las de aquella Ciudad, es extensiva a esa de México, las demás del Reino, me suplicaba, que a fin de evitar litigios y controversias, fuere servido de mandar expedir a su favor para que sólo en su imprenta, y no en otra alguna se puedan que sólo en su imprenta, y no en otra alguna se puedan imprimir los mencionados actos, conclusiones y papeles de convite que se ofrezcan, bajo las penas pecuniarias que tuviera conveniente imponer, y visto lo referido en mi Consejo de las Indias con lo que en su inteligencia, y de los antecedentes expuso mi Fiscal; ha parecido (entre otras como ordenaros y mandaros (como lo [i46] ejecuto) que entretando que se evacuan los particulares que entenderéis por otra Real Cédula, que con la fecha de esta se os dirige y se resuelve otra cosa en el particular, disponga que al mencionado Don Pedro de la Rosa, no se le impida el que en la conformidad que está dispuesto, me dé del Oratorio de San Felipe Neri del Instrumento exhibido por el Teniente Coronel Don Pedro de la Rosa, pidiendo el expediente entréguesele en la forma ordinara, y devuelto testimóniese el recado presentado por la Rosa, devolviéndose el original a la parte, y dése cuenta para proveer lo conveniente. Lo mandó al Exmo. Señor Brigadier don Ciriliaco del Llano, Gobernador Intendente con acuerdo de su Asesor en Puebla a veinte y nueve de Mayo de mil ochocientos diez y nueve 


\section{Cuatro SEllos}

SELLO TERCERo, DOS REALES, AÑOS DE MIL OCHOCIENTOS DIEZ OCHO CIENTO ONCE EXMO. SEÑOR

El Presbítero don Joaquín Furlong, Prepósito de la Congregación de San Felipe Neri de esta ciudad; en el expediente que promuevo para usar de una imprenta en mi Oratorio, como mas haya lugar en derecho digo: que notificado según mi anterior pedimento, el Teniente Coronel Don Pedro de la Rosa, para que manifestare el documento y demás papeles, relativos al privilegio exclusivo que alega, sólo exhibió la Real Cédula de catorce de Agosto de mil setecientos setenta y siete que obra a fojas cinco del expediente.

Bien advertirá V. E. de su contenido, que se refiere a otras reales Cédulas anteriores, siendo la una, de [147] Nueve de septiembre de mil setecientos veinte y cinco y la otra cuya fecha no se cita, expedida en favor de Don Diego Fernández de León. Estas disposiciones soberanas, son puntualmente las que deseo ver, porque ellas darán la luz que necesito para mi gobierno en este asunto: y así vuelvo a suplicar a V. E. que mande notificar al referido Don Pedro de la Rosa, exhiba las mismas reales Cédulas que he dicho, y unidas al expediente se me entreguen, para que examinándolas como debo, o desista de mi proyecto o alegue con dirección de letrado lo que me importe: y por ser justo.

A. V. E. pido que así lo determine: juro, etc.

Rúbricas.

Joaquín Furlong.

Lic. José María

Prepósito

Ponce y Rincón.

Puebla, Junio 9 de i8rig.

\section{$\mathrm{Al}$ Asesor}

Exmo. Señor

No ofrece dificultad la solicitud que en este escrito hace el Reverendo Padre Prepósito de la Congregación del Oratorio, y así defiende a ella V. E. puede disponer se haga todo según por el interesado se pretende.

Puebla, Junio ir de i8ıg. Rúbricas

Puebla, Junio ir de i8ig. Como parece al asesor.

[I48] Dos sellos Sello tercero, Dos Reales, AÑos DE MIL OCHOCIENTOS DIEZ Y SEIS, Y MIL OCHOCIENTOS DIEZ Y SIETE EXEM. SEÑOR

El Presbítero Don Joaquín Furlong, prepósito de la Congregación de San Felipe Neri de esta ciudad, el expediente instruído sobre la imprenta de mi oratorio, por el ocurso más conforme al Teniente Coronel Don Pedro de la Rosa, según mi anterior solicitud, que manifestarse las dos reales cédulas en que funda el privilegio, exclusivo de su casa, que no lo verificaba en el acto, por tenerlas su apoderado en México, que dentro de poco las presentaría; y que suplicaba se le amparase en la posesión que tenía ya pedida del goce del privilegio, pidiendo por último se me intimase que me abstenga de imprimir lo que a él toca, y demandándome los perjuicios que por esto se le hayan ocasionado.

En suma: se queja de que lo he despojado de sus derechos: y con tal idea no sólo ha pedido dos veces en estos autos el amparo de la posesión (en la que bastante se contradice), sino que aún por medio de otros ocursos sueltos ha insistido en su proyecto, sin embargo, de que ignoro el éxito que hayan tenido.

Pero sea lo que fuere, me veo en precisión de contestar al traslado que se me previno de su última respuesta, ya lo hago con dos proposiciones sencillas: primera que don Pedro de la Rosa, no es parte legítima para reclamar aquella posesión; segunda, que aunque lo fuera ni hay ni se ha probado esa alegada posesión. 
En cuanto a lo primer, yo advierto por el tenor de la real cédula de fojas 5, que don Pedro de la Rosa, padre del Teniente Coronel, ocurrió a S. Majestad diciendo que por representación de doña Manuela de la Rosa y Ortega, otra hija suya, había recaído en él la [I49] Imprenta con el privilegio citado; y por tanto implicaba que se le amparase en la posesión que había tenido de aquella gracia.

Esto quiere decir, que don Pedro de la Rosa el viejo, no era dueño de la imprenta ni del privilegio, sino que su hija, doña María Manuela había heredado uno y otro de sus bisabuelos maternos, don Miguel de Ortega y doña Manuela Cerezo, y tal vez, por los derechos de la patria potestad, por otro cualquier motivo, representaba al Rey las acciones de su hija.

Esta se casó después, y tuvo legítima sucesión antes de que muriese su padre: de que infiero según las leyes, que don Pedro ni heredó a su hija, ni tuvo ya voz ni voto para ella, pues que todo debió recaer en sus hijos o en el marido.

Ahora bien, el Teniente Coronel don Pedro de la Rosa, fue hijo del otro don Pedro, en el segundo matrimonio que éste contrajo con una señora Carrera, y por consiguiente, nada puede tocarle de su media hermana la referida doña María Manuela, supuesto que ella, siendo la dueña de la imprenta, murió dejando sucesión legítima, que por derecho excluye para heredar no solo a los hermanos sino a los mismos padres.

Pues de dónde le vienen al Teniente Coronel ese derecho que alega, cuando no lo heredó de su padre, ni éste de la hija, porque ya se sabe que falleció dejando prole, ¿ $\mathrm{Ni}$ cómo quiere se le mantenga en posesión de un privilegio que el Soberano le tenía concedido de otra familia muy distinta?

He aquí la causa única por qué yo pedí la exhibición de las Reales Cédulas primitivas, pues que oyendo por una parte las reconvenciones de [De] la Rosa, para que me abstuviese de imprimir, y teniendo por otra, aquellas seguras noticias, combinadas con el tenor del real rescripto manifestado, creí que sólo compondría esas contradicciones, examinando con detención las cédulas porque se concedió primeramente el privilegio en cuestión.

Allí precisamente ha de decirse, a qué persona o familiar se hizo la gracia, bajo qué condiciones, por [150] cuánto tiempo, y todo lo demás que deseo saber en el particular, para disputarle o no a don Pedro sus pretensiones; pero bien ve V. E. que en más de tres meses que han pasado desde que se le intimó la exhibición de aquellos documentos, todavía no lo verifica, con todo de no haber centenares de leguas de aquí a la capital.

La Real Cédula que ha manifestado hasta ahora, y de que voy hablando, lejos de apoyar sus miras, las destruye, pues bien claro dice, que el privilegio fue concedido a lo menos confirmado a la viuda de Ortega, para ella, sus hijos, herederos y sucesores, y no hallando yo por donde venga tal título a don Pedro de la Rosa, entiendo que ningún derecho tiene a aquella gracia, siempre que por otra disposición soberana no me pruebe que la adquirió.

Vengan pues las que deseo: examinemos su contenido; y si en ellas encuentro la justicia que alega el Teniente Coronel yo le prometo que al momento logrará sus proyectos, porque he dicho y repito, que estoy muy distante de querer originarle mal alguno; pero mientras así no sea, como que las noticias que tengo de su origen, y lo que he visto en la Real Cédula presentada, me dicen que no ha heredado el privilegio; de ahí que el hubiere asentado al principio, no ser parte legítima para pedir la posesión.

Dije en segundo lugar, que su casa no la ha tenido, o por lo menos no la ha probado, y es tan cierto eso, como que en el tiempo que este colegio seminario tuvo una imprenta, no solo daba a su prensa los actos y conclusiones de sus alumnos, sino aún los de Real Colegio Carolino, como puedo justificarlo; y hasta que don Pedro de la Rosa no compró esa imprenta, en la suya, y en la suya en esta se imprimió cuanto se ofrecía. 
Después por la malísima letra que usaba, y por la carestía de su oficina, tomaron muchos sujetos (entiéndase vecinos de esta ciudad) el arbitrio de ocurrir a México para la impresión de sus actos y conclusiones, según que también puedo probarlo; y advierto aquí V. E. los motivos por que dije que no ha habido tal posesión del referido privilegio.

[I5I] Pero aún hay más, porque si estamos al tenor literal de la Real Cédula de Fojas 5, veremos que la gracia concedida no sólo privaba imprimir a las oficinas de esta ciudad, sino también a las de México y demás lugares del Reino; y como nunca he sabido de la capital ni de otra cualquier parte hayan venido a dr a la prensa sus actos, conclusiones ni convites a Puebla, infiero que la imprenta de los Rosas, nunca ha gozado de aquel exclusivo privilegio, o por mejor decir no lo ha poseído pues no lo ha usado.

Para eso creo que hubiera sido necesario el haber presentado la Real Cédula al superior Gobierno de esta N. E. para que le decretase el correspondiente pase, y que este mandara poner al interesado en el goce, y cuasi posesión del privilegio: mas nada de esto veo en el documento que hasta ahora nos ha manifestado don Pedro.

Finalmente advierto allí, que aunque el Soberano mandó a su Virrey de esta N. E. que dispusiera de continuarse aquella gracia a don Pedro el nieto, por representación de su citada hija, también previno que esto se hiciese, entretanto que se evacuaran lo particulares que se le avisaban por otra real cédula dada en la misma fecha, y como no se que resultas hubo sobre aquellos particulares, dudo en muchas cosas y aún de que se hubiere manifestado este real rescripto al Superior Gobierno.

Todas estas especies reunidas, forman un gran comprobante de que no hay ni ha habido la posesión que pretende el Teniente Coronel, como para lograr sus intentos necesita convencerme, lo primer, de que es parte legítima en el goce del privilegio, y lo segundo, que lo ha poseído en quietud y sin contradicción; por eso al principio de este escrito, senté las dos proposiciones que mi entender he probado.

Si yerro en mis conceptos, V. E. tendrá la bondad de advertírmelo; pero si no, ejercítela e intimar seriamente al de la Rosa, que no nos molesta con infundadas pretensiones y continuos recursos, sino que manifieste como se le ha ordenado, los documentos de [152] su justicia, declarando V. E. entretanto, que no tiene lugar en derecho, el amparo en la posesión que solicita y no ha justificado: por tanto.

A. V. E. suplico que así lo decrete y mande, que es justo, etc. Etc.

Rúbricas.

Joaquín Furlong

Puebla Septiembre 23 de i819

Asesor

\author{
Lic. José María \\ Ponce y Rincón \\ (otra)
}

José Ramón Arellano.

\section{RESELLOS}

SELLO TERCERO: DOS REALES: AÑOS DE MIL OCHOCIENTOS CATORCE Y QUINCE

Don Pedro de la Rosa Teniente Coronel retirado del Regimiento de Dragones Provinciales de esta Ciudad en el expediente instruido por parte del R. P. Prepósito del Oratorio de San Felipe Neri de esta ciudad, don Joaquín Furlong sobre que suspenda a mi casa el uso y ejercicio del Real Privilegio que goza en cuanto a impresión de Actos, Conclusiones y Papeles de Convites, sin embargo de haber estado en quieta y pacífica posesión el dilatado tempo de cuarenta y dos años. Dice que al fin de proveer V. E. en justicia sobre lo pedido en materia por el citado Padre Prepósito tuvo a bien mandar con acuerdo a su Asesor que yo exhibiese la Rea Cédula conce- 
dida por S. M desde el año de setenta y siete del siglo anterior en que se expresaba el insinuado privilegio [I53] cumplí a la letra y sin la menor demora, exhibiendo en el acto de la notificación de la citada Real Cédula, suplicando solamente que se me devolviese original quedando de ella testimonio en el expediente que se había comenzado; y que pendiente este artículo se me amparase en la posesión que gozaba, conforme a las Leyes y Autos acordados de la materia.

Ni uno ni otro se ha verificado, pues sin embargo de haber corrido cerca de dos meses no se me ha devuelto la referida Cédula que es puntualmente el formal título en que se funda el derecho exclusivo de mi casa por lo que respecta a los papeles que hayan de imprimirse, ni menos he logrado que se me ampare en la posesión que estaba gozando pacíficamente permitiéndose que se interrumpa arbitraria y voluntariamente, no obstante haberse continuado por más de cuarenta años, como es de público y notorio; y se acredita la interrupción reciente con los tres impresos que debidamente y bajo del rito acostumbrado acompañó.

En este supuesto pido y suplico a la Notaria justificación de V. E. que habiendo aquellos por presentados se sirve mandar se le notifique seria y formalmente en los términos que sean concedidos y de estilo al R. P. Prepósito Don Joaquín Furlong que se abstenga de imprimir en lo susesivo las conclusiones, Actos y Convites que corresponden por especial privilegio a la imprenta de mi casa (sobre cuyo atentado y vejaciones protesto mis recursos) dejándole su derecho a salvo para que por la vía ordinaria dispute cuanto quiera sobre el indicado Privilegio para que con pleno conocimiento de causa y con audiencia de las partes interesadas, previos a los traslados indispensables, se determine el artículo en definitiva conforme a los establecimientos legales.

Asì mismo suplico a V. E. que se me devuelva original de la Real Cédula que tengo exhibida, quedando de ella en el citado expediente el testimonio o testimonios que puedan importar al derecho de R. P. Prepósito del Oratorio de San Felipe Neri con tal que sea como debe ser a su costa. Por tanto: [154] A. V. E. pido y suplico que provea como pido que es justicia; juro en forma de no proceder de malicia y lo necesario, etc.

\section{Rúbricas}

Pedro de la Rosa

Lic. José María Ramos.

Puebla Julio is de i8is

Al Asesor

$$
\begin{gathered}
\text { Ante mí } \\
\text { José Ramón Arellano }
\end{gathered}
$$

\section{Cuatro sellos}

SELLO TERCERO, DOS REALES: AÑOS DE MIL OCHOCIENTOS DIEZ Y OCHO Y OCHOCIENTOS ONCE Don Pedro de la Rosa, Teniente Coronel retirado del Regimiento de Dragones Provinciales de esta Ciudad en el Expediente sobre el privilegio exclusivo de mi Imprenta para que en ella sola se impriman cierta clase de papeles que quiere combatir el R. P. Prepósito de San Felipe, ante V. E. debidamente digo; que después de mis respuestas constantes en Actos y de mi último escrito de quince de julio próximo anterior, he visto que no se ha dictado la Providencia que por tres ocasiones le he suplicado rendidamente siendo como es ejecutiva y tan recomendada por nuestras Leyes, cual es el amparo en una antiquísima posesión de que me ha despojado el Reverendo Padre Prepósito de San Felipe, como documenté de un modo incontestable en mi último ocurso, con los impreso recientes de los que nadie puede imprimir en Puebla, sino en mi casa por el privilegio antiguo que goza concedido por nuestros Soberanos, y en el que se ha fundado la no menos antigua, quieta y no interrumpida posesión de hacer tales impresiones. 
[155] Pero ha sido perturbada en términos que a no verlo sería increíble. Apenas había pedido el R. P. Prepósito que recordase V. E. suspender el uso y ejercicio del Privilegio de mi casa, y cuando yo acababa de suplicar con tan moderación como justicia que se me amparase en la posesión que tenía de más de cuarenta años, cuando sin aguardar la decisión de V. E. y creo que con algún desaire de su Autoridad que ya tenía un conocimiento incoado en el asunto, se comienzan a imprimir en la imprenta del Oratorio, los papeles que sólo yo puedo dar a la luz pública: siendo semejante manejo tanto más reparable y chocante al considerar las buenas cualidades y notorias luces del Reverendo Padre mi contraparte en que cabe la disculpa que habría para otro de circunstancias inferiores, o de conocimientos vulgares.

Porque despreocupadamente conocerá el contrario qe no es fácil satisfacer a esta objeción: o el Padre Prepósito sabiendo mi privilegio y su uso y ejercicio (pues pide su suspensión) creyó necesaria la orden de V. E. para dicha gracia de su uso y ejercicio, o no: si esto último ¿por qué no empezó a imprimir sin temor convites, conclusiones, etc.? Y a qué fin perder el tiempo y quitarlo a V. E. y a su ocupado asesor con pedir mandara que no valiese una cosa nula de suyo, con la figurada suposición: si era necesaria la declaratoria de una autoridad; (y podría jurarme que así lo creyó el Reverendo Padre Prepósito) ¿cómo hallándose el punto de la controversia no sólo irresoluto, sino en su cuna, se conduce la contraria, como si V. E. hubiese fallado definitivamente en mi contra y a su favor? ¿Es acaso lo mismo desear y pretender una cosa que obtenerla? V. E. y su sabio Asesor saben muy bien que entre lo uno y otro hay una enorme distancias que el Reverendo Padre Prepósito ha sabido anonadar juntando de hecho y contra derecho aquellos incombinables extremos.

Es por lo mismo, muy urgente el día la expedición y enérgica práctica de las providencias que en mis dos reyertas y en mi último escrito de quince de julio (y cuya [156] solicitud reitero en el presente) pedí con la debida moderación, pues aunque no ignoro las graves ocupaciones de este Tribunal y la multitud de asuntos a qu atiene, por la naturaleza del mismo, y los incesantes prejuicios (protestados ya y que no me olvidaré de demandar) que el despojo me ha inferido y sigue infiriendo, le hacen, si no me equivoco alguna recomendación por cómo V. E. sabe mejor que yo, el despojado debe ser restituido inmediatamente y ante todas cosas, por el odio que el derecho tiene a los despojantes, quienes si no fuera por la santa severidad de la Ley serían muy capaces de reducir la sociedad a un caos. Por tanto A. V. E. rendidamente suplico provea como en mi anterior ocurso (cuya conclusión he dado por repetida en este) pedí. Juro no ser de malicia y cuanto sea necesario, etc.

$$
\begin{aligned}
& \text { Rúbricas } \\
& \text { Pedro de la Rosa } \\
& \text { Puebla, Agosto 5 de i8ig. }
\end{aligned}
$$

\section{TRES SELLOS}

SELLO TERCER, DOS REALES: AÑOS DE MIL OCHOCIENTOS OCHENTA Y NUEVE

SEÑOR COMANDANTE GENERAL, ETC.

Sin razón extraña el Teniente Coronel Don Pedro de la Rosa que V. E. defiriera a las solicitudes que entabló en sus escritos de diez y nueve de julio último, reducidas la primera a que se le restituyse la posesión que tenía de imprimir exclusivamente, actos, conclusiones y convites, notificándose al Reverendo Padre Prepósito del Oratorio de San Felipe Neri se abstuviera de dar luz pública en su imprenta papeles semejantes; y la segunda a que se le devolviera el original de la Real Cédula que ha exhibido y corre en el Cuaderno Principal [157] al instaurar la primera pudo advertir que si bien en derecho es cierto que al que se le priva de la posesión en que se hallaba se le debe restituir ante todas cosas, también lo es, que juicio de esa clase necesitan con más razón que otros que se legitime la persona; que no toda posesión franquea 
acción para esto y que señaladamente aquella que se tiene en nombre ajeno y no en el propio, desmida al despojado del derecho para intentar un recurso de igual clase.

Pudo reflexionar que si en su imprenta de algunos años a esta parte se han publicado los actos, conclusiones y convites, no ha sido esto porque el derecho de imprimirlos se de él o de ella, pues a de la Rosa mejor que a nadie, al Tribunal de la intendencia y al público le es constante que desde los años de mil setecientos ochenta y ocho, y mil setecientos ochenta y nueve la casa de Don Pedro Pascual de la Rosa ha intervenido en esto de manera que jamás puede decir tener como propio ese derecho.

Pudo considerar también que no era simple hecho de publicar esos impresos el que fundaban incontestablemente su acción para el amparo, pues a pesar de que en los últimos tiempos sólo en su casa se daba a la prensa todo género de escritos, y de libros, no por eso se atrevió a pedir la absoluta supresión de la imprenta del Oratorio, sino que se limitó a pedir la prohibición sólo de piezas determinadas comprobando así que la posesión que demandaba importaba un algo más de particular derecho, como parece debe ser, ya por el perjuicio que el público reciente viéndose precisado a ocurrir a una sola y determinada oficina; y ya por el daño que a los particulares se sigue de quedar privados del libre uso de sus facultades.

Todo esto pudo reflexionar y para ello tratando de abreviar el juicio pendiente con el Reverendo Padre Prepósito exhibir los documentos que se le han pedido, y evitar el recurso de restitución que no le competía, o a lo menos no acreditaba corresponderle, supuesto que ni era suya la posesión del derecho de imprimir con exclusión de todo otro, los apeles referidos, ni esa [158] posesión se justificaba en el modo conveniente, pero ya que él no lo hizo, el Asesor de V. E. tuvo presentes esas sólidas y justas consideraciones con a precisa mira de arreglar sus providencias.

Para que estas fueran cuales debían no quiso apuntar esos méritos. Vió que su exposición correspondía a la parte contraria, y por eso hizo se decretara lo que consta en el auto de veinte y nueve de julio, que no es otra casa que un traslado, pues entendía que el expediente se halla en poder del Padre Don Joaquín Furlong, y por eso habría continuado en silencio poniendo decretos de substanciación simple, sin que de parte de Don Pedro de la Rosa no se instara.

Mas notado la repetición de los recursos en que procurando fundarse las acciones de ese individuo, en realidad se reclama la conducta del Juzgado, se ve en la necesidad indispensable de manifestar los recomendables fundamentos que la Intendencia ha tenido para no deferir como se quiere a la pretensión de la Tosa, repitiendo que en su opinión ni antes ni ahora es accederse a ella, y que sólo se hará digna de consideración si los requisitos que hoy le faltan se suplen: esto es, si acredita el interesado que él en su nombre posee el derecho referido, y que la posesión se halla adornada de las circunstancias en el caso necesario.

La devolución de la Real cédula que presentó don Pedro de la Rosa no se hizo en el principio por que debía obrar original en el expediente para que se cerciorara el Reverendo Padre Furlong de la clase de instrumento que era, y así se decidiera o a pelear, o a convenir con las ideas de el Teniente Coronel, y después no tuvo efecto porque los autos, como consta de la razón del actuario, se hallan fuera en un traslado que pende, debiendo estar el interesado satisfecho de que en oportunidad se hará lo que pretende.

\section{TRES SELLOS}

Ahora no queda el asesor otra cosa que decir que reproducir su concepto expuesto y fundado ya con extensión, creyendo por esto, que lo que V. E puede [I59] s.d.r. DeREchos CINCO PESOS SEIS Y MEDIO REALES mandar siendo servido es, que al mimado Teniente Coronel se haga entender que no estándose hoy en el caso de conceder la restitución que ha pedido por no hallarse preparado el ocurso en la forma que debiera, si quiere continuar lo acrediten los hechos que 
le importan, quedando persuado de que la Real Cédula se le entregará en su tiempo: que si acaso pidiere éste cuando se le entregue, y si no se cumpla con lo mandado en treinta de junio, y veinte y nueve del mes siguiente y que con las resueltas de todo se dé cuenta. Puebla y Agosto 25 de i8ig.

Puebla, Agosto 27 de i8is

Rúbrica

Como parece al Asesor.

\section{SELLO DOCE REALES}

SELLO SEGUNDO: DOCE REALES: AÑOS DE MIL OCHOCIENTOS CATORCE Y QUINCE

YO EL SUSCRITO ESCRIBANO

Publico, uno de los del número de esa ciudad: certifico doy fe en testimonio de verdad que en Autos seguidos en el Tribunal del Señor Gobernador e Intendente, y en mi oficio público entre partes de la una Dona Manuel Hernández Navarro como marido legítimo de doña María de la Rosa, y de la otra Don Pedro de la Rosa padre de la susodicha sobre que pese no usase del privilegio de la imprenta por tocar a la referida Doña María; y sustanciándose el artículo con audiencia de ambas, se pronunció un Auto por dicho Señor Gobernador a los treinta de junio del años pasado de mil setecientos ochenta y ocho, cyo tenor es el siguiente: -Mediante que en la Cesión no pudo comprenderse el Privilegio [160] Auto ReLativo aUto de LOS SEÑORES DE la Real Audiencia Como concedido únicamente a los hijos y herederos de la imprenta (quienes tampoco podía perjudicar en su derecho adquirido en acto mismo de la concesión) y que en este concepto, sólo podían ser materia de aquella los instrumentos de la imprenta. Declarase corresponde actualmente el uso del Privilegio a Doña María de la Rosa y Ortega como descendiente más inmediata de la que lo ganó, y que pues su padre asenta haber comprado a nombre de ella la imprenta, debe entregársela inmediatamente, así por esto, como porque estándole prohibido su uso, le es enteramente inútil, cargando su valor en cuenta de la legítima de la Doña María, a quien se reserva su derecho sobre el punto de inventarios. Lo mandó el Señor Gobernador Intendente con acuerdo de su asesor en Puebla a treinta de junio de mil setecientos ochenta y ocho. -Manuel de Flon- Juan Collado- Ante mí: Ignacio Reyes Mendizábal. Escribano Real y Público. -Del cual por parte del citado Don Pedro de la Rosa se interpuso el recurso de apelación para ante su Alteza los Señores Regente, Presidente y Oidores, de la Corte de México a quien se dió cuenta con dichos autos, en virtud de su Real Provisión, librada a los ocho del citado mes de agosto, del referido año, y seguidose en dicho superior Tribunal la instancia por ambos individuos se sirvió proveer ese Auto. -En la ciudad de México a diez y nueve de mayo de mil setecientos ochenta y nueve: los señores Presidente Regente y Oidores de la Real Audiencia de esta Nueva España: habiendo visto los Autos del remate de una imprenta y privilegio exclusivo de imprimir varias cosas, y los que ha seguido el Postor Don Pedro de la Rosa con Don Manuel Navarro su hijo de afinidad sobre que vinieron a este Tribunal en virtud de la apelación interpuesta por parte de Don Pedro de la Rosa de Auto proveído en treinta de junio del año pasado de ochenta y ocho, por el Gobernador Intendente de Puebla, en que con Dictamen de su asesor declaró corresponder actualmente el uso del privilegio a Doña María de la Rosa y Ortega como descendiente más inmediata de la que anó y pues su padre asienta haber comprado [I6I] OtRo Relativo A nombre de ella la imprenta, deberá entregársela inmediatamente, con lo demás que contiene y ver convino. -Dijeron que confirmaban y confirmaron la determinación apelada del Intendente Gobernador de Puebla, a quien mandaban y mandaron se devuelvan los autos para su ejecución. Y así lo proveyeron y rubricaron. -Señaló con cuatro rúbricas de los señores Beleña- Anda-Moya-Quijada-José Mariano Villaseca. Y notariada a los Procuradores de ambas partes la de el dicho Don Pedro de la Rosa, 
entró suplicando de él, y con vista de lo que se expuso la de don Manuel Hernández Navarro, se proveyó por la Superioridad de su Alteza otro Auto con fecha de veinte y cuatro de Julio del corriente por el que se sirvió declarar insuplicable el de diez y nueva de Mayo de dicho año mandando se devolviesen los de la materia al expresado Señor Gobernador para su ejecución. Rubricado de los señores Veleña Anda-Moya-Quijada- y refrendado de Don José Mariano Villaseca secretario de dicha Real Audiencia,y notariado este a el Procurador del citado, don Pedro volvió a producir un escrito que con el Auto proveído por su Alteza, es de este tenor: los señores Presidente Regente y Oidores de la Real Audiencia de esta Nueva España: habiendo visto los autos del Remate de una Imprenta y privilegio exclusivo, de imprimir varias cosas, y los que ha seguido el Postor Don Pedro de la Rosa con Don Manuel Navarro su hijo de afinidad, sobre que aquel le entregue dicho privilegio, el proveído de diez y nueve del último Mayo en que se confirmó la determinación del Intendente Gobernador de Puebla en que declaró corresponder actualmente el uso del privilegio a Doña María de la Rosa y Ortega, como descendiente más inmediata de la que lo ganó y mandó se la entregase inmediatamente la suplicación interpuesta por parte del referido Don Pedro, de que corrió traslado con Don Manuel Navarro; lo que este expuso en su Escrito de seis del corriente, y lo demás que ver convino, dijeron: que declaraban y declararon insuplicable el [i62] Auto Relativo escrito auto de diez y nueve de Mayo de este año; y en su consecuencia mandaban mandaron se devuelvan los de la materia al Gobernador Intendente de Puebla, para su ejecución. Así lo proveyeron y rubricaron, señalado con cuatro rúbricas de los señores -Beleña-Anfa-MoyaQuijada- y refrendado de Don José Mariano Villaseca secretario de Cámara de dicha Real Audiencia.- Y notoriado éste al Procurador del citado Don Pedro volvió a producir un Escrito con el Auto a él proveído por su Alteza es de este tenor: -Manuel Domingo Chavero por Don Pedro de la Rosa Vecino de Puebla, en los Autos con Don Manuel Navarro sobre una Imprenta como mejor derecho, proceda y con las protestas oportunas, digo: Que por Auto de treinta de Junio del año próximo pasado, mandó, mandó el Intendente Gobernador de la referida Puebla, que mi parte entregará a Navarro en cuenta de a legítima de su mujer el Privilegio que tenía la imprenta, que se gestionó con las letras y muebles que hizo postura, y se le remató ahora diez y siete años en cantidad de trescientos pesos. De este Auto apeló mi parte para esta Real Audiencia, y por el de diez y siete de mayo se confirmó por Vuestra Alteza, mandando devolver los de materia para su ejecución, que se ha declarado insuplicable, por otro de veinte y cuatro del corriente. El Privilegio se le entregó a Navarro por determinación del mismo Intendente de que hay constancia en los autos y así está ejecutada la sentencia en esta parte. Resta solo el que tenga e mismo efecto en cuanto a la entrega de las cinco letras que mi parte recibió, unas bancas viejas, unos treinta poemas, y unos cuantos librillos casi inservibles. Tanto las letras como aquellos muebles están consumidos por los diez y siete años que han pasado, y también porque estos fueron unos trastos y utensilios despreciables, que jamás se aprovechó de ellos tomando la estimación del Privilegio, que como queda dicho, se ha entregado a Navarro. En esta atención la Superioridad de su Alteza se ha de servir declarar, que mi parte cumple exhibiendo los trescientos pesos, en que le remato la Imprenta otorgando recibo Navarro, de esta cantidad pra que si muerta mi [i63] Auto parte hubiere que heredar entre sus hijos, se le descuente a Doña María de la Rosa, de su haber y legítima, para lo cual se dé cuenta con este Escrito -A. V. E. piso y suplico así lo mande que es Justicia, juro, etc.- Licenciado Agustín María Gómez Eguiarte - Manuel Domingo Chavero. -En la ciudad de México a primero de Agosto de mil setecientos ochenta y nueve: los señores Presidente Regente y Oidores de la Real Audiencia de esta Nueva España: habiendo visto los Autos del Remato de una imprenta, y privilegio exclusivo de imprimir varias cosas, y los que han seguido el Postor Don Pedro de la Rosa con Don Manuel Navarro su hijo de afinidad sobre que aquel le entregue 
dicho privilegio; el proveído de veinte y cuatro del último Julio en que se declaró insuplicable, el auto de diez y nueve de Mayo de este año confirmando la determinación del Intendente Gobernador de Puebla, en que declaró corresponder actualmente el uso del privilegio a Doña María de la Rosa y Ortega como descendiente más inmediata de la que lo ganó, y que se le entregase inmediatamente, mandando esta Real Audiencia que para su ejecución se devuelvan dichos Autos al referido Gobernador: El escrito presentado en veinte y ocho del citado Julio por don Pedro de la Rosa, pidiendo se declare haber cumplido, exhibiendo los trescientos pesos en que se le remató la Imprenta, otorgando recibo Navarro, de esta cantidad para que siendo muerto dicho Don Pedro tuviere que heredar entre sus hijos y se les descuente a Doña María de la Rosa de su ha de haber y legítima, Dijeron: que mandaban y mandaron se ponga con los autos el relacionado Escrito, los que se devuelvan al Intendente Gobernador de Puebla quien tomará providencia en el particular. Y así lo proveyeron y rubricaron. -Señores Anda. -Moya-. Salcedo.- José Mariano Villaseca.. En México a siete de Agosto de mil setecientos ochenta y nueve. Yo el Receptor presentes los Procuradores José Fernández de Córdova, y Manuel Domingo Chavero, les hice saber el Auto que antecede y dijeron, los oyen y lo firmaron, doy fe. -Chavero -Córdoba.- Anastasio José Benítez. Escribano Receptor.-Concuerda con sus [164] Relativos autos originales a que me remito, doy fe. -José Mariano Villaseca y devueltos a este Tribunal, mandados pasar por su Señoría a su Asesor, éste previno que par mejor proveer acerca del Pedimento con que dicho don Manuel Navarro los había producido, declarase Don Pedro de la Rosa con juramento en forma sobre la consumpción de las Letras y demás qe comprendió el Remate que se le hizo de la Imprenta, lo que fecho, Don Manuel Navarro justificase lo que le conviniese en orden de acreditar su subsistencia, y a los treinta y uno de Agosto, procedió el citado Don Pedro, a la declaración prevenida expresado por cierto y verdadero que lo que decía a letra la había consumido en balas y munición que vendió por mano del referido Don Manuel Navarro, hallándose de su cajero, a excepción de unos cortos utensilios que hasta la presente mantenía inservibles en su poder, y que en cuanto a los demás muebles de madera no había ningunos, pues los que hoy estaban usando todos eran nuevos, lo que en caso necesario justificaría. Y substanciándose el punto sobre dicha consumpción de moldes entre ambas partes y mandándose por dicho señor Intendente volver los Autos a su Asesor con su Acuerdo proveyó uno de este tenor. -Por cuanto Don Pedro de la Rosa confiesa la consumpción de los moldes, y Don Manuel Hernández Navarro, no la niega, y ya se considere a aquel como comprador de la Imprenta a su nombre, y a el de su hija como Tutor y Curador suyo adquirido para si cuando ha producido por razón del dominio, o del usufructo que le concede la Ley, declarase haber cumplido con la exhibición que hace de los trescientos pesos, y no estar en obligación de reponer lo que se ha con sumido, con la buena fe que prestan cualquiera de aquellos dos títulos, haciéndose saber a la Rosa, no imprima cosa alguna de las que comprende el Privilegio apercibido de que a la primera denuncia justificada, se procederá contra él, a lo que hubiere lugar, y dándose a Navarro si insistiere, en su apelación, el Testimonio que pide para que ocurra donde le convenga, ayudándosele por ahora por pobre. Y mediante advertirse [165] OTRA en el Escrito presentado por este algunas expresiones, que a pesar de la protesta que se hace, ofenden los respetos de este Tribunal, hágase saber a Navarro y su Patrono, guarden en sus alegatos el comedimiento y moderación que se debe apercibidos de que en otra ocasión no se les tratará con la indulgencia que ahora. Lo mando el Señor Gobernador Intendente con acuerdo a su asesor en Puebla a veinte y cinco de septiembre de mil setecientos ochenta y nueve. -Flon. -Collado. -Ante mi, Ignacio Reyes Mendizábal, Escribano, Real y Público.- El cual notariado a ambas partes dieron las respuestas siguientes. -En la ciudad de Los Angeles a treinta días del mes de Septiembre de mil setecientos ochenta y nueve años: Yo el Escribano hice saber el Auto anterior a Don Manuel Navarro en su per- 
sona, de que inteligenciado dijo: que por redimirse (hablando debidamente) de las vejaciones que pueden originársele en lo sucesivo, si interpone el recuso de Apelación que la Ley le franquea; desde luego consiente en el Auto que se le ha notariado suplicando al Señor Gobernador se sirva mandar que exhiba Don Pedro de la Rosa prontamente los trecientos pesos que tiene ofrecidos, corriendo la Notoriedad sobre la cesación del uso del Privilegio, quedando entendido el que responde en medir sus expresiones y arreglarlas a lo que fuere y sea conforme a sus derechos, y esto respondió y firmó, doy fe. -Manuel Hernández Navarro. -Mendizával.-

En la ciudad de Los Angeles a dos de octubre de mil setecientos ochenta y nueve años. Yo el Escribano estando en la casa de la morada de Don Pedro de la Rosa y siendo presente le notifiqué en Persona el Auto de la foja antes de ésta; y así para la exhibición de los trescientos pesos como para que no imprima cosa alguna, de las que comprende el privilegio, apercibido de que a la primera denuncia justificada, se procederá contra él, a lo que hubiere lugar, de todo lo cual, entendido. Dijo: Lo oye, y que cumplirá puntualmente con lo que se previente; a cuyo efecto hace en el acto exhibición de los trescientos pesos que se le mandan dándose de su recibo y entrega la correspondiente [I66] certificación, con razón individual relativa del negocio que ha dado motivo a dicha entrega y con puntual arreglo al tenor de la determinación ejecutoriada por la Superioridad de su Alteza, que parece ser de treinta y uno de Julio del año pasado de ochenta y ocho, en orde a deberse traer a locación en la sucesión hereditaria paterna de Doña María Manuela de la Rosa y Ortega, para su correspondiente rebaja en la porción hereditaria que le toque. Y por lo que mira a el uso del Real Privilegio, se abstendrá el que responde a los mismos términos y circunstancias que refiere: su letra pasando desde luego dicho privilegio a la referida Doña María Manuela de la Rosa y Ortega, mas por cuanto el que responde desea acreditar que en la justa defensa que ha hecho en el presente negocio, no ha llevado otro fin que el de sostener la Venta judicial que se le hizo de la imprenta y su privilegio con todos los requisitos legales y de derecho acostumbrados, y que en esto mismo llevaba también la mira de beneficiar y utilizar a la misma Doña María Manuela, y a su hija menor en la edad pupilar, nieta del que responde conservando en sí e privilegio, para que después de sus días rodara y se continuara en sus hijos porque de otra suerte, se hubiera perdido por el no uso, y atendida a la delicadeza con que se miran los Privilegios, de cuya naturaleza es requisito esencial la continuación de su uso; pues de lo contrario prescribe su subsistencia, con este mismo objeto y con el propio deseo que como padre solicita el bien y alivio ed sus hijos para que no acontezca la desgracia de la cesación de uso de dicho privilegio por falta de moldes y arbitrios para imprimir, de la que por su Señoría se ha declarado su interesada, se allana de buen grado el que corresponde a que sin que sea visto, ni se entienda contravenir a lo mandado, se continúen haciendo las impresiones de convites y conclusiones de esta Ciudad como hasta aquí en Casa e Imprenta del que responde y con arreglo a el mismo Privilegio, sin llevar por ello el menor interés, sino que los frutos y rendimientos de dichas impresiones los perciba y adquiera la parte [167] interesada con sola la rebaja y deducción de los costos y operarlos sin incluirse otra cosa alguna a el menos interin dicha parte interesada se hace de utensilios y moldes necesarios, o lugar para que con sus comedimientos el exponente: Ejemplificando con esto la escandencida expectación del público en negocio de las presentes circunstancias, a lo expuesto en orden a continuarse las impresiones en la Casa e Imprenta del que responde, también lo mueve la justa consideración de que el dicho privilegio como perteneciente a su hija y nieta según se ha declarado no padezca extravío, enajenación, ni otro género de obligación pasiva por don Manuel Navarro, de suerte que de o pugnar este tan conmiserativo y justo comiedimiento del que responde deberá afianzar o satisfacción, el que ha de conservar en sí, dicho privilegio como perteneciente a los intereses de su mujer, en que no tiene otro arbitrio que el de una desnuda administración, sin poderlo 
obligar, enajenar, ni surtirlo en otro en manera alguna, y en el evento de negarse a uno ni a otro, suplica a la integridad del Señor Gobernador Intendente, se sirva en tal caso de mandar hacer saber a el que responde la resulta para deducir en forma los derechos que como padre legítimo de Doña María Manuela y abuelo de la menor le correspondan, exponiendo entonces como lo hará los méritos que concurren en el caso, pues por ahora los reserva para su legítimo y oportuno tiempo en la misma conformidad hace presente el que responde a la integridad del señor Gobernador Intendente que en defensa consabido privilegio sostuvo un reñido y costoso litigio con la parte de los Colegios Seminario y San Pantaleón de esta ciudad, solicitando impedir que de la imprenta de dichos colegios se hiciesen impresiones de convites y conclusiones, y que a el carácter, y nada menos que el de Sagrada Mitra, si hubo que transigir y concertar por Instrumento Público, que paso y se otorgó en esta Ciudad de los Angeles, a seis de Enero del año pasado de mil setecientos setenta y siete por ante Don Mariano Francisco [168] Zambrano Escribano Mayor de Cabildo e Intendencia, conviniéndose en que sin embargo del indicado Privilegio se pudiesen actuar dichas impresiones en la relacionada imprenta de San Pantaleón por lo respectivo solo a los actos, conclusiones y convites de los referidos colegios, y el de San Ignacio, y los que pudieran ocurrir de esta Casa Obispal, como se ha estado verificando hasta el día, lo que hace presente por no ser en su arbitrio hacer novedad, en lo capitulado. Esto respondió y firmó, doy fe.- Pedro de la Rosa.Ignacio Reyes Mendizábal, Escribano Real y Público.- Los trescientos pesos que constan exhibidos por Don Pedro de la Rosa, en la anterior diligencia los he recibido por mano del presente Escribano como marido legítimo de Doña Manuela y Ortega. Y por que conste lo firmé en la Ciudad de los Angeles a dos de octubre de mil setecientos ochenta y nueve - Manuel Hernández Navarro.- Y con ellas vueltos los autos a el Asesor, por el que se proveyó a los seis de octubre del corriente año se previno traslado a Don Manuel Navarro, quien por escrito que produjo, cuyo tenor con el de las últimas diligencias en su virtud y practicadas, con el Auto de treinta y uno de octubre es el siguiente.- Don Manuel Hernández Navarro vecino y del comercio de esta ciudad en los autos seguidos contra don Pedro de la Rosa sobre la exhibición del privilegio de la imprenta, presupuesto su estado, y como más haya lugar en derecho, salgo los favorables y competentes, digo: que según manifiestan mis pedimientos todo el fin, y objeto de mi demanda fue el descubrir y desentrañar que la legítima pertenencia del privilegio era Doña Manuela de la Rosa y de sus sucesores e hijos de nuestro matrimonio, sin que en ello se llevarse el ánimo de zaherir ni vulnerar los respetables fuero que se concilia a la autoridad paterna, confesando aún el subscrito patrono en obsequio de la verdad, paz y cristiana tranquilidad que debe reinar en todos, y en especial entre los de una familia que aún aquella petición que se hizo sobre la aprehensión de la persona de dicho Don Pedro no fue animada del espíritu de ser surtido en efecto, sino una inadvertida e involuntaria expresión [i69] oriunda de la corriente práctica y cláusula que podemos llamar la estampilla usada en pedimientos ejecutivos, de suerte que podemos decir que fue un Lapsum lingüis, y desde luego descubierto el intento dada la correspondiente satisfacción y visto ya que Don Pedro trata de beneficiar a su hija la citada mi mujer, reconociéndola portal no puedo menos, que sin que sea visto decaer en los derechos que le asisten a la susodicha ni innovar en la sentencia cosa alguna, sino antes bien dejándola en su vigor y fuerza, consentir en lo que ese tiene propuesto el relacionado Don Pedro, bajo aquellos mismos términos: continuando las respectivas impresiones de Convites y Conclusiones como hasta aquí, después a vista y contemplación de lo relacionado, y de lo que de ello no se irroga perjuicio alguno a la citada mi mujer, ni a nuestros hijos, no tengo otra cosa que rendir a la disposición del citado don Pedro que el uso de dicho privilegio, bajo la sumisión filial que le es debida, y correspondiente. En estos términos pues se ha de servir V. Señoría acceder a su pretensión y a la mía, según es de justicia, la cual mediante = A.V. 
Señoría suplico provea como pido. Juro en forma y lo necesario, etc., = Manuel Hernández Navarro.= Licenciado Miguel Brillán. = A sus Autos, y a el Asesor, Lo mando el señor Gobernador de Puebla a veinte de octubre de ochenta y nueva.- Flon.= Ante mí. Ignacio Reyes Mendizábal, Escribano Real y Público.= Hágase saber este escrito a Don Pedro de la Rosa, y con lo que dijere, tráigase para proveer. Lo mando el señor Gobernador Intendente con acuerdo de su Asesor, en Puebla a veinte y uno de octubre de mil setecientos ochenta y nueve. $=$ Flon. $=$ Ante mí, Ignacio Reyes Mendizábal, Escriban Real y Público.= En la ciudad de los Angeles a treinta días del mes de octubre de mil setecientos ochenta y nueve años. Yo el Escribano estando en la casa de la morada de Don Pedro de la Rosa, presente el susodicho, le notifiqué en Persona e Auto anterior y traslado por él prevenido, de que inteligenciado dijo: Lo oye, y queda inteligenciado de la anuencia de Don Manuel de Navarro, en lo que tiene propuesto y que en su virtud lo pondrá [I70].

\section{OTRO}

En práctica, que así mismo se le dé la certificación del entero de los trescientos pesos que tine verificado con areglo a lo que tiene pedido.- Esto respondió: y firmó, doy fe.= Pedro de la Rosa Mendizábal.- Hanse a estas partes por avenidas en los términos que proponen, y a la mayor firmeza y validación del convenio, interponía e interpuso su Señoría su Autoridad y Decreto judicial cuanto puede y debe, y dése a [De] la Rosa la certificación que pide su exhibición de trescientos pesos. Lo mandó el Señor Gobernador Intendente con acuerdo de su asesor, en Puebla a treinta y uno de octubre de mil setecientos ochenta y nueve. =Flon.= Collado.= Ante mí Ignacio Reyes Mendizábal, Escribano Real y Público.= Concuerda con lo relativo y a la letra de los Autos que va hecha mención, lo que originales quedan en el Archivo se este Oficio Público de mi cargo, a que me remito. Y porque conste en cumplimento de lo mandado en el último auto insertado, doy el presente a el citado don Pedro de la Rosa; en la ciudad de los Angeles a diez y nueve de noviembre de mil setecientos ochenta y nueve de Aedo, y don Ignacio Reyes Pliego, vecinos de esta ciudad, soy fe.= Ignacio Reyes Mendizábal, Escribano Real y Público.

Exelentisimo SEÑoR.= Don Pedro Pascual de la Rosa, Teniente Coronel retirado de Dragones, ante la notoria justificación de V. E. como más haya lugar en derecho al mío convenga. Digo: que la imprenta de mi casa tiene un privilegio Real de imprimir exclusivamente cierta clase de papeles que en ninguna otra prensa puede darse a la luz. En los años de setecientos setenta y tres, setenta y seis, y ochenta y nueve ha tenido cuestiones judicialmente en esta Intendencia el difunto señor mi padre, para sostener el privilegio, y consta de expedientes que obran en el Archivo de Cabildo: hoy se quiere suscitar igual disputa por el Reverendo padre don Joaquín Furlong, Prepósito del Oratorio de San Felipe Neri de esta ciudad, y con su citado suplico a V. E. me franqueen los testimonios fehacientes que paso a [I7I] designar entregándomelos con estas diligencias originales para hacer de ellos el uso que me convenga.= Una copia autorizada de la Escritura de transacción que celebró mi difunto padre con la imprenta que hubo en los Reales y Pontificios Colegios de San Juan y San Pantaleón, por los años de setenta y siete, cuyo testimonio acompaño en tres fojas útiles, porque necesitado de otro a más de éste: otra igual copias del pleito (cuyo testimonio también acompañó en nueve fojas con la debida solemnidad convenio que lo terminó que tuvieron mi Padre y hermano político don Manuel Hernández Navarro en los años del ochenta y ocho y ochenta y nueve.= Del pleito que desde el año de setenta y tres del siglo pasado siguió también mi repetido Padre don Pedro de la Rosa que obra en dos cuadernos, el primero en ochenta fojas y el segundo e cincuenta y tres en la oficina de Cabildo, necesito testimonio de la letra previa la citación de la parte contraria, del Privilegio Real exclusivo que se halla fojas primera y segunda, y las actuaciones que siguen desde la foja 
tercera hasta la novena inclusive, cuaderno primero. El dictamen de Asesor que se lee a fojas cuarenta y cuatro vuelta y las diligencia que le subsiguen hasta la notificación que se hizo al Bachiller Don Bernardo Lario, fojas cuarenta y siete rostro, Tesorero de los Colegios.= Del Cuaderno Segundo titulado de fuerza, se testimoniaría lo siguiente: la información de Testigos sobre despojo que hizo la imprenta de los colegios, y se haya desde fojas quince rostro, a fojas diez y seis. El dictamen del asesor de los Autos, que se halla de fojas veinte y siete a la veinte y ocho vuelta, y el decreto de conformidad de doce de noviembre de setenta y cuatro.= Sírvase V. E. como le suplico, mandar hacer como he pedido que así es de justicia, juro no proceder con malicia y lo necesario, etc.- Pedro de la Rosa.- Licenciado José María Ramos.-

Al Asesor. Lo mandó el Excelentísimo Señor Comandante General Gobernador Intendente, y lo firmo en Puebla a veinte y uno de agosto de mil ochocientos diez y nueve.= De Llano.= Ante mí, Manuel José Herrera. [172] Por presentado con los documentos que se acompañan previa citación del Reverendo Padre Prepósito del Oratorio de San Felipe, dense al Teniente Coronel Don Pero de la Rosa los testimonios autorizados que solicita de recados y actuaciones que detalladamente refieren en este ocurso, y el mismo interesado devuélvase los que ahora ha exhibido: Lo mandó el Excelentísimo Señor Comandante General Gobernador Intendente, con acuerdo a su Asesor, en Puebla a veinte y cinco de agosto de mil ochocientos diez y nueve.= De Llano.= Anzorena.= Ante mí, Manuel José Herrera.- -------------- En Puebla a treinta y uno de agosto de mil ochocientos diez y nueve. Yo el Escribano habiendo pasado al Oratorio de San Felipe Neri, y preguntado por el Reverendo Padre Prepósito Don Joaquín Furlong, me respondió el portero estar tomando ejercicios, y por esto no podérsele contestar. Y para que conste lo asiento por diligencia que firmé.= Herrera.-

------------ EN Puebla a tres de septiembre de mil ochocientos diez y nueve yo el Escribano estando en el Oratorio de San Felipe Neri, y aposento del Reverendo Padre Prepósito don Joaquín Furlong, y presente en su persona que conozco le cité de ruego y encargo con el Auto antecedente para el efecto que expresa, de que entendido, dijo: Lo oye, y que impuso de la precedente solicitud de Don Pedro de la Rosa, sobre que ya corre Expediente separad, advierte que envuelve capciosidad, y malicia, el pedir testimonio de unos fragmentos y actuaciones sueltas, que tal vez siéndole favorables en alguna parte, o por algún sentido violento, serán contra los derechos del que responde, por lo cual se opone formalmente a que se le ministre tal testimonio de piezas inconexas, pues bien puede De la Rosa pedir originales todos los expedientes, y hacer de ellos el uso debido, por lo que pide que antes de todo se dé cuenta a su Exelencia con esta respuesta que firmó. Doy fe.= Joaquín Furlong.= Manuel José Herrera. [I73] vuELVA este expediente a mi asesor, para proveer lo que sea de justcia. Lo mandó el Excelentísimo Señor Comandante General Gobernador Intendente, Brigadier don Cirilaco de Llano, y lo firmó en Puebla a tres de septiembre de mil ochocientos diez y nueve.= De Llano.= Ante mí= Manuel José Herrera.- ------------Instruyase al Teniente Coronel Don Pedro de la Rosa, de lo expuesto por el Presbítero don Joaquín Furlong, y pidiendo el expediente entréguesele. Lo mandó el Excelentísimo Señor Comandante General Gobernador Intendente, con acuerdo de su asesor, en Puebla a tres de septiembre de mil ochocientos diez y nueve.= De Llano.= Anzorena.- Ante

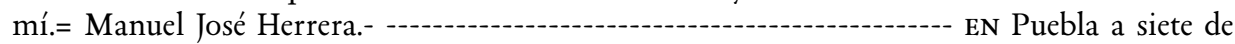
septiembre de mil ochocientos diez y nueve. Yo el Escribano estando en la Casa de la morada del Teniente Coronel don Pedro Pascual de la Rosa, y presente en su persona que conozco, le hice saber la respuesta y auto antecedente, de que entendido dijo: lo oye, y que siendo rara e injusta (habla debidamente) la citada respuesta del contrario, pues quiere compelerlo a que pida testimonio de lo que, no le importa con el objeto seguramente de ir demorando el asunto, insiste en que el Excelentísimo Señor General, manda se le dé testimonio en los términos que ha pedido, y de lo que ha pedido, dejando en libertad al Reverendo Padre Prepósito, pa- 
ra que su merced mande sacarlo íntegro de los cuadernos que cita para que convenza si puede la capaciosidad, etc., que infundadamente atribuye, estando en arbitrio del Tribunal y no del que habla, como con error cree el Reverendo Padre Prepósito, mandar que se saquen los Autos del Archivo de su radicación a lo que no se opone, porque procede con sencillez y justicia. Esto respondió y firmó, doy fe.= Pedro de la Rosa.= Manuel José Herrera.- [I74] MINIstRese al Teniente Coronel don Pedro Pascual de la Rosa, los testimonios que ha pedido, haciéndose antes entender al Reverendo Padre Prepósito don Joaquín Furlong, lo expuesto por aquel, y la libertad en que queda, de pedir las constancias y testmonios que a su dueño importen. Lo mandó el Excelentísimo Señor Comandante General Gobernador Intendente, Brigadier don Ciriaco de Llano, con acuerdo de su Asesor, en Puebla a nueve de septiembre de mil ochocientos diez y nueve.- De Llano.= Ansonera.= Ante mí: Manuel José Herrera.- -------------------EN la ciudad de los Angeles, a once de septiembre de mil ochocientos diez y nueve. Yo el Escribano estando en el oratorio de San Felipe Neri y aposento del Reverendo Padre Prepósito don Joaquín Furlong, en su persona que conozco, le hice saber de ruego y encargo el auto antecedente, de que entendido dijo: que queda entendido de lo que previene el último auto, bajo la protesta de redarguir los testimonios que el contrario pide, siempre que sean contra los derechos del que habla, mayormente por lo que expuso en su anterior respuesta. Esto respondió y firmó. Doy fe.= Joaquín Furlong.= Manuel José Herrera. -CONCUERDA con sus originales, que devolvía al Teniente Coronel don Pedro Pascual de la Rosa, a que me remito. Y para que conste en cumplimiento de lo mandado en el auto inserto, saqué el presente en veinte y dos fojas con esta del papel de los sellos segundo y cuarto, siendo Testigos don Joaquín Gómez de Vargas, don José María Sánchez y don José Emigdio de la Vega, vecinos de esta muy noble y muy leal ciudad de los Angeles, en ella a trece de septiembre de mil ochocientos diez y nueve.

\section{Firmas}

MANUEL JOSE HERRERA

[175] Es bastante este Poder para que el Teniente Coronel Don Pedro de la Rosa se persone por su sobrina la Otorgante en los casos y cosas para que lo faculte por sí o por substituto. Puebla, Octubre 5/819

\section{DOCE REALES}

SELLO SEGUNDO: DOCE REALES: AÑOS DE MIL OCHOCIENTOS CATORCE Y QUINCE

En la ciudad de la Puebla de los Angeles, a primero de septiembre de mil ochocientos diez y nueve años: Ante mí el escribano y testigos doña María Guadalupe Hernández de la Rosa y Ortega, doncella mayor de veinte y cinco años, hábil capaz para regir y administrar sus bienes, fuera de tutela y ajena administración a que doy fe que conozco, Otorga: que de su poder cumplido bastante el que en derecho se requiere y es necesario, mas pueda y deba valer a su tío el Teniente Coronel don Pedro de la Rosa, especial para que a su nombre y representando su propia persona, deudas, derechos y acciones que le toca y pertenecen y en cualesquiera manera le puedan tocar y pertenecer, defienda por todos los artículos, grados e instancias el Real Privilegio que de inmemorial tiempo a la presente gozaron sus antepasados (como también debe gozarlo la comparente) para la impresión de actos, conclusiones y papeles de convite para entierros y demás funciones que se ofrezcan en esta ciudad; y así mismo se le confiere para que haya, reciba, demanda y cobre todas y cualesquiera persona las cantidades de pesos y demás bienes que se le deban o debieren en virtud de escrituras, traspasos, herencias, donaciones, renunciaciones, patrimonios en otra forma, y por instrumentos o sin ellos; y de lo que recibiere o cobraré, otorgue recibos finiquitos, gastos, cartas de pago y otros recaudos 
en forma con cesión de derechos, cancelación de instrumentos y renunciaciones de Leyes de la entrega y su prueba, no siendo las pagas por ante Escribano que de ella de fe; en cuya razón y generalmente para en todos su pleitos causas o negocios civiles o criminales que el presente tiene, y en adelante tuviere con cualesquiera personas y bienes así demandado como defendiendo [176] parezca ante el Rey Nuestro Señor (que Dios guarde muchos años) en sus Reales Audiencias y Cancillerías, Superior Gobierno de este Reino y demás Tribunales Eclesiásticas y Seculares, superiores e inferiores, sus jueces y justicias ante quienes con derecho pueda y deba, y ponga demandas, reconvenciones por mutuas peticiones o como más convenga; responda a las contrarias que conste o niegue: haga pecimientos, requerimientos, citaciones, protestas, súplicas, juramentos, alegaciones, oposiciones, contradicciones, declinatorias, querellas, acusaciones y recusaciones: pida embargos, desembargos, mejoras de ejecución, presiones, solturas, apartamientos, consentimientos, venta y remate de bienes, de que pida y aprehenda, posesión y amparo y la continúe y defienda: presente testigos, Escritos, Escrituras, Testimonios, Testamentos, Cláusulas de ellos, y otros papeles y recaudos que pida y saque de cuyo poder estén y los abone, tache o redarguya, los que de contrario se presentaren civil o criminalmente como le pareciere: pida términos o los renuncie: oiga autos y sentencias, interlocutorios y definitivas, consienta lo favorable apele o suplique de lo perjudicial y sigua el grado por todas instancias hasta su definitiva determinación: gane mandamientos, reales provisiones, cartas de justicia y otros despachos para todos efectos y ante las eclesiásticas censuras generales o particulares, hasta la de anatema que haga leer, publicar, e intimidar, sacando Testimonios de lo que en su virtud resultare, que uno y otro presente donde convenga pidiendo obedecimiento y cumplimento: y haga todos los demás actos, agencias y diligencias, judiciales y extrajudiciales que se requieren y sean necesarias, que para todo lo dicho, su anexo, incidente y dependiente le da este Poder con libre, franca y general administración y facultad de enjuiciar, jurar y sustituirlo en todo o en parte, las veces y en las personas de su satisfacción que les pareciere, revocar substitutos, cobrar d ellos, y nombrar otros de nuevo que a todos releva según derecho, y así lo otorgó y no firmó por no saber, lo hizo a su ruego no de los testigos, siéndolo Don [177] Vicente Bejarano, don José Martínez de Zerdio y don Agustín Berruecos de esta vecindad, doy fe.- A ruego de la otorgante por no saber escribir, Vicente Bejarano. $=$ Ante mí, $=$ Francisco Rangel Lozano, Escribano real Público Interino.-

ES copia a la letra de su original que queda en el Oficio Público que fue de Don José Ignacio del Castillo, el que despachó interinamente y a que me remito, doy fe.=

Rúbricas.

[I78] Dos SELLOS

AÑO DE I8I9

Poder otorgado. por Doña María Guadalupe Hernández de la Rosa, y Ortega, a favor de su tío, el Teniente Coronel Don Pedro de la Rosa, para los efectos que dentro se expresan.

\section{SELLO TERCERO, DOS REALES:}

\section{AÑOS DE MIL OCHOCIENTOS DIEZ Y SEIS Y MIL OCHOCIENTOS DIEZ Y NUEVE}

\section{EXCELENTISIMO SEÑOR}

El Teniente Coronel retirado de Dragones don Pedro Pascual de la Rosa, por su sobrina Doña María Guadalupe Hernández de la Rosa, cuyo poder debidamente acompañado en tres fojas útiles, en el Expediente que sobre el uso y ejercicio exclusivo del privilegio real que ha habido y hay a favor de mi representada para la impresión de cierta clase de papeles que ninguno otro 
puede imprimir en Puebla, he seguido contra la imprenta de San Felipe Neri, y su Reverendo Padre Prepósito su estado supuesto ante V. E. como mejor proceda, y dejando a salvo a cuanto a mi intención pueda favorecer, Dijo: que sin ser visto contestó al último Escrito dando de contrario el veinte y tres de septiembre próximo pasado, de cuyo traslado haré el debido so en el juicio oportuno, pus no quiero que el punto de restitución se ordinarie solo por la vía de instrucción al justificado Tribunal de V. E. me encargaré suscintamente de algunas especies que conciernan al caso del día, y de cuyo relato constante en los documentos que acompaño resultará caducado y que el uso ejercicio de él en mi casa por vivir en ella su dueño, de quien el dueño me constituye [I79] apoderado legítimo, había sido sin interrupción de muchos años a esta parte hasta la apertura del oratorio que fue por marzo o abril de este año, que vino a turbar la quieta y pacífica posesión privilegiada de imprimir papeles de Convite, Actos y Conclusiones exclusivamente, aquí en Puebla, porque aunque mi difunto padre ocurrió al soberano a nombre de su hija doña María Manuela de la Rosa y Ortega (madre de mi sobrina por quien acciono) pretendiendo la confirmación de otro Privilegio, 7 la ampliación de él para la impresión exclusiva de otro género de papeles de México y demás lugares del reino, esto último no se concedió; así como se mandó por el señor don Carlos Tercero en su Real Cédula de catorce de agosto de setecientos setenta y siete que original obra en Autos al Excelentísimo Señor Virrey de méxico que no se impidiese el uso del Privilegio en la conformidad que estaba dispuesto, a saber, para los otros papeles de Puebla: de suerte que el argumento que quiere hacerse con las impresiones de Actos y Convites en México ( y podría añadirse Guadalajara, Oaxaca, Veracruz, etc.) no tiene más fuerza que la que le ha dado una equivocación palpable, confundiendo por que acaso se leyó la Real Cédula con precipitación, las preces de mi difunto padre en representación de su hija y mi hermana, y lo que S. M. fue servido de conceder. Siendo aún más destituida de fuerza la reflexión de que muchos papeles de los de el Privilegio los han mandado imprimirlos en esta ciudad, sino por el dueño del privilegio y nadie mas; pero ya que la parte contraria lo ha entendido como una extensión que nosotros no hemos pensado darle, cual es que a fuerza los dueños de tales papeles los tengan que imprimir aquí, y no donde más les acomode, en tal suposición, digo, que el argumento probaría lo mismo contra el Privilegio y su posesión que si un contrabandista con los fraudes suyos y de los de su delincuente profesión quisiera probar que no hay estancos de S. M.

Yo no dudo de la buena fe, integridad hombría de bien, del Reverendo Padre Prepósito; creo por lo mismo [180] que satisfechas las dudas que le han ocurrido sobre el Privilegio que se trata de impugnar así como de hecho se ha interrumpido su privilegiada posesión, perjudicando a su dueño, a la vista de los términos que acompaño y de que ya hablaré, se desistirá de su pretensión: se abstendrá de imprimir lo que no debe, porque el Rey ha querido prohibírselo a su Reverencia y a todo el que establezca imprenta en la Puebla, y que nos redimirá con tal conducta, a mí de incomodidades, y a la dueña del privilegio, de ulteriores perjuicios, como los ya que se le han irrogado, contra la recta intención del Padre Furlong y a pesar de sus reiteradas protestas.

Enhorabuena que no supiera expresarme con más claridad en mis respuestas y que no advirtiere a informar al principio a mi patrono, que el Privilegio Real era propio y peculiar de mi sobrina, pero jamás dijo que era mío, sino de la casa, porque siempre ha sido de mis parientes muy inmediatos, y jamás aún habiendo otra imprenta ha salido su posesión de la que fue de mi padre y hoy mía, y si de esta sutileza que en los tiempos de Roma habría sido suficientes para que el oratorio obtuviera, porque qui astionem propiam non exerscebat cadebat a causa, quisieran hoy valerse la contraria, sería menester borrar las sabias Leyes nuestras en que tanto reluce la justicia y la equidad de sus soberanos tutores, y en que se manda que los jueces sentencien donde hallan la verdad, y conformen a ella, despreciando, la ridícula, supersticiosa y aún diré judaica materialidad que en ciertos puntos estaba comprada por el dueño común. 
Supóngase pues que hoy se entabla la demanda por doña María Guadalupe mi sobrina: el privilegio que el soberano quiso concederle desde antes del año de setecientos veinte y cinco a la imprenta de Diego Fernández de León, vecino de esta ciudad; el mismo que después confirmó por dos veces el Excelentísimo señor Virrey de esta Nueva España, Marqués de Valero, por sumas, no despreciables en aquella época, con que [I8I] contribuyó al Real Erario doña Manuela Cerezo Viuda de don Miguel Ortega, abuelos terceros de mi sobrina doña Manuela Guadalupe Hernández de la Rosa, y Ortega el mismo que la Real munificencia se dignó conceder a doña Manuela Cerezo en su Real Cédula de nueve de septiembre de setecientos veinte y cinco que corre en testimonio a fojas i y 2 del testimonio que bajo el número $2^{\mathrm{a}}$ en fojas 29 debidamente acompaño; el mismo que no quiso S. M. coartar a la persona de la impetrante, ni a cierto tiempo, sino que lo hizo extensivo por terminantes expresiones de aquella soberana disposición a sus herederos y sucesores; en cuyo número se cuenta su ternieta mi Poderdante, hija de don Manuel Hernández Navarro, y de mi hermana Doña María de la Rosa que como consta del testimonio citado, y del otro marcado con el No. I que también acompaño con la solemnidad de la Ley en 22 fojas, fue segunda nieta de doña Manuela Cerezo: el mismo que cuando Navarro mi cuñado disputó su posesión y propiedad a mi difunto padre (como marido de la madre de mi sobrina, obtuvo sentencia favorable para su uso y ejercicio en esta Intendencia, y en el Primer Tribunal de esta Nueva España, en vista y revista (Testimonio No. I) dejando la impresión por un convenio expreso y solemne de Navarro con mi padre en la Imprenta que hoy es mía y por la también he llamado a otro Privilegio de mi casa, aunque sus utilidades no lo sean y el mismo, par ano cansar la ocupada atención de V. E. que por dos veces, el Tribunal que hoy preside por los años setenta y tres, en juicio contradictorio (testimonio número dos) con el Colegio Seminario de esta ciudad, amparo a mi casa en el goce de otra Real gracia, e íntimo severamente a los colegios que no impresen en su oficina los papeles del Privilegio: de manera que habiéndose ahora el argumento de aquellas impresiones en la imprenta de los colegios, para combatir la gracia, contestaré que las impresiones del tiempo de la usurpación hija de la acodicia, ya V. E. conocerá cuán fuerte apoyo es para la invalidación de la gracia, y que era menester probar que las infracciones de la Ley anulan esta proporción que [182] estoy seguro no querrá, ni aún pensará sostener el Reverendo Padre Prepósito, cuya virtud y talento son tan conocidos: y si se habla de las impresiones hechas después del mes de enero de mil setecientos setena y siete en que mi difunto padre como legítimo administrador de los bienes de su hija doña Manuela Rosa y Ortega pro bono pacis, y por obsequiar a personas de Jerarquía, entre ellas el Ilustradísimo Señor Obispo que gobernaba, cedió temporalmente parte del uso del Privilegio, según la Escritura de transacción o compromiso que en fojas 9 útiles bajo el número 3 acompaña con el debido juramento, si algo prueba con esto el Padre Fulong, es la realidad del Privilegio y que fue de la madre de mi sobrina (cuyo enlace se pone fuera de duda con la certificación que bajo el número Exhibo) supuesto que la Imprenta usurpadora y despojante, tuvo que recibir como por gracia el permiso de imprimir solamente los actos y convites del Seminario de San Ignacio y los que se ofrecieron del Palacio Episcopal y, en qué tiempo, cuando mi padre tenía ganado el punto en el Consejo, circunstancia que realizó su generosidad y con descendencia en obsequio de quienes se dijo. Esta es una verdad, aunque no puedo documentarla, por haberse traspapelado el expediente, así como no hallaba la Cédula en el año de veinte y cinco en cuya edición tenía yo un fuerte interés por mi sobrina, para evitar los graves perjuicios de la Imprenta del Oratorio le ha irrogado desde abril a esta fecha y sobre cuyo relato nadie mejor está instruido que la parte contraria.

Hay ya en las constancias que de una vez he acopiado para todo trance hasta llegar al trono, cuando el Reverendo Padre Prepósito y el justificado Tribunal de V. E pueden apetecer aquellas 
para salir de sus muchas dudas y V. E. para dictar las providencias con que concluiré, y en los términos que las pediré, con apego a Derecho si no me equivoco.

El Reverendo Padre Furlong, hallará en los términos que acompaño, cuando sea tiempo de darle [183] traslado, o en los expedientes originales de donde se entresacó lo que me convenía y nada más (si aún cree que ha habido superchería en lo que pedí se compulsara que el Privilegio lo concedió quien podía quien mientras no lo revoque el mismo soberano aunque carece la libertad de los particulares en alguna pequeña parte, debe subsistir: que no fue por diez o veinte años sino por tiempo indefinido que no se circunscribió a la persona de doña Manuela Cerezo, sino que la concesión fue a ella y a todos sus herederos y sucesores de quienes como he dicho y probado tener nieta Doña María Guadalupe Hernández de la Rosa y Ortega: que la Cédula Real del año de setecientos veinte y cinco, que para lo que respecta a mi familia puede llamarse la Matriz o Primitiva del Privilegio, pues no había caducado ni aquella Real Cédula lo que ratificó solamente, no lo volvió a conceder como aparece se cree de contrario. Si el soberano hubiese dándole la ampliación que se impetraba en esta parte hubiera sido un nuevo Privilegio y el pase del Gobierno un requisito esencial e indispensable.

Todo esto hallará el Reverendo Padre Prepósito así como igualmente no puede ignorar que los Privilegios, como emanados de la potestad legislativa, y como lo denota la misma etimología del nombre, son leyes, aunque no comunes y públicas, y que a las leyes mientras quien pueda no las abroga o deroga, se les debe tributar respeto y obediencia: que los Privilegios, si por la odiosidad de que casi siempre van acompañados no deben ampliarse y ni restringirse conforme a la regla sabidísima de Derecho Favores suni ampliandi, etc., por ser disposiciones soberanas y respetables no deben [184] hallarse impunemente ni aniquilarse al arbitrio y por el capricho de otro individuo que nivelado como vasallo es lo mismo que el agraviado, y de consiguiente destituido de toda autoridad, y aún de la sobra de ella para anular lo que el soberano quiso conceder; intentar tal cosa es cometer un despojo violento como el que le ha inferido a mi poderante el Reverendo Padre Furlong, disminuyendo sus haberes aunque los haya destinado al santo fin que dijo en el escrito en que pidió licencia para abrir su imprenta, pues en realidad de verdad se han aplicado contra la voluntad de su dueño.

He dicho cuanto me parece instruirá suficientemente al tribunal Reproduzco mi disposición a contestar en el plenario de posesión o en el de propiedad cuanto quiera objetarse, si no se aquietan con los fundamentos y poderosos méritos que encierran esos documentos testimoniados con su citación y convincentes por lo respectivo al Tribunal de V. E. de que se me ha despojado violentamente, a mi oficina de la posesión privilegiada, quieta y tranquila de estar imprimiendo exclusivamente los papeles del privilegio de mi sobrina.

En efecto, la parte contraria y aún el Asesor de su Intendencia ha dicho ser evidente que en mi casa se han impreso de muchos años a acá, dudo empero, el segundo si aquella posesión había sido hija de la necesidad, por no haber habido en mucho tiempo más imprenta que la de mi casa, o si era en fuerza del Privilegio que yo alegaba, consta ya de la certeza de este por los documentos compulsados, citada la parte y por consiguiente en tales pruebas y confesiones ninguna duda puede quedar de posesión privilegiada que ha tenido doña María Guadalupe, mi sobrina de imprimir en mi oficina por el convenio escriturado que mi padre hizo con el suyo. (Documento No. 3): consta evidentemente se ha perturbado aquella tranquila posesión por la Imprenta del Oratorio de San Felipe Neri, y sobre ser esta verdad notoria al todo público, lo es no menos al Tribunal de V. E. con los impresos que acompañé a mi [185] me sujeté a la tasación y se regularon ciento cincuenta y ocho fojas de vista de Expedientes Y Documentos. Rúbricas

Escrito en diez y nueve de julio; en tales términos conforme de auto acordado de enero de setecientos setenta y cuatro que rige en la materia, es de vigorosa justicia, que se le restituya 
a mi sobrina la antigua posesión de su Privilegio de que ha sido despojada violentamente, que se restituía se le ampare en ella en toda forma (y esto es lo que se ha pedido antes, y en lo que se ha figurado contradicción el contrario): que se notifique al Reverendo Padre Prepósito de ruego y encargo se abstenga desde hoy en adelante de imprimir en la Imprenta del Oratorio, Actos, Conclusiones ni Convites condenándosele en las costas que me ha hecho litigante y que todo esto se determine por V. E como rendidamente se lo ruego, breve y sumariamente cual exige la naturaleza del juicio, y manda el Auto citado reservando al Reverendo Padre Furlong sus dueños, salvo para que promueva los que crea tener; como más le convenga, por tanto A. V. E. suplico de nuevo, provea como levo pedido y en los términos que he dicho y que se me haga saber la resolución para lo que me importe.

Así es de justicia. Juro en forma de no ser de malicia y lo necesario, etc. $=$ Traslado $=\mathrm{Ve}=$ Testado $=\mathrm{V}$. E. pro lo mismo no vale.=

$$
\text { Lic. José María Ramos. }
$$

Pedro de la Rosa

Puebla, Octubre 7 de i8ig.

Al Asesor

José Ramón Arellano

\section{EXELENTISIMO SEÑOR COMANDANTE GENERAL}

Accionando en el ocurso que antecede, el Teniente Coronel don Pedro de la Rosa, no por sí ni por un [186] derecho propio, sino en representación y con poder de Doña María Guadalupe Hernández de la Rosa, promueve de nuevo el recurso de despojo, que dice le ha inferido el Reverendo Padre Prepósito de la Congregación de San Felipe, haciendo que en la imprenta de esta casa se impriman los papeles de Actos, Conclusiones y Convites, para cuya edición pública tiene esa señora un derecho muy privilegiado; y aunque se extiende en impugnar las especies vertidas por parte del Padre Furlong, sin que por esto se entienda contestar al traslado que se le dió del Ocurso de fojas, la conclusión la reduce a pedir la principal ejecución del Auto acordado de la materia. Derechos Tres pesos Siete Reales

Legitimada como lo está hoy la representación del Teniente Coronel de la Rosa, cuya investidura debía constar siempre para que el Tribunal acomodara a las circunstancias del negocio en sus medidas, no hay embarazo en que se proceda a substanciar el juicio de despojo por aquellos mismos trámites que la disposición citada tiene prevenida, y esto es lo que en rigor de justicia se ha de hacer.

Ella ordena que interpuesto el recurso con la expresión correspondiente, con citación del despojante y señalamiento de prefijo componente término se justifiquen la posesión y el despojo, que si aquel quisiere con nueva igual citación dar justificación en contrario se le admita por los Jueces, y que con vista de todo se determine y ejecute sobre todo sumariamente lo que se tenga por más conforme a justicia.

Esto supuesto parece al Asesor que V. E. siendo servida, puede imponer que así el Teniente Coronel don Pedro de la Rosa con e Reverendo Padre Prepósito, rindan dentro del preciso y perentorio término de quince días las pruebas que estimaren convenir a sus derechos, recibiéndoseles por ante el actuario a quien podrá darse comisión para ese afecto, y que hecho estoy citadas las partes para la determinación, vuelva el expediente a la vista del que consulta, haciéndose saber ahora las [187] partes con el fin indicado, la presente providencia.

Puebla y octubre i4 de i8ig.

Rúbricas Ansorema.

Puebla, Octubre i8, i819

Como parece al Asesor.

José Ramón Arellano 
En la ciudad de los Angeles, a veinte y dos de octubre de ochocientos diez y nueve, yo, el escribano, habiendo pasado a la casa del Teniente Coronel don Pedro Pascual de la Rosa, siendo presente en su persona, le hice saber el dictamen y auto antecedentes según y en la forma que se manda y entendido dijo lo oye y que aunque pensó renunciar la prueba por haberla sobre abundantemente en autos de los dos extremos de la quieta posesión en que entabla la dueña del privilegio y la interrupción de ella por la imprenta del Oratorio; pero como los escritos del R. P. Prepósito están llenas de propuestas de que procede de buena fe y que se jacta luego que le conste de privilegio pide se le haga saber la providencia a dicho Padre Prepósito y si visto los autos no se abstiene y desiste, sino que los pide para probar que no ha inferido el despojo de que se ha quejado el que habla en tal caso se le entregue para probar con testigos que lo hará en veinte y cuatro horas.

Ešto respondió Doy fe

\section{Ramírez}

En la ciudad de los Angeles, a veinte y tres de octubre de ochocientos diez y nueve, yo el Escribano habiendo pasado al Oratorio de San Felipe Neri y estando con el R. P. Prepósito en su persona la hice saber lo mandado [188] de que entendido dijo: se le entregue este Expediente para con acuerdo de su abogado responder por cuyo motivo así lo verifiqué, doy fe. $(\mathrm{R} .=\mathrm{de}$ ruego y encargo. $=\mathrm{V}$. C.

$$
\text { Ramírez. }
$$

\section{SELLO TERCERO, DOS REALES:}

AÑOS DE MIL OCHOCIENTOS DIEZ Y OCHOCIENTOS ONCE.-

El Teniente Coronel retirado don Pedro de la Rosa, por mi sobrina Doña Guadalupe Hernández de la Rosa, en el expediente que sigo con el Reverendo Padre Prepósito del Oratorio de San Felipe de esta ciudad sobre el despojo que la imprenta de dicha comunidad ha inferido del uso del Privilegio que tiene dicha señor para imprimir exclusivamente cierta clase de papeles ante V. E. como mejor proceda, digo: Que fiado en las protestas prodigadas en los escritos contrarios de la buena fe con que se decía proceder, y cejar de la instancia luego que se cerciorasen de la verdad, y consistencia del Privilegio, dije que este tribunal mando que en el término de quince días probáramos lo que nos incumbía, que aunque podía renunciar otra prueba por constar con notoriedad pública y de autos los dos extremos que debe acreditar todo despojado a saber la posesión de más de año (aquí ha habido quieta y tranquila más de cuarenta) y la usurpación y despojo ella, pero sin embargo creyendo como entonces creerá verdaderas, las referidas protestas del Padre Furlong, suspendía dar mi prueba hasta que hechos saber al último lo dispuesto por el Tribunal viera yo si importó en los documentos agregados a los autos: y que hacen ver a un ciego la realidad de el privilegio, se abstendría de su solicitud, en cuyo caso era mi prueba más inútil, que se insistía en aquella se me entregaré el cuaderno para rendir mis testigos.

Se notarió al Padre lo determinado y mi respuesta: pidió los Autos para imponerse y hablar con su patrono, y hace [189] veinte días se los tiene allá sin dar plumada ni decir cosa alguna, sin embargo de que mi patrono habló ahora diez días con el de él Padre haciéndole ver que el término de prueba estaba al vencerse y entonces quedó de que aquel mismo día iba a hablar con el Presbítero y le visara al siguiente su resolución.

Espera que esperarás nos hemos estado veinte días no han sido bastantes a dar la prueba del Padre Furlong, ni bastarán veinte meses porque es imposible que pruebe (y más cuando tiene confesado lo contrario en sus escritos) que doña María Guadalupe no estaba en posesión quieta y tranquila de su Privilegio y que la Imprenta de San Felipe usurpando el uso de él, la ha despojado. 
Está vista la buena fe protestada tantas veces, y es menester carecer hasta de sentido común para no conocer que no hay más objeto en tan raras dilaciones que citarse aprovechando de las impresiones que días ha, debían haber cesado allí: por lo mismo y habiendo estado en mano del Padre todo el tiempo designado para la prueba que ha dejado correr no sólo sin promover nada, sino teniendo a mí con las manos atadas no me queda más recurso que el de pedir a V. E. que en el día se le saquen los autos sin excusa ni pretexto a la contraria, los cuales puestos en el oficio, que se proceda a recibir, por mi parte la información que está dada en veinte y cuatro horas, y que en el mismo término (aunque podría pedir que ninguna se le... recibiere ya por su culpable omisión) de la parte contraria la suya serán mis (testigos) examinados sobre el pleito, conocimiento de las partes y demás generales.

Idem. Si la imprenta de mi casa estaba en la quieta y tranquila posesión del uso del Privilegio de mi sobrina doña Guadalupe Hernández de la Rosa de muchos años a esta parte hasta que en este año interrumpió de hecho, aquella posesión de la Imprenta de Oratoria, imprimiendo convites y conclusiones, como hasta el día. Idem, De público y notorio, pública voz y fama, etc. Y dada esta información, sin que se admita ocurso contrario que toque al plenario de posesión o propiedad [19o] V. E. Se ha de servir sentencia el juicio sumario que tengo entablado en los términos que pedí en mis anteriores escritos: así es de justicia juro no ser de malicia, y pido expresa condenación de costas por la notoria temeridad de mi contrario.

Pedro de la Rosa

Lic. José María Ramos

Puebla, noviembre i3 de i8ı

Al Asesor

Ante mí.

Intendencia.

Juan de Castro y Andrade

Notifíquese a la persona que haya firmado el conocimiento de los autos que se refieren, los devuelva inmediatamente y dese cuenta ara con arreglo a su mérito y estado proveer lo conveniente. Lo mandó el Excmo. Señor Comandante General Gobernador Intendente Brigadier don Cirilaco de Llano con acuerdo de su asesor en Puebla a dos de diciembre de mil ochocientos diez y nueve.

Ansorenal.

\section{Ante Mí}

José Ramírez Arellano

En la ciudad de los Angeles a tres de diciembre de ochocientos diez y nueve. Yo el escribano habiendo pasado a el Oratorio de San Felipe Neri y estando con el R. P. Prepósito en su persona de ruego y encargo, le hice saber lo mandado en el anterior auto de que entendido, dijo: Que el día de mañana pondrá en la oficina los autos que se reclaman. Este respondió doy fe E. R. de ruego y encargo.- V. E.

Ramírez.

[III] SELLo TERCERo, DOS REALES:

AÑOS DE MIL OCHOCIENTOS DIEZ Y SEIS, Y MIL OCHOCIENTOS DIEZ Y SIETE

EXMO. SEÑOR

El Teniente Coronel Don Pedro de la Rosa por su sobrina Doña María Guadalupe Hernández sobre el privilegio para imprimir exclusivamente cierta clase de papeles, cuyo ejercicio le ha usurpado la imprenta del Oratorio de San Felipe Neri, ante V. E. digo: Que ni el término de 
quince días que se le concedieron al Padre Furlong para probar, ni otro mes más, ha bastado para que entregue los autos, a pesar de habérsele notificado hace días que los pusiera en el oficio inmediatamente, contestando que hoy los pondría pues los tenía su abogado.

Ya es intolerable tal manejo, pues un juicio sumario no va durando mucho más que un ordinario y para que no quede en arbitrio del Padre al estarse aprovechando de lo que tiene cierta ciencia que es representada, V. E. se ha de servir mandar que inmediatamente se le vuelva a notificar al Padre o al que haya firmado el conocimiento de el Expediente, los entregue en el día en virtud de rebeldía que le acuso en Auto, pidiendo se le condene en las costas de ella; que si no los entrega pase el Alguacil mañana y los saque con apremio de donde se hallen, que puestos en el oficio, se haga la recepción de m prueba dentro de veinte y cuatro horas en las que por equidad se admita la suya al contrario, sin prorrogarle ni una hora más, y que se termine el punto posesorio, porque sino el daño que está infiriendo, es continuo y protesto demandárselo por la conducta que está observando en este juicio. Por tanto A. V. E. suplico provea como pido: es de justicia, juro lo necesario, etc.

Lic. José María Ramos.

Pedro de la Rosa

Puebla, diciembre de I8I9

Entere a lo mandado

Ante mí José Ramón Arellano. [192] Al tiempo de pasar a hacerle saber al R. P. Prepósito las providencias antecedentes puso los autos de que se trata en esta oficina. Puebla, diciembre once de ochocientos diez y nueve.

Puebla, diciembre I4 de i8i9

$\mathrm{Al}$ asesor

Ante mí

José Ramón Arellano

Corran traslado de este ocurso a las partes.

SELLO TERCERO, DOS REALES:

AÑos DE MIL OCHOCIENTOS DIEZ Y SEIS Y MIL OCHOCIENTOS DIEZ Y SIETE

El Presbítero don Joaquín Furlong, Prepósito de la Congregación de San Felipe Neri de esta ciudad, en el expediente seguido ante V. E. con el Teniente Coronel don Pedro de la Rosa, sobre la imprenta de mi Oratorio, en estado supuesto, como más haya lugar por derecho digo: que tuvieron su principio estos autos: por el ocurso que dirigí a este mismo Tribunal, solicitando que [De] la Rosa exhibiese el Real Privilegio que alegaba tener, para imprimir él sólo en esta ciudad, los actos: Conclusiones y Convites, que en ella se ofrecieran.

Insistí en mi pretensión a virtud de que los méritos alegados en mis escritos de fechas 3,8 , y ıо: ya que aunque tuvo efecto la manifestación de las Reales Cédulas que yo deseaba ver para mi gobierno y dirección; pero los resultados han sido muy distintos a lo que esperaba; pues que concluido aquel artículo que promoví, ahora pretende don Pedro de la Rosa, instruir un nuevo Juicio sobre posesión del soñado privilegio.

Pero es el caso, que si yo pedí ante V. E. como actor que se previene a la Rosa la edición de los documentos, esto fue [193] en el justo y muy seguro concepto de ser V. E. un Juez competente, por el fuero militar de que goza: más que ahora él pretenda demandarme como actor, y que yo sea el reo en este Juzgado, me parece que está muy fuera del orden y de toda jurisprudencia. Porque o bien sea por mis personales fueros, o ya por los de toda la Congregación sagrada 
que presido, nadie puede decirme, que en el punto que sé que se trata, estoy sujeto a contestar ante V. E. la demanda de Don Pedro. No es ella acerca de materias de Gobierno o policía; no sobre curaduría de menores o albaceargo; ni de alguna otras en que entiendo que los eclesiásticos pierden su particular fuero.

Además advierto, que la demanda contraria, no viene (porque no puede venir) en términos de mutua reconversión; en cuyo caso, también confieso que estaría mi Congregación obligada a contestarla en este propio tribunal, sino una cosa tan distinta, como se manifiesta al primer golpe de vista, sin necesidad de ocurrir a lo profundo de la legislación para conocerlo.

Yo pedí según he dicho, y el expediente comprueba, que el Teniente Coronel manifiesta sus alegados privilegios. Lo hizo ya, aunque con alguna dilación y trabajo: por consiguiente, me instruí de lo que intentaba, y tenemos el asunto concluido. Pero querer que ahora como en necesaria consecuencias de este artículo, esté yo sujeto a contestar aquí mismo en el juicio de posesión, que con tanto ardor promueve don Pedro, me parece que ninguna Ley puede obligarme a eso.

$\mathrm{Ni}$ aunque yo voluntariamente pudiera hacerlo, pues que como no soy dueño ni árbitro de los privilegios sagrados que disfruta mi persona y comunidad, tampoco está en mis facultades renunciarlas; y por tanto, ni el contestar ante V. E. demanda contraria.

Si elegí este Tribunal para dirigir mi acción contra la Rosa, eso fue muy debido porque él es súbdito de V. E. por muchos títulos; y si anuncié que litigaría también la validación o nulidades del privilegio, ya se entiende que esto lo hubiera hecho como actor, más de ningún modo en clase de reo, en un tribunal que no me compete. [194] Finalmente, aunque en mi escrito de fecha io me dediqué un poco a refutar su pretendido privilegio, y aún parece que me dispuse a contestarle, fue solamente por ver si llegaba a desengañarse con mis razones de sus infundadas solicitudes; pero nunca jamás pensé en sujetar mi congregación a hacer las veces de reo en este asunto ante $V$. E. pues que ni está ello en mi arbitrio, aunque quisiera ni debo prescindir de los privilegios que los cánones sagrados y las leyes españolas nos dispensan.

Así que, insistiendo don Pedro de la Rosa como efectivamente insiste en sus quejas de despojado contra mí, no respondo otra cosa, sino con la excepción declinatoria de fuero, que formalmente opongo, pues se ha visto que yo y mi Oratorio, no podemos ser reos demandados en este Tribunal, por el fuero eclesiástico que para eso nos protege: que la demanda contraria no es sobre alguno de los casos que se exceptúan de aquella regla general, y por último, que ni bajo el aspecto de reconvención o mutua petición, es admisible en este Juzgado la demanda de don Pedro.

Sírvase V. E. declararlo así, mandando en consecuencia se le notifique, que si continúa en sus pretensiones, ocurra a mi Juez competente; y que se me devuelva original el escrito de la $\mathrm{r}^{\mathrm{a}}$ foja con las actuaciones de la $2^{\mathrm{a}}$ para mi resguardo, por tanto A. V. E. suplico que provea en todo como he dicho por ser justo, juro etc.
Joaquín Furlong
Lic. José María
Prepósito
Ponce y Rincón

Córrase traslado de este curso a la parte del Teniente Coronel don Pedro de la Rosa. Lo mandó el Excelentísimo Señor Comandante General Gobernador Intendente Brigadier don Ciriaco de Llano con acuerdo de su Asesor en Puebla a veinte y dos de Diciembre de mi ochocientos diez y nueve.

(Rúbricas)

M. de Anzorena

Ante mí José Ramón de Arellano 
[195] En la ciudad de los Angeles a veinte y tres de diciembre de ochocientos diez y nueve. Yo el escribano habiendo pasado a la casa del Teniente Coronel don Pedro Pascual de la Rosa e su persona le notifiqué el traslado prevenido y dijo se le entreguen los Autos, esto respondió. Doy fe.

\section{SELLO TERCERO: DOS REALES:}

\section{AÑOS DE MIL OCHOCIENTOS VEINTE Y VEINTE Y UNO EXELENTISIMO SEÑOR}

Doña María Guadalupe Hernández Ortega de la Rosa (sin revocar el poder que tengo dado a mi tío el Teniente Coronel don Pedro Pascual de la Rosa que se halla fuera de la ciudad) en el expediente que sigo contra la imprenta de San Felipe, por haberse usurpado el Privilegio de imprimir cierta clase de papeles cuyo producido se han estado tomando contra la voluntad de su dueño, su estado supuesto y el artículo instruido sobre declinar la Jurisdicción V. E. ante su justificación, digo: que despreciando la solicitud del Padre Furlong, se ha de servir V. E. mandar que inmediatamente se me reciba la información que V. E. ha mandado, y en que consintió el contrario tomando los Autos, y en seguida de aquella se le intime se abstenga de imprimir lo que no le toca; y le consta ya de cierta ciencia, y en los demás que se haga como tengo pedido en mis anteriores.

Al leer aquella protesta del Padre Furlong en fojas i2, he dicho y repito que estoy distante de querer originarle mal alguno que tontamente creí que era la hija de la sinceridad; supuse que desengañado el que dice que quería desengañarnos con su escrito de fojas io no continuaría perjudicándose y por eso sentó la respuesta de fojas ioo [196] vuelta, pero al ver la conducta con que se ha seguido este litigio, y la infeliz fecundidad de expedientes para prolongar el goce de que es ajeno, he conocido prácticamente la evidencia de aquella sagrada máxima: "Operabus credite et non verbis".

Aquí plantó sus solicitudes al Padre Furlong. Aquí ha hecho aquellas protestas desmentidas por sus hechos. Aquí abrumado del peso de la justicia que me asiste, y desengañado con los documentos de mi Privilegios (que soñado como es no lo contrastara la parte contraria) no temiendo que responder, toma el huidero de acogerse a su fuero, no porque crea obtener allí sitio para alargar otro año la conclusión de un fuero, no porque en la demora de está bonanza: Aquí contestó e su Escrito de fojas I) en tono bien firme, porque creyó que cantaba victoria, con aquel débil y equivocado alegato, y aunque ahora dice que se dedicó un poco a refutar el pretendo y como que se dispuso a contestar, V. E. calificará si contestó o sólo hizo la intención. Así como si el refugio a que ocurre, y que es el colmo en las pruebas de una mala fe, será siquiera tolerable.

Parece que la parte contraria se ha dedicado a estudiar el pleito que por el año de setecientos setenta y tres comenzó en esta Intendencia (entonces sólo era Gobierno), mi abuelo don Pedro de la Rosa, contra el Colegio Tridentino de San Pantaleón, supo parte de nuestro Privilegio, como hoy la imprenta del Padre Furlong: y que su Reverencia se ha propuesto por modelo el giro de aquel expediente cuantos pasos dió el tesorero de aquel colegio: hasta aquí va exactamente ajustada la conducta de dicho padre Furlong, en los débiles fundamentos para haber interrumpido la quieta, pacífica y antigua posesión de mi familia en el goce de mi Privilegio: en el anhelo de aprovecharse de los productos de aquel, siendo ajenos; y por último en la graciosa declinatoria, queriendo que el despojo que ante V. E he reclamado como mutua petición contra el demandante de mis documentos vaya al eclesiástico como lo pretendió entonces el tesorero de los colegios pontificios alegando el mismo fuero eclesiástico que el Padre Furlong: ahora lo que le falta es, que en seguida de la [197] declaración de V. E. la que debo sea amparada en 
la posesión luego de restituida a ella, y notificado y apercibido el Padre Furlong se abstenga de esta y semejantes usurpaciones pena de perdimiento e los moldes y pertrechos de su imprenta con las demás a que haya lugar, interponga recurso para que lo pierda en la superioridad como perdió su modelo el recurso de fuerza por querer conocer el eclesiástico de igual disputa a la de el Padre Furlong, a título de que la Imprenta de San Pantaleón correspondía a una comunidad eclesiástica y su tesorero eclesiástico como lo es el Padre Prepósito y su Congregación.

En el Expediente original citado que obra en el oficio de esta Intendencia, de donde se sacó el testimonio número 2 que corre a fojas 47 y siguiente de este $2^{\circ}$ consta (y así se ve a fojas 56 y 59 de otros testimonios en este Expediente) que aún siendo la imprenta en el Colegio Tridentino de cuenta del Señor Obispo y eclesiásticos sus administradores como el Padre Furlong de la de el Oratorio, y la congregación, declaró S. A. que el Provisor de aquella época a donde se refugió (como ahora quiere hacerlo el Padre Prepósito) el tesorero de los Colegios, hacía fuerza en otro conocimiento y mandó que se devolvieran los auto a este Tribunal par que el señor Gobernador don José Merino y Zaballos, antecesor de V. E. continuara en la secuela del negocio, como de hecho siguió amparó en la posesión y privó a la imprenta de San Pantaleón de seguir imprimiendo los papeles cuya edición había usurpado. Ruego a V. E. se sirva volver a ver el testimonio de el Dictamen de nueve de mayo de mil setecientos setenta y seis del Asesor de Gobierno don José de Agesta y Echeverría, fojas 59, 60 y 6i de este cuaderno y las resolución de S. A. y pedimento fiscal originales de que no pedí testimonio porque nunca creí tanta injusticia y tenacidad de la parte contraria como estoy palpando. La simple lectura de otros documentos no dejará duda a V. E. ni a su ilustrado Asesor, de que en un pleito idéntico no le valió al Tesorero del Colegio Seminario y Tridentino querer tomar iglesia, y tampoco debe valerle inmunidad a mi contrario.

La Real Audiencia de México en su determinación de que hacía fuerza el Provisor de Puebla de San Pantaleón con [198] mi abuelo, dijo bien claramente que era ajeno a su jurisdicción y propio de la de el Juez Civil a la manera que en los albaceazgos, puntos de Gobierno y demás que cita el Padre Furlong; en que equivocadamente dice que los Eclesiásticos pierden su fuero, debiendo decir que en tales casos nunca la tuvieron, lo que debe preceder a la acción de perderlo.

Y no lo han tenido, porque aunque las personas sean eclesiásticas, los asuntos son profanos, civiles y de la inspección de los Jueces Seculares por eso en una quiebra ruidosa acaecida en Sevilla de una comunidad religiosa, queriendo ésta que sus jueces fueren eclesiásticos por serlo la parte fallida, el Sabio y Supremo Consejo de la Nación declaró que pues la quiebra había sido comerciando, los juzgasen los Jueces seculares, el hecho es inconcluso, dudo que el Padre Furlong tan instruido no lo haya visto; y dudo también que no conozca que una oficina de imprenta es un ramo profano de comercio, y que puede ser su administrador un lego o un eclesiástico cuando sus productos son dedicados a obras de piedad, con su Reverencia ha hecho aquí, aunque en mi perjuicio y contra mi voluntad. Pero ni la cualidad de su persona, ni el santo fin a que dice, y no dudo, ha consagrado los productos de mi Privilegio ni descularizan (permítaseme esta expresión) el tráfico de la imprenta ni la sacan de la esfera del conocimiento de el Gobierno Civil, como quiere el Padre Furlong y como la ejecutoria citada de S. A. dice que no debe ser, Haciendo notable fuerza que las luchas del Padre Prepósito o cuando sed propuso desengañarnos del error que nunca hemos padecido sobre mi Privilegio, o siquiera cuando en veinte y tres de octubre (más ha de dos meses) pidió el expediente para salir a la larga distancia con la bella ocurrencia de la declinatoria, no hubiera ocurrídosele ni de chanza que era reo y clérigo; y por último para concluir hace fuerza que cuando el Asesor de V. E. que 
sabe leyes tiene perspicacia e integridad en su dictamen de I4 de octubre último hablando de mi con la atención que es tan propia de una educación fina, haya asentado que en virtud de los documentos tengo "un derecho muy privilegiado para la edición pública" de los papeles que contra todo viento y marea está imprimiendo el Padre Furlong, este Padre [I99] Prelado no vea habiendo leído mis papeles, mas que un privilegio soñado, supuesto, etc. Baste y por lo expuesto V. E. se ha de servir mandar hacer como pedí en mi conclusión; así es de justicia y que al Padre Furlong se conden en todas las costas por su evidente temeridad. Juro no ser de malicia.

Lic. José María Ramos

María Guadalupe Hernández

P. la R.

Enero 14 de 1820

Ante mí José Ramón Arellano, $\mathrm{Al}$ asesor

(rúbricas)

Excelentísimo Señor Intendente, etc.

Si es del agrado de V. E. puede disponer se cite a las partes para la sentencia del artículo de Declinatoria promovido últimamente y que ahora se dé cuenta. Puebla. Febrero 7 de 1820.

Puebla Febrero io de 1820

Como parece a Asesor

Amorenal.

De Ra...

Ante mí

En la ciudad de los Angeles a diez de febrero

SELLO TERCERO, DOS REALES:

AÑOS DE MIL OCHOCIENTOS VEINTE Y VEINTE Y UNO

EXELENTISIMO SEÑOR

Doña María Guadalupe Hernández ante V. E. como menor proceda digo: que mi tío el Teniente Coronel D. Pedro de la Rosa a mi nombre y con poder mío, ha seguido en este Tribunal un expediente contra el R. Padre Prepósito del [200] Oratorio de San Felipe Neri de esta ciudad, acerca de que no dé a luz en su imprenta, ciertos papeles para lo que yo tengo un Real Privilegio exclusivo heredado de mis abuelos; y habiendo tenido yo composición con otro Reverendo Padre como que soy la dueña del Privilegio, lo hago presente a V. E. para que se dé por concluido este expediente en el estado que tengo, pues además revocó el poder que para tal pleito le conferí a mi citado tío: Por tanto.

A. V. E. Suplico que teniéndome por desistida de esa instancia provea como he dicho: juro lo necesario y que para esto no he sido compulsa ni apremiada.

María Guadalupe Hernández

Puebla I5 de Marzo de 1820.

Al Asesor

de... (Rúbrica).

EXCELENTISIMO SEÑoR INTENDENTE, etc.

Doña María Guadalupe Hernández por quien había gestionado el Teniente Coronel don Pedro de la Rosa en este asunto manifiesta en el ocurso que procede que revocando el poder que tenía dado a ese individuo quiere se dé por concluido el negocio a virtud de estar compuesta con el Reverendo Padre Prepósito del Oratorio de San Felipe. 
Esto supuesto lo que corresponde hacer es que esa señora por ante el Actuario reconozca y ratifique bajo la solemnidad del juramento el escrito dado últimamente, y que hecho esto se haya por revocado el poder con que obrava don Pedro de la Rosa, a quién se le hará saber esto [20I] oportunamente se instruya al Padre Prepósito de lo ocurrido se tenga por concluida la instancia promovida por aquel, y que el expediente se archiva mándelos V. E. resolviendo sino lo que fuere de su agrado. Puebla y Marzo 20 de 1820.

Amorenal. (Rúbrica)

Puebla Marzo 23 de 1820.

Como parece al Asesor de Llano

Ante mí José Ramón Arellano

En la ciudad de los Angeles a veinte y ocho de marzo de mil ochocientos veinte. Yo el Excelentísimo, habiendo pasado el Colegio de San José de Gracia a efecto de poner en ejecución lo mandado en el antecedente auto y para ello estando presente su rectora doña Catalina Manuela González de la Torre, requerida para que me manifestase a doña María Guadalupe Hernández me respondió no poderlo verificar, sin expresa orden del rector Presbítero don José Linares y para que conste lo siento por diligencia. Doy fe. Ramírez [202] En la ciudad de los Angeles a seis de abril de mil ochocientos veinte. yo el Escribano habiéndose vuelto al Colegio de San José de Gracia a virtud de la licencia que su Rector Don Luis Linares concedió para la diligencia mandada practicar y estando en la reja compareció doña María Guadalupe Hernández quien estando presente asentó llamarse así, ser española natural y vecina de esta ciudad de estado doncella de veinte y cinco años de edad cumplidos a quien a presencia de la doña receptora doña Catalina Manuela González de la Torre le recibió juramento que hizo por Dios Nuestro Señor y la Señal de la Santa cruz según derecho por lo que ofreció decir vedad en lo que se supiere y fuera preguntado y habiéndole manifestado y leído de principio a fin el Escrito antecedente, dijo: que está formado según y cómo lo mando hacer: que la firma que se halla a su calce es de puño y letra de una niña que se halla en este mismo Colegio llamada Doña María Gertrudis Arias por la que va hablando no sabe firmar pero que todo su contenido es cierto y verdadero y por lo mismo lo ratifica y reproduce de nuevo en todas sus partes y no teniendo que añadir o quitar cosa alguna en el se afirma por su juramento que fecho tiene en que se afirmó y no firmó porque dijo no saber. Doy fe.

Ante mí,

José Ramón Arellano.

En la ciudad de los Angeles a siete de abril de ochocientos veinte, yo el Escribano habiendo pasado a la casa del Teniente Coronel don Pedro de la Rosa a efecto de cumplir con lo mandado y estando con el Presbítero con Mariano de la Rosa su hijo me aseguró que su padre se hallaba en México que él tenia poder bastante como lo acreditaba con en que [203] exhibía en el acto y agrego en cuya virtud le hice saber de ruego y encargo lo prevenido en el antecedente auto de que entendido dijo lo oye y siéndole gravosa la determinación que se le hace sabe desde luego hablando con el debido respeto, apela de ella para esta su Alteza Real Audiencia, cuyo recurso formalizará en el día suplicado que testimoniado que sea el poder que presente se le devuelva por necesitario para otros asuntos. Esto respondió. Doy fe.

Mariano de la Rosa.

Este día ha ocurrido el Presbítero don Ma....

\section{Ramirez.}


SELLO TERCERO: DOS REALES:

AÑOS DE MIL OCHOCIENTOS VEINTE Y VEINTE Y UNO

\section{EXCELENTISIMO SEÑOR}

El presbítero don Mariano de la Rosa representado la persona por mi padre don Pascual de la Rosa, que se haya ausente: como mejor proceda y bajo las protestas oportunas, digo: que seguidos autos con el padre Prepósito del Oratorio de San Felipe Neri de esta ciudad sobre que se abstuviera de imprimir convites, actos o conclusiones se ha determinado el punto definitivamente a favor del expresado Padre Prepósito, y siéndole muy perjudicial el nominado mi padre esa resolución, y mucho mas por la ocurrencia que ha dado merito a ella, acerca de la cual hay mucho que alegar; pues el fundamento en el que se descansa es hablado con el debido respeto, legal; apelo desde luego de dicha resolución a nombre de dicho mi Padre, para ante su Alteza Real Audiencia del Distrito, y en cuyo superior tribunal protesto presentarme en grado a mejorar el recurso, y expresar lo que tenga por agravios; en cuyo concepto suplico, que habiéndolo [204] V. E. por interpuesto, se sirva suspender todo procedimiento, en el asunto, como es de riguroso derecho. Por tanto y dejando a salvo los demás recursos, que la ley me franquea.

A. V. E. suplico provea como pido, que es justicia, juro en forma, lo necesario con protesta de costas.

$$
\text { Mariano de la Rosa }
$$

Lic. Manuel López
Torrecilla

En la ciudad de los Ángeles a catorce de abril de ochocientos veinte Yo el Escribano habiendo pasado a la casa del Presbítero Don Mariano de la Rosa estando presente en su persona de ruego y encargado le hice saber lo mandado en el anterior Decreto en la parte que le toca de que quedó entendido. Doy fe.

La Rosa

\section{Ramírez}

Sea notorio a los que presente vieren como Yo don Pedro Pascual de la Rosa. Teniente Coronel retirado del Regimiento de Dragones Provinciales de esta ciudad, y vecino de ella, otorgo que doy mi poder cumplido y bastante el que en derecho se requiere y es necesario a mi hijo don Mariano de la Rosa y Mendia, subdiácono de este obispado general para que a mi nombre y a mi representación de mi propia persona derechos y acciones, rija, gobierne y administre mis bienes, arrendando las raíces a personas, por los tiempos, precios, bajo las calidades y condiciones que capitulare, obligándome a que los arrendamientos serán ciertos y seguros, durante ellos no se quitaran las fincas por ninguna causa, titulo o razón, que para ello causa gracia de darle otras tales, y tan buenas en equivalente paraje por el mismo precio y tiempo. Para que pueda venderlas a quien más bien visto le fuere por los precios [205] en lo que ajustare el contado o finado, declarando que la cantidad en que vendiese es el justo y verdadero valor, que al presente número las fincas, y que no valen más, y valiendo de la demasía o exceso en cualquier cantidad que se haga a los compradores gracia y donación, pura, mera, perfecta e irrevocable por contrato firme entre vivos, conforme a derecho con renuncia de la Ley o de Ordenamiento Real fecha en Cortes de Alcalá de Enares que hasta de las compras y ventas que se celebran por más o menos de la mitad del justo precio, y término de cuatro años que por ella tiene asignado para pedir rescisión del contrato o suplemento a su verdadero valor cuyo auxilio con el de la enorme enormísima lesión y engaño así mismo renuncie y me desista y aparte de todos los derechos y acciones reales y pesonales de propiedad, posesión, señorío y otros que a las 
fincas tengo y me pertenecen, y los ceda, renuncie, transfiera y traspase en los compradores a quienes de su posesión y poder bastante en derecho para su aprehensión constituyéndome en el ínterin por su inquilino precario en forma para darla cada que se me pida: Para que pueda acomodar y acomodde toda clase de sirvientes, asignándoles los salarios y raciones que sean regulares, quitando, a otros a éstos con causa o sin ella, pueda aceptar y acepte las herencias que me toquen accediendo en todos los derechos en que fuere instruido con beneficio de inventarios y protestación de no confundir mis derechos y acciones usando para su inmunidad de los recursos legales que me patrocinen y favorezcan y siendo necesarias algunas cantidades de pesos para cualesquiera fines las puedan solicitar y solicite del cofre de esta Santa Iglesia Catedral, u otras, o de las Arcas de cualesquiera conventos, colegios, obras pías o pesonal, particulares que se le proporcionase, haciendo en el asiento todas las diligencias que sean oportunas hasta su consecución obligándome a pagar lo que así fuere por término que se le diere y en el ínterin, sus réditos de cinco por ciento en cada un año de los que corriesen hasta total redención: para que pida y tome cuentas a todas las personas que me las deban dar haciéndoles cargos recibiéndoles sus descargos justos competentes y a derecho conformes nombrando para ello terceros contadores, partidores y apreciadores, instando en que las otras partes por la suya los [206] nombren y en su rebeldía o discordia Real Justicia de Oficio y las pruebas o adiciones en todo o en parte pidiendo se vuelvan a hacer de nuevo hasta que estén a toda su satisfacción y haya percibida demanda y cobre el alcance o alcances que de ellos resultare, lo que de los arrendamientos y ventas que hiciere se restare o adeudare con los demás pesos de oro, plata, joyas, eclavos, mercadería, semillas, ganado frutos, esquilmos y otros bienes racies, muebles o semovientes que se me deban y debieran en virtud de escrituras, vales, cédulas, libranzas, conocimientos, cuentas de libro, sentencias, traspasos, herencias, donaciones, renunciaciones, futuras sucesiones, o por los instrumentos, auténticos, simples o sin ellos, y de lo que percibiere y cobrare, otorgue recibos, cartas de pago, finiquitos, gastos y otros recados en forma con cesión de derechos, cancelación de instrumentos y renunciación de las leyes del no entrego (por) su prueba y excepción del dinero no contado no siento la paga por ante Escribano que la certifique en cuya razón para todos mis pleitos, causas y negocios que al presente tengo y en adelante se me ofrecieren con cualesquiera persona bienes han sido mandando como dependiendo: pueda parecer y parezca ante el Rey Nuestro Señor (que Dios guarde muchos años) en sus reales audiencias, cancillerías, superior gobierno de esta Nueva España, y demás Tribunales Superiores e Inferiores sus Jueces y Justicias Eclesiásticas y seculares que con derecho pueda y deba: $Y$ ponga demandas recovencione por mutuas peticiones o como más convenga, responda a las contrarias que conteste o niegue, y haga pedimentos, requerimientos, citaciones, protestas, súplicas, juramentos, alegaciones, oposiciones, contradicciones y declinatorias que imparta; recuse Jueces, letrados, escribanos y otros Ministros jurando las recusaciones y apartándose de ellas cuando convenga. Ponga querellas y acusaciones, pida embargos, desembargos, entregas de ejecución, mejoras, prisiones, solturas, apartamientos, consentimientos, desestimientos, ventas y remate de bienes de que pida aprehenda, posesión y amparo, que continúe defienda, presente testigos, escritos, escrituras, probanzas, testimonios, testamentos, cláusulas de ellos y otros papeles y recados que pida y saque de cuyo poder estén y los abone, tracte y redargulla las que de contrario e presentaren del [207] modo que le pareciere, haga autos y sentencias, interlocutorios y definitivas, consienta lo favorable y de lo adverso y perjudicial apele y suplique siguiendo el grado por todos artículos e instancias hasta su final conclusión y determinación, pide testimonios o los renuncie: gane mandamientos, reales provisiones, cartas de justicia y otros despachos por todos efectos y ante las Eclesiásticas para descubrir bienes y revelar secretos, censurar generales y particulares, que haga leer públicas o 
íntimas hasta la de anatema sacando testimonio de lo que en virtud se obrare que uno otro presente donde convenga pidiendo su obedecimiento y cumplimiento. $Y$ haga todos los demás actos, agencias y diligencias jurídicas y extrajudiciales que se requieran, y con cualesquiera de mis deudores las quitas quiebras sueltas y esperas por las cantidades que por bien tuviere. Pueda transferir, concertar y convenir los asuntos que me ocurran bajo de las cantidades y condiciones que capitulare con cecion de los derechos que me tocan, y aceptación de los que me dieren: $\mathrm{Y}$ así mismo comprometa mis pleitos, deudas y diferencias en manos y parecer de jueces, árbitros, arbitradores, juris amigables componedoras, dándoles poder y término y prorrogándoles el necesario, concediéndoles facultad para que lo prorroguen para su Juicio y sentencia con la pena convencional y la parte obediente, y la que dieren consienta o reclame o albedrío de obediente, y la que dieren consienta o reclame o albedrio de ben varón con la fianza de la Ley Real de Madrid, la cual y demás de mi favor renuncié otorgando sobre los efectos de este Poder la Escritura o Escrituras que se pidieren y fuesen necesarias con las cláusulas, salarios, sumisiones, relaciones de prueba y renunciaciones de leyes de fuero, poderío y sumisión a las justicia competentes del conocimiento de su causas y demás del caso, y para su mayor validación sean importantes, que de la suerte que le hiciere y otorgare de esa misma desde ahora para entonces lo otorgo, apruebo y ratifico, y me obligo a su observancia, paga, guarda y cumplimiento. Y a la firmeza de este Poder y lo que en su virtud se operase con mis bienes habidos y por haber, y lo doy a los Jueces y Justicias de su Magestad que de sus causadas conforme a derecho puedan y deban conocer para que a ello me compelan y apremien como si fuerse por sentencia [208] consentida y pasada en autoridad de cosa juzgada, renuncio las leyes y privilegios de mi favor y defensa con la que prohíbe la general renunciación. Y por cuanto soy apoderado de varios sujetos, vecinos de esta ciudad, y fuera de ella desde luego se entenderán substituidos en dicho mi hijo generalmente los poderes que me tengan conferidos para que use de ellos y siga practicando los negocios que dejó don corriente hasta su conclusión: que para dicho su anexo insidente y dependiente le doy este Poder con libre, franca y general administración, sin que por falta de cláusula, requisito o circunstancia de aquí no se exprese deje de obrar los efectos a que se dirige este Poder, pues la que se eche menos o se extrañe esa misma la he aquí por inserta e incorporada como si en efecto estuviese con facultad de no enjuiciar, jurar y substituir en todo o en parte las veces y en las personas de su satisfacción que le pareciere, revocar, substitutos, cobrar de ellos y nombrar otros de nuevo que a todos releva según derecho que es fecho en la muy noble y muy Leal Ciudad de la Puebla de los Angeles a treinta y uno de Mayo de mil ochocientos diez y seis.- Y el otorgante a quien yo el Excelentísimo doy fe conozco así lo otorgo y firmo siendo testigos don Miguel de la Victoria, D. José María Sánchez y don Joaquín Gómez de Vargas de esta vecindad, doy fe. = Pedro de la Rosa. == Ante mí Manuel José Herrer. = Concuerda con su original que queda en el Protocolo de este oficio mayor público de cabildo del qque es propietario el Capitán don Antoni Ruiz de Adorno, a que me remito. Y para que conste de este traslado día de su otorgamiento en seis fojas del papel del Sello Segundo y Cuarto, siendo testigos los instrujentales, doy fe.= Aquí un signo.= Manuel José Herrera.

Concuerda literalmente con el poder original que presentó el Presbítero don Mariano de la Rosa y le he devuelto con esta fecha en cumplimento de lo mandado en el anterior auto porque conste pongo el presente en Puebla a catorce de abril de mil ochocientos veinte.

Res el Poder de José Ramón Arellano La Rosa [209] Nicolás Rodríguez Calvo por el Teniente Coronel don Pedro de la Rosa, ante V. A. como mejor proceda, digo: que doña María Guadalupe Hernández, sobrina carnal de mi parte como hija de una hermana suya, es poseedora de un privilegio real en que su M. se dignó conceder a uno de los ascendientes, y a los suce- 
sores de él, que pudiesen imprimir privativa y exclusivamente, actos y conclusiones literarias, y todo género de convites en la jurisdicción de Puebla, más no teniendo imprenta propia el padre de la dicha doña Guadalupe y conociendo que esta es una mujer naturalmente inocente y falta de talento, con tanto extremo que debe refutarse por mentecata, trató con don Pedro de la Rosa padre mi parte que luego que aquel falleciese la recogiera en su casa, y usara del referido privilegio, dándole en compensación cierta cuota anual por parte de pago de alimentos.

A consecuencia de esto y del mismo parentezco de mi parte con Doña Guadalupe, habiendo quedado enteramente desamparada cuando murieron sus padres, la recogió mi parte en su casa, y la mantuvo como hija suya con la correspondiente decencia, sin escasearla cosa alguna por el espacio de muchos años; usando mi parte del privilegio quieta y pacíficamente en la imprenta que tiene en aquella ciudad.

En tales circunstancias comenzó el Padre Prepósito del Oratorio de San Felipe a imprimir actos y demás en la imprenta que nuevamente manifestó y mi parte se opuso a ello, no tanto como su tutor y curador ad Bona, y por el interés propio que en esto tenía, más no habiendo podido convencer en lo extrajudicial al Padre Prepósito, hubo de presentarse en forma ante Vtro, Gobernador de aquella provincia, en cuyo juzgado siguió e pleito varios trámites. Y como viendo el Padre Prepósito que el fallo le había de ser muy adverso, se tomó el arbitrio de que en ocasión de mi parte se hallaba ausente de Puebla en esta capital, fueron a seducir a la inocente doña Guadalupe por conducto de una criada, y por otros medios poco correctos, hasta obligarla a que se saliese de la casa de mi parte, que reputaba como suya, se le puso en un colegio practicándose las diligencias previas a su entrada, sin saber por quién aunque bien se deja entender el autor de todo esto: [210] Se le privo estrechísimamente la comunicación con sus parientes, y al fin se le hizo otorgar un poder, revocado el que tenia conferido a mi parte. A consecuencia se presentó a su nombre un escrito con el mismo poder diciendo que había tenido composición con el que padre Prepósito y que se diera por concluido el pleito, a lo cual accedió Vuestro Gobernador de conformidad con dictamen del Teniente Letrado de aquella ciudad; pero son haber oído ni citado a mi parte, ni héchole saber aún la dicha revocación como era de justicia: y solo si se le notificó a su Apoderado el Auto referido.

Considerándolo gravoso como en efecto lo es para muchos motivos, apeló de él para en esta Real Audiencia con protesta de mejorar el Recurso y ejecutándolo como más haya lugar en derecho. Suplico a V. A. que habiéndolo por mejorado se sirva mandar que inmediatamente se libre la Real Provisión Ordinaria, para la remisión de los de la materia citando las partes.

A. V. A. Suplico provea como pido es justicia, juro, etc.

Lic. Esteban Pérez Rivas

Nicolás Rodríguez Calvo

Enero ig de dicho: Se hizo Real Provisión

\section{E D U L A}

Don Fernando Séptimo por la gracia de Dio, Rey de Castilla de león, de Aragón, de las Dos Cicilias, de Jerusalén, de Navarra, de Granada, de Toledo, de Valencia, de Galicia, de Mallorca, de Sevilla, de Cerdeña, de Córdova, de Córcega, de Murcia, Jaen, de los Algarbes, de Algecira, de Gibraltar, de loas Ilsas de Canaria, de las Indias Orientales y Occidentales. [2II] islas y tierra firme, del Mar Océano, Archi Duque de Austria, Duque de Borgoña de Brabante y Miklan, Conde de Abspurgo, de Flandes, Tirol y Barcelona, señor Vizcaya y de Molina, etc., a Vos de Intendente Gobernador de la Provincia de Puebla; sabed: como ante el Presidente y Oidores de mi Audiencia que reside en la ciudad de México de mi Nueva España se presentó un escrito del tenor que sigue: $=$ 
M. P. S. = Nicolás Rodríguez Calvo por el teniente Coronel don Pedro de la Rosa ante V. A. como mejor proceda, digo: que Doña María Guadalupe Hernández, sobrina carnal de mi parte como hija hermana mía, es poseedora de un privativa y exclusivamente actos y conclusiones literarias y todo género de convites en la jurisdicción de Puebla; mas no teniendo Imprenta propia el padre de la dicha doña Guadalupe, y conociendo que esta mujer naturalmente inocente y falta de talento, con tanto extremo, que debe reputarse por mentecata, trató con don Pedro de la Rosa padre de mi parte que luego de que aquel falleciese, la recogieran en su casa y usara del referido privilegio dándole en compensación cierta cuota anual para parte del pago de sus alimentos. $=\mathrm{A}$ consecuencia de esto y del intimo parentesco de mi parte con doña Guadalupe, habiendo quedado enteramente desamparado cuando murieron sus padres, la recogió mi parte en su casa y la mantuvo como una hija suya con la correspondiente descendencia, sin escasearla cosa alguna por el espacio de muchos años, usando mi parte del privilegio quieta y pacíficamente en la imprenta que tiene en aquella ciudad. En tales circunstancias comenzó el padre prepósito del oratorio de San Felipe a imprimir actos y demás en la Imprenta que nuevamente ha puesto, y mi pate se opuso a ello, no tanto como apoderado de su sobrina sino como su tutor y curador adbona y por el interés propio que en esto tenía: más no habiendo podido convencer en lo extrajudicial al padre Prepósito hubo de presentarse en forma ante vuestro Gobernador de aquella Provincia, en cuyo juzgado siguió el pleito varios trámites y conociendo el padre prepósito que le fallo le había de ser adverso, se tomó el arbitrio de que en ocasión que [212] mi parte se hallaba ausente de Puebla en esta capital fueron a seducir a la inocente doña Guadalupe por conducto de una criada y por otros medios pocos decorosos, hasta obligarla a que se saliese e la casa de mi parte que reputaba como suya: se le puso en un colegio practicándose las diligencias previas a su entrada, sin saberse por quien, aunque bien se deja entender el autor de todo esto: se le privo estrechísimamente la comunicación con sus parientes y al fin se le hizo otorgar un poder, revocando el que tenía conferido a mi parte.= A consecuencia se presentó a su nombre un escrito con el mismo poder diciendo que había tenido composición con el padre Prepósito y que se diera por concluido el pleito; a lo que accedió nuestro -Gobernador de conformidad con dictamen del Teniente Letrado de aquella ciudad, pero sin haber oído ni contado a mi parte hizóle saber aun la dicha revocación como era de justicia y solo si se le notificó a su Apoderado el Autor referido.= Considerándolo gravoso, como en efecto lo es, por muchos motivos, apeló él para esta Real Audiencia, con protesta de mejor el recurso y ejecutándolo como más haya lugar en derecho, suplico a V. A. que habiéndolo por mejorado, se sirva mandar que inmediatamente se libre la Real Provisión Ordinaria para la remisión de los de la materia, citadas las partes A. V. A. suplico provea como pido, que en justicia: juro, etc.= Licenciado Esteban Pérez Rivas.- Nicolás Rodríguez Calvo. Y por decreto de diez y ocho del corriente mando mi Audiencia se librase la Real Provisión Ordinaria de apelaciones. Y para que lo así determinado tenga el debido cumplimiento, con acuerdo del mismo Tribunal, he tenido a bien expedir esta mi Real Provisión por lo cual os mando, que siendo definitivos ordinarios los autos instruidos sobre el asunto que se expresa los remítales, íntegros, originales, cerrados y sellados a manos del infrascrito Escribano de Cámara; y si fueron ejecutivos, no haréis dicha remisión hasta estar primero para la parte de su deuda principal y dudando sobre si lo son o no, lo consultareis con Asesor; y en caso de remitirlos, citareis en forma y conforme a derecho a las partes para que por si o Apoderado instruido y expresado ocurran a contestar, con apercibimiento de estrados en forma. Dada en la cuidad de México a Diez y nueve de abril de mil ochocientos veinte. [213] Yo Luis Calderón, Essno. De S. M. de Cámara interino de esta Real Audiencia Mayor Honorario de la Gobernación y Guerra de la Nueva España, la hice escribir por su mandato con acuerdo de su presidente y oidores. 


\section{SELLO TERCERO: DOS REALES:}

\section{AÑOS DE MIL OCHOCIENTOS VEINTE Y UNO}

El presbítero: D. Mariano de la Rosa como apoderado de mi padre don Pedro de la Rosa, en los autos que ha seguido con el padre prepósito del Oratorio de San Felipe Neri, sobre impresión de actos y conclusiones literarias, como mejor proceda, digo: que habiendo interpuesto el recurso de apelación del auto en que se declararon por concluidos los de la materia, se ha tenido a bien expedir la Real Provisión que solemnemente exhibo para que se le remita los Autos citadas las partes, lo que suplico a V. E. se sirva disponer que se ejecute a la mayor brevedad que sea posible.

A. V. E. pido que así lo provea por ser justicia, juro lo necesario etc.

Lic. Esteban Pérez Rivas. Mariano de la Rosa.

En la ciudad de los Ángeles a seis de mayo de ochocientos veinte yo el Escribano, habiendo pasado al Colegio de San José de Gracia, con la licencia y permiso que ya tiene concedido su rector don José Linares, hice comparecer ante mí a doña Guadalupe Gómez como encargada por enfermedad de la rectora doña Catalina González de la Torre, le recibió juramento que hizo por Dios Nuestro Señor y la Señal de la Santa Cruz, según derecho por el ofreció decir verdad en lo que [214] Supiere y fuere preguntada y siéndolo como se manda, dijo: que la dueña del privilegio es ella misma y la por quien se ha gestionado en este asunto, y que aunque no fue ella con la que se practicó la diligencia del diez de febrero, si lo hizo su tía doña María Manuela Mendia a quien la declara le encargó saliese a contestar a su nombre por no firmar lo que así se verifico y por lo mismo cualesquiera otra diligencia que sobre el particular se ofrezca, se deberá entender con la que responde y habiéndole manifestado la diligencia corriente a fojas ciento doce, dijo que la forma con que se haya suscrita no la conoce, pero si la puso su tía porque ella misma se lo dijo cuando le suplicó saliese a contestar en cuya virtud le cité para la remisión de estos autos para la remisión de ellos a la soberanía de S.A. de que quedo entendida y se dio por citada, siendo testigos doña María Guadalupe Gómez y don Mariano Ortiz. Doy fe. Ramírez.

En la ciudad de los Angeles a nueve de mayo de ochocientos veinte, yo el Escribano habiendo pasado al oratorio de San Felipe Neri y estando con el Reverendo padre Prepósito, en su persona, le cite para la remisión de estos autos como está mandado y en consecuencia, dijo: lo oye, y que no siendo ya parte de este juicio don Pedro de la Rosa, por habérsele revocado el poder de su sobrina que era el único fundamento de sus ocursos, no encuentra mérito alguno para que se siga por él solo y a su nombre la segunda instancia, a demás de que en caso de admitiré la apelación debíase en concepto del que responda, para la capitanía general, pues el expediente se ha seguido ante S. E. como Comandante de Brigada por el fuero militar de que goza el citado don Pedro, contra quien se presenta el que contesta, pidiendo la exhibición de estos documentos; y por ultimó reitera su alejato de fojas io6, insistiendo en la declinatoria de fuero que tiene interpuesta, y suplicando al Exmo. Señor General se designe resolver con especial pronunciamiento en estos tres puntos, antes de remitir los actos a la soberanía de S. A. la Real Audiencia , con [215] Condenación e costos a la Rosa, por la visible malicia y temerida con que aquí ha litigado. Eşo respondió y firmó. Doy Fe.

Luis Alonso Ramirez.

Puebla y Mayo i6 de I820

$\mathrm{Al}$ asesor de

Ante Mi José Ramón Arellano 
En atención a que admita por S. A. la Real Audiencia del Reino la apelación interpuesta por parte de don Pedro de la Rosa no toca a este Tribunal la resolución de los puntos que el anterior respuesta se tomaron, y pueden representarse en el Tribunal Superior, llévese a debido efecto la remisión prevenida en auto de veinte y siete de abril citado por ella al Reverendo Padre Prepósito y a la parte de la Rosa. Se mandó S. E. con acuerdo de su asesor en Puebla a diez y nueve de mayo de mil ochocientos veinte.

Amorenal

Ante Mi José Ramón Arellano

M. de .....

En la ciudad de los Angeles a veinte y cinco de mayo de ochocientos veinte, Yo el Escribano estando con el Presbítero don Mariano de la Rosa en su persona le cité como se manda en el anterior auto para la remisión de estos Actos de que quedó entendido y se dió por citado exponiendo que en la capital ha de aguitar este asunto el Procurador don Nicolás Rodríguez Calvo. Esto respondió. Doy Fe.

Mariano de la Rosa.

Ramirez.

[216] En la ciudad de los Angeles a veinte y seis de mayo de ochocientos veinte. Yo el Escribano habiendo pasado al Oratorio de San Felipe Neri y estando con el R. P. Prepósito de él en su persona le hice saber lo prevenido en el anterior auto de ruego y encargo y éste como se manda y en su consecuencia dijo: que supuesto que don Pedro de la Rosa y su hijo insisten en las temeridades que el expediente manifiesta y que este debe ir a la superioridad, ocurrirá el que corresponde a S. A. la Real Audiencia, por medio de su apoderado don José Volante y Ocaris, protestando desde ahora de mandar costas, y todo lo demás a que halla lugar en justicia.

Esto respondió. Doy fe. G. R. de ruego y encargo.= V. E.

Joaquín Furlong

Ramírez.

[217] Los Intendentes de Puebla dan cuenta a V. A. con los Autos seguidos entre el R. P. Prepósito del Oratorio de San Felipe Neri y D. Pedro de la Rosa, sobre erección de una imprenta.

México, Mayo 2I, 820

A sus antecedentes y dése cuenta Oidores

Manilla / Medina / M. P. S.

Doy cuenta a V. A. en foja 133 con los Autos formados en mi Tribunal a instancia del R. P. Prepósito de este Oratorio de la Congregación San Felipe Neri don Joaquín Furlong sobre ereccion de una imprenta nueva a favor de dicho Oratorio, por cuyo motivo el Teniente Coronel don Pedro de la Rosa se opuso a que se imprimieran ciertos papeles por asegurar tener privilegios para poderlos imprimir solo él, en vista de todo lo ocurrido V. A. determinará lo que tenga por oportuno.- Puebla Mayo 26 de 1820, M. P. S. Ciriaco de...

En la Real Audiencia de Esta Nueva Espala, a $3^{\mathrm{I}}$ de Mayo de 1820 , se encomendaron estos asuntos al Relator Licenciado Puchet.

Por haberme expresádome ambas partes no querer agitar estos Autos por ahora no han pasado al relator Julio 3 I de $820 . .$. 


\section{APÉNDICE 2}

\section{BIBLIOGRAFÍA DE LOS IMPRESOS POBLANOS consultados en la Biblioteca Nacional de México}

Esta bibliografía está organizada de forma cronológica, del documento más temprano al más reciente, y los campos están separados por comas. El registro empieza con el nombre de autor o institución que aparece consignada en la base de datos de la Biblioteca Nacional de México, le sigue el título de la obra, el taller tipográfico donde se imprimió, el nombre normalizado del taller, el año de publicación, la clave topográfica con la que se encuentra en el acervo y el número de sistema del catálogo Nautilo. Asimismo se da la nomenclatura con la cual se registraron las tomas fotográficas de cada libro, pues servirá para identificar a qué edición pertenecen las referencias visuales del material tipográfico de cada taller cuando se describen las letrerías, ornamentos y viñetas. La lista está dividida en dos grupos: los libros revisados y los que no se revisaron.

\section{Ejemplo:}

Nombre de autor o institución: Palafox y Mendoza, Juan de

Titulo: Historia real sagrada, loz de principes y sobditos,

Taller tipográfico: Francisco Robledo,

Nombre normalizado del taller: Francisco Robledo,

Año de publicación: 1643 ,

Clave topográfica y el número de sistema del Nautilo. RSM I643 P6PAL.h, 2090I,

Nomenclatura de las tomas fotográficas de cada libro: 1643 Pal His.

\section{Libros revisados}

I. Puebla (Diócesis), Por los beneficiados del Obispado de la Puebla de los Angeles, clero, y fiscal eclesiastico del, y por las ciudades, pueblos, y demás consortes de aguella diócesis con los padres regulares de las sagradas ordenes de S. Domingo, S. Francisco y San Agustín sobre las doctrinas de que fueron remowidos, y dichos beneficiados estan posseyendo en conformidad del $S$. concilio, patronazgo real, cédulas y prowisiones reales, con presentación del virrey, colación canonica del ordinario, y aprobación de su magestad [s.n., s.l.], I642, RSM I642 P6PUE, 20900, I642 Pue Ben.

2. Palafox y Mendoza, Juan de, Historia real sagrada, loz de principes y svbditos, Francisco Robledo, Francisco Robledo, I643, RSM I643 P6PaL.h, 20901, I643 Pal His.

3. —_ Alegaciones en favor del clero, estado eclesiastico, i secular españoles, EG indios del Obispado de la Puebla de los Angeles Sobre las doctrinas, que en execucion del S. Concilio de Trento, cedulas, i prousiones reales, remowió en el su il ustrissimo obispo don Juan de Palafox i Mendoza, del Consejo de su Magestad, i del Real de las Indias, el año de 1640 En el pleito con las sagradas religiones de S. Domingo, S. Francisco, $i$ S. Agustin [s.n.], I644, RFO 271.2097247F PAL.a, 342354, I644 Pal Ale.

4. — Carta pastoral, $y$ dictamenes de curas de almas [s.n.], I646, RSM I646 P6PAL, 20908, ${ }_{1} 646$ Pal Car.

5. Anónimo, Informes gre contiene efta alegacion: Informe del Illustrifsimo feñor D. Iua de Palafoxy Mendoça [s.n.], I647, RSM I647 P6INF, 20903, I647 Ano Inf.

6. Palafox y Mendoza, Juan de, Al rey nuestro señor satisfacion al Memorial de los religiosos de la Compañia del Nombre de Iesus de la Nueva-España por la dignidad episcopal de la Puebla de los Angeles sobre execucion, y obediencia del breve apostolico de N. Santissimo Padre Innocencio $X$ expedido en su favor a XIIII de mayo de M.DC.XLVIII. y pasado repetidamente, y mandado executar por el Supremo Consejo de las Indias en el qual determinó Su Santidad veinte y seis decretos sacramentales, y iurisdiccionales, importantes al bien de las almas [s.n.], I652, RSM 49, 342367, 1652 Pal Rey. 
7. Iglesia Católica (México), Voto y ivramento de la congregacion de Nvestra Señora la Virgen Maria, por Iuan de Borja Infante, I654, RSM I654 P6IGL, 338403, I654 Igl Vot.

8. Peralta Castañeda, Antonio de, Sermón de la puríssima concepción de la Virgen María Nuestra Señora, Iuan de Borja Infante, I654, RSM I654 P6PER, 382429, I654 Per Ser.

9. Escamilla, Juan B., La cordera del cielo : vida y milagros de Santa Tnes de Monte Policiano, por la viuda de Iuan de Borja y Gandia, 1657, I657 P6ESC, 377163, I657 Esc Cor.

Io. Letona, Bartholomé de, Perfecta religiosa, fray Bartholome de Letona, por la Uiuda de Juan de Borja, I662, RFO I662 P6LET, 40454, I662 Let Per.

II. Ossorio Escobar y Llamas, Diego, Relación del celebre inbileo de las missiones, y doctrinas, prblicado, y administrado por los padres de la Compañia de Jesús, este año de mil seiscientos y sesenta y siete en la ciudad de la Puebla de los Angéles, En la imprenta de la viuda de Iuan de Borja y Gandia, I668, LAF 625, 559522, 1668 Oss Rel.

I2. Borges, Pedro de. Sermon que predicó... a la profesión de la madre María de la Encarnación religiosa descalca del Conventos de la glor iosa sancta Theresa de Iesvs de esta ciudad a treza de diziembre de mil seiscientos, y setenta, y dos, Vda. de Juan de Borja y Gandia, I673, R 252.8 MIs.7, 341627, I673 Bor Ser.

I3. Asenjo y Crespo, Ignacio de, Exercicio practico de la volnntad de Dios, Imp. de Miguel de Ortega, I68I, RSM I68I P6ASE, 20975, I68I Ase Exe.

14. Carrillo, Juan, Vida, y prodigios de la venerable madre Sor Inanna de la Crvz. Del Orden Tercera de $N$. P. S. Francisco, en la Sagra de Toledo / escrita por el M. R. P. Fr. Iuan Carrillo, Lector jubilado religioso de dicha Orden de la Santa Provincia de Castilla. Dedicala El contador Domingo Fernandez Valcacer Recetor y Contador del Tribunal de quentas Sindico delas limosnas de la Venerable Orden Tercera de Penitencia de Nuestro Serapbico Padre San Francisco de la Ciudad dela Puebla. Diego Fernández de León Mercader de Libros debajo de los Portales de la Playa, I684, RSM I684 P6CAR, 20322, I684 Car Vid.

I5. Gorospe, Juan de, Sermon gve en la solemnissima festividad de la gloriosa Resureccion denuestra vida Christo Señor Nuestro predicó, Diego Fernández de León, I684, R 252.8 MIS.3, 34I657, I684 Gor Ser.

16. Rodríguez, Matías, fray, Explicacion de las sesenta, y cinco proposiciones probibidas por la santidad de N. M. S. P. Innocencio XI. mandadas publicar por el excellentissimo señor don Diego Sarmiento de Valladares, Obispo Inquisidor General y publicadas por el Santo Tribunal de la Inguisicion de esta Nueva España en siete de abril de mil seiscientos y ochenta, Diego Fernández de León, I684, RSM I684 P6ROD, 20323, I684 Rod Exp.

I7. Izquierdo, Sebastián, Practica de los exercicios espritvales de N. padre S. Ignacio, Diego Fernández de León, I685, RSM 1685 P6IZQ, 20327, I685 Izq Pra.

18. Nebrija, Elio Antonio de, Explicación de los libros grarto y grinto de la grammatica, conforme al Arte de Antonio de Nebrïa, Diego Fernández de León, I685, RSM I685 P6LEB, 20328, 1685 Neb Exp.

19. Robles, Juan de, Sermon, que predicó el padre Iuan de Robles, en la festividad del gloriosissimo patriarcha S. Ignacio de Loyola, en el Collegio del Espiritu Santo de la Puebla, a 3 I de iulio, de este año de 1685 , Impr. de Diego Fernández de León, I685, SS, I654 P6PER 382431, 1685 Rob Ser.

20. Veedor José, Instrvccion, y doctrina de novicios, sacada de la de San Bvenaventura, y de las provincias de Descalsos de N. P. San Francisco, de San Ioseph, y de San Pablo, nuevamente emmendada, añadida, y ajustada al pso, y estilo de esta de San Diego de México, Diego Fernández de León, I685, RSM I685 P6VEe, 20329, I685 Vee Ins.

2I. Navarro de San Antonio, Bartolomé, Sermon qve en la festividad, este año de 85 transferida de la Aparicion de Nvestra Señora de Gvadalope, predicó, Diego Fernández de León, I686, 252.8 MIS.3 y I622 M4ZEP (hay dos ejemplares), 341658, I686 Nav Ser.

22. Ponce de León, Nicolás de, Historia de la singvlar vida, de el venerable hermano fray Christoval de Molina religioso lego de la Orden de N. P. San Agustín. Hüo de el illustrissimo Convento de Nuestra Señora de Gracia de la misma Orden; de la ciudad de la Puebla de los Angeles donde reciviò el babito, y muriò. Diego Fernández de León, I686, RSM I686 P6PON, 20332, I686 Pon His. 
23. Castaneira, Juan, Epilogo metrico de la vida y virtvdes de el venerable padre Fr. Sebastian de Aparicio natural de la Gudina (en Galicia) é Hijo de el Orden Seraphico en esta Provincia de el Santo Evangelio de Mexico. Diego Fernández de León, I689, I689 P6CAs, 2034I, I689 Cas Epi.

24. Valtierra, Manuel de, Sermon panegyrico de el glorioso confessor san Rogue en el día Octavo de la Fiesta que en su Hospital de la Ciudad de Puebla de los Angeles celebran, Miguel de Vargas, Joseph de Peralta y Nicolás Venite Predicolo el P. Manuel de Vatierr de la Compañia de IESUS. Sacanlo a luz los tres piadosos Musicos de la Fiesta y lo Consagran al Mesmo Esclarecido Confessor de Christo San Rogue. Con licencia en la Puebla de los Angeles, en la Imprenta de Diego Fernández de León, año de i689, en la Imprenta de Diego Fernández de León, I689, 252.8 MIs.3, I689 Val Ser.

25. Ávila, Juan de, Mercurio panegyrico, que explicò, y leyò el R. P. fray Juan de Avila, predicador general jubilado, calificador del santo oficio, y guardian del Convento de San Gabriel de Cbolula, de el orden de N. P. S. Francisco : sermón que dixo en la Segunda Dominica de Adviento, en la publicación de la Santa Bulla de Cruzada en la Iglesia Cathedral de la Puebla de los Angeles. Año de 1689, Diego Fernández de León, I690, I645 P6PER 382434, I690 Avi Mer.

26. Bustamante y Medrano, Juan Manuel de, Oración evangelica de los Dolores de la Madre de Dios al pie de sv crvz, Diego Fernández de León, I690, R 252.8 MIS.3, 341652, I690 Bus Ora.

27. Surius, Laurentius, Exercicios divinos, revelados al venerable Nicolás Eschio y referidos por Laurencio Surio, Diego Fernández de León, I690, I690 P6suR 20346, I69o Sur Exe.

28. Núñez de Miranda, Antonio, Explicacion theorica, y practica aplicacion del libro quarto del Contemptus mundi; para prepararse, $y$ dar fructuosamente gracias en la frequente comunion, Diego Fernández de León [I69I], I69I P6NUÑ, 20349, I69I Nuñ Exp.

29. Sánchez, Francisco, Thesoro regolar en compendioso sumario de indulgencias ciertas, que gozan los religiosos, religiosas, terceros, y terceras de las Ordenes Sagradas, entrequienes ay comunicacion reciproca de semejantes gracias, y lo demas, g[ue] por concesion apostolica la turieren, Diego Fernández de León, I69I, RSM I69I P6san, 20350, I69I San The.

30. Jaymes Ricardo Villavicencio, Diego, Luz y methodo, de confesar idolatras, y destierro de idolatrias, debajo del tratado sigviente, Diego Fernández de León, I692, RSM I692 P6JAY (uno en fotocopia), 20351, I692 JayLuz.

31. Juan de la Madre de Dios, Breve summa de la oracion mental y de su exercicio, conforme se practica en los noviciados de los carmelitas descalzo, en la impr. de Diego Fernández de León, I692, RFO 338339, I692 Jua Bre.

32. Santander, Sebastián de, Sermon panegírico, que en la solemne fiesta con que celebra el Convento de nuestro padre Santo Domingo de la ciudad de los Angeles á la Sagrada Virgen Santa Rosa de Santa Maria, Diego Fernández de León [I692], 252.8 MIS.3, 341659, I692 San Ser.

33. Barcia y Zambrana, José de, Epistola exhortatoria en orden a gve los predicadores evangelicos no priven de la doctrina à las almas en los sermones de fiestas, Imprenta de Diego Fernández de León, Impressor y mercader de libros en el Portal de las Flores, I693, I693 P6BAR 20358, I693 Bar Epi.

34. Delgado y Buenrostro, Antonio, Historias varias canonicas moralizadas en sermones consagrados a la soberana magestad de la Emperatriz de los cielos la Virgen Maria, madre de Dios y Señora Nuestra del Rosario, En la imprenta de Diego Fernández de León, I693, RSM I693 P6DEL, 340005, I693 Del His.

35. Gómez de la Parra, José, Panegyrica oratio in laudem Fidelissimi Illius magni servi fundatoria eximï Congregationis Oratorï de Urbe Divi Philipi Neri Ouam in Oratorio Civitatis Angelopolitanae Americae Septentrionalis, Ex off. Plantiniana Didaci Fernandez de Leo, I693, RFO 252.8 MIS.3, 341830, I693 Gom Pan.

36. Delgado y Buenrostro, Antonio, Oracion evangelica del milagroso indice de la providencia del inclito patriarca San Cayetano, Diego Fernández de León, I695, 252.8 MIS.3, 341655, I695 Del Ora. 
37. Pawlowski, Daniel, Locucion de Dios al corazon de el religioso en el retiro sagrado de los exercicios espirituales, Impresso en el Colegio de la Compañía de Jesús, I695, RSM I695 P6PAW, 334677, I695 Paw Loc.

38. Robles, Juan de, Idea de buen prelado, y medio que deve seguir en su govierno, en la Impr. del Capitán Juan de Villa Real, I695, I695 P6RoB, 382440, I695 Rob Ide.

39. Saldaña y Ortega, Antonio de, Oración enangélica del principe, y cabeza de la iglesia nuestro esclarecido P. y señor S. Pedro en la Santa Iglesia Cathedral de dicha ciudad de Anteguera, en la Impr. del Capitán Juan de Villa Real, I695 [i.e. I696], ss, I695 P6RoB, 38244I, I695 Sal Ora.

40. Delgado y Buenrostro, Antonio, Oración sagrada que bizo sobre el verso septimo del psalmo cincuenta en la santa iglesia Cathedral de la Puebla de los Angeles, el dia viernes de los Dolores de la Madre de Dios por la tarde, con la circunstancia de ponerse a vista de los fieles una bermosa esfinge de rostro de nuestro señor Jesuchristo (que llaman Veronica) iluminada de resplendores de glori, Juan de Villa Real, I696, 252.8 MIs.5, 341568, I696 Del Ora.

4I. Torres, Ignacio de, Séláb mystico de la iglesia nuestro esclarescido padre, y señor San Pedro, Capitán Juan de Villa Real [1696], 252.8 MIS.3, 341661, I696 Tor Sél.

42. Pawlowski, Daniel, Locucion de Dios al corazon del religioso en el retiro sagrado de los exercicios espirituales, por los Herederos del Capitan Juan de Villa Real, I697, RSM I697 P6PAW, 425192, I697 Paw Loc.

43. Jesuitas, Reglas de la Compañia de Jesus, en el Colegio del Espiritu Santo, por los Herederos del Capitan Juan de Villa Real, I698, sвo, г698 р6JEs, 425029, I698 Jes Reg.

44. Cruz, Francisco Antonio de la, Declamación fúnebre, que en las exequias, que consagrò à su amabilissimo pastoR ilustrissimo, y excelentissimo señor doctor d. Manuel Fernández de Santa Cruz, el Colegio Real de S. Juan , y S. Pedro, Impr. de los herederos del capitán Juan Villa Real, en el Portal de las Flores, I699, SS, I699 P6T0R 382438, I699 Cru Dec.

45. Gómez de la Parra, José, Panegyrico foneral de la vida en la mverte de el Illmo. y Excmo. Señor Doct D. Manvel Fernandez de Santa Crvz Obispo de la Puebla de los Angeles en la Nueva España, por los Herederos del Capitan Juan de Villa-Real [I699], MB, I699 P6GoM, 4250I3, I699 Gom Pan. 46. Marín, Manuel, Sermón fonebre exemplar sin exemplo en la mverte de la señora doña Geronyma de la O, y Santa Marina, Herederos del Capitan Juan de Villa Real, I699, R 252.8 MIS.3, 34I656, I699 Mar Ser.

47. Moreno, Francisco, Sermón funeral, que en las honras, que el Orden Tercero de Penitencia de $N$. Seráfico P. S. Francisco de esta ciudad de los Angeles, bizo à la muerte del illmo. y excmo. sr. dr. d. Manuel Fernandez de Santa Cruz, cuyo ministro fué, por los Herederos de el Capitan Juan de Villa Real, en el Portal de las Flores, I699, SS, I699 P6TOR 382443, I699 Mor Ser.

48. Torres, Ignacio de, Funebre cordial declamación en las exequias del illmo. y excmo. señor doctor d. Manuel Fernández de Sancta Cruz obispo de la Sancta Iglesia de la Puebla celebradas en el Convento de Religiosas Recoletas de Santa Monica, fundacion de su Excellencia, por los Herederos del Capitán Juan de Villa Real, en el Portal de las Flores [I699], ss, I699 P6TOR 382445, I699 Tor Fun.

49. Agustinos, Regla del glorioso doct de la iglesia S. Agustin, en la Imprenta de los Herederos del capitan Juan de Villa Real, en el Portal de las Flores, I70I, RSM I70I P6AGU, 425508, I70I Agu Reg.

50. Gómez de la Parra, José, Grano de trigo fecundo de virtudes en la vida, fecundisimo por la succession en la muerte, la catholica magestad del Rey nuestro Señor Don Carlos segondo, que Dios aya assumpto panegyrico foneral que predico a las funebres exequias, que en su magnifica iglesia cathedral celebró el ilustrisimo Señor venerable eclesiastico cavildo sede vacante a expensas de la nobilisima imperial ciudad de la Puebla de los Angeles de la Nueva España, el día nuebe de mayo de I 70 I años y consagra a la suprema augusta, real soberana proteccion de Nuestro Catholico monarcha Don Felipe Qunto, Rey de España, emperador de las Indias el Doctor JOseph Gómez dela Parra, canonigo magistral de dicha santa iglesia cathedral de Valladilid 
ovispado de Michoacán; fue colegial y rector en el insigne colegio, ya mayor de nuestra Señora de todos Santos de la ciudad de México, actual cathedratico de prima de theologia y regente de los estudios en los reales colegios de S. Pedro y S. Iuan de esta ciudad de donde es originario examinador synodal de este obispado, Por los Herederos del Capitan Juan de Villa Real, I7or, LaF 592, 558510, I70 Ano Gra.

51. Anónimo, Reales preceptos executados en acreditadas obsernaciones de afectos con que la muy noble insigne y leal ciudad de Tlaxcala manifesto desempeños asi en los sentimientos por la falta de nuestro Rey Señor Don Carlos Segundo de gloriosa memoria como en el crecido jubilo a la jura de la catholica magestad de nuestro Rey y Señor Don Phelipe Quinto, que Dios guarde, celebrada el primero dia de mayo de este año de I7or al cuydadoso desvelo del capitan y sargento mayor D. Martín de Herrera y Soto Mayor governador y theniente de capitan general de dicha ciudad y provincia por su magestad a quien el capitan Antonio Carlos de Castañeda, originario de ella D. C. O., Por los herederos del capitan Juan de Villareal, I7OI, LAF 592, 558515, I70r Ano Rea.

52. Iglesia Católica, Sentencia apostólica definitiva de la precedencia en todos los actos publicos, y privados, de la seraphica descalcez y mas estrecha observancia regular de N. S. P. S. Francisco, en la Provincia de San Diego de México, en la Impr. del Capitan Sebastian de Guevara y Rios, I70I, RSM I70I P6Lun, 382454, I70I Igl Sen.

53. Luna, Antonio de, Sermón del glorioso padre S. Diego, que en su fiesta titular celebrada á devocion de el capitan Don Patricio de Soto y Carrillo, alcalde mayor de la ciudad de Huexotzinco, el dia doce de noviembre de I700, en la Impr. de los Herederos del Capitan Juan de Villa Real [I70I], ss, I70I P6LuN, 382453, I70I Lun Ser.

54. Betlemitas (México), Constitociones de la Compañia Bethlemitica, approbadas. y confirmadas por la santidad de Innocencio ondezimo. Ereccion en religion, y diferentes breves, concedidos en distintos tiempos a favor de dicha compañia, en la Imprenta Nueva D. Joseph Perez, I707, RSM I707 M4BET, 20847, 1707 Bet Con.

55. Boneta y Laplana, José, Gritos del purgatorio y medios para acallarlos, Diego Fernández de León, I708, RFO I708 р6воN, 329695, I708 Bon Gri.

56. Gómez de la Parra, José, Famosos trivmphos y victoriosos tropheos gre el dia I5 de jolio del año I708, el primero de el festivo triduo, gre celebró el IIImo. V. Dean y Cabildo, sede bacante de la santa Iglesia Cathedral de la ciudad de la Puebla de los Angeles en la Nueva España en honor de la immaculada Concepcion de Maria SS. N. S. su titular para dar gracias á Dios N. S. por el feliz nacimiento de su alteza el Sr. D. Lvis I, Joseph Perez [1709], R 252.8 MIS.I, 264458, I709 Gom Fam.

57. Anónimo, Derecho de el doctor D. Diego de Estrada Galindo de la santa iglesia de Guadalaxara, a la tenuta, y propiedad, de el mayorazgo, que se fundò de bienes de D. Dionisia de Carbaxal probado en este informe, por la Viuda de Diego Fernández de León, I710, 413 LAF, 551656, i710 Car Der.

58. Menéndez, Juan Thomas, Oración fúnebre en las honras de la muy noble, y virtuosa señora da. Aldonza de Ormachea exemplar en la vida, y religiosa en su muerte celebradas en su Convento de Señoras Religiosas Recoletas de Santa Catharina de Sena de esta ciudad de la Havana el dia 5 de noviembre de I7og años I predicola el M. R. P. M. fray Juan Thomas Menéndez, del orden de Seraphico, cathedratico de prima de sagrada theologia..., en la Impr. Plantiniana de d. Joseph Perez [I7Io], R I708 M4BER 382456, I7Io Men Ora.

59. Gómez de la Parra, José, Importantissimas, y verdaderas resoluciones para ecclesiasticos, que dessean ajustarse a los sagrados ritos de la missa, Imp. Plantiniana de Miguel de Ortega y Bonilla, I7I2, RSM I712 P6GOM, 20464, I712 Gom Imp.

6o. Puebla (Diócesis), Constitociones para la contaduria de la iglesia cathedral de la Puebla de los Angeles, Imprenta de Miguel de Ortega y Bonilla, I713, RSM 1713 P6PUE, 20468, I713 Pue Con.

6I. Santander, Sebastián de. Oración fúnebre que predicó ... en las honras de la V. M. María de San Joseph... Sacalo a loz el Cap. D. Onofre de Arteaga, y Frías, Viuda de Miguel de Ortega Bonilla [I7I9], R 252.8 MIS.I, 297660, I719 San Ora. 
62. Torres, Miguel de, San Pedro de Alcantara, reformador redemptor : sermon que en el Convento de la inclyta Virgen, y martyr Sta. Barbara, de Franciscos Descalzos, en la Ciudad de la Puebla de los Angeles I predicó Fr. Miguel de Torres de el Real orden Militar de N. S. de la Merced, Juan Francisco de Ortega y Bonilla, I72I, RSM I690 M4CAS, 341622, I72I Tor San (DF).

63. Sánchez de Figueroa, Antonio, acusado. Defensa jurídica, en que se informa a los señores alcaldes de la Real Sala de el Crimen de esta Corte, de los meritos, y justicia, que para la absolucion deffinitiva assisten a D. Antonio Sánchez de Figueroa, en causa criminal, que contra èl se sigue por la muerte executada en Juan Joseph de Almanza, maestro de boticario, que fue en esta ciudad, Juan Francisco de Ortega y Bonilla, I722, RFO o82.I GUE.216, 342602, I722 Alm Def (DF).

64. Franciscanos Tercera Orden, Gloriosso principio de la esclarecida orden Tercera de N. S. P. San Francisco : epilogo de su Santa Regla, indulgencias, que ganan los que toman en ella el Havito, y professan, privilegios que le son concedidos, y absoluciones plenarias, que pueden recibir à la bora de la muerte, y en otros muchos dias del año: por muchos Summos pontifices concedidas; y vltimamente confirmadas por el señor Innocencio XI / dale a la estampa con ferviente desseo del aprovechamiento de sus hermanos terceros, vno de los señores Officiales actuales de la Venerable Mesa, y de segundo año, Juan Francisco de Ortega y Bonilla, I722, RFO 93-44408, 333431, I722 Ano Glo (DF).

65. Gil, Alonso, Directorio para religiosas, por la Viuda de Miguel de Ortega Bonilla, I722, RFO I7I5 o6CRI, 323046, I722 Gil Dir.

66. Anónimo, Breve relación de lo sucedido entre el emperador de la Gran China, y el Illmo. Señor Mezzabarba, legado del summo pontifice á aguel Imperio, tocante á los ritos sinicos, sacada del archivo del EmperadoR año de I722, En la Imprenta Plantiniana de Juan Francisco de Ortega y Bonilla, I723, LAF 6I3, 340407, I723 Ano Bre (DF).

67. Moro, Gerardo, Informe en derecho sobre que la Compañia de el Real Assiento de la Gran Bretaña, establecida para la introduccion de esclavos negros, en estas Indias, debe declararse libre, y exempta de la paga de los reales derechos, comprehendidos en el nombre de alcavala, en todos los puertos, y demàs lugares de la tierra adentro de esta America, por lo que toca à las ropas, y mercaderias de sus navios annuales, igualmente, no de sus negros y sobre que aunque esto no procediera assi, deben aclararse libres de su contribucion los efectos de repressalias, sin que ni en el vno, ni en el otro caso deba Su Magestad hazer rebaja, ni descuento à los assentistas indianos, de la renta annual escribelo Don Gerardo Moro, Juan Francisco de Ortega y Bonilla, I724, RSM I724 M4MOR 20723, I724 Mor Inf (DF).

68. Anónimo, Razones devotamente persuasivas para celebridad de la fiesta de la conversión de San Ignacio de Loyola, fundador de la Sagrada Compañia de Jesús; y que annualmente pueda celebrarse por asumpto de los panegyricos, interin, que se ocurre à la sancta sede apostolica, para la determinación de su culto especial, como en la conversión de otros sanctos, que pidio el Excmo. Señor D. Juan Vazquez de Acuña, margues de casa fuerte, EG c. vi Rey governador y capitan gl. de esta Nueva España y presidente de su real audiencia EG c. cerca de vn sermon predicado á este incluyto patriarcha en la yglesia de N. Señora de Aranzazu de esta corte, y lo dió a la estampa el Dr. D. Juan Ignacio de Castorena y Vrsua, capellan de honor y predicador de su magestad cathedratico de prima de sagrada escritura, en la real pniversidad de esta corte, thesorero dignidad y electo maestre escuela de esta S. iglesia metropolitana de México c, Por Juan Francisco de Ortega y Bonilla, I724, LAF 577, 557755, I724 Vaz Raz.

69. Iglesia Católica, Manual de administrar los santos sacramentos : conforme á la reforma de Paulo $V$. y Vrbano VIII / dispuesto por el R. P. Fr. Augustin de Vetancurt, ex lector de theologia, predicador general jubilado, Juan Francisco de Ortega y Bonilla, I724, RSM I724 M4IGL, 20722, I724 Vet Man (DF).

70. Tercero, José, Para mayor gloria de Dios, Santa Christina la admirable, en la Imprenta de la Viuda de Miguel de Ortega y Bonilla, en el Portal de las Flores, I726, RSM I726 P6TER 375059, I726 Ter Par. 
7I. Vázquez Gastelu, Antonio, Arte de lengra mexicana, por Diego Fernández de Leo[n] y por su original en la Imprenta de Francisco Xavier de Morales y Salazar, impressor y mercader de libros en el Portal de Borja, 1726, I726 P6vaZ, 37506o, I726 Vaz Art.

72. Martínez de Trillanes, Gaspar Isidro, Directorio, que para las ceremonias de el altar y de el choro en todos los dias de el año, deve observarse en esta Sancta Iglesia Cathedral, de la ciudad de los Angeles, Viuda de Miguel de Ortega Bonilla, I728, RSM I728 P6MAR 375082, I728 Mar Dir.

73. Segura, Francisco Ildefonso, Consultas varias, morales, y mysticas, por la Viuda de Miguel de Ortega y Bonilla, I728, RSM I728 P6SEG, 375083, I728 Seg Con.

74. Vázquez Salgado, Antonio, Discurso sagrado, bistorico, y chronologico, Viuda de Miguel de Ortega y Bonilla, I728, RSM I728 P6VAZ, 375084, I728 Vaz Dis.

75. Jesuitas, Informe, que baze la provincia de la Compañia de Jesvs, de esta Nveba España, por lo gve toca à la parte de sus Missiones, como legataria del Officio y VARA DE ALGUACIL MAIOR del Real, y Apostolico Tribunal de la Santa Cruzada, de este Reyno, en desagravio, y defensa de la buena memoria, y vienes del Br. D. Francisco de Orosco, Presbytero, del Obispado de Valladolid, en Indias, difuncto, propietario de este Officio, Eximio promotor del Culto divino, ardientissimo de la conversion de las almas, y liberalismo benefactor de los Suios, y Estraños, Viuda de Miguel de Ortega y Bonilla, I729, LAF I29, 534656, I729 Jes Inf.

76. Villalobos, Joaquín Antonio de, Relox de sombras en gve, con las de la muerte de Nuestro redemptor Jesu-Christo, por la Viuda de Miguel de Ortega y Bonilla en el Portal de las Flores, I729, RSM I729 P6VIL, 375095, I729 Vil Rel.

77. Moreno, Jerónimo, Reglas ciertas, y precisamente necessarias para juezes, y ministros de justicia de las Indias, y para sus confessores, por la Viuda de Miguel de Ortega, y Bonilla en el Portal de las Flores, I732, MB SBO, I732 P6MOR 426812, I732 Mor Reg.

78. Anónimo, Carta pastoral a los padres parrochos predicadores y confessores y a todos los feligresses del obispado de Anteguera, valle de Oaxaca, Imprenta nueva de Francisco Xavier de Morales y Salazar, I733, 4I2 LAF 55I544, I733 Ano Car.

79. Quintana, Agustín de, Confessonario en lengua mixe, Viuda de Miguel de Ortega y Bonilla, I733, RSM I733 P6QUI, 42679I, I733 Qui Con.

8o. Dallo y Zavala, Manuel Romualdo, Sermon panegyrico, que en la solemnissima fiesta de N. G. padre Santo Domingo de Grzman, en sv convento de la Pvebla, con assistencia de el ilustrissimo, i venerable señor Dean, $i$ Cavildo; dixo el dia 4 de agosto de este año de 1734 , Francisco Xavier de Morales y Salazar I734, R 252.8 MIS.7, 341549, I734 Dal Ser.

8I. Villalobos, Joaquín Antonio de, Honroso obelisco, que sobre las cenizas de el sepulchro, de el señor doctor Don Miguel Nieto de Almiron, maestre-escuela, gre fue de la Sancta Iglesia Cathedral de la Puebla, levanta la obsequiosa veneración, à la memoria de su ajustada vida, y á las disposiciones de su preciosa muerte, en la bistórica, y panegyrica narración de sus heroycas virtudes, que para exemplar de señores sacerdotes, para modelo de zelosos curas, para norma de ilustres prevendados, en la Officina de la Viuda de Miguel de Ortega y Bonilla, en el Portal de las Flores, I734, RSM I734 P6VIL, 427217, I734 Vil Hon.

82. Dallo y Zavala, Manuel Romualdo, Sermón de la gloriosa madre Santa Monica, que en su iglesia de Religiosas Recoletas Agustinas de la Ciudad de los Angeles, con assistencia de el Ilmo, señor don Benito Crespo, su dignissimo Obispo, dixo el dia I4 de mayo de I735, Francisco Xavier de Morales i Salazar, I735, R 252.8 MIS.5, 341566, I735 Dal Ser.

83. Méndez de Cisneros, Gaspar Antonio, [Censura conforme a derecho canónico por sacar con violencia a unos indios refugiados en la catedral de Puebla, debido al pleyto entre el alcalde Joseph de Cardenas y el obispo de Puebla Benito Crespo, s.n., s.l.], I742, 4I4 LAF, 4I4, 55I732, I742 Men Cen.

84. Convento de Nuestra Señora de la Concepción (Puebla), Regla y constitociones, que ban de gnardar las religiosas, de los conventos de Nuestra Señora de la Concepción, y la Santissima Trinidad de la 
Ciudad de los Angeles, en la Imprenta de la Viuda de Miguel de Ortega y Bonilla, I744, I744 P6CoN, 428I9I, I744 Con Reg.

85. López Cordero, Antonio, Vida de la esclarecida Virgen dulcissima esposa de N. Señor Jesu Christo. Santa Ines de Monte Policiano, En la Puebla por la Viuda de Miguel de Ortega y Bonilla, en el Portal de las Flores, I744, CGV, I744 P6LOP, 428206, I744 Lop Vid.

86. Loayzaga, Manuel de, Historia de la milagrosissima imagen de nuestra señora de Occotlan, que se venera Extramuros de la Ciudad de Tlaxcala, En la imprenta de la Viuda de Miguel de Ortega y Bonilla, en el Portal de las Flores, I745, CGV, I745 p6loa, 428285, 1745 Loa His.

87. Nicolás de Jesús María, El escudo de armas del claro linage de la antigua casa de los Toledos mexorado el de la noblesa terrena en el de la bidalguía religiosa, por la Viuda de Miguel de Ortega y Bonilla, I745, Ss, I739 M4ANG, 382459, I745 Nic Esc.

88. __ El para siempre de Sta. Theresa, por la Viuda de Miguel de Ortega y Bonilla, I745, ss, I739 M4ANG, 382457, I745 Nic Par.

89. Diego de San Francisco, Manual de exercicios de el señor San Joseph, patriarcha grande, varon admirable, protector de la militante iglesia, esposo amabilissimo de la Madre de Dios, y adoptivo padre de el Hijo de Dios, por la Viuda de Miguel de Ortega y Bonilla, I746, ss, I746 P6DIE, 382458, 1746 Die Man.

90. Origen de la imagen y advocación de Nuestra Señora del Refogio, solemne pompa, con que celebró su primera fiesta la ciudad de la Puebla de los Angeles, el día 4 de julio de este año de 1747, Imprenta de la viuda de Miguel de Ortega y Bonilla, I747, LAF, 577, 1747 Ano Ori .

91. Anónimo, Relacion de los rayos, que el dia 22, y 29 de julio de este año de 1747 cayeron en la Capilla, que en la Santa Iglesia Cathedral de la Puebla de los Angeles está dedicada al glorioso Patriarca S. Ignacio de Loyola, sacada de la información Juridica, que se bizo en la misma Ciudad de la Puebla, en el mes de septiembre del mismo año [certificación de Juan Antonio de Oviedo, s.n., I747], MB SBO, I747 P6REL, 4286i6, i747 Ano Rel.

92. Manuel de Santa Teresa, Instructorio espiritual de los Terceros, Terceras, y Beatas de Nuestra Señora del Carmen, por la Vda. de Miguel de Ortega y Bonilla, en el Portal de las Flores, I749, RSM I749 P6MAN, 20997, I749 Man Ins.

93. Anónimo [El mostruo de Extremadura ...], Viuda de Miguel de Ortega y Bonilla [I753], 86r.o8 MIS.I3, 290234, I753 Ano Mon.

94. Miqueorena, Agustín de, Vida de la venerable madre Michaela Josepha de la Purificacion, Viuda de Miguel de Ortega y Bonilla, en el Portal de las Flores, I755, RSM I755 P6MIQ, 20383, I755 Miq Vid.

95. Carmelitas, Regla primitiva, y Constituciones de los religiosos descalzos del Orden de la bienaventurada Virgen Maria del Monte Carmelo, de la primitiva observancia, de la congregacion de España : confirmadas por N. M. S. P. y Sr. Alexandro Papa VI dia tercero de julio del año de 1658 el quarto de su pontificado, en la Imprenta de la Viuda de Miguel de Ortega y Bonilla, I756, RSM I756 P6CAR 20390, I756 Car Reg.

96. Montúfar Juan José Mariano, El verbi gracia de Dios Sr. S. Miguel Archangel, sermón panegyrico, que en su suntuario del milagro predicó de accidente presenta el santissimo sacramento Juan Joseph Mariano MonteueaR el dia 29. de septiembre de este año de 1755, Imprenta de la viuda de Miguel Ortega y Bonilla I756, 576 LAF, 557698, I756 Mon Ver.

97. Villa Sánchez, Juan de, Sermon del gran padre, y Dr. S. Augustin, predicado el dia 4 de septiembre del año de 1749 en el religiosissimo Convento de señoras religiosas Augustinas Recoletas de Santa Monica, de esta Ciudad de los Angeles, en la Imprenta de la Viuda de Miguel de Ortega y Bonilla, 1758, RSM I758 P6VIL, 20415, I758 Vil Ser.

98. Anónimo, Rosario de agonizantes : modo devoto de auxiliar à moribundos recomendando sus almas a $N$. Misericordioso redemptor Jesu-Christo : por la intercession de su Santissima Madre invocada con la devocion 
del santissimo Rosario : puede usarse de modo de exercicios de la Buena Muerte, ofreciendo estas piadosas oraciones de su propria alma / dispuesto por un religioso sacerdote del sagrado orden de predicadores del Convento de N. P. Santo Domingo de la Puebla de los Angeles, en la Imprenta de Christoval Thadeo de Ortega, I759, RFO I7I5 06CRI, 324067, I759 Ano Ros.

99. Montaña, José Isidro, El corazón de las rosas, Sepultado entre fragancias, Impressa en el Colegio Real de San Ignacio de la Puebla, i765, 619 LAF, 559063, i765 Mon Cor.

ıоo. Pérez de Velasco, Andrés Miguel, El pretendiente de curatos instruido para si lograre su pretencion, y desengaño para que si no es unicamente la honra de Dios, y el bien de las almas, quien le mueve, desista de pretender y no sea cura, En la Imprenta del Colegio Real de S. Ignacio, I765, RSM I765 P6PER 20512, 1765 Per Pre.

Ior. Galindo, Gregorio, Rubricas del missal romano reformado, En el Colegio Real de San Ignacio de dicha Ciudad, I766, RSM I766 P6GAL, 20518, I766 Gal Rub.

I02. Lárraga, Francisco de, Promptuario de la theologia moral, Colegio Real de S. Ignacio de la Puebla de los Angeles, i766, RFo i766 P6LAR 329708, i766 Lar Pro.

I03. Pérez de Velasco, Andrés Miguel, El ayudante de cura instruido en el porte a que le obliga su dignidad, en los deberes a que le estrecha su empleo, y en la fructuosa practica de su ministerio, en el Colegio Real de San Ignacio, I766, RSM I766 P6PER 20521, I766 Per Ayu.

I04. Venegas, Miguel, Manual de parrochos, para administrar los santos sacramentos, y executar las demás sagradas funciones de su ministerio, En la Imprenta del Colegio Real de San Ignacio de la Puebla, I766, RSM 1766 P6VEN, 20522, 1766 Ven Man.

I05. Anónimo, Rasgo breve de la grandeza guanajuateña, generoso desempeño con que celebrò la regocyada dedicación del sumptuoso templo de la sagrada Compañia de Jesus, que â sus expensas erigiò, en la Imprenta del Real Colegio de San Ignacio, I767, RSM I767 P6RAS, 20529, I767 Ano Ras.

Io6. Fabián y Fuero, Francisco, Carta pastoral, [s.n., I767], I767 P6FAB, 342175, I767 Fab Car.

I07. Moral y Castillo de Altra, José Antonio, La reyna madre sobremanera admirable, digna de la memoria de los buenos, sabia y beroyna; sermon panegyrico funebre, gue en las reales exequias de la Sra. Da. Isabel Farnesio, celebradas en la santa iglesia Cathedral de la Puebla de los Angeles el día 29 de enero de I767, Colegio Real de San Ignacio, I767, R 252.8 MIS.I, 341573, I767 Mor Rey.

108. Soria, Francisco José de, La assumpcion triumphante a los cielos de la soberana Reyna de la gloria María nuestra señora. Impresso en el Colegio Real de San Ignacio de la Puebla de los Angeles, 1767, LAF 590, 558192, 1767 Sor Ass.

I09. Alzate y Ramírez, José Antonio, Breve descripción de los festivos sucesos de esta ciudad de Puebla, Impresa en el Colegio Real de San Ignacio de la Puebla, I768, LAF 619, 558924, I768 Alz Bre.

IIo. Puebla (Diócesis), Carta pastoral del Ilmo. Sr. Dr. D. Francisco Fabian y Fuero, obispo de la Puebla de los Angeles, del consejo de su magestad Egc [s.n., I768], RSM I768 P6PUE, 20533, I768 Pue Car.

III. Rodríguez de Rivas y Velasco, Diego, Carta pastoral que el Ilmo. Sr. Dr. D. Diego Rodriguez de Rivas y Velasco escribio a las religiosas de su Obispado de Guadalaxara con el motivo de la Real Cedula expedida por S. M. en el real sitio del Pardo à Ig de Marzo de 1768 à fin de preservar del contagio del fanatismo à las religiosas de la filiación [s.n., I768?], RFO I774 M4NUÑ, 333335, I768 Rod Car.

II2. Anónimo, [Vida del venerable siervo de Dios fr. Sebastián de Aparicio, s.n., I769], EPO, 923.246 SEB.v, 42667, 1769 Ano Vid.

II3. Puebla (Diócesis), [Los dos sacramentos de eucaristía y extremaunción, s.n.], I769, R 252.8 MIS.I, 341570, 1769 Pue Dos.

II4. Carmelitas, Coleccion de providencias dadas a fin de establecer la santa vida com [s.n., I770], RSM I770 P6CAR 2054I, I770 Car Col I.

II5. Puebla (Diócesis), Colección de providencias diocesanas del obispado de la Puebla de los Angeles, En la imprenta del Real Seminario Palafoxiano, I770, RFO I770 P6PUE, 332219, I770 Dio Col. 
II6. Fabián y Fuero, Francisco. Catalogus controversiarum, et resolutionum, insupèrgue decretum pro observantia, Typis \& ad usum Seminarii Palafoxiani, I770, RFO I770 P6FAB SEM, 330187, I770 Fab Cat.

II7. — Colección de providencias dadas a fin de establecer la Santa vida comun a que se dio principio en el dia tres de Diciembre domingo primero de adviento del año proximo pasado de mil setecientos setenta y nueve; en los cinco numerosos conventos de Santa Catarina de Sena, Purisima Concepcion, SantisimaTrinidad, Santa Inés de Monte-Policiano Máximo Dr. S. Geronymo, religiosas calzadas de esta ciudad de Puebla de los Angeles... [s.n.], I770, RFO I770 P6FAB, 333336, I770 Fab Col.

II8. Iglesia Católica, Decreto pontificio expedido en I3 de diciembre de 1769 en que se aprueban todos los procesos pertenecientes a la causa de beatificacion de nuestro Ilmo. Excmo. y Ve. siervo de Dios D. Juan de Palafox y Mendoza, obispo que fue de este Obispado de la Puebla de los Angeles, y despues de Osma, Reales y Pontificios Colegios de San Pedro y S. Juan, Reales y Pontificios, Colegios de San Pedro y S. Juan, I770, rfo 208 IGL.b, 342732, I770 Igl Dec.

IIg. Barrio y Patiño, Joannes, Assertiones theologico-criticae, sacris cùm conciliorum, tùm etiàm bistoriae EG disciplinae ecclesiasticae IV. seculi fontibus hasuticae, quas sub divi petri pontificis maximi, apostolorumque peincipis, validissimo preasidio publicè tuendas objicit in Angelopolis palafoxiano seminario, Tip. Seminario, 1772, LAF 264, 538277, 1772 Ano Ass.

I20. Anónimo, Assertiones theologico-criticae, E sacris túm conciliorum tum eriam bistoriae et disciplinae ecclesiasticae D. seculi fontibus haustae, Typis ejusdem seminarï anno domini, Seminario Palafoxiano, I773, LAF 559729, I773 Ano Ass.

I2I. Convento de Santa Catalina de Siena (Puebla), Regla, y constituciones que han de guardar las religiosas de los conventos de Santa Catarina de Sena, y Santa Inés de Monte Polociano de la ciudad de los Angeles, en el Seminario Palafoxiano de dicha ciudad, I773, R I773 P6REG, 34I754, I773 Con Reg.

I22. Soria, Francisco José de, Manual de egercicios para los desagravios de Christo Señor Nuestro, por los Herederos de la Viuda de Miguel Ortega, en el Portal de las Flores, I773, RSM I773 P6sor 20624, I773 Sor Man.

I23. Abreu, Juan de, Desagravios dolorosos de la Santisima Virgen Maria, Nuestra Señora, por los agravios ignominiosos de Christo nuestro redentor, por los Herederos de la Viuda de Miguel de Ortega, en el Portal de las Flores, I774, RSM I774 P6ABR 20549, I774 Abr Des.

I24. Jorge Más Theóphoro, Carta a una religiosa para su desengaño y dirección / Jorge Más Theóphoro, Imprenta del Seminario Palafoxiano de la Puebla de los Ángeles, I774, I774, 55824I, I774 Jor Car.

125. López Gonzalo, Victoriano, Nos Dn. Victoriano López Gonzalo por la divina gracia, y de la Santa Sede Apostolica, Obispo de la Puebla de los Angeles, del Consejo de su Magestad... [s.n., I774], I77I M4BUC, 432952, 1774 Lop Lop.

I26. Reyes, José de los, Margarita serafica : con que se adorna el alma para subir a ver a su esposo Jesús : la ciudad triunfante de Jerusalen / dispuesta por el R. P. Fr. Joseph de los Reyes; lleva añadido al principio un consejo muy util del zelosísimo Doctor Boneta, Herederos de la Vda. de Miguel Ortega, I793, 242.8 REY.m. I775, 529896, I775 Rey Mar.

127. Levanto, Leonardo, Cathecismo de la doctrina christiana, en lengua zapoteca, Impreso con las Licencias necesarias en la Puebla por la Viuda de Miguel de Ortega: y por su Original en la Oficina Palafoxiana de Dicha Ciudad, año de I776, R I776 P6LEv, 4311ro, I776 Lev Cat. I28. López Gonzalo, Victoriano, Dn. Victoriano Lopez Gonzalo por la divina gracia, y de la santa sede apostolica, Obispo de la Puebla de los Angeles, del Consejo de su Mag. Eбc. [s.n., I777], R I777 M4LOP, 342763, 1777 Lop Vic.

I29. Galindo, Gregorio, Rúbricas del misal romano reformado, en la Oficina nueva del Seminario Palafoxiano, I778, RSM I778 P6GAL, 2057I, I778 Gal Rub. 
I30. Negri, Vicente, Clamores y llantos del büo pródigo, ó, Afectos de una anima penitente y convertida á Dios, En la Oficina de D. Pedro de la Rosa, en el Portal de las Flores, I778, RSM I778 P6NEG, 20572, 1778 Neg Cla.

I3I. Santa María y Ulloa, Pedro, Relox perfecto, En su nueva Imprenta Matritense, en el Portal de las Flores, Pedro de la Rosa, I778, R I778 P6san, 432778, I778 San Rel.

132. Díaz de Gamarra y Dávalos, Juan Benito, Errores del entendimiento bumano, en la Oficina del Real y Pontificio Seminario Palafoxîano, I78I, RFo 3324I5, I78I Ben Err.

133. Fernández de Otañez, Andrés, Formulario manual de las ceremonias que se practican para recibir el abito de la inclita militar Orden de Calatrava, en la Oficina de D. Pedro de la Rosa, 1783, I783 P6FER 432673, I783 Fer For.

134. Zamora, Santiago de, Explicación de la sintaxis, según las reglas del arte del P. Juan Luis de la Cerda de la Compañia de Jesus, en la Oficina de D. Pedro de la Rosa, en el Portal de las Flores, 1785, RFO I785 P6ZAM.e, 433730, 1785 Zam Exp.

135. $\longrightarrow$ Prosodia, o, Tiempo de la sylaba latina, segun el libro quinto del arte del P. Juan Luis de la Cerda, de la Compañia de Jesus, en la Imprenta de D. Pedro de la Rosa, en el Portal de las Flores, I785, I785 P6ZAM, 2124I2, I785 Zam Pro.

136. Veriztain y Romo, José Mariano, Oracion fúnebre, que en las solemnes exequias que se celebraron por el alma del serenisimo señor D. Luis Antonio Jayme de Borbon, Infante de España, en la iglesia de Santa María del Real Sitio de San Ildefonso, el día 4 de septiembre de este año, Real Seminario Palafoxiano, I786, R 252.8 MIS.I, 34I633, I786 Ver Ora.

137. Enciso y Tejada, Mariano, Ordenanzas que debe guardar la muy noble y leal Ciudad de la Puebla de los Angeles, del Reyno de Nueva España, en la Oficina de Don Pedro de la Rosa, en el Portal de las Flores, I787, R I787 P6ENc, 434247, I787 Enc Ord.

138. Bellati, Antonio Francesco, Arte de encomendarse a Dios, ó sea, Virtudes de la oracion, en la Oficina de Don Pedro de la Rosa, con letra nueva abierta en la misma oficina, I788, RFO I788 P6BEL, 322940, I788 Bel Art.

139. Agustinos, Regla del glorioso doctor de la iglesia N. G. P. S. Agustin, que han de guardar las religiosas de los conventos de Santa Catarina de Sena y Santa Ines de Monte Policiano, de la orden de N. P. Santo Domingo, establecidos en esta ciudad de la Puebla de los Angeles : Con las ordenanzas y constituciones que para su perfecta práctica ban hecho los Illmôs. señores obispos de esta dicha Diócesis de la Puebla : mandados guardar y reducidas á mas clara y mejor disposicion. por el Illss. Exmô y venerable señor D. Juan de Palafox y Mendoza, Of. del Real Seminario Palafoxîano, I789, RSM I789 P6AGU, 20695, I789 Agu Reg.

I40. Anónimo, Advertencias y preceptos útiles para la clase de menores, Pedro de la Rosa, I789, R I789 P6PRE, 341924, I789 Ano Adv.

I4I. L Relación de los méritos, y exercicios literarios del doctor don Francisco Xavier Conde y Oquendo [s.n.] 1789, RFO 920 MIS.I, 342242, I789 Ano Con.

I42. $\longrightarrow$ Preceptos para la primera clase de gramática, Pedro de la Rosa, en el Portal de las Flores, I789, RSM 1789 P6PRE, 20696, I789 Ano Pre.

I43. Chávez, Juan Antonio de, Comulgador augustiniano, en la Oficina de Don Pedro de la Rosa, I789, RFO I789 P6CHA, 335124, I789 Cha Com.

I44. Díaz y Tirado, José Atanasio, Sermon panegyrico que en la plausible y festiva imperial coronacion del Santisimo Patriarca Señor San Joseph, celebrada el dia veinte y seis de septiembre del año de mil setecientos ochenta y ocho en la ciudad de la Puebla de los Angeles, Real Seminario Palafoxiano, I789, R 252.8 MIS.I, 341576, I789 Dia Ser.

145. Castro, José Agustín de, Acto de contricion : poema místico que decia D. Joseph Agustín de Castro, y lo dedica al Illmo. Sor. D. Salvador de Biempica y Sotomayor, Imprenta de Don Pedro de la Rosa, I79I, LAF 158, 535938, I79I Cas Act. 
I46. Genovese, José María, La soledad christiana en que a la luz del cielo se consideran las eternas verdades, en la Imprenta de D. Pedro de la Rosa, I79I, RSM I79I P6GEN, 207I4, I79I Gen Sol.

I47. Anónimo, Institutiones logicae / Ioachimi Valdezi et Bazani, Angelópoli, Apud D. Petrum de la Rosa, tipographum, I793, LAF 629, 559706, I793 Ano Ins .

148. Galindo, Mateo, Explicacion de la syntaxis, segun las reglas del Arte de Antonio de Nebrija, Oficina de D. Pedro de la Rosa, en el Portal de las Flores, I793, RSM I793 P6GAL, 20846, I793 Gal Exp. I49. Reyes, José de los, Margarita seráfica, con que se adorna el alma para subir á ver á su esposo Jesus a la ciudad triunfante de Jerusalen... Lleva añadido al principio un Consejo muy util del zelosisimo Doctor Boneta..., en la Imprenta de D. Pedro de la Rosa, en la Puebla de los Angeles, I793, RSM I793 P6REY, 20842, I793 Rey Mar.

150. Zamora, Santiago de, Explicación de la sintaxis, según las reglas del arte del P. Juan Luis de la Cerda de la Compañia de Jesus, en la Oficina de D. Pedro de la Rosa, I793, RFo I793 P6ZaM, 327357, I793 Zam Exp.

151. Anónimo, Conclusiones ex quatuor enangeliorum libris erutae in reg. ac. Pontif. Seminar. Palafox. Deo auspice defendendae Bernardus María Cueto utraque in sopbia baccalaureo, Ex Typograph. Ejusd. Seminar. Palafox, 1794, LAF 629, 559759, I794 Ano Con .

152. —_ Notiones praeliminares ad meliorem conciliorum et bistoriae ecclesisticae intelligentiam, túm quaestiones quae circa, bistoriam EG disciplinam ecclesiásticam primi saeculi agitari solent, Typis Ejusdem Seminarij Palafoxiani, 1794, LAF 629, 559761, I794 Ano Not .

153. Bellati, Antonio Francesco, Arte de encomendarse a Dios, ó sea, Virtudes de la oracion, en la Imprenta de Don Pedro de la Rosa, I794 P6BEL, I29553, I794 Bel Art.

154. Diatallevi, Alexandro, Soliloguios del alma con Dios, en los quales, segun e $[l]$ orden de los versos del Miserere se expresan los efectos mismos de David y se acomodan al penitente cristiano, en la Oficina de D. Pedro de la Rosa, I794, RFo I794 P6DIA, 434308, I794 Dia Sol.

155. Pérez Martínez, Antonio Joaquín, Sermón que para concluir el novenario celebrado en esta Santa Iglesia Catedral de la Puebla de los Angeles, por via de desagravios al Todopoderoso, e implorando la felicidad de las armas católicas en la presente guerra contra Francia, predicó el día II de septiembre de I794, entre las solemnidades de la misa cantada, Real Seminario Palafoxiano [I794], R 252.8 MIS.I, 34I57I, I794 Per Ser.

156. Anónimo, El Dr. D. Joseph Miguel Guridi y Alcozer consta su carrera literaria [s.n.], I795, RFo, 920 MIS.I, 342198, I795 Ano Gur.

157. Hospital Real de San Pedro (Puebla), Resumen de los enfermos que ban entrado a curarse en el hospital Real y General de S. Pedro Apóstol de la ciudad de Puebla de los Angeles, desde el último de diciembre de I793, basta igual día de 1794 [s.n., I795], R 082.I GUE.490, 342792, I795 Hos Res.

158. Celt, Pablo, El pecador arrepentido, Of. de D. Pedro de la Rosa, I796, RSM I796 P6CEL, 21040, I796 Cel Pec.

159. Galindo, Mateo, Explicacion de la syntaxis, segun las reglas del arte de Antonio de Nebrïa nuevamente añadido con un suplemtno singular á las reglas / por el P. Mateo Galindo de la Compañia de Jesus, Oficina de D. Pedro de la Rosa, I796, RSM 1796 P6GAL, 21041, 1796 Gal Exp.

I6o. Reyes, José de los, Margarita serafica, con que se adorna el alma, para subir a ver a su esposo Jesus á la Ciudad triunfante de Jerusalen, En la Oficina de Don Pedro de la Rosa, I796 P6REY, I82545, I796 Rey Mar.

I6I. Anónimo, Relación de los méritos, exercicios literarios y eclesiásticos deldoctor don Urbano Antonio Díaz de las cuevas [s.n.], Pedro de la Rosa, I797, RFO 920 MIS.I, 342253, I797 Ano Día.

I62. _ Compendio de los méritos del Lic. D. Agustín Joseph de Echeverría [s.n.], Pedro de la Rosa, I797, RFO 920 MIS.I, 342196, I797 Ano Ech.

I63. $\longrightarrow$ Relación de los méritos, y exercicios literarios del doctor D. Juan García y Valtierra [s.n.], Pedro de la Rosa [I797], R 920 MIS.I, 342248, I797 Ano Gar. 
I64. Anónimo, La gloria de Israel, la alegria del pueblo santo cifrada en el contenido de tres decretos de suma importancia al bien espiritual de las almas. : A devoción de varias personas de e sta ciudad y de la Nueva Veracruz, quienes la ponen baxo la proteccion de Maria Santisima Señora Nuestra, y de los Santos Angeles de nuestra guarda, Pedro de la Rosa, I797, R 252.8 MIS.L, 341579, I797 Ano Glo.

I65. Instrucción para inocular las viruelas y método de curarlas con facilidad, y acierto, Pedro de la Rosa, I797, R o82.I GUE.502, 3428I2, I797 Ano Ins.

I66. — Relación de méritos del doctor D. Ignacio Méndez Quiñones [s.n.], Pedro de la Rosa [I797], R 920 MIS.I, 346050, I797 Ano Men.

167. El Dr. D. Urbano Antonio Díaz de las Cuevas consta que es originario de la ciudad de Tepeaca [s.n.], Pedro de la Rosa, I797, 920 MIS.I, 342199, I797 Ano Mex.

I68. _ Relación de los méritos y exercicios literarios del doctor Joseph Nicolas del Moral y Sarabia,

[Pedro de la Rosa, I797], R 920 MIS.I, 342247, I797 Ano Mor.

I69. — Relación de los méritos, y exercicios literarios del doctor D. Joseph Francisco Ordozgoyti y Goycoechea [Pedro de la Rosa, 1797], 920 MIS.I, 342246, I797 Ano Ord.

170. _ Relación de los méritos y exercicios literarios del doctor don Agustin Joseph Roxano Mudarra [s.n., I797], R 920 MIS.I, 34224I, I797 Ano Rox.

I7I. —_ Relación de los méritos y exercicios literarios del Dr. don Francisco de Castro Zambrano y Avila [s.n.], I797, RFO 920 MIS.I, 342243, I797 Ano Zam.

172. Castro, José Agustín de, Miscelánea de poesías sagradas /por D. Joseph Agustin de Castro, en la Oficina de Don Pedro de la Rosa, I797, RSM I797 P6CAs, 21047, I797 Cas Mis.

173. Hospital Real de San Pedro (Puebla), Resumen de los enfermos, que ban entrado á curarse en el Hospital Real y General de S. Pedro Apóstol de la ciudad de Puebla de los Angeles desde el último de diciembre de I795, hasta igual día de 1796 [s.n.], I797, R 082.I GUE.504, 342813, I797 Hos Res.

I74. Milanensis, Michael, Botica general de remedios experimentados, Pedro de la Rosa, I797, R o82.I GUE.505, 3428I4, 1797 Mil Bot.

175. Puebla [Don Manuel de Flon... por quanto... el... virrey de este reyno deseando evitar... la propagación... de viruelas..., s.n.], I797, R o82.I GUE.496, 342796, I797 Pue Vir.

176. Anónimo, Reglas de la buena crianza civil y christiana, utilísimas para todos, y singularmente para los que cuidan de la educación de los niños, á quienes las deberán explicaR inspirándoles insensiblemente su práctica en todas ocurrencias, En la Oficina de Don Pedro de la Rosa, I802, RSM I8o2 P6REg, 20750, 1802 Ano Reg.

I77. Brown, John, Epitome de los elementos de medicina [s.n.], I802, R o82.I GUE.538, 342823, I802 Bro Epi.

178. Anónimo, Epítome [s.n., I8o8], LAF 155, 536275, 1808 Ano Epi.

179. Ovando, Antonio, fray, Calendario y modo de rezar la horas canónica, los años de 1808. bisexto, y I809 : para la provincia del arcangel San Miguel y santos angeles de la Puebla : segun el rito del sagrado orden de predicadores / dispuesto por el R. P. Fr. Antonio Ovando, maestro de sagrada teologia, calificador del Sto. Oficio; impr. por orden de N. M. R. P. P. Fr. Francisco Xavier Saldivar prior provincial de dicha provincia, en la Oficina de Don Pedro de la Rosa [I808], R I808 M4OvA, 43470I, I8०8 Ova Cal.

180. García Quiñones, José, Descripción de las demostraciones con que la muy noble y muy noble leal ciudad de la Puebla de los Angeles, segunda de este reyno de Nueva España, con su presidente el señor D. Manuel de Flon, conde de la Cadena Gobernador político y militar en ella, intendente de su provincia, coronel de los Reales exércitos, y comandante de la segunda brigada : el Illmô. Sr. Dr. D. Manuel Ignacio González del Campillo, del Consejo de S. M. meritisimo Obispo de esta Diocesi, con su M. I. V. Sr. Dean y cabildo: los magistrados : los cuerpos canónicos y políticos : el gobernador de naturales con su República y el generoso vecindario solemnizaron la pública proclamación y el juramento pleyto bomenage que la mañana del treinta y uno de agosto de mil ochocientos ocho prestó el pueblo á nuestro angusto, inclito, amado y muy 
deseado monarca el señor don Fernando de Borbón séptimo de este nombre..., en la imprenta de D. Pedro de la Rosa, I809, RSM 1809 P6GAR 20664, 1809 Gar Des.

18I. Iglesia Católica, Manual para la precisa, pronta y fácil administración de los Santos Sacramentos, arreglado al ritual del No. SS. P. Paulo Quinto. I formado por órden del Exmmô. y venerable siervo de Dios Juan Palafox y Mendoza ... mando observar puntualmente así por dicho venerable señor como por otros Illmôs. señores obispos sucesores suyos, cuyos decretos se insertan, Pedro de la Rosa, 1809, I8०9 P6IGL, I65824, I809 Igl Man.

182. Iglesia Católica, Manual de párrocos para la administración de los sacramentos, y demás funciones parroquiales, en la Imprenta de D. Pedro de la Rosa, I81o, RSM I8Io P6IGL, 20599, I8Io Ano Man. 183. Espinosa, Rafael, Arenga patriótica que en la plaza principal de la capital de Puebla, por encargo de la junta cívica pronunció el cuidadano Rafael Espinosa, capitan de caballería y secretario de la comandancia general de este Estado el I 6 de septiembre de I830, en memoria de la Independencia dado en Dolores el año de I8Io, Imprenta á cargo del ciudadano José de la Rosa, I8Io, LAF I4I, 536I67, I8Io Esp Are. I84. González del Campillo, Manuel Ignacio, Pastoral que el ilustrísimo Señor Dôr. D. Manuel Ignacio Gonzalez del Campillo dignisimo obispo de la Puebla de los Angeles dirige a sus diocesanos [s.n.], I81o, LAF I67, LAF 43Z7, LAF 44I, 552820, I81o Gon Pas.

185. Jiménez de las Cuevas, José Antonio, Plática moral, y una de las treinta y tres, que por mañana, tarde y noche se tuvieron en el solemnísimo novenario y quatro días posteriores, que con suma edificación de los fieles se ban celebrado en la iglesia del Espíritu Santo de la ciudad de la Puebla de los Angeles á bonor de estos soberanos espiritus nuestros custodios, implorando del Todopoderoso la pacificación interior del reyno contra los insurgentes de la tierra á dentro, Pedro de la Rosa, I8Io, RSM I8Io P6IIM, 20598, I8Io Jim Pla. I86. Cámara de Diputados de México, Papel que la diputación mexicana dirige al Excmo. Señor Secretario de Estado y del despacho de la guerra, Oficina de Troncoso Hermanos [I8II], LAF 328, 541705, i8II Cam Pap.

187. Anónimo, Exâmen de novios, ó, Práctica para exâminar la libertad y babilidad de los que pretenden contraer matrimonio, según las instrucciónes que rigen en el obispado de la Puebla de los Angeles, en la Oficina de D. Pedro de la Rosa, I8ı2, I8I2 P6EXA, 20675, I8ı2 Ano Exa.

188. Capuchinas, Regla de la gloriosa Santa Clara, con las Constituciones de las Monjas Capuchinas del Santísimo Crucifixo de Roma. Reconocidas y reformadas por el padre general de los Capucbinos, y con las adiciones á los estatutos de dicha regla. Sacadas de las que el ilustrísimo Sr. D. Alonso de Coloma, Ob. de Barcelona dió á las Monjas Capuchinas de la misma ciudad, en el principio de la fundación el año de I603, que después la Santidad de Paulo $V$, de felice recordación, por breve particular concedió á la abadesa y monjas del Convento de Santa Clara de Valencia, Pedro de la Rosa, I8I7, I8I7 P6CAP, 208I6, I8I7 Cap Reg. 189. Anónimo, Clara y sucinta exposición del pequeño catecismo : impreso en el idioma mexicano siguiendo el orden mismo de sus preguntas y respuestas, para la mejor instrucción de los feligreses indios, y de los que comienzan á aprender dicho idioma / por un sacerdote devoto de la Madre Santisima de la Luz, bajo cuyo amparo la pone, y á cuy a honra la dedica. $Y$ á beneficio de la gente pobre se expenden á dos reales cada exemplar, Oficina del Oratorio de S. Felipe Néri, I8I9, RSM i8I9 P6Cla, 20753, I8I9 Ano Cla. 190. Iglesia Católica, Sumario de las muchas y grandes indulgencias concedidas por los Sumos Pontífices a la Cofradía de la Cinta de nuestro padre San Agustín, con la invocación de Nuestra Señora la Virgen María de la Consolación, y nuevamente declaradas por N. Smô. P. Clemente X, en su Breve que comienza: Ex injuncto EGc. en veinte y siete de marzo de mil seiscientos setenta y cinco, en la Imprenta del Oratorio de S. Felipe Neri, I8I9, I8I9 P6IGL, 20756, r8I9 Igl Sum.

19I. Dusault, Jean Paul, Cologuios con Jesucristo en el Santísimo Sacramento del altar, en la Imprenta del Oratorio de San Felipe Neri, I8I9, I8I9 P6Dus, 20755, I8I9 Mor Col.

192. Pérez Martínez, Antonio Joaquín, Panegirico de Santa Catalina de Sena, Oficina del Oratorio de S. Felipe Neri, I8I9, I8I9 P6PER NER 533149, i8ig Per Pan (hay dos ejemplares). 
193. Poblanos liberales, Exito del proceso formado a D. Manuel López Guerrero [s.n., I82-], R LAF 206, 536753, I82- Pob Exi.

194. Anónimo, El agradecido, Imprenta del Gobierno, I820, LAF 127, 534183, I820 Ano Agr.

I95. L La batea de las babas, Oficina de D. Pedro de la Rosa, I820, LAF 253, 536896, I820 Ano Bat.

196. Clamores de Nopalucan, Oficina del Gobierno, I820, LAF 127, 534172, I820 Ano Cla.

197. $\longrightarrow$ Electores parroguiales : nombrados ayér por los ciudadanos de esta ciudad para darla ayuntamiento en la mañana del proximo domingo 18 del corriente [s.n., I820], LAF I27, 534170, 1820 Ano Ele. 198. —_ El genio de la libertad, Impr. de Moreno, I820, LAF 260, 207 LAF 443, 537598, 1820 Ano Gen.

199. — El Militar Ciudadano, Imprenta de D. Pedro de la Rosa, I820, LaF I45, 535775, 1820 Ano Mil.

200. Napoléon, Napoleón en la isla de Sta. Elena : escritor de su vida política, Imprenta Liberal, i82o, I820 P6NAP, 2058I, I820 Ano Nap.

20I. Anónimo, Representación que hace á S. M. las Córtes el Ayuntamiento de la Puebla de los Angeles, para que en esta ciudad cabeza de provincia, se establezca diputación provincial, como la dispone la constitución, Imprenta del Gobierno, I820, LAF 392, 534180, I820 Ano Rep.

202. — El rey, Oficina de D. Pedro de la Rosa, I820, LAF 127, 534179, I820 Ano Rey.

203. — Los vecinos de Tepeaca, Imprenta del Gobierno, I820, LAF 127, 534181, I820 Ano Vec.

204. — Las victimas del Japón, Imprenta Liberal, I820, LAF 152, 534313, 1820 Ano Vic.

205. — Viva el rey por la constitución, Oficina de la Rosa, I820, LAF 127, 534178, I820 Ano Viv. 206. Antonio, obispo de la Puebla, Manifiesto del obispo de la Puebla de los Angeles a sus diocesanos [1820, jun. 27], Oficina del Gobierno, I820, LAF 238, 537930, I820 Ant Man.

207. Ceballos, Fernando, Observaciones sobre reforma eclesiástica / obra pósthuma del P. Fr. Fernando Cevallos, en la Oficina del Gobierno, 1820, 1820 P6CEB, 20580, 1820 Ceb Obs.

208. Anónimo, La verdad amarga pero es preciso decirla, Imprenta Liberal, I820, LAF 22I, LAF 43I, 54III2, I820 Dav Ver.

209. Díaz Gamboa, José María, Exercicio devoto del ultimo viernes de cada mes : para venerar al Santisimo Cristo, que con el titulo de la Buena Muerte está colocado en el santuario de los Gozos / Dispuesto por José María Diaz Gamboa, esclavo de este Divino señor y a solicitud y expensas de un devoto, añadida la tradicion de esta santa imagen, Oficina de D. Pedro de la Rosa, I82O, R I793 M4SAR 434272, I820 Die Exe.

210. Federico, Los proyectos de los incrédulos sobre la destrucción de los regulares; y la invasión de los bienes eclesiásticos / descubiertos en las obras de Federico el grande rey de Prusia, traducción libre del italiano, con notas, Oficina del Gobierno, I820, LAF I49, 53173I, I820 Fed Pro.

2II. El frayle despreocupado, El frayle despreocupado : carta de religioso amante de la religión, del rey de la nación á un eclesiástico escrupuloso... [El frayle despreocupado], Impr. de D. Pedro de la Rosa, 1820, LAF 26I, 537956, 1820 Fra Fra.

212. Iturri, Francisco, Carta crítica sobre la bistoria de América del señor D. Juan Bautista Muñoz / escrita de Roma por D. Francisco Iturri, Of. del Gobierno, 1820, LAF 438, 552904, I820 Itu Car.

213. J. N. T., Carta al pensador megicano, Oficina del Gobierno, I820, LAF 416, 551823, I820 Jnt Car. 214. Anónimo, La Abeja Poblana, Imprenta Liberal, I820, 320.972 ABE.p, 501926, I820 La Abeja (HeMEROTECA, FR).

215. Troncoso, Juan Nepomuceno, Aviso al pueblo, Oficina de D. Pedro de la Rosa, I820, LaF I27, 534175, 1820 Tro Avi.

216. Varela y Ulloa, Manuel, Desengaño al público, Oficina de D. Pedro de la Rosa, I820, LAF I27, 534184, 1820 Var Des. 
217. Anónimo, Alabanzas a la Santísima Virgen del Rosario / impresas con las licencias necesarias por un devoto esclavo de esta santísima señora, en la Oficina de D. Pedro de la Rosa, I82I, I82I P6ALA, 20740, I821 Ano Ala.

218. $\longrightarrow$ El aventurero : núm. 4, Imprenta liberal de Moreno Hermanos, I821, LAF I27, 532789, I821 Ano Ave.

219. — Credencial de elector de partido, Oficina de D. Pedro de la Rosa, impresor de gobierno, I82I, LAF I27, 532813, I82I Ano Cre.

220. _. El enfermo santificado por el buen uso de su enfermedad : obra utilísima á toda clase de personas I tr. del francés al castellano por un sacerdote de este obispado, impreso en la Oficina de D. Pedro de la Rosa, 1821, I82I P6ENF, 2074I, I821 Ano Enf.

221. — El Farol : Periódico semanario de la Puebla de los Angeles en el Imperio mejicano, Imp. Liberal de Moreno Hnos., I82I, HM, 056 FAR.p, 315957, I82I Ano Far (Hemeroteca, FR). 222. _. Lista de los vecinos honrados que ba nombrado el illtre. ayuntamiento constitucional, para que contribuyan á la seguridad pública con sus auxilios de rondas nocturnas, con arreglo al reglamento económico aprobado por el exemo sr. gefe superior político, de que se les entregará cópia certificada [s.n.] I82I, LAF I27, 532812, 1821 Ano Lis.

223. — Lista de los señores electores nombrados en las juntas parroguiales de esta ciudad y su comarca, Oficina de D. Pedro de la Rosa, impresor de gobierno, [I82I], LAF I27, 532827, I82I Ano Lis2.

224. - Noticia documentada de las últimas ocurrencias con el Sr. D. Francisco Novella, mariscal de campo, sub-inspector de artillería y comandante general interino de la plaza de Méjico, mandadas publicar por el Sr. D. Agustín de Iturbide primer gefe de la nación, para conocimiento y satisfacción de las provincias, Oficina del Gobierno Imperial, I82I, LAF 395, 5328I6, I82I Ano Not.

225. —u Qujas de la América a su madre patria de los agravios recibidos por sus hermanos, Imprenta Liberal, I820, LAF 221, 540735, I821 Ano Que.

226. — La regencia gobernadora interna del imperio a todos sus babitantes, Oficina de D. Pedro de la Rosa, impresor de gobierno político militar y de hacienda, I82I, LAF I27, 532810, I82I Ano Reg.

227. — Respuesta al papel inserto en el diario de Veracruz num. 24 de 8 de Noviembre de I820, al Ulamado amigo de la paz, Imprenta Imperial, I82I, LAF 22I, 540607, I821 Ano Res.

228. _ Triunfo de la libertad de la imprenta, Imprenta liberal de Troncoso Hermanos, I82I, LAF I27, 532826, I821 Ano Tri.

229. $\longrightarrow$ Viva el grande egercito imperial megicano de las tres garantias, Imprenta liberal de Troncoso Hermanos, I82I LAF, I26, 535116, I821 Ano Viv.

230. El verdadero amante de Puebla. Contra el pretendido amigo de Puebla : autor del papel de ayer / El verdadero amante de Puebla, Imprenta liberal de Moreno Hermanos, I82I, LAF I27, 532807, I82I Ber Con.

23I. B. L. M., Copia a la letra de la representacion, que por conducto de la estafeta se dirigió al excmó. señor D. Ciriaco de Llano..., Of. de Pedro de la Rosa, I821, LAF 206, 536736, 1821 Blm Cop.

232. Carrasco, Lorenzo, Patetico alegorico discurso sobre las tres garantias: religion, libertad y union, que en solemne accion de gracias por las victorias del Egército Imperial Trigarante, implorando elpatrocinio de Maria Santisima, celebraron en la Iglesia del Oratorio de S. Felipe Neri, los Sres. intendente interino, con los gefes y empleados de las oficinas de Hacienda pública y otros patriotas benemeritos de la ciudad de Antequera, Valle de Oajaca. Lo dijo en 28 de agosto de ${ }_{1} 821$, Imp. Liberal de Moreno Hermanos [I82I], I82I P6CAR 342I47, I82i Car Pat.

233. Fernández de Lizardi, José Joaquín, El primer gefe de ejército Imperial de las tres garantías, a los babitantes de Puebla, Oficina del Gobierno Imperial, I821, LAF 258, 532204, I82I Fer Pri. 
234. Iturbide, Agustín de, Poblanos ilustres, Oficina del Gobierno (Cholula), I821, LAF 127, 532822, I82I Itu Pob.

235. J. N. T., Derechos y obligaciones del ciudadano : comprende ocho artículos distribuidos en igual número de cartas, Imprenta Liberal, I82I, LAF 22I, 54072I, I82I Jnt Der.

236. Mendizábal y Zubialdea, Luis de, Fábulas políticas y militares, de Ludovico Lato-Monte [seud.], Pedro de la Rosa, I821, I82I P6MEN, 20742, I82I Men Fab.

237. México (Virreinato), Paráfrasis de la proclama de I2 de agosto de I82I, última del Sr. Novella, Of. del Gob. Imperial [I82I], R 972.04I08 MIS.I, 34215I, I82I Mex Par.

238. Moreno, José María, Poesías / del Br. D. Jose Maria Moreno, Imprenta Liberal de Troncoso Hermanos, I821, I821 P6MoR 343049, I82I Mor Poe.

239. Pérez Martínez, Antonio Joaquín, Discurso que bizo a la junta electoral de provincia, el illmo. sr. dr. d. Antonio Joaguín Perez obispo de la Puebla de los Angeles, acabada la solemne misa que se cantó en la Santa Iglesia Catedral..., Of. del Gobierno, I821, LAF 206, 536731, 1821 Per Dis.

240. El preguntón, Preguntas al hablador, Oficina de D. Pedro de la Rosa, I821, LAF I26, 534529, I82I Pre Pre.

24I. Rejón, Manuel Crescencio, El Amigo del Pueblo : segundo periodico que se pública en esta ciudad de la Puebla en uso de los derechos gloriosamente restablecidos por las invencibles armas del Egército Imperial de las tres Garantias, Imprenta liberal de Moreno Hermanos, I82I, LAF I27, 5328I4, I82I Rej Ami.

242. Santa-Anna, Antonio López de, Manifiesto, que hace al público el teniente coronel D. Antonio López de Santana, comandante general de la provincia de Veracruz, sobre lo ocurrido con la persona del coronel $D$. Manuel de la Concha asesinado al amanecer del día 5 del corriente en los extramuros de la villa de Jalapa, Camino de Veracruz, Oficina de Don Pedro de la Rosa, impresor de Gobierno, I821, LAF I26, 531873, 182i San Man.

243. Tornel, José María, Manifiesto, que bace al público el teniente coronel D. Antonio López de Santana, comandante general de la provincia de Veracruz, sobre lo ocurrido con la persona del coronel D. Manuel de la Concha asesinado al amanecer del día 5 del corriente en los extramuros de la villa de Jalapa, Camino de Veracruz, Antonio López de Santana, Oficina de Don Pedro de la Rosa, impresor de Gobierno, I821, LAF I26, 531873, I821 Tor Man.

\section{Libros que no se revisaron}

244. Mazihcatzin y Escobar, Nicolás Joseph Faustinos, Dia seis de cada mes : dedicado al esclarecido y gloriosisimo Sr. S. Nicolas Obispo el Magno : que se reza en su parroguia y barrio de Panotlan de la muy noble, insigne y siempre leal ciudad de Tlaxcalan / Dispuesto por D. Nicolas Joseph Mazinhcatzin y Escobar indio cazique, bachiller en artes, en el Colegio Real de S. Ignacio de la Puebla, I785, RSM I790 M4DIA, 434090.

245. García, Andrés, Sermón que saca a la luz el Illmo. Sr. Dr. Juan Antonio de Lardizábal y Elorza, obispo de la Puebla..., Viuda de Miguel de Ortega y Bonilla, I733, G, 208 MIs.5I, I254I7.

246. Cifuentes, Luis de, Panegyrica oracion gre a la soleme dedicacion del Templo Metropolitano de Mexico, por la Vda. de Iuan de Borja y Gandia, 1656, I6I2 M4VAL, 341640.

247. Rodríguez de Rivas y Velasco, Diego, Carta pastoral que el Ilmo. Sr. Dr. D. Diego Rodriguez de Rivas y Velasco escribio a su clero secular y regular encargandole el cumplimiento de su obligación en la enseñanza de la doctrina de Christo en el pulpito, y los confessionarios, y el exercicio de la charidad con los pobres, y personas miserables [s.n., I767?], RFO I774 M4NUÑ, 431397.

248. Fabián y Fuero, Francisco, Colección de providencias dadas a fin de establecer la santa vida común, a que se diò principio en el dia tres de diciembre Domingo primero de adviento del año proximo pasado de mil setecientos sesenta y nueve, en los cinco numerosos Conventos de Santa Catarina de Sena, Purisima Concepcion, Santisima Trinidad, Santa Ines de Monte-Policiano, y maximo doctor San Geronymo, religiosas calzadas de esta ciudad de la Puebla de los Angeles... [s.n.], I769, I770 P6PUE, 332220. 
249. Pouget, François-Aimé, Institutiones catholicae in modum catecheseos, E Typis Palafoxianis, I769, RFO 230.2 POU.i. I765, 403754.

250. Rodríguez de Rivas y Velasco, Diego, Carta pastoral que el Ilmo. Sr. Dr. D. Diego Rodriguez de Rinas y Velasco Obispo de la Ciudad de Guadalaxara, en el Nuevo Reyno de la Galicia, escribiò à su Grey, encargandole el cumplimiento de su obligacion, con la observancia de los preceptos de amar à Dios sobre todas las cosas, y al Proximo como â sì mismo [s.n., I769?], I774 M4NUÑ, 43I4I5.

251. López Gonzalo, Victoriano D., Victoriano Lopez Gonzalo, por la divina gracia, y de la Santa sede apostólica Obispo de la Puebla de los Angeles, del Consejo de S. M. EGc. [s.n., I778], I777 M4LOP, 2056I. 252. Puebla (Diócesis) [Precauciones que se deben observar en el exâmen de quienes desean contraber matrimonio, s.n., I778], R 208.2 PUE.d, 342764 .

253. González de la Zarza, Juan Antonio, Siestas dogmaticas, En la Oficina de D. Pedro de la Rosa, I781, I78I P6GON, 325187.

254. López Gonzalo, Victoriano. D., Victoriano López Gonzalo... A todos los fieles á quienes tocar pueda: Salud en nuestro Señor Jesu-Christo, que es la verdadera Salud [s.n., I784], I784 P6PUE, 234652.

255. Moral y Castillo de Altra, Juan Anselmo, Sermon que con motivo de la dedicacion, y estrenas de la iglesia del convento de Carmelitas Descalzos de la ciudad de Tehuacan; en el dia, que el mismo religiosísimo convento celebra la fiesta de los Cinco Señores, sus patronos, y titulares de la dicha iglesia, predicó en ella el 19 de enero de 1783 el Dr. D. Juan Anselmo del Moral, y Castillo de Antra, colegial antiguo, y rector del eximio teólogo de San Pablo..., impreso en el Real y Pontificio Seminario Palafoxiano, 1784, I787 M4BAD, 20677.

256. Ripalda, Jerónimo de, Catecismo y exposicion breve de la doctrina christiana, En la Oficina de D. Pedro de la Rosa, I784, I784 P6RIP, 433394.

257. González de la Zarza, Juan Antonio, Siestas dogmaticas, en las que con estilo dulce, claro y llano, por un niño es cabalmente instruido un ranchero en las quatro partes principales de la doctrina christiana, en la Imprenta de D. Pedro de la Rosa, en el Portal de las Flores, I786, I786 P6GON, 434I30, x. 258. Anónimo, Reales exếquias celebradas en la Santa Iglesia Catedral de la Puebla de los Angeles, por el alma del señor D. Carlos tercero, rey católico de España y de las Indias, en los dias y y 10 de julio de I789, en el Real Seminario Palafoxiano, I789, I789 P6REA, 20699.

259. Genovesi y Tomay, Joseph Maria Ignacio, Lecciones espirituales para los ocho dias de exercicios, Imprenta de D. Pedro de la Rosa, I79I, RSM 333843.

260. Anónimo [Relacion de meritos y exercicios literarios que como opositor a la canongia lectoral vacante en esta Santa Iglesia Catedral de la Puebla de los Angeles, presenta á la benigna atencion de V. S. I. El Lic. do D. Francisco Xavier Conde y Pineda, s.n.], I79I, R 92OF MIS.I, 342267.

26r. Moral y Castillo de Altra, Juan Anselmo, Pláticas doctrinales de contrición, confesión, y satisfación, en la Imprenta de Pedro de la Rosa, I792, I792 P6MOR 20895.

262. Sermon que con motivo de la dedicación y estrenas de la iglesia del Convento de Carmelitas Descalzos de la Ciudad de Tebuacan, en la Oficina de D. Pedro de la Rosa, I792, I792 P6MOR 20896. 263. Ramos de Vilches, Rafael, Receta para curación de dolores reumáticos, venéreos y escorbúticos, P. de la Rosa [I794], R o82.I GUE.483, 342789.

264. Anónimo, Venerandum certamen : sacram utique contentionem, Ex Typograph. Ejusd. Seminar. Palafox., 1794, 559749.

265. _ Saynete intitulado El día de lotería, en la Oficina de D. Pedro de la Rosa, I795, R 8o8.8 MIS.7, 406323 .

266. _ El Dr. D. Joseph Miguel Guridi y Alcozer consta su carrera literaria [s.n., I795], 920 MIS.I, 342198.

267. Moral y Castillo de Altra, Juan Anselmo, Pláticas doctrinales de contrición, confesión, y satisfación, en la Oficina de D. Pedro de la Rosa, I796, RSM I796 P6MOR y 234.I66 MORE.p. (hay dos ejemplares), 21042. 
268. Moral y Castillo de Altra, Juan Anselmo, Sermon que con motivo de la dedicación y estrenas de la iglesia del Convento de Carmelitas Descalzos de la ciudad de Tehuacan, en la Oficina de D. Pedro de la Rosa, I796, RSM I796 P6MOR y 234.I66 MORE.p. (hay dos ejemplares), 2 IO43.

269. Anónimo, Licdo D. Gaspar Manuel Maxias y Reynoso [s.n., I797], R 920 MIS.I, 342203.

270. Salazar Jimenez, José Antonio, Oración cívica, pronunciada por el cuidadano licenciado José Antonio Salazar Jimenez, el día I6 de septiembre de 1852, Imprenta de José María Macías. [i8??], 536192.

27I. Anónimo, Orden imperial de Guadalupe, Oficina de D. Pedro de la Rosa, impresor del gobierno. [18??], 532759 .

272. Puebla, Colección de los decretos y órdenes más importantes que expidió el Congreso Constituyente del Estado de Puebla en los años de, Gobierno [18??], D342.7247 PUEBL.c, 210669.

273. Anónimo [Por disposición del bonorable congreso se dan al público los documentos siguientes, gobierno supremo del estado libre y soberano de Veracruz], Imprenta del ciudadano Pedro de la Rosa [I8??], 552235 .

274. Ibarra, Francisco [El C. Francisco Ibarra, gobernador del Estado libre y Soberano de Puebla [s.n., I8??], 47I LAF, 55464I.

275. Iglesia Católica, Nos D. Manuel Ignacio González del Campillo, arcediano de esta Santa Iglesia, Obispo electo y Gobernador de su Obispado, del consejo de S. M. EGc [s.n., I803?], 56I LAF, 556615.

276. Anónimo [Relación de los méritos y ejercicios literarios del doctor D. Joseph Nicolás del Moral y Sarabia ..., s.n., I806?], 920F MIs.l, 47309.

277. Memorial que á favor de la juventud de la ciudad y obispo de la Puebla de los Ángeles en promoción de su mejor educación presentan a los señores pudientes y demás amantes de la patria, los individuos que intentan formar la junta de caridad con este piadoso destino, Oficina de D. Pedro de la Rosa, I807, $395 \mathrm{LAF}, 550079$.

278. González del Campillo, Manuel Ignacio, Exhortación del Ilustrísimo Señor Obispo de Puebla a sus diocesanos [s.n.], I808, LAF I66, 536566.

279. Garay, Martín de, Pueblos de Galicia / Martín de Garay, Imprenta de D. Pedro de la Rosa, I809, LAF I83, 54I9I4.

280. Ripalda, Jerónimo de, Catecismo y exposición breve de la doctrina christiana [s.n.], I8Io, RSM I8Io P6RIP, 20600.

281. Hospital Real de San Pedro (Puebla), Estado sumario del Hospital General de San Pedro Apóstol de la ciudad de la Puebla de los Angeles, que desde su erección está baxo la inmediata inspección y protección del Excmo. Sr. Obispo, e illmo. Sr. Dean y Cabildo de la Santa Iglesia Catedral, quienes nombran anualmente dos o tres capitulares para la asistencia diaria al mismo hospital, con el objeto de que los pobres enfermos de nada carezcan, y puedan quejarse de faltas que sufren, y que los fondos se distribuyan con lamayor legalidad y economía posible en los paidosísimos fines a que estan dedicados-- se pone a continuación el número de [s.n.], 1812, 362.97247 HOSP.e, 341932.

282. Hospital Provisional de San Francisco Javier (Puebla), Resultado del hospital provisional de San Francisco Xavier de esta ciudad de la Puebla de los Angeles, desde el siete de diciembre, primero de su establecimiento, hasta el treinta y uno del mismo de este año de I8I2 [s.n.] I8I3, 362.97247 HOS.R 341933.

283. Puebla Junta de Sanidad, Cartilla o sea método sencillo de curar á los pobres de pidémia, que en el presente año aflige a los habitantes de esta ciudad, Pedro de la Rosa, I8I3, R 6I4.097247 PUE.c, 342832.

284. Castillo, Fidel del, El sacerdocio real de los christianos, caracterizado en el Santisimo nombre de Jesus. Sermon panegirico, que en la solemne primera misa celebrada el dia de la circuncision de nuestro SalvadoR por el padre fray José de Trigueros, colegial teólogo-- en donde se imprimió el año de I793, y se reimprime en la Puebla de los Angeles (con permiso superior) para gloria de Dios, que en cierto modo es imprescindible de la de sus ministros, que gimen al ver ajada por los profanos su belleza, que es sócio del Señor Pedro de la Rosa, I8I4, I8I4 P6CAs, 20857. 
285. Calapis Matos, José, México 29 de Mayo [s.n.], I8I5, 312 LAF, 54096I.

286. Moyano, Tomás, Extracto del suplemento a la gaceta de Madrid del martes 30 de mayo de 1816 ,

Imprenta liberal de Moreno y Hermanos, I815, 556142.

287. Pérez Martínez, Antonio Joaquín, Reglamento para las escuelas gratuitas de niñas educandas esta-

blecidas en los conventos de religiosas de la Puebla de los Angeles, Pedro de la Rosa, I818, 308 MIS.I29, I59150.

288. - Reglamento para las escuelas gratuitas de niñas educandas establecidas en los conventos religiosos de la Puebla de los Angeles, Pedro de la Rosa, I818, RFO 323742.

289. — Panegirico de Santa Clara, Oficina del Oratorio de S. Felipe Néri, I819, I8I9 P6PER 40240.

290. Panes, José Antonio, Panegírico que en el aniversario de la consagración de la Iglesia de Nuestra Señora de la Merced de esta ciudad de Puebla de los Angeles, Oficina del Oratorio de S. Felipe Neri, i8r9, EPO, 202 MIS.I, 34706I.

29I. Junta Pública de la Real de Caridad y Sociedad Patriótica, Séptima Junta pública de la Real de Caridad y Sociedad Patriótica para la buena educación de la juventud en la ciudad de la Puebla de los Angeles en el reyno de Nueva España, Impr. del Oratorio de S. Felipe Neri, I819, ss, 37, 562543.

292. Anónimo, Cañon de a cuatro disparado a metralla contra las reflexiones de D. Manuel Yglesias, y crítica burlesca de ellas en este segundo diálogo de los Morenos, y gracias que se dan al Excmo. Sor. Virey por haber concedido la igualdad á estos. El que tubiere su tejado de vidrio, no tire piedras al del vecino, va de cuento y tenga paciencia, Imprenta Liberal, I820, $535^{8} 77$.

293. — El protestante al hablador, Impr. de Pedro de la Rosa [1820], 260 LAF, 537343.

294. —— Electores : nombrados por los compromisos de las parroguias de esta ciudad para la junta de partido [s.n., I820], LAF 127, 53417I.

295. J. V., Espiritu constitucional, Impr. Liberal [I820], G, 5IOCED I-3 SOL, $5375^{24}$.

296. Anónimo, Cuadro Histórico y espantoso de la inquisición : que se publica en esta capital para la ilustración de aquellas personas que han ignorado lo que era aquél horrible despota y cruel tribunal, Impr. de Don Pedro de la Rosa [1820?], LAF 218, 247, 540 LAF, 538945.

297. Pérez Martínez, Antonio Joaquín, Manifiesto del obispo de la Puebla de los Angeles á sus diocesanos, Oficina del Gobierno [1820], LAF 261, 534176.

298. Ciscar, Francisco, Instruccion para los Ayuntamientos Constitucionales, Juntas Provinciales, y Gefes Politicos Superiores, Oficina del Gobierno, I820, LAF 4, 530856.

299. Anónimo, Libertad de imprenta, Imprenta Liberal de Moreno Hermanos, I820, LAF I49, 531816. 300. El Hablador El Juicio de los Locos, Oficina de D. Pedro de la Rosa, I820, LAF I42, 533280. 30I. Anónimo, Llegadita al Escrupuloso, Oficina de D. Pedro de la Rosa, I820, I42 LAF, 533674. 302. Anónimo, La Carreta, Oficina del Gobierno, I820, 534635.

303. J. M. D. G., La ingratitud, Impr. de Don Pedro de la Rosa, I820, I43 LAF, 534960.

304. El telescopio sin lentes, El destierro con honor, Oficina del Gobierno, I820, LAF I43, 535031.

305. J. M. F. C., El militar imparcial, Oficina del Gobierno, I820, LAF I43, LAF 257, 535055.

306. J. M. D. G., Entierro de huesos del despotismo, Oficina de Pedro de la Rosa, I820, LAF I43, 535208.

307. — El enemigo acérrimo de los anti-mónacos, Oficina de Pedro de la Rosa, I820, LAF I43, 535212.

308. J. V., Espíritu constitucional, Impr. Liberal, I820, I43 LAF, 535268.

309. Las señoritas de la Bombé, Sentimiento de las currutacas, Imprenta de don Pedro de la Rosa, I820, I46 LAF, 535588.

310. J. M. D. N., Animo a los liberales y azotes a los serviles, Imprenta Liberal, I820, I46, 22I LAF, 535608.

3II. Anónimo, El Genio de la Libertad, Oficina de D. Pedro de la Rosa, I820, I45, 26I LAF, 535778. 312. — El protestante al hablador, Oficina de D. Pedro de la Rosa, I820, I46 LAF, 535803. 
313. Anónimo, Apología del diario de Veracruz : carta al buen ciudadano, autor de un papel intitulado análisis del romance de Veracruz [s.n.], I820, LAF, I5I,22I. 253 LAF, 536543.

314. —— El militar ciudadano, Imprenta de D. Pedro de la Rosa, I820, 253 LAF, 536615.

315. $\longrightarrow$ El machacarreta : o defensa de un carmelita en carta de un amigo a su corresponsal, Imprenta Liberal, 1820, 536786.

316. — Declamación de un militar [s.n.], I820, 253 LAF, 53688o.

317. $E[l] . M[$ oledor]. C[onstitucional], El moledor constitucional al pensador megicano, Of. del Gobierno, I820, I5I, 25I LAF, 5372II.

318. El Hablador, Enfermedad y muerte desgraciada del pobre entremetido, Impr. del Gobierno, I820, 25I LAF, 537246.

319. Anónimo, Clamores de Nopalucan [s.n.], I820, 26I LAF, 537902.

320. — La ingratitud: Diálogo entre el cuidadano y su doméstico, Imp. de D. Pedro de la Rosa, I820, 244 LAF, 53904I.

32I. M. T., Defensa de los americanos contra el que impugnó la iniciativa en el suplemento del noticioso general núm. 74I, Oficina del Gobierno, I820, 243 LAF, 539592.

322. Anónimo, El tejedor y su compadre : un almuerzo para toda la familia y varios convidados, y entre ellos un soldado español de Europa, Oficina del Gobierno, I820, 242 LAF, 539737.

323. —_ El tejedor y su compadre : está de visita Don Anselmo que de intento ba venido á platicar; si no sucediera asi, nadie oyera su conversación, Oficina del Gobierno, I820, 242 LAF, 539742.

324. — El tejedor y su compadre : prosigue la conversación con D. Anselmo, Oficina del Gobierno, I820, 242 LAF, 539746.

325. Lardizábal y Uribe, Manuel de, Informe hecho al ministro universal por un funcionario público,

Oficina de Pedro de la Rosa, 1820, 243, 540077.

326. G. C., Las victimas del Japón, Imprenta Liberal, I820, 243 LAF, 540112.

327. F. M., Centinela contra los serviles, Imprenta Liberal, I820, 221 LAF, 540737.

328. Merino, Felis, El liberal al público, Imprenta Liberal, I820, 22I LAF, 540739.

329. J. N. T., Dar que van dando, Imprenta Liberal, I820, 22I LAF, 54074I.

330. Cano Manuel, Antonio, Real decreto sobre la responsabilidad de los jueces, y demás empleados públi-

cos, cuando falten al desempeño de sus oficios, Oficina de D. Pedro de la Rosa, I820, 340 LAF, 541556.

331. Pérez Martínez, Antonio Joaquín, Discurso que bizo a los electores de provincia en la catedral de la

Puebla de los Angeles el illmo Señor Dr. Don Antonio Joaguín Pérez Martínez Obispo de la misma Diócesis

el día I7 de septiembre de I820, Oficina del Gobierno, 1820, 541564.

332. J. N. T., Fabula política, Imprenta Liberal, I820, 344 LAF, 542512.

333. Anónimo, Victoria de los serviles, y honrosa retirada del partido liberal, Imprenta Liberal, I820, 443 LAF, 553387.

334. — Defensa de los padres jesuitas por los poblanos, Impresa en la oficina de D. Pedro de la Rosa, 1820, 542 LAF, 556152.

335. — Asunto muy necesario a la felicidad de la iglesia, Oficina del Gobierno [182I], 254 LAF, 540152.

336. García, Carlos, A los babitantes de la provincia de puebla, Impresa en la Oficina de D. Pedro de

la Rosa [I82I], 393 LAF, 550270.

337. Anónimo, Prospecto, Imprenta Liberal de Moreno Hermanos [1821], I49 LAF, 531768.

338. — Capitulación acordada para la evacuación de la ciudad de Puebla, entre los Sres. coroneles D.

Juan de Horbegoso y D. Saturnino Samaniego, por parte del excmo. Sr. D. Ciriaco de Llano, Oficina de D. Pedro de la Rosa [1821], I27,4I6 LAF, 532808.

339. — Capitulación, Imprenta Portátil del Ejército de las Tres Garantías [182I], I27 LAF, 532809 . 
340. Anónimo, Diario político militar mejicano, lunes Io de septiembre de I82I, San Nicolás Tolentino, Oficina del Gobierno Imperial [I82I], I27 LAF, 5328II.

341. L Lista de los señores alcaldes, regidores y sindicos que ban de componer el Illtre. ayuntamiento constitucional del año próximo de 1822 , segundo de la independencia de este imperio, Oficina de D. Pedro de la Rosa, impresor de gobierno [I82I], I27 LAF, 532829.

342. — Valor y constancia es nuestra divisa, Oficina de D. Pedro de la Rosa [1821], 254 LAF, 540761 .

343. $\longrightarrow$ Noticias curiosas, Impr. Liberal de Moreno Hermanos, [I82I], $972.4^{8}$ NOt.c 2I, 6I8I31, x, microfilme.

344. Deposición del virey D. Juan Ruiz de Apodaca, conde del Venadito, Of. del Gob. Imperial, [I82I], 972.04I08 MIS.I, 342I52.

345. México (Virreinato), Manifiesto que por conducto del señor gobernador intendente y gefe político de esta provincia bace á sus moradores el Excmo. señor capitán general y gefe superior político D. Juan O-Donojú, Gobierno Imperial [182I], 972.04108 MIS.I, 342153.

346. P. F. J. A., Bienvenida al Exmo. Sr. D. Juan O-Donojú, Imprenta Liberal de Moreno Hermanos [I82I], 972.04108 MIS.I, 342154.

347. Anónimo [Libertad de imprenta, s.n., I82I], I49 LAF, 531775.

348. — Lista de los vecinos honrados que ha nombrado el illtre. ayuntamiento constitucional, para que contribuyan á la seguridad pública con sus auxilios de rondas nocturnas, con arreglo al reglamento económico aprobado por el exemo sr. gefe superior político, de que se les entregará cópia certificada [s.n., I82I], I27 LAF, $5328 \mathrm{I} 2$.

349. Iturbide, Agustín de, Ciudadanos militares de la septima y novena división del ejercito imperial mexicano [s.n., I82I], I27 LAF, 532819.

350. Santa-Anna, Antonio López de, Proclama del impánido teniente coronel D. Antonio López de Santana, avisando a los habitantes del pueblo de Perote la toma de aquel Fuerte, Of. del Gobierno, I82I, 972.04108 MIS.I, 342157.

351. Casas, Bartolomé de las, El indio esclavo, Imprenta Liberal de Moreno Hermanos, I821, 1821 P6CAs, 342167.

352. Anónimo, Formas de gobierno, Imprenta Liberal de Moreno Hermanos, I82I, I49 LAF, 531787. 353. — Libertad de imprenta, Imprenta Liberal de Moreno Hermanos, I82I, I49 LAF, 531798. 354. —_ Primera piedra de nuestro edificio social, Imprenta Liberal de Moreno Hermanos, I82I, I49 LAF, 531805.

355. — Pregunta, Imprenta Liberal de Moreno Hermanos, I821, I49 LAF, 531809.

356. L Hoy es día de comunicados, Imprenta Liberal de Moreno Hermanos, I82I, I49 LAF, 531821.

357. — Anti-autonomía, Imprenta Liberal de Moreno Hermanos, I82I, I49 LAF, 531823.

358. _ Sigue la anti-autonomía, Imprenta Liberal de Moreno Hermanos, I821, 531824.

359. — Reflexiones políticas, Imprenta Liberal de Moreno Hermanos, I821, 531828.

360. - Sigue el papel de Oajaca, Imprenta Liberal de Moreno Hermanos, 1821, 531830.

361. Anónimo, El papel de hoy, Oficina del Gobierno Imperial, I821, 532788.

362. Noticias de Veracruz de 3 I de octubre de I82I, Oficina de D. Pedro de la Rosa, impresor de gobierno, I821, 53279I.

363. — Pascuas a un militar, Imprenta Liberal de Troncoso Hermanos, I821, 532794.

364. — El negocio de los negocios, Oficina del Gobierno, I821, 532802.

365. Copca, Bernardo, Manifiesto del nuevo consulado de Puebla, Imprenta Liberal de Moreno Hermanos, I821, 532803 .

366. Anónimo, Concordato de España, Oficina de D. Pedro de la Rosa, impresor del gobierno, I821, 534167 . 
367. Iturbide, Agustín de, Catolicos sentimientos del sr. generalisimo don Agustín de Iturbide, Oficina del Gobierno, I821, 534759 .

368. Anónimo, Noticias curiosas, Imprenta Liberal de Moreno Hermanos, I821, 535290.

369. Bustamante, Carlos María de, Galeria de principes mejicanos, Imprenta Liberal de Moreno y Hermanos, I821, 53647 I.

370. Llano, Ciriaco de [Refutación al Pasquin en apoyo a Iturbide durante su estancia en Querétaro el 3 de julio de I82I, s.n.], I82I, 206 LAF, 536734 .

37I. Pradt, Dominique Georges Frédéric de Riom de Prolhiac de Fourt de, Apóstrofe que hace la América, en nombre de sus bijos los americanos, Impr. Liberal de Troncoso Hermanos, 1821, 536742. 372. Anónimo, Segunda carta del poblano al mejicano, Oficina del Gobierno Imperial, I821, 5368II.

373. $\longrightarrow$ A las valientes tropas del ejército imperial mejicano de las Tres Garantías, Pedro de la Rosa, I82I, 539835 .

374. L Lo muy necesario, Oficina de Pedro de la Rosa, impresor del Gobierno, I821, 540012. 375. J. A. C., Concejo á todos los soldados del Ejército Imperial Tri-garante, Impr. Liberal de Moreno Hermanos, I821, 540019.

376. E. D. L., Realizado en Puebla el importante voto de un ciudadano, Oficina de Pedro de la Rosa, impresor de gobierno, I821, 540070.

377. Anónimo, Para esto se biso la imprenta, Oficina del Gobierno Imperial, I821, 540135.

378. Mier Quatemoczin, Juan Rosillo de, Manifiesto sobre la inutilidad de los provinciales de las religiones en esta America, Impreso en la Oficina de D. Pedro de la Rosa, I821, 540205.

379. —— Enseñar al que no sabe, Oficina de D. Pedro de la Rosa, I821, 540216.

380. Anónimo, Galeria de antiguos principes mejicanos dedicada a la suprema potestad nacional que les sucediere en el mando para su mejor gobierno, Oficina del Gobierno Imperial, I821, 540388.

381. Lentimientos y heroismo del general de la provincia de veracruz, Impreso en la Oficina de D. Pedro de la Rosa, I821, 540450.

382. — Voto general de la nación, Oficina de D. Pedro de la Rosa, I821, 541909.

383. — Atenta contestación a la proclama del Excmo. Sr. O-Donoju de 3. del presente dirïida por un Americano en el angusto nombre de su patria, Impr. Liberal de Troncoso Hermanos, I82I, 542148.

384. — Manifiesto del Illmo. Sr Obispo de la puebla de los angeles á todos sus amados Diocesamos [s.n.], I821, 393 LAF, 550074 .

385. O'Donojú, Juan de, Segunda proclama del señor O-Donoju, Oficina del Gobierno Imperial, I821, 550139 .

386. Troncoso, Juan Nepomuceno, $A$ los señores oficiales y soldados del ejercito nacional de las tres garantías, Imprenta Liberal de Troncoso Hermanos, 1821, 550251.

387. Anónimo, Contestación á la proclama dada en Méjico por el exmo sr. Virey D. Francisco Novella, por el regimiento de dragones imperiales de la libertad, primero en las operaciones bostiles sobre la capital, Oficina del Gobierno Imperial, 1821, 550260.

388. Quintanar, Luis, Partes oficiales, Oficina del Gobierno Imperial, I82I, 550397.

389. Anónimo, Noticia interesante, Imp. de José María Macias, I82I, 550420.

390. L Representación del excelentisimo ayuntamiento de Mejico al comandante accidental de armas de la misma cuidad mariscal de campo Don Francisco Novella, Imprenta del Gobierno, 1821, 550477.

39I. Iturbide, Agustín de, Comunicación oficial del primer gefe del ejercito imperial de las tres garantias, Reimpreso en la Oficina del Gobierno Imperial, I821, 550493.

392. Anónimo, Noticias de Mejico, sacadas del Noticioso general del viernes 28 de diciembre de I82I, Reimpresa en la Oficina de D. Pedro de la Rosa, I821, 550494.

393. — Noticias fidedignas sacadas de una carta de Méjico, fecha 30 de septiembre, Oficina de Don

Pedro de la Rosa, I821, 550496. 
394. Anónimo, Marcha alusiza a los heroicos hechos del Excmo. Sr. D. Agustín de Iturbide, generalisimo de mar y tierra, y Presidente de la regencia del Imperio Mejicano, Oficina de D. Pedro de la Rosa, 1821, 55167i.

395. Díaz Gamboa, José María, Al Señor Don Agustín de Iturbide, Oficina de D. Pedro de la Rosa, I821, 551685 .

396. - Proclama al ejército imperial tri-garante, Oficina del Gobierno Imperial, I82I, 552566, x. 397. Filalethes. FRDUP, Oficina del Gobierno Imperial, I821, 553096.

398. I. M., Manifiesto que hace al público un ciudadano del regimiento de Dragones de España, Imprenta Liberal, I82I, 553356.

399. Lamadrid, Estevan, Oración cívica, pronunciada por el cuidadano Estevan Lamadrid, el día 27 de setiembre de 1852, Imprenta de José María Macías [s.a.], 536188.

40o. Lafragua, José María, Francisco Pavón y José Marái Marín suplican á U. asista al acto de filosofía que sustentarà José María Lafragua la mañana I7 del corriente en el Colegio del Estado, Tip. Gubernamental, Gobierno [s.a.], 538278 .

40I. Castillo Grajeda, José del, Compendio de la vida, y virtudes de la venerable Catharina de San Juan, en la Imprenta de Diego Fernández de León, I692, I692 P6CAs, 20353.

402. Calderón, Juan Alonso, Memorial birtórico, ivridico, político, de las iglesia catedral de la Pvebla de los Angeles, en la Nueva-España: dobre restitvirla las armas reales de Castilla, León, Aragón y Navarra que poso en la capilla mayor de sv iglesia de que ha sido despoiada inivsfamente / Ivan Alonso Calderón [s.n., I7??], R D348.7247F CAL.m, 341903.

403. Torres, Miguel de, Dechado de principes ecclesiasticos, que dibujò con su exemplaR virtuosa, y ajustada vida el Illust. y Exc. señor doctor D. Manuel Fernandez de S.Cruz, y Sabagun, Imp. de la Viuda de Miguel de Ortega y Bonilla, i7i6, I7I6 P6TOR 2047I.

404. Salcedo Fita y Peralta, Juan de, Escvela de la razon, Viuda de Miguel de Ortega y Bonilla, I725, RSM I725 P6SAL, 20730. 


\section{APÉNDICE 3 \\ GLOSARIO $^{804}$}

a bando: Es una cita extensa que se separa del texto principal, formando un párrafo en sí misma con otra indentación o compuesto en una fuente diferente o en menor puntaje que el texto principal. Cuando la cita es breve, se compone sin separarla del texto principal y generalmente va entre comillas (RB).

a ordinal, u ordinal: Véase letras (RB).

abanico: Ir desigualando los pliegos de la jornada cuando se va tirando para cogerlos con más facilidad uno a uno para ponerlos en el tímpano ( $\mathrm{S}$ y $\mathrm{V})$.

abertura: Se refiere a la dimensión de la boca en letras como C, c, S, s, a y e. Los diseños humanistas como Bembo y Centaur tienen aberturas grandes; en cambio, los diseños románticos como Bodoni y los realistas como Helvética tienen aberturas pequeñas. Las aberturas muy grandes se dan en las inscripciones griegas arcaicas y en las fuentes que derivan de ellas (RB). abrir papel: Ir abriendo los cuadernillos que se mojaron el día antes, y se pusieron uno sobre otro, para extenderlo y quitarle las arrugas, gualdrapeándolo, sentando los lomos y cargándolo con piedras (S y V).

aguamanil: Un botecito de hoja de lata con su asa y cañoncito para tener el aceite y poderle echar sin desperdiciarse en los cascos, matriz y bandas ( $\mathrm{S}$ y V).

agudo: Es un acento utilizado sobre vocales -á é í ó ú ý ź- en checo, español-idioma en el que también se lo conoce como tilde-, francés, gaélico, húngaro, islandés, italiano, navajo y otros idiomas, y sobre consonantes -ć ń í ś ź- en croata, polaco, sánscrito transliterado y vasco. En chino, se usa con vocales y con una nasal -á é í ó ń ú ź- para marcar el tono ascendente. También se usa con consonantes en cirílico $-\Gamma ́$ y y con todas las vocales en griego. Las versiones en minúsculas y mayúsculas de las seis vocales agudas básicas aparecen en las fuentes latinas de texto de estándar Iso. Las fuentes paneuropeas generalmente incluyen tanto formas minúsculas como mayúsculas de las cinco consonantes agudas básicas y la vocal del islandés antiguo ǽ. La schwa aguda $\mu$, la o abierta y las vocales nasales agudas del atabascano -i u \} Ë Û- están presentes solamente en fuentes especializadas (RB).

agujetas: Las arrugas que salen en el papel e impresión ( $\mathrm{S}$ y V).

ajustar: Ir formando planas, las que deben estar todas iguales, para lo cual se tiene una regleta con el largo (S y V).

ajustar punturas: Ponerlas iguales con las de otras prensas para la uniformidad (S y V).

alcance: El oficial que va primero haciendo planas, acabado el original, o cerca de acabarle, si no tiene bastante para la plana, da al que le sigue en una galera, señalando con yeso la plana que es, o 5, 7, 9, \&c., una línea compuesta con el título y folio, para que vaya formando planas, y éste hace lo mismo con el que le sigue (S y V).

aldino: Se refiere a una casa editorial que operaba en Venecia, entre 1494 y 1515 , bajo la conducción de Aldo Manuzio. La mayor parte de los tipos de Aldo - que incluyeron redondas, cursivas y griegas - fue grabada por Francesco Griffo, de Boloña. A todo tipo que se parece a los de Griffo, como a todo diseño tipográfico que se parece a los de Manuzio, se le llama

${ }^{804}$ Las entradas de este glosario proceden de dos libros: Joseph de Sigüenza y Vera. Adición al Mecanismo del arte de la imprenta para facilidad de los operarios que le profesan. Madrid: Imprenta de la Compañía, I822, y Robert Bringhurst. Los elementos del estilo tipográfico. México: Libraria, FCE, 2008; las entradas procedentes del primero se señalarán con las iniciales ( $\mathrm{S}$ y V) y las del segundo con (RB). 
aldino. Poliphilus de Monotype y la redonda Bembo son reconstrucciones aldinas, aunque sus compañeras en cursiva no lo son. En este momento no hay ninguna cursiva o griega aldinas en el mercado (RB).

altas y bajas: Las mayúsculas de tipo móvil se disponían en una caja que se acomodaba arriba de la que contenía las minúsculas. Por eso a aquéllas se las conoce como altas y a éstas, como bajas. Hoy los alfabetos latino, griego y cirílico son de dos cajas (RB).

alto real: Es aquella altura mayor que tiene una fundición respecto del alto regular de las demás; no pudiendo por este motivo jugar con ninguna de ellas (S y V).

altura de las mayúsculas: Es la distancia desde la línea de base de un alfabeto hasta la línea de las mayúsculas, es decir, la altura aproximada de las letras mayúsculas. Muchas veces esa altura es menor que la altura de las ascendentes, aunque a veces es mayor. Véanse también línea de base $\mathrm{y}$ altura $\mathrm{x}(\mathrm{RB})$.

altura $\mathrm{x}$ : Es la distancia entre la línea de base y la altura media de las minúsculas sin ascendentes ni descendentes $-\mathrm{a}, \mathrm{c}, \mathrm{e}, \mathrm{m}, \mathrm{n}, \mathrm{o}, \mathrm{r}, \mathrm{s}, \mathrm{u}, \mathrm{v}, \mathrm{w}, \mathrm{x}, \mathrm{z}-\mathrm{y}$ la altura media del torso de las que sí tienen ascendentes o descendentes $-\mathrm{b}, \mathrm{d}, \mathrm{h}, \mathrm{k}, \mathrm{p}, \mathrm{q}, \mathrm{y}-$. La relación de la altura $x$ con la altura de las mayúsculas es una carácterística importante de cualquier fuente de tipos latinos de dos cajas, y la relación de la altura $x$ con la longitud de las ascendentes y descendentes es una propiedad crucial de cualquier minúscula latina o griega. Véanse también altura de las mayúsculas y línea de base (RB).

alzar: Poner por orden alfabético las jornadas que se han impreso de una obra, cogiendo los pliegos uno a uno de cada signatura (S y V).

alzas: Pedacitos de papel pastoso que se ponen sobre el patrón donde no imprime bien, para igualar la impresión (S y V).

ángulo de inclinación: Es el ángulo del asta y las ascendentes y descendentes de las letras con respecto a la vertical. La mayoría de las cursivas (pero no todas) tienen inclinación hacia la derecha de entre $2^{\circ}$ y $20^{\circ}$. Véase también eje (RB).

apaisado: Lo que va de un extremo a otro del pliego mas ancho que alto (S y V).

apóstrofo: También llamado coma elevada o comilla de cierre en inglés, francés, italiano y muchos otros idiomas, es una marca de elisión. A partir de ese uso, este símbolo se convirtió también en señal del posesivo en inglés. En lingüística un apóstrofo como superíndice (no debe confundirse con el acento agudo) es el símbolo estándar de una consonante glótica: $\wedge^{\wedge} \sim$ _, etcétera. Por conveniencia estos símbolos se convierten muchas veces en consonantes seguidas por apóstrofos normales: m' p' q', etcétera. Las consonantes con apóstrofo son frecuentes en la tipografía. En checo las $d$ y $t$ con apóstrofo (d' y t', cuyas formas mayúsculas son $\check{D}$ y $\breve{T}$ ) son letras del alfabeto; lo mismo sucede con l' y L' en eslovaco; ch', k', u', l', s', t', tl', ts', x', x'y sus correspondientes mayúsculas (escritas con apóstrofos, no con anticircunflejo) son letras del alfabeto en tlingit. Usado como un caracter en sí mismo, el apóstrofo sirve muchas veces para señalar el cierre glotal o saltillo. En Unicode, esas funciones se distinguen con mucho cuidado. Véanse también comillas, comillas mecanográficas, cierre glotal y gancho palatal (RB). apóstrofo invertido: Es una forma mutante de las comillas dobles y sencillas. Aparecen en varias fuentes estadounidenses de publicidad y texto grabadas en los primeros años del siglo xx y en algunas fabricadas a finales de ese siglo (RB).

apretador: Una tira de baldes que se ciñe a la mano, al tiempo de hacer las balas, a fin de que no dañen las cuerdas (S y V).

apuntar: Clavar los pliegos en las punturas para su sujeción, y ajustar el registro. arrendadores: Son unas sortijas donde se atan las cuerdas para colgar el papel impreso a secarse $(\mathrm{S}$ y V). 
arroba: Símbolo de una medida de masa y de volumen. El correo electrónico le dio nueva vida, pues en inglés significa at, "en”; pocas veces está bien diseñado. En un texto normal, sin embargo, no tiene ninguna función (RB).

ascendentes y descendentes: Cualquier parte del diseño de la letra que se extiende por encima de la altura $x$, como en $\mathrm{b}, \mathrm{d}, \mathrm{f}$, o por debajo de la línea de base, como en p y q (RB).

asta: Es el trazo principal más o menos recto que no es parte de la curva o panza. La letra $o$ no tiene asta; la letra $l$ consiste solamente en asta y remates (RB).

asterisco: Generalmente es un superíndice utilizado para señalar referencias y palabras clave. En la tipografía europea también se usa muchísimo para marcar el año de nacimiento de una persona (como se usa la daga, en sustitución de una cruz, para marcar el año de la muerte). En filología indica formas "fetales" o hipotéticamente reconstruidas. El asterisco tiene muchas formas. Aparece en las primeras escrituras pictográficas sumerias. Es un símbolo gráfico con por lo menos cinco mil años de vida (RB).

atar: La acción de recoger la letra y ponerla en tablones concluida la impresión ( $\mathrm{S}$ y $\mathrm{V}$ ).

atar: Sujetar con un bramante la plana o galerada después de compuesta, para que las letras no se desunan (S y V).

atender: Llevar gran cuidado con lo que pronuncia quien lee las pruebas para replicar si falta algo del original, o dice otra cosa (S y V).

ayudante: El compañero o muchacho aprendiz que le ayuda, así para dar tinta, como hacer las demás cosas que le mande $(\mathrm{S}$ y $\mathrm{V})$.

baca: Una cuerda gorda de cáñamo para hacer andar el tablón de la prensa (S y V).

bala: Es una versión más grande del punto medio, utilizada sobre todo como marca tipográfica importante. Las balas suelen usarse para marcar elementos en una lista; se pueden usar como los números, fuera de la columna; también se componen centrados en el renglón para separar grandes bloques de texto. Véase punto medio (RB).

balones: Las dos porciones de lana que tienen las balas $(\mathrm{S}$ y V).

bandolera: Un pedazo de cuerda gorda que los aprendices se echan por los hombros para sostener las formas y llevarlas con mas facilidad (S y V).

barniz: El compuesto de aceite de linaza y otros ingredientes (S y V).

barra: Es un trazo oblicuo que utilizaban los escribas medievales y muchos escritores posteriores como si fuera una coma. También se utiliza para construir fracciones a nivel (por ejemplo $\varpi / 3$ ), representar una ruptura de línea cuando se compone verso en prosa y, en el caso de fechas, direcciones y otros textos, como signo de separación. Compárese con el solidus, es decir, con la diagonal o barra de fracciones (RB).

bastarda: Una clase de letra gótica (RB).

bastardilla: Véase cursiva (RB).

bigotes: Las rayas en figura de lanzadera ( $\mathrm{S}$ y V).

birlies: Los blancos que quedan en las planas cortas por acabarse la narración, o seguir algún titulo u otra cosa diferente (S y V).

bizcorneado: El pliego que, por estar mal apuntado fuera del lomo, está torcido (S yV).

blanco: Véase línea de blanco (RB).

blanco: El papel sin imprimir (S y V).

blanco: Las planas que se echan primero en prensa para imprimir por una cara del pliego, que son la mitad de que consta, como en $8^{\circ}$, ocho planas, en $12^{\circ}$, doce $(S$ y V).

braga: $\mathrm{El}$ pergamino con que se viste la frasqueta en el encarnado (S y V).

breve: Es un acento utilizado en vocales y consonantes en lenguas como malayo, rumano, turco, vietnamita y algunas formas de coreano transliterado. En inglés se usa en transcripciones de fonética informal para marcar vocales cortas. En la escritura de la métrica y la prosodia es 
el signo de una vocal o sílaba cuantitativamente corta. También se usa en la $i$ rusa (й, cuya forma cursiva es й) y en otra vocal, y̆, en bielorruso y uzbeko. El breve siempre es redondo y no debe confundirse con el anticircunflejo angular. También se llama corto (RB).

breve invertido: Signo diacrítico que se usa con las vocales y una consonante silábica.,$-{ }^{1} 0$ " $i$ (y las correspondientes letras en cirílico, $\cdot$, 1/4 \% 3/4 1/2) - para marcar el tono largo descendente en serbocroata. Aunque no se emplean en la escritura común, estas formas se usan en la enseñanza, en lingüística y en algunas ediciones de poesía métrica. Hay muy pocas fuentes que incluyen el breve invertido o los signos compuestos en los cuales se utiliza. No se debe confundir con el circunflejo, que tiene una punta en el medio. También se le conoce como domo o arco, aunque en español convendría llamarlo antibreve (RB).

caballo: Dar con la frasqueta en el molde por no cerrarla bien al echarla (S y V).

cabecera: Los adornos que se ponen en las planas antes de los títulos (S y V).

cabeza centrada: Es un encabezado o un título centrado sobre el texto. Compárese con cabeza lateral (RB).

cabeza lateral: Es una cabeza secundaria o subcabeza que se compone alineada a la izquierda

(más raramente, a la derecha) o levemente sangrada. Compárese con cabeza centrada (RB).

caja alta y baja: La alta consta de 96 cajetines, y la baja de 42, en los cuales se echan las letras. Su

largo es de una vara y i dedos, y su ancho media vara y dos dedos (S y V).

caja de texto: Es la parte de la página que se destina al texto (RB).

cajista: El oficial que coordina las letras, formando líneas y planas hasta concluir toda la obra

que se pone a su cuidado: debe estar impuesto en la ortografía, así castellana como latina, y

leer perfectamente ambas lenguas para cumplir mejor su desempeño ( $\mathrm{S}$ y V).

calderón: Es una vieja marca de escritura que se emplea al comienzo de un párrafo o sección

principal del texto. Los tipógrafos siguen utilizándolo para ese propósito y, en ocasiones,

como marca de referencia. En las fuentes bien diseñadas se ofrecen calderones con cierta personalidad -en lugar del estándar 9f, muy flojo y ya demasiado visto-. En la antigüedad también se empleaba un signo del mismo nombre, pero distinta figura, para indicar los miles en las cantidades (RB).

calles: Son aquellos claros de palabra a palabra, que caen uno debajo de otro en tres o cuatro líneas seguidas, los cuales afean la composición ( $\mathrm{S}$ y V).

cancilleresca: Es una clase de letras cursivas con ligaduras adicionales, y ascendentes y descendentes curvadas y alargadas. Muchas - pero no todas- son las cancillerescas son formas con trazo caligráfico $(\mathrm{RB})$.

capa: La porción de esta letra atada que cabe en el ámbito de la tabla, poniendo otra encima de ésta, y entre una y otra cinco o más papeles para que no se hiera la de abajo: no deben ponerse mas de tres capas, dejando como un dedo de hueco alrededor, para que no se caiga la letra $(\mathrm{S}$ y V).

capillas: Los pliegos que se sacan para el autor de cada signatura que se tira (S y V). capitular: Es una mayúscula inicial que se introduce en el texto. Compárese con capitular alta (RB).

capitular alta: Es una mayúscula inicial, de puntaje mayor que el resto del texto, que se eleva por arriba de la primera línea del párrafo en vez de estar incrustada en éste (RB).

caracter no alfabético: Dícese de los signos tipográficos que se utilizan con el alfabeto, pero no tienen un lugar en el orden alfabético. Los diacríticos como el acento agudo, el circunflejo, la diéresis y el anticircunflejo son caracteres no alfabéticos; también lo son el asterisco, la daga, el calderón, la coma y los paréntesis $(\mathrm{RB})$.

casar: Coordinar las planas, para que doblado el pliego vengan seguidas ( $\mathrm{S}$ y V). cascos: Dos pellejos de carnero de que se forran las balas por la parte exterior (S y V). 
cedilla: Es un signo diacrítico que se utiliza con consonantes, como la ç en catalán, francés, náhuatl y portugués, y la ç y la ş en turco. En letón y en rumano se prefiere la subcoma. No hay que confundirlo con el ogonek o gancho nasal, que se curva hacia el lado contrario y se usa solamente con vocales (RB).

ceja: El borde de la caja alta y baja (S y V).

chibalete: Son dos maderos, uno alto y otro más bajo, cada uno con su zapata atravesando otro madero desde el chico al alto en declive para poner la caja baja y alta, quedando sentadas en la misma forma, a fin de tomar la letra con más comodidad. El madero donde sienta la caja baja tiene de alto una vara y ocho dedos, dejándole su espiga para apoyo de dichas cajas; el de atrás, siete cuartas: antes de las zapatas está atravesado otro madero, quedando en todo el ancho de una vara menos ocho dedos. Se necesitan dos para cada caja (S y V).

cícero: Es una unidad de medida igual a I2 puntos Didot. Es la contraparte de la pica, pero el cícero es levemente mayor que ésta: equivale a $4.52 \mathrm{~mm}$ o o.178 pulgadas. Véase punto (RB). cierre glotal: El cierre glotal es un sonido en busca de caracter: se trata de un sonido básico en muchas lenguas que ahora se escriben en letras latinas, pero carece de símbolo tradicional en los alfabetos latino, griego y cirílico. Los lingüistas usan el caracter ? o ? -un signo de interrogación mutilado- para representarlo, pero el símbolo que más se usa cuando se componen textos es el apóstrofo. En árabe transliterado, la coma invertida o comilla de abrir (') se usa comúnmente para representar la letra 'ain ( $(\varepsilon)$, cuyo símbolo fonético es $\dot{\text { o }}$ $f$, y el apóstrofo (') se usa para hamza ( $\varepsilon$, , , l, etcétera), el cierre glotal arábigo. También se lo conoce como saltillo. Véanse apóstrofo, coma invertida superior y comillas (RB).

circunflejo: Es un diacrítico que se utiliza en las vocales -â ê î ô $\hat{u} \hat{w} \hat{y}-$ en lenguas como el cree, el francés, el galés, el portugués, el rumano, el vietnamita y muchas otras. En textos multiculturales (por ejemplo textos en los que aparecen el árabe, el griego, el hebreo y el sánscrito) se usa a veces como sustituto del macron para marcar las vocales largas. En el tai transliterado un circunflejo significa un tono descendente (RB).

cita: Lo que se pone después de dicho contexto por medio de llamadas para darle más claridad; va en letra más chica $(\mathrm{S}$ y $\mathrm{V})$.

colgador: Es un palo largo, redondo, con una tabla delgada al extremo como de tres cuartas de largo y poco más de una de ancho, la cual acaba en disminución, y es donde se pone el papel a porciones para colocarlo en las cuerdas, poniendo en los extremos unos pliegos doblados por largo llamados muletas, para que el aire no levante los otros, y también cuando se acaba jornada para conocerse ( $\mathrm{S}$ y V).

colgar: La acción de poner el papel en las cuerdas (S y V).

color: Es la tonalidad de un tipo cuando se compone en masa, lo cual no equivale a hablar del peso de la fuente misma. Las siguientes carácterísticas afectan el color del tipo: espaciado de las palabras y las letras, interlineado, frecuencia de mayúsculas, por no mencionar las propiedades de la tinta y el papel con que se imprime. Véase también peso (RB).

coma: Es un marca gramatical que desciende de las más antiguas prácticas de escritura. En alemán, como pasa en muchas lenguas de Europa oriental, se usa para indicar el inicio de una cita. En Europa y algunos países de América Latina también se usa como punto decimal. En el uso norteamericano, la coma separa miles; Europa prefiere un espacio y buena parte de Latinoamérica, un punto. Así Io,000,000 = $10000000=10.000 .000$, pero un número como I०,০or es tipográficamente ambiguo: podría significar tanto diez y un milésimo como diez mil uno. Véase comillas (RB).

componedor: Es un listón de madera de un dedo de grueso y otro de alto, teniendo un hueco como de dos partes de él forrado con una hoja de hierro o latón, para que la madera no se estropee. Los hay de varios tamaños, y han de estar a escuadra (S y V). 
componer: La acción de ir cogiendo las letras de la caja para formar la palabra que se ha leído. composición: El conjunto de líneas hechas planas (S y V).

comprobar: Ver si está bien enmendado lo que se corrigió en las pruebas (S y V).

contorneada: Es una letra en la cual los trazos principales están ahuecados o perfilados, aunque el contorno se deja más o menos intacto. Las fuentes contorneadas hacen que la letra tenga un color más claro y, al mismo tiempo, preservan las formas y proporciones de la fuente original. Si en vez de ahuecar los trazos se dibuja una línea alrededor de la parte exterior de las letras, para luego extraer la forma original entera, se consiguen letras más gordas que las originales y con menor resolución $(\mathrm{RB})$.

contraforma: Es el espacio en blanco encerrado en el diseño de una letra; puede estar completamente rodeado por el trazo, como en $d \mathrm{u} o$, o en forma parcial, como en $c \mathrm{o} m$. También se conoce como contorno interno. (RB).

contraste: En el análisis de los diseños de letras, se refiere generalmente al grado de contraste entre los trazos gruesos y los trazos finos de una letra dada. En las fuentes románticas como Bulmer y Bodoni, el contraste es alto. En las fuentes sin modulación, como Gill Sans y Futura, el contraste es bajo o sencillamente no existe (RB).

corchete: Rasgo que abraza dos, tres o más líneas ( $\mathrm{S}$ y V).

corondel: Es la columna en blanco -aunque a veces lleva un filete- entre dos columnas de texto o entre los márgenes del lomo, cuando quedan dos bloques de texto pareados (RB).

corondeles: Otros listones de hierro que se ponen después de las guarniciones, arrimados a los tornillos para apretar los moldes sin perjudicar la madera (S y V).

corrales: La composición que lleva muchos espacios entre palabra y palabra.

corregir: Enmendar las erratas, u otra cosa que esté señalada en las pruebas.

corte delantero: Es el borde o margen exterior de una página de libro; es decir, el borde o margen opuesto al del lomo (RB).

cran: Es un canalito que tiene la letra para que cuando entre en el componedor quede hacia la izquierda, pues de lo contrario quedaría al revés, conociéndose por el tacto: las extranjeras lo tienen al contrario ( $\mathrm{S}$ y V).

crucero: El hierro que está en medio de la rama, embutido en unas cajas para poderlo quitar y poner $(\mathrm{S}$ y V).

crucero: El que atraviesa de folio a folio $(\mathrm{S}$ y $\mathrm{V})$.

cuadrados: Son unas piezas de metal para poner los blancos entre las líneas de los títulos y en donde se acaba párrafo: los hay de cuatro, tres, dos y una y media líneas.

cuadrados altos: Son lo mismo, excepto ser más altos, y sirven para amparar la letra en el encarnado (S y V).

cuadrados bajos: Se usan en la composición quebrada, u orlada, en donde hay mucho claro y el prensista no puede echar tapón para que no manche ( $\mathrm{S}$ y V).

cuadrados gordos: Éstos sirven para hacer las imposiciones, birlíes y planas en blanco. Son de dos líneas de texto su grueso, y tres de ancho (S y V).

cuadratín: En tanto unidad de medida, es equivalente a una pica. También se denomina así a un cuadrado cuyo lado mide lo mismo que el tipo: en un texto en is pt, el cuadratín es un cuadrado de ir pt por lado (RB).

cuadratines de eme: Son los que equivalen a una eme de la fundición, sirviendo regularmente para sangrar las líneas (S y V).

cuadratines de ene: Los que equivalen a una ene. Así éstos como los cuadrados son cuadriláteros (S y V).

cuerpo (I): Respecto de los tipos móviles, es la medida del bloque de metal del cual emerge la imagen, tallada en espejo de la letra impresa. (2) Respecto de la fotocomposición y la 
tipografía digital, es la medida de la cara rectangular del bloque en la que estaría montada la letra si fuera metálica y tridimensional, en lugar de ser una imagen en dos dimensiones. Este "bloque" se conserva como referencia al definir cuerpo e interlínea. Véase puntaje (RB). cursina: Es una clase de letras más parecida a las que se escriben a mano que a las redondas, pero menos adornadas que las caligráficas. Se desarrollaron a partir de la escritura manual carolingia en la Italia del siglo xv. En la mayor parte de las cursivas, las letras separadas se conectan a través de remates transitivos. También se conoce como bastardilla $\mathrm{o}$, por influencia del inglés, itálica (RB).

cursiva: Letra que se asemeja a la de pluma, que llaman bastardilla (S y V).

curvas: Son las astas generalmente redondas o elípticas que forman el trazo básico de letras como C, G, O en mayúsculas, y las letras b, c, e, o, p en minúsculas (RB).

daga: Es una marca para referencias, utilizada sobre todo con las notas al pie. En la tipografía europea también es símbolo de la muerte y se utiliza para marcar el año del deceso o los nombres de personas muertas; en la lexicografía se usa para marcar formas obsoletas. En la edición de textos clásicos las dagas se emplean para marcar pasajes que se consideran corruptos. También se la llama obelisco, óbelo o cruz (RB).

dar el alcance: La acción de dar la línea con el título y folio en la galera, juntamente con el original si hay que hacer algunas líneas para que se vaya ajustando $(\mathrm{S}$ y V).

darse: Lo mismo que macularse (S y V).

de doble caja: Un alfabeto de doble caja es, en realidad, dos alfabetos unidos. El alfabeto latino moderno, que usted está leyendo ahora, es un buen ejemplo. Tiene caracteres de caja alta y caja baja, o sea mayúsculas y minúsculas, muy ligadas pero tan fáciles de distinguir como el Senado y la Cámara de Diputados. Los alfabetos de una sola caja (el árabe, el hebreo y el devanagari, por ejemplo) no hacen esta distinción. Una fuente normal de tipo redondo es de tres cajas si incluye mayúsculas, minúsculas y versalitas (RB).

de una caja: Esta expresión define a los alfabetos que tienen solamente una caja -como el árabe, el hebreo, el tailandés y el tibetano- y también muchas fuentes redondas para encabezados. Compárese con de doble caja (RB).

defecto: Los pliegos que salen faltos en la jornada (S y V).

defectos: La porción de pliegos que sale de más en algunas signaturas después de haberse alzado toda la obra $(\mathrm{S}$ y V).

descolgar: La de quitarle de ellas después de seco para llevarle al alzador (S y V).

diacrítico: son los signos ortográficos que confieren un valor especial a otros signos, por ejemplo la tilde, la diéresis, el macrón, etcétera. Pueden colocarse de tres maneras: sobre el signo afectado (supraescrito), debajo del signo (infraescrito) o lateral (laterales). Los supraescritos se dividen en acentuales y especiales. Los acentuales son los acentos, el ápex y los espíritus. Los especiales: la virgulilla, el punto supraescrito, la diéresis y la sobrerraya. Los suscritos son la cedilla, el subpunto y la subraya. Los laterales comprenden los índices (índice, superíndice, subíndice, apóstrofo) (RB).

diente: Ladearse la plana del blanco a un lado y no caer sobre la de la retiración perfectamente, excepto cuando hay sangría, pues entonces tiene que salir el hueco que ocupe lo que esté sangrado (S y V).

diéresis: Es un signo diacrítico utilizado con vocales - $\ddot{a}$ ë ï ö ü $\ddot{w} \ddot{y}-$ en muchos idiomas, entre ellos el albanés, el dinka, el estonio, el finés, el alemán, el sueco, el turco, el galés y, con menos frecuencia, en otros como el inglés, el griego, el español, el portugués y el francés. Algunos lingüistas distinguen entre el umlaut, que indica un cambio en la pronunciación de una sola vocal (como en la palabra alemana schön), y la diéresis, que marca la separación de las vocales adyacentes (como en el vocablo francés naïve). El símbolo tipográfico es el mismo, 
pero en inglés y las lenguas romances, el término correcto es siempre diéresis, mientras que umlaut es correcto para la mayoría de las otras lenguas en las cuales se utiliza el símbolo. Excepto en el caso de la letra galesa $\ddot{w}$ y las africanas \pm y $\S$, las vocales con diéresis están presentes en la mayor parte de las fuentes latinas de texto. También se conoce como crema. En húngaro hay dos formas de diéresis: el doble punto, que se usa para las vocales cortas, y el doble agudo o diéresis larga, para las vocales largas (ü es la forma larga de ü). La letra ÿ es una vocal que se usa a veces en francés arcaico. Sigue siendo necesaria en la forma moderna de unos cuantos nombres propios, tanto de personas como de lugares. También es una forma alternativa de la ligadura $\ddot{y}$ en flamenco (RB).

dígitos: Cada fuente de texto incluye normalmente por lo menos un grupo de dígitos, que deberían ser (y generalmente no son) los dígitos no alineados o las cifras elzevirianas (osf, por old style figures). Los voladitos se usan para potencias, superíndices y numeradores en las fracciones; los subíndices se usan para esa función y como denominadores en las fracciones. Para las fórmulas químicas y los subíndices matemáticos se necesitan dígitos alineados por debajo de la base (RB).

dígitos alineados: Dígitos de la misma altura. Generalmente es sinónimo de dígitos de caja alta, pero algunos dígitos alineados son más chicos y más ligeros que las letras mayúsculas (RB).

dígitos con ascendentes y descendentes: Véase dígitos no alineados o elzevirianos (RB).

dígitos de caja alta: Son dígitos - I 2345 6- diseñados para combinar en tamaño y color con las mayúsculas. Compárese con dígitos no alineados (RB).

dígitos de caja baja: Véase dígitos no alineados (RB).

dígitos elzevirianos: Véase dígitos no alineados (RB).

dígitos no alineados: Son dígitos - I 2345 6- diseñados para combinarse con las letras minúsculas en tamaño y color. En su mayor parte tienen ascendentes y descendentes. También se les llama dígitos Old Style o elzeverianos. Compárese con dígitos de caja alta y dígitos alineados (RB).

dígrafo: es el grupo de dos letras que representan un solo sonido. La Academia llama letra doble a la que se representa con dos signos, como la ch, ll, rr, o la que procede de la unión de otras como ç y $\tilde{\mathrm{n}}(\mathrm{RB})$.

dingbat: Es una clase de signos o símbolos tipográficos a la que muchos desdeñan porque no tiene una relación obvia con el alfabeto. Muchos dingbats son pictogramas - pequeñas imágenes de iglesias, aeroplanos, personas, teléfonos, etcétera, que se utilizan en la industria turística- y otros son más abstractos -cruces, símbolos cartográficos, los palos de la baraja-. Compárese con florón. También se les conoce como topos o bolos (RB).

distribuir: Esta misma acción de echar la letra en su cajetín correspondiente para llenar la caja y seguir componiendo: conviene mucho leer bien la palabra que se va a deshacer para no echar erratas (S y V).

distribuir: Repartir bien la tinta por las balas para que no salga apegotada (S y V).

divisorio: Es una tabla delgada de cerca de media vara de largo y tres dedos de ancho, con una hendedura al pie que sobresale, donde encaja el original, sujetándole con el mordante, teniendo al extremo un hierro para fijarla en la caja donde más acomode $(\mathrm{S}$ y V).

dos puntos: Es una marca gramatical heredada de las escrituras europeas medievales. También se utiliza en matemáticas para señalar cocientes y en lingüística como marca de prolongación. En la retórica y prosodia clásicas los dos puntos (en inglés el singular es colon, y el plural cola) señalan una cláusula larga y una coma, una cláusula corta $(\mathrm{RB})$.

echar forma: La acción de echar las planas en la prensa (S y V).

eje: En tipografía, el eje de una letra generalmente significa el eje del trazo, que a su vez revela el eje de la pluma o de cualquier otra herramienta utilizada para formar la letra. Si una letra tiene trazos gruesos y trazos finos, busque los gruesos y extiéndalos para formar líneas. Esas 
líneas revelan el eje (o ejes, en plural: puede haber muchos simultáneamente). No se debe confundir con el ángulo de inclinación (RB).

eje bumanista: Es un eje oblicuo que refleja la inclinación natural de la mano que escribe (RB). eje racionalista: Es el eje vertical típico de los diseños neoclásicos y románticos (RB).

empapelar: Guarnecer los cajetines de papel por su suelo para que no se estropee la letra, ni menos se vayan por las rendijas de uno a otro ( $\mathrm{S}$ y $\mathrm{V})$.

empaquetar: La acción de poner las postetas en la prensa destinada para este efecto, las cuales se van colocando de cinco en cinco, pie con cabeza, hasta que no caben más; y, bien apretadas, se atan con dos cuerdas (S y V).

en bandera derecha: Es un párrafo que se compone con el margen izquierdo uniforme y el margen derecho dentado. Para ser más preciso, uno debería decir alineado a la izquierda: 1: dentado a la derecha (RB).

en bandera izquierda: Lo opuesto al párrafo en bandera derecha: aquí se compone con el margen derecho uniforme y el margen izquierdo dentado. Un buen ejemplo son las cornisas de las páginas pares de este libro (RB).

en tendido: La disposición que se da al molde ocupando todo el pliego desdoblado, bien sea a lo largo, o a lo ancho, que se llama apaisado (S y V).

encaballado: Desunirse la composición metiéndose entre las líneas, o bien espacios o letras ( $\mathrm{S}$ y V). encuentros: En las obras de encarnado los claros que han de ocupar las palabras, así de negro como de color; y también en la impresión el venir bien las palabras, que no monten unas sobre otras (S y V).

enderezar: Poner las líneas iguales o derechas, bien sea en la galera o en la prensa, por tener algún vicio y no estar derechas ( $\mathrm{S}$ y $\mathrm{V})$.

entremeter: Mezclar papel seco entre lo mojado por estar demasiado húmedo ( $\mathrm{S}$ y V).

espaciar: Meter espacios anchos o regletas entre las líneas para que esté desahogado (S y V).

espacio de pelo: Generalmente mide $\mathrm{M} / 24$ (RB).

espacio duro: Véase espacio irrompible $(\mathrm{RB})$.

espacio eme: Distancia igual al puntaje del tipo. Así, un espacio eme mide I2 pt en un tipo de I2 pt, y ir pt en uno de ir pt. También se le llama cuadratín (RB).

espacio ene: Es la mitad de un espacio eme. Para evitar malos entendidos en inglés, cuando se dan instrucciones oralmente, los tipógrafos hablan de los espacios eme como muttons ("carne de carnero") y de los espacios ene como nuts ("nueces") (RB).

espacio entre palabras: El diseño de cada fuente incluye un espacio natural para separar palabras.

Cuando el tipo se compone en bandera, el espacio entre palabras es constante; cuando se justifica, el espacio entre palabras se vuelve elástico (RB).

espacio fino: En el mundo de los tipos móviles, es un espacio que mide $\mathbf{M} / 5$, un quinto de cuadratín. En la composición por computadora, a veces es $\mathrm{M} / 6 \mathrm{o} \mathrm{M/8,} \mathrm{aunque} \mathrm{para} \mathrm{al-}$ gunos autores es un espacio de un punto. Compárese con espacio grueso, espacio mediano y espacio de pelo (RB).

espacio grueso: Es un espacio que suele medir $\mathrm{M} / 3$, un tercio de cuadratín (RB).

espacio irrompible: Es el espacio entre palabras que no puede usarse para separarlas en un cambio de línea. También se llama espacio duro (RB).

espacio mediano: Es un espacio que mide $\mathrm{M} / 4$, es decir, un cuarto de cuadratín (RB).

espacios anchos: Los que se ponen entre línea y línea para hacer más hermosa la impresión ( $\mathrm{S}$ y V). espacios de imprimir: Los que sirven para las rayas delgadas o gordas, tan altos como la letra (S y V). espacios: Piececitas del mismo metal de la fundición más bajos que la letra, los cuales sirven para dividir las dicciones. Son de tres o cuatro clases: gordos, medianos y delgados para poder proporcionar los claros (S y V). 
estrado: La tarima que está alrededor de la prensa, sobre la cual están trabajando. En algunas imprentas no se usa, pues no sirve sino de embarazo (S y V).

florón: Es un ornamento de horticultor. Es decir, un ornamento tipográfico que generalmente tiene la forma de una hoja o una flor. Algunos florones se diseñan para componerse en combinación o en grupo, de suerte que - desde un punto de vista tipográfico- funcionan como papel tapiz (RB).

florón: Ornamento de inspiración vegetal; cuando es una hoja de hiedra también se le conoce como hedera, nombre de esa planta en latín. Es uno de los ornamentos tipográficos más antiguos, que aparece ya en inscripciones antiguas en griego (RB).

folio: En bibliografía, es un pliego u hoja escrita, pero en tipografía un folio es generalmente un número de página, no la página misma $(\mathrm{RB})$.

folio ciego: Es una página que se cuenta en la paginación, pero que no lleva ningún folio visible (RB).

folio inicial: Un folio, en tanto número de página, que se coloca abajo, al pie de la página, cuando los folios en otras páginas se colocan cerca de la parte superior. Los folios iniciales se suelen usar al principio de los capítulos en la tradición inglesa (RB).

forma: Aquellas planas que entran en el blanco y la retiración ( $\mathrm{S}$ y V).

fornituras: La porción de letras que faltan después de compuesta toda la fundición, como aa, ce, \&c. para acabalar las suertes sobrantes (S y V).

forros: Otros dos que tienen por la parte interior $(\mathrm{S}$ y V).

fracciones adaptadas: Es una fracción (como 5/64) que no se incluye en la fuente y que, por tanto, hay que componer a demanda a partir de signos separados (RB).

fractura: Es una de las clases de letra gótica. (RB)

frayle: La parte del molde que queda sin imprimir por falta de bala al tiempo de dar tinta $(\mathrm{S}$ y $\mathrm{V})$.

fuente: Conjunto de letras y otros signos tipográficos. En el mundo de los tipos móviles, la fuente es un alfabeto con todos sus caracteres accesorios, en un puntaje determinado. En la fotocomposición, generalmente significa el surtido estándar de patrones con los que se forma la paleta de signos, sin tener en cuenta el puntaje, o la película concreta o el rollo en el que se guardan esos patrones. En el mundo del tipo digital, la fuente es la paleta de signos o la información digital que la codifica. (La forma como antes se escribía en inglés la palabra fount -en lugar de font- no sólo tiene el mismo significado, sino también la misma pronunciación) (RB).

fundición: Las arrobas del grado completo de letra que se manda hacer al fundidor (S y V).

galera: Es una tabla más larga que ancha, con tres listones al canto con su canal, para que por él entre y salga la volandera con facilidad y se pueda echar la forma en la prensa, que para eso tiene su mango. Es donde el cajista va formando las planas: las hay de diferentes medidas, según los moldes: las regulares tienen de largo media vara, y de ancho una cuarta y tres dedos $(\mathrm{S}$ y V).

galerada: Este mismo conjunto de líneas sin hacer planas, llenándola toda ( $\mathrm{S}$ y V).

gota: Es una forma circular al final del brazo, pie o frente de letras como a, c, f, j, r, y. Las gotas se presentan en muchas redondas y cursivas del periodo romántico, en algunas fuentes realistas y en muchas fuentes recientes de inspiración romántica. Por ejemplo: Bodoni, Scotch Roman y Haas Clarendon; también se conoce como gancho o ápice. Véanse remate de pico y remate en forma de lágrima (RB).

gótica: Lo gótico es en la tipografía tan vago como en la arquitectura: un nombre general para una gran variedad de formas que surgieron sobre todo en el norte de Europa. Como los edificios góticos, los tipos góticos pueden ser macizos o leves. Muchas veces son altos y 
puntiagudos, pero también pueden ser redondos. Las categorías de letras góticas incluyen a la bastarda, la fractura, la rotunda y la textura (RB).

grado: La diferencia así en el cuerpo como en el ojo de una letra a otra, por ejemplo de peticano a misal (S y V).

granear: Comer parte del cuerpo de la letra para que junte mejor con la que sigue, principalmente en la cursiva ( $\mathrm{S}$ y V).

grave: Es un acento usado con vocales -à è ì ò ù ỳ- en francés, italiano, portugués, catalán, vietnamita y muchas otras lenguas. En el chino transliterado se usa con vocales -à è ì ò ù ã- para marcar el tono descendente. En gaélico, el grave se usa en lugar del macrón para marcar vocales alargadas. Las cinco vocales graves básicas están presentes en la mayor parte de las fuentes latinas (RB).

gualdrapear: Volver el papel de cabecera a pie, para varias cosas como el $\mathrm{I}^{\circ}{ }^{\circ}(\mathrm{S}$ y V).

guantes: La propina o regalo que los autores dan a los oficiales ( $\mathrm{S}$ y V).

guarniciones: Listones de varios tamaños y gruesos más bajos que el alto de la letra, los cuales sirven para amparar los moldes y proporcionar los márgenes; unos sirven para las cabeceras, otros para los cruceros, otros para el pie, y otros para los lados, dándoles los nombres según para donde sirven, como: cabeceras, lados, pies, cruceros, medianiles (S y V).

guión: Es el más corto de los guiones. Para enfatizar su tamaño, se le conoce como guión corto (RB). guión bajo: Es un carácter estándar en ISO, que tiene la posición de una línea en la base del renglón. No se debe confundir con el subrayado, aunque también se llama subraya (RB).

guiones: Las fuentes latinas de texto incluyen, como mínimo, un guión eme (guión largo, raya), un guión ene (guión medio, signo de menos) y un guión (guión corto). A veces incluyen un guión para dígitos y un guión de tres cuartos de eme (semirraya), y más raramente un guión de un tercio de eme (RB).

bumanista: Los diseños humanistas se originaron entre los humanistas del Renacimiento italiano y siguen existiendo hasta el día de hoy. Son de dos tipos primarios: redonda y cursiva, y provienen de las mayúsculas redondas y las minúsculas carolingias. Los diseños humanistas muestran el claro rastro de la pluma con punta ancha (péndola), sostenida por un escriba diestro. Tienen un trazo modulado y un eje humanista (RB).

bumo: El que se echa en el barniz para dar el negro, que es el polvo que sale de la pez quemada $(\mathrm{S}$ y V).

igualar punturas: Ponerlas iguales una con otra, a una misma distancia.

imponer: Poner cuadrados entre plana y plana para que queden los márgenes correspondientes $(\mathrm{S}$ y V).

imposición: El todo de estos cuadrados, que se compone de medianiles y cruceros (S y V).

impresión: El todo de una obra ya impresa (S y V).

impresión ciega: En la jerga de la prensa tipográfica, impresión ciega significa que se imprime sin tinta, produciendo así una huella de los caracteres sin color. También se conoce como grabado (RB).

imprimir: La acción de estampar o señalar las letras que están puestas en el molde (S y V).

interlínea negativa: Es una interlínea más chica que el cuerpo. Por ejemplo, el tipo de I6 puntos compuesto a I4 puntos tiene interlínea negativa (I6/I4) (RB).

interlinea sólida: Es un tipo de composición sin interlineado adicional o con la interlínea igual al puntaje del tipo. Un párrafo compuesto en II/I о I2/ı2 tiene un interlineado sólido (RB). interlineado: Originalmente era una tira de metal suave (a veces el mismo del tipo y en ocasiones de bronce) utilizada para definir el espaciado vertical entre líneas. Ahora es la distancia vertical entre la línea de base de un renglón y la línea de base del siguiente (RB). 
ir en alcance: Es partir el original entre dos o más oficiales, haciendo cada uno un trozo en galerada, señalando dónde se ha de empezar (S y V).

itálica: Véase cursiva (RB).

jornada: La porción de ejemplares que se tira en cada pliego, como i 500, 2000 (S y V).

jornada: La porción de papel que se tira en cada pliego, siendo obra seguida (S y V).

justificación: Ajuste de la longitud de la línea de modo que se alinee tanto a la derecha como a la izquierda. Los caracteres latinos suelen justificarse o alinearse a la izquierda, con dentado a la derecha $(\mathrm{RB})$.

justificar: Es igualar la línea para que venga sin discrepar nada con la línea o líneas ya compuestas según la medida; también es igualar los títulos o cosas extraordinarias con las emes de la fundición en que vaya la obra, teniendo cuidado si va espaciado y que no se olvide algún espacio entre eme y eme ( $\mathrm{S}$ y $\mathrm{V}$ ).

kern: (I) Es la parte de una letra que se extiende hacia el espacio de otra. En muchos alfabetos la $\mathrm{f}$ redonda sobresale hacia la derecha, la $\mathrm{j}$ redonda hacia la izquierda y la $f$ cursiva hacia ambos lados. (2) Ajustar el kerning significa alterar el espaciado de ciertas combinaciones de letras - To o $V A$, por ejemplo- de modo que el "excedente" de una se proyecte sobre o por debajo del "faltante" de la otra. También se le llama acoplamiento (RB).

ladrón: La partícula de papel que quita señalar las letras en el pliego, y quedan impresas en ella (S y V).

lagrimal: Véase remate en forma de lágrima (RB).

lector: El que lee las pruebas primeras para corregirlas antes de ir al autor, o atiende a leerlas, y lo mismo los pliegos primeros de prensa ( $\mathrm{S}$ y V).

letras: Hay por lo menos tres variedades de letras en una fuente latina común. Generalmente hay todo un alfabeto básico de minúsculas y mayúsculas y un alfabeto parcial de voladitas. Éstas se pueden usar para abreviar números ordinales: en español, $2^{\mathrm{a}}, 2^{\circ}$ (segunda, segundo); en inglés, $\mathrm{I}^{\mathrm{st}}, 2^{\text {nd }}, 3^{\text {rd }}$ (first, second, third); en francés, $\mathrm{I}^{\mathrm{re}}, 2^{\mathrm{e}}$ (première, deuxième), etcétera. También se utilizan en algunas abreviaturas verbales, como $4^{\circ}=$ cuarto; $8^{\circ}=$ octavo; $\mathbf{N}^{\circ}$ = número (en el inglés actual la mayor parte de esas formas son arcaicas). El alfabeto Iso básico incluye solamente dos letras superiores, la a ordinal y la o ordinal, esenciales para componer texto en lenguas romances. En las fuentes "expertas" u OpenType se consigue un conjunto más completo -convencionalmente limitado a a de il m norst-. Estas fuentes usualmente incluyen versalitas, además de altas, bajas y los voladitos. Las fuentes paneuropeas completas incluyen también todo un conjunto de caracteres cirílicos y griegos. Algunas incluyen caracteres con trazos caligráficos y antiguallas como la s larga (I) y sus ligaduras. Nótese que la identidad de las letras varía de lengua a lengua. El dígrafo $c h$, por ejemplo, se ve como una letra única en checo y lituano (tal como ocurrió en español hasta 1994); $U$ es una sola letra en vasco (y también lo fue en español); $d d, f f, n g, l, p h, r h$, th son letras únicas en galés, y en serbocroata los dígrafos $d z$, $l$; nj son letras únicas (que corresponden a las letras cirílicas џ, љ у њ) (RB).

letras caladas: Las que tienen labores ( $\mathrm{S}$ y V).

letras de dos puntos: Las que sirven para los carteles y títulos, al igual que para empezar los capítulos. Tienen el cuerpo de dos líneas de la fundición que se nombran como de lectura, que son dos líneas de ésta. Para espaciarlas y justificarlas se usa de la fundición de peticano para la de lectura, de la de misal para la de entredós; para la de breviario de la parangona, por venir justas a dos líneas de dichos grados (S y V).

ligadura: Son dos o más letras unidas para formar un solo caracter. La secuencia ffi, por ejemplo, forma una ligadura en la mayoría de las fuentes latinas (RB). 
ligaduras: Las fuentes básicas Iso sólo albergan dos ligaduras tipográficas, $f i$ y $f$. Las rígidas definiciones del conjunto de signos que no prevén ninguna ligadura adicional (como $f f$, $f f i, f l, f f)$ son muy peligrosas para la tipografía. Las ligaduras requeridas por el diseño de la fuente individual de tipos deberían residir siempre en la fuente básica. Las ligaduras léxicas $\propto, A, \alpha, E \mathrm{y} \beta$ son caracteres Unicode propiamente dichos, y por ello aparecen como entradas en este apéndice. En cambio, las ligaduras tipográficas como $f i$ y st son ligaduras contextuales, no letras (RB).

línea: Lo mismo que renglón ( $\mathrm{S}$ y $\mathrm{V})$.

línea de base o estándar: Ya sea escrito a mano o compuesto con tipos móviles, el alfabeto latino en minúscula implica un marco invisible que consta por lo menos de cuatro líneas: la línea de las ascendentes, la altura $x$, la línea de base y la línea de las descendentes. La primera es la línea a la que llegan las ascendentes en letras como b, d, h, k, l. La segunda señala la parte superior de letras como a, c, e, m, x, y el torso de letras como b, d, h. La línea de base es aquella en que todas las letras se asientan. La línea de las descendentes limita por abajo a letras como p y q. En algunos casos hay una la línea de las mayúsculas, que marca el borde superior de las letras mayúsculas como $\mathrm{H}$, y no siempre coincide con la línea de las ascendentes. Normalmente, las letras redondeadas como e y o suelen morder la línea de base. Las letras con punta como $\mathrm{v}$ y w suelen perforarla, mientras que los remates inferiores de letras como h y m generalmente se asientan con precisión sobre ella (RB).

línea de blanco: Es el espacio de una línea completa sin texto (RB).

Ulamada: Las letras de números que se ponen para denotar adónde corresponden las citas ( $\mathrm{S}$ y V). M/3: Es un tercio de espacio eme: por ejemplo, 4 pt en tipo de I2 pt, o 8 pt en tipo de 24 pt.

macularse: Ir dejando la impresión, al tiempo de retirarse, la tinta en el patrón por defecto del barniz (S y V).

maculaturas: Los pliegos mojados que se van poniendo entre el patrón y el pliego que se retira para precaver este inconveniente, los que se remudan a menudo. También son todos aquellos pliegos impresos que se echan a perder, o de suyo no sirven ( $\mathrm{S}$ y V).

mal asiento: No afirmar bien las balas al molde, señalando a medias letras ( $\mathrm{S}$ y V).

manchar: Cuando por haber mucho claro, o estar algún cuadrado o espacio alto, o mal cortada la frasqueta, sale impresa alguna cosa que no es letra (S y V).

manecilla: La mano del tipógrafo no es ni un puño que golpea ni una palma lista para el saludo. Es una mano silenciosa que señala. Sin embargo, con demasiada frecuencia se la viste con suntuosidad excesiva, por ejemplo, con mancuernillas. Es una invención barroca, pero no aparece en el grupo de caracteres Iso estándar y hay que buscarla en fuentes suplementarias. $(\mathrm{RB})$

mantillas: Unas bayetas, o frisa, que se meten en el hueco del tímpano para que hagan colchón y ayuden a imprimir (S y V).

materia: Todo el contexto de la obra, que no es cita (S y V).

medianil: El que se pone en medio de las planas, de arriba abajo (S y V).

medida: Es el ancho que debe tener la plana según el papel y tamaño, tomándola por las emes de parangona, para lo cual se pondrán en el componedor cuadrados de la misma, justificándolo con aquella letra que venga bien, para que las líneas salgan iguales a dichas emes: si van otros en la misma obra, se comprobará la medida para que todo sea igual, que se llama comprobar la medida. En las obras de encarnado se tomará ésta por los cuadrados de la fundición en que vaya la obra, a causa del color.

membrete: En las relaciones de méritos, el extracto (S y V). 
mocarro: El convite que hace el nuevo oficial a los demás compañeros, para lo cual el maestro a cuyo cargo ha estado lo hace reconocer por oficial, dándole todo lo que ha ganado aquella semana para ayuda del gasto (S y V).

modulación: Es una variación - generalmente, cíclica y predecible- en el ancho del trazo. En los diseños de letras "monocromáticos" (sin modulación), como Frutiger, el trazo es siempre del mismo ancho. En una fuente como Bembo o Centaur, el trazo está basado en los movimientos de una péndola, lo cual hace que haya trazos finos cruzados y trazos verticales más gruesos. Cuando las letras se escriben con ese instrumento, la modulación regular es automática (RB).

mojar: La acción de mojar el papel para poderse imprimir (S y V).

mojar a baño. Meter todo el cuadernillo extendido en el agua.

mojar a barco: Mojar el cuadernillo doblado por el lomo para que forme canal, por donde entra el agua, bailándole todo menos el lomo (S y V).

mojar gualdrapeado: Colocar los lomos del cuadernillo a un lado y a otro (S y V).

molde: Cualquiera cosa compuesta (S y V).

moledor: Un artesón o payla donde se hace la operación de mezclar este polvo con el barniz, a fuerza de menearlo (S y V).

mordante: Es una regla de madera de un pie de largo y dos dedos de ancho, abierta por el medio hasta cerca del extremo por donde se agarra; sirve para asegurar el original y señalar adonde se llega (S y V).

morder: No señalar alguna parte de la impresión por no haber cortado bien la frasqueta, o haber algún ladrón (S y V).

morralla: El material que queda de otras fundiciones después de atada la letra (S y V).

ojo: Sinónimo de asta curva; también se usa para referirse a la parte del tipo que, entintada, toca

el papel e imprime. Un ojo grande supone una gran altura $x$, mientras que un ojo abierto supone una abertura considerable (RB).

olvidado: Todo aquello que se deja por componer al cajista (S y V).

original: El todo de la obra, bien sea impreso o manuscrito, por donde el cajista va componiendo. orlas: Lo mismo que viñetas (S y V).

palmear: Dar con la mano o con el tamborilete en el molde, para que bajen las letras que estén altas (S y V).

papel abarquillado: El que por secarse las puntas se levantan, formando bolsa en el medio del pliego (S y V).

papel encerado: El que está más seco que húmedo $(\mathrm{S}$ y V).

paguete: El conjunto de las postetas ya atado, al cual se le pone a la cabecera y al pie tres o cuatro maculaturas para defensa de la impresión ( $\mathrm{S}$ y V).

párrafo: Es una variante de doble $s$, que ahora se utiliza sobre todo como referencia en códigos manuales y textos legales, cuando se citan secciones particulares. (El plural, que significa párrafos, se escribe duplicando el signo: $\S \S$.) Véase también calderón (RB).

párrafo francés: Es un párrafo compuesto con la primera línea a todo lo ancho de la columna y las líneas subsiguientes sangradas, como se hace con las diferentes entradas en este glosario (RB).

pasar: Ir mirando todas las postetas hoja por hoja para ver si falta o sobra algún pliego, las que se van doblando para empaquetarlas después ( $\mathrm{S}$ y V).

pasar: Leer las pruebas con mucho cuidado después de haberlas visto el autor, las cuales se señalan desde el número y hasta la última de cada pliego, para que el cajista sepa las que son de blanco y de retiración, aunque éste las debe señalar en la galera con yeso para no errar. pastel: Echar la tinta en el molde sin conocimiento, ni distribuirla como se debe (S y V). 
pastel: Se llama así el conjunto de letras de diferentes fundiciones, de cuando se hace pedazos una plana o forma $(\mathrm{S}$ y V).

patín: Véase remate $(\mathrm{RB})$.

patrón: El pliego que se pone en el tímpano para modelo y medida de los demás pliegos que se van a imprimir (S y V).

perdido: La porción de papel que se moja de más en cada cosa que se imprime, para que no salga falta $(\mathrm{S}$ y V).

perfil: El rasguito sutil de la letra (S y V).

peso: Es la oscuridad (negrura) de una fuente, independientemente de su tamaño. Véase también $\operatorname{color}(\mathrm{RB})$.

pica: Es una unidad de medida igual a I2 puntos. Hoy se usan dos picas diferentes: (I) para el impresor tradicional, la pica es equivalente a $4.22 \mathrm{~mm}$ o 0.166 pulgadas: cerca de un sexto de pulgada, aunque no exactamente; ésa es la unidad habitual británica y estadounidense para medir el ancho y el alto de la caja. (2) La pica PostScript es exactamente un sexto de pulgada: 0.I666666... La diferencia entre las dos unidades es más o menos 0.03 por ciento. (La contraparte europea de la pica es el cícero, que es 7 por ciento más grande) (RB).

pisar: Hacer el apriete para imprimir (S y V).

pisar: Poner el papel mojado para pruebas entre el tímpano y el pliego que se imprime, para quebrantarlo y quitarle la humedad (S y V).

pleca: La pleca vertical se usa en matemáticas como signo de valor absoluto (se utilizan dos, encerrando las cifras: $|-3|)$; en estudios de prosodia, para marcar una cesura, y en cálculo de proposiciones (donde se le llama barra de Sheffer), como señal de no conjunción. En el trabajo bibliográfico se utilizan tanto las plecas dobles como las simples. También se llama cesura. Véase barra (RB).

posteta: La porción de ocho o más pliegos que se apuntan juntos $(\mathrm{S}$ y V).

posteta: Los pliegos cogidos que resultan de la rueda. A fin de que los lomos no se estropeen, convendría fuera la posteta de ir y I2 pliegos (S y V).

prensa: La máquina destinada para el efecto de imprimir, compuesta de varias piezas ( $\mathrm{S}$ y V). prensa de empaquetar: Se compone de cuatro pilares de madera de siete pies de largo, amarrados a dos tablas colocadas a la cabecera y pie, con sus canales para que entren las cuerdas que atan las postetas, sujetos a los extremos con abrazaderas de hierro para mayor seguridad, ocupando su ámbito poco más de medio pliego de marca: en el medio tiene un husillo de madera metido en el agujero de la tabla de encima, y en su cepa, que tiene dos cercos de hierro, un ojo por donde se mete un pasador para dar vueltas al husillo y apretar: está sujeta a unas tablas gordas, también con canales hacia abajo, las cuales suben y bajan con el husillo por entre los pilares $(\mathrm{S}$ y $\mathrm{V})$.

prensista: El oficial que imprime, a cuyo cargo está todo lo tocante a la prensa y, por tanto, responsable de las faltas que se noten en la impresión ( $\mathrm{S}$ y V).

pruebas: Sacar a mano el pliego después de compuesto en medios pliegos húmedos, o según el molde, para leerle y corregirle.

puente: Dos palos cortos iguales que se ponen de punta a punta en las planas cortas en folio, $\mathrm{y}$ en las en blanco en $4^{\circ}(\mathrm{S}$ y V).

punta: Una como lesna derecha con su mango de madera, la cual sirve para corregir, sacando las letras con la punta, y con el plano del mango bajar las que se ponen en su lugar ( $\mathrm{S}$ y V). puntaje: Originalmente era la altura de la cara del bloque de metal en que se había fundido cada una de las letras individuales. En los tipos digitales, es la altura de su equivalente invisible: un rectángulo que define el espacio en que se inscribe cada letra, y no el tamaño de la letra misma. El cuerpo se expresa en puntos, pero los tamaños europeos se dan generalmente en 
puntos Didot, que son 7 por ciento más grandes que los puntos que se usan en Gran Bretaña y Estados Unidos (RB).

puntilla: Una aguja metida en un palito redondo para limpiar los borrones (S y V).

punto: (I) Para la medida británica y estadounidense, un punto es un doceavo de pica, lo cual significa que mide $0.3515 \mathrm{~mm}$ o 0.01383 pulgadas. En números redondos, hay 72 puntos por pulgada, o 28.5 puntos por centímetro. (2) El punto es más grande en Europa continental, donde se usan las unidades Didot. En números redondos, hay 26.5 puntos Didot por centímetro, y 67.5 por pulgada (RB).

punto: Es el signo normal para el final de una oración en todas las lenguas de Europa. Pero también es una letra del alfabeto tlingit, que se pronuncia como una oclusión glotal. En fonética, es el signo del límite silábico (RB).

punto y coma: Es una marca gramatical, un híbrido entre la coma y los dos puntos, derivado de una práctica europea de escritura. Sin embargo, en griego se usa como signo de interrogación (RB).

puntos de conducción: Es una hilera de puntos uniformemente espaciados que a veces se necesitan para unir un texto alineado a la izquierda con numerales alineados a la derecha, en un índice general o un contexto parecido (RB).

rabo: Lo que cobran los oficiales el sábado sin haberlo hecho, como si son dos pliegos los que han tirado o compuesto en la semana, poner tres; desquitándolo, a veces, al fin de la obra (S y V).

recado: El material que junta el cajista para hacer una obra, como dos o tres pliegos de letra, títulos, líneas de blanco, etcétera, y en la prensa hacer y limpiar las balas para empezar a trabajar (S y V)

reclamo: La sílaba que se pone después de la signatura, con la cual empieza la plana que sigue. Hoy ya no se estila.

recodo: La vuelta que tienen algunas barras, dejándolas curvas para que el tiro se quede corto (S y V).

recorrer: Meter una o más palabras en la composición ya hecha, pasando sílabas, o lo necesario, de una línea a otra; o ir pasando líneas de una plana a otra por su orden, todo con mucho cuidado (RB).

redobles: Un remosqueo mayor, doblando cada letra su impresión ( $\mathrm{S}$ y V).

redonda: Es la letra que se usa para texto corrido. Se define por ausencia: no es negrita, no es cursiva, no es versalita (RB).

rebaba: La señal que hace el hombro de la letra, y también el esconce que hay en ella hacia el ojo, para que no manche (S y V).

regente: El oficial a cuyo cargo está la dirección y gobierno de todas las operaciones pertenecientes a la imprenta, estando sujetos a sus órdenes los demás oficiales. Siempre es cajista ( $\mathrm{S}$ y V). registro: Caer las líneas de la retiración encima de las del blanco, sin discrepar (S y V).

regleta: Es de madera delgada, la cual sirve para sacar la línea del componedor, enderezar con su auxilio la plana y coger las tomadas para distribuir; también sirve para medir las planas y no echar línea de más ni de menos; son de varios tamaños ( $\mathrm{S}$ y V).

regletas de espada: Listones delgaditos para arreglar mejor los márgenes $(\mathrm{S}$ y $\mathrm{V})$.

reimpresión: Volver a imprimir (S y V).

remate: Es un trazo agregado al comienzo o al final de los fustes principales de una letra. En el alfabeto redondo, los remates suelen ser trazos reflexinos que terminan el asta principal de la letra y pueden ser unilaterales o bilaterales (son unilaterales si se proyectan solamente hacia un lado del asta, como en la cabeza de la $\mathrm{T}$ y en el pie de la $\mathrm{L}$, y bilaterales si se proyectan hacia ambos lados, como los remates en el pie de la $\mathrm{T}$ y la cabeza de la $\mathrm{L}$ ). Los remates transi- 
tivos - trazos suaves de entrada o salida - suelen aparecer en las cursivas. Hay muchos términos descriptivos para los remates, especialmente para los de las fuentes redondas. Pueden no sólo ser unilaterales y bilaterales, sino también largos o cortos, gruesos o angostos, con punta o romos, angulados o suaves, horizontales o verticales, oblicuos, triangulares y muchos más. En las góticas, textura y fractura son generalmente en forma de diamante. También se conocen como terminales. Véanse las entradas siguientes y sanserif (RB).

remate abrupto y suave: Los remates son abruptos si se separan del fuste principal bruscamente, en un ángulo, o suaves si fluyen suavemente a partir del fuste principal o hacia él. En la literatura tipográfica más antigua, los remates suaves se describen generalmente en inglés como adnate (RB).

remate bilateral: Los remates bilaterales se extienden a ambos lados del fuste y son siempre reflexinos. Son característicos de ciertas redondas, mientras que los remates unilaterales son característicos de las carolingias y cursivas (RB).

remate de pico: Es un espolón muy pronunciado que se encuentra particularmente en la $\mathrm{f} y$ a veces en a, c, j, r, y, sobre todo en muchas redondas del siglo Xx, y, en menor grado, también en cursivas (RB).

remate egipcio: Es un remate suave o angulado del mismo grosor que el asta principal. Los remates de bloque son marca de fábrica de los tipos llamados egipcios y clarendon, dos grupos de fuentes realistas producidas en grandes cantidades desde principios del siglo XIX (RB).

remate en forma de lágrima: Es una hinchazón, semejante a una lágrima, al final del brazo de letras como a, c, f, g, j, r, y. Este rasgo es típico de las fuentes de finales del Renacimiento, del barroco y del periodo neoclásico, aunque está presente en muchas fuentes recientes que se inspiran en aquéllas. Ejemplos: Jannon, Van Dijck, Kis, Caslon, Fournier, Baskerville, Bell, Walbaum, Zapf International, Galliard. Véanse gota y remate de pico (RB).

remate reflexino: Es un tipo de remate en el que el trazo de la pluma regresa por donde ya había pasado. Los remates reflexivos son típicos de las fuentes redondas, incluyendo la fuente en que están compuestas estas palabras. Estos remates siempre suponen un pequeño, pero brusco, freno en el trazo y un regreso del dibujo hacia la dirección desde la que provenía. En general, son bilaterales. Véase remate transitivo (RB).

remate transitivo: Es un tipo de remate que fluye directamente hacia el asta o desde ella, sin volver sobre sí mismo. Son frecuentes en las cursivas. Generalmente, los remates transitivos son unilaterales: se extienden solamente hacia un lado del asta. Véase remate reflexino (RB).

remiendo: Toda cosa suelta que se imprime o hace fuera de la obra, como carteles, esquelas (S y V). remosquear: Salir la letra impresa con una rebaba, por rehuirse la prensa o el papel (S y V). repasar: Dar humedad, donde la necesite, con una esponja al papel ya mojado (S y V).

repicar: Volver a apuntar los pliegos que ya han estado apuntados (S y V).

retiración: La otra mitad de planas, para imprimirlas por la otra cara (S y V).

retiración: Lo mismo respecto de la otra cara $(\mathrm{S}$ y V).

retirar: Imprimir por la espalda de lo que está ya impreso $(\mathrm{S}$ y V).

rociar: Echar agua a soplo en las orillas del papel cuando están secas, y también al tímpano $(\mathrm{S}$ y V).

romana: Se dice de los diseños generalmente ligeros, preferidos por los escribas humanistas y tipógrafos en la Italia de los siglos XV y XVI. La letra romana es la contraparte del estilo románico en arquitectura, así como la gótica es la contraparte tipográfica del gótico (RB). ropa: Lo que se mete en las cabeceras para que suba o baje el molde ( $\mathrm{S}$ y V).

rotunda: Es una de las clases de letra gótica (RB).

rúbrica: En estas obras, todo lo que es color ( $\mathrm{S}$ y V). 
rueda: El círculo de jornadas que se ponen en las tablas para tomar los pliegos. Si son muchos los abecedarios y éstos van en duernos o ternos, se promediará en dos o tres veces ( $\mathrm{S}$ y V). s larga: Esta forma más alta de la $s$ se parece a la $f$ sin la barra cruzada. (Es importante notar que la forma redonda generalmente tiene un espolón a la izquierda.) La slarga se utilizaba normalmente en inglés hasta finales del siglo XVIII. Era la forma común de la $s$ en las posiciones inicial y media. La $s$ corta se usaba en finales de palabra y (generalmente) como la segunda $s$ de un par. La unión de $s$ corta y $s$ larga forma la ligadura $\beta$, que se sigue usando en alemán. La s larga sigue usándose rutinariamente en fuentes góticas, redondas y cursivas, aunque es arcaica. Muchas veces la s larga necesita un conjunto de ligaduras mucho más amplio, entre otras $\mathrm{fb}, \mathrm{fh}, \mathrm{fi}, \mathrm{fk}, \mathrm{ll}, \mathrm{Il}, \mathrm{Ili}, \mathrm{ml}(\mathrm{RB})$.

saltillo: Véase cierre glotal (RB).

sangrar: Meter una línea más que las otras hacia adentro, con un cuadratín de eme o según más convenga (RB).

sanserif: Se dice de los diseños de letras sin remates. El nombre proviene de la influencia del normando en el anglosajón durante la formación del idioma en Inglaterra. También se conocen como paloseco (RB).

secantes: Los que se echan en el aceite de linaza cuando se cuece, y queda dicho en la obra, tratando de la tinta (S y V).

signatura: Es aquella letra que se pone a lo último de la plana para gobierno de los impresores, alzadores y libreros (S y V).

símbolos monetarios: La mayor parte de los conjuntos de caracteres Iso de diseño reciente incluye seis símbolos monetarios genuinos $-\$ € £ f ¥ \$-$ y un signo genérico $-\not<-$. El llamado "símbolo general monetario", el sputnik, no tiene función tipográfica, solamente ocupa un lugar en la fuente para que se coloque allí un símbolo monetario local (rupia, peseta). El signo de centavo (\$), ahora una reliquia tipográfica, es igualmente irrelevante para la mayor parte del trabajo tipográfico actual, la única razón para seguir ofreciéndolo como caracter es la nostalgia. El signo de la $\mathrm{S}$ cruzada $\mathbf{- \$}$ - desciende de un antiguo símbolo del chelín. El mismo signo se utiliza para el dólar, el peso, el sol, el escudo, el yuan, etcétera. El signo de la libra esterlina, una L cursiva cruzada, representa a la libra latina (también es el origen de la abreviatura $l b$, utilizada para la libra avoirdupois, el sistema de pesos basado en la libra de 16 onzas que se utiliza en los países anglosajones). El signo $£$ se utiliza actualmente no sólo para la moneda inglesa, sino para la libra, lira o livre de muchos países africanos y de los estados de Medio Oriente. El símbolo del gulden holandés es $f$, por florín, que es el viejo nombre de la moneda. Este símbolo suele grabarse en una versión más corta y más ancha que la minúscula cursiva normal $f$, el símbolo para el shekel, la moneda de Israel (del hebreo shegel) (RB).

sombras: No salir la letra con la limpieza necesaria, y como extendida (S y V).

suerte: El conjunto de una letra, como de pp, ss (S y V).

tablas: Sirven para poner las formas después de impresas: las hay de diferentes tamaños, según los moldes (S y V).

tablón: El conjunto de muchas planas o tomadas atadas, que se van colocando en una tabla para guardar la letra (S y V).

tacas: El alza o suplemento que se pone debajo de aquella letra que por ser baja no sale, principalmente en las de madera ( $\mathrm{S}$ y V).

tacas: En el encarnado de un molde, las cortaduras de la braga colocadas en el patrón para

ayudar a que imprima el encarnado (S y V).

tamaño del tipo: Véase puntaje (RB). 
tapón: Un poco de papel que se pega a la frasqueta, o se pone a mano cuando está el molde orlado y hay bastante claro de cuadrados, para que no manche (S y V).

tendido: El molde que ocupa toda la rama, sin llevar crucero $(\mathrm{S}$ y V).

tener cera: Haber muchas erratas (S y V).

terminal. Véase remate $(\mathrm{RB})$.

textura: Es una de las clases de letra gótica (RB).

tilde: Es un signo diacrítico utilizado en las vocales de muchas lenguas (estonio, kikuyu, por-

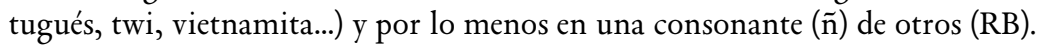

tinta: La mezcla que se hace con el humo, bermellón, en el barniz (S y V).

tipo: Es una pieza única de metal; es decir, una letra u otro caracter en un estilo y tamaño particulares. En el mundo de los tipos digitales, donde las letras no tienen existencia física sino cuando se les imprime, en inglés la palabra type quedó desplazada por glyph. Un "glifo" es una versión - una encarnación conceptual, no material- de un símbolo abstracto llamado caracter. Así, A y a son "glifos" alternativos para el mismo caracter (en la misma fuente) (RB). tirar: Lo mismo que imprimir (S y V).

tirar de codete: Tirar con el brazo encogido, no apretando como se debe (S y V).

tiro: La acción de apretar la barra para imprimir, la cual consta de dos tiempos, por lo que se llama tiro primero y tiro segundo a las dos divisiones de la rama (S y V).

título: El principio de la obra, y de los capítulos, y también los que se ponen al empezar las planas con el folio (S y V).

tomada: Es la porción de líneas juntas que se toman para echar la letra en la caja, la cual se moja con una esponja para hacerlo con más brevedad y mejor (S y V).

torcido: La composición cuyas líneas no están perfectamente iguales.

torta: La letra nueva que viene de casa del fundidor envuelta en papeles y atada en forma de ladrillos (S y V).

trazo caligráfico: Un diseño de letra con trazos caligráficos siempre busca evocar el lujo. Algunas letras con estos trazos llevan florituras, otras simplemente ocupan más espacio. Generalmente las letras de esta clase son cursivas y, en consecuencia, de origen italiano. Las verdaderas mayúsculas en cursiva (diferentes de las mayúsculas redondas con ángulo de inclinación) son letras con trazo caligráfico (RB).

velador: Un listón de madera o hierro que se clava en la pierna de la prensa para colgar el candil, para velar $(\mathrm{S}$ y V).

versal: Es la mayúscula con la que antiguamente comenzaban todos los versos, aunque gramaticalmente no hiciera falta (RB).

versales: Las letras mayúsculas o de caja alta $\mathrm{x}$.

versalillas: Otras mayúsculas, aunque la mitad menos que las otras, pero en el mismo cuerpo (S y V). viñetas: Los adornos para principio de obras y títulos, $\mathrm{u}$ otras cosas (S y V).

virgulilla: Es un caracter inusual en textos, pero importante en lógica simbólica y matemáticas, donde significa similaridad; en lexicografía significa repetición. La lógica simbólica lo usa para indicar la negación pero, para evitar confusiones, se refiere el signo angular de negación lógica $(\neg)$. La mayor parte de las fuentes tienen una virgulilla, no una tilde, en esa posición. En Unicode la virgulilla verdadera tiene una dirección diferente. No se debe confundir con la tilde, un carácter más pequeño que se usa como diacrítico (RB).

volver el papel: Después de acabado el blanco, volver toda la porción tirada de derecha a izquierda para que vengan bien las planas de la retiración con las tiradas del blanco, esto es, seguidas ( $\mathrm{S}$ y V).

zelador de prensas: El que cuida de ellas, y da las cosas necesarias a los demás prensistas para el trabajo (S y V). 

APÉNDICE 4
CATÁLOGO DE AUTÓGRAFOS DE TIPÓGRAFOS
E IMPRESORES COLONIALES POBLANOS

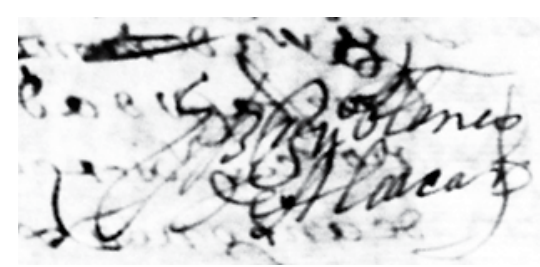

Juan Blanco de Alcázar

\section{mannul delos ofiros}

Manuel de los Olivos (Pérez Salazar, p. 308)

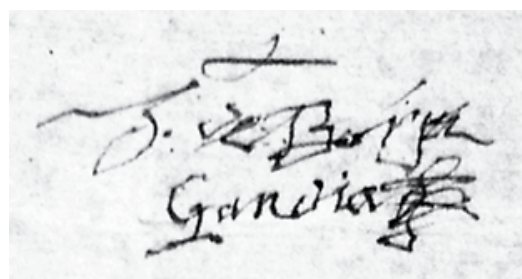

Juan de Borja y Gandia

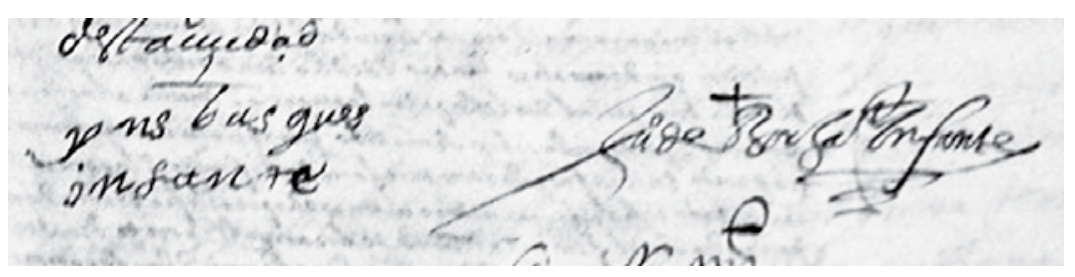

JInés Vatsquez, viuda de Borja y Gandia y Juan de Borja Infante

(Imagen: gentileza de Mercedes Salomón Salazar) 


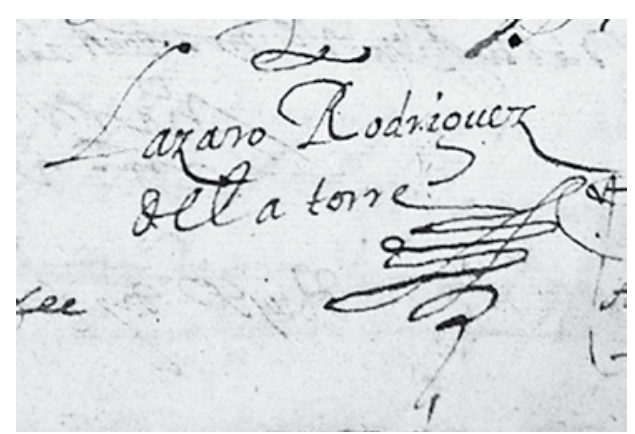

Lázaro Rodríguez de la Torre

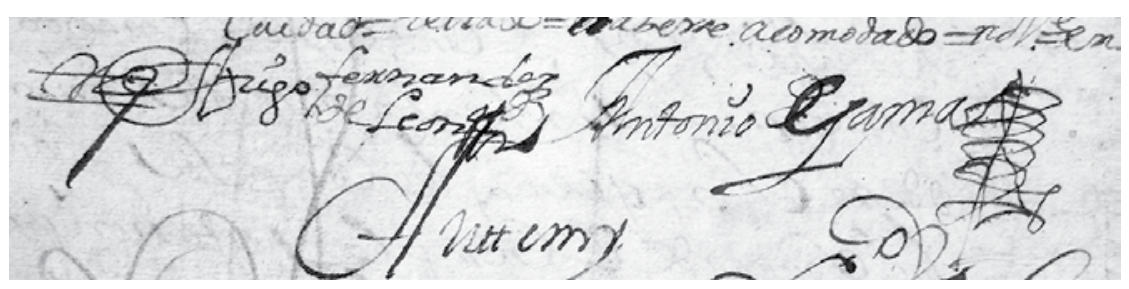

Diego Fernández de León y Antonio de Gama

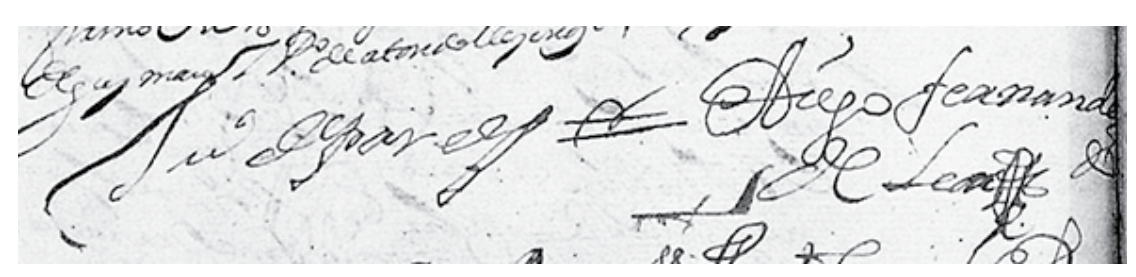

Juan de Paredez y Diego Fernández de León

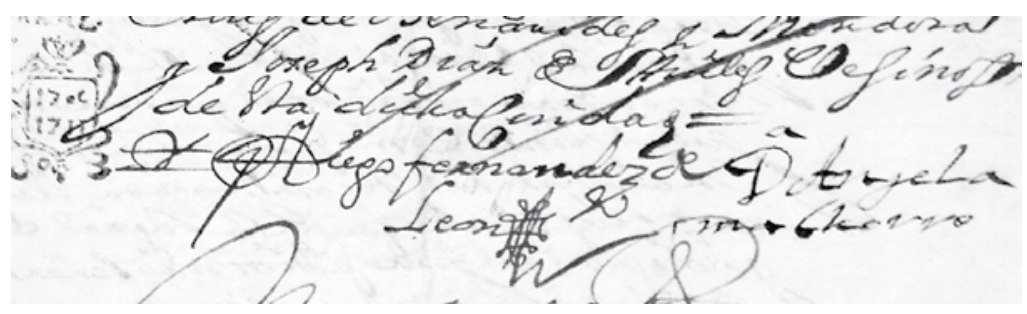

Diego Fernández de León y Ángela Machorro 
FUENTES DOCUMENTALES Y ESTUDIOS CONSULTADOS

(9)

763

Hunan?litha Re

Juan de Villarreal (Pérez Salazar, p. 329)

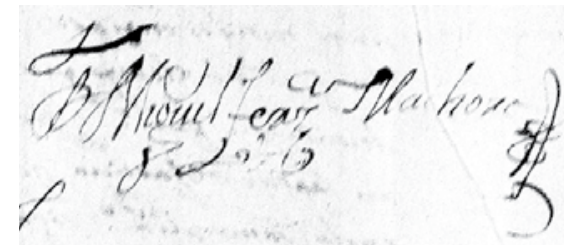

Miguel León Machorro

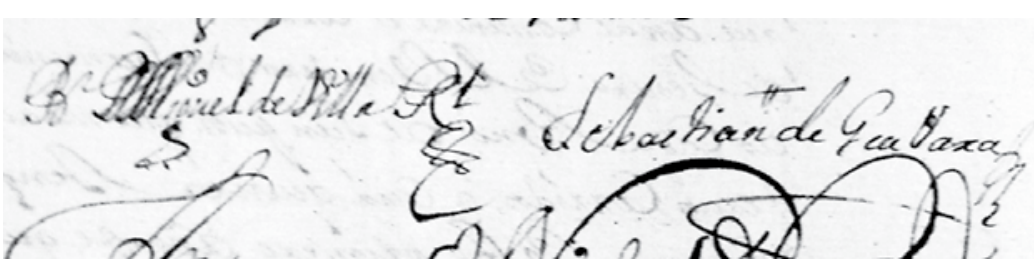

Br. Miguel de Villarreal y Sebastián de Guevara

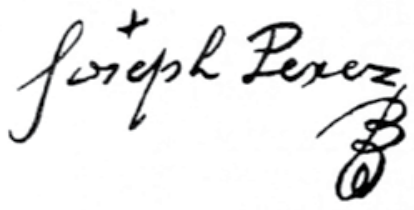

Joseph Pérez (Pérez Salazar, p. 333)

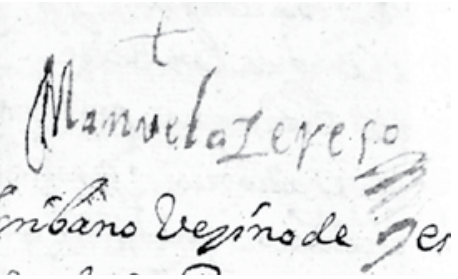

Manuela Cerezo, viuda de Miguel Ortega y Bonilla

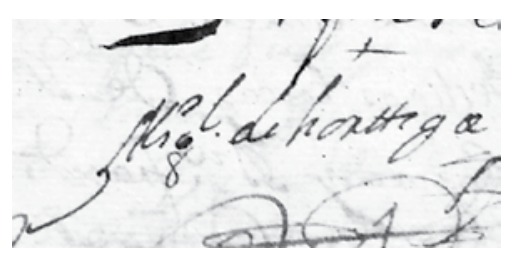

Miguel Ortega y Bonilla

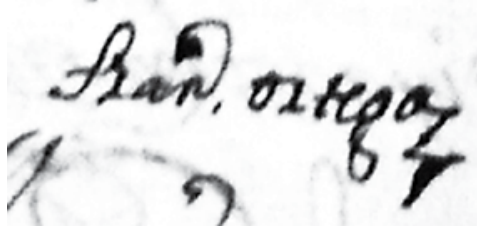

Francisco de Ortega 


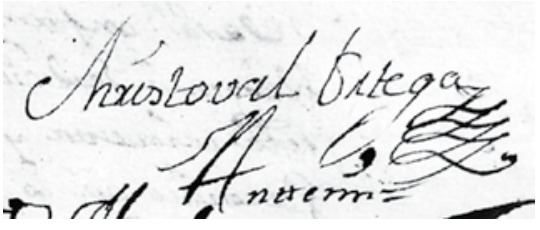

Cristóbal de Ortega

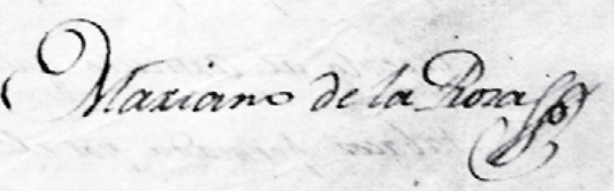
Mariano de la Rosa

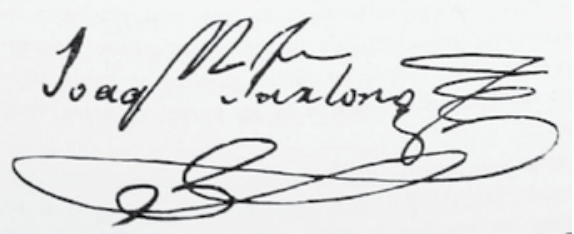

Joaguín Furlong (Pérez Salazar, p. 359)

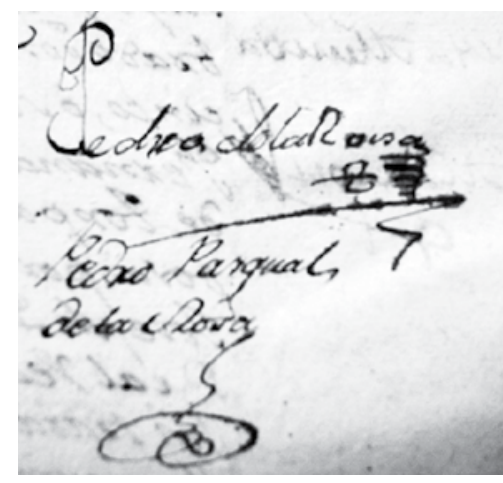

Pedro de la Rosa y Pedro Pascual de la Rosa

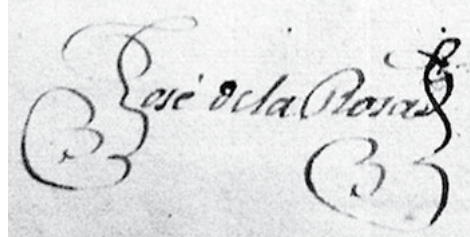

José de la Rosa

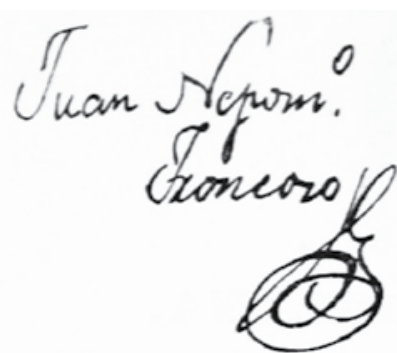

Juan Nepomuceno Troncoso (Pérez Salazar, p. 36I)

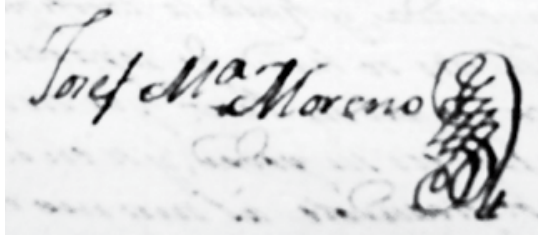

José Ma. Moreno

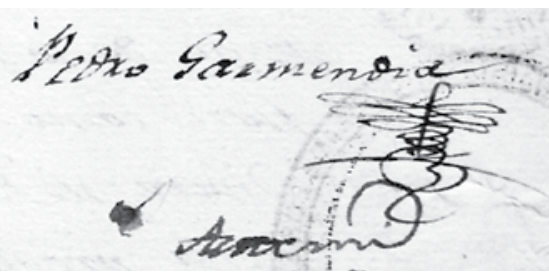

Pedro Garmendia 
Historia de la imprenta y la tipografia colonial en Puebla de los Angeles (I642-I82I) (PDF) Tercera parte se terminó en marzo de 2018

En su composición se utilizaron tipos Leidener TTW I4, I2, I0.5, 9.5 y 8.5 puntos y Plasma de 8 puntos.

La edición consta de 500 ejemplares impresos en papel cultural de 90 gramos. Instituto de Investigaciones Bibliográficas Coordinación editorial:

Hilda Leticia Domínguez Márquez

Corrección de pruebas:

Javier Ortiz Cortés Mora Silvia Jáuregui y Zentella $†$ Ma. Bertha V. Guillén

Diseño de originales:

Hilda Angelina Maldonado Gómez Formación:

Hilda Angelina Maldonado Gómez Edición gráfica:

Erika Lizbeth Pelayo Rodríguez

Cuidado de la edición:

Yael Coronel Navarro

Marina Garone Gravier

Ma. Bertha V. Guillén 
Puebla fue la segunda ciudad en México $-\mathrm{y}$ tan sólo la tercera en toda la América española- en acoger el arte ideado por Gutenberg a mediados del siglo xv. En Historia de la imprenta y la tipografía en Puebla de los Ángeles (1642-1821) Marina Garone Gravier emprende un minucioso recorrido, desde mediados del siglo XVII hasta la independencia mexicana, para mostrar las características formales, materiales y visuales de lo producido por las imprentas poblanas, lo que permite identificar las particularidades de cada taller y generar un extenso compendio visual de los tipos de imprenta utilizados en los impresos novohispanos de esa ciudad. Gracias a esto, el lector irá reconociendo los aspectos técnicos y comerciales en que se desenvolvían las añejas imprentas y, al mismo tiempo, percibirá la evolución de letras, grabados y ornamentos.

Tras una introducción al funcionamiento, las características y las profesiones habituales en los talleres durante el periodo de la imprenta manual, la obra se ocupa de cada siglo de la imprenta colonial, a partir de un abundante conjunto de fuentes documentales inéditas y del estudio material de los impresos angelopolitanos resguardados por la Biblioteca Nacional de México. La autora describe los avatares de las oficinas que funcionaron en la Colonia, presenta datos sobre algunas operaciones comerciales así como abundantes noticias sobre los propietarios y cajistas implicados, a la vez que ofrece una amplio registro de los documentos de archivo consultados y un catálogo de autógrafos de los impresores.

En esta novedosa obra sobre la historia de la imprenta en Puebla, Garone Gravier presenta el resultado de un trabajo de larga duración, con una perspectiva interdisciplinaria que le permite ofrecer un aspecto poco tratado de la cultura impresa latinoamericana: el análisis del patrimonio tipográfico regional a partir del estudio material de los libros y la reconstrucción de los repertorios de capitulares, letrerías, ornamentos y grabados de cada impresor y taller, para así rastrear, en algunos casos notables, el origen de los insumos y dar pistas para el estudio de las intrincadas relaciones de Puebla con otras tradiciones tipográficas tanto de México como de Europa. 